\title{
问

Study of the Characteristics, Satisfaction, and Organizational Commitment of Faculty Members at Ten Colleges Affiliated with the Council for Christian Colleges and Universities

Curtis J. Taylor

Dordt College, curtis.taylor@dordt.edu

Follow this and additional works at: https://digitalcollections.dordt.edu/faculty_work

Part of the Higher Education Commons

\section{Recommended Citation}

Taylor, C. J. (2005). Study of the Characteristics, Satisfaction, and Organizational Commitment of Faculty Members at Ten Colleges Affiliated with the Council for Christian Colleges and Universities. Retrieved from https://digitalcollections.dordt.edu/faculty_work/18

This Dissertation is brought to you for free and open access by Dordt Digital Collections. It has been accepted for inclusion in Faculty Work Comprehensive List by an authorized administrator of Dordt Digital Collections. For more information, please contact ingrid.mulder@dordt.edu. 


\title{
Study of the Characteristics, Satisfaction, and Organizational Commitment of Faculty Members at Ten Colleges Affiliated with the Council for Christian Colleges and Universities
}

\author{
Abstract \\ This study examined the reasons why faculty members choose to teach at Christian colleges, their \\ commitment to their institution, and their satisfaction with various job-related issues and values. It \\ analyzed comparisons between the characteristics and satisfaction of faculty members at Christian \\ colleges and faculty members in other types of American institutions of higher education.
}

An on-line survey was administered to all faculty members at 10 diverse institutions affiliated with the Council for Christian Colleges and Universities. Useable responses were received from 238 full-time faculty members. The response rate was approximately $33 \%$.

Survey items were categorized as follows: demographic variables; researcherdesigned questions regarding reasons for initial affiliation, current satisfaction, and areas of concern; the 15 items of the Organizational Commitment Questionnaire (OCQ); and 70 items from the National Study of Postsecondary Faculty (NSOPF).

Data from the OCQ and the NSOPF questions were analyzed by means of one-way ANOVA to determine mean differences between respondents on 11 independent variables. One-sample t-tests were used to compare the respondents' mean scores on the NSOPF items with mean scores from the national NSOPF surveys.

The primary reasons that faculty members gave for choosing to teach at a Christian college were a desire to work in a Christian environment and the institution's mission. They expressed concern that demands on faculty at their institutions are too heavy and their wages and benefits are insufficient. xiv

Analysis of the OCQ results indicated significant organizational commitment on the part of faculty to their Christian colleges. One-way ANOVA analysis found statistically significant differences on over 30 of the comparisons made with the 11 independent variables $(p<.05)$. Results indicated that commitment levels were significantly higher for females, those over age 60 , and faculty who were working at their alma mater.

Analysis of the NSOPF results indicated strong satisfaction regarding various workrelated variables. Statistically significant differences were found between the mean scores of respondents and the NSOPF studies on 43 of the items, with the faculty in this study demonstrating greater satisfaction on 35 of these items $(\mathrm{p}<.05)$.

\section{Keywords}

lowa State University, Council for Christian Colleges and Universities, Christian colleges, faculty satisfaction, Organizational Commitment Questionnaire, National Study of Postsecondary Faculty

\section{Disciplines}

Education | Higher Education

\section{Comments}

- A dissertation submitted to the graduate faculty in partial fulfillment of the requirements for the degree of DOCTOR OF PHILOSOPHY, Iowa State University

- Larry H. Ebbers, Major Professor 
- (C) 2005 Curtis J. Taylor

Creative Commons License

(c) $)(\mathrm{BO})$

This work is licensed under a Creative Commons Attribution-NonCommercial-No Derivative Works 4.0 International License. 


\title{
A study of the characteristics, satisfaction, and organizational commitment of faculty members at ten colleges affiliated with the Council for Christian Colleges and Universities
}

by

Curtis J. Taylor

\author{
A dissertation submitted to the graduate faculty \\ in partial fulfillment of the requirements for the degree of \\ DOCTOR OF PHILOSOPHY
}

Major: Education (Higher Education)

Program of Study Committee:

Larry H. Ebbers, Major Professor

Virginia Arthur

Sharon Drake

Daniel C. Robinson

Margaret Torrie

Iowa State University

Ames, Iowa 


\section{Graduate College \\ Iowa State University}

This is to certify that the doctoral dissertation of

Curtis J. Taylor

has met the dissertation requirements of Iowa State University

Major Professor

For the Major Program 


\section{DEDICATION}

To my wife, Sheryl, without whose love, support, encouragement, and occasional gentle prodding, this project would never have been completed. Thank you.

To my children, Ian, Willem, and Mia, who endured long days and nights without my presence while I muddled through the process. Thank you.

To my parents, who provided the seeds for my development through a nurturing Christian home and a selfless devotion to Christian education. Thank you.

To Carl Zylstra and Dordt College, who provided me the resources and time necessary to complete this project. Thank you.

To Larry Ebbers, who never gave up on me, and encouraged me when the road looked too long to travel. Thank you.

And to my God, through Whom all things are possible. Soli Deo Gloria! 


\section{TABLE OF CONTENTS}

LIST OF TABLES $\quad$ v

PREFACE viii

ABSTRACT X xiii

CHAPTER 1. INTRODUCTION $\quad 1$

CHAPTER 2. REVIEW OF LITERATURE 5

CHAPTER 3. METHODOLOGY 34

$\begin{array}{lll}\text { CHAPTER 4. FINDINGS } & 43\end{array}$

CHAPTER 5. CONCLUSIONS, DISCUSSION, AND RECOMMENDATIONS 120

APPENDIX A: ADDITIONAL TABLES 149

APPENDIX B: SURVEY INSTRUMENT 284

APPENDIX C: CCCU INSTITUTIONS 299

APPENDIX D: HUMAN SUBJECTS APPROVAL 304

$\begin{array}{ll}\text { REFERENCES } & 306\end{array}$

BIOGRAPHICAL SKETCH 


\section{LIST OF TABLES}

Table 1. Sample distribution by gender $\quad 43$

Table 2. Sample distribution by age $\quad 44$

Table 3. Sample distribution by institution $\quad 45$

Table 4. Sample distribution by church membership requirement 45

Table 5. Sample distribution by type of undergraduate alma mater $\quad 46$

Table 6. Sample distribution by highest degree earned $\quad 47$

Table 7. Sample distribution by academic rank $\quad 47$

Table 8. Sample distribution by years teaching (career) $\quad 48$

Table 9. Sample distribution by years teaching (institution) $\quad 48$

Table 10. Sample distribution by expected age of retirement 49

Table 11. Sample distribution by academic field 50

Table 12. Sample distribution by academic divisions 51

Table 13. Reasons for initial affiliation with current institution 53

Table 14. Currently appreciate most about current institution 54

Table 15. Most problematic characteristics of current institution 56

Table 16. OCQ descriptive statistics 58

Table 17. Reliability statistics for the 15 OCQ questions 59

Table 18. Total variance explained for OCQ questions 60

Table 19. ANOVA results of OCQ questions by gender 62

Table 20. ANOVA results of OCQ questions by age 63

Table 21. ANOVA results of OCQ questions by institution 65 
Table 22. ANOVA results of OCQ questions by church membership requirement

Table 23. ANOVA results of OCQ questions by alma mater

Table 24. ANOVA results of OCQ questions by years teaching (career)

Table 25. ANOVA results of OCQ questions by years teaching (institution)

Table 26. ANOVA results of OCQ questions by expected age of retirement

Table 27. ANOVA results of OCQ questions by academic field

Table 28. Descriptive statistics for job satisfaction questions

Table 29. Descriptive statistics for reasons for leaving current institution

Table 30. Descriptive statistics for desired mix of roles in new position

Table 31. Descriptive statistics for importance of characteristics in new position

Table 32. Descriptive statistics for statements regarding academic issues

Table 33. Results of one-sample t-tests of means between study participants and NSOPF participants on job satisfaction questions

Table 34. Results of one-sample t-tests of means between study participants and NSOPF participants on reasons for leaving current institution

Table 35. Results of one-sample t-tests of means between study participants and NSOPF participants on desired mix of roles in new position

Table 36. Results of one-sample t-tests of means between study participants and NSOPF participants on importance of characteristics in new position

Table 37. Results of one-sample t-tests of means between study participants and NSOPF participants on statements regarding academic issues

Table 38. ANOVA results of NSOPF questions by gender

Table 39. ANOVA results of NSOPF questions by age 
Table 41. ANOVA results of NSOPF questions by church membership requirement

Table 42. ANOVA results of NSOPF questions by alma mater

Table 43. ANOVA results of NSOPF questions by highest degree earned

Table 44. ANOVA results of NSOPF questions by academic rank

Table 45. ANOVA results of NSOPF questions by years of teaching (career)

108

Table 46. ANOVA results of NSOPF questions by years of teaching (institution)

Table 47. ANOVA results of NSOPF questions by expected age of retirement

Table 48. ANOVA results of NSOPF questions by academic field 


\section{PREFACE}

The life of a college faculty member can be beset by competing loyalties. Initially, an aspiring academic may have to choose between developing skills that will help him excel as a teacher or a researcher. This choice may need to be made at the time an institution is selected at which he will complete his graduate studies. After graduation, a prospective faculty member must choose an institution at which to work that will reward the particular skills and abilities that he has developed. As his career progresses, he may have to balance his loyalty to an academic specialty with his commitment to a more broadly defined academic major or department. He may also have to divide his time and energy between service to the institution at which he is employed and involvement with a tight-knit community of scholars in his field of expertise. And these choices do not even take into account whether he has additional family considerations that must be factored in to his decision-making.

For a faculty member with strong religious convictions, another choice must be made. He must choose between working at an institution that recognizes, accepts, and encourages his religious convictions, or one that may, at best, tacitly accept his beliefs, but that expressly prohibits the public expression of those beliefs.

The choices for a college or university are no less difficult. When appointing faculty members, academic administrators and boards must consider the needs of the institution, department, and students and balance those needs against the available resources and pool of potential candidates. For Christian colleges that espouse a particular set of philosophical or 
theological beliefs, the pool of acceptable candidates can be significantly smaller than that for a public or secular college or university.

Perhaps, at the outset, an example taken from a small, private, church-related college would help to clarify some of the issues that both faculty members and Christian colleges face. The institution was founded approximately half-a-century ago by members of a church denomination that wanted a regional Christian college to train teachers for their local private Christian schools. Until that time, nearly all Christian school teachers were educated at another college affiliated with the denomination, but located over 500 miles away.

For 50 years, the college has maintained a very close relationship with its founding denomination. Although not officially owned by the denomination, the college is recognized and heavily supported by members of the denomination. Over its history, the percentage of students from the denomination has decreased from nearly $100 \%$ at its founding to its current level of just over 60\%; however, nearly all Board of Trustees members belong to the denomination, and all its faculty members are required to be members of the denomination and assent to their support of the educational mission and philosophy of the college.

Faculty members who are not members of the denomination when they apply for employment are interviewed to ascertain their support of the college policy and their willingness to join the denomination. These faculty members are given up to two years to join the denomination after accepting employment at the college.

For nearly 40 years, during which time the college continued to enroll primarily students from the founding denomination, this policy was well understood, and generally accepted by the Board, constituency, students and faculty. The Board reaffirmed the policy 
several times during its first four decades. In recent years, however, the policy has come under greater scrutiny and criticism by faculty, students, and some constituents.

Initially this criticism came from individuals who expressed a desire to be allowed to join similar denominations that were open to more contemporary styles of worship and greater involvement of women in church government and leadership. They articulated that the college's students were becoming increasingly more denominationally diversified, and the faculty and Board should mirror that change. Several times over the years, requests were made to the President for exemptions to the Board church membership policy, but these requests were ordinarily denied (exceptions occasionally being made for members of the clergy in other denominations).

More recently still the requests have begun to change, due to changes in the denomination itself. Since the late 1980 s over $10 \%$ of the denomination's members have left the denomination to join or form more conservative denominations or churches. These former members of the denomination disagree with the founding denomination's decision to allow women to hold church office and become ministers. Most have joined churches affiliated with denominations that do not allow these ecclesiastical practices.

In the mid-1990s the Board of Trustees approved a change in its bylaws to add six new board members from other denominations that strongly support the college. This change fueled the interest of faculty and some potential faculty members who wished to belong to more conservative denominations. The college administration began to receive requests from faculty and applicants for exemptions to the church membership policy in order to join the denominations that were now represented on the Board of Trustees. 
In the early 2000s, the Board convened a sub-committee to study whether to reconsider the policy. After six months of study, during which they received significant comment from faculty on both sides of the issue, the sub-committee reported back to the Board. Their report recommended that although there was significant evidence and opinion that the policy could be reconsidered, the evidence for not changing the policy at that time was more compelling. Central to their evidence was the college's long association with the denomination, the denomination's unwavering support of Christian education, and the Board's determination that the beliefs of the denomination best epitomized the educational philosophy of the college.

The decision was not received well by some faculty who desired a policy change. A number of faculty members again requested an exemption to the policy to join a new church in the community; the Board denied the requests. Several faculty members subsequently left the college to accept positions at other Christian colleges with less-stringent church membership requirements.

This is only one example of the importance of a Christian college recruiting and hiring faculty members who accept and are committed to the mission, philosophy and policies of the institution. It also recognizes the importance of faculty members considering their own personal beliefs and needs before making the choice to accept employment at such an institution. In this example, perhaps the institution was not sufficiently clear about its church membership expectation, or maybe the faculty members who were no longer satisfied with or committed to the institution had not clarified their own personal beliefs or expectations. 
This study will address these issues-specifically the choice of a faculty member to seek and hold employment at a committed Christian college or university and the factors related to his satisfaction with that choice and commitment to the chosen institution. 


\begin{abstract}
This study examined the reasons why faculty members choose to teach at Christian colleges, their commitment to their institution, and their satisfaction with various job-related issues and values. It analyzed comparisons between the characteristics and satisfaction of faculty members at Christian colleges and faculty members in other types of American institutions of higher education.
\end{abstract}

An on-line survey was administered to all faculty members at 10 diverse institutions affiliated with the Council for Christian Colleges and Universities. Useable responses were received from 238 full-time faculty members. The response rate was approximately 33\%.

Survey items were categorized as follows: demographic variables; researcherdesigned questions regarding reasons for initial affiliation, current satisfaction, and areas of concern; the 15 items of the Organizational Commitment Questionnaire (OCQ); and 70 items from the National Study of Postsecondary Faculty (NSOPF).

Data from the OCQ and the NSOPF questions were analyzed by means of one-way ANOVA to determine mean differences between respondents on 11 independent variables. One-sample t-tests were used to compare the respondents' mean scores on the NSOPF items with mean scores from the national NSOPF surveys.

The primary reasons that faculty members gave for choosing to teach at a Christian college were a desire to work in a Christian environment and the institution's mission. They expressed concern that demands on faculty at their institutions are too heavy and their wages and benefits are insufficient. 
Analysis of the OCQ results indicated significant organizational commitment on the part of faculty to their Christian colleges. One-way ANOVA analysis found statistically significant differences on over 30 of the comparisons made with the 11 independent variables $(p<.05)$. Results indicated that commitment levels were significantly higher for females, those over age 60, and faculty who were working at their alma mater.

Analysis of the NSOPF results indicated strong satisfaction regarding various workrelated variables. Statistically significant differences were found between the mean scores of respondents and the NSOPF studies on 43 of the items, with the faculty in this study demonstrating greater satisfaction on 35 of these items $(p<.05)$. 


\section{CHAPTER 1.}

\section{INTRODUCTION}

A 1976 meeting of the Association of American Colleges addressed the contemporary mission of church-related colleges. A summary of this meeting indicated six factors that help church-related institutions achieve their mission. They are: 1) the centrality of the faculty members; 2) strong interaction among faculty and students; 3) personal development of faculty and students; 4) the integration of curriculum and outcomes; 5) a high percentage of students from the sponsoring denomination; and 6) a strong relationship with the sponsoring denomination (Achieving the Mission, 1977).

The 1966 Danforth Commission proposed a schema that describes three different archetypes of church-related colleges (Pattillo \& Mackenzie, 1966). The three types are: 1) defender of the faith college; 2) non-affirming college; and 3) free Christian college. (A fourth type, the church-related university, is not relevant to this research project).

Defender of the faith colleges are instituted to train leaders for particular denominations. They have a strong clarity of purpose and exert a strong religious influence on students. They are orthodox in their theology, and may be seen as counter-cultural in their curricular and extracurricular activities. Denominational loyalty is important, and financial support by the denomination is usually significant (Pattillo \& Mackenzie, 1966).

Non-affirming colleges are church-related, but give little attention to religion. They usually have a historical tie to a particular denomination, but do not maintain the theological tenets of the denomination. In fact, the curriculum has been secularized to such an extent that many students may not even realize that the institution is church-related. Typically, the 
denomination maintains a presence on the board of trustees, and may even supply a small portion of the operating budget of the institution, but other connections are minimal (Pattillo \& Mackenzie, 1966).

Free Christian colleges are those that place a high emphasis on Christian thought and action, but do not attempt to control their students or faculty. A free Christian college "does not tell its students what they must believe, but it does expect them to grapple with the basic religious and philosophical questions and arrive at a considered position of their own” (Pattillo \& Mackenzie, 1966, p. 194). These institutions may or may not have a relationship with a specific denomination, but aside from providing spiritual leadership, the denomination usually does not exert much influence.

A number of $19^{\text {th }}$ and $20^{\text {th }}$ century church-related colleges not only have resisted the secularization described in the Danforth “non-affirming colleges” category, but also have continued staunchly to maintain their religious focus up to the present time. These institutions are most commonly known as “committed Christian colleges” (Burtchaell, 1998, p. 743). Burtchaell defines committed Christian colleges as biblical, conservative, enthusiastic, and informal in ritual, plain in manners, with a tendency toward Wesleyan or Calvinist theology. In Burtchaell's book, The Dying of the Light, he quotes David Reisman as much being much less flattering in his description of these committed Christian colleges as “claustrophobic” (1998, p. 743).

In terms of the Danforth schema, committed Christian colleges--the focus of this study--are best categorized as a combination of defender of the faith colleges and free Christian colleges. Not all of them are linked to specific denominations, but all maintain a close adherence to Christian theology and probably would consider themselves as defenders 
of the faith. Some are more willing than others to allow students to wrestle with issues without providing a prescribed religious answer.

Perhaps the best exemplars of these types of committed Christian colleges in the United States today are the 175 member and affiliate-member institutions of the Council for Christian Colleges and Universities (CCCU). This study will focus on faculty from 10 member institutions of the CCCU. A description of this organization and its member institutions may be found in the review of the literature and a listing of the institutions is included in Appendix C.

\section{Purpose of this Study}

This study was designed to examine the reasons why faculty members choose to affiliate with a committed Christian college (specifically, 10 member institutions of the CCCU). It addresses their commitment to their current institution, and their satisfaction with various job-related values and issues. It also makes comparisons between the characteristics and satisfaction of faculty members at committed Christian colleges and faculty members in general in American institutions of higher education. It is hoped that this research will assist academic administrators at these institutions in selecting candidates who possess the characteristics and values that will best fit with the mission and philosophy of their institution.

\section{Research Questions}

The primary research questions used to guide this study were:

1. What are the critical factors involved in a faculty member's decision to initially accept a job at a CCCU institution? 
2. What are the critical factors involved in a faculty member choosing to remain in a position at a CCCU institution?

3. What are the critical factors that are considered most problematic by faculty members working at a CCCU institution?

4. Are there significant differences in the commitment of faculty to their institution among the faculty at 10 selected CCCU institutions based on the following characteristics: gender, age, current institution, church membership requirement, type of undergraduate alma mater (specifically, whether they are working at the institution at which they completed their undergraduate degree, another CCCU institution, another non-CCCU Christian college, or a public college or university), highest degree earned, academic rank, years of teaching experience (in their career and at their current institution), expected age of retirement, and academic field?

5. Are there significant differences in measures of satisfaction with or opinions about selected job components between faculty members at selected CCCU institutions and faculty members in general at US colleges and universities?

6. Are there significant differences in measures of satisfaction with or opinions about selected job components or values between faculty members at selected CCCU institutions based on the following characteristics: gender, age, current institution, church membership requirement, type of undergraduate alma mater, highest degree earned, academic rank, years of teaching experience (in their career and at their current institution), expected age of retirement, and academic field? 


\section{CHAPTER 2.}

\section{REVIEW OF LITERATURE}

Four threads of knowledge and research come together as a conceptual framework for this study: 1) the nature and characteristics of committed Christian colleges; 2) the nature and characteristics of college faculty members; 3) satisfaction of faculty members and their commitment to their institution and its mission; and 4) the historical reluctance of an institution to hire its own graduates as faculty members (known as faculty inbreeding).

\section{Christian Colleges}

In colonial America, all colleges were innately Christian. The primary mission of each of the earliest institutions of higher education in America was to train Christian clergy and leaders. Brubacher and Rudy (1976) state that the college was a "local encampment of the universal 'militia' of Christ” (p. 7) designated to "provide a supply of clergymen ... [and] ensure that the youth were piously educated in good letters and manners” (Rudolph, 1990, p. 7).

At the time of the Revolutionary War, America still had only nine colonial colleges. All but the University of Pennsylvania had been founded by religious organizations. Within 100 years the United States had 250 colleges, but up to 700 others had opened and failed to survive (Rudolph, 1990). Many of the failed colleges had been opened by religious denominations that sought to place their own theological mark on higher education; however, the reason they did not thrive was their sectarian nature (Rudolph, 1990). They failed to recognize that America was a diverse nation that was in transition from a colonial Calvinistic worldview to an expansionist humanistic worldview. 
This transition resulted in a conflict between the conservative old-guard at many colonial and early $19^{\text {th }}$ century institutions and the progressive youth and society of the middle $19^{\text {th }}$ century. If a college did not change to recognize the diversity of American values and the moderation of religious thought, as did all of the early colonial colleges, it was not likely to survive. Multiple revivals caused a temporary metamorphosis in individual students, and might even change the nature of an entire institution, but in the end, secularism triumphed over denominationalism (Rudolph, 1990).

The late $19^{\text {th }}$ and early $20^{\text {th }}$ centuries witnessed an ongoing secularization of formerly denominational colleges. Much of this secularization was the result of an evolving understanding of the doctrine of the separation of church and state (Brubacher \& Rudy, 1976; Cameron, 1994; Dannelly, 1931) and the rise of the scientific method (Rudolph, 1990). Ringenberg (1984) identified characteristics that marked the secularization of church-related institutions, including the weakening of explicit Christian language in public statements and the lessening of restrictions on the theological beliefs of faculty members.

Clarence M. Dannelly wrote an article in 1931 in the Journal of Higher Education that provided five reasons why denominational colleges should not be allowed to disappear entirely from the landscape of American higher education. His reasons were: 1) Christian colleges recognize "the strategic place of the teacher in the educational process and seeks to employ in its faculty only those men and women who are active, aggressive Christians” (p. 186); 2) during the college years, a church college is "the most wholesome place to study" (p. 187); 3) church colleges lead their students to a "definite Christian philosophy of life” (p. 187); 4) the church college provides a "Christian atmosphere” for its students (p. 188); and 5) the church college trains students for “avocational work in the church” (p. 189). 
A small number of protestant, evangelical, church-related colleges resisted the secularization that had occurred on many campuses during the early $20^{\text {th }}$ century. As mentioned above, not all of these colleges remain tied to specific church denominations, but they do maintain a close adherence to their founding Christian theology. The member institutions of the Council for Christian Colleges and Universities (CCCU) are examples of these types of institutions.

The CCCU had its genesis in 1971 with the formation of a 10 member Christian College Consortium (Consortium). The Consortium had as its statement of purpose: to promote the purposes of evangelical Christian higher education in the church and in society through the promotion of cooperation among evangelical colleges, and in that conviction, to encourage and support scholarly research among Christian scholars for the purpose of integrating faith and learning; to initiate programs to improve the quality of instructional programs and encourage innovation in member institutions; to conduct research into the effectiveness of the educational programs of the member colleges, with particular emphasis upon student development; to improve the management efficiency of the member institutions; to expand the human, financial, and material resources available to member institutions; to explore the feasibility of a university system of Christian colleges; and to do and perform all and everything which may be necessary and proper for the conduct of the activities of this organization in furtherance of the purposes heretofore expressed (quoted in Patterson, 2001, p. 32).

The Consortium added four additional institutions during the mid-1970s. By 1975 a growing number of like-minded Christian colleges desired to join with the Consortium in 
order to collectively address a number of perceived legal threats, but the presidents of the organizing institutions were not interested in allowing the organization to grow any larger. Instead, they instructed their executive director to draw up plans for a wholly-owned subsidiary organization that could accommodate those institutions that were interested in membership (Patterson, 2001).

The new organization, the Christian College Coalition (Coalition), was launched in 1976 with 38 original institutions, including all 14 of the original Consortium institutions. This institution had as its agenda:

(1) the monitoring of legislation, judicial activity, and public opinion on matters which could affect the freedom of Christian colleges to function educationally and religiously; (2) the development of unified positions on critical issues for presentation to other organizations, governmental bodies, and public policy formers; and (3) the development of an offensive position on potential erosions of religious and educational freedom in the Christian college movement” (quoted in Patterson, 2001, p. 43).

By 1981 the logistics of managing two separate organizations, with two separate boards of directors under one administrator had become very difficult, so the Coalition legally separated from the Consortium. The Consortium continues to this day as an organization of 13 member institutions, all of whom are also members of the CCCU. The Consortium’s primary mission consists of providing:

a unique opportunity for presidents and other college officers to meet together on a regular basis with a relatively small group of peers from similar institutions to discuss the most urgent issues facing the evangelical Christian church, American higher 
education in general, and Christian higher education in particular, and then to determine how individually or corporately we focus on these issues (Christian College Consortium, 1997).

During the 1980s the newly-formed CCCU experienced a period of unprecedented growth, doubling in size in its first five years as a separate organization. These years also witnessed the addition of several student programs and faculty development initiatives, the publication of a yearly college guide and a series of textbooks, and a \$2.1 million capital campaign. The 1990s were a time of slower growth in the number of new members, but witnessed, instead, the strengthening of academic programs and national recognition (Patterson, 2001). A name change in 1995 from the Coalition of Christian Colleges to the Council for Christian Colleges and Universities attempted to distance the organization from the conservative Christian Coalition and to recognize that the organization exists to serve [hence the use of the word for rather than of] both Christian colleges and universities (Patterson, 2001, p. 81).

The CCCU membership currently consists of over 100 protestant, Christian, institutions across the United States and Canada and nearly 70 institutional affiliates in over 20 countries. The mission of the CCCU, as a professional association of academic institutions is "to advance the cause of Christ-centered higher education and help institutions to effectively integrate biblical faith, scholarship and service" (Council for Christian Colleges \& Universities, 2000).

The CCCU provides numerous programs and services to its member institutions and affiliates. According to the CCCU website (2000), the most current list of programs and services includes: 
- annual conferences for presidents, administrative officers, and professional staff, and executive leadership development institutes for new presidents and chief academic officers,

- national and regional faculty development workshops,

- coordination of sabbatical opportunities among CCCU institutions,

- a congress on multi-cultural issues,

- $\quad$ student study programs in Washington DC, China, England, Costa Rica, Los Angeles, Egypt, and Russia,

- a tuition waiver exchange program between participating CCCU institutions,

- collaborative projects on assessment, retention, and faculty development,

- governmental lobbying,

- collaborative recruitment projects, including the publication of Peterson's Christian Colleges \& Universities,

- collaborative research projects on administrator/faculty/presidential compensation and enrollment trends, and,

- $\quad$ publication of Research in Christian Higher Education, and numerous other publications and resource guides.

All CCCU member institutions must adhere to the following criteria:

- Institutional type and accreditation: Primary orientation as a four-year college or university in North America with curriculum rooted in the arts and sciences. U.S. institutions must have full non-probationary regional accreditation.

- Christ-centered mission: A public mission based upon the centrality of Jesus Christ and evidence of how faith is integrated with the institution's academic and 
student life programs.

- Employment policy: A current hiring policy which requires of each full-time faculty member and administrator a personal faith in Jesus Christ.

- Cooperation: A commitment to advancing the cause of Christian higher education through active participation in the programs of the Council, payment of the annual dues and special assessments, and institutional practices which have been, are now, and will continue to be supportive of other Council members.

- Financial Integrity: Institutional fund raising activities which are consistent with the standards of the Evangelical Council for Financial Accountability and demonstration of responsible financial operations (Council for Christian Colleges \& Universities, 2000).

In addition to the required criteria, member institutions of the CCCU are similar in many other ways. Literature regarding the CCCU institutions indicates numerous characteristics that most seem to share. These institutions strive to integrate faith and learning (Edwards, 1999; Peterson's, 1999; Wolterstorff, 1984), develop in students a Christian world view (Crabtree, 1996; “How my Christian,” 1993; Parsons \& Fenwick, 1996) offer caring academic communities for students (Cameron, 1994; Tonsor, 1970; “Why attend,” 1992), employ scholarly Christian faculty (Carlburg, 1994; Peterson’s, 1999; Thompson, 1995), are more affordable than people perceive them to be (Carlburg, 1994; Crabtree, 1996; "Why attend,” 1992), provide living conditions that espouse Christian values (Carlburg, 1994; Kleiner, 1999), and recently have experienced an enrollment boom (Frame, 1997; Olsen, 1996). 
One issue that has been leveled at Christian colleges in the past is that they do not allow faculty members and students to pursue their work in an environment that allows for true academic freedom. Academic Freedom is defined by philosopher Arthur Lovejoy as "the freedom of the teacher or research worker in higher institutions of learning to investigate and discuss the problems of his science and to express his conclusions, whether through publications or in the instruction of students without interference from political or ecclesiastical authority” (1930, p. 84).

In a 1998 article in Academe, Jonathan Alger pointed out that the American Association of University Professors (AAUP) "has long been guided by the so-called 'limitations clause in the AAUP's 1940 Statement of Principles on Academic Freedom and Tenure, which says simply that 'limitations of academic freedom because of religious or other aims of the institution should be clearly stated in writing at the time of the appointment”” (p. 61). Nevertheless, "some of the most vexing academic freedom issues faced by the Association over the years have arisen at religiously affiliated institutions” (Alger, 1998, p. 61).

In 1997 an AAUP meeting in Chicago pulled together faculty and academic administrators from a variety of religiously affiliated institutions to discuss academic freedom. In an address prepared for that conference, Martin Marty, a religious historian from the University of Chicago, described the academic freedom controversy at Christian colleges as a conflict in approaches to the pursuit of truth. "Academics are supposed to pursue truth through reason. Those in the biblical tradition, Jews and Christians alike, informed by reason, are also responsible to a 'God of Truth’ or 'the true God’” (Marty, 1998, p.64). He suggests that conflicts over academic freedom arise when "scholars intend to be responsible 
to both approaches to truth” (Marty, 1998, p. 64). Alger, counsel to the AAUP and organizer of the conference, echoed Marty when he said, "In addressing tough issues of academic freedom within the unique circumstances at religiously affiliated institutions, that moral leadership will entail continuous dialogue and interaction as all of the participants struggle with their vision of the search for truth” (Alger, 1998, p. 61).

Marty proposed that church-related institutions can be divided into four different categories, each with varying degrees of conflict with regard to academic freedom: 1) Catholic institutions, 2) mainstream Protestant institutions, 3) African-American Protestant institutions, and 4) Evangelical institutions. At Catholic institutions, Marty suggests that issues of academic freedom relate most directly to the amount of ecclesiastical authority currently being exercised by the Vatican (1998, p. 65). Mainstream Protestant institutions rarely experience questions of academic freedom, due in part to an understanding that "the search for truth can be grounded in religious traditions as well as in post-Enlightenment rationalism” (Marty, 1998, p. 65). Marty states that African-American Protestant institutions report little conflict between classroom truth and ecclesiastical authority.

Evangelical institutions have the highest incidents of clashes with regard to academic freedom. Marty reports that "stories of faculty not getting tenure-or even losing it—at colleges and seminaries in these settings are not uncommon. The pressure on academic freedom at Southern Baptist institutions grew so intense that some schools, including Wake Forest and Baylor Universities, severed ties to their conventions, while still preserving informal ties to the Baptist traditions that so many leaders in those schools cherish. They simply don’t want to fall under arbitrary ecclesiastical authority” (Marty, 1998, p. 65). 
Marty believes some of the criticism leveled at religious colleges is unfair. "The religious want to be allowed on the same playing field with secular academics; they are routinely ruled out-of-bounds when they refer to sources of authority other than reason and rationality, while others, who may also curtail academic freedom, are given a free pass” (Marty, 1998, p. 66). He suggests, "Religiously affiliated colleges and universities can serve in a special vocation, one that gets obscured by heresy trials. Their personnel are called on to raise questions about human existence that may often get slighted in the day-to-day workings of secular and tax-based universities. These colleges have as part of their mission to privilege humanistic and theological texts that can point students to profound sets of meanings that often go overlooked in other curricula. Graduate school professors will testify to the quality of well-educated alumni from such undergraduate institutions.”

Anthony Diekema, former president of Calvin College, would agree with Marty. Diekema (2000) argues for a different type of academic freedom at a Christian college; one that is framed by the worldview of the institution. He suggests that the relationship between an institution and its faculty should more resemble a covenant than a contract, and that both parties should have an explicit understanding of the way that truth and meaning are contextualized at the institution.

In a 1999 study published in Religious Education, Cooper reports on a related issue. His study examined the attitudes of faculty members in Southern Baptist colleges and universities toward the integration of their Christian faith and their academic disciplines across faculty ranks and demographic factors (p. 382).

All the faculty members in Cooper's study had positive attitudes toward integration of faith and discipline. There was a difference, however, in where faculty members favored that 
integration. While there was no difference between tenured and non-tenured faculty in their support for integration outside of the classroom, tenured faculty were not as positive about integrating faith and discipline in class (Cooper, 1999, p. 389). Interestingly, however, as faculty members aged, their support for in and out-of-class integration increased (Cooper, 1999, p. 390). The study also suggested that tenured faculty members were less supportive of institution-wide integration of faith and discipline than their non-tenured counterparts. Another important factor reported by Cooper is that faculty who graduated from churchrelated undergraduate institutions were not more likely to support integration; however, Southern Baptist faculty members were more interested in integration issues than those from other denominations, possibly because they have "been conditioned through the Southern Baptist community to hold attitudes which encourage, consciously or unconsciously, the integration of faith and academic discipline” (1999, p. 393). Cooper suggests "this finding underscores the essential need within Southern Baptist higher education for the selection and retention of faculty who are Southern Baptist in their faith” (1999, p. 392).

Examples of incidences where faculty members at Christian colleges are confronted with issues of academic freedom are occasionally reported in the media. In 1997 an associate professor at Old Dominion University, Scott Cairns, had a tenure-track position as a full professor at Seattle Pacific University (a CCCU institution) rescinded after it was learned that he had published his "playfully erotic musings about poetry” in a poem entitled "Interval with Erato" in the Winter 1997 edition of The Paris Review. ("Professor loses," 1997). The chairman of the English department at the time of the offer, subsequently resigned his chairmanship after learning that the offer had been withdrawn. 
In 2000 a faculty member at Wheaton College in Illinois was not reappointed because he "failed to develop the necessary basic competence in the integration of Faith and Learning, particularly in the classroom setting” (McMurtrie, 2002, p. A12). The same article described several similar incidents where faculty members where either denied reappointment or subjected to intense scrutiny about their religious beliefs at other Christian colleges affiliated with the Council for Christian Colleges and Universities in Ohio, Washington, Michigan, and Minnesota.

In 2001 two professors were forced to leave the Southwestern Baptist Theological Seminary in Fort Worth, Texas for their failure to sign the "Baptist Faith and Message" statement of the Southern Baptist Convention (Jacobson, 2001).

\section{College Faculty}

Since colonial times, the primary mission of the college faculty member has been teaching. Today's threefold model of teaching, research, and service was not the required job description for America’s first faculty members. Rudolph (1990) states that colonial college faculty "believed that in serving the cause of knowledge and truth by promoting liberal education, they were serving the cause of religion” (p. 159), and “only rarely were the professors scholars” (p. 158). It was Thomas Jefferson, in 1824, who hired the first academically trained faculty for his fledgling University of Virginia, five of whom were imported from Europe (Rudolph, 1990).

As colleges changed in the $18^{\text {th }}$ and $19^{\text {th }}$ centuries, so did the requirements for faculty members. Until the latter $19^{\text {th }}$ century faculty followed a clergy model (Braskamp \& Ory, 1994); however, the increase in the number of scientific courses and specialization of 
programs during the $19^{\text {th }}$ century resulted in the addition of research duties for many faculty members (Brubacher \& Rudy, 1976; Rudolph, 1990). By the early 20 ${ }^{\text {th }}$ century, research became the most important criterion for faculty advancement (Rudolph, 1990).

"From what began as a small group of tutors instructing prospective ministers at Harvard College emerged a profession where instruction was only one facet of the overall role of a faculty member” (Tierney \& Rhoads, 1994, p. 11). Today’s faculty members have many job duties. Fairweather (1996) states that faculty members must assume the roles of teacher, adviser, researcher, university citizen, departmental colleague, and consultant. Furthermore, the generic duties of instruction and research are broken down into many subdivisions. Instruction includes formal classroom instruction, independent instruction, advising, counseling, grading, course preparation, and development. Research encompasses preparation, conducting research, preparing and reviewing articles or books, attending professional meetings, and seeking funding (Fairweather, 1996).

Braskamp and Ory (1994) further dissect the teaching, research, professional service, and citizenship classification of faculty work. Teaching is made up of instructing, advising, supervising, guiding, and mentoring students. It also includes developing learning activities and participating in professional development. Research and creative activity consists of conducting research, producing creative works, editing and managing creative works, and participating in funded research and creative projects. Professional service and practice consists of using their skills and knowledge to solve society’s problems by means of conducting applied research and evaluation, disseminating knowledge, developing new practices and procedures, participating in partnerships with other agencies, and performing 
clinical service. Finally, citizenship includes contributing to professional associations, to the local campus, and to the larger civic community.

A 1988 National Study of Postsecondary Faculty Report (Russell, Fairweather, Hendrickson, \& Zimbler, 1991) indicates that full-time faculty at all accredited colleges and universities spend $56 \%$ of their time on teaching, $16 \%$ on research, $13 \%$ on administration, and $16 \%$ on other activities. They average 53 hours per week at work if tenured, and 55 hours per week if not tenured. Over the two years preceding the survey, full-time faculty produced an average of 2 articles in refereed journals, 0.6 book chapters and monographs, 0.6 book reviews, 1.5 other reports, and 4.3 professional presentations (Russell, Fairweather, Hendrickson, \& Zimbler, 1991). Faculty at research institutions spend significantly more time on research (31\%), while faculty at liberal arts institutions spend much more time on teaching (68\%) (Fairweather, 1996).

A 1994 study conducted by McPherren examined 148 public and private institutions with student FTE of 3,000 or less. Seventy-five of the 148 were CCCU institutions. McPherren found that faculty workload at CCCU colleges does not differ significantly from workload at other public and private colleges. However, she did find that the smaller the enrollment of the institution, the larger the workload required of faculty.

Faculty have a significant influence on the success and satisfaction of students. In their book, Involving Colleges, Kuh et al. (1991) state that students long for personal relationships with faculty members. Students seek these interactions both in and out of class. Faculty at involving colleges are more likely to be available for students outside of class. They also tend to be satisfied with their work and with their institution. 
A 1994 study of one CCCU institution by Lamport supports the research of Kuh et al. Lamport reports that students attribute informal interaction with faculty as positive influence on personal growth, intellectual growth, career goals, educational aspirations, and on the entire college experience. They perceive faculty to be interested in students and in teaching, and they describe faculty to be personable, caring, and encouraging. Students with higher grade point averages are more influenced by faculty interaction and more satisfied with that interaction than are their colleagues with low grade point averages.

\section{Organizational Commitment and Job Satisfaction}

An important factor in determining the success and satisfaction of an employee in his work setting is his commitment to the organization. Mowday, Porter, and Steers (1982) define organizational commitment as “the relative strength of an individual's identification with and involvement in a particular organization” (p. 27). This commitment is characterized by at least three factors: “(a) a strong belief in and acceptance of the organization’s goals and values; (b) a willingness to exert considerable effort on behalf of the organization; and (c) a strong desire to maintain membership in the organization” (p. 27). They suggest that the major influences on organizational commitment can be grouped into three major categories: (a) personal characteristics; (b) job- or role-related characteristics; and (c) work experiences (Mowday, Porter, \& Steers, 1982, p. 27).

Mowday, Porter, and Steers (1982) review research that suggests the components that make up each of these three major categories. The personal characteristics consist of, among other things, age, educational level, gender, race, and tenure level. Job- or role-related characteristics consist of job scope, participation in decision-making, role ambiguity, role 
conflict, and task requirements. Finally, work experiences consist of organizational dependability, perceived pay equity and group norms regarding hard work, personal importance to the organization, positive attitudes toward the organization, and social involvement in the organization.

Numerous researchers have conducted studies using the instrument developed by Porter, Steers, Mowday, and Boulian (1974) to measure organizational commitment—-the Organizational Commitment Questionnaire (OCQ). In fact, in a comprehensive metaanalysis of organizational commitment, Mathieu and Zajac (1990) reported that the OCQ was used in 103 of the 174 studies that their analysis reviewed. Several studies that investigated the use of the OCQ with college or university faculty will be discussed below, in addition to several studies related to the OCQ’s test-retest reliability.

Brookover (2002) assessed organizational commitment levels among faculty members at Clemson University, to determine their attitudinal commitment to the university. One hundred ninety two faculty members completed a survey containing the OCQ. Brookover found a statistically significant positive relationship between attitudinal commitment level and the importance a faculty member feels their work and goals have to organizational goal attainment. Statistically significant difference in the level of attitudinal commitment were found based on degree attainment from Clemson and gender.

Carroll (2002) administered the OCQ to 352 employees at a church-related university. She found that workplace experiences were more predictive of affective commitment than was employee-organizational values congruence. She also found a moderately high level of organizational commitment among the employees. 
Harshbarger (1989) used the OCQ to measure faculty commitment at four doctoralgranting universities in the southeastern United States. Surveys were returned by 496 participants. Harshbarger used t-tests to compute correlation coefficients between commitment scores and six independent variables (age, gender, tenure status, terminal degree, years since degree, and years at the university). He found no statistically significant differences. He also used one-way ANOVA to examine possible relationships between commitment scores and academic discipline or faculty rank. He found no statistically significant relationship between academic discipline and the OCQ score. There was a significant difference in the variable of faculty rank; associate professor respondents scored significantly lower on commitment than their colleagues at other ranks.

McCaul and Hinsz (1995) administered the OCQ to 356 employees in two manufacturing companies as part of a battery of five tests. They reported OCQ means that were consistent with those reported by Mowday, Steers, and Porter (1979). In addition, they repeated the process six months later and found high test-retest reliability for organizational commitment $(r=.75)$. This result was favorably compared to the results reported by Mowday, Steers, and Porter (1979) of $r=.53$ to $r=.75$. Lam (1998) conducted a similar test-retest study with sales supervisors in Hong Kong. He tested the 104 participants at a 10week interval and found a test-retest reliability of $r=.59$.

Meehan (2001) used the OCQ to analyze faculty perceptions of their input into decision-making and their level of organizational commitment, and to analyze any differences based upon whether or not the faculty participated in collective bargaining. The sample included 850 full-time faculty members at 10 private colleges and universities in the United States. Meeehan found no significant differences in faculty perceptions toward input 
into decision-making and level of organizational commitment at unionized and nonunionized institutions, but a moderately high correlation between organizational commitment and input into decision making at both unionized and non-unionized institutions;

Poppens (2001) administered the OCQ to 344 faculty members and administrators at six private institutions of higher education in the Midwest. Poppens was studying the perceived and preferred organizational culture types and the levels of organizational commitment of the participants. Her results indicated that individuals whose perceived organizational culture types were in the same or in agreement with their preferred types had statistically significant higher levels of commitment than those whose perceived and preferred organizational culture types were dissimilar. Similar institutional differences were found. Slight increases in the level of commitment were seen with increased age and years at the institution. Poppens used multiple regression analysis to determine the predictive value of the various variables, and found that agreement or disagreement of individuals culture types were substantially more predictive than the other independent variables tested.

There has been some criticism of the OCQ in its ability to distinguish between the factors associated with organizational commitment and its predictive validity. Benkhoff (1997) leads the way in this criticism. First, she points out that in the Mathieu and Zajac (1990) meta-analysis cited earlier, only 7 of the 48 variables they analyzed appear consistently significant. They are: marital status, ability, salary, skill variety and job scope, task interdependence, leader communication, and participative leadership.

Benkhoff postulates that the reason that organizational commitment has been so difficult to measure by the OCQ is that the instrument does not appear to be as homogenous as Mowday, Porter, and Steers have claimed. She criticizes their use of internal consistency 
as a measure of homogeneity (Benkhoff, 1997, p. 115), a low inter-item reliability as extrapolated from the reported Cronbach alpha coefficients (Benkhoff, 1997, p. 116), a lack of benchmarks regarding internal consistency of the instrument (Benkhoff, 1997, pp. 116117), and the lack of evidence to support a claim for homogeneity of the three-dimensional commitment scales (Benkhoff, 1997, p. 117).

Benkhoff concludes that on the basis of her analysis "one has to reject the hypothesis that the three dimensions of the OCQ represent aspects of the same underlying concept” (Benkhoff, 1997, p. 128). She warns that if managers are using the OCQ, they may not be measuring all of the components that contribute to a comprehensive model of organizational commitment. She acknowledges that the OCQ does adequately measure a sense of belonging and satisfaction, but does not address the concept of motivation and "managers concerned about both turnover and work performance have to be aware of the need to apply a different set of policies in each case” (Benkhoff, 1997, p. 128).

Several additional studies have examined the relationship between faculty members and the Christian colleges at which they work. Niehoff (1995) found that whether the core values of an employee and the institution are complimentary is important. He stated that "an important factor in building shared values is the hiring and retention of persons who are predisposed to become attached to the organization and committed to its values” (Niehoff, 1995, p. 202). He calls this concept mission value congruence. In his study of 500 employees at a Jesuit university he observed correlations between job satisfaction, organizational commitment, and mission value congruence.

Niehoff's study found that job satisfaction (whether a person is happy at what they do) was related to the academic degree of the employee, the job classification of the 
employee, and years of employment at the university (1995, p. 145). He found that organizational commitment (whether a person identifies with and is involved in their organization) was related to the religious affiliation of the employee (1995, p. 145). Niehoff also found that academic degree, age, gender, job classification and religious affiliation positively are related to mission value congruence (1995, p. 146). Niehoff reported that mission value congruence increased with age, but he found it interesting to note that the correlation was negative with regard to academic degree. The strongest correlation in his study was between mission value congruence and religious affiliation. He summarized his study by stating "it can be presumed that a cohort of satisfied, committed individuals sharing mission values can be an important leaven for mission and service. Clearly these individuals have the potential to influence institutional life significantly” (Niehoff, 1995, p. 13).

Using multiple regression to identify the factors most highly associated with job satisfaction in middle managers who were attendees at the Association of Christians in Student Development (ACSD) national conference, Ellis (2001) found that ideological fit (the degree of congruence between the organization's ideology and the person’s ideology), relationship with students, autonomy and age all influenced job satisfaction, with ideological fit having the most influence.

In her work on faculty job satisfaction, Hagedorn (2000) proposed a model of job satisfaction based on the concept of triggers and mediators. Triggers are "significant life events that may either be related or unrelated to the job” (p. 6). Mediators are described as a “variable or situation that influences (moderates) the relationships between other variables or situations producing an interaction effect.” (Hagedorn, 2000, p. 6) The model postulates six triggers: 1) change in life stage, 2) change in family-related or personal circumstances, 3) 
change in rank or tenure, 4) transfer to new institution, 5) change in perceived justice, and 6) change in mood or emotional state. The model also includes three types of mediators: 1) motivators and hygienes, 2) demographics, and 3) environmental conditions. Finally, the model proposes a metric for determining the extent of job satisfaction: 1) appreciation, 2) acceptance or tolerance, and 3) disengagement.

Validation for Hagedorn’s model was accomplished by using data from the 1993 National Study of Postsecondary Faculty (Kirshstein, Matheson, \& Jing, 1997). Mediators for the model included: achievement, recognition, work itself, responsibility, advancement, salary, gender, ethnicity, institutional type, academic discipline, collegial relationships, student quality or relationships, administration, and institutional climate or culture (Hagedorn, 2000, p. 13). Hagedorn used a multiple regression model to determine the predictive ability of the mediators on a global measure of job satisfaction among college faculty and found that the model was highly significant $(p<.0001)$ and explained nearly 50\% of the variance of job satisfaction (2000, p.13). The most highly predictive mediators were the work itself, salary, relationships with administration, student quality and relationships, and institutional climate and culture. Hagedorn's analysis of the six triggers indicated that on average, job satisfaction increases with age, is affected by family-related circumstances with married faculty reporting greater satisfaction, is negatively impacted by change in rank or institution, and is positively associated with a perceived high level of justice in the institution (2000, p. 14).

Other researchers have studied the manner in which faculty at Christian colleges respect and promote the mission of the institution at which they work. Ramirez and Brock (1996) addressed the different ways in which faculty members respond to the mission 
statement of a CCCU institution as it relates to their teaching of medicine. They found that there were "striking similarities and dissimilarities” (Ramierz \& Brock, 1996, p. 16) in the interpretation of the mission of the institution. Browde (1976) states that the faculty at a Christian college must “respect the college's professed conviction and uphold the right of the same to exist” (p. 7).

Other studies of faculty at both private non-Christian and Christian colleges address faculty involvement, satisfaction, and morale. A 1995 study of CCCU faculty by Sheridan found that the more connected faculty members are to an institution, the more involved they are likely to be in institutional decision making. He also states "there is evidence to suggest that a 'religion gap’ exists among faculty members that contributes to a lower level of involvement in institutional decision-making among those whose religious identity is at variance with the employing institution” (Sheridan, 1995, p. 4631).

Flowers (1992) states that CCCU faculty have significantly higher levels of satisfaction and morale than do faculty members at other liberal arts colleges. He lists the variables of supportive work environment, trust and respect among colleges, captivation with work, and religious and character role modeling as contributing factors for this higher satisfaction.

A 1987 study by the Council of Independent Colleges reports on high and low morale institutions. The study indicates that there are several factors that contribute to high morale at a private college, including the culture of the workplace, career anchors ["the work-related needs, values and talents that are the primary underlying motivations for one's career” (Splete, 1987, p. 11)], participation in institutional decision-making, perception of student remedial work and tenure decisions, salary range, and institutional support for faculty vitality 
(Splete, 1987). Splete appears to echo Niehoff when he says that "high morale colleges have congruent cultures and a strong sense of identity” (1987, p. 4).

The research cited seems to indicate a positive relationship between faculty members and their CCCU institutions. One negative issue, however, should be mentioned. In her 1997 doctoral dissertation, Garlett reports on some negative career impediments faced by women faculty at CCCU institutions. Cagney (1997), reporting on Garlett’s research, states in Christianity Today that "relatively few women faculty at Christian colleges attain the higher ranks of associate or full professor” (p. 72), even though nationally women are making up an increasingly larger percentage of faculty (Magner, 1999). This fact may be attributed to a significantly lower number of women faculty in CCCU schools that hold doctoral degrees than men, however Garlett indicates that female faculty face resistance from students and colleagues that is not related to academic preparation. She states that some male students resent having a woman in authority over them, while colleagues occasionally tell them that they are hurting their families by working. A 1991 study by Johnsrud supports Garlett’s research. Johnsrud states that female academics face discrimination and are promoted less regularly than their male counterparts.

\section{Faculty Inbreeding}

The final thread of the conceptual framework for this study deals with the phenomenon of academic or "faculty inbreeding." Faculty inbreeding is defined as "the practice of selecting former students of an institution as members of its faculty” (Eells \& Cleveland, 1935/1999, p. 579). Historically this phenomenon has been considered to be negative because it is perceived to stifle creativity, promote academic stagnation, and result 
in faculty who are less productive (Conrad \& Wyer, 1982; Dutton, 1980; Eells \& Cleveland, 1935/1999; Miller, 1977). President Charles Eliot of Harvard was perhaps most influential in giving faculty inbreeding a bad name when in 1908 he called it, "natural, but not wise” (Conrad \& Wyer, 1982, p. 45). This comment is ironic since in 1919, 64\% of Harvard's faculty had obtained degrees from that institution (Conrad \& Wyer, 1982).

The literature on faculty inbreeding is somewhat sparse. The primary studies of inbreeding, most of which claimed that inbreeding was largely negative, are over 70 years old. Of primary importance in this era of research were Miller (1918), McNeely (1932), and Eells and Cleveland (1935/1999). Later studies, including McGee (1960), Hargens and Farr (1973), Miller (1977), Dutton (1980), and Conrad and Wyer (1982), were less pessimistic about faculty inbreeding. More recently a number of studies, including Dattilo (1987), Runkel (1987), Moe (1988), Stewart (1992), and Pan (1993) examined the phenomenon in various contexts. A brief summary of several of these studies is provided below.

Eells and Cleveland (1935/1999) was a hallmark study, even though it provided only descriptive statistics about the number of inbred faculty in various types of institutions. The study was interesting and thorough enough, however, to be republished 64 years later in the September/October 1999 issue of The Journal of Higher Education. The Eells and Cleveland study considered 16,837 faculty, 34\% of whom were graduates of the institutions at which they were working. Eells and Cleveland used as their criterion for being inbred whether faculty members had received any or all of their training in the institution in which they were teaching. Larger institutions were found, on average, to be more inbred than smaller ones; however, greater inbreeding was found in private institutions than ones under public control. Eells and Cleveland also found that inbreeding declines as academic rank increases. 
Interestingly, even though they reported only descriptive statistics and conducted no tests of any dependent variables, Eells and Cleveland made several negative statements about faculty inbreeding, and encouraged institutions to give serious thought to discontinuing the practice. Miller (1977) reported on the status of faculty inbreeding in nursing programs. He also conducted an analysis of education and social work programs to compare the level of inbreeding in those professional preparation programs with that of nursing. Miller found a much higher percentage of inbreeding in nursing programs (48\%) than in either social work (39\%) or education (31\%).

Like Eells and Cleveland, Miller (1977) did not test any dependent variables; however, he did hypothesize about the implications of inbreeding. Miller surmised that inbreeding leads to a lack of creativity and innovation on the part of inbred faculty and a lack of objectivity in the hiring process of new faculty members. As positive implications, however, Miller listed lower costs to recruit faculty, lower salaries for inbred faculty, increased loyalty of inbred faculty, and greater access to information about inbred candidates during the hiring process. He went on to point out that it has always been assumed that inbreeding is negative; however, for a young field like nursing, inbreeding is one means to address a significant faculty shortage.

Dutton (1980) studied the impact of inbreeding and immobility on the professional role and scholarly performance of academic scientists. He found that inbreeding, in and of itself, does not result in significant negative consequences. Inbred faculty are initially just as productive in their teaching, research, and writing as non-inbred faculty. There is a divergence of performance, however, later in their careers. Dutton hypothesized that “immobile faculty, although not initially less productive, tend to fall behind their mobile 
colleagues in later years, even after differences in departmental prestige, career age, and academic role are taken into account” (1980, p. 18).

Conrad and Wyer (1982) provide an excellent historical overview of the practice of faculty inbreeding. They thoroughly review the early studies of McNeely (1932) and Eells and Cleveland (1935/1999), as well as the later studies of McGee (1960) and Hargens and Farr (1973). Conrad and Wyer suggest that faculty inbreeding no longer should be viewed with as much negativity as in the past. They state that "prohibitions against inbreeding are based on the fear that institutional vitality will be harmed, that institutional parochialism and reduced productivity will result” (Conrad \& Wyer, 1982, p. 46).

Conrad and Wyer (1982) go on to state, however, that the inability to change and accept new ideas is not necessarily linked to the institution at which a faculty member obtained his or her education. Furthermore, in contemporary academe there is much more interaction between faculties at different institutions than at the time of the earlier studies that decried inbreeding. They also hypothesize that the lack of mobility that is observed by Hargens and Farr may be due to sociological shifts that have occurred since the data for that study were collected in 1966. Lack of mobility for inbred faculty may be due to the fact that families are less willing to re-locate than in the past, and an increasing emphasis on the part of institutions to hire women and minorities, thus overlooking their own inbred faculty.

Conrad and Wyer (1982) found that there were important differences between inbred faculty and those that were hired from the outside. Inbred faculty were found to spend less time teaching and preparing for teaching than outsiders. They were also found to spend less time on research and writing, but more time on advising students and administrative tasks. No major differences were found in the production of scholarly work. However, when the 
measures of productivity were adjusted for the amount of time devoted to research, inbred faculty were found to be more productive than were outsiders in research and writing.

Several recent doctoral dissertations support the view that inbreeding may not have the negative consequences that were believed earlier to be the case. Dattilo (1987) found no significant differences in scholarly productivity between inbred and non-inbred nursing faculty. Runkel (1987) found a reduction in presidential inbreeding in liberal arts colleges between 1968 and 1983, but stated that inbreeding had a positive impact on the career paths of the presidents that she studied. Moe (1988) found a decrease in faculty inbreeding in chemistry departments at doctoral-granting institutions over the past three decades. Moe’s study also supported the work of Dutton (1980), in that mobility, rather than inbreeding, may be a more negative factor. Stewart (1992) reports a reduction in the amount of inbreeding in mathematics departments in American colleges and universities. Finally, Pan (1993) suggests that selective faculty inbreeding be given a rightful place in higher education. He argued that negative perceptions of inbreeding by some department chairs at 11 land grant universities were not supported by the data regarding productivity in research and writing.

\section{Summary}

The literature review for this study consisted of four components: 1) the nature and characteristics of committed Christian colleges; 2) the nature and characteristics of college faculty members; 3) the satisfaction of faculty members and their commitment to their institution and its mission; and 4) the historical reluctance of an institution to hire its own graduates (known as faculty inbreeding). 
The section on the nature and characteristics described the rise of Christian colleges as part of the fabric of colonial America. It traced their development through the $19^{\text {th }}$ and $20^{\text {th }}$ centuries, demonstrating how many colleges severed their ties with their founding denominations.

In the early 1970s a group of colleges formed a new organization that later became the Council for Christian Colleges and Universities. This organization now consists of over 100 like-minded committed Christian colleges who collaborate on conferences, professional development activities, study-abroad programs, and governmental lobbying efforts. The various characteristics and requirements for institutional membership in the CCCU were defined.

This section also discussed one of the primary criticisms that is often leveled at committed Christian colleges — a perceived lack of academic freedom on the part of faculty members. The review discussed several different perspectives on this issue.

The section on college faculty members described the rise of the role of faculty members in early American colleges. It went on to discuss the current roles and expectations that are placed on contemporary faculty members by both secular and Christian colleges.

The third component of the literature review described research that has been conducted on the nature of employees' commitment to their organizations and their job satisfaction, focusing most heavily on the work of Mowday, Porter, and Steers (1982), Porter, Steers, Mowday, and Boulian (1974), and Mowday, Steers, and Porter (1979). Examples of other research conducted using the Organizational Commitment Questionnaire, including some studies and analyses that were moderately critical of the instrument, were reviewed. 
The work of Niehoff (1995) related to mission value congruence of faculty members at a Jesuit university also was discussed.

Particular attention was paid to the work of several researchers who studied satisfaction at member colleges of the CCCU. Haggedorn's study of job satisfaction (2000), Sheridan's study of CCCU faculty morale (1995), and Flower's examination of morale (1992) were considered. Each of these studies indicated a positive relationship between faculty members and their CCCU institutions.

The final thread of the literature review discussed the phenomenon of faculty (or “academic”) inbreeding. Faculty inbreeding is the institutional practice of hiring its own graduates as members of its faculty. Traditionally, this practice has been frowned upon, with avoidance of it reaching its zenith in the early $20^{\text {th }}$ century. Recent studies have shown that earlier concerns about lack of scholarly productivity by “inbred” faculty are largely overstated (Conrad \& Wyer, 1982; Dattilo, 1987; Dutton, 1980; Miller, 1977; Pan, 1993). 


\section{CHAPTER 3. \\ METHODOLOGY}

\section{Pilot Research}

The researcher began the investigation by creating a pilot survey that was sent to the faculty of three small, private Christian colleges, all church-related, and affiliated with the CCCU. The survey was approved by the Iowa State University Human Subjects Review Committee prior to its distribution. The institutions were selected based on the investigator's knowledge of the institutions and their diverse geography and characteristics.

The institutions varied in their selectivity. The U.S. News \& World Report selectivity ratings—based on admissions acceptance rates for all students and the average high school class standing and SAT/ACT scores of those who enrolled—was used to judge institutional selectivity. One of the institutions was a more selective institution of approximately 2,000 undergraduate students. The second was a less selective institution of approximately 1,000 undergraduate students. The third was a selective institution of approximately 1,500 undergraduate students. The institutions were located in three different regions: one in the Southeast, one in the Midwest, and one in the West.

The chief academic officer (CAO) at each of the institutions was contacted via email and telephone to determine institutional willingness to participate in a faculty survey and possible faculty interviews. Once permission was granted, the CAO provided the email addresses of all of the current full-time faculty members. The survey was emailed to every faculty member on the email lists, following an introductory email message from the CAO to the faculty, requesting that they complete the survey if they were willing. 
The survey consisted of 10 open-ended questions. The questions focused on why the individual chose to seek employment at the institution, his or her term of employment and satisfaction with the institution, and his or her reasons for teaching at a Christian college. Approximately $20 \%$ of the faculty responded to the email survey. The researcher used the responses to determine which faculty members might be interested in follow-up interviews, and to formulate questions that could be used for those interviews.

The faculty members at each institution who returned the survey were contacted again via email to determine whether they would be willing to participate in a personal interview. Appointments were made via email and follow-up telephone calls. The investigator then traveled to each of the institutions between May and July 2000 and conducted personal interviews with all faculty members who had initially completed a survey and consented to a personal interview.

The researcher conducted approximately 40 interviews on the three campuses. Each interview was approximately 30 minutes in length. The questions that were asked included:

- Why did you choose to work at this institution?

- What characteristics about the institution influenced your decision?

- What personal or professional characteristics or experiences influenced your decision?

- How long have you been teaching at this institution?

- Have you ever considered leaving this institution? If so, why? If not, why not?

- What is the best thing about working at this institution?

- What is most problematic about working at this institution?

- Did you attend this institution or another Christian college as a student? 
- Did you have any specific experiences as a student that influenced your decision to return to a Christian college?

- How is your current experience similar to or different from when you were a student at a Christian college?

The interviews were tape recorded, and the researcher took notes during the interview. The tape recordings and notes were subsequently destroyed once the primary research project was begun.

\section{Primary Research}

\section{Survey design}

The primary research component of this study consisted of a multiple-choice and fillin-the-blank questionnaire (the instrument can be found in Appendix B). The researcher used the questions and answers given in the pilot interviews to formulate several forced-choice questions and to guide the selection of the other items that were used in the final survey instrument. The entire survey consisted of 118 items.

The items on the questionnaire were divided into four categories: 18 demographic questions, 20 researcher-developed questions, 15 items from the Organizational Commitment Questionnaire (OCQ) by Mowday, Steers, and Porter (1979), and 70 questions selected from the National Study of Postsecondary Faculty (Russell, Fairweather, Hendrickson, \& Zimbler, 1991; Zimbler, 2001) developed by the U.S. Department of Education.

The survey was approved by the Iowa State University Human Subjects Review Committee prior to its distribution. 


\section{Selection of institutions}

The researcher developed a list of approximately 20 institutions associated with the CCCU, based on their location, their denominational affiliation, their size, and their selectivity. The list then was shared with the researcher's advisor and a panel of experts consisting of three executive officers at the CCCU who have significant knowledge of the institutions.

Several of the institutions were eliminated from the list based on the recommendation of the CCCU officers. Their concerns were based primarily on personal knowledge of the institutions. In one case, a new chief academic officer had recently begun his job; in another case, the institution was experiencing significant financial difficulties. The researcher trusted the judgment of the panel of experts and eliminated those institutions from consideration.

The panel suggested other institutions for consideration that maintained the balance of location, denominational affiliation, size and selectivity that the researcher was seeking to achieve. A final list of 12 institutions was agreed upon by the panel of experts.

The researcher then contacted the Chief Academic Officers of the 12 institutions via email and telephone to inquire as to their willingness to participate in the study. Ten of the CAOs indicated a willingness to participate, while two CAOs indicated that the timing was not appropriate for their participation in the study.

The 10 remaining institutions represented a cross-section of colleges within the CCCU. They were located in 10 different states ( 1 in the West, 1 in the Southwest, 4 in the Midwest, and 4 in the Southeast). They were split evenly between urban, suburban, and rural campuses. They represented 9 different church denominations. They ranged in size from approximately 950 undergraduates to approximately 2,000 graduates during the 2003-04 
academic year (the average number of undergraduates at all 10 institutions was 1,400). The 10 institutions varied in admissions selectivity from less selective to more selective, based on the U.S. News and World Report criteria. The percent of applicants who were admitted to the institutions varied from $72 \%$ to $100 \%$, with an average admitted percentage of $84 \%$.

\section{Data collection}

The researcher electronically administered the survey to the faculty at the 10 selected institutions. The CAOs were asked to send an email message to all full and part-time faculty members of their institution. The message contained an introductory statement by the CAO, indicating an institutional willingness to participate, and urging faculty members to participate in the survey. The message also included the following paragraph from the researcher:

My name is Curtis Taylor, and I serve as Assistant to the President at Dordt College in Sioux Center, Iowa. I am also a Ph.D. candidate in Higher Education at Iowa State University, and it is in the latter capacity that I am asking for your cooperation and assistance in the collection of data for my dissertation research. The topic of my doctoral dissertation, broadly defined, is Christian college faculty. I am interested in exploring the factors (personal and institutional) that impact a faculty member's decision to teach at a Christian college that is a member of the Council for Christian Colleges and Universities (CCCU). I am also interested in studying the organizational commitment of faculty members to their institution, and their understanding of and satisfaction with various issues at their institution. I have corresponded with the chief academic officer at your institution and have received 
permission to contact you and ask you to complete a survey. You can find the survey at http://homepages.dordt.edu/ curtis/faculty_survey.htm. All you have to do is click on this link and follow the directions to complete the survey. Thank you, in advance, for your cooperation and assistance.

The time of administration varied by institution due to the academic calendar at the start of the spring semester. The first CAO to send out the link to the survey did so on January 14, 2004. The final CAO to send out the link to the survey did so on March 1, 2004. On February 10, 2004 the researcher emailed the CAOs of all institutions and asked for the following paragraph to be sent to the same group of faculty:

My name is Curtis Taylor, and I serve as Assistant to the President at Dordt College in Sioux Center, Iowa. A short time ago, your Chief Academic Officer sent you an email message that included a paragraph from me. In that message, I asked for your assistance with my dissertation research. A number of you responded by taking the survey that I have assembled regarding the factors that impact a faculty member's decision to teach at a Christian college. I am hoping that some of you who did not respond at the time may now have the time to do so. You can find the survey at http://homepages.dordt.edu/ curtis/faculty_survey.htm. All you have to do is click on this link and follow the directions to complete the survey. Thank you, in advance, for your cooperation and assistance.

Data collection for the 10 institutions was anticipated to be closed on March 1, 2004; however, since one of the institutions did not distribute the link until that date, the researcher postponed the end of data collection until March 16, 2004, at which time 258 responses had been received. 
The researcher had asked the CAOs to distribute the survey to all full- and part-time faculty members at their institutions, if possible. Since they were using email lists to distribute the survey, some of the CAOs were not able to provide an exact number of faculty members from their institution to whom the survey was distributed. The most recent IPEDs data (2003) from all 10 institutions indicated that the institutions had a combined total of 727 full-time faculty members and 598 part-time faculty members.

\section{Data management}

The first question on the survey asked participants to provide the last four digits of their Social Security number as a means for the researcher to check for duplicate responses. As surveys were submitted, a time code was applied to each submission. The 258 responses were reviewed in an attempt to determine if any duplicate surveys were submitted inadvertently by participants. In seven cases, the researcher made a determination that responses were duplicated. In each case, 2 adjacent responses were received from respondents who supplied exactly the same four-digit Social Security number. In each case, one of the surveys contained no additional data, while the other survey was completed. The 7 duplicate responses were deleted, leaving 251 valid responses to the survey.

Out of the 251 valid responses to the survey, 238 were from full-time faculty members and 13 were from part-time faculty members. The response rate for the 727 fulltime faculty members was $32.7 \%$. The response rate for part-time faculty members was 2.1\%. Based on the low number of responses from part-time faculty members, the researcher, in consultation with his major professor, decided to eliminate the part-time faculty member responses from consideration in the remainder of the study. 
There were useable responses from all 10 institutions, varying from a low of 9 responses at one institution to a high of 35 from another. Two respondents did not indicate an institutional affiliation.

\section{Data cleaning}

Surveys were submitted on-line in a comma-delimited format. The researcher was able to download the data from each survey into SPSS for analysis. Prior to any analysis with SPSS, the data were examined for possible input errors. In the case of several items, the participants did not submit data in the format that had been requested.

In items 15, 17, 18, 20, and 23 participants were asked to indicate the number of years they had been involved in a particular activity. The researcher had expected participants to respond with a discrete number of years (e.g., 3 years or 27 years); however, some participants responded with a number that included a half-year (e.g., 3.5 years or 27.5 years). The responses of those participants who did not respond with a discrete number were rounded up to the nearest discrete number. The researcher made the assumption that, since the survey was administered during the second semester, participants who responded with a half-year likely were reflecting on the fact that the academic year was not yet completed. [The primary reason for choosing this method was that many of the participants who responded with a half year had indicated that they had been involved in the activity for .5 years. The researcher chose to round those responses up to 1 year, and did likewise for other similar responses.]

In item 21 participants were asked to indicate the age at which they expected to retire from college teaching. Again, the researcher had expected participants to respond with a 
discrete age, but the survey allowed for a string of data to be entered. Some participants entered a range instead of a discrete age (e.g., between 66 and 70). In these instances, and other similar situations with other variables, the researcher selected the median age of the numbers represented in the string.

In the case of item 114 (Student Services are taking an increasingly heavy share of available resources at my institution), the electronic survey was coded inadvertently so that all responses were assigned the same value. Item 114 therefore was eliminated from all calculations. 


\section{CHAPTER 4.}

\section{FINDINGS}

\section{General Characteristics of the Sample}

Several demographic characteristic variables were included in the survey instrument to assist in the description of the sample and to be used as independent variables in subsequent analysis. The following tables will present frequencies and percentages for gender, age, institution, church membership requirement, type of alma mater, highest degree earned, academic rank, years teaching (career), years teaching (institution), expected age of retirement and academic field.

\section{Gender}

Of the 238 respondents, 89 were female (37.7\%) and 147 were male (62.3\%). Two members of the sample did not indicate their gender.

Table 1 . Sample distribution by gender

\begin{tabular}{|l|r|r|r|}
\hline \hline Gender & Frequency & Percent & Valid Percent \\
\hline Female & 89 & 37.4 & 37.7 \\
\hline Male & 147 & 61.8 & 62.3 \\
\hline Sub-Total & 236 & 99.2 & 100.0 \\
\hline Missing & 2 & .8 & \\
\hline Total & 238 & 100.0 & \\
\hline \hline
\end{tabular}

Age

The age of participants was categorized by decades. Eight participants were in their 20s (3.4\%), 41 in their 30s (17.3\%), 61 in their 40s (25.7\%), 87 in their 50s (36.7\%), 35 in 
their 60 s $(14.8 \%), 4$ in their 70s (1.7\%), and one participant indicated that he was in his 80 s (.4\%). One person in the sample did not indicate his age.

Table 2. Sample distribution by age

\begin{tabular}{|l|r|r|r|}
\hline \hline \multicolumn{1}{|c|}{ Age } & Frequency & Percent & $\begin{array}{c}\text { Valid } \\
\text { Percent }\end{array}$ \\
\hline $20-29$ & 8 & 3.4 & 3.4 \\
\hline $30-39$ & 41 & 17.2 & 17.3 \\
\hline $40-49$ & 61 & 25.6 & 25.7 \\
\hline $50-59$ & 87 & 36.6 & 36.7 \\
\hline $60-69$ & 35 & 14.7 & 14.8 \\
\hline $70-70$ & 4 & 1.7 & 1.7 \\
\hline Over 80 & 1 & .4 & .4 \\
\hline Sub-Total & 237 & 99.6 & 100.0 \\
\hline Missing & 1 & .4 & \\
\hline Total & 238 & 100.0 & \\
\hline \hline
\end{tabular}

\section{Institution}

Valid surveys were completed by faculty members from all 10 institutions. The number of surveys from each institution varied from a high of 35 at Institution 5 to a low of 9 at Institution 8. Two members of the sample did not indicate the institution at which they worked.

As mentioned above, since the exact number of faculty who received the survey at each institution was unknown, it was difficult to determine the institutional return rates. An estimate of the number of possible faculty participants at each institution was based on IPEDS data from 2003, and the estimated response rate for each institution was calculated from a low of $17.8 \%$ at Institution 4 to a high of $59.1 \%$ at Institution 10 . The estimated overall response rate was $32.5 \%$. 
Table 3. Sample distribution by institution

\begin{tabular}{|l|r|r|r|r|c|}
\hline \hline \multicolumn{1}{|c|}{ Institution } & Frequency & Percent & $\begin{array}{c}\text { Valid } \\
\text { Percent }\end{array}$ & $\begin{array}{c}\text { Number of Full - } \\
\text { Time Faculty } \\
\text { (IPEDS 2003) }\end{array}$ & $\begin{array}{c}\text { Estimated } \\
\text { Percentage of } \\
\text { Full-Time Faculty }\end{array}$ \\
\hline Institution 1 & 29 & 12.2 & 12.3 & 90 & 32.2 \\
\hline Institution 2 & 19 & 8.0 & 8.1 & 78 & 24.4 \\
\hline Institution 3 & 29 & 12.2 & 12.3 & 76 & 38.2 \\
\hline Institution 4 & 19 & 8.0 & 8.1 & 107 & 17.8 \\
\hline Institution 5 & 35 & 14.7 & 14.8 & 98 & 35.7 \\
\hline Institution 6 & 14 & 5.9 & 5.9 & 66 & 21.2 \\
\hline Institution 7 & 24 & 10.1 & 10.2 & 70 & 34.3 \\
\hline Institution 8 & 9 & 3.8 & 3.8 & 30 & 30.0 \\
\hline Institution 9 & 32 & 13.4 & 13.6 & 68 & 47.1 \\
\hline Institution 10 & 26 & 10.9 & 11.0 & 44 & 59.1 \\
\hline Sub-Total & 236 & 99.2 & 100.0 & 727 & 32.5 \\
\hline Missing & 2 & .8 & & & \\
\hline Total & 238 & 100.0 & & & \\
\hline \hline
\end{tabular}

\section{Church membership requirement}

The survey asked participants to indicate whether the institution at which they work has a church membership requirement. Of the 238 respondents, 40 (16.8\%) indicated that their institution did have such a requirement, and 198 respondents (83.2\%) indicated that their institution did not require membership in a particular denomination.

Table 4. Sample distribution by church membership requirement

\begin{tabular}{|l|l|r|r|r|}
\hline \hline \multicolumn{2}{|c|}{ Church Required } & Frequency & Percent & Valid Percent \\
\hline Valid & $\begin{array}{l}\text { Membership } \\
\text { Required }\end{array}$ & 40 & 16.8 & 16.8 \\
\hline & $\begin{array}{l}\text { Membership } \\
\text { Not Required }\end{array}$ & 198 & 83.2 & 83.2 \\
\hline & Total & 238 & 100.0 & 100.0 \\
\hline
\end{tabular}




\section{Alma mater}

To analyze any faculty inbreeding characteristics, participants were asked to indicate the type of institution they attended as an undergraduate student. Seventy-six (31.9\%) indicated that they attended the institution at which they currently work, 59 (24.8\%) that they attended another institution that is a member of the CCCU; 26 (10.9\%) that they attended another Christian college that is not affiliated with the CCCU, and 77 (32.4\%) indicated that they attended a non-Christian college or university.

Table 5. Sample distribution by type of undergraduate alma mater

\begin{tabular}{|l|r|r|r|}
\hline \hline Type of Undergraduate Alma Mater & Frequency & Percent & Valid Percent \\
\hline Current Institution & 76 & 31.9 & 31.9 \\
\hline Another CCCU Institution & 59 & 24.8 & 24.8 \\
\hline $\begin{array}{l}\text { Another non-CCCU Christian } \\
\text { Institution }\end{array}$ & 26 & 10.9 & 10.9 \\
\hline Non-Christian Institution & 77 & 32.4 & 32.4 \\
\hline Total & 238 & 100.0 & 100.0 \\
\hline \hline
\end{tabular}

\section{Highest degree earned}

Participants were asked to indicate the highest degree that they had earned. The doctoral degree was reported as the highest degree by 149 participants (62.6\%), the Specialist’s or a professional degree by 7 (2.9\%), a master's degree by 81 (34.0\%), and some graduate work not resulting in a degree by 1 participant (.4\%). 
Table 6. Sample distribution by highest degree earned

\begin{tabular}{|l|r|r|r|}
\hline \multicolumn{1}{|c|}{ Highest Degree } & Frequency & \multicolumn{1}{c|}{ Percent } & Valid Percent \\
\hline Doctoral Degree & 149 & 62.6 & 62.6 \\
\hline $\begin{array}{l}\text { Specialist's or Professional } \\
\text { Degree }\end{array}$ & 7 & 2.9 & 2.9 \\
\hline Master's Degree & 81 & 34.0 & 34.0 \\
\hline $\begin{array}{l}\text { Graduate Work not resulting in } \\
\text { a Degree }\end{array}$ & 1 & .4 & .4 \\
\hline Total & 238 & 100.0 & 100.0 \\
\hline
\end{tabular}

\section{Academic rank}

When asked to indicate their current academic rank, the rank of professor was the most frequent response with 80 individuals (33.6\%); 67 participants (28.2\%) said they hold the rank of associate professor; 79 were assistant professors (33.2\%); and 12 (5.0\%) indicated that they were either Instructor, Technical, or Other.

Table 7. Sample distribution by academic rank

\begin{tabular}{|l|r|r|r|}
\hline \multicolumn{1}{c|}{ Academic Rank } & Frequency & \multicolumn{1}{c|}{ Percent } & Valid Percent \\
\hline Other (Instructor/Technical) & 12 & 5.0 & 5.0 \\
\hline Assistant Professor & 79 & 33.2 & 33.2 \\
\hline Associate Professor & 67 & 28.2 & 28.2 \\
\hline Professor & 80 & 33.6 & 33.6 \\
\hline Total & 238 & 100.0 & 100.0 \\
\hline \hline
\end{tabular}

\section{Years teaching}

Study respondents were asked to indicate the number of years that they have been teaching at all institutions and the number of years that they have been teaching at their current institution. The responses were given in discrete years, but re-coded into three groups (1-5 years, 6-11 years, and 12 or more years) for analysis. 
In the case of teaching at all institutions, 43 (18.2\%) indicated they have been teaching for 1-5 years, 55 (23.3 \%) for 6-11 years; and 138 (58.5\%) for 12 or more years. Two respondents did not indicate how long they have been teaching.

Table 8. Sample distribution by years teaching (career)

\begin{tabular}{|l|r|r|r|}
\hline \hline \multicolumn{1}{|c|}{ Years Teaching (Career) } & Frequency & Percent & Valid Percent \\
\hline 1-5 years & 43 & 18.1 & 18.2 \\
\hline 6-11 years & 55 & 23.1 & 23.3 \\
\hline 12 or more years & 138 & 58.0 & 58.5 \\
\hline Sub-Total & 236 & 99.2 & 100.0 \\
\hline Missing & 2 & .8 & \\
\hline Grand Total & 238 & 100.0 & \\
\hline \hline
\end{tabular}

In the case of the number of years that they have taught at their current institution, 75 (31.5\%) indicated that they have been teaching there for 1-5 years, 64 (26.9\%) for 6-11 years, and 99 (41.6\%) for 12 or more years.

Table 9. Sample distribution by years teaching (institution)

\begin{tabular}{|l|c|c|c|}
\hline \hline Years Teaching (Current Institution) & Frequency & Percent & $\begin{array}{c}\text { Valid } \\
\text { Percent }\end{array}$ \\
\hline 1-5 years & 75 & 31.5 & 31.5 \\
\hline 6-11 years & 64 & 26.9 & 26.9 \\
\hline 12 or more years & 99 & 41.6 & 41.6 \\
\hline Total & 238 & 100.0 & 100.0 \\
\hline \hline
\end{tabular}

\section{Expected age of retirement from teaching}

When asked at what age they expect to stop teaching at the college or university level, the largest number of respondents indicated 65 years of age (33.9\%). The second highest was $70(25.1 \%)$. The mean age for retirement was 66 years of age (valid $N=227$ ) and the 
standard deviation was 5.7 years. Eleven participants did not indicate an age at which they expect to stop teaching.

Table 10. Sample distribution by expected age of retirement

\begin{tabular}{|c|c|c|c|c|c|}
\hline Age & Frequency & Percent & Valid Percent & & \\
\hline 57 or Less & 9 & 3.8 & 4.0 & & \\
\hline 58 & 1 & .4 & .4 & & \\
\hline 60 & 14 & 5.9 & 6.2 & & \\
\hline 62 & 10 & 4.2 & 4.4 & Valid $N$ & 227 \\
\hline 63 & 2 & .8 & .9 & Missing $N$ & 11 \\
\hline 64 & 4 & 1.7 & 1.8 & Mean & 66.27 \\
\hline 65 & 77 & 32.4 & 33.9 & Median & 65.00 \\
\hline 66 & 19 & 8.0 & 8.4 & Mode & 65 \\
\hline 67 & 12 & 5.0 & 5.3 & Std. Deviation & 5.726 \\
\hline 68 & 8 & 3.4 & 3.5 & Variance & 32.783 \\
\hline 70 & 57 & 23.9 & 25.1 & Skewness & -.038 \\
\hline 72 & 5 & 2.1 & 2.2 & & \\
\hline 75 & 5 & 2.1 & 2.2 & & \\
\hline 80 or more & 4 & 1.7 & 1.8 & & \\
\hline Sub-Total & 227 & 95.4 & 100.0 & & \\
\hline Missing & 11 & 4.6 & & & \\
\hline Grand Total & 238 & 100.0 & & & \\
\hline
\end{tabular}

\section{Academic field}

A list of 29 academic fields was provided from which participants could choose their academic field, based on the Classification of Instructional Programs (CIP) taxonomy of the National Center for Education Statistics. The most frequently cited field was Education with 34 responses (14.3\%). Seven of the categories did not have any responses and Interdisciplinary Studies had only one response (.4\%). Six individuals did not indicate their field of teaching. 
Table 11. Sample distribution by academic field

\begin{tabular}{|c|c|c|c|}
\hline Field of Teaching & Frequency & Percent & Valid Percent \\
\hline Business & 20 & 8.4 & 8.6 \\
\hline Communications & 17 & 7.1 & 7.3 \\
\hline Computer Science & 2 & .8 & .9 \\
\hline Education & 34 & 14.3 & 14.7 \\
\hline English and Literature (incl ESL and Linguistics) & 13 & 5.5 & 5.6 \\
\hline Fine Arts (Art, Music, Drama) & 27 & 11.3 & 11.6 \\
\hline Foreign Languages & 4 & 1.7 & 1.7 \\
\hline Health Sciences & 7 & 2.9 & 3.0 \\
\hline Interdisciplinary Studies & 1 & .4 & .4 \\
\hline Law & 3 & 1.3 & 1.3 \\
\hline Library Science & 8 & 3.4 & 3.4 \\
\hline Mathematics and Statistics & 6 & 2.5 & 2.6 \\
\hline Natural Sciences-Biological Sciences & 13 & 5.5 & 5.6 \\
\hline Natural Sciences-Physical Sciences & 8 & 3.4 & 3.4 \\
\hline Other Fields & 12 & 5.0 & 5.2 \\
\hline Public Affairs (incl Social Work) & 2 & .8 & .9 \\
\hline Philosophy/Religion/Theology & 28 & 11.8 & 12.1 \\
\hline Psychology & 12 & 5.0 & 5.2 \\
\hline Recreation/Physical Education & 3 & 1.3 & 1.3 \\
\hline Social Sciences and History & 12 & 5.0 & 5.2 \\
\hline Sub-Total & 232 & 97.5 & 100.0 \\
\hline No Response & 6 & 2.5 & \\
\hline Grand Total & 238 & 100.0 & \\
\hline
\end{tabular}

Since there were not enough respondents in many of the fields to allow for subsequent analysis, the academic fields were grouped into traditional categories or divisions. The CIP codes do not provide for a natural division of courses into liberal arts and sciences, so the courses were divided according to the taxonomy in Table 10. The frequencies for each of the categories are provided below. 
Table 12. Sample distribution by academic divisions

\begin{tabular}{|c|c|c|c|c|}
\hline Division & Academic Fields & Frequency & Percent & Valid Percent \\
\hline \multirow[t]{5}{*}{ Humanities } & & 70 & 30.3 & 31.0 \\
\hline & English and Literature & & & \\
\hline & Fine Arts (Art, Music, Drama) & & & \\
\hline & Foreign Languages & & & \\
\hline & Philosophy/Religion/Theology & & & \\
\hline \multirow[t]{5}{*}{ Physical Sciences } & & 29 & 12.2 & 12.5 \\
\hline & Computer Science & & & \\
\hline & Math & & & \\
\hline & Natural Sciences-Biological Sciences & & & \\
\hline & Natural Sciences-Physical Sciences & & & \\
\hline \multirow[t]{8}{*}{ Pre-Professional } & & 77 & 32.4 & 33.2 \\
\hline & Business & & & \\
\hline & Education & & & \\
\hline & Health Sciences & & & \\
\hline & Law & & & \\
\hline & Library Science & & & \\
\hline & Public Affairs & & & \\
\hline & Recreation/Physical Education & & & \\
\hline \multirow[t]{4}{*}{ Social Sciences } & & 41 & 17.2 & 17.7 \\
\hline & Communications & & & \\
\hline & Psychology & & & \\
\hline & Social Sciences (including History) & & & \\
\hline \multirow[t]{3}{*}{ Other } & & 13 & 5.5 & 5.6 \\
\hline & Interdisciplinary Studies & & & \\
\hline & Other Fields & & & \\
\hline Missing & & 6 & 2.5 & \\
\hline Total & & 238 & 100.0 & \\
\hline
\end{tabular}

\section{Questions Developed from Pilot Study}

The researcher developed three questions based on the pilot study that was conducted in the summer of 2000. The responses from the initial pilot survey and subsequent personal interviews were converted into three questions that attempted to isolate reasons for initial affiliation with the institution, what faculty members currently appreciate most about the institution, and what they find most problematic about the institution. The results of these questions are presented below. 


\section{Reasons for initial affiliation with current institution}

Respondents were asked why they initially chose to accept a position with the institution at which they currently work. They were allowed to choose up to three reasons from a list of 18 characteristics that had been formulated during the pilot interview process. In Table 13 the frequencies and percentages for each of the 18 characteristics are listed by first, second and third choice. Totals and cumulative percentages for each reason are also provided. The five most frequently cited reasons for initially choosing to accept a job at the current institution were: 1) Christian Environment/Atmosphere (22.5\%), 2) Institutional Mission/Philosophy (15.1\%), 3) Location of the Institution (11.7\%), 4) Denomination of the Institution (9.8\%) and 5) Only Institution that offered me a job (6.2\%). 
Table 13. Reasons for initial affiliation with current institution

\begin{tabular}{|c|c|c|c|c|c|c|c|c|}
\hline \multirow[b]{2}{*}{ Reason } & \multicolumn{2}{|c|}{$\begin{array}{c}\text { Initially Accept } \\
1^{\text {st }} \\
\end{array}$} & \multicolumn{2}{|c|}{$\begin{array}{l}\text { Initially Accept } \\
\text { 2nd }\end{array}$} & \multicolumn{2}{|c|}{$\begin{array}{c}\text { Initially Accept } \\
\text { 3rd }\end{array}$} & \multirow{2}{*}{$\begin{array}{l}\text { Item } \\
\text { Total }\end{array}$} & \multirow{2}{*}{$\begin{array}{c}\text { Cum. } \\
\text { Percent }\end{array}$} \\
\hline & Freq. & Percent & Freq. & Percent & Freq. & Percent & & \\
\hline $\begin{array}{l}\text { Christian } \\
\text { Environment/Atmosphere }\end{array}$ & 80 & $33.8 \%$ & 48 & $21.7 \%$ & 18 & $9.3 \%$ & 147 & $22.5 \%$ \\
\hline $\begin{array}{l}\text { Institutional } \\
\text { Mission/Philosophy }\end{array}$ & 38 & $16.0 \%$ & 35 & $15.8 \%$ & 25 & $13.0 \%$ & 98 & $15.1 \%$ \\
\hline Location of Institution & 19 & $8.0 \%$ & 31 & $14.0 \%$ & 26 & $13.5 \%$ & 76 & $11.7 \%$ \\
\hline $\begin{array}{l}\text { Denomination of } \\
\text { Institution }\end{array}$ & 22 & $9.3 \%$ & 27 & $12.2 \%$ & 15 & $7.8 \%$ & 64 & $9.8 \%$ \\
\hline $\begin{array}{l}\text { Only Institution that } \\
\text { offered me a job }\end{array}$ & 22 & $9.3 \%$ & 7 & $3.2 \%$ & 11 & $5.7 \%$ & 40 & $6.2 \%$ \\
\hline Other & 21 & $8.9 \%$ & 3 & $1.4 \%$ & 9 & $4.7 \%$ & 33 & $5.1 \%$ \\
\hline $\begin{array}{l}\text { Personal Friendship with } \\
\text { Colleagues }\end{array}$ & 9 & $3.8 \%$ & 10 & $4.5 \%$ & 14 & $7.3 \%$ & 33 & $5.1 \%$ \\
\hline $\begin{array}{l}\text { Reputation of } \\
\text { Institution/Program }\end{array}$ & 8 & $3.4 \%$ & 7 & $3.2 \%$ & 17 & $8.8 \%$ & 32 & $4.9 \%$ \\
\hline $\begin{array}{l}\text { Characteristics/Quality of } \\
\text { Students }\end{array}$ & 1 & $0.4 \%$ & 14 & $6.3 \%$ & 11 & $5.7 \%$ & 26 & $4.0 \%$ \\
\hline $\begin{array}{l}\text { Administrative } \\
\text { Leadership }\end{array}$ & 1 & $0.4 \%$ & 10 & $4.5 \%$ & 14 & $7.3 \%$ & 25 & $3.8 \%$ \\
\hline $\begin{array}{l}\text { Opportunities for } \\
\text { spouse/family }\end{array}$ & 10 & $4.2 \%$ & 5 & $2.3 \%$ & 8 & $4.1 \%$ & 23 & $3.5 \%$ \\
\hline $\begin{array}{l}\text { Academic Quality of } \\
\text { Colleagues }\end{array}$ & 1 & $0.4 \%$ & 8 & $3.6 \%$ & 9 & $4.7 \%$ & 18 & $2.8 \%$ \\
\hline Wages and Benefits & 2 & $0.8 \%$ & 8 & $3.6 \%$ & 6 & $3.1 \%$ & 16 & $2.5 \%$ \\
\hline Academic Freedom & 1 & $0.4 \%$ & 6 & $2.7 \%$ & 6 & $3.1 \%$ & 13 & $2.0 \%$ \\
\hline $\begin{array}{l}\text { Quality of } \\
\text { Facilities/Resources }\end{array}$ & 1 & $0.4 \%$ & 2 & $0.9 \%$ & 1 & $0.5 \%$ & 4 & $0.6 \%$ \\
\hline Acceptance of Diversity & 1 & $0.4 \%$ & 0 & $0.0 \%$ & 1 & $0.5 \%$ & 2 & $0.3 \%$ \\
\hline $\begin{array}{l}\text { Opportunities to conduct } \\
\text { Research }\end{array}$ & 0 & $0.0 \%$ & 0 & $0.0 \%$ & 1 & $0.5 \%$ & 1 & $0.2 \%$ \\
\hline $\begin{array}{l}\text { Professional } \\
\text { Development Funds }\end{array}$ & 0 & $0.0 \%$ & 0 & $0.0 \%$ & 1 & $0.5 \%$ & 1 & $0.2 \%$ \\
\hline Total & 237 & $16.0 \%$ & 221 & $100.0 \%$ & 193 & $100.0 \%$ & 652 & $100.0 \%$ \\
\hline Missing & 1 & & 17 & & 45 & & 63 & $8.8 \%$ \\
\hline Grand Total & 238 & & 238 & & 238 & & 714 & \\
\hline
\end{tabular}

\section{Currently appreciate most about current institution}

After choosing the top three reasons why they initially affiliated with the institution, respondents were given the opportunity to indicate what they currently appreciate the most about the institution at which they work from the same list of 18 characteristics. In Table 14 the frequencies and percentages for each of the 18 characteristics are listed by first, second 
and third choice. Totals and cumulative percentages for each reason are also provided. The five most frequently cited characteristics were: 1) Christian Environment/Atmosphere (23.3\%), 2) Institutional Mission/Philosophy (15.9\%), 3) Personal Friendship with Colleagues (12.0\%), 4) Characteristics/Quality of Students (10.8\%) and 5) Location of the Institution (7.0\%).

Table 14. Currently appreciate most about current institution

\begin{tabular}{|c|c|c|c|c|c|c|c|c|}
\hline \multirow[b]{2}{*}{ Reason } & \multicolumn{2}{|c|}{$\begin{array}{c}\text { Currently } \\
\text { Appreciate } 1^{\text {st }}\end{array}$} & \multicolumn{2}{|c|}{$\begin{array}{c}\text { Currently } \\
\text { Appreciate 2nd }\end{array}$} & \multicolumn{2}{|c|}{$\begin{array}{c}\text { Currently } \\
\text { Appreciate 3rd }\end{array}$} & \multirow{2}{*}{$\begin{array}{l}\text { Item } \\
\text { Total }\end{array}$} & \multirow{2}{*}{$\begin{array}{l}\text { Cum. } \\
\text { Percent }\end{array}$} \\
\hline & Freq. & Percent & Freq. & Percent & Freq. & Percent & & \\
\hline $\begin{array}{l}\text { Christian } \\
\text { Environment/Atmosphere }\end{array}$ & 86 & $37.1 \%$ & 49 & $21.5 \%$ & 22 & $10.3 \%$ & 158 & $23.3 \%$ \\
\hline $\begin{array}{l}\text { Institutional } \\
\text { Mission/Philosophy }\end{array}$ & 46 & $19.8 \%$ & 34 & $14.9 \%$ & 27 & $12.7 \%$ & 107 & $15.9 \%$ \\
\hline $\begin{array}{l}\text { Personal Friendship with } \\
\text { Colleagues }\end{array}$ & 26 & $11.2 \%$ & 30 & $13.2 \%$ & 25 & $11.7 \%$ & 81 & $12.0 \%$ \\
\hline $\begin{array}{l}\text { Characteristics/Quality of } \\
\text { Students }\end{array}$ & 16 & $6.9 \%$ & 28 & $12.3 \%$ & 29 & $13.6 \%$ & 73 & $10.8 \%$ \\
\hline Location of Institution & 4 & $1.7 \%$ & 17 & $7.5 \%$ & 26 & $12.2 \%$ & 47 & $7.0 \%$ \\
\hline Administrative Leadership & 9 & $3.9 \%$ & 13 & $5.7 \%$ & 24 & $11.3 \%$ & 46 & $6.8 \%$ \\
\hline $\begin{array}{l}\text { Academic Quality of } \\
\text { Colleagues }\end{array}$ & 7 & $3.0 \%$ & 13 & $5.7 \%$ & 15 & $7.0 \%$ & 35 & $5.2 \%$ \\
\hline $\begin{array}{l}\text { Reputation of } \\
\text { Institution/Program }\end{array}$ & 7 & $3.0 \%$ & 7 & $3.1 \%$ & 12 & $5.6 \%$ & 26 & $3.9 \%$ \\
\hline $\begin{array}{l}\text { Denomination of } \\
\text { Institution }\end{array}$ & 5 & $2.2 \%$ & 10 & $4.4 \%$ & 8 & $3.8 \%$ & 23 & $3.4 \%$ \\
\hline Academic Freedom & 11 & $4.7 \%$ & 8 & $3.5 \%$ & 3 & $1.4 \%$ & 22 & $3.3 \%$ \\
\hline $\begin{array}{l}\text { Opportunities for } \\
\text { spouse/family }\end{array}$ & 5 & $2.2 \%$ & 7 & $3.1 \%$ & 7 & $3.3 \%$ & 19 & $2.8 \%$ \\
\hline Wages and Benefits & 2 & $0.9 \%$ & 3 & $1.3 \%$ & 8 & $3.8 \%$ & 13 & $1.9 \%$ \\
\hline Other & 5 & $2.2 \%$ & 0 & $0.0 \%$ & 3 & $1.4 \%$ & 8 & $1.2 \%$ \\
\hline $\begin{array}{l}\text { Opportunities to conduct } \\
\text { research }\end{array}$ & 1 & $0.4 \%$ & 3 & $1.3 \%$ & 1 & $0.5 \%$ & 5 & $0.7 \%$ \\
\hline $\begin{array}{l}\text { Only Employment } \\
\text { Opportunity Available to } \\
\text { me }\end{array}$ & 1 & $0.4 \%$ & 1 & $0.4 \%$ & 2 & $0.9 \%$ & 4 & $0.6 \%$ \\
\hline $\begin{array}{l}\text { Quality of facilities or } \\
\text { resources }\end{array}$ & 0 & $0.0 \%$ & 3 & $1.3 \%$ & 1 & $0.5 \%$ & 4 & $0.6 \%$ \\
\hline Acceptance of Diversity & 1 & $0.4 \%$ & 2 & $0.9 \%$ & 0 & $0.0 \%$ & 3 & $0.4 \%$ \\
\hline $\begin{array}{l}\text { Professional } \\
\text { Development Funds }\end{array}$ & 0 & $0.0 \%$ & 0 & $0.0 \%$ & 0 & $0.0 \%$ & 0 & $0.0 \%$ \\
\hline Total & 232 & $100.0 \%$ & 228 & $100.0 \%$ & 213 & $100.0 \%$ & 673 & $100.0 \%$ \\
\hline Missing & 6 & $2.5 \%$ & 10 & $4.2 \%$ & 25 & $10.5 \%$ & 41 & $5.7 \%$ \\
\hline Grand Total & 238 & & 238 & & 238 & & 714 & \\
\hline
\end{tabular}




\section{Most problematic characteristics of current institution}

In the last of this series of three questions, respondents were asked to indicate what they found most problematic about working at their current institution. Again, this list of 20 characteristics was created from the list of responses the researcher received while conducting the pilot interviews. In Table 15 the frequencies and percentages for each of the 20 characteristics are listed by first, second and third choice. Totals and cumulative percentages for each reason are also provided. The five most frequently cited characteristics that they find most problematic about the institution at which they work are: 1) Demands on faculty are too heavy (19.1\%), 2) Wages or benefits are insufficient (15.1\%), 3) Ineffective

administrative or academic leadership (9.6\%), 4) Quality of facilities or resources (8.9\%) and 5) Change happens to slowly (8.7\%). 
Table 15. Most problematic characteristics of current institution

\begin{tabular}{|c|c|c|c|c|c|c|c|c|}
\hline & Most & st & Most & $\begin{array}{l}\text { oblematic } \\
\text { nd }\end{array}$ & Most $\mathrm{F}$ & $\begin{array}{l}\text { oblematic } \\
\text { ird }\end{array}$ & Item & \\
\hline Reason & Freq. & Percent & Freq. & Percent & Freq. & Percent & Total & Percent \\
\hline $\begin{array}{l}\text { Demands on faculty are } \\
\text { too heavy }\end{array}$ & 64 & $28.4 \%$ & 22 & $11.2 \%$ & 24 & $15.6 \%$ & 110 & $19.1 \%$ \\
\hline $\begin{array}{l}\text { Wages or benefits are } \\
\text { insufficient }\end{array}$ & 33 & $14.7 \%$ & 31 & $15.8 \%$ & 23 & $14.9 \%$ & 87 & $15.1 \%$ \\
\hline $\begin{array}{l}\text { Ineffective administrative } \\
\text { or academic leadership }\end{array}$ & 16 & $7.1 \%$ & 24 & $12.2 \%$ & 15 & $9.7 \%$ & 55 & $9.6 \%$ \\
\hline $\begin{array}{l}\text { Quality of facilities or } \\
\text { resources }\end{array}$ & 25 & $11.1 \%$ & 17 & $8.7 \%$ & 9 & $5.8 \%$ & 51 & $8.9 \%$ \\
\hline $\begin{array}{l}\text { Change happens too } \\
\text { slowly }\end{array}$ & 27 & $12.0 \%$ & 11 & $5.6 \%$ & 12 & $7.8 \%$ & 50 & $8.7 \%$ \\
\hline $\begin{array}{l}\text { Lack of professional } \\
\text { development resources }\end{array}$ & 10 & $4.4 \%$ & 24 & $12.2 \%$ & 10 & $6.5 \%$ & 44 & $7.7 \%$ \\
\hline Other & 8 & $3.6 \%$ & 7 & $3.6 \%$ & 16 & $10.4 \%$ & 31 & $5.4 \%$ \\
\hline Quality of students & 5 & $2.2 \%$ & 8 & $4.1 \%$ & 11 & $7.1 \%$ & 24 & $4.2 \%$ \\
\hline $\begin{array}{l}\text { Institutional values not } \\
\text { sufficiently clarified }\end{array}$ & 6 & $2.7 \%$ & 11 & $5.6 \%$ & 5 & $3.2 \%$ & 22 & $3.8 \%$ \\
\hline $\begin{array}{l}\text { Lack of flexibility among } \\
\text { colleagues or students }\end{array}$ & 4 & $1.8 \%$ & 10 & $5.1 \%$ & 5 & $3.2 \%$ & 19 & $3.3 \%$ \\
\hline $\begin{array}{l}\text { Too much denominational } \\
\text { influence }\end{array}$ & 6 & $2.7 \%$ & 3 & $1.5 \%$ & 7 & $4.5 \%$ & 16 & $2.8 \%$ \\
\hline $\begin{array}{l}\text { Hostile political } \\
\text { environment }\end{array}$ & 5 & $2.2 \%$ & 8 & $4.1 \%$ & 3 & $1.9 \%$ & 16 & $2.8 \%$ \\
\hline $\begin{array}{l}\text { Nepotism among faculty } \\
\text { or staff }\end{array}$ & 2 & $0.9 \%$ & 5 & $2.6 \%$ & 3 & $1.9 \%$ & 10 & $1.7 \%$ \\
\hline Location of institution & 3 & $1.3 \%$ & 3 & $1.5 \%$ & 2 & $1.3 \%$ & 8 & $1.4 \%$ \\
\hline $\begin{array}{l}\text { Change happens too } \\
\text { quickly }\end{array}$ & 2 & $0.9 \%$ & 3 & $1.5 \%$ & 2 & $1.3 \%$ & 7 & $1.2 \%$ \\
\hline Curriculum is too broad & 3 & $1.3 \%$ & 3 & $1.5 \%$ & 1 & $0.6 \%$ & 7 & $1.2 \%$ \\
\hline $\begin{array}{l}\text { Curriculum is too } \\
\text { professionalized }\end{array}$ & 3 & $1.3 \%$ & 2 & $1.0 \%$ & 2 & $1.3 \%$ & 7 & $1.2 \%$ \\
\hline $\begin{array}{l}\text { Discrimination against } \\
\text { faculty or students }\end{array}$ & 1 & $0.4 \%$ & 2 & $1.0 \%$ & 2 & $1.3 \%$ & 5 & $0.9 \%$ \\
\hline $\begin{array}{l}\text { Too little denominational } \\
\text { influence }\end{array}$ & 0 & $0.0 \%$ & 1 & $0.5 \%$ & 2 & $1.3 \%$ & 3 & $0.5 \%$ \\
\hline Curriculum is too narrow & 2 & $0.9 \%$ & 1 & $0.5 \%$ & 0 & $0.0 \%$ & 3 & $0.5 \%$ \\
\hline Total & 225 & $100.0 \%$ & 196 & $100.0 \%$ & 154 & $100.0 \%$ & 577 & $100.0 \%$ \\
\hline Missing & 13 & $5.5 \%$ & 42 & $17.6 \%$ & 84 & $35.3 \%$ & 139 & $19.4 \%$ \\
\hline Grand Total & 238 & & 238 & & 238 & & 716 & \\
\hline
\end{tabular}

\section{Organizational Commitment Questionnaire}

The online survey contained the 15 items from the Organizational Commitment

Questionnaire (OCQ) by Mowday, Steers, and Porter (1979). The OCQ consists of 9 
positively worded items and 6 negatively worded items and uses a 7-point Likert-type format. Respondents were asked to choose from the following responses for each item: strongly disagree $($ value $=1)$, moderately disagree $($ value $=2)$, slightly disagree $($ value $=3$ ), neither disagree nor agree $($ value $=4)$, slightly agree $($ value $=5)$, moderately agree $($ value $=$ 6 ), or strongly agree (value $=7$ ).

A mean score was calculated for each of the 15 questions and the scores for the negatively worded items were inverted for analysis, so that all scores were evaluated according to the same scale. (Mowday, Steers, and Porter [1979] negatively worded and inverted the scores of these 6 items to reduce response bias). Due to this reason, it should be noted carefully in all further discussion that a higher score for a negatively worded item indicates disagreement with the statement. Question 15 (Deciding to work for this institution was a definite mistake on my part) received the highest mean score (6.69), while Question 4 (I would accept almost any type of job assignment in order to keep working for this institution) received the lowest mean score (2.94). Results of the OCQ (ranked from highest to lowest scores) can be found in Table 16. 
Table 16. OCQ descriptive statistics

\begin{tabular}{|c|c|c|c|c|}
\hline $\begin{array}{l}\text { Listed below are a series of statements that represent possible } \\
\text { feelings that individuals might have about the institution for which } \\
\text { they work. With respect to your own feelings about the particular } \\
\text { institution for which you are now working, please indicate the } \\
\text { degree of your agreement or disagreement with each statement by } \\
\text { checking one of the seven alternatives adjacent to each statement }\end{array}$ & $N$ & Mean & $\begin{array}{c}\text { Standard } \\
\text { Error }\end{array}$ & $\begin{array}{l}\text { Standard } \\
\text { Deviation }\end{array}$ \\
\hline $\begin{array}{l}\text { OCQ 1: I am willing to put in a great deal of effort beyond that } \\
\text { normally expected in order to help this institution to be successful. }\end{array}$ & 236 & 6.37 & .058 & .892 \\
\hline $\begin{array}{l}\text { OCQ 2: I talk up this institution to my friends as a great institution } \\
\text { to work for. }\end{array}$ & 236 & 5.94 & .088 & 1.345 \\
\hline OCQ 3: I feel very little loyalty to this institution. (reversed) & 235 & 5.70 & .129 & 1.972 \\
\hline $\begin{array}{l}\text { OCQ 4: I would accept almost any type of job assignment in order } \\
\text { to keep working for this institution. }\end{array}$ & 236 & 2.94 & .112 & 1.722 \\
\hline $\begin{array}{l}\text { OCQ 5: I find my values and the institution's values are very } \\
\text { similar. }\end{array}$ & 236 & 6.03 & .078 & 1.197 \\
\hline OCQ 6: I am proud to tell others that I am part of this institution. & 234 & 6.19 & .079 & 1.211 \\
\hline $\begin{array}{l}\text { OCQ 7: I could just as well be working for a different institution as } \\
\text { long as the type of work were similar. (reversed) }\end{array}$ & 234 & 4.17 & .113 & 1.721 \\
\hline $\begin{array}{l}\text { OCQ 8: The institution really inspires the very best in me in the } \\
\text { way of job performance. }\end{array}$ & 235 & 5.01 & .102 & 1.570 \\
\hline $\begin{array}{l}\text { OCQ 9: It would take very little change in my present } \\
\text { circumstances to cause me to leave this institution. (reversed) }\end{array}$ & 235 & 5.56 & .101 & 1.544 \\
\hline $\begin{array}{l}\text { OCQ 10: I am extremely glad that I chose this institution to work for } \\
\text { over others I was considering at the time I joined. }\end{array}$ & 233 & 5.78 & .091 & 1.396 \\
\hline $\begin{array}{l}\text { OCQ 11: There's not too much to be gained by sticking with this } \\
\text { institution indefinitely. (reversed) }\end{array}$ & 234 & 5.40 & .109 & 1.673 \\
\hline $\begin{array}{l}\text { OCQ 12: Often I find it difficult to agree with this institution's } \\
\text { policies on important matters relating to its employees. (reversed) }\end{array}$ & 234 & 4.58 & .119 & 1.814 \\
\hline OCQ 13: I really care about the fate of this institution. & 236 & 6.60 & .056 & .867 \\
\hline $\begin{array}{l}\text { OCQ 14: For me this is the best of all possible institutions for which } \\
\text { to work. }\end{array}$ & 235 & 5.25 & .110 & 1.682 \\
\hline $\begin{array}{l}\text { OCQ 15: Deciding to work for this institution was a definite mistake } \\
\text { on my part. (reversed) }\end{array}$ & 233 & 6.69 & .058 & .890 \\
\hline OCQ Mean (from listwise valid $N$ ) & 223 & 5.48 & .030 & 1.76 \\
\hline
\end{tabular}


Mowday, Steers, and Porter (1979) calculated an overall mean for all 15 questions, and used that score as a benchmark score for various groups or individuals. In their study of nine groups of employees in various settings (e.g., hospital, bank business, auto company), they reported mean scores from a low of 4.0 to a high of 6.1 , with group standard deviations on the mean from .90 to 1.30 . The mean OCQ score for participants in this study was within the range they experienced, at 5.48, with a standard deviation of slightly higher than their study (1.76).

Mowday, Steers, and Porter (1979) reported three different estimates of internal consistency and reliability (coefficient alpha, item analysis, and factor analysis). Regarding coefficient alpha, they reported a Cronbach’s alpha range from .82 to .93 over the nine samples. The Cronbach’s alpha for the 15 OCQ questions in this study was .89 (see Table 17 below for reliability statistics), which compares favorably with the results from Mowday, Steers, and Porter. They reported item analysis range of .36 to .72, while the item analysis for the respondents in this study ranged from .34 to .76.

Table 17. Reliability statistics for the 15 OCQ questions

\begin{tabular}{|c|c|c|}
\hline \hline $\begin{array}{c}\text { Cronbach's } \\
\text { Alpha }\end{array}$ & $\begin{array}{c}\text { Cronbach's Alpha } \\
\text { Based on } \\
\text { Standardized Items }\end{array}$ & N of Items \\
\hline .885 & .899 & 15 \\
\hline \hline
\end{tabular}

The factor analyses conducted for each of the nine samples by Mowday, Steers, and Porter (1979) generally resulted in a single-factor solution, which supported their claim of a single underlying construct (p. 232). Where two factors emerged, the resulting eigenvalue for the second factor never exceeded 1.0. An analysis conducted on the respondents in this study resulted in three factors with eigenvalues greater than 1.0. The results of this analysis 
are displayed in Table 18. The percentage of common variance explained by the first factor was approximately $43 \%$, while factors two and three combined to explain an additional $15 \%$ of the variance for a total variance explained by the three factors of 58\%. This result was much lower than the 83\% to 93\% results reported by Mowday, Steers, and Porter (1979).

Table 18. Total variance explained for OCQ questions

\begin{tabular}{|c|c|c|c|c|c|c|}
\hline \multirow[b]{2}{*}{ Component } & \multicolumn{3}{|c|}{ Initial Eigenvalues } & \multicolumn{3}{|c|}{ Extraction Sums of Squared Loadings } \\
\hline & Total & $\%$ of Variance & Cumulative \% & Total & $\%$ of Variance & Cumulative \% \\
\hline 1 & 6.499 & 43.327 & 43.327 & 6.499 & 43.327 & 43.327 \\
\hline 2 & 1.195 & 7.967 & 51.294 & 1.195 & 7.967 & 51.294 \\
\hline 3 & 1.053 & 7.018 & 58.312 & 1.053 & 7.018 & 58.312 \\
\hline 4 & .937 & 6.250 & 64.562 & & & \\
\hline 5 & .763 & 5.088 & 69.650 & & & \\
\hline 6 & .678 & 4.517 & 74.168 & & & \\
\hline 7 & .627 & 4.181 & 78.348 & & & \\
\hline 8 & .588 & 3.921 & 82.270 & & & \\
\hline 9 & .535 & 3.564 & 85.833 & & & \\
\hline 10 & .482 & 3.215 & 89.048 & & & \\
\hline 11 & .441 & 2.942 & 91.990 & & & \\
\hline 12 & .406 & 2.706 & 94.696 & & & \\
\hline 13 & .354 & 2.358 & 97.054 & & & \\
\hline 14 & .260 & 1.734 & 98.788 & & & \\
\hline 15 & .182 & 1.212 & 100.000 & & & \\
\hline
\end{tabular}

Extraction Method: Principal Component Analysis.

\section{Comparisons of Organizational Commitment between}

\section{Independent Variables in this Study}

The use of Analysis of Variance (ANOVA) techniques allows for comparisons between various dependent and independent variables in this study. The researcher conducted multiple one-way ANOVAs using participant responses on the OCQ items as dependent variables and the list of independent variables described as "general characteristics of the sample” earlier in this chapter. In the cases where there were more than two 
comparisons within a variable, a Tukey post hoc test was run to determine which mean differences were statistically significant. In all instances in this study where findings are reported as statistically significant, a $p<.05$ level was used to determine significance. The variables considered in this analysis were: gender, age, institution, church membership requirement, type of alma mater, highest degree earned, academic rank, years teaching (career), years teaching (institution), expected age of retirement and academic field. The results as they pertain to each independent variable will be described below.

\section{Gender}

A one-way ANOVA was performed to determine whether there were any observed differences between females and males with regard to the questions of the OCQ. Statistically significant differences in means at the .05 level were found on 8 of the 15 questions in the OCQ and in the overall OCQ mean. In each case, the mean scores for the female participants were statistically higher than those of the male participants. Those results are displayed in Table 19. Descriptive statistics for females and males on all 15 questions and the OCQ mean can be found in Appendix A. 
Table 19. ANOVA results of OCQ questions by gender

\begin{tabular}{|c|c|c|c|c|c|c|}
\hline OCQ Question & Source & $\begin{array}{l}\text { Sum of } \\
\text { Squares }\end{array}$ & $d f$ & $\begin{array}{l}\text { Mean } \\
\text { Square }\end{array}$ & $F$ & Sig. \\
\hline \multirow{3}{*}{$\begin{array}{l}\text { OCQ 2: I talk up this institution to } \\
\text { my friends as a great institution to } \\
\text { work for. }\end{array}$} & Between Groups & 15.339 & 1 & 15.339 & 8.732 & .003 \\
\hline & Within Groups & 407.567 & 232 & 1.757 & & \\
\hline & Total & 422.906 & 233 & & & \\
\hline \multirow{3}{*}{$\begin{array}{l}\text { OCQ 5: I find my values and the } \\
\text { institution's values are very similar. }\end{array}$} & Between Groups & 5.692 & 1 & 5.692 & 4.000 & .047 \\
\hline & Within Groups & 330.154 & 232 & 1.423 & & \\
\hline & Total & 335.846 & 233 & & & \\
\hline \multirow{3}{*}{$\begin{array}{l}\text { OCQ 6: I am proud to tell others } \\
\text { that I am part of this institution. }\end{array}$} & Between Groups & 15.470 & 1 & 15.470 & 10.951 & .001 \\
\hline & Within Groups & 324.926 & 230 & 1.413 & & \\
\hline & Total & 340.397 & 231 & & & \\
\hline \multirow{3}{*}{$\begin{array}{l}\text { OCQ 7: I could just as well be } \\
\text { working for a different institution as } \\
\text { long as the type of work were } \\
\text { similar. (reversed) }\end{array}$} & Between Groups & 26.055 & 1 & 26.055 & 9.148 & .003 \\
\hline & Within Groups & 655.045 & 230 & 2.848 & & \\
\hline & Total & 681.099 & 231 & & & \\
\hline \multirow{3}{*}{$\begin{array}{l}\text { OCQ 9: It would take very little } \\
\text { change in my present } \\
\text { circumstances to cause me to } \\
\text { leave this institution. (reversed) }\end{array}$} & Between Groups & 15.001 & 1 & 15.001 & 6.410 & .012 \\
\hline & Within Groups & 540.578 & 231 & 2.340 & & \\
\hline & Total & 555.579 & 232 & & & \\
\hline \multirow{3}{*}{$\begin{array}{l}\text { OCQ 11: There's not too much to } \\
\text { be gained by sticking with this } \\
\text { institution indefinitely. (reversed) }\end{array}$} & Between Groups & 13.941 & 1 & 13.941 & 5.067 & .025 \\
\hline & Within Groups & 635.518 & 231 & 2.751 & & \\
\hline & Total & 649.459 & 232 & & & \\
\hline \multirow{3}{*}{$\begin{array}{l}\text { OCQ 13: I really care about the } \\
\text { fate of this institution. }\end{array}$} & Between Groups & 8.098 & 1 & 8.098 & 11.160 & .001 \\
\hline & Within Groups & 168.334 & 232 & .726 & & \\
\hline & Total & 176.432 & 233 & & & \\
\hline \multirow{3}{*}{$\begin{array}{l}\text { OCQ 14: For me this is the best of } \\
\text { all possible institutions for which to } \\
\text { work. }\end{array}$} & Between Groups & 28.184 & 1 & 28.184 & 10.379 & .001 \\
\hline & Within Groups & 627.301 & 231 & 2.716 & & \\
\hline & Total & 655.485 & 232 & & & \\
\hline \multirow{3}{*}{ OCQ Mean } & Between Groups & 9.868 & 1 & 9.868 & 12.348 & .001 \\
\hline & Within Groups & 185.395 & 232 & .799 & & \\
\hline & Total & 195.263 & 233 & & & \\
\hline
\end{tabular}

\section{Age}

To determine whether there were differences between age groups on the OCQ questions, one-way ANOVA tests were performed. Because the category “over 80” had only one respondent, it was collapsed into the “70-79” age group, creating a new range called "70 and above." It was determined that there were differences in means between groups on two of the 15 questions and the overall OCQ mean. A Tukey post hoc test of pairwise 
comparisons was performed to determine which of the means differed from each other. The results indicated that on question 8 (This institution really inspires the very best in me in the way of job performance) the 70 and above age group scored significantly lower than all 5 other age groups. On question 13 (I really care about the fate of this institution) the 20-29 age group scored significantly lower those respondents in their 30s, 40s, and 50s. Finally, on the overall OCQ mean, the respondents in their 30s scored significantly lower than respondents in their 60s. The ANOVA results for statistically significant comparisons are displayed in Table 20. Descriptive statistics for all participants by age are in Appendix A.

Table 20. ANOVA results of OCQ questions by age

\begin{tabular}{|l|l|r|r|r|r|r|}
\hline \hline \multirow{2}{*}{ OCQ Question } & \multicolumn{1}{c|}{ Source } & $\begin{array}{c}\text { Sum of } \\
\text { Squares }\end{array}$ & \multicolumn{1}{c|}{$d f$} & \multicolumn{1}{c|}{$\begin{array}{c}\text { Sean } \\
\text { Square }\end{array}$} & \multicolumn{1}{c|}{$F$} & Sig. \\
\hline $\begin{array}{l}\text { OCQ 8: The institution really inspires } \\
\text { the very best in me in the way of job } \\
\text { performance. }\end{array}$ & Between Groups & 50.169 & 5 & 10.034 & 4.419 & .001 \\
\cline { 2 - 7 } & Within Groups & 517.677 & 228 & 2.271 & & \\
\cline { 2 - 7 } & Total & 567.846 & 233 & & & \\
\hline \multirow{2}{*}{$\begin{array}{l}\text { OCQ 13: I really care about the fate } \\
\text { of this institution. }\end{array}$} & Between Groups & 12.112 & 5 & 2.422 & 3.423 & .005 \\
\cline { 2 - 7 } & Within Groups & 162.083 & 229 & .708 & & \\
\cline { 2 - 7 } & Total & 174.196 & 234 & & & \\
\hline \multirow{2}{*}{ OCQ Mean } & Between Groups & 9.912 & 5 & 1.982 & 2.468 & .033 \\
\cline { 2 - 7 } & Within Groups & 183.911 & 229 & .803 & & \\
\cline { 2 - 8 } & Total & 193.824 & 234 & & & \\
\hline \hline
\end{tabular}

\section{Institution}

The data were analyzed using one-way ANOVA techniques to determine whether there were differences between responses from faculty at the various institutions on the OCQ questions. It was determined that there were differences in means between institutions on 4 of the 15 questions and the overall OCQ mean. A Tukey post hoc test of pairwise comparisons was performed to determine which of the means differed from each other. The results indicated that on questions 2, 6, and 9 (I talk up this institution to my friends as a 
great institution to work for, I am proud to tell others that I am a part of this institution, and It would take very little change in my present circumstances to cause me to leave this institution) Institution 5 scored significantly higher than Institution 6. On question 12 (Often I find it difficult to agree with this institution's policies on important matters relating to its employees) Institution 9 score significantly higher than Institution 7. Finally, on the overall OCQ mean, the ANOVA indicated a significantly significant difference $(F[9,224]=2.038)$, however the Tukey post hoc test did not indicate which institution(s) varied from the others. An LSD post hoc analysis was conducted to determine which comparisons were significantly different. The LSD uses t-tests to perform all pairwise comparisons between group means, without making an adjustment to the error rate for multiple comparisons. The LSD post hoc analysis indicated that the OCQ mean for Institution 1 was significantly higher than that of Institution 6, that the OCQ mean for Institution 5 was significantly higher than Institutions 3, 4, and 6, and that the mean for Institution 9 was also significantly higher than that of Institutions 3, 4, and 6. The ANOVA results for statistically significant comparisons are displayed in Table 21. Descriptive statistics for all participants by Institution are in Appendix A. 
Table 21. ANOVA results of OCQ questions by institution

\begin{tabular}{|c|c|c|c|c|c|c|}
\hline OCQ Question & Source & $\begin{array}{c}\text { Sum of } \\
\text { Squares }\end{array}$ & $d f$ & $\begin{array}{l}\text { Mean } \\
\text { Square }\end{array}$ & $F$ & Sig. \\
\hline \multirow{3}{*}{$\begin{array}{l}\text { OCQ 2: I talk up this institution to my } \\
\text { friends as a great institution to work } \\
\text { for. }\end{array}$} & Between Groups & 38.046 & 9 & 4.227 & 2.477 & .010 \\
\hline & Within Groups & 382.232 & 224 & 1.706 & & \\
\hline & Total & 420.278 & 233 & & & \\
\hline \multirow{3}{*}{$\begin{array}{l}\text { OCQ 6: I am proud to tell others that } \\
\text { I am part of this institution. }\end{array}$} & Between Groups & 27.745 & 9 & 3.083 & 2.185 & .024 \\
\hline & Within Groups & 313.285 & 222 & 1.411 & & \\
\hline & Total & 341.030 & 231 & & & \\
\hline \multirow{3}{*}{$\begin{array}{l}\text { OCQ 9: It would take very little } \\
\text { change in my present circumstances } \\
\text { to cause me to leave this institution. } \\
\text { (reversed) }\end{array}$} & Between Groups & 49.243 & 9 & 5.471 & 2.402 & .013 \\
\hline & Within Groups & 507.976 & 223 & 2.278 & & \\
\hline & Total & 557.219 & 232 & & & \\
\hline \multirow{3}{*}{$\begin{array}{l}\text { OCQ 12: Often I find it difficult to } \\
\text { agree with this institution's policies on } \\
\text { important matters relating to its } \\
\text { employees. (reversed) }\end{array}$} & Between Groups & 61.640 & 9 & 6.849 & 2.174 & .025 \\
\hline & Within Groups & 699.257 & 222 & 3.150 & & \\
\hline & Total & 760.897 & 231 & & & \\
\hline \multirow{3}{*}{ OCQ Mean } & Between Groups & 14.974 & 9 & 1.664 & 2.038 & .036 \\
\hline & Within Groups & 182.843 & 224 & .816 & & \\
\hline & Total & 197.817 & 233 & & & \\
\hline
\end{tabular}

\section{Church membership requirement}

A one-way ANOVA was performed to determine whether there were any observed differences between participants at institutions with and without a church membership requirement with regard to the questions of the OCQ. Statistically significant differences in means at the .05 level were found on 4 of the 15 questions in the OCQ. In each case, those faculty members who work at institutions that require their faculty members to belong to a particular church or denomination had statistically significant higher scores than those at institutions that do not require membership in a particular denomination. Those results are displayed in Table 22. Descriptive statistics for all 15 questions and the OCQ mean with regard to this criterion can be found in Appendix A. 
Table 22. ANOVA results of OCQ questions by church membership requirement

\begin{tabular}{|c|c|c|c|c|c|c|}
\hline OCQ Question & Source & $\begin{array}{l}\text { Sum of } \\
\text { Squares }\end{array}$ & $d f$ & $\begin{array}{l}\text { Mean } \\
\text { Square }\end{array}$ & $F$ & Sig. \\
\hline \multirow{3}{*}{$\begin{array}{l}\text { OCQ 2: I talk up this institution to my } \\
\text { friends as a great institution to work } \\
\text { for. }\end{array}$} & Between Groups & 15.067 & 1 & 15.067 & 8.597 & .004 \\
\hline & Within Groups & 410.102 & 234 & 1.753 & & \\
\hline & Total & 425.169 & 235 & & & \\
\hline \multirow{3}{*}{$\begin{array}{l}\text { OCQ 6: I am proud to tell others that } \\
\text { I am part of this institution. }\end{array}$} & Between Groups & 6.321 & 1 & 6.321 & 4.372 & .038 \\
\hline & Within Groups & 335.405 & 232 & 1.446 & & \\
\hline & Total & 341.726 & 233 & & & \\
\hline \multirow{3}{*}{$\begin{array}{l}\text { OCQ 7: I could just as well be } \\
\text { working for a different institution as } \\
\text { long as the type of work were similar. } \\
\text { (reversed) }\end{array}$} & Between Groups & 21.608 & 1 & 21.608 & 7.494 & .007 \\
\hline & Within Groups & 668.892 & 232 & 2.883 & & \\
\hline & Total & 690.500 & 233 & & & \\
\hline \multirow{3}{*}{$\begin{array}{l}\text { OCQ 11: There's not too much to be } \\
\text { gained by sticking with this institution } \\
\text { indefinitely. (reversed) }\end{array}$} & Between Groups & 14.731 & 1 & 14.731 & 5.363 & .021 \\
\hline & Within Groups & 637.307 & 232 & 2.747 & & \\
\hline & Total & 652.038 & 233 & & & \\
\hline
\end{tabular}

\section{Alma mater}

A one-way ANOVA was conducted to determine whether there were any statistically significant differences between respondents on the questions of the OCQ based upon the type of undergraduate institution that they attended. Statistically significant differences in mean scores were observed on three of the 15 items. A Tukey post hoc analysis indicated that participants who attended another non-CCCU Christian college scored significantly higher than those who attended a CCCU Christian college on question 6 (I am proud to tell others that I am part of this institution). In question 7 (I could just as well be working for a different institution as long as the type of were were similar) those who attended the institution at which they currently work scored significantly higher than those who attended another CCCU institution and those who attended a non-Christian college scored higher than those who attended another CCCU institution. Finally, on question 13 (I really care about the fate of this institution), those faculty members who attended the institution at which they 
work scored significantly higher than those who attended a non-Christian college. Results for statistically significant means are displayed in Table 23. Descriptive statistics for all 15 questions and the OCQ mean with regard to Alma Mater are in Appendix A.

Table 23. ANOVA results of OCQ questions by alma mater

\begin{tabular}{|l|l|r|r|r|r|r|}
\hline \multicolumn{1}{|c}{ OCQ Question } & \multicolumn{1}{c|}{ Source } & $\begin{array}{c}\text { Sum of } \\
\text { Squares }\end{array}$ & \multicolumn{1}{c|}{$d f$} & \multicolumn{1}{c|}{$\begin{array}{c}\text { Sean } \\
\text { Square }\end{array}$} & \multicolumn{1}{c|}{$F$} & Sig. \\
\hline \hline $\begin{array}{l}\text { OCQ 6: I am proud to tell others that } \\
\text { I am part of this institution. }\end{array}$ & \multicolumn{1}{|c|}{ Between Groups } & 15.252 & 3 & 5.084 & 3.582 & .015 \\
\cline { 2 - 7 } & Within Groups & 326.475 & 230 & 1.419 & & \\
\cline { 2 - 7 } & Total & 341.726 & 233 & & & \\
\hline $\begin{array}{l}\text { OCQ 7: I could just as well be } \\
\text { working for a different institution as } \\
\text { long as the type of work were similar. } \\
\text { (reversed) }\end{array}$ & Between Groups & 34.063 & 3 & 11.354 & 3.978 & .009 \\
\cline { 2 - 7 } & Within Groups & 656.437 & 230 & 2.854 & & \\
\cline { 2 - 7 } & Total & 690.500 & 233 & & & \\
\hline \multirow{2}{*}{$\begin{array}{l}\text { OCQ 13: I really care about the fate } \\
\text { of this institution. }\end{array}$} & Between Groups & 5.919 & 3 & 1.973 & 2.679 & .048 \\
\cline { 2 - 7 } & Within Groups & 170.839 & 232 & .736 & & \\
\cline { 2 - 7 } & Total & 176.758 & 235 & & & \\
\hline \hline
\end{tabular}

\section{Highest degree earned}

A one-way ANOVA was performed to determine whether there were any observed differences in OCQ responses between faculty members with differing levels of educational attainment. The analysis indicated no statistically significant differences in responses.

Descriptive statistics for OCQ responses by educational degree can be found in Appendix A.

\section{Academic Rank}

Similarly, one-way ANOVA techniques were used to determine whether there were statistically significant differences in OCQ responses between faculty members of different ranks. No such differences in means were found. Mean scores by academic rank can be found in Appendix A. 


\section{Years teaching (career)}

When one-way ANOVA tests were run on the OCQ questions, using the "years teaching (career)" as the independent variable, two questions produced statistically significant results. On question 9 (It would take very little change in my present circumstances to cause me to leave this institution) those faculty who had taught 12 or more years scored significantly higher than faculty who had been teaching for only 6-11 years. On question 15 (Deciding to work for this institution was a definite mistake on my part) those faculty members who had taught for 1-5 years scored significantly higher than those who had taught for 6-11 years. Results for statistically significant means are displayed in Table 24. Mean scores for all 15 questions and the OCQ mean with regard to years teaching (career) are in Appendix A.

Table 24. ANOVA results of OCQ questions by years teaching (career)

\begin{tabular}{|c|c|c|c|c|c|c|}
\hline OCQ Question & Source & $\begin{array}{c}\text { Sum of } \\
\text { Squares }\end{array}$ & $d f$ & $\begin{array}{c}\text { Mean } \\
\text { Squar } \\
\text { e }\end{array}$ & $F$ & Sig. \\
\hline \multirow{3}{*}{$\begin{array}{l}\text { OCQ 9: It would take very little } \\
\text { change in my present circumstances } \\
\text { to cause me to leave this institution. } \\
\text { (reversed) }\end{array}$} & Between Groups & 15.030 & 2 & 7.515 & 3.187 & .043 \\
\hline & Within Groups & 542.318 & 230 & 2.358 & & \\
\hline & Total & 557.348 & 232 & & & \\
\hline \multirow{3}{*}{$\begin{array}{l}\text { OCQ 15: Deciding to work for this } \\
\text { institution was a definite mistake on } \\
\text { my part. (reversed) }\end{array}$} & Between Groups & 7.597 & 2 & 3.798 & 4.922 & .008 \\
\hline & Within Groups & 175.962 & 228 & .772 & & \\
\hline & Total & 183.558 & 230 & & & \\
\hline
\end{tabular}

\section{Years teaching (institution)}

When the 15 questions of the OCQ were analyzed using one-way ANOVA techniques and years teaching (institution) as the independent variable, only one of the questions showed statistically different means among the three groups. On question 7 (I 
could just as well be working for a similar institution as long as the type of work were similar) the faculty members who had been at the institution for 12 or more years scored significantly higher than those who had only been at the institution for 1-5 years. Results for statistically significant means are displayed in Table 25. Descriptive statistics for all 15 questions and the OCQ mean with regard to years teaching (institution) are in Appendix A.

Table 25. ANOVA results of OCQ questions by years teaching (institution)

\begin{tabular}{|l|l|r|r|r|r|c|}
\multicolumn{1}{c|}{ OCQ Questions } & \multicolumn{1}{c|}{ Source } & $\begin{array}{c}\text { Sum of } \\
\text { Squares }\end{array}$ & \multicolumn{1}{c|}{$d f$} & \multicolumn{1}{c|}{$\begin{array}{c}\text { Mean } \\
\text { Square }\end{array}$} & $F$ & Sig. \\
\hline \hline $\begin{array}{l}\text { OCQ 7: I could just as well be } \\
\text { working for a different institution as } \\
\text { long as the type of work were similar. } \\
\text { (reversed) }\end{array}$ & Between Groups & 18.341 & 2 & 9.170 & 3.152 & .045 \\
\cline { 2 - 8 } & Within Groups & 672.159 & 231 & 2.910 & & \\
\cline { 2 - 8 } & Total & 690.500 & 233 & & & \\
\hline \hline
\end{tabular}

\section{Expected age of retirement}

A one-way ANOVA was performed to determine whether there were any observed differences between participants' scores on the OCQ items based on their anticipated age of retirement from teaching. Because each of the participants had entered a discreet age for their expected age of retirement, the ages were collapsed into three groups $(1=60$ or less, $2=$ 61-65, and $3=66$ and above). Statistically significant differences in means at the .05 level were found on 2 of the 15 questions in the OCQ. In each case, those faculty members who anticipated retiring at age 60 or below had lower scores than those who anticipate retirement at age 66 or above. Those results are displayed in Table 26. Descriptive statistics for all 15 questions and the OCQ mean with regard to this criterion can be found in Appendix A. 
Table 26. ANOVA results of OCQ questions by expected age of retirement

\begin{tabular}{|l|l|r|r|r|r|c|}
\hline \multicolumn{1}{c|}{ OCQ Questions } & \multicolumn{1}{c|}{ Source } & $\begin{array}{c}\text { Sum of } \\
\text { Squares }\end{array}$ & \multicolumn{1}{c|}{ df } & \multicolumn{1}{c|}{$\begin{array}{c}\text { Sean } \\
\text { Square }\end{array}$} & \multicolumn{1}{c|}{$F$} & Sig. \\
\hline $\begin{array}{l}\text { OCQ 9: It would take very little } \\
\text { change in my present circumstances } \\
\text { to cause me to leave this institution. } \\
\text { (reversed) }\end{array}$ & Between Groups & 16.649 & 2 & 8.325 & 3.497 & .032 \\
\cline { 2 - 8 } & Within Groups & 526.060 & 221 & 2.380 & & \\
\cline { 2 - 8 } & Total & 542.710 & 223 & & & \\
\hline $\begin{array}{l}\text { OCQ 11: There's not too much to be } \\
\text { gained by sticking with this institution } \\
\text { indefinitely. (reversed) }\end{array}$ & Between Groups & 21.095 & 2 & 10.548 & 3.904 & .022 \\
\cline { 2 - 8 } & Within Groups & 597.119 & 221 & 2.702 & & \\
\cline { 2 - 8 } & Total & 618.214 & 223 & & & \\
\hline \hline
\end{tabular}

\section{Academic field}

The final comparison made regarding the OCQ items related to the academic field of participants. Using one-way ANOVA techniques, it was determined that statistically significant differences were evident on 2 of the 15 questions. In each case, faculty members in pre-professional programs (business, education, health sciences, law, library science, public affairs, and recreation/physical education) scored higher than their counterparts in the social sciences (communications, psychology, social sciences [including history]). Results for the two significantly different means are indicated in Table 27 and descriptive statistics for all 15 questions and the OCQ mean can be found in Appendix A.

Table 27. ANOVA results of OCQ questions by academic field

\begin{tabular}{|c|c|c|c|c|c|c|}
\hline OCQ Questions & Source & $\begin{array}{l}\text { Sum of } \\
\text { Squares }\end{array}$ & $d f$ & $\begin{array}{c}\text { Mean } \\
\text { Square }\end{array}$ & $F$ & Sig. \\
\hline \multirow{3}{*}{$\begin{array}{l}\text { OCQ 6: I am proud to tell others that } \\
\text { I am part of this institution. }\end{array}$} & Between Groups & 20.526 & 4 & 5.132 & 3.815 & .005 \\
\hline & Within Groups & 299.943 & 223 & 1.345 & & \\
\hline & Total & 320.469 & 227 & & & \\
\hline \multirow{3}{*}{$\begin{array}{l}\text { OCQ 10: I am extremely glad that I } \\
\text { chose this institution to work for over } \\
\text { others I was considering at the time I } \\
\text { joined. }\end{array}$} & Between Groups & 22.736 & 4 & 5.684 & 3.005 & .019 \\
\hline & Within Groups & 419.942 & 222 & 1.892 & & \\
\hline & Total & 442.678 & 226 & & & \\
\hline
\end{tabular}




\section{Questions from the National Study of Postsecondary Faculty}

The remaining items in the survey were taken from the National Study of Postsecondary Faculty (Russell, Fairweather, Hendrickson, \& Zimbler, 1991; Zimbler, 2001). Items were selected from both the instrument used in 1988 and the 1999 edition of the NSOPF, since not all of the pertinent questions had appeared in the most recent (1999) version. The first set of questions from the NSOPF survey focused on the satisfaction of respondents with various characteristics of their job. The items were scored on a four-point range, with 1 = Very Dissatisfied, 2 = Somewhat Dissatisfied, 3 = Somewhat Satisfied, and 4 $=$ Very Satisfied. Means of the various items varied from a high of $3.79(N=235, S D=$ .484) for The authority I have to make decisions about content and methods in the courses I teach to a low of $2.34(N=204, S D=.876)$ for Research Assistance that I receive. Items, in rank-order by means, are listed in Table 28. 
Table 28. Descriptive statistics for NSOPF satisfaction questions

\begin{tabular}{|c|c|c|c|c|}
\hline $\begin{array}{l}\text { How satisfied or dissatisfied do you personally feel about } \\
\text { each of the following aspects of your job at your current } \\
\text { institution }\end{array}$ & $N$ & Mean & $\begin{array}{c}\text { Standard } \\
\text { Error }\end{array}$ & $\begin{array}{l}\text { Standard } \\
\text { Deviation }\end{array}$ \\
\hline $\begin{array}{l}\text { The authority I have to make decisions about the content and } \\
\text { methods in the courses I teach }\end{array}$ & 235 & 3.79 & .032 & .484 \\
\hline Institutional mission or philosophy & 236 & 3.65 & .035 & .544 \\
\hline Quality of my colleagues in my department & 234 & 3.50 & .044 & .676 \\
\hline My overall satisfaction with my job here & 236 & 3.46 & .041 & .628 \\
\hline $\begin{array}{l}\text { The authority I have to make decisions about what courses I } \\
\text { teach }\end{array}$ & 235 & 3.43 & .052 & .794 \\
\hline My job security & 236 & 3.40 & .052 & .806 \\
\hline Quality of leadership in my department & 236 & 3.38 & .055 & .849 \\
\hline $\begin{array}{l}\text { The authority I have to make decisions about other aspects of } \\
\text { my job }\end{array}$ & 234 & 3.36 & .044 & .668 \\
\hline Reputation of my department & 237 & 3.36 & .052 & .793 \\
\hline Spouse employment opportunities in this geographic area & 214 & 3.29 & .053 & .780 \\
\hline Freedom to do outside consulting & 226 & 3.27 & .048 & .727 \\
\hline Overall reputation of the institution & 234 & 3.22 & .050 & .771 \\
\hline Quality of chief administrative officers at my institution & 236 & 3.12 & .060 & .924 \\
\hline Quality of faculty leadership at my institution & 236 & 3.12 & .052 & .806 \\
\hline The opportunity for advancement in rank at my institution & 234 & 3.11 & .060 & .915 \\
\hline $\begin{array}{l}\text { The mix of teaching, research, administration, and service that I } \\
\text { am required to do }\end{array}$ & 234 & 3.09 & .052 & .791 \\
\hline Spirit of cooperation between faculty at this institution & 237 & 3.08 & .050 & .763 \\
\hline Quality of students whom I have taught here & 237 & 3.08 & .049 & .755 \\
\hline My work load & 237 & 2.87 & .056 & .859 \\
\hline $\begin{array}{l}\text { Availability of support services and equipment (clerical support, } \\
\text { computers, etc.) }\end{array}$ & 237 & 2.87 & .058 & .893 \\
\hline My benefits & 236 & 2.84 & .058 & .889 \\
\hline Interdepartmental cooperation at this institution & 236 & 2.80 & .053 & .814 \\
\hline Relationship between administration and faculty at this institution & 236 & 2.79 & .060 & .917 \\
\hline Teaching assistance that I receive & 216 & 2.69 & .060 & .886 \\
\hline My salary & 237 & 2.65 & .057 & .884 \\
\hline Time available for keeping current in my field & 235 & 2.44 & .058 & .882 \\
\hline Quality of my research facilities and support & 226 & 2.41 & .056 & .839 \\
\hline Research assistance that I receive & 204 & 2.34 & .061 & .876 \\
\hline
\end{tabular}

The second set of NSOPF questions dealt with possible reasons why the respondents may leave their current position. Respondents were asked "If you were to leave your current institution, how likely is it that you would do so to...” The questions were based on a 3point Likert-type range, with $1=$ Not likely at all, $2=$ Somewhat likely, and $3=$ Very Likely They varied from a high of $2.16(N=237, S D=.914)$ for Leave to Retire to $1.19(N=235$, $S D=.473$ ) for Leave to Study. The responses and descriptive statistics are listed in Table 29. 
Table 29. Descriptive statistics for reasons for leaving current institution

\begin{tabular}{|l|r|r|r|r|}
\hline \hline \multicolumn{1}{|c|}{$\begin{array}{c}\text { If you were to leave your current institution, how likely is it that } \\
\text { you would do so to? }\end{array}$} & $N$ & \multicolumn{1}{c|}{ Mean } & $\begin{array}{r}\text { Standard } \\
\text { Error }\end{array}$ & $\begin{array}{r}\text { Standard } \\
\text { Deviation }\end{array}$ \\
\hline Return to school as a student & 235 & 1.19 & .031 & .473 \\
\hline $\begin{array}{l}\text { Accept employment in consulting or other for-profit business or } \\
\text { industry or become self-employed }\end{array}$ & 235 & 1.60 & .046 & .706 \\
\hline Accept employment at a secular college or university & 234 & 1.64 & .043 & .662 \\
\hline Accept employment in a non-profit organization & 234 & 1.72 & .041 & .633 \\
\hline Accept employment at another Christian college or university & 235 & 2.02 & .044 & .673 \\
\hline Retire & 237 & 2.16 & .059 & .914 \\
\hline \hline
\end{tabular}

The next set of questions from the NSOPF asked participants "If you were to leave your current institution to accept another position, would you want to do more, less or about the same of the following as you currently do?” Again, a 3 point Likert range was used, with $1=$ More of this, 2 = Same amount, and $3=$ Less of this. Participants in this study were most interested in increasing their level of research (mean $=1.57, N=232, S D=.640$ ) and least interested in having more administration (mean $=2.28, N=2.31, S D=.680$ ) at another position. Table 30 shows the descriptive statistics for all questions.

Table 30. Descriptive statistics for desired mix of roles in new position

\begin{tabular}{|l|r|r|r|r|}
\hline $\begin{array}{c}\text { If you were to leave your current institution to accept another } \\
\text { position, would you want to do more, less or about the same } \\
\text { amount of the following as you currently do? }\end{array}$ & $N$ & Mean & $\begin{array}{c}\text { Standard } \\
\text { Error }\end{array}$ & $\begin{array}{c}\text { Standard } \\
\text { Deviation }\end{array}$ \\
\hline Research & 232 & 1.57 & .042 & .640 \\
\hline Teaching & 233 & 2.14 & .038 & .581 \\
\hline Service & 234 & 2.15 & .037 & .560 \\
\hline Advising & 232 & 2.23 & .035 & .538 \\
\hline Administration & 231 & 2.28 & .045 & .680 \\
\hline \hline
\end{tabular}

The fourth set of questions on the survey that were drawn from the NSOPF questionnaire asks the participants, "If you were to leave your current institution to accept another position, how important would each of the following items be in your decision to accept another position?” The questions were rated on the following range: $1=$ Not 
important, 2 = Somewhat important, and 3 = Very important. The highest-rated item was $a$ full-time position (mean $=2.74, N=232, S D=.585$ ) and the lowest rated item was a parttime position $($ mean $=1.30, N=228, S D=.571)$. (Since all the faculty respondents who were considered in this study held full-time positions, the highest and lowest rated items in this category are not unexpected.) The second highest rated items (tied) were Excellent Colleagues $($ mean $=2.66, N=238, S D=.482)$ and Institutional mission or philosophy that is compatible with my own views (mean $=2.66, N=237, S D=.517)$. The second lowest rated item, at $1.94(N=224, S D=.909)$, was Good environment/schools for my children. The rest of the questions from this section, along with descriptive statistics, are listed in Table 31.

Table 31. Descriptive statistics for importance of characteristics in new position

\begin{tabular}{|c|c|c|c|c|}
\hline $\begin{array}{c}\text { If you were to leave your current institution to accept another } \\
\text { position, how important would each of the following items be in } \\
\text { your decision to accept another position? }\end{array}$ & $N$ & Mean & $\begin{array}{l}\text { Standard } \\
\text { Error }\end{array}$ & $\begin{array}{l}\text { Standard } \\
\text { Deviation }\end{array}$ \\
\hline A full-time position & 232 & 2.74 & .038 & .585 \\
\hline Excellent Colleagues & 238 & 2.66 & .031 & .482 \\
\hline $\begin{array}{l}\text { Institutional mission or philosophy that is compatible with my } \\
\text { own views }\end{array}$ & 237 & 2.66 & .034 & .517 \\
\hline Benefits & 238 & 2.65 & .033 & .512 \\
\hline Academic Freedom & 238 & 2.58 & .036 & .551 \\
\hline Good instructional facilities and equipment & 237 & 2.55 & .037 & .563 \\
\hline Job Security & 237 & 2.54 & .040 & .621 \\
\hline Affordable Housing & 235 & 2.51 & .040 & .609 \\
\hline Good geographic location & 235 & 2.44 & .041 & .627 \\
\hline Salary Level & 238 & 2.44 & .036 & .561 \\
\hline Excellent Students & 238 & 2.43 & .037 & .567 \\
\hline Position Level & 237 & 2.35 & .040 & .609 \\
\hline Opportunities for advancement & 238 & 2.32 & .044 & .679 \\
\hline New institution is a Christian college & 238 & 2.28 & .046 & .712 \\
\hline No pressure to publish & 238 & 2.16 & .047 & .723 \\
\hline Good research facilities and equipment & 236 & 2.13 & .043 & .666 \\
\hline Good job for my spouse & 227 & 2.10 & .056 & .848 \\
\hline Good environment/schools for my children & 224 & 1.94 & .061 & .909 \\
\hline A part-time position & 228 & 1.30 & .038 & .571 \\
\hline
\end{tabular}

The final set of questions to which participants were asked to respond asked them to "Indicate the extent to which you agree or disagree with each of the following statements." 
The scale for these questions was 1 = Strongly Disagree, 2 = Somewhat Disagree, $3=$ Somewhat Agree, and $4=$ Strongly Agree. The question with the highest mean score was If I had it to do over again, $I$ would choose an academic career (mean $=3.78, N=238, S D=$ .514). The lowest scored item in this category was Research/publications should be the primary criterion for promotion of college faculty (mean $=1.91, N=238, S D=.693)$. The rest of the questions and descriptive statistics can be found in Table 32.

Table 32. Descriptive statistics for statements regarding academic issues

\begin{tabular}{|c|c|c|c|c|}
\hline $\begin{array}{c}\text { Please indicate the extent to which you agree or disagree with } \\
\text { each of the following statements. }\end{array}$ & $N$ & Mean & $\begin{array}{l}\text { Standard } \\
\text { Error }\end{array}$ & $\begin{array}{l}\text { Standard } \\
\text { Deviation }\end{array}$ \\
\hline If I had it to do over again, I would choose an academic career & 238 & 3.78 & .033 & .514 \\
\hline $\begin{array}{l}\text { It is important for faculty to participate in governing their } \\
\text { institution }\end{array}$ & 237 & 3.64 & .036 & .562 \\
\hline $\begin{array}{l}\text { Teaching effectiveness should be the primary criterion for } \\
\text { promotion of faculty }\end{array}$ & 237 & 3.31 & .043 & .659 \\
\hline $\begin{array}{l}\text { Faculty who are members of racial or ethnic minorities are } \\
\text { treated fairly at my institution }\end{array}$ & 234 & 3.28 & .051 & .773 \\
\hline Female faculty members are treated fairly at my institution & 236 & 3.25 & .049 & .757 \\
\hline $\begin{array}{l}\text { My institution effectively meets the educational needs of entering } \\
\text { students }\end{array}$ & 235 & 3.23 & .046 & .701 \\
\hline $\begin{array}{l}\text { Faculty promotions should be based at least in part on formal } \\
\text { student evaluations }\end{array}$ & 238 & 2.95 & .050 & .769 \\
\hline The tenure system in higher education should be preserved. & 237 & 2.81 & .061 & .943 \\
\hline $\begin{array}{l}\text { The administrative function is taking an increasingly heavy share } \\
\text { of available resources at my institution }\end{array}$ & 232 & 2.75 & .057 & .867 \\
\hline $\begin{array}{l}\text { Years of service/advanced degree should be the primary } \\
\text { criterion for promotion of college faculty }\end{array}$ & 236 & 2.48 & .050 & .769 \\
\hline $\begin{array}{l}\text { State or federally mandated assessment requirements have } \\
\text { improved the quality of undergraduate education at my institution }\end{array}$ & 229 & 2.23 & .055 & .828 \\
\hline $\begin{array}{l}\text { Research/publications should be the primary criterion for } \\
\text { promotion of college faculty }\end{array}$ & 238 & 1.91 & .045 & .693 \\
\hline
\end{tabular}




\section{Comparison with National NSOPF Means}

As mentioned above, the previous five sets of questions were drawn from the National Study of Postsecondary Faculty (Abraham et al., 2002; Russell, Fairweather, Hendrickson, \& Zimbler, 1991). The researcher was able, therefore, to compare the responses of the participants in this study with the responses of a national group of faculty members. In order to make these comparisons, the researcher consulted the Public Use Data Analysis System CD-Rom (Zimbler, 2001) to determine the national means for full-time faculty who were surveyed on the various questions. The researcher then conducted onesample t-tests to determine whether the means of the sample statistics from this study differed from the means of the national survey data on each of the 65 questions from which data were available from the NSOPF study. Forty-three of the t-tests indicated significant differences in the means at the $p<.05$ level or lower. The results of all of the t-tests that did not indicate any significant differences between the mean scores are in Appendix A.

The first category dealt with faculty members’ satisfaction with various aspects of their current job. This category accounted for 30 of the t-tests. Twenty-two of the 30 t-tests indicated that the means of the sample from this study and the NSOPF study were significantly different (all less than $p<.05$ level). In 20 of the 22 tests with significant results, the mean scores of the respondents in this study were higher than the mean scores of the national sample. In the other 2 tests, the mean scores of the national survey participants were higher than the respondents in this study. The results of the 22 significant t-tests in this category are listed in Table 33. 
Table 33. Results of one-sample t-tests of means between study participants and NSOPF participants on job satisfaction questions

\begin{tabular}{|c|c|c|c|c|c|c|}
\hline $\begin{array}{c}\text { How satisfied or } \\
\text { dissatisfied do you } \\
\text { personally feel about } \\
\text { each of the following } \\
\text { aspects of your job at } \\
\text { your current institution }\end{array}$ & $\begin{array}{l}\text { Sample } \\
\text { Mean }\end{array}$ & $\begin{array}{l}\text { NSOPF } \\
\text { Mean }\end{array}$ & $\begin{array}{c}\text { Mean } \\
\text { Difference }\end{array}$ & T-score & $\begin{array}{l}\text { Degrees } \\
\quad \text { of } \\
\text { Freedom }\end{array}$ & $\begin{array}{l}\text { 2-tailed } \\
\text { significance }\end{array}$ \\
\hline $\begin{array}{l}\text { Time available for } \\
\text { keeping current in my } \\
\text { field }\end{array}$ & 2.44 & 2.68 & -0.237 & -4.128 & 234 & .000 \\
\hline My work load & 2.87 & 3.06 & -0.187 & -3.343 & 236 & .001 \\
\hline $\begin{array}{l}\text { The authority I have to } \\
\text { make decisions about } \\
\text { the content and } \\
\text { methods in the courses } \\
\text { I teach }\end{array}$ & 3.79 & 3.71 & 0.081 & 2.582 & 234 & .010 \\
\hline $\begin{array}{l}\text { Quality of students } \\
\text { whom I have taught } \\
\text { here }\end{array}$ & 3.08 & 2.95 & 0.126 & 2.567 & 236 & .011 \\
\hline $\begin{array}{l}\text { Spouse employment } \\
\text { opportunities in this } \\
\text { geographic area }\end{array}$ & 3.29 & 3.07 & 0.215 & 4.033 & 213 & .000 \\
\hline $\begin{array}{l}\text { The authority I have to } \\
\text { make decisions about } \\
\text { other aspects of my job }\end{array}$ & 3.36 & 3.14 & 0.219 & 5.017 & 233 & .000 \\
\hline $\begin{array}{l}\text { My overall satisfaction } \\
\text { with my job here }\end{array}$ & 3.46 & 3.21 & 0.252 & 6.162 & 235 & .000 \\
\hline $\begin{array}{l}\text { Spirit of cooperation } \\
\text { between faculty at this } \\
\text { institution }\end{array}$ & 3.08 & 2.82 & .260 & 5.248 & 236 & .000 \\
\hline $\begin{array}{l}\text { Relationship between } \\
\text { administration and } \\
\text { faculty at this institution }\end{array}$ & 2.79 & 2.50 & .288 & 4.830 & 235 & .000 \\
\hline $\begin{array}{l}\text { Interdepartmental } \\
\text { cooperation at this } \\
\text { institution }\end{array}$ & 2.80 & 2.51 & .291 & 5.490 & 235 & .000 \\
\hline $\begin{array}{l}\text { Availability of support } \\
\text { services and equipment } \\
\text { (clerical support, } \\
\text { computers, etc.) }\end{array}$ & 2.87 & 2.58 & .293 & 5.058 & 236 & .000 \\
\hline $\begin{array}{l}\text { Quality of my } \\
\text { colleagues in my } \\
\text { department }\end{array}$ & 3.50 & 3.20 & .300 & 6.788 & 233 & .000 \\
\hline My job security & 3.40 & 3.06 & 0.338 & 6.450 & 235 & .000 \\
\hline $\begin{array}{l}\text { The opportunity for } \\
\text { advancement in rank at } \\
\text { my institution }\end{array}$ & 3.11 & 2.75 & 0.361 & 6.037 & 233 & .000 \\
\hline $\begin{array}{l}\text { Quality of leadership in } \\
\text { my department }\end{array}$ & 3.38 & 2.92 & .457 & 8.270 & 235 & .000 \\
\hline
\end{tabular}


Table 33. (continued)

\begin{tabular}{|l|r|r|r|r|r|r|}
\hline \hline $\begin{array}{l}\text { Quality of chief } \\
\text { administrative officers } \\
\text { at my institution }\end{array}$ & 3.12 & 2.64 & .479 & 7.957 & 235 & .000 \\
\hline $\begin{array}{l}\text { Quality of faculty } \\
\text { leadership at my } \\
\text { institution }\end{array}$ & 3.12 & 2.54 & .579 & 11.028 & 235 & .000 \\
\hline $\begin{array}{l}\text { Quality of my research } \\
\text { facilities and support }\end{array}$ & 2.41 & 1.81 & .597 & 10.693 & 225 & .000 \\
\hline $\begin{array}{l}\text { Institutional mission or } \\
\text { philosophy }\end{array}$ & 3.65 & 3.02 & .633 & 17.867 & 235 & .000 \\
\hline $\begin{array}{l}\text { The mix of teaching, } \\
\text { research, } \\
\text { administration, and } \\
\text { service that I am } \\
\text { required to do }\end{array}$ & 3.09 & 2.45 & .644 & 12.448 & 233 & .000 \\
\hline $\begin{array}{l}\text { Teaching assistance } \\
\text { that I receive }\end{array}$ & 2.69 & 1.62 & 1.065 & 17.679 & 215 & .000 \\
\hline $\begin{array}{l}\text { Research assistance } \\
\text { that I receive }\end{array}$ & 2.34 & 1.14 & 1.198 & 19.544 & 203 & .000 \\
\hline \hline
\end{tabular}

In the second set of questions from the survey in this study, only two questions from the survey could be compared with national NSOPF data. Of those two questions, only one of the one-sample t-tests yielded a significant difference between means. The results of that analysis are in Table 34.

Table 34. Results of one-sample t-tests of means between study participants and NSOPF participants on reasons for leaving current institution

\begin{tabular}{|c|c|r|r|r|r|r|}
\hline $\begin{array}{c}\text { If you were to leave your } \\
\text { current institution, how } \\
\text { likely is it that you would } \\
\text { do so to? }\end{array}$ & $\begin{array}{c}\text { Sample } \\
\text { Mean }\end{array}$ & $\begin{array}{c}\text { NSOPF } \\
\text { Mean }\end{array}$ & $\begin{array}{c}\text { Mean } \\
\text { Difference }\end{array}$ & $\begin{array}{c}\text { Degrees } \\
\text { of } \\
\text { Treedom }\end{array}$ & $\begin{array}{c}\text { 2-tailed } \\
\text { significance }\end{array}$ \\
\hline Retire & 2.16 & 1.28 & .876 & 14.754 & 236 & .000 \\
\hline \hline
\end{tabular}

The next set of questions where comparisons between the NSOPF data and the responses from participants in this study were made dealt with the mix of roles that faculty members would desire if they were to leave their current position. The means of five 
different questions were compared, and three of the one-sample t-tests produced significant differences in the means. Those three questions are listed in Table 35.

Table 35. Results of one-sample t-tests of means between study participants and NSOPF participants on desired mix of roles in new position

\begin{tabular}{|l|c|c|c|c|c|c|}
\hline \hline $\begin{array}{c}\text { If you were to leave your } \\
\text { current institution to } \\
\text { accept another position, } \\
\text { would you want to do } \\
\text { more, less or about the } \\
\text { same amount of the } \\
\text { following as you currently } \\
\text { do? }\end{array}$ & $\begin{array}{c}\text { Sample } \\
\text { Mean }\end{array}$ & $\begin{array}{c}\text { NSOPF } \\
\text { Mean }\end{array}$ & $\begin{array}{c}\text { Mean } \\
\text { Difference }\end{array}$ & T-score & $\begin{array}{c}\text { Freedom } \\
\text { of }\end{array}$ & $\begin{array}{c}\text { 2-tailed } \\
\text { significance }\end{array}$ \\
\hline Administration & 2.28 & 2.18 & .097 & 2.170 & 230 & .031 \\
\hline Teaching & 2.14 & 2.01 & .132 & 3.458 & 232 & .001 \\
\hline Advising & 2.23 & 1.92 & .308 & 8.731 & 231 & .000 \\
\hline \hline
\end{tabular}

Nineteen comparisons between respondents in this study and faculty in the national NSOPF study were made regarding the importance of various elements in a decision to accept another position. Of the 19 one-sample t-tests that were conducted in this category, 9 indicated significant mean differences at the $p<.05$ level or lower. In 4 of the comparisons, the means of the participants from this study were lower than the NSOPF means, and in 5 of the comparisons, the means of respondents in this study were higher. The results of the significant t-tests can be seen in Table 36. 
Table 36. Results of one-sample t-tests of means between study participants and NSOPF participants on importance of characteristics in new position

\begin{tabular}{|l|c|c|c|c|c|c|}
\hline $\begin{array}{c}\text { If you were to leave your } \\
\text { current institution to } \\
\text { accept another position, } \\
\text { how important would each } \\
\text { of the following items be in } \\
\text { your decision to accept } \\
\text { another position? }\end{array}$ & $\begin{array}{c}\text { Sample } \\
\text { Mean }\end{array}$ & $\begin{array}{c}\text { NSOPF } \\
\text { Mean }\end{array}$ & $\begin{array}{c}\text { Mean } \\
\text { Difference }\end{array}$ & T-score & $\begin{array}{c}\text { Degrees } \\
\text { of } \\
\text { Freedom }\end{array}$ & $\begin{array}{c}\text { 2-tailed } \\
\text { significance }\end{array}$ \\
\hline $\begin{array}{l}\text { Good } \\
\text { environment/schools for } \\
\text { my children }\end{array}$ & 1.94 & 2.28 & -.338 & -5.566 & 223 & .000 \\
\hline Good geographic location & 2.44 & 2.55 & -.107 & -2.627 & 234 & .009 \\
\hline A part-time position & 1.30 & 1.41 & -.107 & -2.837 & 227 & .005 \\
\hline Salary Level & 2.44 & 2.53 & -.089 & -2.441 & 237 & .015 \\
\hline $\begin{array}{l}\text { Institutional mission or } \\
\text { philosophy that is } \\
\text { compatible with my own } \\
\text { views }\end{array}$ & 2.66 & 2.58 & .082 & 2.457 & 236 & .015 \\
\hline Affordable Housing & 2.51 & 2.33 & .176 & 4.441 & 234 & .000 \\
\hline A full-time position & 2.74 & 2.56 & .177 & 4.613 & 231 & .000 \\
\hline No pressure to publish & 2.16 & 1.97 & .190 & 4.046 & 237 & .000 \\
\hline Position Level & 2.35 & 2.14 & .206 & 5.204 & 236 & .000 \\
\hline \hline
\end{tabular}

A final set of comparisons between study participants and NSOPF faculty respondents was made regarding questions in which participants were asked to indicate their agreement with several statements. Nine one-sample t-tests were run, and 8 indicated significant differences between the means of the NSOPF study participants and the participants in this study at the $p<.05$ level or less. Four of the comparisons yielded higher NSOPF means and 5 yielded higher means for the respondents in this study. 
Table 37. Results of one-sample t-tests of means between study participants and NSOPF participants on statements regarding academic issues

\begin{tabular}{|l|c|c|c|c|c|c|}
\hline $\begin{array}{l}\text { Please indicate the extent } \\
\text { to which you agree or } \\
\text { disagree with each of the } \\
\text { following statements. }\end{array}$ & $\begin{array}{c}\text { Sample } \\
\text { Mean }\end{array}$ & $\begin{array}{c}\text { NSOPF } \\
\text { Mean }\end{array}$ & $\begin{array}{c}\text { Mean } \\
\text { Difference }\end{array}$ & T-score & $\begin{array}{c}\text { Degrees } \\
\text { of } \\
\text { Freedom }\end{array}$ & $\begin{array}{c}\text { 2-tailed } \\
\text { significance }\end{array}$ \\
\hline $\begin{array}{l}\text { State or federally } \\
\text { mandated assessment } \\
\text { requirements have } \\
\text { improved the quality of } \\
\text { undergraduate education } \\
\text { at my institution }\end{array}$ & 2.23 & 3.05 & -.823 & -15.046 & 228 & .000 \\
\hline $\begin{array}{l}\text { Years of service/advanced } \\
\text { degree should be the } \\
\text { primary criterion for } \\
\text { promotion of college } \\
\text { faculty }\end{array}$ & 2.48 & 3.06 & -.581 & -11.614 & 235 & .000 \\
\hline $\begin{array}{l}\text { Research/publications } \\
\text { should be the primary } \\
\text { criterion for promotion of } \\
\text { college faculty }\end{array}$ & 1.91 & 2.12 & -.212 & -4.726 & 237 & .000 \\
\hline $\begin{array}{l}\text { The tenure system in } \\
\text { higher education should } \\
\text { be preserved. }\end{array}$ & 2.81 & 3.02 & -.206 & -3.358 & 236 & .001 \\
\hline $\begin{array}{l}\text { Teaching effectiveness } \\
\text { should be the primary } \\
\text { criterion for promotion of } \\
\text { faculty }\end{array}$ & 3.31 & 3.21 & .098 & 2.289 & 236 & .023 \\
\hline $\begin{array}{l}\text { Female faculty members } \\
\text { are treated fairly at my } \\
\text { institution }\end{array}$ & 3.25 & 3.08 & .174 & 3.535 & 235 & .000 \\
\hline $\begin{array}{l}\text { Faculty who are members } \\
\text { of racial or ethnic } \\
\text { minorities are treated fairly } \\
\text { at my institution }\end{array}$ & 3.28 & 3.08 & .202 & 3.996 & 233 & .000 \\
\hline $\begin{array}{l}\text { If I had it to do over again, } \\
\text { I would choose an } \\
\text { academic career }\end{array}$ & 3.78 & 3.31 & .472 & 14.149 & 237 & .000 \\
\hline \hline
\end{tabular}

\section{Comparisons of NSOPF Responses between Independent Variables in this Study}

The researcher conducted multiple one-way ANOVAs using participant responses on the 70 NSOPF items as dependent variables and the list of independent variables described as "general characteristics of the sample" earlier in this chapter. In the cases where there were more than two comparisons within a variable, a Tukey post hoc test was run to determine which mean differences were statistically significant. The variables considered in this 
analysis were: gender, age, institution, church membership requirement, type of alma mater, highest degree earned, academic rank, years teaching (career), years teaching (institution), expected age of retirement and academic field. The results as they pertain to each independent variable will be described below.

\section{Gender}

A one-way ANOVA was performed to determine whether there were any observed differences between females and males with regard to the questions of the NSOPF. Statistically significant differences in means at the .05 level were found on 17 of the 70 NSOPF items. In 14 of the 17 cases, the female respondents had statistically significant higher scores than the male respondents. On three questions the scores of the male respondents were significantly higher than those of the female respondents. Those three questions were: 1) If you were to leave your current institution, how likely is it that you would do so to: Leave for another Christian College?; 2) If you were to leave your current institution to accept another position, how important would each of the following items be in your decision to accept another position: A full-time position; and 3) Please indicate the extent to which you agree or disagree with each of the following statements: Female faculty members are treated fairly at my institution. The results for all 17 questions are displayed in Table 38. Descriptive statistics for females and males on all 70 questions can be found in Appendix A. 
Table 38. ANOVA results of NSOPF questions by gender

\begin{tabular}{|c|c|c|c|c|c|c|}
\hline $\begin{array}{l}\text { How satisfied or dissatisfied do you } \\
\text { personally feel about each of the } \\
\text { following aspects of your job at your } \\
\text { current institution }\end{array}$ & Source & $\begin{array}{c}\text { Sum of } \\
\text { Squares }\end{array}$ & $d f$ & $\begin{array}{c}\text { Mean } \\
\text { Square }\end{array}$ & $F$ & Sig. \\
\hline \multirow{3}{*}{ Overall reputation of the institution } & Between Groups & 9.085 & 1 & 9.085 & 16.419 & .000 \\
\hline & Within Groups & 127.260 & 230 & .553 & & \\
\hline & Total & 136.345 & 231 & & & \\
\hline \multirow{3}{*}{ Reputation of my department } & Between Groups & 3.966 & 1 & 3.966 & 6.494 & .011 \\
\hline & Within Groups & 142.289 & 233 & .611 & & \\
\hline & Total & 146.255 & 234 & & & \\
\hline \multirow{3}{*}{ Institutional mission or philosophy } & Between Groups & 1.407 & 1 & 1.407 & 4.831 & .029 \\
\hline & Within Groups & 67.555 & 232 & .291 & & \\
\hline & Total & 68.962 & 233 & & & \\
\hline \multirow{3}{*}{$\begin{array}{l}\text { Quality of chief administrative officers } \\
\text { at my institution }\end{array}$} & Between Groups & 4.220 & 1 & 4.220 & 5.024 & .026 \\
\hline & Within Groups & 194.891 & 232 & .840 & & \\
\hline & Total & 199.111 & 233 & & & \\
\hline \multirow{3}{*}{$\begin{array}{l}\text { Quality of faculty leadership at my } \\
\text { institution }\end{array}$} & Between Groups & 7.632 & 1 & 7.632 & 12.380 & .001 \\
\hline & Within Groups & 143.018 & 232 & .616 & & \\
\hline & Total & 150.650 & 233 & & & \\
\hline \multirow{3}{*}{$\begin{array}{l}\text { Quality of students whom I have } \\
\text { taught here }\end{array}$} & Between Groups & 4.879 & 1 & 4.879 & 9.065 & .003 \\
\hline & Within Groups & 125.419 & 233 & .538 & & \\
\hline & Total & 130.298 & 234 & & & \\
\hline \multirow{3}{*}{$\begin{array}{l}\text { My overall satisfaction with my job } \\
\text { here }\end{array}$} & Between Groups & 2.519 & 1 & 2.519 & 6.526 & .011 \\
\hline & Within Groups & 89.554 & 232 & .386 & & \\
\hline & Total & 92.073 & 233 & & & \\
\hline $\begin{array}{l}\text { If you were to leave your current } \\
\text { institution, how likely is it that you } \\
\text { would do so to? }\end{array}$ & Source & $\begin{array}{c}\text { Sum of } \\
\text { Squares }\end{array}$ & $d f$ & $\begin{array}{c}\text { Mean } \\
\text { Square }\end{array}$ & $F$ & Sig. \\
\hline \multirow{3}{*}{ Leave for another Christian College } & Between Groups & 3.041 & 1 & 3.041 & 6.897 & .009 \\
\hline & Within Groups & 101.852 & 231 & .441 & & \\
\hline & Total & 104.893 & 232 & & & \\
\hline $\begin{array}{l}\text { If you were to leave your current } \\
\text { institution to accept another position, } \\
\text { how important would each of the } \\
\text { following items be in your decision to } \\
\text { accept another position? }\end{array}$ & Source & $\begin{array}{c}\text { Sum of } \\
\text { Squares }\end{array}$ & $d f$ & $\begin{array}{c}\text { Mean } \\
\text { Square }\end{array}$ & $F$ & Sig. \\
\hline \multirow{3}{*}{ Salary Level } & Between Groups & 1.861 & 1 & 1.861 & 6.032 & .015 \\
\hline & Within Groups & 72.186 & 234 & .308 & & \\
\hline & Total & 74.047 & 235 & & & \\
\hline \multirow{3}{*}{ Opportunities for advancement } & Between Groups & 1.978 & 1 & 1.978 & 4.347 & .038 \\
\hline & Within Groups & 106.442 & 234 & .455 & & \\
\hline & Total & 108.419 & 235 & & & \\
\hline
\end{tabular}


Table 38. (continued)

\begin{tabular}{|c|c|c|c|c|c|c|}
\hline \multirow{3}{*}{ Benefits } & Between Groups & 1.560 & 1 & 1.560 & 6.061 & .015 \\
\hline & Within Groups & 60.249 & 234 & .257 & & \\
\hline & Total & 61.809 & 235 & & & \\
\hline \multirow{3}{*}{$\begin{array}{l}\text { Good instructional facilities and } \\
\text { equipment }\end{array}$} & Between Groups & 2.927 & 1 & 2.927 & 9.571 & .002 \\
\hline & Within Groups & 71.260 & 233 & .306 & & \\
\hline & Total & 74.187 & 234 & & & \\
\hline \multirow{3}{*}{ Excellent Students } & Between Groups & 1.772 & 1 & 1.772 & 5.603 & .019 \\
\hline & Within Groups & 74.004 & 234 & .316 & & \\
\hline & Total & 75.775 & 235 & & & \\
\hline \multirow{3}{*}{ Good geographic location } & Between Groups & 1.703 & 1 & 1.703 & 4.478 & .035 \\
\hline & Within Groups & 87.876 & 231 & .380 & & \\
\hline & Total & 89.579 & 232 & & & \\
\hline \multirow{3}{*}{ A full-time position } & Between Groups & 1.569 & 1 & 1.569 & 4.631 & .032 \\
\hline & Within Groups & 77.253 & 228 & .339 & & \\
\hline & Total & 78.822 & 229 & & & \\
\hline \multirow{3}{*}{ A part-time position } & Between Groups & 5.746 & 1 & 5.746 & 18.987 & .000 \\
\hline & Within Groups & 67.793 & 224 & .303 & & \\
\hline & Total & 73.540 & 225 & & & \\
\hline $\begin{array}{l}\text { Please indicate the extent to which } \\
\text { you agree or disagree with each of } \\
\text { the following statements. }\end{array}$ & Source & $\begin{array}{c}\text { Sum of } \\
\text { Squares }\end{array}$ & $d f$ & $\begin{array}{c}\text { Mean } \\
\text { Square }\end{array}$ & $F$ & Sig. \\
\hline \multirow{3}{*}{$\begin{array}{l}\text { Female faculty members are treated } \\
\text { fairly at my institution }\end{array}$} & Between Groups & 5.277 & 1 & 5.277 & 9.539 & .002 \\
\hline & Within Groups & 128.347 & 232 & .553 & & \\
\hline & Total & 133.624 & 233 & & & \\
\hline
\end{tabular}

\section{Age}

To determine whether there were differences between age groups on the questions of the NSOPF, one-way ANOVA tests were performed. As mentioned above, because the category “over 80” had only one respondent, it was collapsed into the “70-79” age group, creating a new range called "70 and above.” It was determined that there were differences in means between groups on 22 of the 70 questions of the NSOPF. A Tukey post hoc test of pairwise comparisons was performed to determine which of the means differed from each other. 
Many of the significant differences between groups indicated higher mean scores for older faculty. On several questions after the prompt "How satisfied or dissatisfied to you personally feel about each of the following aspects of your job at your current institution" the 60-69 year old age group answered more favorably than those faculty members in the 30-39 year old age range. Those questions were: 1) Overall reputation of the institution; 2) Reputation of my department; 3) Institutional mission or philosophy; 4) Interdepartmental cooperation at this institution; and 5) Spirit of cooperation between faculty at this institution (60-69 also scored higher than 40-49 on this question). Respondents in the 60-69 year old age range also scored higher than respondents in the 50-59 year old age range on the question Relationship between administration and faculty at this institution.

The ANOVA analysis indicated significant mean differences in three questions in this category at the .05 level or below ("How satisfied or dissatisfied to you personally feel about each of the following aspects of your job at your current institution”) however a Tukey post hoc analysis did not indicate the categories that created the significant response. A LSD post hoc analysis was conducted to determine which comparisons were demonstrating significant differences. This analysis indicated that the respondents in their 60s and those who are 70 or older gave stronger responses than those respondents in their 30s and 50s on the questions Quality of students whom I have taught here and My overall satisfaction with my job here. Respondents in their 60s and those 70 and over also scored significantly higher than those in their 30s, 40s, and 50s on Teaching assistance that I receive.

The question "If you were to leave your current institution, how likely is it that you would do so to...” produced mixed results. The response Leave to retire showed older respondents answering more favorably than younger faculty. Those in their 50s, 60s, and 70s 
scored higher than those in their 20s and 30s. Respondents in their 60s also scored significantly higher than respondents in their 40 s or 50 s.

Two other questions with this prompt, however, received stronger support from younger participants. Respondents in their 20s, 30s, 40s and 50s indicated that they would be more likely to Accept employment at another Christian college or university than those in their 60s. Similarly, on the question Accept employment at a secular college or university respondents in their 20s, 30s, and 40s responded more favorably than those in their 60s. Respondents in their 20s also scored significantly higher than those in their 40s and 50s on this question.

Older faculty members also showed significantly higher mean scores on the prompt "If you were to leave your current institution to accept another position, would you want to do more, less or about the same amount of the following as you currently do" than their younger counterparts. Regarding Service, faculty members over 70 scored higher than those in the 20-29 year old age range and the 50-59 year old age range. Those participants in their 60s scored higher than those 70 or older regarding their responses to Administration.

The final prompt in which there were significantly different responses with regard to age was "If you were to leave your current institution to accept another position, how important would each of the following items be in your decision to accept another position?” The responses in this category indicated that younger participants had stronger opinions regarding the importance of various factors than older participants. On the response Job security, faculty members in their 30s, 40s, and 50s scored higher than those in their 60s. Respondents in the 40-49 year old age range also scored higher than those in their 50s and 60s on the issue of Opportunities for advancement. Participants in their 20s, 30s, 40s and 
50s all scored significantly higher than those in their 60s with regard to Good job for my spouse. The issue of Good environment/schools for my children received stronger responses from faculty members in their 30s and 40s than those in the 50-59, 60-69, and 70 or over age ranges.

On this same prompt, those respondents in their 20s, 30s, 40s, and 50s had higher mean scores on the importance of a Full-time position than those in their 60s, while the respondents in their 60s responded more favorably to Part-time position than those in their 40s or 50s. Finally, as above, the Tukey post hoc analysis was not definitive regarding the prompt No pressure to publish, however the LSD post hoc analysis revealed that respondents in the 60-69 and 70 and above age ranges scored significantly higher than those in their 20s, 30s, and 50s.

The ANOVA results for statistically significant comparisons are displayed in Table 39. Descriptive statistics for all participants by age are in Appendix A. 
Table 39. ANOVA results of NSOPF questions by age

\begin{tabular}{|c|c|c|c|c|c|c|}
\hline $\begin{array}{l}\text { How satisfied or dissatisfied do you } \\
\text { personally feel about each of the } \\
\text { following aspects of your job at your } \\
\text { current institution }\end{array}$ & Source & $\begin{array}{l}\text { Sum of } \\
\text { Squares }\end{array}$ & $d f$ & $\begin{array}{c}\text { Mean } \\
\text { Square }\end{array}$ & $F$ & Sig. \\
\hline \multirow{3}{*}{ Overall reputation of the institution } & Between Groups & 9.934 & 5 & 1.987 & 3.511 & .004 \\
\hline & Within Groups & 128.461 & 227 & .566 & & \\
\hline & Total & 138.395 & 232 & & & \\
\hline \multirow{3}{*}{ Reputation of my department } & Between Groups & 8.965 & 5 & 1.793 & 2.964 & .013 \\
\hline & Within Groups & 139.136 & 230 & .605 & & \\
\hline & Total & 148.102 & 235 & & & \\
\hline \multirow{3}{*}{ Institutional mission or philosophy } & Between Groups & 3.944 & 5 & .789 & 2.773 & .019 \\
\hline & Within Groups & 65.136 & 229 & .284 & & \\
\hline & Total & 69.081 & 234 & & & \\
\hline \multirow{3}{*}{$\begin{array}{l}\text { Relationship between administration } \\
\text { and faculty at this institution }\end{array}$} & Between Groups & 10.497 & 5 & 2.099 & 2.617 & .025 \\
\hline & Within Groups & 183.699 & 229 & .802 & & \\
\hline & Total & 194.196 & 234 & & & \\
\hline \multirow{3}{*}{$\begin{array}{l}\text { Interdepartmental cooperation at this } \\
\text { institution }\end{array}$} & Between Groups & 7.388 & 5 & 1.478 & 2.334 & .043 \\
\hline & Within Groups & 144.995 & 229 & .633 & & \\
\hline & Total & 152.383 & 234 & & & \\
\hline \multirow{3}{*}{$\begin{array}{l}\text { Spirit of cooperation between faculty } \\
\text { at this institution }\end{array}$} & Between Groups & 8.963 & 5 & 1.793 & 3.238 & .008 \\
\hline & Within Groups & 127.342 & 230 & .554 & & \\
\hline & Total & 136.305 & 235 & & & \\
\hline \multirow{3}{*}{$\begin{array}{l}\text { Quality of students whom I have } \\
\text { taught here }\end{array}$} & Between Groups & 8.437 & 5 & 1.687 & 3.096 & .010 \\
\hline & Within Groups & 125.338 & 230 & .545 & & \\
\hline & Total & 133.775 & 235 & & & \\
\hline \multirow{3}{*}{ Teaching assistance that I receive } & Between Groups & 10.325 & 5 & 2.065 & 2.729 & .021 \\
\hline & Within Groups & 158.168 & 209 & .757 & & \\
\hline & Total & 168.493 & 214 & & & \\
\hline \multirow{3}{*}{$\begin{array}{l}\text { Spouse employment opportunities in } \\
\text { this geographic area }\end{array}$} & Between Groups & 6.680 & 5 & 1.336 & 2.259 & .050 \\
\hline & Within Groups & 122.418 & 207 & .591 & & \\
\hline & Total & 129.099 & 212 & & & \\
\hline \multirow{3}{*}{$\begin{array}{l}\text { My overall satisfaction with my job } \\
\text { here }\end{array}$} & Between Groups & 5.102 & 5 & 1.020 & 2.736 & .020 \\
\hline & Within Groups & 85.409 & 229 & .373 & & \\
\hline & Total & 90.511 & 234 & & & \\
\hline $\begin{array}{l}\text { If you were to leave your current } \\
\text { institution, how likely is it that you } \\
\text { would do so to? }\end{array}$ & Source & $\begin{array}{l}\text { Sum of } \\
\text { Squares }\end{array}$ & $d f$ & $\begin{array}{c}\text { Mean } \\
\text { Square }\end{array}$ & $F$ & Sig. \\
\hline \multirow{3}{*}{ Leave to Retire } & Between Groups & 42.394 & 5 & 8.479 & $\begin{array}{r}12.70 \\
5\end{array}$ & .000 \\
\hline & Within Groups & 153.487 & 230 & .667 & & \\
\hline & Total & 195.881 & 235 & & & \\
\hline \multirow{3}{*}{$\begin{array}{l}\text { Accept employment at another } \\
\text { Christian college or university }\end{array}$} & Between Groups & 16.186 & 5 & 3.237 & 8.314 & .000 \\
\hline & Within Groups & 88.776 & 228 & .389 & & \\
\hline & Total & 104.962 & 233 & & & \\
\hline
\end{tabular}


Table 39. (continued)

\begin{tabular}{|c|c|c|c|c|c|c|}
\hline \multirow{3}{*}{$\begin{array}{l}\text { Accept employment at a secular } \\
\text { college or university }\end{array}$} & Between Groups & 12.278 & 5 & 2.456 & 6.214 & .000 \\
\hline & Within Groups & 89.713 & 227 & .395 & & \\
\hline & Total & 101.991 & 232 & & & \\
\hline $\begin{array}{l}\text { If you were to leave your current } \\
\text { institution to accept another position, } \\
\text { would you want to do more, less or } \\
\text { about the same amount of the } \\
\text { following as you currently do? }\end{array}$ & Source & $\begin{array}{l}\text { Sum of } \\
\text { Squares }\end{array}$ & $d f$ & $\begin{array}{l}\text { Mean } \\
\text { Square }\end{array}$ & $F$ & Sig. \\
\hline \multirow{3}{*}{ Service } & Between Groups & 4.610 & 5 & .922 & 3.118 & .010 \\
\hline & Within Groups & 67.132 & 227 & .296 & & \\
\hline & Total & 71.742 & 232 & & & \\
\hline \multirow{3}{*}{ Administration } & Between Groups & 7.315 & 5 & 1.463 & 3.315 & .007 \\
\hline & Within Groups & 98.876 & 224 & .441 & & \\
\hline & Total & 106.191 & 229 & & & \\
\hline $\begin{array}{l}\text { If you were to leave your current } \\
\text { institution to accept another position, } \\
\text { how important would each of the } \\
\text { following items be in your decision to } \\
\text { accept another position? }\end{array}$ & Source & $\begin{array}{l}\text { Sum of } \\
\text { Squares }\end{array}$ & $d f$ & $\begin{array}{l}\text { Mean } \\
\text { Square }\end{array}$ & $F$ & Sig. \\
\hline \multirow{3}{*}{ Job Security } & Between Groups & 8.772 & 5 & 1.754 & 4.928 & .000 \\
\hline & Within Groups & 81.885 & 230 & .356 & & \\
\hline & Total & 90.657 & 235 & & & \\
\hline \multirow{3}{*}{ Opportunities for advancement } & Between Groups & 8.006 & 5 & 1.601 & 3.666 & .003 \\
\hline & Within Groups & 100.889 & 231 & .437 & & \\
\hline & Total & 108.895 & 236 & & & \\
\hline \multirow{3}{*}{ No pressure to publish } & Between Groups & 7.197 & 5 & 1.439 & 2.849 & .016 \\
\hline & Within Groups & 116.710 & 231 & .505 & & \\
\hline & Total & 123.907 & 236 & & & \\
\hline \multirow{3}{*}{ Good job for my spouse } & Between Groups & 12.393 & 5 & 2.479 & 3.648 & .003 \\
\hline & Within Groups & 149.465 & 220 & .679 & & \\
\hline & Total & 161.858 & 225 & & & \\
\hline \multirow{3}{*}{$\begin{array}{l}\text { Good environment/schools for my } \\
\text { children }\end{array}$} & Between Groups & 35.492 & 5 & 7.098 & 10.434 & .000 \\
\hline & Within Groups & 147.629 & 217 & .680 & & \\
\hline & Total & 183.121 & 222 & & & \\
\hline \multirow{3}{*}{ A full-time position } & Between Groups & 17.719 & 5 & 3.544 & 13.035 & .000 \\
\hline & Within Groups & 61.173 & 225 & .272 & & \\
\hline & Total & 78.892 & 230 & & & \\
\hline \multirow{3}{*}{ A part-time position } & Between Groups & 4.930 & 5 & .986 & 3.154 & .009 \\
\hline & Within Groups & 69.097 & 221 & .313 & & \\
\hline & Total & 74.026 & 226 & & & \\
\hline
\end{tabular}




\section{Institution}

The data were analyzed using one-way ANOVA techniques to determine whether there were differences between responses from faculty at the various institutions on the NSOPF questions. It was determined that there were differences in means between institutions on 21 of the 70 questions. A Tukey post hoc test of pairwise comparisons was performed to determine which of the means differed from each other. On 17 of the 21 comparisons, the Tukey post hoc test indicated the different mean comparisons. On the other 4 comparisons, the LSD post hoc method was used to determine the significant differences.

For the prompt "How satisfied or dissatisfied do you personally feel about each of the following aspects of your job at your current institution,” significant differences were found on 13 of the questions. On My Benefits, participants from Institution 1 scored significantly lower than those from Institutions 3, 6, and 9 and faculty at Institution 4 also scored significantly lower than those at Institution 9. On Availability of support services and equipment respondents from Institutions 4 and 5 scored significantly higher than their counterparts at Institution 8. Regarding Overall reputation of the institution, Institution 5's faculty members scored higher than those from Institutions 3, 4, 6, and 10. On Quality of leadership in my department, participants from Institution 5 scored higher than those at Institution 3. Regarding Quality of chief administrative officers at my institution, respondents from Institution 9 scored higher than respondents at Institution 7.

The question Quality of my colleagues in my department was one in which the LSD post hoc analysis was used to determine that faculty at Institutions 2 and 5 scored significantly higher than those at Institutions 3, 7, and 10, participants from Institutions 6 and 
9 scored significantly higher than those at Institution 3, and Institution 9's faculty scored significantly higher than faculty at Institution 10 .

Responses from Institution 9 were significantly higher than those from Institution 3 on both Quality of faculty leadership at my institution and Relationship between administration and faculty at this institution. The faculty from Institution 10 scored significantly lower than those at both Institutions 2 and 9 on Interdepartmental cooperation at this institution and lower than those at Institutions 2, 5, and 10 on Spirit of cooperation between faculty at this institution. On the question Quality of students whom I have taught here participants from Institution 5 scored significantly higher than those from Institutions 2, 3, 6, 9, and 10. Institution 5's faculty also scored higher than those at Institution 2 on Teaching assistance that I receive. Finally, on the last question with this prompt, the respondents from Institution 7 scored significantly higher than those of Institution 10 on the question Spouse employment opportunities in this geographic area.

In the next category, the only significant difference between comparison means was for the question If you were to leave your current institution, how likely is it that you would do so to return to school? On that question, participants from Institutions 3 and 4 scored higher than those at Institution 5, participants from Institution 4 scored higher than participants at Institution 6, and the respondents from Institution 10 scored significantly higher than those at Institutions 1, 5, 6, 7, 8, and 9. This question was another one in which the LSD post hoc analysis was used.

The next category of questions was in response to the prompt "If you were to leave your current institution to accept another position, how important would each of the following items be in your decision to accept another position?” On the response 
Opportunities for advancement, Institution 6's faculty scored significantly lower than those from Institutions 3, 5, and 10 and on the response Excellent students, participants from Institution 10 scored lower than those from Institutions 1, 3, and 5. The response Good job for my spouse was the third for which the LSD post hoc analysis was used. This analysis indicated that faculty at Institution 2 scored significantly lower than those at Institutions 4, 5, 7, 9, and 10, faculty from Institution 3 scored lower than those working at Institutions 4, 5, and 9, and faculty from Institution 8 scored lower than those employed at Institutions 4, 5, and 9. Finally in this category, on the question Good geographic location Institution 7’s participants scored significantly lower than those from Institutions 3 and 5.

The final category of questions in this section of comparisons by institution was in response to the prompt "Please indicate the extent to which you agree or disagree with each of the following statements.” On the question The tenure system in higher education should be preserved respondents from Institution 1 scored significantly higher than those from Institution 7. The question The administrative function is taking an increasingly heavy share of available resources at my institution required a LSD post hoc analysis to determine that participants from Institutions 1, 4, 6, and 8 scored significantly higher than those from Institutions 5, 9, and 10 and that respondents from Institutions 3 and 7 scored higher than respondents from Institutions 5 and 10. And finally, on the question My institution effectively meets the educational needs of entering students respondents from Institution 5 scored higher than those from Institutions 3, 9, and 10. The ANOVA results for statistically significant comparisons are displayed in Table 40. Descriptive statistics for all participants by Institution are in Appendix A. 
Table 40. ANOVA results of NSOPF questions by institution

\begin{tabular}{|c|c|c|c|c|c|c|}
\hline $\begin{array}{l}\text { How satisfied or dissatisfied do you } \\
\text { personally feel about each of the } \\
\text { following aspects of your job at your } \\
\text { current institution }\end{array}$ & Source & $\begin{array}{l}\text { Sum of } \\
\text { Squares }\end{array}$ & $d f$ & $\begin{array}{c}\text { Mean } \\
\text { Square }\end{array}$ & $F$ & Sig. \\
\hline \multirow{3}{*}{ My Benefits } & Between Groups & 26.074 & 9 & 2.897 & 4.080 & .000 \\
\hline & Within Groups & 159.075 & 224 & .710 & & \\
\hline & Total & 185.150 & 233 & & & \\
\hline \multirow{3}{*}{$\begin{array}{l}\text { Availability of support services and } \\
\text { equipment (clerical support, } \\
\text { computers, etc.) }\end{array}$} & Between Groups & 16.730 & 9 & 1.859 & 2.458 & .011 \\
\hline & Within Groups & 170.181 & 225 & .756 & & \\
\hline & Total & 186.911 & 234 & & & \\
\hline \multirow{3}{*}{ Overall reputation of the institution } & Between Groups & 18.951 & 9 & 2.106 & 3.915 & .000 \\
\hline & Within Groups & 119.394 & 222 & .538 & & \\
\hline & Total & 138.345 & 231 & & & \\
\hline \multirow{3}{*}{$\begin{array}{l}\text { Quality of leadership in my } \\
\text { department }\end{array}$} & Between Groups & 13.392 & 9 & 1.488 & 2.143 & .027 \\
\hline & Within Groups & 155.514 & 224 & .694 & & \\
\hline & Total & 168.906 & 233 & & & \\
\hline \multirow{3}{*}{$\begin{array}{l}\text { Quality of chief administrative officers } \\
\text { at my institution }\end{array}$} & Between Groups & 15.506 & 9 & 1.723 & 2.093 & .031 \\
\hline & Within Groups & 184.379 & 224 & .823 & & \\
\hline & Total & 199.885 & 233 & & & \\
\hline \multirow{3}{*}{$\begin{array}{l}\text { Quality of my colleagues in my } \\
\text { department }\end{array}$} & Between Groups & 9.455 & 9 & 1.051 & 2.416 & .012 \\
\hline & Within Groups & 96.540 & 222 & .435 & & \\
\hline & Total & 105.996 & 231 & & & \\
\hline \multirow{3}{*}{$\begin{array}{l}\text { Quality of faculty leadership at my } \\
\text { institution }\end{array}$} & Between Groups & 14.208 & 9 & 1.579 & 2.565 & .008 \\
\hline & Within Groups & 138.456 & 225 & .615 & & \\
\hline & Total & 152.664 & 234 & & & \\
\hline \multirow{3}{*}{$\begin{array}{l}\text { Relationship between administration } \\
\text { and faculty at this institution }\end{array}$} & Between Groups & 15.315 & 9 & 1.702 & 2.111 & .030 \\
\hline & Within Groups & 180.570 & 224 & .806 & & \\
\hline & Total & 195.885 & 233 & & & \\
\hline \multirow{3}{*}{$\begin{array}{l}\text { Interdepartmental cooperation at this } \\
\text { institution }\end{array}$} & Between Groups & 14.988 & 9 & 1.665 & 2.665 & .006 \\
\hline & Within Groups & 140.612 & 225 & .625 & & \\
\hline & Total & 155.600 & 234 & & & \\
\hline \multirow{3}{*}{$\begin{array}{l}\text { Spirit of cooperation between faculty } \\
\text { at this institution }\end{array}$} & Between Groups & 15.471 & 9 & 1.719 & 3.171 & .001 \\
\hline & Within Groups & 121.993 & 225 & .542 & & \\
\hline & Total & 137.464 & 234 & & & \\
\hline \multirow{3}{*}{$\begin{array}{l}\text { Quality of students whom I have } \\
\text { taught here }\end{array}$} & Between Groups & 15.767 & 9 & 1.752 & 3.349 & .001 \\
\hline & Within Groups & 117.697 & 225 & .523 & & \\
\hline & Total & 133.464 & 234 & & & \\
\hline \multirow{3}{*}{ Teaching assistance that I receive } & Between Groups & 18.398 & 9 & 2.044 & 2.804 & .004 \\
\hline & Within Groups & 150.195 & 206 & .729 & & \\
\hline & Total & 168.593 & 215 & & & \\
\hline \multirow{3}{*}{$\begin{array}{l}\text { Spouse employment opportunities in } \\
\text { this geographic area }\end{array}$} & Between Groups & 13.057 & 9 & 1.451 & 2.529 & .009 \\
\hline & Within Groups & 116.474 & 203 & .574 & & \\
\hline & Total & 129.531 & 212 & & & \\
\hline
\end{tabular}


Table 40. (continued)

\begin{tabular}{|c|c|c|c|c|c|c|}
\hline $\begin{array}{c}\text { If you were to leave your current } \\
\text { institution, how likely is it that you } \\
\text { would do so to? }\end{array}$ & Source & $\begin{array}{l}\text { Sum of } \\
\text { Squares }\end{array}$ & $d f$ & $\begin{array}{l}\text { Mean } \\
\text { Square }\end{array}$ & $F$ & Sig. \\
\hline \multirow{3}{*}{ Return to school as a student } & Between Groups & 3.837 & 9 & .426 & 2.102 & .030 \\
\hline & Within Groups & 45.228 & 223 & .203 & & \\
\hline & Total & 49.064 & 232 & & & \\
\hline $\begin{array}{l}\text { If you were to leave your current } \\
\text { institution to accept another position, } \\
\text { how important would each of the } \\
\text { following items be in your decision to } \\
\text { accept another position? }\end{array}$ & Source & $\begin{array}{l}\text { Sum of } \\
\text { Squares }\end{array}$ & $d f$ & $\begin{array}{l}\text { Mean } \\
\text { Square }\end{array}$ & $F$ & Sig. \\
\hline \multirow{3}{*}{ Opportunities for advancement } & Between Groups & 8.225 & 9 & .914 & 2.061 & .034 \\
\hline & Within Groups & 100.194 & 226 & .443 & & \\
\hline & Total & 108.419 & 235 & & & \\
\hline \multirow{3}{*}{ Excellent Students } & Between Groups & 7.256 & 9 & .806 & 2.665 & .006 \\
\hline & Within Groups & 68.371 & 226 & .303 & & \\
\hline & Total & 75.627 & 235 & & & \\
\hline \multirow{3}{*}{ Good job for my spouse } & Between Groups & 14.195 & 9 & 1.577 & 2.295 & .018 \\
\hline & Within Groups & 148.464 & 216 & .687 & & \\
\hline & Total & 162.659 & 225 & & & \\
\hline \multirow{3}{*}{ Good geographic location } & Between Groups & 9.365 & 9 & 1.041 & 2.832 & .004 \\
\hline & Within Groups & 82.297 & 224 & .367 & & \\
\hline & Total & 91.662 & 233 & & & \\
\hline $\begin{array}{l}\text { Please indicate the extent to which } \\
\text { you agree or disagree with each of } \\
\text { the following statements. }\end{array}$ & Source & $\begin{array}{l}\text { Sum of } \\
\text { Squares }\end{array}$ & $d f$ & $\begin{array}{l}\text { Mean } \\
\text { Square }\end{array}$ & $F$ & Sig. \\
\hline \multirow{3}{*}{$\begin{array}{l}\text { The tenure system in higher } \\
\text { education should be preserved. }\end{array}$} & Between Groups & 18.181 & 9 & 2.020 & 2.390 & .013 \\
\hline & Within Groups & 190.202 & 225 & .845 & & \\
\hline & Total & 208.383 & 234 & & & \\
\hline \multirow{3}{*}{$\begin{array}{l}\text { The administrative function is taking } \\
\text { an increasingly heavy share of } \\
\text { available resources at my institution }\end{array}$} & Between Groups & 19.900 & 9 & 2.211 & 3.193 & .001 \\
\hline & Within Groups & 153.035 & 221 & .692 & & \\
\hline & Total & 172.935 & 230 & & & \\
\hline \multirow{3}{*}{$\begin{array}{l}\text { My institution effectively meets the } \\
\text { educational needs of entering } \\
\text { students }\end{array}$} & Between Groups & 10.475 & 9 & 1.164 & 2.494 & .010 \\
\hline & Within Groups & 104.520 & 224 & .467 & & \\
\hline & Total & 114.996 & 233 & & & \\
\hline
\end{tabular}

\section{Church membership requirement}

A one-way ANOVA was performed to determine whether there were any observed differences between participants at institutions with and without a church membership 
requirement with regard to the questions of the NSOPF. Statistically significant differences in means at the .05 level were found on 9 of the 70 questions in the NSOPF. In all but one case, those faculty members who work at institutions that require their faculty members to belong to a particular church or denomination had statistically significant higher scores than those at institutions that do not require membership in a particular denomination. On the question The administrative function is taking an increasingly heavy share of available resources at my institution this trend was reversed, and faculty who work at institutions where membership in a particular denomination is not required had significantly higher scores than those at institutions with a church membership requirement. The results are displayed in Table 41. Descriptive statistics for all 70 questions with regard to this criterion can be found in Appendix A. 
Table 41. ANOVA results of NSOPF questions by church membership requirement

\begin{tabular}{|c|c|c|c|c|c|c|}
\hline $\begin{array}{l}\text { How satisfied or dissatisfied do you } \\
\text { personally feel about each of the } \\
\text { following aspects of your job at your } \\
\text { current institution }\end{array}$ & Source & $\begin{array}{c}\text { Sum of } \\
\text { Squares }\end{array}$ & $d f$ & $\begin{array}{c}\text { Mean } \\
\text { Square }\end{array}$ & $F$ & Sig. \\
\hline \multirow{3}{*}{ Overall reputation of the institution } & Between Groups & 8.829 & 1 & 8.829 & 15.803 & .000 \\
\hline & Within Groups & 129.615 & 232 & .559 & & \\
\hline & Total & 138.444 & 233 & & & \\
\hline \multirow{3}{*}{ Reputation of my department } & Between Groups & 7.370 & 1 & 7.370 & 12.271 & .001 \\
\hline & Within Groups & 141.145 & 235 & .601 & & \\
\hline & Total & 148.515 & 236 & & & \\
\hline \multirow{3}{*}{ Institutional mission or philosophy } & Between Groups & 1.878 & 1 & 1.878 & 6.497 & .011 \\
\hline & Within Groups & 67.631 & 234 & .289 & & \\
\hline & Total & 69.508 & 235 & & & \\
\hline \multirow{3}{*}{$\begin{array}{l}\text { Spirit of cooperation between faculty } \\
\text { at this institution }\end{array}$} & Between Groups & 2.326 & 1 & 2.326 & 4.044 & .045 \\
\hline & Within Groups & 135.151 & 235 & .575 & & \\
\hline & Total & 137.477 & 236 & & & \\
\hline \multirow{3}{*}{$\begin{array}{l}\text { Quality of students whom I have } \\
\text { taught here }\end{array}$} & Between Groups & 5.053 & 1 & 5.053 & 9.164 & .003 \\
\hline & Within Groups & 129.580 & 235 & .551 & & \\
\hline & Total & 134.633 & 236 & & & \\
\hline \multirow{3}{*}{ Teaching assistance that I receive } & Between Groups & 4.717 & 1 & 4.717 & 6.160 & .014 \\
\hline & Within Groups & 163.876 & 214 & .766 & & \\
\hline & Total & 168.593 & 215 & & & \\
\hline $\begin{array}{l}\text { If you were to leave your current } \\
\text { institution to accept another position, } \\
\text { how important would each of the } \\
\text { following items be in your decision to } \\
\text { accept another position? }\end{array}$ & Source & $\begin{array}{l}\text { Sum of } \\
\text { Squares }\end{array}$ & $d f$ & $\begin{array}{l}\text { Mean } \\
\text { Square }\end{array}$ & $F$ & Sig. \\
\hline \multirow{3}{*}{ Good geographic location } & Between Groups & 4.557 & 1 & 4.557 & 12.145 & .001 \\
\hline & Within Groups & 87.418 & 233 & .375 & & \\
\hline & Total & 91.974 & 234 & & & \\
\hline $\begin{array}{l}\text { Please indicate the extent to which } \\
\text { you agree or disagree with each of } \\
\text { the following statements. }\end{array}$ & Source & $\begin{array}{c}\text { Sum of } \\
\text { Squares }\end{array}$ & $d f$ & $\begin{array}{c}\text { Mean } \\
\text { Square }\end{array}$ & $F$ & Sig. \\
\hline \multirow{3}{*}{$\begin{array}{l}\text { The administrative function is taking } \\
\text { an increasingly heavy share of } \\
\text { available resources at my institution }\end{array}$} & Between Groups & 3.655 & 1 & 3.655 & 4.950 & .027 \\
\hline & Within Groups & 169.845 & 230 & .738 & & \\
\hline & Total & 173.500 & 231 & & & \\
\hline \multirow{3}{*}{$\begin{array}{l}\text { My institution effectively meets the } \\
\text { educational needs of entering } \\
\text { students }\end{array}$} & Between Groups & 5.075 & 1 & 5.075 & 10.753 & .001 \\
\hline & Within Groups & 109.972 & 233 & .472 & & \\
\hline & Total & 115.047 & 234 & & & \\
\hline
\end{tabular}




\section{Alma mater}

A one-way ANOVA was conducted to determine whether there were any statistically significant differences between respondents on the questions of the NSOPF based upon the type of undergraduate institution that they attended. Statistically significant differences in mean scores were observed on 9 of the 70 items. A Tukey post hoc analysis was conducted to determine which comparisons accounted for the significant mean differences. This analysis was able to determine the significant comparisons in 6 of the questions. A LSD post hoc analysis was conducted to determine the results in the other 3 questions.

The first category of questions, which were in response to the prompt "How satisfied or dissatisfied do you personally feel about each of the following aspects of your job at your current institution," contained 4 of the significant mean comparisons. With regard to My job security and Availability of support services and equipment, respondents who are working at their alma mater scored significantly higher than those who did their undergraduate studies at a non-CCCU Christian college and those who attended a secular college or university. For the question Overall reputation of the institution, respondents who are working at their alma mater reported greater satisfaction than those who attended another CCCU institution. An LSD post hoc analysis indicated that respondents who are employed at their alma mater scored significantly higher than those who attended a secular college or university with regard to the question Quality of faculty leadership at my institution.

The next category of questions that contained significant mean differences between respondent groups was in response to the prompt "If you were to leave your current institution to accept another position, how important would each of the following items be in your decision to accept another position?” Respondents who are working at their alma mater 
scored significantly lower on the question Academic freedom than those who attended either a non-CCCU Christian college or a secular institution. Respondents who attended the college at which they are working or another CCCU Christian college had significantly higher responses to the question New institution is a Christian college than those who attended a secular college or university. Finally, faculty members who attended a nonCCCU Christian college indicated that a part-time position was more important to them than it was to faculty who attended a CCCU college other than the one at which they are currently working or those who attended a secular college or university.

The final category of questions in this particular analysis that displayed significant mean differences was in response to the prompt "Please indicate the extent to which you agree or disagree with each of the following statements.” Respondents who are working at their alma mater and those who attended a non-CCCU Christian college both agreed more strongly with the statement Teaching effectiveness should be the primary criterion for promotion of faculty than those faculty members who attended a secular university. Finally, an LSD post hoc analysis was used on the question My institution effectively meets the educational needs of entering students to determine that respondents who are working at their alma mater and those who attended a non-CCCU Christian college had higher means than those who attended another CCCU institution for their undergraduate studies. Results for statistically significant mean differences are displayed in Table 42. Descriptive statistics for all 70 questions with regard to Alma Mater are in Appendix A. 
Table 42. ANOVA results of NSOPF questions by alma mater

\begin{tabular}{|c|c|c|c|c|c|c|}
\hline $\begin{array}{l}\text { How satisfied or dissatisfied do you } \\
\text { personally feel about each of the } \\
\text { following aspects of your job at your } \\
\text { current institution }\end{array}$ & Source & $\begin{array}{l}\text { Sum of } \\
\text { Squares }\end{array}$ & $d f$ & $\begin{array}{c}\text { Mean } \\
\text { Square }\end{array}$ & $F$ & Sig. \\
\hline \multirow{3}{*}{ My job security } & Between Groups & 10.037 & 3 & 3.346 & 5.446 & .001 \\
\hline & Within Groups & 142.522 & 232 & .614 & & \\
\hline & Total & 152.559 & 235 & & & \\
\hline \multirow{3}{*}{$\begin{array}{l}\text { Availability of support services and } \\
\text { equipment (clerical support, } \\
\text { computers, etc.) }\end{array}$} & Between Groups & 6.316 & 3 & 2.105 & 2.697 & .047 \\
\hline & Within Groups & 181.887 & 233 & .781 & & \\
\hline & Total & 188.203 & 236 & & & \\
\hline \multirow{3}{*}{ Overall reputation of the institution } & Between Groups & 6.601 & 3 & 2.200 & 3.838 & .010 \\
\hline & Within Groups & 131.844 & 230 & .573 & & \\
\hline & Total & 138.444 & 233 & & & \\
\hline \multirow{3}{*}{$\begin{array}{l}\text { Quality of faculty leadership at my } \\
\text { institution }\end{array}$} & Between Groups & 5.644 & 3 & 1.881 & 2.968 & .033 \\
\hline & Within Groups & 147.034 & 232 & 634 & & \\
\hline & Total & 152.678 & 235 & & & \\
\hline $\begin{array}{l}\text { If you were to leave your current } \\
\text { institution to accept another position, } \\
\text { how important would each of the } \\
\text { following items be in your decision to } \\
\text { accept another position? }\end{array}$ & Source & $\begin{array}{l}\text { Sum of } \\
\text { Squares }\end{array}$ & $d f$ & $\begin{array}{c}\text { Mean } \\
\text { Square }\end{array}$ & $F$ & Sig. \\
\hline \multirow{3}{*}{ Academic Freedom } & Between Groups & 3.347 & 3 & 1.116 & 3.804 & .011 \\
\hline & Within Groups & 68.636 & 234 & .293 & & \\
\hline & Total & 71.983 & 237 & & & \\
\hline \multirow{3}{*}{ New institution is a Christian college } & Between Groups & 7.791 & 3 & 2.597 & 5.409 & .001 \\
\hline & Within Groups & 112.347 & 234 & .480 & & \\
\hline & Total & 120.139 & 237 & & & \\
\hline \multirow{3}{*}{ A part-time position } & Between Groups & 4.533 & 3 & 1.511 & 4.864 & .003 \\
\hline & Within Groups & 69.586 & 224 & .311 & & \\
\hline & Total & 74.118 & 227 & & & \\
\hline $\begin{array}{l}\text { Please indicate the extent to which } \\
\text { you agree or disagree with each of } \\
\text { the following statements. }\end{array}$ & Source & $\begin{array}{c}\text { Sum of } \\
\text { Squares }\end{array}$ & $d f$ & $\begin{array}{c}\text { Mean } \\
\text { Square }\end{array}$ & $F$ & Sig. \\
\hline \multirow{3}{*}{$\begin{array}{l}\text { Teaching effectiveness should be the } \\
\text { primary criterion for promotion of } \\
\text { faculty }\end{array}$} & Between Groups & 4.458 & 3 & 1.486 & 3.531 & .016 \\
\hline & Within Groups & 98.057 & 233 & .421 & & \\
\hline & Total & 102.515 & 236 & & & \\
\hline \multirow{3}{*}{$\begin{array}{l}\text { My institution effectively meets the } \\
\text { educational needs of entering } \\
\text { students }\end{array}$} & Between Groups & 3.819 & 3 & 1.273 & 2.644 & .050 \\
\hline & Within Groups & 111.228 & 231 & .482 & & \\
\hline & Total & 115.047 & 234 & & & \\
\hline
\end{tabular}




\section{Highest degree earned}

A one-way ANOVA was performed to determine whether there were any observed differences in NSOPF responses between faculty members with differing levels of educational attainment. The analysis indicated statistically significant mean differences for 12 of the 70 questions at the .05 level or lower. A Tukey post hoc analysis determined the significant comparisons for 11 of the questions and an LSD post hoc analysis was used to determine the significant comparison on the $12^{\text {th }}$ question.

The first category of questions were in response to the prompt "How satisfied or dissatisfied do you personally feel about each of the following aspects of your job at your current institution?” For five of the questions: My workload, Time available for keeping current in my field, Quality of my research facilities and support, Teaching assistance that I receive, and Research assistance that I receive, respondents with a master's degree were significantly more satisfied than their counterparts with doctoral degrees. On one question, The opportunity for advancement in rank at my institution, faculty members with doctoral degrees were more satisfied than those faculty members with only a master's degree.

The next question in which there were significant differences between mean scores was in response to the question If you were to leave your current institution, how likely is it that you would do so to return to school as a student? On this question, faculty members with a master's degree were significantly more likely to leave than those with a doctoral degree.

When asked "If you were to leave your current institution to accept another position, would you want to do more, less or about the same amount of the following as you currently do” faculty members with a doctoral degree had significantly higher mean scores than those 
with a master's degree when it related to Teaching and Service, but had significantly lower scores than their counterparts with a master's degree when asked about Research. The comparison for Service was made using the LSD post hoc analysis techniques.

The final category with significant mean differences was "If you were to leave your current institution to accept another position, how important would each of the following items be in your decision to accept another position?” Faculty members with master’s degrees found Salary level more important than those faculty members with a specialist or professional degree, and faculty members with a master's degree rated A part-time position as more important than those faculty members with doctoral degree. Results for statistically significant mean differences are displayed in Table 43. Descriptive statistics for all 70 questions with regard to highest degree are in Appendix A. 
Table 43. ANOVA results of NSOPF questions by highest degree earned

\begin{tabular}{|c|c|c|c|c|c|c|}
\hline $\begin{array}{l}\text { How satisfied or dissatisfied do you } \\
\text { personally feel about each of the } \\
\text { following aspects of your job at your } \\
\text { current institution }\end{array}$ & Source & $\begin{array}{l}\text { Sum of } \\
\text { Squares }\end{array}$ & $d f$ & $\begin{array}{c}\text { Mean } \\
\text { Square }\end{array}$ & $F$ & Sig. \\
\hline \multirow{3}{*}{ My Work Load } & Between Groups & 7.463 & 2 & 3.732 & 5.215 & .006 \\
\hline & Within Groups & 166.723 & 233 & .716 & & \\
\hline & Total & 174.186 & 235 & & & \\
\hline \multirow{3}{*}{$\begin{array}{l}\text { The opportunity for advancement in } \\
\text { rank at my institution }\end{array}$} & Between Groups & 6.432 & 2 & 3.216 & 3.921 & .021 \\
\hline & Within Groups & 188.667 & 230 & .820 & & \\
\hline & Total & 195.099 & 232 & & & \\
\hline \multirow{3}{*}{$\begin{array}{l}\text { Time available for keeping current in } \\
\text { my field }\end{array}$} & Between Groups & 6.585 & 2 & 3.293 & 4.344 & .014 \\
\hline & Within Groups & 175.077 & 231 & .758 & & \\
\hline & Total & 181.662 & 233 & & & \\
\hline \multirow{3}{*}{$\begin{array}{l}\text { Quality of my research facilities and } \\
\text { support }\end{array}$} & Between Groups & 6.769 & 2 & 3.384 & 4.956 & .008 \\
\hline & Within Groups & 151.614 & 222 & .683 & & \\
\hline & Total & 158.382 & 224 & & & \\
\hline \multirow{3}{*}{ Teaching assistance that I receive } & Between Groups & 10.013 & 2 & 5.006 & 6.697 & .002 \\
\hline & Within Groups & 158.480 & 212 & .748 & & \\
\hline & Total & 168.493 & 214 & & & \\
\hline \multirow{3}{*}{ Research assistance that I receive } & Between Groups & 6.877 & 2 & 3.438 & 4.636 & .011 \\
\hline & Within Groups & 148.345 & 200 & .742 & & \\
\hline & Total & 155.222 & 202 & & & \\
\hline $\begin{array}{l}\text { If you were to leave your current } \\
\text { institution, how likely is it that you } \\
\text { would do so to? }\end{array}$ & Source & $\begin{array}{l}\text { Sum of } \\
\text { Squares }\end{array}$ & $d f$ & $\begin{array}{l}\text { Mean } \\
\text { Square }\end{array}$ & $F$ & Sig. \\
\hline \multirow{3}{*}{ Return to school as a student } & Between Groups & 4.419 & 2 & 2.210 & $\begin{array}{r}10.65 \\
0 \\
\end{array}$ & .000 \\
\hline & Within Groups & 47.927 & 231 & .207 & & \\
\hline & Total & 52.346 & 233 & & & \\
\hline $\begin{array}{l}\text { If you were to leave your current } \\
\text { institution to accept another position, } \\
\text { would you want to do more, less or } \\
\text { about the same amount of the } \\
\text { following as you currently do? }\end{array}$ & Source & $\begin{array}{l}\text { Sum of } \\
\text { Squares }\end{array}$ & $d f$ & $\begin{array}{l}\text { Mean } \\
\text { Square }\end{array}$ & $F$ & Sig. \\
\hline \multirow{3}{*}{ Research } & Between Groups & 5.565 & 2 & 2.782 & 7.127 & .001 \\
\hline & Within Groups & 89.007 & 228 & .390 & & \\
\hline & Total & 94.571 & 230 & & & \\
\hline \multirow{3}{*}{ Teaching } & Between Groups & 3.606 & 2 & 1.803 & 5.581 & .004 \\
\hline & Within Groups & 73.980 & 229 & .323 & & \\
\hline & Total & 77.586 & 231 & & & \\
\hline \multirow{3}{*}{ Service } & Between Groups & 2.078 & 2 & 1.039 & 3.401 & .035 \\
\hline & Within Groups & 70.249 & 230 & .305 & & \\
\hline & Total & 72.326 & 232 & & & \\
\hline
\end{tabular}


Table 43. (continued)

\begin{tabular}{|l|l|r|r|r|r|r|}
\hline \hline $\begin{array}{c}\text { If you were to leave your current } \\
\text { institution to accept another position, } \\
\text { how important would each of the } \\
\text { following items be in your decision to } \\
\text { accept another position? }\end{array}$ & \multicolumn{1}{c|}{ Source } & $\begin{array}{c}\text { Sum of } \\
\text { Squares }\end{array}$ & df & $\begin{array}{r}\text { Mean } \\
\text { Square }\end{array}$ & $F$ & Sig. \\
\hline \multirow{4}{*}{ Salary Level } & Between Groups & 2.425 & 2 & 1.213 & 3.944 & .021 \\
\cline { 2 - 7 } & Within Groups & 71.938 & 234 & .307 & & \\
\cline { 2 - 8 } & Total & 74.363 & 236 & & & \\
\hline \multirow{4}{*}{ A part-time position } & Between Groups & 4.226 & 2 & 2.113 & 6.780 & .001 \\
\cline { 2 - 8 } & Within Groups & 69.801 & 224 & .312 & & \\
\cline { 2 - 8 } & Total & 74.026 & 226 & & & \\
\hline \hline
\end{tabular}

\section{Academic rank}

One-way ANOVA techniques were similarly used to determine whether there were statistically significant differences in NSOPF responses between faculty members of different ranks at or below the .05 significance level. The results of the analysis indicated significant mean differences on 11 of the 70 NSOPF items. The Tukey post hoc analysis indicated the comparisons with significant mean differences in 10 of the 11 questions and the LSD post hoc analysis indicated the significant comparison in the $11^{\text {th }}$ question.

The first category of questions, "How satisfied or dissatisfied do you personally feel about each of the following aspects of your job at your current institution” produced two questions with significant mean differences. On the question of My job security, those faculty members who were full professors scored significantly higher than those who were assistant professors, and on the question of The opportunity for advancement in rank at my institution, faculty at the professor level were more satisfied than all three other ranks.

The next category, "If you were to leave your current institution, how likely is it that you would do so to” had three questions with significant comparisons. Full professors scored higher on Leave to retire than did assistant professors. Respondents at the 
instructor/technical level scored higher than those at the associate professor and professor level on the response Return to school as a student. Assistant professors scored higher than full professors on that question as well. Finally, participants at the instructor/technical level indicated that it was more likely that they would leave to Accept employment at a secular college or university than either associate or full professors.

When asked "If you were to leave your current institution to accept another position, would you want to do more, less or about the same amount of the following as you currently do” full professors indicated that they would prefer to do more Advising than did associate professors.

The category of questions that began with the prompt "If you were to leave your current institution to accept another position, how important would each of the following items be in your decision to accept another position” produced the same results for three questions: Opportunities for advancement, Good environment/schools for my children, and A part-time position. In each of these three cases, assistant professors had significantly higher mean scores than full professors.

The final category of questions was in response to the prompt "Please indicate the extent to which you agree or disagree with each of the following statements.” To the question, Years of service/advanced degree should be the primary criterion for promotion of college faculty, associate professors responded more favorably than full professors. The LSD post hoc analysis was used to make this determination. On the last question of this category with significant differences on mean scores full professors had a significantly higher mean score than assistant professors on the question The administrative function is taking an increasingly heavy share of available resources at my institution. Results for statistically 
significant mean differences are displayed in Table 44. Descriptive statistics for all 70

questions with regard to academic rank are in Appendix A.

Table 44. ANOVA results of NSOPF questions by academic rank

\begin{tabular}{|c|c|c|c|c|c|c|}
\hline $\begin{array}{l}\text { How satisfied or dissatisfied do you } \\
\text { personally feel about each of the } \\
\text { following aspects of your job at your } \\
\text { current institution }\end{array}$ & Source & $\begin{array}{c}\text { Sum of } \\
\text { Squares }\end{array}$ & $d f$ & $\begin{array}{c}\text { Mean } \\
\text { Square }\end{array}$ & $F$ & Sig. \\
\hline \multirow{3}{*}{ My job security } & Between Groups & 7.253 & 3 & 2.418 & 3.860 & .010 \\
\hline & Within Groups & 145.306 & 232 & .626 & & \\
\hline & Total & 152.559 & 235 & & & \\
\hline \multirow{3}{*}{$\begin{array}{l}\text { The opportunity for advancement in } \\
\text { rank at my institution }\end{array}$} & Between Groups & 13.610 & 3 & 4.537 & 5.749 & .001 \\
\hline & Within Groups & 181.501 & 230 & .789 & & \\
\hline & Total & 195.111 & 233 & & & \\
\hline $\begin{array}{l}\text { If you were to leave your current } \\
\text { institution, how likely is it that you } \\
\text { would do so to? }\end{array}$ & Source & $\begin{array}{l}\text { Sum of } \\
\text { Squares }\end{array}$ & $d f$ & $\begin{array}{l}\text { Mean } \\
\text { Square }\end{array}$ & $F$ & Sig. \\
\hline \multirow{3}{*}{ Leave to Retire } & Between Groups & 11.101 & 3 & 3.700 & 4.632 & .004 \\
\hline & Within Groups & 186.122 & 233 & .799 & & \\
\hline & Total & 197.224 & 236 & & & \\
\hline \multirow{3}{*}{ Return to school as a student } & Between Groups & 3.520 & 3 & 1.173 & 5.547 & .001 \\
\hline & Within Groups & 48.863 & 231 & .212 & & \\
\hline & Total & 52.383 & 234 & & & \\
\hline \multirow{3}{*}{$\begin{array}{l}\text { Accept employment at a secular } \\
\text { college or university }\end{array}$} & Between Groups & 7.588 & 3 & 2.529 & 6.153 & .000 \\
\hline & Within Groups & 94.536 & 230 & .411 & & \\
\hline & Total & 102.124 & 233 & & & \\
\hline $\begin{array}{l}\text { If you were to leave your current } \\
\text { institution to accept another position, } \\
\text { would you want to do more, less or } \\
\text { about the same amount of the } \\
\text { following as you currently do? }\end{array}$ & Source & $\begin{array}{l}\text { Sum of } \\
\text { Squares }\end{array}$ & $d f$ & $\begin{array}{l}\text { Mean } \\
\text { Square }\end{array}$ & $F$ & Sig. \\
\hline \multirow{3}{*}{ Advising } & Between Groups & 2.894 & 3 & .965 & 3.437 & .018 \\
\hline & Within Groups & 63.998 & 228 & .281 & & \\
\hline & Total & 66.892 & 231 & & & \\
\hline $\begin{array}{l}\text { If you were to leave your current } \\
\text { institution to accept another position, } \\
\text { how important would each of the } \\
\text { following items be in your decision to } \\
\text { accept another position? }\end{array}$ & Source & $\begin{array}{c}\text { Sum of } \\
\text { Squares }\end{array}$ & $d f$ & $\begin{array}{c}\text { Mean } \\
\text { Square }\end{array}$ & $F$ & Sig. \\
\hline \multirow{3}{*}{ Opportunities for advancement } & Between Groups & 4.343 & 3 & 1.448 & 3.226 & .023 \\
\hline & Within Groups & 105.022 & 234 & .449 & & \\
\hline & Total & 109.366 & 237 & & & \\
\hline
\end{tabular}


Table 44. (continued)

\begin{tabular}{|c|c|c|c|c|c|c|}
\hline \multirow{3}{*}{$\begin{array}{l}\text { Good environment/schools for my } \\
\text { children }\end{array}$} & Between Groups & 9.231 & 3 & 3.077 & 3.868 & .010 \\
\hline & Within Groups & 175.015 & 220 & .796 & & \\
\hline & Total & 184.246 & 223 & & & \\
\hline \multirow{3}{*}{ A part-time position } & Between Groups & 2.660 & 3 & .887 & 2.779 & .042 \\
\hline & Within Groups & 71.459 & 224 & .319 & & \\
\hline & Total & 74.118 & 227 & & & \\
\hline $\begin{array}{l}\text { Please indicate the extent to which } \\
\text { you agree or disagree with each of } \\
\text { the following statements. }\end{array}$ & Source & $\begin{array}{l}\text { Sum of } \\
\text { Squares }\end{array}$ & $d f$ & $\begin{array}{l}\text { Mean } \\
\text { Square }\end{array}$ & $F$ & Sig. \\
\hline \multirow{3}{*}{$\begin{array}{l}\text { Years of service/advanced degree } \\
\text { should be the primary criterion for } \\
\text { promotion of college faculty }\end{array}$} & Between Groups & 5.075 & 3 & 1.692 & 2.933 & .034 \\
\hline & Within Groups & 133.819 & 232 & .577 & & \\
\hline & Total & 138.894 & 235 & & & \\
\hline \multirow{3}{*}{$\begin{array}{l}\text { The administrative function is taking } \\
\text { an increasingly heavy share of } \\
\text { available resources at my institution }\end{array}$} & Between Groups & 10.577 & 3 & 3.526 & 4.934 & .002 \\
\hline & Within Groups & 162.923 & 228 & .715 & & \\
\hline & Total & 173.500 & 231 & & & \\
\hline
\end{tabular}

\section{Years teaching (career)}

When one-way ANOVA tests were run on the NSOPF questions, using the "years teaching (career)" as the independent variable, 12 questions produced statistically significant results. A Tukey post hoc analysis was used to determine the comparisons that produced the significant mean differences.

When asked "How satisfied or dissatisfied do you personally feel about each of the following aspects of your job at your current institution,” faculty members who had been teaching for 1-5 years indicated greater satisfaction than those who had been teaching for 12 or more years on My work load, Time available for keeping current in my field, and Quality of chief administrative officers at my institution. Their satisfaction was also greater than those whose teaching career had spanned 6-11 years on Time available for keeping current in my field and My job security. Faculty members whose teaching careers were 12 years or greater responded more favorably than those who had been teaching 6-11 years on $M y$ job 
security and The authority I have to make decisions about other aspects of my job and more favorably than those teaching for 1-5 years on the question Spouse employment opportunities in this geographic area.

Faculty members who had been teaching for 12 or more years indicated that if they were to leave their current institution, they were more likely to Leave to retire than the other two groups. The group of faculty who had been teaching for only 1-5 years indicated that they were more likely to leave to Accept employment at a secular college or university than those whose teaching careers spanned 12 or more years.

When asked "If you were to leave your current institution to accept another position, would you want to do more, less or about the same amount of the following as you currently do,” faculty members with 12 or more years of teaching experience indicated that they would prefer to do more Administration than either of the two other groups.

The last question with significant mean differences in this category asked participants “If you were to leave your current institution to accept another position, how important would each of the following items be in your decision to accept another position?” Participants who had taught for 12 or more years had significantly higher mean scores on Good instructional facilities and Excellent colleagues than did those who had taught for 1-5 years. Faculty members with 6-11 years of teaching experience also rated Excellent colleagues as more important than those with 1-5 years experience. Finally, those faculty members with 6-11 years had higher mean scores than those with 12 or more years of teaching experience on Good environment/schools for my children. Results for statistically significant means are displayed in Table 45. Descriptive statistics for all 70 questions with regard to years teaching (career) are in Appendix A. 
Table 45. ANOVA results of NSOPF questions by years of teaching (career)

\begin{tabular}{|c|c|c|c|c|c|c|}
\hline $\begin{array}{l}\text { How satisfied or dissatisfied do you } \\
\text { personally feel about each of the } \\
\text { following aspects of your job at your } \\
\text { current institution }\end{array}$ & Source & $\begin{array}{c}\text { Sum of } \\
\text { Squares }\end{array}$ & $d f$ & $\begin{array}{c}\text { Mean } \\
\text { Square }\end{array}$ & $F$ & Sig. \\
\hline \multirow{3}{*}{ My Work Load } & Between Groups & 6.179 & 2 & 3.090 & 4.299 & .015 \\
\hline & Within Groups & 166.732 & 232 & .719 & & \\
\hline & Total & 172.911 & 234 & & & \\
\hline \multirow{3}{*}{ My job security } & Between Groups & 11.702 & 2 & 5.851 & 9.631 & .000 \\
\hline & Within Groups & 140.337 & 231 & .608 & & \\
\hline & Total & 152.038 & 233 & & & \\
\hline \multirow{3}{*}{$\begin{array}{l}\text { The authority I have to make } \\
\text { decisions about other aspects of my } \\
\text { job }\end{array}$} & Between Groups & 2.759 & 2 & 1.379 & 3.142 & .045 \\
\hline & Within Groups & 100.547 & 229 & .439 & & \\
\hline & Total & 103.306 & 231 & & & \\
\hline \multirow{3}{*}{$\begin{array}{l}\text { Time available for keeping current in } \\
\text { my field }\end{array}$} & Between Groups & 9.791 & 2 & 4.895 & 6.554 & .002 \\
\hline & Within Groups & 171.788 & 230 & .747 & & \\
\hline & Total & 181.579 & 232 & & & \\
\hline \multirow{3}{*}{$\begin{array}{l}\text { Quality of chief administrative officers } \\
\text { at my institution }\end{array}$} & Between Groups & 5.905 & 2 & 2.953 & 3.599 & .029 \\
\hline & Within Groups & 189.501 & 231 & .820 & & \\
\hline & Total & 195.406 & 233 & & & \\
\hline \multirow{3}{*}{$\begin{array}{l}\text { Spouse employment opportunities in } \\
\text { this geographic area }\end{array}$} & Between Groups & 4.428 & 2 & 2.214 & 3.764 & .025 \\
\hline & Within Groups & 123.525 & 210 & .588 & & \\
\hline & Total & 127.953 & 212 & & & \\
\hline $\begin{array}{l}\text { If you were to leave your current } \\
\text { institution, how likely is it that you } \\
\text { would do so to? }\end{array}$ & Source & $\begin{array}{c}\text { Sum of } \\
\text { Squares }\end{array}$ & $d f$ & $\begin{array}{c}\text { Mean } \\
\text { Square }\end{array}$ & $F$ & Sig. \\
\hline \multirow{3}{*}{ Leave to Retire } & Between Groups & 11.287 & 2 & 5.643 & 7.120 & .001 \\
\hline & Within Groups & 183.888 & 232 & .793 & & \\
\hline & Total & 195.174 & 234 & & & \\
\hline \multirow{3}{*}{$\begin{array}{l}\text { Accept employment at a secular } \\
\text { college or university }\end{array}$} & Between Groups & 4.127 & 2 & 2.063 & 4.862 & .009 \\
\hline & Within Groups & 97.179 & 229 & .424 & & \\
\hline & Total & 101.306 & 231 & & & \\
\hline $\begin{array}{l}\text { If you were to leave your current } \\
\text { institution to accept another position, } \\
\text { would you want to do more, less or } \\
\text { about the same amount of the } \\
\text { following as you currently do? }\end{array}$ & Source & $\begin{array}{c}\text { Sum of } \\
\text { Squares }\end{array}$ & $d f$ & $\begin{array}{c}\text { Mean } \\
\text { Square }\end{array}$ & $F$ & Sig. \\
\hline \multirow{3}{*}{ Administration } & Between Groups & 5.331 & 2 & 2.665 & 6.004 & .003 \\
\hline & Within Groups & 100.337 & 226 & .444 & & \\
\hline & Total & 105.668 & 228 & & & \\
\hline
\end{tabular}


Table 45. (continued)

\begin{tabular}{|c|c|c|c|c|c|c|}
\hline $\begin{array}{l}\text { If you were to leave your current } \\
\text { institution to accept another position, } \\
\text { how important would each of the } \\
\text { following items be in your decision to } \\
\text { accept another position? }\end{array}$ & Source & $\begin{array}{l}\text { Sum of } \\
\text { Squares }\end{array}$ & $d f$ & $\begin{array}{c}\text { Mean } \\
\text { Square }\end{array}$ & $F$ & Sig. \\
\hline \multirow{3}{*}{$\begin{array}{l}\text { Good instructional facilities and } \\
\text { equipment }\end{array}$} & Between Groups & 2.537 & 2 & 1.269 & 4.103 & .018 \\
\hline & Within Groups & 71.743 & 232 & .309 & & \\
\hline & Total & 74.281 & 234 & & & \\
\hline \multirow{3}{*}{ Excellent Colleagues } & Between Groups & 1.627 & 2 & .813 & 3.558 & .030 \\
\hline & Within Groups & 53.255 & 233 & .229 & & \\
\hline & Total & 54.881 & 235 & & & \\
\hline \multirow{3}{*}{$\begin{array}{l}\text { Good environment/schools for my } \\
\text { children }\end{array}$} & Between Groups & 6.369 & 2 & 3.184 & 3.964 & .020 \\
\hline & Within Groups & 176.752 & 220 & .803 & & \\
\hline & Total & 183.121 & 222 & & & \\
\hline
\end{tabular}

\section{Years teaching (institution)}

When the 70 questions of the NSOPF were analyzed using one-way ANOVA techniques and years teaching (institution) as the independent variable, 12 of the questions showed statistically different means among the three groups. The Tukey post hoc analysis revealed the significant mean comparisons in this category.

When responding to the question "How satisfied or dissatisfied do you personally feel about each of the following aspects of your job at your current institution” faculty members who had been teaching at their current institution for 12 or more years had higher mean scores than those who had only been at the institution for 6-11 years on the issues of My job security and The authority I have to make decisions about other aspects of my job. Their scores were also higher than those with 1-5 years of teaching service at the institution on $M y$ job security and Spouse employment opportunities in this geographic area. Faculty with only 1-5 years of service at the institution had higher mean scores than those with 6-11 years 
on Time available for keeping current in my field and a higher mean score than those with 12 or more years at the institution on Quality of chief administrative officers at my institution.

Regarding their responses to "If you were to leave your current institution, how likely is it that you would do so to,” faculty members with 12 or more years of teaching experience at the institution indicated that they were significantly more likely to Leave to retire than either of the other two groups. Faculty members with 1-5 years at the institution said had higher mean scores than those who had been at the institution for 12 or more years on Return to school as a student and Accept employment at a secular college or university and a higher mean score than those with 6-11 years at the institution on the Accept employment at a secular college or university as well.

Participants who had taught at their current institution for 12 or more years had a significantly higher mean score than both other groups with regard to Administration on the question "If you were to leave your current institution to accept another position, would you want to do more, less or about the same amount of the following as you currently do?” If they were to leave their current institution to accept another position, faculty with 12 or more years of service at that institution indicated that the fact that the New institution is a Christian college was significantly more important to them than it was to faculty with only 1-5 years of experience at the institution.

Finally, the analysis indicated that faculty with 12 or more years of teaching experience at their current institution indicated greater agreement with the statements Research/publications should be the primary criterion for promotion of college faculty and The administrative function is taking an increasingly heavy share of available resources at my institution than did faculty who had been teaching at the institution for 1-5 years. Results 
for statistically significant means are displayed in Table 46. Descriptive statistics for all 70 questions with regard to years teaching (institution) are in Appendix A.

Table 46. ANOVA results of NSOPF questions by years of teaching (institution)

\begin{tabular}{|c|c|c|c|c|c|c|}
\hline $\begin{array}{l}\text { How satisfied or dissatisfied do you } \\
\text { personally feel about each of the } \\
\text { following aspects of your job at your } \\
\text { current institution }\end{array}$ & Source & $\begin{array}{c}\text { Sum of } \\
\text { Squares }\end{array}$ & $d f$ & $\begin{array}{c}\text { Mean } \\
\text { Square }\end{array}$ & $F$ & Sig. \\
\hline \multirow{3}{*}{ My job security } & Between Groups & 8.954 & 2 & 4.477 & 7.264 & .001 \\
\hline & Within Groups & 143.605 & 233 & .616 & & \\
\hline & Total & 152.559 & 235 & & & \\
\hline \multirow{3}{*}{$\begin{array}{l}\text { The authority I have to make } \\
\text { decisions about other aspects of my } \\
\text { job }\end{array}$} & Between Groups & 3.028 & 2 & 1.514 & 3.468 & .033 \\
\hline & Within Groups & 100.819 & 231 & .436 & & \\
\hline & Total & 103.846 & 233 & & & \\
\hline \multirow{3}{*}{$\begin{array}{l}\text { Time available for keeping current in } \\
\text { my field }\end{array}$} & Between Groups & 5.388 & 2 & 2.694 & 3.539 & .031 \\
\hline & Within Groups & 176.587 & 232 & .761 & & \\
\hline & Total & 181.974 & 234 & & & \\
\hline \multirow{3}{*}{$\begin{array}{l}\text { Quality of chief administrative officers } \\
\text { at my institution }\end{array}$} & Between Groups & 6.392 & 2 & 3.196 & 3.833 & .023 \\
\hline & Within Groups & 194.286 & 233 & .834 & & \\
\hline & Total & 200.678 & 235 & & & \\
\hline \multirow{3}{*}{$\begin{array}{l}\text { Spouse employment opportunities in } \\
\text { this geographic area }\end{array}$} & Between Groups & 7.367 & 2 & 3.683 & 6.358 & .002 \\
\hline & Within Groups & 122.245 & 211 & .579 & & \\
\hline & Total & 129.612 & 213 & & & \\
\hline $\begin{array}{l}\text { If you were to leave your current } \\
\text { institution, how likely is it that you } \\
\text { would do so to? }\end{array}$ & Source & $\begin{array}{l}\text { Sum of } \\
\text { Squares }\end{array}$ & $d f$ & $\begin{array}{c}\text { Mean } \\
\text { Square }\end{array}$ & $F$ & Sig. \\
\hline \multirow[t]{3}{*}{ Leave to Retire } & Between Groups & 18.961 & 2 & 9.481 & $\begin{array}{r}12.44 \\
5 \\
\end{array}$ & .000 \\
\hline & Within Groups & 178.262 & 234 & .762 & & \\
\hline & Total & 197.224 & 236 & & & \\
\hline \multirow{3}{*}{ Return to school as a student } & Between Groups & 1.693 & 2 & .847 & 3.875 & .022 \\
\hline & Within Groups & 50.690 & 232 & .218 & & \\
\hline & Total & 52.383 & 234 & & & \\
\hline \multirow{3}{*}{$\begin{array}{l}\text { Accept employment at a secular } \\
\text { college or university }\end{array}$} & Between Groups & 6.309 & 2 & 3.154 & 7.605 & .001 \\
\hline & Within Groups & 95.815 & 231 & .415 & & \\
\hline & Total & 102.124 & 233 & & & \\
\hline
\end{tabular}


Table 46. (continued)

\begin{tabular}{|c|c|c|c|c|c|c|}
\hline $\begin{array}{l}\text { If you were to leave your current } \\
\text { institution to accept another position, } \\
\text { would you want to do more, less or } \\
\text { about the same amount of the } \\
\text { following as you currently do? }\end{array}$ & Source & $\begin{array}{l}\text { Sum of } \\
\text { Squares }\end{array}$ & $d f$ & $\begin{array}{c}\text { Mean } \\
\text { Square }\end{array}$ & $F$ & Sig. \\
\hline \multirow[t]{3}{*}{ Administration } & Between Groups & 8.637 & 2 & 4.319 & $\begin{array}{r}10.08 \\
5\end{array}$ & .000 \\
\hline & Within Groups & 97.631 & 228 & .428 & & \\
\hline & Total & 106.268 & 230 & & & \\
\hline $\begin{array}{l}\text { If you were to leave your current } \\
\text { institution to accept another position, } \\
\text { how important would each of the } \\
\text { following items be in your decision to } \\
\text { accept another position? }\end{array}$ & Source & $\begin{array}{l}\text { Sum of } \\
\text { Squares }\end{array}$ & $d f$ & $\begin{array}{c}\text { Mean } \\
\text { Square }\end{array}$ & $F$ & Sig. \\
\hline \multirow[t]{3}{*}{ New institution is a Christian college } & Between Groups & 4.069 & 2 & 2.035 & 4.120 & .017 \\
\hline & Within Groups & 116.069 & 235 & .494 & & \\
\hline & Total & 120.139 & 237 & & & \\
\hline $\begin{array}{l}\text { Please indicate the extent to which } \\
\text { you agree or disagree with each of } \\
\text { the following statements. }\end{array}$ & Source & $\begin{array}{l}\text { Sum of } \\
\text { Squares }\end{array}$ & $d f$ & $\begin{array}{c}\text { Mean } \\
\text { Square }\end{array}$ & $F$ & Sig. \\
\hline \multirow{3}{*}{$\begin{array}{l}\text { Research/publications should be the } \\
\text { primary criterion for promotion of } \\
\text { college faculty }\end{array}$} & Between Groups & 3.487 & 2 & 1.743 & 3.708 & .026 \\
\hline & Within Groups & 110.480 & 235 & .470 & & \\
\hline & Total & 113.966 & 237 & & & \\
\hline \multirow{3}{*}{$\begin{array}{l}\text { The administrative function is taking } \\
\text { an increasingly heavy share of } \\
\text { available resources at my institution }\end{array}$} & Between Groups & 5.577 & 2 & 2.788 & 3.803 & .024 \\
\hline & Within Groups & 167.923 & 229 & .733 & & \\
\hline & Total & 173.500 & 231 & & & \\
\hline
\end{tabular}

\section{Expected age of retirement}

A one-way ANOVA was performed to determine whether there were any observed differences between participants' scores on the NSOPF items based on their anticipated age of retirement from teaching. Because each of the participants had entered a discreet age for their expected age of retirement, the ages were collapsed into three groups $(1=60$ or less, $2=$ 61-65, and $3=66$ and above). Statistically significant differences in means at the .05 level were found on 8 of the 70 questions. A Tukey post hoc analysis was conducted to determine the comparisons that yielded the statistically significant comparisons. 
The first category of questions with significant differences between mean scores was in response to the prompt, "If you were to leave your current institution, how likely is it that you would do so to?” On the first question, Accept employment at another Christian college or university, those faculty members who expected to retire at age 66 or higher had higher mean scores than those who anticipated retiring at 61-65 years of age. The second question in this category, Accept employment in consulting or other for-profit business or industry or become self-employed, produced higher scores for those who are expecting to retire at age 60 or younger than both of the other two groups.

The second category of questions was in response to the prompt, "If you were to leave your current institution to accept another position, would you want to do more, less or about the same amount of the following as you currently do?” In the case of Research, those who expected to retire at age 66 or higher scored lower than both other groups, but with regard to Administration, the group that anticipated retiring at age 61-65 scored higher than those who planned to retire from teaching at age 60 or younger.

With regard to the prompt, "If you were to leave your current institution to accept another position, how important would each of the following items be in your decision to accept another position?” those that anticipated retirement at age 66 or higher had higher mean scores than those who expected to retire between age 61 and 65 on the question New institution is a Christian college. On the response A part-time position, the group that said that they hope to retire at age 60 or younger scored higher than those that expect to retire at age 66 or higher.

The final category of questions was in response to the prompt, "Please indicate the extent to which you agree or disagree with each of the following statements.” On the 
statement, The tenure system in higher education should be preserved, those that said that they expect to retire at age 66 or higher had higher mean scores than those that anticipated retiring at age 60 or lower. And finally, on the statement, If I had it to do over again, I would choose an academic career, the group that anticipated retiring from teaching at age 60 or lower scored lower than either of the other two groups. Those results are displayed in Table 47. Descriptive statistics for all 70 questions with regard to this criterion can be found in Appendix A. 
Table 47. ANOVA results of NSOPF questions by expected age of retirement

\begin{tabular}{|c|c|c|c|c|c|c|}
\hline $\begin{array}{l}\text { If you were to leave your current } \\
\text { institution, how likely is it that you } \\
\text { would do so to? }\end{array}$ & Source & $\begin{array}{l}\text { Sum of } \\
\text { Squares }\end{array}$ & $d f$ & $\begin{array}{c}\text { Mean } \\
\text { Square }\end{array}$ & $F$ & Sig. \\
\hline \multirow{3}{*}{$\begin{array}{l}\text { Accept employment at another } \\
\text { Christian college or university }\end{array}$} & Between Groups & 3.752 & 2 & 1.876 & 4.283 & .015 \\
\hline & Within Groups & 97.243 & 222 & .438 & & \\
\hline & Total & 100.996 & 224 & & & \\
\hline \multirow{3}{*}{$\begin{array}{l}\text { Accept employment in consulting or } \\
\text { other for-profit business or industry or } \\
\text { become self-employed }\end{array}$} & Between Groups & 7.451 & 2 & 3.725 & 8.021 & .000 \\
\hline & Within Groups & 103.109 & 222 & .464 & & \\
\hline & Total & 110.560 & 224 & & & \\
\hline $\begin{array}{l}\text { If you were to leave your current } \\
\text { institution to accept another position, } \\
\text { would you want to do more, less or } \\
\text { about the same amount of the } \\
\text { following as you currently do? }\end{array}$ & Source & $\begin{array}{c}\text { Sum of } \\
\text { Squares }\end{array}$ & $d f$ & $\begin{array}{c}\text { Mean } \\
\text { Square }\end{array}$ & $F$ & Sig. \\
\hline \multirow{3}{*}{ Research } & Between Groups & 5.096 & 2 & 2.548 & 6.444 & .002 \\
\hline & Within Groups & 86.602 & 219 & .395 & & \\
\hline & Total & 91.698 & 221 & & & \\
\hline \multirow{3}{*}{ Administration } & Between Groups & 2.948 & 2 & 1.474 & 3.239 & .041 \\
\hline & Within Groups & 99.215 & 218 & .455 & & \\
\hline & Total & 102.163 & 220 & & & \\
\hline $\begin{array}{l}\text { If you were to leave your current } \\
\text { institution to accept another position, } \\
\text { how important would each of the } \\
\text { following items be in your decision to } \\
\text { accept another position? }\end{array}$ & Source & $\begin{array}{l}\text { Sum of } \\
\text { Squares }\end{array}$ & $d f$ & $\begin{array}{l}\text { Mean } \\
\text { Square }\end{array}$ & $F$ & Sig. \\
\hline \multirow{3}{*}{ New institution is a Christian college } & Between Groups & 5.489 & 2 & 2.745 & 5.645 & .004 \\
\hline & Within Groups & 108.899 & 224 & .486 & & \\
\hline & Total & 114.388 & 226 & & & \\
\hline \multirow{3}{*}{ A part-time position } & Between Groups & 2.683 & 2 & 1.342 & 4.128 & .017 \\
\hline & Within Groups & 70.203 & 216 & .325 & & \\
\hline & Total & 72.886 & 218 & & & \\
\hline $\begin{array}{l}\text { Please indicate the extent to which } \\
\text { you agree or disagree with each of } \\
\text { the following statements. }\end{array}$ & Source & $\begin{array}{l}\text { Sum of } \\
\text { Squares }\end{array}$ & $d f$ & $\begin{array}{c}\text { Mean } \\
\text { Square }\end{array}$ & $F$ & Sig. \\
\hline \multirow{3}{*}{$\begin{array}{l}\text { The tenure system in higher } \\
\text { education should be preserved }\end{array}$} & Between Groups & 5.881 & 2 & 2.941 & 3.399 & .035 \\
\hline & Within Groups & 192.938 & 223 & .865 & & \\
\hline & Total & 198.819 & 225 & & & \\
\hline \multirow{3}{*}{$\begin{array}{l}\text { If I had it to do over again, I would } \\
\text { choose an academic career }\end{array}$} & Between Groups & 2.239 & 2 & 1.120 & 4.353 & .014 \\
\hline & Within Groups & 57.611 & 224 & .257 & & \\
\hline & Total & 59.850 & 226 & & & \\
\hline
\end{tabular}




\section{Academic field}

The final comparison made regarding the NSOPF items related to the academic field of participants. Using one-way ANOVA techniques, it was determined that statistically significant differences in mean scores were evident on 17 of the 70 questions at the .05 significance level or better. The Tukey post hoc analysis indicated the comparisons with significant mean differences in 14 of the 17 questions and the LSD post hoc analysis indicated the significant comparison in the other three questions with significant differences.

The first set of questions in which significant mean differences were found between members of different academic fields was in response to the prompt "How satisfied or dissatisfied do you personally feel about each of the following aspects of your job at your current institution?” Regarding My work load, Overall reputation of the institution, and Research assistance that I receive, members of the Pre-Professional fields had significantly higher means than those in the Humanities, Physical Sciences, and Social Sciences. The LSD post hoc analysis technique was used to determine differences on the Research assistance question. Faculty in pre-professional programs ad higher means than those in the Humanities and Physical Sciences on the questions relating to Time available for keeping current in my field and Quality of students whom I have taught here. The LSD post hoc techniques were used for each of these questions as well. Regarding Quality of leadership in my department and Teaching assistance that I receive, faculty members in the Preprofessional programs had higher mean scores than those in the Humanities. Faculty in the "Other" academic field category scored higher than those in the Humanities on the questions Quality of leadership in my department and Reputation of my department. The final question with significant mean differences in this category was Quality of my research facilities and 
support, in which faculty in the Pre-Professional fields had higher mean scores than those in the Physical Sciences.

In response to the question "If you were to leave your current institution to accept another position, would you want to do more, less or about the same amount of the following as you currently do” faculty in Pre-Professional fields and the "Other” category had significantly lower mean scores than those in the Humanities with regard to Teaching. With regard to Administration, faculty in the Humanities, Physical Sciences, and Social Sciences all had higher mean scores than those in the "Other" category and those in the Physical Sciences also had statistically higher mean scores than faculty in the Pre-Professional fields.

The third set of questions which had significant mean differences with regard to academic field were in response to the prompt, "If you were to leave your current institution to accept another position, how important would each of the following items be in your decision to accept another position?” Faculty members in the Humanities had higher mean scores than those in the Physical Sciences with regard to Opportunities for advancement. Faculty members from both the Physical Sciences and Pre-Professional fields had higher scores than those in the Humanities regarding No pressure to publish. Finally, those faculty members in the Social Sciences had higher mean scores than their counterparts in PreProfessional fields with regard to Academic Freedom.

The final category of questions dealt with the extent to which faculty members agree or disagree with various statements. Concerning the statement The tenure system in higher education should be preserved, faculty members in the Humanities had significantly higher mean scores than those in Pre-Professional fields. With regard to The administrative function is taking an increasingly heavy share of available resources at my institution, faculty in the 
Physical Sciences had statistically higher mean scores than those in the Pre-Professional fields. And in the last question with significantly different mean scores, Faculty who are members of racial or ethnic minorities are treated fairly at my institution, those faculty members from the Humanities and the Physical Sciences scored significantly higher than those in the Social Sciences. Results for the significantly different means by academic field are indicated in Table 48 and descriptive statistics for all 70 questions can be found in Appendix A.

Table 48. ANOVA results of NSOPF questions by academic field

\begin{tabular}{|c|c|c|c|c|c|c|}
\hline $\begin{array}{l}\text { How satisfied or dissatisfied do you } \\
\text { personally feel about each of the } \\
\text { following aspects of your job at your } \\
\text { current institution }\end{array}$ & Source & $\begin{array}{l}\text { Sum of } \\
\text { Squares }\end{array}$ & $d f$ & $\begin{array}{c}\text { Mean } \\
\text { Square }\end{array}$ & $F$ & Sig. \\
\hline \multirow{3}{*}{ My Work Load } & Between Groups & 16.956 & 4 & 4.239 & 6.146 & .000 \\
\hline & Within Groups & 155.884 & 226 & .690 & & \\
\hline & Total & 172.840 & 230 & & & \\
\hline \multirow{3}{*}{$\begin{array}{l}\text { Time available for keeping current in } \\
\text { my field }\end{array}$} & Between Groups & 9.123 & 4 & 2.281 & 3.013 & .019 \\
\hline & Within Groups & 169.549 & 224 & .757 & & \\
\hline & Total & 178.672 & 228 & & & \\
\hline \multirow{3}{*}{ Overall reputation of the institution } & Between Groups & 8.713 & 4 & 2.178 & 3.949 & .004 \\
\hline & Within Groups & 123.019 & 223 & .552 & & \\
\hline & Total & 131.732 & 227 & & & \\
\hline \multirow{3}{*}{ Reputation of my department } & Between Groups & 6.162 & 4 & 1.540 & 2.568 & .039 \\
\hline & Within Groups & 135.561 & 226 & .600 & & \\
\hline & Total & 141.723 & 230 & & & \\
\hline \multirow{3}{*}{$\begin{array}{l}\text { Quality of leadership in my } \\
\text { department }\end{array}$} & Between Groups & 10.545 & 4 & 2.636 & 4.001 & .004 \\
\hline & Within Groups & 148.238 & 225 & .659 & & \\
\hline & Total & 158.783 & 229 & & & \\
\hline \multirow{3}{*}{$\begin{array}{l}\text { Quality of my research facilities and } \\
\text { support }\end{array}$} & Between Groups & 8.463 & 4 & 2.116 & 3.097 & .017 \\
\hline & Within Groups & 146.896 & 215 & .683 & & \\
\hline & Total & 155.359 & 219 & & & \\
\hline \multirow{3}{*}{$\begin{array}{l}\text { Quality of students whom I have } \\
\text { taught here }\end{array}$} & Between Groups & 6.019 & 4 & 1.505 & 2.828 & .026 \\
\hline & Within Groups & 120.250 & 226 & .532 & & \\
\hline & Total & 126.268 & 230 & & & \\
\hline \multirow{3}{*}{ Teaching assistance that I receive } & Between Groups & 16.370 & 4 & 4.093 & 5.798 & .000 \\
\hline & Within Groups & 145.412 & 206 & .706 & & \\
\hline & Total & 161.782 & 210 & & & \\
\hline
\end{tabular}


Table 48. (continued)

\begin{tabular}{|c|c|c|c|c|c|c|}
\hline \multirow{3}{*}{ Research assistance that I receive } & Between Groups & 7.518 & 4 & 1.879 & 2.565 & .040 \\
\hline & Within Groups & 142.151 & 194 & .733 & & \\
\hline & Total & 149.668 & 198 & & & \\
\hline $\begin{array}{l}\text { If you were to leave your current } \\
\text { institution to accept another position, } \\
\text { would you want to do more, less or } \\
\text { about the same amount of the } \\
\text { following as you currently do? }\end{array}$ & Source & $\begin{array}{c}\text { Sum of } \\
\text { Squares }\end{array}$ & $d f$ & $\begin{array}{c}\text { Mean } \\
\text { Square }\end{array}$ & $F$ & Sig. \\
\hline \multirow{3}{*}{ Teaching } & Between Groups & 5.383 & 4 & 1.346 & 4.262 & .002 \\
\hline & Within Groups & 70.106 & 222 & .316 & & \\
\hline & Total & 75.489 & 226 & & & \\
\hline \multirow{3}{*}{ Administration } & Between Groups & 7.945 & 4 & 1.986 & 4.623 & .001 \\
\hline & Within Groups & 94.517 & 220 & .430 & & \\
\hline & Total & 102.462 & 224 & & & \\
\hline $\begin{array}{l}\text { If you were to leave your current } \\
\text { institution to accept another position, } \\
\text { how important would each of the } \\
\text { following items be in your decision to } \\
\text { accept another position? }\end{array}$ & Source & $\begin{array}{c}\text { Sum of } \\
\text { Squares }\end{array}$ & $d f$ & $\begin{array}{c}\text { Mean } \\
\text { Square }\end{array}$ & $F$ & Sig. \\
\hline \multirow{3}{*}{ Opportunities for advancement } & Between Groups & 4.839 & 4 & 1.210 & 2.714 & .031 \\
\hline & Within Groups & 101.191 & 227 & .446 & & \\
\hline & Total & 106.030 & 231 & & & \\
\hline \multirow{3}{*}{ No pressure to publish } & Between Groups & 7.078 & 4 & 1.769 & 3.523 & .008 \\
\hline & Within Groups & 114.021 & 227 & .502 & & \\
\hline & Total & 121.099 & 231 & & & \\
\hline \multirow{3}{*}{ Academic Freedom } & Between Groups & 3.007 & 4 & .752 & 2.537 & .041 \\
\hline & Within Groups & 97.732 & 225 & .434 & & \\
\hline & Total & 102.591 & 229 & & & \\
\hline $\begin{array}{l}\text { Please indicate the extent to which } \\
\text { you agree or disagree with each of } \\
\text { the following statements. }\end{array}$ & Source & $\begin{array}{c}\text { Sum of } \\
\text { Squares }\end{array}$ & $d f$ & $\begin{array}{c}\text { Mean } \\
\text { Square }\end{array}$ & $F$ & Sig. \\
\hline \multirow{3}{*}{$\begin{array}{l}\text { The tenure system in higher } \\
\text { education should be preserved }\end{array}$} & Between Groups & 13.792 & 4 & 3.448 & 4.049 & .003 \\
\hline & Within Groups & 192.442 & 226 & .852 & & \\
\hline & Total & 206.234 & 230 & & & \\
\hline \multirow{3}{*}{$\begin{array}{l}\text { The administrative function is taking } \\
\text { an increasingly heavy share of } \\
\text { available resources at my institution }\end{array}$} & Between Groups & 11.885 & 4 & 2.971 & 4.150 & .003 \\
\hline & Within Groups & 158.239 & 221 & .716 & & \\
\hline & Total & 170.124 & 225 & & & \\
\hline \multirow{3}{*}{$\begin{array}{l}\text { Faculty who are members of racial or } \\
\text { ethnic minorities are treated fairly at } \\
\text { my institution }\end{array}$} & Between Groups & 8.054 & 4 & 2.014 & 3.831 & .005 \\
\hline & Within Groups & 117.209 & 223 & .526 & & \\
\hline & Total & 125.263 & 227 & & & \\
\hline
\end{tabular}




\section{CHAPTER 5.}

\section{CONCLUSIONS, DISCUSSION, AND RECOMMENDATIONS}

\section{Summary of the Study}

This research project was undertaken to examine the reasons why faculty members choose to affiliate with a committed Christian college and to measure their commitment to their current institution and their satisfaction with various job-related values and issues. It also sought to make comparisons between the characteristics and satisfaction of faculty members at committed Christian colleges and faculty members in general in American institutions of higher education.

Four threads of knowledge and research were examined as a conceptual framework for this study: 1) the nature and characteristics of committed Christian colleges; 2) the nature and characteristics of college faculty members; 3) satisfaction of faculty members and their commitment to their institution and its mission; and 4) the historical reluctance of an institution to hire its own graduates as faculty members (known as faculty inbreeding).

A 118-item survey was administered on-line to all faculty members at 10 colleges affiliated with the Council for Christian Colleges and Universities (CCCU). Useable responses were received from 238 faculty members. The response rate was determined to be approximately 33\%.

The survey items were divided into four separate categories: 1) demographic and independent variables, 2) researcher-designed items to examine reasons for initial and current affiliation and critical areas of concern, 3) 15 items from the Organizational Commitment Questionnaire (OCQ) by Mowday, Steers, and Porter (1979), and 4) items from the National 
Study of Postsecondary Faculty (Russell, Fairweather, Hendrickson, \& Zimbler, 1991; Zimbler, 2001).

The primary research questions used to guide this study were:

1. What are the critical factors involved in a faculty member's decision to initially accept a job at a CCCU institution?

2. What are the critical factors involved in a faculty member choosing to remain in a position at a CCCU institution?

3. What are the critical factors that are considered most problematic by faculty members working at a CCCU institution?

4. Are there significant differences in the commitment of faculty to their institution among the faculty at 10 selected CCCU institutions based on the following characteristics: gender, age, current institution, church membership requirement, type of undergraduate alma mater, highest degree earned, academic rank, years of teaching experience (in their career and at their current institution) expected age of retirement, and academic field?

5. Are there significant differences in measures of satisfaction with or opinions about selected job components between faculty members at selected CCCU institutions and faculty members in general at US colleges and universities?

6. Are there significant differences in measures of satisfaction with or opinions about selected job components or values between faculty members at selected CCCU institutions based on the following characteristics: gender, age, current institution, church membership requirement, type of undergraduate alma mater, highest degree earned, academic rank, years of teaching 
experience (in their career and at their current institution) expected age of retirement, and academic field?

\section{Discussion of the Results Vis-À-Vis the Research Questions}

\section{Question 1: What are the critical factors involved in a faculty member's decision to initially accept a job at a CCCU institution?}

The two most frequently stated reasons for initially choosing to accept employment at the institution at which they were the Christian environment or atmosphere and the institutional mission or philosophy. These choices are logical, since over $67 \%$ of the faculty surveyed in this study are graduates of Christian college. In the pilot study conducted by the researcher, these reasons were also most often cited. These responses support Dannelly's contention (1931) that one of the primary foci of Christian colleges is to lead students to a Christian philosophy of life and to provide a Christian atmosphere for academic endeavors.

Closely related to these two responses were those that indicated that the denomination of the institution was an important reason for them to choose that particular institution at which to work. The combination of these three responses accounted for over $44 \%$ of the total responses to this question and nearly $60 \%$ of their first choices. It is apparent to this researcher that these faculty members were eager to accept a job, first and foremost, at a Christian college.

As far as their first choice of reasons, location and lack of any other job offers were the only other responses that were chosen by more than $5 \%$ of respondents; however, location was a strong second and third choice for respondents. It appears that once a faculty 
member has made a choice to work at a Christian college, location becomes a strong motivator in the choice of that institution.

One other factor worth mentioning was that the reputation of the institution or its programs was not a frequent first or second choice, but it accounted for nearly $9 \%$ of respondents third choices.

\section{Question 2: What are the critical factors involved in a faculty member choosing to remain in a position at a CCCU institution?}

Similar to their reasons for initially choosing to accept a job at a particular institution, the overall totals indicated that respondents felt that the Christian environment or atmosphere and the institutional mission or philosophy were the things that they currently appreciated most about their institutions. These two responses accounted for nearly $60 \%$ of the first choices for faculty members. Interestingly, the particular denomination of the institution did not remain an important characteristic for faculty once they were employed, as only $2 \%$ of the respondents indicated that this was the thing that they currently appreciated most about their institution.

Two factors displayed more significant impact on a faculty member’s current appreciation, as compared to their initial reason for choosing a position. Personal friendships with colleagues was selected $12 \%$ of the time in this category, as compared to only $5 \%$ in the former question, and characteristics and quality of students accounted for $11 \%$ of the current responses as compared to only $4 \%$ of their initial choice to affiliate. One final note-location of the institution fell in its relative standing from $12 \%$ of responses in the initial choice to affiliate to $7 \%$ with regard to current appreciation. 
Question 3: What are the critical factors that are considered most problematic by faculty members working at a CCCU institution?

A wide variety of issues selected cited by faculty as being problematic, but only two responses received a total of more than $10 \%$ of the total responses. Demands on faculty received over one-quarter of the first choice votes and nearly $20 \%$ of all responses, and insufficient wages or benefits was cited approximately in approximately $15 \%$ of the first choices and total responses. As a second choice ineffective administrative or academic leadership and lack of professional resources were each mentioned by $12 \%$ of the respondents and slowness of change was mentioned as a first choice by $12 \%$ of the respondents.

Question 4: Are there significant differences in the commitment of faculty to their institution among the faculty at 10 selected CCCU institutions based on the following characteristics: gender, age, current institution, church membership requirement, type of undergraduate alma mater, highest degree earned, academic rank, years of teaching experience (in their career and at their current institution) expected age of retirement, and academic field?

The 15 items of the Organizational Commitment Questionnaire (Mowday, Steers \& Porter, 1979) indicated a strong commitment on the part of faculty members to the institution at which they worked. The OCQ utilizes a 7-point Likert-type scale (from strongly disagree to strongly agree) to measure responses. The mean score for all participants on all questions was 5.5, which placed it midway between slightly agree and moderately agree. Every item in the OCQ was rated in the agree range, with the exception of item 4 (I would accept almost 
any type of job assignment in order to keep working for this institution), which received an average score of 2.94 (slightly disagree). Since all respondents are full-time faculty members at their institutions, it is reasonable to assume that they are not interested in just "any type of job assignment." If this item is removed in the calculation of the overall mean, the mean score jumps to approximately 5.7.

Of specific interest in this study was whether differences in commitment scores would be observed based on any individual characteristics. Analysis of Variance tests were conducted using 10 different independent variables: gender, age, institution, church membership, type of alma mater, highest degree earned, academic rank, years teaching (career), years teaching (institution), expected age of retirement, and academic field. Harshbarger (1989) reported finding no statistically significant differences based on several similar independent variables; however, ANOVA testing in this study resulted in 31 statistically significant differences in mean scores based on the independent variables tested.

The highest number of mean score differences were found when comparing based on gender. Female faculty members had higher mean scores on 7 of the 15 items, and the overall OCQ mean, indicating greater commitment to their institution than their male counterparts. These findings appear somewhat contrary to Gartlett (1997) who reported that female faculty members face resistance from students and colleagues at their CCCU institutions and to the results of the satisfaction items on the NSOPF surveys (Russell, Fairweather, Hendrickson, \& Zimbler, 1991; Zimbler, 2001) in which mean satisfaction scores for women were typically lower than those for men.

The only other categories in which there were significant differences in the Overall OCQ mean score were when age and institution were used as independent variables. In the 
case of age, younger faculty members (in their 30s) had significantly lower OCQ scores than their older counterparts (in their 60s), signifying lower institutional commitment. This difference makes sense, since the older faculty members are likely to have been teaching at the institution for a much longer time. When institution was used as an independent variable, two institutions were observed to have significantly higher mean scores than three others, indicating that the faculty at those two institutions demonstrated higher organizational commitment than those at the other three. There was not one single institution that had higher mean scores on any one item than all of the other institutions.

The rest of the significant comparisons were on specific OCQ items, rather than the overall mean score. On four of the questions, faculty members who were required to belong to the denomination which oversees or supports the institution indicated higher mean scores than those who did not have such a requirement. This indicates greater commitment on their part to their institution than those faculty members at institutions without such a requirement. This finding is interesting, especially in light of the example given in the preface to this study. It appears that a church membership requirement is not a detriment to the satisfaction of participants in this study.

With regard to their alma mater, faculty members who attended the institution at which they were working scored significantly higher than those who attended other colleges scored higher on two items. This is particularly interesting to this researcher in light of the studies that eschewed the practice of faculty inbreeding (Conrad \& Wyer, 1982; Dutton, 1980; Eells \& Cleveland, 1935/1999; Miller, 1977). However, interestingly, faculty members who attended a non-Christian undergraduate institution scored significantly higher 
on I could just as well be working for a different institution as long as the type of work were similar than their counterparts who had attended another CCCU institution.

The ANOVA results from the independent variables highest degree earned and academic rank showed no significant differences on the OCQ scores. The independent variable, academic field, showed a greater commitment to the organization on two of the questions by faculty members who taught in pre-professional programs than their counterparts in the social sciences.

The last three independent variables (years teaching-career, years teaching-institution, and expected age of retirement) showed several differences in mean scores on individual OCQ items. In each case, those faculty members who had been teaching longer, or who expected to teach to an older age had higher mean scores on the items, perhaps demonstrating a stronger commitment to the institution.

\section{Question 5: Are there significant differences in measures of satisfaction with or opinions about selected job components between faculty members at selected CCCU institutions and faculty members in general at US colleges and universities?}

The 70 items from the NSOPF instrument (Russell, Fairweather, Hendrickson, \& Zimbler, 1991; Zimbler, 2001) that were used in this study offered an opportunity for comparisons between both the participants in the study and faculty members who have participated in the national survey conducted by the National Center for Education Statistics.

The 28 items that addressed faculty members satisfaction with their current position (scored on a 4-point Likert type scale) indicated strong levels of satisfaction. On all but three items, the responses fell in the satisfied category, with only time available for keeping 
current in my field, quality of my research facilities and support, and research assistance that I receive scoring lower than a 2.5 (midpoint between very dissatisfied and very satisfied). In 18 of the questions, respondents scored between somewhat satisfied and very satisfied.

The results of two particular questions mirrored the results of a researcher-designed question that is described above. Respondents indicated strong satisfaction with the institutional mission or philosophy and with their colleagues at the institution.

The questions that addressed reasons why a faculty member might leave their institution indicated satisfaction as well, with retirement being listed as the most likely reason for severing the relationship with their current institution. Only one other reason (accept employment at another Christian college or university) fell in the somewhat likely category.

Five questions addressed the type of work in which faculty members would like to be engaged if they were to move to another institution. Scores indicated that faculty members appreciate the current mix of activities in which they are currently engaged, since nearly all of the responses fell in the range of "same amount." The only role that they would appreciate doing more of in a different position is that of research.

In the next set of questions, the importance of colleagues and the institutional mission or philosophy to faculty members at these 10 Christian colleges was again reiterated. In this set of questions respondents were asked what characteristics would be important in another position. These two responses again received the highest degree of importance, along with benefits, academic freedom, and good instructional facilities and equipment. Somewhat contrary to other findings in the study, the fact that the new institution is a Christian college, while still being “somewhat important” ranked $14^{\text {th }}$ in importance of the 19 questions. 
The final set of questions from the NSOPF posed a list of 12 statements to which faculty members were asked to indicate their agreement or disagreement. Faculty members indicated agreement with nine of the statements to varying degrees, with highest scores for their choice of an academic career, the importance of faculty governance, and their support for teaching effectiveness as the primary criterion for faculty promotion. The three statements with which they expressed disagreement related to years of teaching as the primary criterion for faculty promotions, the efficacy of assessment at improving undergraduate education at their institution, and the importance of research and publications in faculty promotions, the final question receiving the lowest score.

The comparisons between respondents in this study and the responses from faculty members who have participated in the National Study of Postsecondary Faculty were very interesting. Using one-sample t-tests to compare the means of the two samples, the researcher found significant mean differences between the two samples on 43 of the 65 questions from the NSOPF.

On the questions that dealt with satisfaction with particular elements of their current positions, the faculty members in this study had greater satisfaction on 20 of the 22 items that demonstrated significantly different mean scores. They are more satisfied with their coworkers, their academic leaders, their students, their facilities and resources, the mix of teaching/research/administration, and their opportunities for advancement. They were significantly less satisfied, however, with their workload and the time that they have to keep current in their field. This may reflect the observation of McPherren (1994) that while overall faculty workload at CCCU colleges does not differ significantly from the national norms, the smaller the enrollment of the institution, the greater the teaching workload 
required by faculty. The greatest differences between the responses of these two groups fell in their satisfaction with teaching and research assistance, with participants in this study scoring more than a one point higher than those in the national sample for each of these two categories.

The questions that dealt with the importance of various characteristics in choosing to accept a position at a different institution, respondents in this study were less interested in personal/family characteristics than respondents in the national survey; they placed a lower importance on the environment and schools for their children and the geographic location of the new institution. They also rated salary lower than their national counterparts. However, as discussed above, the mission or philosophy of the new institution was considered a more important factor, as was a lack of pressure to publish in the new position.

The final set of questions from the NSOPF that were posed to participants in this study indicated a lower agreement with the efficacy of state or federally mandated assessment activities to improve undergraduate education on the part of respondents than those in the national study. Respondents in this study also had different opinions as to the tenure and promotion processes in higher education. They placed a lower value on research/publications and years of service/advanced degree in the promotion process and a higher value on teaching effectiveness as a criterion for promotion, perhaps because of the nature of their institutions as teaching, rather than research-focused institutions. As a group, they also found it less important that the tenure process in higher education should be continued.

Faculty members in this study felt more strongly that both female faculty members and faculty who are members of racial or ethnic minorities are treated fairly at their 
institution than those respondents in the national study. This is interesting, because as a whole, faculty at colleges affiliated with the CCCU have less gender, ethnic and racial diversity than the faculty sample in the NSOPF.

In summary, as a group, faculty members in this study appear to have an overall higher satisfaction level with the characteristics of their positions and the people with whom they work than those who answered the same questions in the national study.

Question 6: Are there significant differences in measures of satisfaction with or opinions about selected job components or values between faculty members at selected CCCU institutions based on the following characteristics: gender, age, current institution, church membership requirement, type of undergraduate alma mater, highest degree earned, academic rank, years of teaching experience (in their career and at their current institution) expected age of retirement, and academic field?

As with the responses to the OCQ items in the survey, an analysis of variance between mean scores on the NSOPF questions was also conducted based on the same set of independent variables. With regard to gender, the results indicated many statistically significant differences between the responses of males and females. On the whole, females were more satisfied with the characteristics of their current job, including its overall reputation, their departmental reputation, the quality of their colleagues, leadership, and students, and the institutional mission or philosophy. However, when considering what would be important in a new position if they were to leave their current institution, they placed a higher emphasis on salary, benefits, facilities, excellent students, and location than 
their male colleagues. Male faculty members placed a greater importance on the availability of a full-time job, if they were to consider a different position.

Above it was mentioned that as a group, the CCCU respondents in this study felt more strongly that female faculty members are treated fairly at their institutions. However, the ANOVA results indicated a significant difference between the male and female respondents in this study. Although they still fell within the 'agree' range on this question, females had significantly lower mean scores on this question than males.

When age was used as an independent variable to compare responses between participants on the NSOPF items, more often than not, a bi-modal distribution of scores tended to be observed. Those faculty who were older (60s and 70s) appeared to be more satisfied with their positions than those who were in their middle years (30s, 40s, and 50s), but often faculty members in their 20s also appeared to be more satisfied than those in their middle years. These results seem to mirror those of Hagedorn (2000), since faculty members in their middle years are likely to be experiencing greater changes in family-related circumstances. Older faculty members were more satisfied with the reputation of their institutions, the cooperation they have with colleagues, the quality of their students and the institution's mission or philosophy.

Not surprisingly, faculty members in their 60s and 70s had higher mean scores relating to their intention to leave in order to retire than those who were younger, and those in their middle years indicated a greater willingness to leave to teach at another Christian college than those who were nearer to retirement age.

As with the results from the OCQ analysis of variance, the ANOVA results for the NSOPF seemed to indicate that there were differences in satisfaction between faculty at 
several of the institutions. A visual analysis of the 21 questions that showed significant mean differences between scores on the NSOPF questions tended to cluster between 5 of the 10 institutions. Two of the institutions tended to have higher mean scores than three of the other institutions.

Similar to the results obtained from the analysis of variance between institutions who require their faculty to belong to a particular denomination and those who do not, the faculty at those institutions with a church membership requirement tended to be more satisfied than those who were not required to belong to a particular denomination. This is possibly the result of a greater overall commitment to the organization, or a stronger sense of mission value congruence as suggested by Niehoff (1995). These faculty members had greater satisfaction with the reputation of their department and institution, the institutional mission or philosophy and the quality of their students. They also felt more strongly that their institution meets the educational needs of entering students. One interesting note, faculty who worked at institutions that require membership in a particular denomination also felt that the administrative function is taking a greater share of the available resources at their institutions.

The next independent variable, alma mater, also seemed to indicate that those faculty members who had a stronger connection to their institution were more satisfied with their current position. Faculty members who attended the institution at which they work as an undergraduate student scored more highly than those who attended other types of institutions on several of the questions in the survey. They, and their counterparts who attended another CCCU institution, also were more likely to indicate that if they were to leave their current position, they would be more likely to choose to work at another Christian college. Finally, 
the faculty members who are working at their alma mater felt less strongly about the importance of academic freedom and felt more strongly that teaching effectiveness should be the primary criterion in faculty promotions.

An interesting observation in this analysis was that attendance at another CCCU Christian college did not necessarily produce greater satisfaction. Attendees of another CCCU institution reported lower satisfaction with the overall institutional reputation and their belief that their current institution meets the educational needs of entering students than those who are working at their alma mater. This could be due to the fact that faculty members who are working at their alma mater have biased recollections of their undergraduate experience that flavors their current experience.

The level of educational attainment of faculty members did appear to have a modest impact their satisfaction level. Faculty members who have completed the master's degree were more satisfied than those with doctoral degrees with their current positions with regard to workload, time to keep current, teaching and research assistance and research facilities and support. However, as expected, those with doctoral degrees were more satisfied with their opportunities for advancement in rank at their current institution.

A comparable analysis, using academic rank as an independent variable, produced somewhat different results. There were no significant differences between various academic ranks on many of the satisfaction variables. However, as expected, those faculty members who are full professors were more satisfied with their job security and their opportunity for advancement than their counterparts whose positions were at a lower academic rank.

Advancement opportunities appear to be on the minds of faculty with lower academic rank. Full professors were more likely to leave to retire than assistant professors, and 
instructors were more likely to leave to return to school as a student and to leave their current job to accept employment at a secular institution than full professors and associate professors. This latter category could indicate a lower level of commitment to their institution or, simply, a realization that they may need to seek other employment in order to advance in rank. Faculty members at the assistant professor level were more interested in both opportunities for advancement and good environment and schools for their children than were full professors. While it is not always the case that faculty members at a lower academic rank are necessarily younger than their counterparts at higher academic ranks, it is a likely assumption that age and family situations are contributing factors to these responses.

The bi-modal results that appeared in the analysis by age and highest degree earned were observed again when the two variables years teaching (career) and years teaching (institution) were analyzed. Although these two variables were analyzed independently, the results for both are very similar. Faculty members who had only been teaching for 1-5 years were more satisfied with several characteristics of their positions (primarily workloadrelated) than those who had been teaching for a longer period of time. However, faculty who had been teaching for a longer period of time were more satisfied with the opportunities they have to influence their work and institution.

Similar to other individual variables, those faculty who have been teaching for more than 12 years were more likely to leave to retire than those with a shorter teaching career, but junior faculty with only 1-5 years of teaching experience were more likely to leave to teach at a secular institution than those with more teaching experience. For faculty in the middle category (6-11 years of teaching experience) good schools, opportunities for spouses, and excellent colleagues were more important than those with only 1-5 years of experience. 
The last age-related independent variable was slightly different in its orientation. It asked faculty to estimate the age at which they felt that they might retire from teaching. There were three interesting result in this category. One was that faculty who expected to retire at age 60 or younger were more likely to indicate that they would leave their current position to accept employment in consulting or not-for-profit business than were faculty who expected to retire at an older age. A second characteristic is that these faculty members were also less likely to respond that if they had it to do over again, they would choose an academic career. Finally, if they were to leave their current position they were more interested in seeking part-time employment than their colleagues. These three questions seem to indicate a relationship between lack of satisfaction and an earlier expected retirement age—or a desire to seek some other type of employment in addition to their faculty responsibilities.

The final independent variable, academic field, produced 17 significant differences in mean scores on the NSOPF questions. Overall, those faculty in the pre-professional fields were observed to be more satisfied than their counterparts in the other fields on the various work-related characteristics. They had greater appreciation for their students, the amount of assistance that they receive in their positions, and were also more satisfied with the level of academic freedom that they experience.

\section{Summary of the Results}

There are many factors that contribute to the decision to choose a particular job, but faculty members at these 10 Christian colleges indicated that their decisions to initially accept employment at these particular institutions was strongly influenced by the mission and 
philosophy of the institution, a sense of a strong Christian environment at the institution, and, in some cases, the particular denominational affiliation of the institution.

While the mission and Christian environment of the institution remain strong factors in their decision, the influences of excellent students and strong relationships and collegiality with colleagues are two very significant motivators for the faculty members in this study to remain at their particular institutions. Both of these results support the work of Kuh et al. (1991) and Lamport (1994).

The participants in this study are strongly committed to their institutions, but they still find many things to be problematic or dissatisfying about their current employment. They are frustrated with the heavy demands of their positions and the paucity of key resources, such as a lack of time to keep current in their field, the quality of research facilities and support, and the research assistance that they receive. They are also concerned about the insufficiency of wages or benefits. Some also reported concerns about ineffective administrative or academic leadership.

Results from the Organizational Commitment Questionnaire (OCQ) questions and mean score indicate a strong commitment on the part of these Christian college faculty members to their institutions, supporting the work of Ellis (2001), Niehoff (1995), Sheridan (1995), and Flowers (1992). The mean score of female faculty members on the OCQ items was significantly higher than that their male counterparts, indicating a stronger sense of commitment to their institution. This trend is contrary to some of the other research concerning female faculty members that was reviewed (Gartlett, 1997; Russell, Fairweather, Hendrickson, \& Zimbler, 1991; Zimbler, 2001). However, perhaps the impact of the caring academic community that these institutions espouse (Cameron, 1994) and the Christian 
values that these institutions attempt to instill (Carlburg, 1994; Kleiner, 1999) is a causal factor that contributes to female faculty members feeling more identification with and commitment to their institution.

The satisfaction of these participants with the characteristics of their work (based on their responses to questions from the National Study of Postsecondary Faculty) was strong. Nearly all responses were well in the satisfied range of the scale. In general, the respondents in this study had higher mean scores for satisfaction with their jobs than the participants in the national NSOPF studies to which they were compared. The primary exceptions to this were their lower satisfaction regarding their workload and available time, and the lower significance they placed on the importance of academic freedom, the traditional tenure process, and their participation in research and scholarly publications. The perceived lower concern for academic freedom issues support the research of Marty (1998), Diekema (2000), and Cooper (1999).

Several independent variables were observed to impact the satisfaction of faculty members at these institutions. Female respondents were more satisfied with many aspects of their jobs than their male counterparts. Older faculty members and those who had been at the institution for a longer period of time were more satisfied than those who were in the earlier years of their career. Those faculty members who were graduates of the institution at which they currently work were more satisfied than others, as were participants who work at institutions with church membership requirements for faculty members. 


\section{Limitations of the Study}

As a novice researcher, it is easy to find limitations in one's work. This study was not without errors, omissions and wrong turns. A brief list of limitations follows.

\section{Breadth of the study}

This research study was too broadly constructed. The researcher should have limited the number of research questions and more closely focused the topics to be investigated. Individual studies could have been conducted on each of the six research questions posed in this study. The scope of the study did not allow for thorough, in-depth analysis of some of the causal relationships that may be present in the data.

\section{Amount of data}

The use of an online instrument allows for immediate, and usually accurate, collection and transmittal of data; however this should not be seen as license to ask more questions than are necessary or appropriate. Several of the questions were superfluous to the study and could have been eliminated (e.g., the number of years in a part-time position, the reasons why a person might leave his or her current institution, and the desired level of various work components in a new position). Several others were poorly constructed and, thus, did not allow for their use in meaningful analysis (e.g., whether a faculty member was in a part-time position by choice and the number of years in a part-time position). A shorter survey may have resulted in a greater response rate. 


\section{Clarity of some of the questions}

There were several questions in the study that asked participants to determine the “fairness” of treatment on their campus of several sub-groups. Two such questions were: Female faculty members are treated fairly at my institution and Faculty who are members of racial or ethnic minorities are treated fairly at my institution. Even though these questions were taken directly from the National Study of Postsecondary Faculty, it is possible that the term "fairly" could have been construed differently by faculty who participated in this study. This could have resulted in different types of responses by male and female faculty members or by faculty members who are members of racial or ethnic minority groups and those who are not, thus resulting in apparent contradictions of responses.

Another such issue could pertain to the word "research.” Several questions asked faculty members to address the resources that their institutions provide for research activities and the value of research endeavors in their promotion and tenure process. It was noted several times in the study that teaching is the primary work-activity for faculty members at CCCU institutions and research is a secondary or tertiary activity. For this reason, research could have been construed by some participants in this study as "keeping up with the research in a person's field of study," while for others it may have been thought of as “conducting original research for the purpose of ascertaining new insights.” Again, this

possible confusion regarding a term in the question could have resulted in some contradictory responses. 


\section{Identification and communication with the participants}

Since this study was meant to be anonymous, the researcher communicated via email to the participants through the chief academic officer at the various institutions. Mechanically, this process worked well, but it did not allow for verification of the number of participants in the study, nor did it allow the researcher to manage the timing of the study in an expedient manner. In addition, this process may have caused faculty members who were dissatisfied with their current institution to use caution in their responses, or not respond to the survey at all, out of concern that their chief academic officer may have access to their responses. Direct communication with the participants by the researcher would have improved this study.

\section{Lack of generalization}

The faculty members of only 10 institutions within the Council for Christian Colleges and Universities were surveyed. This represents less than $10 \%$ of the member institutions in this diverse organization. While a panel of experts was used to select the institutions, and significant attempts were made to diversify the types and locations of the institutions, concern should be taken when generalizing the the results of the study to all of the member institutions.

In addition, the comparisons made with NSOPF survey data should be seen as generalizations. The data from this study was collected from faculty at small, private, Christian colleges, while the NSOPF data were the aggregate of all NSOPF respondents. 


\section{Number of responses and return rate}

The population of full-time faculty members at the 10 institutions is approximately 725. The number of useable responses from full-time faculty members in this study was 238, resulting in an approximate return rate of 33\%, therefore those faculty members who responded to the survey may not have been representative of the entire population. Perhaps they were more likely to respond because they are more satisfied with their position and institution than others who did not respond.

Another delimiting factor was the variance in the number of responses between institutions, from a low of 9 to a high of 35. These numbers make analysis of variation by institutions a difficult task.

\section{Lack of data on part-time faculty members}

The extremely low response rate from part-time faculty members $(2.1 \%$ of the useable responses) did not allow for appropriate statistical analysis, so the responses were omitted. Data from part-time faculty members at CCCU colleges on these topics would be interesting to analyze, but such analysis was not possible in this research study.

\section{Perspective of the researcher}

Although every attempt was made by the researcher to maintain his objectivity and professional distance when constructing and conducting this study, it must be noted that the researcher is a product of, and employee at, a committed Christian college (although not one of the institutions surveyed in this study). It is possible that this fact may have contributed to inadvertent biases that may have impacted the study in some way. 


\section{Recommendations for Practice}

Although this study may not have contributed significantly to a broad understanding of the nature and understanding of faculty members at committed Christian colleges, it does provide some preliminary statistical data to support anecdotal observations regarding the satisfaction of this group. Several practical recommendations for Christian college administrators and boards can be made based on this study.

\section{Institutional mission}

All employees, but particularly faculty members, should have an understanding of, appreciation for, and belief in the mission and philosophy of the Christian college for which they work. In every question that related to this topic, the faculty members in this study indicated that the Christian environment and the influence of the institutional mission were fundamental to their satisfaction and continued affiliation with the institution. The findings of the 1977 report from the Association of American Colleges (Achieving the Mission) indicated that committed faculty are crucial to the ability of church-related institutions to achieve their missions.

In the faculty hiring process, committed Christian colleges should be open and direct about the nature of their mission and the expectations of faculty members to understand, support, and implement the stated goals of the mission to avoid the "striking ... dissimilarities” of interpretation of college mission reported by Ramierez and Brock (1996, p. 16). They should be forthright about the expectations for membership in a particular denomination, if such a requirement exists. They should explain the nuances of the institutional culture that may be impacted by their values and philosophy. And they should 
make efforts to educate and enfold faculty members who may not come from the particular tradition or denomination that founded and maintains the institution particularly if they hope to overcome the “religion gap” described by Sheridan (1995, p. 4631) "between faculty members whose identity is at variance with the employing institution.”

\section{Hiring alumni}

Committed Christian college should not be afraid to hire their own graduates. The research regarding the faculty inbreeding shows that the former concerns and aversion to this phenomenon are beginning to lessen. Colleges and universities often rely on their graduates to be strong ambassadors for the institution in their work roles and in their communities. If this is the case, why should they shy away from hiring their graduates to begin this process of inculcation and appreciation for the institution in their students? This study provided some evidence that faculty members who are alumni of the institution have greater satisfaction with their jobs and commitment to their institution than their colleagues from other undergraduate institutions. It is illogical, and not supported by the current research, for institutions to subscribe to an outdated taboo that suggests that faculty inbreeding is inappropriate.

\section{Wage and benefit inequities}

Administrators and boards of committed Christian colleges should address perceived wage and benefit inequities on the part of their faculty members. In nearly every category and question, faculty members in this study were more satisfied than their counterparts at other colleges and universities in the United States. However, their responses on questions 
related to wages and benefits demonstrated statistically significant lower satisfaction scores than the national average.

While the adage that Christian educators are more willing to make financial sacrifices because of their commitment to the cause of Christian education may be true in part, it does not rectify the perceived, or real, inequity that these faculty members feel regarding their remuneration. Leaders of committed Christian colleges must be in tune to the market forces that impact their faculty members and treat them morally and fairly in their compensation structure.

\section{Opportunities for spouses and families}

Closely related to being aware of possible wage and benefit inequities, administrators should do what they can in their institutions and in their communities to promote and encourage good employment opportunities for spouses and the availability of good schools for the children of faculty members. Many faculty members in the study indicated that these two factors were significant to their satisfaction level at their current institution, or would be so if they were to seek employment elsewhere.

College administrators should communicate regularly with school administrators regarding the quality of schools. If the institution has an undergraduate education program, every effort should be made to collaborate on student internships and teacher professional development opportunities.

College administrators should also play an active role in the civic and business communities, in order to promote their institution and develop good will towards its faculty members and their spouses. And, when appropriate, colleges should not be afraid to hire the 
spouses of faculty members for jobs within the institution. Of course, the ill effects of nepotism and its potential side-effects must always be weighed, but if best practices in hiring, supervision, and evaluation are followed, these effects can likely be adequately minimized.

\section{Workload of faculty}

Administrators at committed Christian colleges should also be aware that their faculty members feel overworked, especially those with higher academic rank and more years of service to the institution. According to Russell, Fairweather, Hendrickson, and Zimbler (1991), faculty members in the United States work between 53 and 55 hours per week. While this study did not ascertain the number of hours that faculty members at the institutions surveyed in this study worked, it is safe to assume that they are close to the national average. The study did indicate, however, that faculty members at these institutions felt overworked, and were frustrated with the amount of time that they have to remain current in their fields. It is possible that this frustration could lead to burnout and lack of effectiveness on the part of faculty members.

\section{Collaboration opportunities}

Administrators of committed Christian colleges should promote opportunities for collegiality and collaboration between the faculty members on their campuses. The sense of appreciation and regard that respondents have for their colleagues was a consistent theme in this study. After their appreciation for the institutional mission and Christian environment on their campuses, they rated their relationships with excellent colleagues as the next most important thing that they appreciate about their jobs. 


\section{Suggestions for Further Research}

As mentioned above, even though this study was quite broad in its scope, there are several areas which provide ample opportunities for further research and reflection. Several of those items are described below.

This study focused only on 10 institutions that are part of the Council for Christian Colleges and Universities. A replication of some of the components of this study, in shorter surveys with greater and broader participation, would allow for a better understanding and greater generalization of the findings herein.

One very interesting adaptation of the study would be to include enough part-time faculty members to be able to determine whether differences exist in their organizational commitment and job satisfaction, particularly since the trend for many institutions, including those in the CCCU, to hire greater number of part-time faculty members is increasing.

Also mentioned above was the lack of this study to examine contributing factors to and causal relationships between several of the factors in this study. It would be important to study the contributing factors to the lower satisfaction of mid-level and mid-aged faculty members, as well as the contributing factors to the higher satisfaction of female faculty members. Using multiple regression analysis techniques, one might also be able to determine the extent to which specific variables in this study are contributing to the satisfaction and organizational commitment of faculty members at these institutions.

Another recommendation for further research would be to identify the characteristics that may contribute to differences between satisfaction and organizational commitment levels that exist between male and female faculty members, and the differences that were apparent 
on the various campuses of the CCCU. Due to the breadth of this study and the low response rate from several institutions, such comparisons between institutions were unable to be made. Further elaboration on the study could also be carried out by surveying administrative staff and other personnel who have significant contact with students on the campuses of the CCCU institutions. If it is true, as suggested in materials from the CCCU (Council for Christian Colleges \& Universities, 2000), that member institutions must provide evidence of how faith is integrated with the institution's academic and student life programs, then it follows that other employees in the institution should share in the support of the institution's mission. 
APPENDIX A.

ADDITIONAL TABLES 
OCQ descriptive statistics by gender

\begin{tabular}{|c|c|c|c|c|c|}
\hline OCQ Questions & Gender & $N$ & Mean & $\begin{array}{l}\text { Standard } \\
\text { Deviation }\end{array}$ & $\begin{array}{l}\text { Standard } \\
\text { Error }\end{array}$ \\
\hline \multirow{3}{*}{$\begin{array}{l}\text { OCQ 1: I am willing to put in a great deal of effort } \\
\text { beyond that normally expected in order to help this } \\
\text { institution to be successful. }\end{array}$} & Female & 89 & 6.40 & .888 & .094 \\
\hline & Male & 145 & 6.34 & .899 & .075 \\
\hline & Total & 234 & 6.36 & .894 & .058 \\
\hline \multirow{3}{*}{$\begin{array}{l}\text { OCQ 2: I talk up this institution to my friends as a great } \\
\text { institution to work for. }\end{array}$} & Female & 89 & 6.26 & 1.153 & .122 \\
\hline & Male & 145 & 5.73 & 1.420 & .118 \\
\hline & Total & 234 & 5.93 & 1.347 & .088 \\
\hline \multirow{3}{*}{$\begin{array}{l}\text { OCQ 3: I feel very little loyalty to this institution. } \\
\text { (reversed) }\end{array}$} & Female & 89 & 6.00 & 1.907 & .202 \\
\hline & Male & 144 & 5.53 & 1.968 & .164 \\
\hline & Total & 233 & 5.71 & 1.954 & .128 \\
\hline \multirow{3}{*}{$\begin{array}{l}\text { OCQ 4: I would accept almost any type of job } \\
\text { assignment in order to keep working for this institution. }\end{array}$} & Female & 89 & 3.17 & 1.720 & .182 \\
\hline & Male & 145 & 2.79 & 1.705 & .142 \\
\hline & Total & 234 & 2.93 & 1.717 & .112 \\
\hline \multirow{3}{*}{$\begin{array}{l}\text { OCQ 5: I find my values and the institution's values are } \\
\text { very similar. }\end{array}$} & Female & 89 & 6.22 & 1.085 & .115 \\
\hline & Male & 145 & 5.90 & 1.255 & .104 \\
\hline & Total & 234 & 6.03 & 1.201 & .078 \\
\hline \multirow{3}{*}{$\begin{array}{l}\text { OCQ 6: I am proud to tell others that I am part of this } \\
\text { institution. }\end{array}$} & Female & 88 & 6.51 & 1.061 & .113 \\
\hline & Male & 144 & 5.98 & 1.260 & .105 \\
\hline & Total & 232 & 6.18 & 1.214 & .080 \\
\hline \multirow{3}{*}{$\begin{array}{l}\text { OCQ 7: I could just as well be working for a different } \\
\text { institution as long as the type of work were similar. } \\
\text { (reversed) }\end{array}$} & Female & 89 & 4.58 & 1.565 & .166 \\
\hline & Male & 143 & 3.90 & 1.759 & .147 \\
\hline & Total & 232 & 4.16 & 1.717 & .113 \\
\hline \multirow{3}{*}{$\begin{array}{l}\text { OCQ 8: The institution really inspires the very best in } \\
\text { me in the way of job performance. }\end{array}$} & Female & 89 & 5.19 & 1.507 & .160 \\
\hline & Male & 145 & 4.90 & 1.606 & .133 \\
\hline & Total & 234 & 5.01 & 1.572 & .103 \\
\hline \multirow{3}{*}{$\begin{array}{l}\text { OCQ 9: It would take very little change in my present } \\
\text { circumstances to cause me to leave this institution. } \\
\text { (reversed) }\end{array}$} & Female & 89 & 5.88 & 1.338 & .142 \\
\hline & Male & 144 & 5.35 & 1.636 & .136 \\
\hline & Total & 233 & 5.55 & 1.547 & .101 \\
\hline \multirow{3}{*}{$\begin{array}{l}\text { OCQ 10: I am extremely glad that I chose this } \\
\text { institution to work for over others I was considering at } \\
\text { the time I joined. }\end{array}$} & Female & 89 & 5.92 & 1.448 & .153 \\
\hline & Male & 143 & 5.69 & 1.361 & .114 \\
\hline & Total & 232 & 5.78 & 1.396 & .092 \\
\hline \multirow{3}{*}{$\begin{array}{l}\text { OCQ 11: There's not too much to be gained by sticking } \\
\text { with this institution indefinitely. (reversed) }\end{array}$} & Female & 88 & 5.70 & 1.562 & .167 \\
\hline & Male & 145 & 5.20 & 1.714 & .142 \\
\hline & Total & 233 & 5.39 & 1.673 & .110 \\
\hline \multirow{3}{*}{$\begin{array}{l}\text { OCQ 12: Often I find it difficult to agree with this } \\
\text { institution's policies on important matters relating to its } \\
\text { employees. (reversed) }\end{array}$} & Female & 89 & 4.65 & 1.816 & .192 \\
\hline & Male & 143 & 4.52 & 1.826 & .153 \\
\hline & Total & 232 & 4.57 & 1.820 & .119 \\
\hline \multirow{3}{*}{ OCQ 13: I really care about the fate of this institution. } & Female & 89 & 6.83 & .406 & .043 \\
\hline & Male & 145 & 6.45 & 1.034 & .086 \\
\hline & Total & 234 & 6.59 & .870 & .057 \\
\hline \multirow{3}{*}{$\begin{array}{l}\text { OCQ 14: For me this is the best of all possible } \\
\text { institutions for which to work. }\end{array}$} & Female & 89 & 5.67 & 1.321 & .140 \\
\hline & Male & 144 & 4.96 & 1.820 & .152 \\
\hline & Total & 233 & 5.23 & 1.681 & .110 \\
\hline
\end{tabular}


OCQ descriptive statistics by gender (continued)

\begin{tabular}{|l|l|r|r|r|r|}
\hline \hline \multirow{2}{*}{$\begin{array}{l}\text { OCQ 15: Deciding to work for this institution was a } \\
\text { definite mistake on my part. (reversed) }\end{array}$} & Female & 89 & 6.83 & .727 & .077 \\
\cline { 2 - 6 } & Male & 142 & 6.60 & .975 & .082 \\
\cline { 2 - 6 } & Total & 231 & 6.69 & .893 & .059 \\
\hline \multirow{3}{*}{ OCQ Mean } & Female & 89 & 5.713 & .76498 & .08109 \\
\cline { 2 - 6 } & Male & 145 & 5.290 & .96429 & .08008 \\
\cline { 2 - 6 } & Total & 234 & 5.451 & .91544 & .05984 \\
\hline \hline
\end{tabular}


OCQ descriptive statistics by age

\begin{tabular}{|c|c|c|c|c|c|}
\hline OCQ Questions & $\begin{array}{c}\text { Age } \\
\text { Range }\end{array}$ & $N$ & Mean & $\begin{array}{l}\text { Standard } \\
\text { Deviation }\end{array}$ & $\begin{array}{l}\text { Standard } \\
\text { Error }\end{array}$ \\
\hline \multirow{7}{*}{$\begin{array}{l}\text { OCQ 1: I am willing to put in a great deal of effort } \\
\text { beyond that normally expected in order to help this } \\
\text { institution to be successful. }\end{array}$} & $20-29$ & 7 & 6.00 & .577 & .218 \\
\hline & $30-39$ & 41 & 6.12 & 1.077 & .168 \\
\hline & $40-49$ & 61 & 6.48 & .906 & .116 \\
\hline & $50-59$ & 86 & 6.40 & .885 & .095 \\
\hline & $60-69$ & 35 & 6.46 & .701 & .118 \\
\hline & $\begin{array}{l}70 \text { and } \\
\text { above }\end{array}$ & 5 & 6.60 & .548 & .245 \\
\hline & Total & 235 & 6.37 & .893 & .058 \\
\hline \multirow{7}{*}{$\begin{array}{l}\text { OCQ 2: I talk up this institution to my friends as a great } \\
\text { institution to work for. }\end{array}$} & $20-29$ & 7 & 6.00 & 1.000 & .378 \\
\hline & $30-39$ & 41 & 5.85 & 1.459 & .228 \\
\hline & $40-49$ & 61 & 6.13 & 1.218 & .156 \\
\hline & 50-59 & 86 & 5.77 & 1.444 & .156 \\
\hline & $60-69$ & 35 & 6.17 & .985 & .166 \\
\hline & $\begin{array}{l}70 \text { and } \\
\text { above }\end{array}$ & 5 & 6.60 & .548 & .245 \\
\hline & Total & 235 & 5.96 & 1.309 & .085 \\
\hline \multirow{7}{*}{$\begin{array}{l}\text { OCQ 3: I feel very little loyalty to this institution } \\
\text { (reversed) }\end{array}$} & $20-29$ & 7 & 5.29 & 1.799 & .680 \\
\hline & $30-39$ & 40 & 5.18 & 2.229 & .352 \\
\hline & $40-49$ & 61 & 5.61 & 2.052 & .263 \\
\hline & $50-59$ & 86 & 5.88 & 1.869 & .202 \\
\hline & $60-69$ & 35 & 6.23 & 1.629 & .275 \\
\hline & $\begin{array}{l}70 \text { and } \\
\text { above }\end{array}$ & 5 & 5.20 & 2.387 & 1.068 \\
\hline & Total & 234 & 5.71 & 1.968 & .129 \\
\hline \multirow{7}{*}{$\begin{array}{l}\text { OCQ 4: I would accept almost any type of job } \\
\text { assignment in order to keep working for this institution. }\end{array}$} & $20-29$ & 7 & 2.57 & 1.902 & .719 \\
\hline & $30-39$ & 41 & 2.73 & 1.689 & .264 \\
\hline & $40-49$ & 61 & 2.98 & 1.678 & .215 \\
\hline & $50-59$ & 86 & 2.88 & 1.676 & .181 \\
\hline & $60-69$ & 35 & 3.26 & 1.930 & .326 \\
\hline & $\begin{array}{l}70 \text { and } \\
\text { above }\end{array}$ & 5 & 3.60 & 2.074 & .927 \\
\hline & Total & 235 & 2.94 & 1.725 & .113 \\
\hline
\end{tabular}


OCQ descriptive statistics by age (continued)

OCQ 5: I find my values and the institution's values are very similar.

OCQ 5: I find my values and the institution's values are
very similar.

OCQ 6: I am proud to tell others that I am part of this institution.

\begin{tabular}{|c|c|c|c|c|}
\hline $20-29$ & 7 & 5.57 & 1.397 & .528 \\
\hline 30-39 & 41 & 5.93 & 1.212 & 189 \\
\hline $40-49$ & 61 & 6.03 & .966 & .124 \\
\hline 50-59 & 86 & 5.95 & 1.413 & .152 \\
\hline 60-69 & 35 & 6.43 & .948 & .160 \\
\hline $\begin{array}{l}70 \text { and } \\
\text { above }\end{array}$ & 5 & 6.20 & .447 & .200 \\
\hline Total & 235 & 6.03 & 1.198 & .078 \\
\hline $20-29$ & 7 & 5.86 & 1.464 & .553 \\
\hline 30-39 & 40 & 6.03 & 1.349 & .213 \\
\hline $40-49$ & 61 & 6.28 & 1.113 & .142 \\
\hline 50-59 & 85 & 6.09 & 1.342 & 146 \\
\hline $60-69$ & 35 & 6.46 & .852 & . 144 \\
\hline $\begin{array}{l}70 \text { and } \\
\text { above }\end{array}$ & 5 & 6.60 & .548 & .245 \\
\hline Total & 233 & 6.19 & 1.214 & .080 \\
\hline $20-29$ & 7 & 3.43 & 1.988 & .751 \\
\hline 30-39 & 41 & 4.10 & 1.744 & .272 \\
\hline $40-49$ & 61 & 4.03 & 1.612 & .206 \\
\hline $50-59$ & 84 & 4.11 & 1.763 & .192 \\
\hline 60-69 & 35 & 4.89 & 1.641 & .277 \\
\hline $\begin{array}{l}70 \text { and } \\
\text { above }\end{array}$ & 5 & 3.80 & 1.643 & .735 \\
\hline Total & 233 & 4.18 & 1.719 & .113 \\
\hline $20-29$ & 7 & 4.86 & 1.345 & .508 \\
\hline 30-39 & 41 & 4.71 & 1.569 & .245 \\
\hline $40-49$ & 60 & 5.23 & 1.358 & . 175 \\
\hline 50-59 & 86 & 5.09 & 1.606 & . 173 \\
\hline $60-69$ & 35 & 5.31 & 1.430 & .242 \\
\hline $\begin{array}{l}70 \text { and } \\
\text { above }\end{array}$ & 5 & 2.20 & 1.643 & .735 \\
\hline Total & 234 & 5.03 & 1.561 & . 102 \\
\hline $20-29$ & 7 & 5.14 & 1.676 & .634 \\
\hline 30-39 & 40 & 5.20 & 1.572 & .249 \\
\hline $40-49$ & 61 & 5.57 & 1.565 & .200 \\
\hline 50-59 & 86 & 5.49 & 1.614 & . 174 \\
\hline $60-69$ & 35 & 6.20 & 1.132 & 191 \\
\hline $\begin{array}{l}70 \text { and } \\
\text { above }\end{array}$ & 5 & 6.20 & .837 & .374 \\
\hline Total & 234 & 5.57 & 1.538 & .101 \\
\hline $20-29$ & 7 & 5.29 & .951 & .360 \\
\hline 30-39 & 40 & 5.40 & 1.722 & .272 \\
\hline $40-49$ & 59 & 5.85 & 1.436 & 187 \\
\hline 50-59 & 86 & 5.79 & 1.321 & .142 \\
\hline $60-69$ & 35 & 6.23 & 1.060 & .179 \\
\hline $\begin{array}{l}70 \text { and } \\
\text { above }\end{array}$ & 5 & 5.80 & 1.304 & .583 \\
\hline Total & 232 & 5.79 & 1.394 & .091 \\
\hline
\end{tabular}

OCQ 10: I am extremely glad that I chose this institution to work for over others I was considering at the time I joined.

OCQ 7: I could just as well be working for a different institution as long as the type of work were similar. (reversed)

OCQ 8: The institution really inspires the very best in me in the way of job performance.

OCQ 9: It would take very little change in my present circumstances to cause me to leave this institution. (reversed) 
OCQ descriptive statistics by age (continued)

OCQ 11: There's not too much to be gained by sticking with this institution indefinitely. (reversed)

OCQ 12: Often I find it difficult to agree with this institution's policies on important matters relating to its employees. (reversed)

OCQ 13: I really care about the fate of this institution.

OCQ 14: For me this is the best of all possible institutions for which to work.

\begin{tabular}{|c|c|c|c|c|}
\hline $20-29$ & 7 & 5.14 & 1.676 & .634 \\
\hline 30-39 & 41 & 4.98 & 1.782 & .278 \\
\hline $40-49$ & 60 & 5.23 & 1.750 & .226 \\
\hline $50-59$ & 85 & 5.49 & 1.616 & .175 \\
\hline $60-69$ & 35 & 6.06 & 1.327 & .224 \\
\hline $\begin{array}{l}70 \text { and } \\
\text { above }\end{array}$ & 5 & 5.60 & 1.673 & .748 \\
\hline Total & 233 & 5.41 & 1.661 & .109 \\
\hline $20-29$ & 7 & 4.43 & 1.718 & .649 \\
\hline $30-39$ & 40 & 4.80 & 1.682 & .266 \\
\hline $40-49$ & 60 & 4.33 & 1.772 & .229 \\
\hline $50-59$ & 86 & 4.43 & 1.991 & .215 \\
\hline $60-69$ & 35 & 5.17 & 1.543 & .261 \\
\hline $\begin{array}{l}70 \text { and } \\
\text { above }\end{array}$ & 5 & 4.80 & 1.789 & .800 \\
\hline Total & 233 & 4.59 & 1.815 & .119 \\
\hline $20-29$ & 7 & 5.57 & 2.070 & .782 \\
\hline 30-39 & 41 & 6.44 & 1.074 & .168 \\
\hline $40-49$ & 61 & 6.66 & .602 & .077 \\
\hline $50-59$ & 86 & 6.60 & .871 & .094 \\
\hline 60-69 & 35 & 6.91 & .284 & .048 \\
\hline $\begin{array}{l}70 \text { and } \\
\text { above }\end{array}$ & 5 & 6.60 & .548 & .245 \\
\hline Total & 235 & 6.60 & .863 & .056 \\
\hline $20-29$ & 7 & 5.14 & 1.773 & .670 \\
\hline 30-39 & 41 & 4.71 & 2.040 & .319 \\
\hline $40-49$ & 60 & 5.55 & 1.478 & .191 \\
\hline $50-59$ & 86 & 5.17 & 1.661 & .179 \\
\hline 60-69 & 35 & 5.63 & 1.395 & .236 \\
\hline $\begin{array}{l}70 \text { and } \\
\text { above }\end{array}$ & 5 & 5.40 & 1.817 & .812 \\
\hline Total & 234 & 5.26 & 1.672 & .109 \\
\hline $20-29$ & 7 & 7.00 & .000 & .000 \\
\hline 30-39 & 40 & 6.40 & 1.464 & .231 \\
\hline $40-49$ & 61 & 6.70 & .760 & .097 \\
\hline $50-59$ & 85 & 6.72 & .766 & .083 \\
\hline $60-69$ & 34 & 6.94 & .239 & .041 \\
\hline $\begin{array}{l}70 \text { and } \\
\text { above }\end{array}$ & 5 & 6.80 & .447 & .200 \\
\hline Total & 232 & 6.70 & .874 & .057 \\
\hline $20-29$ & 7 & 5.152 & .73203 & .27668 \\
\hline $30-39$ & 41 & 5.184 & 1.03824 & .16215 \\
\hline $40-49$ & 61 & 5.477 & .90618 & .11602 \\
\hline $50-59$ & 86 & 5.438 & .92820 & .10009 \\
\hline $60-69$ & 35 & 5.876 & .62059 & .10490 \\
\hline $\begin{array}{l}70 \text { and } \\
\text { above }\end{array}$ & 5 & 5.467 & .70396 & .31482 \\
\hline Total & 235 & 5.461 & .91011 & .05937 \\
\hline
\end{tabular}

OCQ 15: Deciding to work for this institution was a definite mistake on my part. (reversed)

OCQ Mean 
OCQ descriptive statistics by institution

\begin{tabular}{|c|c|c|c|c|c|}
\hline OCQ Questions & Institution & $N$ & Mean & $\begin{array}{l}\text { Standard } \\
\text { Deviation }\end{array}$ & $\begin{array}{l}\text { Standard } \\
\text { Error }\end{array}$ \\
\hline \multirow{11}{*}{$\begin{array}{l}\text { OCQ 1: I am willing to put in a great deal of effort } \\
\text { beyond that normally expected in order to help this } \\
\text { institution to be successful. }\end{array}$} & Institution 1 & 29 & 6.45 & .736 & .137 \\
\hline & Institution 2 & 19 & 6.16 & 1.259 & .289 \\
\hline & Institution 3 & 29 & 6.31 & .850 & .158 \\
\hline & Institution 4 & 19 & 5.95 & 1.079 & .247 \\
\hline & Institution 5 & 35 & 6.46 & .980 & .166 \\
\hline & Institution 6 & 14 & 6.14 & 1.292 & .345 \\
\hline & Institution 7 & 24 & 6.50 & .511 & .104 \\
\hline & Institution 8 & 9 & 6.56 & .527 & .176 \\
\hline & Institution 9 & 32 & 6.38 & .871 & .154 \\
\hline & Institution 10 & 24 & 6.63 & .576 & .118 \\
\hline & Total & 234 & 6.37 & .894 & .058 \\
\hline \multirow{11}{*}{$\begin{array}{l}\text { OCQ 2: I talk up this institution to my friends as a } \\
\text { great institution to work for. }\end{array}$} & Institution 1 & 29 & 5.97 & 1.017 & .189 \\
\hline & Institution 2 & 19 & 5.95 & 1.508 & .346 \\
\hline & Institution 3 & 29 & 5.66 & 1.203 & .223 \\
\hline & Institution 4 & 19 & 5.37 & 1.606 & .368 \\
\hline & Institution 5 & 35 & 6.51 & .702 & .119 \\
\hline & Institution 6 & 14 & 5.14 & 2.179 & .582 \\
\hline & Institution 7 & 24 & 5.75 & 1.751 & .357 \\
\hline & Institution 8 & 9 & 5.78 & 1.093 & .364 \\
\hline & Institution 9 & 32 & 6.44 & .759 & .134 \\
\hline & Institution 10 & 24 & 5.96 & 1.459 & .298 \\
\hline & Total & 234 & 5.94 & 1.343 & .088 \\
\hline \multirow{11}{*}{$\begin{array}{l}\text { OCQ 3: I feel very little loyalty to this institution } \\
\text { (reversed) }\end{array}$} & Institution 1 & 29 & 6.21 & 1.449 & .269 \\
\hline & Institution 2 & 19 & 6.00 & 1.732 & .397 \\
\hline & Institution 3 & 29 & 5.45 & 1.863 & .346 \\
\hline & Institution 4 & 19 & 5.63 & 1.422 & .326 \\
\hline & Institution 5 & 35 & 5.63 & 2.276 & .385 \\
\hline & Institution 6 & 14 & 4.64 & 2.620 & .700 \\
\hline & Institution 7 & 24 & 5.83 & 1.761 & .359 \\
\hline & Institution 8 & 8 & 6.25 & 2.121 & .750 \\
\hline & Institution 9 & 32 & 6.16 & 1.648 & .291 \\
\hline & Institution 10 & 24 & 4.92 & 2.620 & .535 \\
\hline & Total & 233 & 5.69 & 1.978 & .130 \\
\hline
\end{tabular}


OCQ descriptive statistics by institution (continued)

\begin{tabular}{|c|c|c|c|c|c|}
\hline \multirow{11}{*}{$\begin{array}{l}\text { OCQ 4: I would accept almost any type of job } \\
\text { assignment in order to keep working for this } \\
\text { institution. }\end{array}$} & Institution 1 & 29 & 2.76 & 1.845 & .343 \\
\hline & Institution 2 & 19 & 2.26 & 1.558 & .357 \\
\hline & Institution 3 & 29 & 2.97 & 1.880 & .349 \\
\hline & Institution 4 & 19 & 2.32 & 1.529 & .351 \\
\hline & Institution 5 & 35 & 3.06 & 1.731 & .293 \\
\hline & Institution 6 & 14 & 2.71 & 1.326 & .354 \\
\hline & Institution 7 & 24 & 3.42 & 1.381 & .282 \\
\hline & Institution 8 & 9 & 2.89 & 1.900 & .633 \\
\hline & Institution 9 & 32 & 3.16 & 1.816 & .321 \\
\hline & Institution 10 & 24 & 3.46 & 1.888 & .385 \\
\hline & Total & 234 & 2.95 & 1.725 & .113 \\
\hline \multirow{11}{*}{$\begin{array}{l}\text { OCQ 5: I find my values and the institution's } \\
\text { values are very similar. }\end{array}$} & Institution 1 & 29 & 6.24 & .786 & .146 \\
\hline & Institution 2 & 19 & 5.84 & 1.573 & .361 \\
\hline & Institution 3 & 29 & 6.03 & 1.117 & .208 \\
\hline & Institution 4 & 19 & 5.84 & 1.214 & .279 \\
\hline & Institution 5 & 35 & 6.17 & 1.175 & .199 \\
\hline & Institution 6 & 14 & 5.07 & 1.900 & .508 \\
\hline & Institution 7 & 24 & 6.25 & 1.073 & .219 \\
\hline & Institution 8 & 9 & 6.44 & .527 & .176 \\
\hline & Institution 9 & 32 & 6.06 & 1.162 & .205 \\
\hline & Institution 10 & 24 & 5.96 & 1.122 & .229 \\
\hline & Total & 234 & 6.03 & 1.201 & .078 \\
\hline \multirow{11}{*}{$\begin{array}{l}\text { OCQ 6: I am proud to tell others that I am part of } \\
\text { this institution. }\end{array}$} & Institution 1 & 29 & 6.24 & 1.091 & .203 \\
\hline & Institution 2 & 18 & 6.06 & 1.697 & .400 \\
\hline & Institution 3 & 28 & 6.00 & 1.122 & .212 \\
\hline & Institution 4 & 19 & 5.79 & 1.398 & .321 \\
\hline & Institution 5 & 35 & 6.74 & .505 & .085 \\
\hline & Institution 6 & 14 & 5.36 & 1.781 & .476 \\
\hline & Institution 7 & 24 & 6.29 & 1.160 & .237 \\
\hline & Institution 8 & 9 & 5.78 & .972 & .324 \\
\hline & Institution 9 & 32 & 6.38 & 1.070 & .189 \\
\hline & Institution 10 & 24 & 6.21 & 1.285 & .262 \\
\hline & Total & 232 & 6.19 & 1.215 & .080 \\
\hline \multirow{11}{*}{$\begin{array}{l}\text { OCQ 7: I could just as well be working for a } \\
\text { different institution as long as the type of work were } \\
\text { similar. (reversed) }\end{array}$} & Institution 1 & 28 & 4.54 & 1.856 & .351 \\
\hline & Institution 2 & 19 & 3.63 & 2.087 & .479 \\
\hline & Institution 3 & 29 & 4.07 & 1.831 & .340 \\
\hline & Institution 4 & 19 & 4.16 & 1.537 & .353 \\
\hline & Institution 5 & 34 & 4.74 & 1.504 & .258 \\
\hline & Institution 6 & 14 & 3.57 & 1.828 & .488 \\
\hline & Institution 7 & 24 & 3.83 & 1.633 & .333 \\
\hline & Institution 8 & 9 & 3.67 & 1.732 & .577 \\
\hline & Institution 9 & 32 & 4.38 & 1.737 & .307 \\
\hline & Institution 10 & 24 & 4.04 & 1.517 & .310 \\
\hline & Total & 232 & 4.16 & 1.728 & .113 \\
\hline
\end{tabular}


OCQ descriptive statistics by institution (continued)

OCQ 8: The institution really inspires the very best in me in the way of job performance.

\begin{tabular}{|c|c|c|c|c|}
\hline Institution 1 & 29 & 5.10 & 1.566 & .291 \\
\hline Institution 2 & 19 & 5.16 & 1.675 & .384 \\
\hline Institution 3 & 29 & 4.28 & 1.579 & .293 \\
\hline Institution 4 & 19 & 4.95 & 1.177 & .270 \\
\hline Institution 5 & 35 & 5.40 & 1.594 & .269 \\
\hline Institution 6 & 14 & 4.57 & 1.828 & .488 \\
\hline Institution 7 & 24 & 5.04 & 1.429 & .292 \\
\hline Institution 8 & 9 & 5.11 & 1.537 & .512 \\
\hline Institution 9 & 32 & 5.28 & 1.486 & .263 \\
\hline Institution 10 & 23 & 5.00 & 1.784 & .372 \\
\hline Total & 233 & 5.01 & 1.574 & .103 \\
\hline Institution 1 & 29 & 5.97 & 1.149 & .213 \\
\hline Institution 2 & 19 & 5.37 & 1.535 & .352 \\
\hline Institution 3 & 28 & 5.04 & 1.856 & .351 \\
\hline Institution 4 & 19 & 5.37 & 1.342 & .308 \\
\hline Institution 5 & 35 & 6.17 & 1.175 & .199 \\
\hline Institution 6 & 14 & 4.50 & 2.210 & .591 \\
\hline Institution 7 & 24 & 5.54 & 1.444 & .295 \\
\hline Institution 8 & 9 & 5.78 & 1.563 & .521 \\
\hline Institution 9 & 32 & 5.91 & 1.228 & .217 \\
\hline Institution 10 & 24 & 5.25 & 1.847 & .377 \\
\hline Total & 233 & 5.57 & 1.550 & .102 \\
\hline Institution 1 & 29 & 5.86 & 1.125 & .209 \\
\hline Institution 2 & 19 & 5.95 & 1.649 & .378 \\
\hline Institution 3 & 28 & 5.43 & 1.399 & .264 \\
\hline Institution 4 & 19 & 5.21 & 1.903 & .436 \\
\hline Institution 5 & 35 & 6.23 & 1.308 & .221 \\
\hline Institution 6 & 14 & 5.57 & 1.399 & .374 \\
\hline Institution 7 & 24 & 5.92 & 1.060 & .216 \\
\hline Institution 8 & 9 & 6.56 & .527 & .176 \\
\hline Institution 9 & 32 & 5.63 & 1.476 & .261 \\
\hline Institution 10 & 22 & 5.68 & 1.393 & .297 \\
\hline Total & 231 & 5.78 & 1.394 & .092 \\
\hline Institution 1 & 29 & 5.69 & 1.514 & .281 \\
\hline Institution 2 & 19 & 5.37 & 1.832 & .420 \\
\hline Institution 3 & 29 & 5.00 & 1.909 & .354 \\
\hline Institution 4 & 19 & 5.11 & 1.761 & .404 \\
\hline Institution 5 & 35 & 5.94 & 1.305 & .221 \\
\hline Institution 6 & 14 & 5.21 & 1.847 & .494 \\
\hline Institution 7 & 24 & 4.79 & 1.744 & .356 \\
\hline Institution 8 & 9 & 5.22 & 1.787 & .596 \\
\hline Institution 9 & 32 & 6.03 & 1.062 & .188 \\
\hline Institution 10 & 23 & 4.91 & 2.021 & .421 \\
\hline Total & 233 & 5.40 & 1.676 & .110 \\
\hline
\end{tabular}

OCQ 11: There's not too much to be gained by sticking with this institution indefinitely. (reversed)
OCQ 9: It would take very little change in my present circumstances to cause me to leave this institution. (reversed)

OCQ 10: I am extremely glad that I chose this institution to work for over others I was considering at the time I joined. 
OCQ descriptive statistics by institution (continued)

\begin{tabular}{|c|c|c|c|c|c|}
\hline \multirow{11}{*}{$\begin{array}{l}\text { OCQ 12: Often I find it difficult to agree with this } \\
\text { institution's policies on important matters relating to } \\
\text { its employees. (reversed) }\end{array}$} & Institution 1 & 28 & 4.86 & 1.649 & .312 \\
\hline & Institution 2 & 19 & 4.16 & 2.218 & .509 \\
\hline & Institution 3 & 29 & 4.17 & 1.671 & .310 \\
\hline & Institution 4 & 19 & 4.79 & 1.653 & .379 \\
\hline & Institution 5 & 35 & 4.57 & 1.883 & .318 \\
\hline & Institution 6 & 14 & 4.50 & 2.210 & .591 \\
\hline & Institution 7 & 24 & 3.50 & 1.956 & .399 \\
\hline & Institution 8 & 9 & 5.00 & 1.225 & .408 \\
\hline & Institution 9 & 32 & 5.38 & 1.519 & .268 \\
\hline & Institution 10 & 23 & 4.74 & 1.573 & .328 \\
\hline & Total & 232 & 4.57 & 1.815 & .119 \\
\hline \multirow{11}{*}{$\begin{array}{l}\text { OCQ 13: I really care about the fate of this } \\
\text { institution. }\end{array}$} & Institution 1 & 29 & 6.86 & .441 & .082 \\
\hline & Institution 2 & 19 & 6.26 & 1.447 & .332 \\
\hline & Institution 3 & 29 & 6.52 & .688 & .128 \\
\hline & Institution 4 & 19 & 6.47 & .513 & .118 \\
\hline & Institution 5 & 35 & 6.69 & 1.051 & .178 \\
\hline & Institution 6 & 14 & 6.50 & 1.092 & .292 \\
\hline & Institution 7 & 24 & 6.38 & 1.135 & .232 \\
\hline & Institution 8 & 9 & 6.56 & .726 & .242 \\
\hline & Institution 9 & 32 & 6.69 & .592 & .105 \\
\hline & Institution 10 & 24 & 6.75 & .676 & .138 \\
\hline & Total & 234 & 6.59 & .870 & .057 \\
\hline \multirow{11}{*}{$\begin{array}{l}\text { OCQ 14: For me this is the best of all possible } \\
\text { institutions for which to work. }\end{array}$} & Institution 1 & 28 & 5.75 & 1.175 & .222 \\
\hline & Institution 2 & 19 & 4.79 & 2.016 & .463 \\
\hline & Institution 3 & 29 & 4.97 & 1.973 & .366 \\
\hline & Institution 4 & 19 & 4.84 & 1.708 & .392 \\
\hline & Institution 5 & 35 & 5.63 & 1.516 & .256 \\
\hline & Institution 6 & 14 & 4.21 & 2.225 & .595 \\
\hline & Institution 7 & 24 & 5.42 & 1.349 & .275 \\
\hline & Institution 8 & 9 & 5.00 & 1.414 & .471 \\
\hline & Institution 9 & 32 & 5.59 & 1.604 & .283 \\
\hline & Institution 10 & 24 & 5.25 & 1.700 & .347 \\
\hline & Total & 233 & 5.25 & 1.687 & .111 \\
\hline \multirow{11}{*}{$\begin{array}{l}\text { OCQ 15: Deciding to work for this institution was a } \\
\text { definite mistake on my part. (reversed) }\end{array}$} & Institution 1 & 29 & 6.93 & .258 & .048 \\
\hline & Institution 2 & 19 & 6.26 & 1.593 & .365 \\
\hline & Institution 3 & 29 & 6.59 & 1.053 & .195 \\
\hline & Institution 4 & 19 & 6.26 & 1.408 & .323 \\
\hline & Institution 5 & 33 & 6.91 & .384 & .067 \\
\hline & Institution 6 & 14 & 6.64 & .842 & .225 \\
\hline & Institution 7 & 24 & 6.71 & .751 & .153 \\
\hline & Institution 8 & 9 & 6.78 & .441 & .147 \\
\hline & Institution 9 & 32 & 6.84 & .574 & .101 \\
\hline & Institution 10 & 23 & 6.65 & .935 & .195 \\
\hline & Total & 231 & 6.69 & .893 & .059 \\
\hline
\end{tabular}


OCQ descriptive statistics by institution (continued)

\begin{tabular}{|l|l|r|r|r|r|}
\hline \hline \multirow{5}{*}{} & Institution 1 & 29 & 5.660 & .75684 & .14054 \\
\cline { 2 - 6 } & Institution 2 & 19 & 5.260 & 1.31954 & .30272 \\
\cline { 2 - 5 } & Institution 3 & 29 & 5.193 & .87837 & .16311 \\
\cline { 2 - 6 } & Institution 4 & 19 & 5.204 & 1.02619 & .23542 \\
\cline { 2 - 6 } & Institution 5 & 35 & 5.754 & .59864 & .10119 \\
\cline { 2 - 6 } OCQ Mean & Institution 6 & 14 & 4.957 & 1.11113 & .29696 \\
\cline { 2 - 6 } & Institution 7 & 24 & 5.411 & .83421 & .17028 \\
\cline { 2 - 6 } & Institution 8 & 9 & 5.511 & .75056 & .25019 \\
\cline { 2 - 6 } & Institution 9 & 32 & 5.752 & .77232 & .13653 \\
\cline { 2 - 6 } & Institution 10 & 24 & 5.336 & 1.09676 & .22388 \\
\cline { 2 - 6 } & Total & 234 & 5.453 & .92141 & .06023 \\
\hline \hline
\end{tabular}


OCQ descriptive statistics by church membership

\begin{tabular}{|c|c|c|c|c|c|}
\hline OCQ Questions & $\begin{array}{c}\text { Church } \\
\text { Membership }\end{array}$ & $N$ & Mean & $\begin{array}{l}\text { Standard } \\
\text { Deviation }\end{array}$ & $\begin{array}{l}\text { Standard } \\
\text { Error }\end{array}$ \\
\hline \multirow{3}{*}{$\begin{array}{l}\text { OCQ 1: I am willing to put in a great deal of effort } \\
\text { beyond that normally expected in order to help this } \\
\text { institution to be successful. }\end{array}$} & $\begin{array}{l}\text { Membership } \\
\text { Required }\end{array}$ & 40 & 6.43 & 1.083 & .171 \\
\hline & $\begin{array}{l}\text { Membership } \\
\text { Not } \\
\text { Required }\end{array}$ & 196 & 6.36 & .850 & .061 \\
\hline & Total & 236 & 6.37 & .892 & .058 \\
\hline \multirow{3}{*}{$\begin{array}{l}\text { OCQ 2: I talk up this institution to my friends as a } \\
\text { great institution to work for. }\end{array}$} & $\begin{array}{l}\text { Membership } \\
\text { Required }\end{array}$ & 40 & 6.50 & .961 & .152 \\
\hline & $\begin{array}{l}\text { Membership } \\
\text { Not } \\
\text { Required }\end{array}$ & 196 & 5.83 & 1.385 & .099 \\
\hline & Total & 236 & 5.94 & 1.345 & .088 \\
\hline \multirow{3}{*}{$\begin{array}{l}\text { OCQ 3: I feel very little loyalty to this institution } \\
\text { (reversed) }\end{array}$} & $\begin{array}{l}\text { Membership } \\
\text { Required }\end{array}$ & 40 & 5.50 & 2.287 & .362 \\
\hline & $\begin{array}{l}\text { Membership } \\
\text { Not } \\
\text { Required }\end{array}$ & 195 & 5.74 & 1.905 & .136 \\
\hline & Total & 235 & 5.70 & 1.972 & .129 \\
\hline \multirow{3}{*}{$\begin{array}{l}\text { OCQ 4: I would accept almost any type of job } \\
\text { assignment in order to keep working for this } \\
\text { institution. }\end{array}$} & $\begin{array}{l}\text { Membership } \\
\text { Required }\end{array}$ & 40 & 3.13 & 1.757 & .278 \\
\hline & $\begin{array}{l}\text { Membership } \\
\text { Not } \\
\text { Required }\end{array}$ & 196 & 2.90 & 1.717 & .123 \\
\hline & Total & 236 & 2.94 & 1.722 & .112 \\
\hline \multirow{3}{*}{$\begin{array}{l}\text { OCQ 5: I find my values and the institution's } \\
\text { values are very similar. }\end{array}$} & $\begin{array}{l}\text { Membership } \\
\text { Required }\end{array}$ & 40 & 6.13 & 1.181 & .187 \\
\hline & $\begin{array}{l}\text { Membership } \\
\text { Not } \\
\text { Required }\end{array}$ & 196 & 6.01 & 1.203 & .086 \\
\hline & Total & 236 & 6.03 & 1.197 & .078 \\
\hline \multirow{3}{*}{$\begin{array}{l}\text { OCQ 6: I am proud to tell others that I am part of } \\
\text { this institution. }\end{array}$} & $\begin{array}{l}\text { Membership } \\
\text { Required }\end{array}$ & 40 & 6.55 & .986 & .156 \\
\hline & $\begin{array}{l}\text { Membership } \\
\text { Not } \\
\text { Required }\end{array}$ & 194 & 6.11 & 1.242 & .089 \\
\hline & Total & 234 & 6.19 & 1.211 & .079 \\
\hline \multirow{3}{*}{$\begin{array}{l}\text { OCQ 7: I could just as well be working for a } \\
\text { different institution as long as the type of work were } \\
\text { similar. (reversed) }\end{array}$} & $\begin{array}{l}\text { Membership } \\
\text { Required }\end{array}$ & 39 & 4.85 & 1.424 & .228 \\
\hline & $\begin{array}{l}\text { Membership } \\
\text { Not } \\
\text { Required }\end{array}$ & 195 & 4.03 & 1.747 & .125 \\
\hline & Total & 234 & 4.17 & 1.721 & .113 \\
\hline \multirow{3}{*}{$\begin{array}{l}\text { OCQ 8: The institution really inspires the very best } \\
\text { in me in the way of job performance. }\end{array}$} & $\begin{array}{l}\text { Membership } \\
\text { Required }\end{array}$ & 40 & 5.15 & 1.833 & .290 \\
\hline & $\begin{array}{l}\text { Membership } \\
\text { Not } \\
\text { Required }\end{array}$ & 195 & 4.98 & 1.514 & .108 \\
\hline & Total & 235 & 5.01 & 1.570 & .102 \\
\hline \multirow{3}{*}{$\begin{array}{l}\text { OCQ 9: It would take very little change in my } \\
\text { present circumstances to cause me to leave this } \\
\text { institution. (reversed) }\end{array}$} & $\begin{array}{l}\text { Membership } \\
\text { Required }\end{array}$ & 40 & 5.90 & 1.411 & .223 \\
\hline & $\begin{array}{l}\text { Membership } \\
\text { Not } \\
\text { Required }\end{array}$ & 195 & 5.49 & 1.564 & .112 \\
\hline & Total & 235 & 5.56 & 1.544 & .101 \\
\hline
\end{tabular}


OCQ descriptive statistics by church membership (continued)

OCQ 10: I am extremely glad that I chose this institution to work for over others I was considering at the time I joined.

OCQ 11: There's not too much to be gained by sticking with this institution indefinitely. (reversed)

OCQ 13: I really care about the fate of this institution.

OCQ 12: Often I find it difficult to agree with this institution's policies on important matters relating to its employees. (reversed)

OCQ 14: For me this is the best of all possible
institutions for which to work.

OCQ 15: Deciding to work for this institution was a definite mistake on my part. (reversed)

OCQ Mean

\begin{tabular}{|c|c|c|c|c|}
\hline $\begin{array}{l}\text { Membership } \\
\text { Required }\end{array}$ & 39 & 6.13 & 1.281 & .205 \\
\hline $\begin{array}{l}\text { Membership } \\
\text { Not } \\
\text { Required }\end{array}$ & 194 & 5.71 & 1.410 & .101 \\
\hline Total & 233 & 5.78 & 1.396 & .091 \\
\hline $\begin{array}{l}\text { Membership } \\
\text { Required }\end{array}$ & 40 & 5.95 & 1.239 & .196 \\
\hline $\begin{array}{l}\text { Membership } \\
\text { Not } \\
\text { Required }\end{array}$ & 194 & 5.28 & 1.730 & .124 \\
\hline Total & 234 & 5.40 & 1.673 & .109 \\
\hline $\begin{array}{l}\text { Membership } \\
\text { Required }\end{array}$ & 39 & 4.59 & 1.846 & .296 \\
\hline $\begin{array}{l}\text { Membership } \\
\text { Not } \\
\text { Required }\end{array}$ & 195 & 4.58 & 1.813 & .130 \\
\hline Total & 234 & 4.58 & 1.814 & .119 \\
\hline $\begin{array}{l}\text { Membership } \\
\text { Required }\end{array}$ & 40 & 6.78 & .423 & .067 \\
\hline $\begin{array}{l}\text { Membership } \\
\text { Not } \\
\text { Required }\end{array}$ & 196 & 6.56 & .929 & .066 \\
\hline Total & 236 & 6.60 & .867 & .056 \\
\hline $\begin{array}{l}\text { Membership } \\
\text { Required }\end{array}$ & 40 & 5.68 & 1.526 & .241 \\
\hline $\begin{array}{l}\text { Membership } \\
\text { Not } \\
\text { Required }\end{array}$ & 195 & 5.16 & 1.702 & .122 \\
\hline Total & 235 & 5.25 & 1.682 & .110 \\
\hline $\begin{array}{l}\text { Membership } \\
\text { Required }\end{array}$ & 38 & 6.82 & .609 & .099 \\
\hline $\begin{array}{l}\text { Membership } \\
\text { Not } \\
\text { Required }\end{array}$ & 195 & 6.67 & .934 & .067 \\
\hline Total & 233 & 6.69 & .890 & .058 \\
\hline $\begin{array}{l}\text { Membership } \\
\text { Required }\end{array}$ & 40 & 5.688 & .76197 & .12048 \\
\hline $\begin{array}{l}\text { Membership } \\
\text { Not } \\
\text { Required }\end{array}$ & 196 & 5.404 & .94189 & .06728 \\
\hline Total & 236 & 5.452 & .91867 & .05980 \\
\hline
\end{tabular}


OCQ descriptive statistics by alma mater

\begin{tabular}{|c|c|c|c|c|c|}
\hline OCQ Questions & Alma Mater & $N$ & Mean & $\begin{array}{c}\text { Std. } \\
\text { Deviation }\end{array}$ & Std. Error \\
\hline \multirow{5}{*}{$\begin{array}{l}\text { OCQ 1: I am willing to put in a great } \\
\text { deal of effort beyond that normally } \\
\text { expected in order to help this } \\
\text { institution to be successful. }\end{array}$} & Current Institution & 76 & 6.38 & .848 & .097 \\
\hline & Another CCCU Institution & 59 & 6.37 & .869 & .113 \\
\hline & $\begin{array}{l}\text { Another non-CCCU } \\
\text { Christian Institution }\end{array}$ & 26 & 6.42 & .703 & .138 \\
\hline & Non-Christian Institution & 75 & 6.33 & 1.018 & .118 \\
\hline & Total & 236 & 6.37 & .892 & .058 \\
\hline \multirow{5}{*}{$\begin{array}{l}\text { OCQ 2: I talk up this institution to my } \\
\text { friends as a great institution to work } \\
\text { for. }\end{array}$} & Current Institution & 76 & 6.03 & 1.306 & .150 \\
\hline & Another CCCU Institution & 59 & 5.78 & 1.378 & .179 \\
\hline & $\begin{array}{l}\text { Another non-CCCU } \\
\text { Christian Institution }\end{array}$ & 26 & 6.27 & 1.041 & .204 \\
\hline & Non-Christian Institution & 75 & 5.87 & 1.446 & .167 \\
\hline & Total & 236 & 5.94 & 1.345 & .088 \\
\hline \multirow{5}{*}{$\begin{array}{l}\text { OCQ 3: I feel very little loyalty to this } \\
\text { institution (reversed) }\end{array}$} & Current Institution & 76 & 5.63 & 2.045 & .235 \\
\hline & Another CCCU Institution & 58 & 5.91 & 1.657 & .218 \\
\hline & $\begin{array}{l}\text { Another non-CCCU } \\
\text { Christian Institution }\end{array}$ & 26 & 6.23 & 1.478 & .290 \\
\hline & Non-Christian Institution & 75 & 5.41 & 2.231 & .258 \\
\hline & Total & 235 & 5.70 & 1.972 & .129 \\
\hline \multirow{5}{*}{$\begin{array}{l}\text { OCQ 4: I would accept almost any } \\
\text { type of job assignment in order to } \\
\text { keep working for this institution. }\end{array}$} & Current Institution & 76 & 3.28 & 1.852 & .212 \\
\hline & Another CCCU Institution & 59 & 2.80 & 1.584 & .206 \\
\hline & $\begin{array}{l}\text { Another non-CCCU } \\
\text { Christian Institution }\end{array}$ & 26 & 2.50 & 1.606 & .315 \\
\hline & Non-Christian Institution & 75 & 2.87 & 1.703 & .197 \\
\hline & Total & 236 & 2.94 & 1.722 & .112 \\
\hline \multirow{5}{*}{$\begin{array}{l}\text { OCQ 5: I find my values and the } \\
\text { institution's values are very similar. }\end{array}$} & Current Institution & 76 & 6.07 & 1.159 & .133 \\
\hline & Another CCCU Institution & 59 & 6.02 & 1.167 & .152 \\
\hline & $\begin{array}{l}\text { Another non-CCCU } \\
\text { Christian Institution }\end{array}$ & 26 & 6.46 & .647 & .127 \\
\hline & Non-Christian Institution & 75 & 5.85 & 1.372 & .158 \\
\hline & Total & 236 & 6.03 & 1.197 & .078 \\
\hline \multirow{5}{*}{$\begin{array}{l}\text { OCQ 6: I am proud to tell others that } \\
\text { I am part of this institution. }\end{array}$} & Current Institution & 76 & 6.26 & 1.170 & .134 \\
\hline & Another CCCU Institution & 59 & 5.92 & 1.222 & .159 \\
\hline & $\begin{array}{l}\text { Another non-CCCU } \\
\text { Christian Institution }\end{array}$ & 26 & 6.81 & .491 & .096 \\
\hline & Non-Christian Institution & 73 & 6.11 & 1.350 & .158 \\
\hline & Total & 234 & 6.19 & 1.211 & .079 \\
\hline \multirow{5}{*}{$\begin{array}{l}\text { OCQ 7: I could just as well be } \\
\text { working for a different institution as } \\
\text { long as the type of work were similar. } \\
\text { (reversed) }\end{array}$} & Current Institution & 76 & 4.47 & 1.604 & .184 \\
\hline & Another CCCU Institution & 59 & 3.53 & 1.736 & .226 \\
\hline & $\begin{array}{l}\text { Another non-CCCU } \\
\text { Christian Institution }\end{array}$ & 26 & 4.19 & 1.650 & .324 \\
\hline & Non-Christian Institution & 73 & 4.36 & 1.751 & .205 \\
\hline & Total & 234 & 4.17 & 1.721 & .113 \\
\hline
\end{tabular}


OCQ descriptive statistics by alma mater (continued)

\begin{tabular}{|c|c|c|c|c|c|}
\hline \multirow{5}{*}{$\begin{array}{l}\text { OCQ 8: The institution really inspires } \\
\text { the very best in me in the way of job } \\
\text { performance. }\end{array}$} & Current Institution & 75 & 4.95 & 1.668 & .193 \\
\hline & Another CCCU Institution & 59 & 4.98 & 1.432 & .186 \\
\hline & $\begin{array}{l}\text { Another non-CCCU } \\
\text { Christian Institution }\end{array}$ & 26 & 5.62 & 1.023 & .201 \\
\hline & Non-Christian Institution & 75 & 4.89 & 1.705 & .197 \\
\hline & Total & 235 & 5.01 & 1.570 & .102 \\
\hline \multirow{5}{*}{$\begin{array}{l}\text { OCQ 9: It would take very little } \\
\text { change in my present circumstances } \\
\text { to cause me to leave this institution. } \\
\text { (reversed) }\end{array}$} & Current Institution & 76 & 5.75 & 1.471 & .169 \\
\hline & Another CCCU Institution & 59 & 5.36 & 1.423 & .185 \\
\hline & $\begin{array}{l}\text { Another non-CCCU } \\
\text { Christian Institution }\end{array}$ & 25 & 6.00 & 1.118 & .224 \\
\hline & Non-Christian Institution & 75 & 5.39 & 1.785 & .206 \\
\hline & Total & 235 & 5.56 & 1.544 & .101 \\
\hline \multirow{5}{*}{$\begin{array}{l}\text { OCQ 10: I am extremely glad that I } \\
\text { chose this institution to work for over } \\
\text { others I was considering at the time I } \\
\text { joined. }\end{array}$} & Current Institution & 75 & 5.87 & 1.427 & .165 \\
\hline & Another CCCU Institution & 58 & 5.57 & 1.272 & .167 \\
\hline & $\begin{array}{l}\text { Another non-CCCU } \\
\text { Christian Institution }\end{array}$ & 26 & 6.08 & 1.197 & .235 \\
\hline & Non-Christian Institution & 74 & 5.76 & 1.515 & .176 \\
\hline & Total & 233 & 5.78 & 1.396 & .091 \\
\hline \multirow{5}{*}{$\begin{array}{l}\text { OCQ 11: There's not too much to be } \\
\text { gained by sticking with this institution } \\
\text { indefinitely. (reversed) }\end{array}$} & Current Institution & 75 & 5.56 & 1.687 & .195 \\
\hline & Another CCCU Institution & 59 & 5.41 & 1.510 & .197 \\
\hline & $\begin{array}{l}\text { Another non-CCCU } \\
\text { Christian Institution }\end{array}$ & 26 & 5.85 & 1.541 & .302 \\
\hline & Non-Christian Institution & 74 & 5.07 & 1.793 & .208 \\
\hline & Total & 234 & 5.40 & 1.673 & .109 \\
\hline \multirow{5}{*}{$\begin{array}{l}\text { OCQ 12: Often I find it difficult to } \\
\text { agree with this institution's policies on } \\
\text { important matters relating to its } \\
\text { employees. (reversed) }\end{array}$} & Current Institution & 76 & 4.61 & 1.933 & .222 \\
\hline & Another CCCU Institution & 58 & 4.60 & 1.611 & .211 \\
\hline & $\begin{array}{l}\text { Another non-CCCU } \\
\text { Christian Institution }\end{array}$ & 26 & 5.15 & 1.690 & .331 \\
\hline & Non-Christian Institution & 74 & 4.34 & 1.867 & .217 \\
\hline & Total & 234 & 4.58 & 1.814 & .119 \\
\hline \multirow{5}{*}{$\begin{array}{l}\text { OCQ 13: I really care about the fate } \\
\text { of this institution. }\end{array}$} & Current Institution & 76 & 6.79 & .471 & .054 \\
\hline & Another CCCU Institution & 59 & 6.51 & .878 & .114 \\
\hline & $\begin{array}{l}\text { Another non-CCCU } \\
\text { Christian Institution } \\
\end{array}$ & 26 & 6.73 & .452 & .089 \\
\hline & Non-Christian Institution & 75 & 6.43 & 1.187 & .137 \\
\hline & Total & 236 & 6.60 & .867 & .056 \\
\hline \multirow{5}{*}{$\begin{array}{l}\text { OCQ 14: For me this is the best of all } \\
\text { possible institutions for which to work. }\end{array}$} & Current Institution & 76 & 5.45 & 1.747 & .200 \\
\hline & Another CCCU Institution & 58 & 5.16 & 1.508 & .198 \\
\hline & $\begin{array}{l}\text { Another non-CCCU } \\
\text { Christian Institution }\end{array}$ & 26 & 5.65 & 1.294 & .254 \\
\hline & Non-Christian Institution & 75 & 4.97 & 1.830 & .211 \\
\hline & Total & 235 & 5.25 & 1.682 & .110 \\
\hline
\end{tabular}


OCQ descriptive statistics by alma mater (continued)

\begin{tabular}{|l|l|r|r|r|r|}
\hline \hline \multirow{4}{*}{$\begin{array}{l}\text { OCQ 15: Deciding to work for this } \\
\text { institution was a definite mistake on } \\
\text { my part. (reversed) }\end{array}$} & Current Institution & 76 & 6.75 & .802 & .092 \\
\cline { 2 - 5 } & Another CCCU Institution & 58 & 6.62 & .895 & .118 \\
\cline { 2 - 5 } & $\begin{array}{l}\text { Another non-CCCU } \\
\text { Christian Institution }\end{array}$ & 25 & 6.96 & .200 & .040 \\
\cline { 2 - 5 } & Non-Christian Institution & 74 & 6.59 & 1.084 & .126 \\
\cline { 2 - 5 } & Total & 233 & 6.69 & .890 & .058 \\
\hline \multirow{5}{*}{ OCQ Mean } & Current Institution & 76 & 5.575 & .91447 & .10490 \\
\cline { 2 - 5 } & Another CCCU Institution & 59 & 5.337 & .87742 & .11423 \\
\cline { 2 - 5 } & $\begin{array}{l}\text { Another non-CCCU } \\
\text { Christian Institution }\end{array}$ & 26 & 5.762 & .59484 & .11666 \\
\cline { 2 - 6 } & Non-Christian Institution & 75 & 5.311 & 1.01481 & .11718 \\
\cline { 2 - 5 } & Total & 236 & 5.452 & .91867 & .05980 \\
\hline \hline
\end{tabular}


OCQ descriptive statistics by highest degree earned

\begin{tabular}{|c|c|c|c|c|c|}
\hline OCQ Questions & Highest Degree & $N$ & Mean & $\begin{array}{l}\text { Standard } \\
\text { Deviation }\end{array}$ & $\begin{array}{l}\text { Standard } \\
\text { Error }\end{array}$ \\
\hline \multirow{4}{*}{$\begin{array}{l}\text { OCQ 1: I am willing to put in a great } \\
\text { deal of effort beyond that normally } \\
\text { expected in order to help this institution } \\
\text { to be successful. }\end{array}$} & Master's Degree & 80 & 6.36 & .698 & .078 \\
\hline & $\begin{array}{l}\text { Specialist's or } \\
\text { Professional Degree }\end{array}$ & 7 & 6.43 & .535 & .202 \\
\hline & Doctoral Degree & 148 & 6.36 & .998 & .082 \\
\hline & Total & 235 & 6.37 & .893 & .058 \\
\hline \multirow{4}{*}{$\begin{array}{l}\text { OCQ 2: I talk up this institution to my } \\
\text { friends as a great institution to work for. }\end{array}$} & Master's Degree & 80 & 6.09 & 1.285 & .144 \\
\hline & $\begin{array}{l}\text { Specialist's or } \\
\text { Professional Degree }\end{array}$ & 7 & 6.29 & .951 & .360 \\
\hline & Doctoral Degree & 148 & 5.84 & 1.390 & .114 \\
\hline & Total & 235 & 5.94 & 1.346 & .088 \\
\hline \multirow{4}{*}{$\begin{array}{l}\text { OCQ 3: I feel very little loyalty to this } \\
\text { institution (reversed) }\end{array}$} & Master's Degree & 79 & 5.51 & 2.165 & .244 \\
\hline & $\begin{array}{l}\text { Specialist's or } \\
\text { Professional Degree }\end{array}$ & 7 & 6.00 & 2.236 & .845 \\
\hline & Doctoral Degree & 148 & 5.78 & 1.858 & .153 \\
\hline & Total & 234 & 5.69 & 1.974 & .129 \\
\hline \multirow{4}{*}{$\begin{array}{l}\text { OCQ 4: I would accept almost any type } \\
\text { of job assignment in order to keep } \\
\text { working for this institution. }\end{array}$} & Master's Degree & 80 & 3.21 & 1.666 & .186 \\
\hline & $\begin{array}{l}\text { Specialist's or } \\
\text { Professional Degree }\end{array}$ & 7 & 3.29 & 2.215 & .837 \\
\hline & Doctoral Degree & 148 & 2.77 & 1.723 & .142 \\
\hline & Total & 235 & 2.94 & 1.725 & .113 \\
\hline \multirow{4}{*}{$\begin{array}{l}\text { OCQ 5: I find my values and the } \\
\text { institution's values are very similar. }\end{array}$} & Master's Degree & 80 & 6.13 & 1.118 & .125 \\
\hline & $\begin{array}{l}\text { Specialist's or } \\
\text { Professional Degree }\end{array}$ & 7 & 6.29 & .951 & .360 \\
\hline & Doctoral Degree & 148 & 5.97 & 1.253 & .103 \\
\hline & Total & 235 & 6.03 & 1.200 & .078 \\
\hline \multirow{4}{*}{$\begin{array}{l}\text { OCQ 6: I am proud to tell others that I } \\
\text { am part of this institution. }\end{array}$} & Master's Degree & 80 & 6.35 & .982 & .110 \\
\hline & $\begin{array}{l}\text { Specialist's or } \\
\text { Professional Degree }\end{array}$ & 7 & 6.71 & .756 & .286 \\
\hline & Doctoral Degree & 146 & 6.07 & 1.327 & .110 \\
\hline & Total & 233 & 6.18 & 1.212 & .079 \\
\hline \multirow{4}{*}{$\begin{array}{l}\text { OCQ 7: I could just as well be working } \\
\text { for a different institution as long as the } \\
\text { type of work were similar. (reversed) }\end{array}$} & Master's Degree & 80 & 4.14 & 1.712 & .191 \\
\hline & $\begin{array}{l}\text { Specialist's or } \\
\text { Professional Degree }\end{array}$ & 7 & 4.43 & 1.988 & .751 \\
\hline & Doctoral Degree & 146 & 4.17 & 1.731 & .143 \\
\hline & Total & 233 & 4.17 & 1.725 & .113 \\
\hline \multirow{4}{*}{$\begin{array}{l}\text { OCQ 8: The institution really inspires } \\
\text { the very best in me in the way of job } \\
\text { performance. }\end{array}$} & Master's Degree & 79 & 5.08 & 1.500 & .169 \\
\hline & $\begin{array}{l}\text { Specialist's or } \\
\text { Professional Degree }\end{array}$ & 7 & 5.43 & 1.397 & .528 \\
\hline & Doctoral Degree & 148 & 4.95 & 1.622 & .133 \\
\hline & Total & 234 & 5.01 & 1.572 & .103 \\
\hline \multirow{4}{*}{$\begin{array}{l}\text { OCQ 9: It would take very little change } \\
\text { in my present circumstances to cause } \\
\text { me to leave this institution. (reversed) }\end{array}$} & Master's Degree & 79 & 5.66 & 1.543 & .174 \\
\hline & $\begin{array}{l}\text { Specialist's or } \\
\text { Professional Degree }\end{array}$ & 7 & 5.57 & 1.272 & .481 \\
\hline & Doctoral Degree & 148 & 5.51 & 1.567 & .129 \\
\hline & Total & 234 & 5.56 & 1.547 & .101 \\
\hline
\end{tabular}


OCQ descriptive statistics by highest degree earned (continued)

\begin{tabular}{|c|c|c|c|c|c|}
\hline \multirow{4}{*}{$\begin{array}{l}\text { OCQ 10: I am extremely glad that I } \\
\text { chose this institution to work for over } \\
\text { others I was considering at the time I } \\
\text { joined. }\end{array}$} & Master's Degree & 79 & 5.90 & 1.317 & .148 \\
\hline & $\begin{array}{l}\text { Specialist's or } \\
\text { Professional Degree }\end{array}$ & 7 & 5.43 & 1.272 & .481 \\
\hline & Doctoral Degree & 146 & 5.75 & 1.442 & .119 \\
\hline & Total & 232 & 5.79 & 1.394 & .091 \\
\hline \multirow{4}{*}{$\begin{array}{l}\text { OCQ 11: There's not too much to be } \\
\text { gained by sticking with this institution } \\
\text { indefinitely. (reversed) }\end{array}$} & Master's Degree & 79 & 5.23 & 1.818 & .205 \\
\hline & $\begin{array}{l}\text { Specialist's or } \\
\text { Professional Degree }\end{array}$ & 7 & 6.14 & 1.464 & .553 \\
\hline & Doctoral Degree & 147 & 5.46 & 1.597 & .132 \\
\hline & Total & 233 & 5.40 & 1.674 & .110 \\
\hline \multirow{4}{*}{$\begin{array}{l}\text { OCQ 12: Often I find it difficult to agree } \\
\text { with this institution's policies on } \\
\text { important matters relating to its } \\
\text { employees. (reversed) }\end{array}$} & Master's Degree & 80 & 4.66 & 1.828 & .204 \\
\hline & $\begin{array}{l}\text { Specialist's or } \\
\text { Professional Degree }\end{array}$ & 7 & 4.14 & 2.116 & .800 \\
\hline & Doctoral Degree & 146 & 4.56 & 1.808 & .150 \\
\hline & Total & 233 & 4.58 & 1.818 & .119 \\
\hline \multirow{4}{*}{$\begin{array}{l}\text { OCQ 13: I really care about the fate of } \\
\text { this institution. }\end{array}$} & Master's Degree & 80 & 6.61 & .834 & .093 \\
\hline & $\begin{array}{l}\text { Specialist's or } \\
\text { Professional Degree }\end{array}$ & 7 & 7.00 & .000 & .000 \\
\hline & Doctoral Degree & 148 & 6.57 & .905 & .074 \\
\hline & Total & 235 & 6.60 & .869 & .057 \\
\hline \multirow{4}{*}{$\begin{array}{l}\text { OCQ 14: For me this is the best of all } \\
\text { possible institutions for which to work. }\end{array}$} & Master's Degree & 80 & 5.35 & 1.568 & .175 \\
\hline & $\begin{array}{l}\text { Specialist's or } \\
\text { Professional Degree }\end{array}$ & 7 & 6.00 & 1.414 & .535 \\
\hline & Doctoral Degree & 147 & 5.14 & 1.748 & .144 \\
\hline & Total & 234 & 5.24 & 1.681 & .110 \\
\hline \multirow{4}{*}{$\begin{array}{l}\text { OCQ 15: Deciding to work for this } \\
\text { institution was a definite mistake on my } \\
\text { part. (reversed) }\end{array}$} & Master's Degree & 80 & 6.84 & .605 & .068 \\
\hline & $\begin{array}{l}\text { Specialist's or } \\
\text { Professional Degree }\end{array}$ & 7 & 6.86 & .378 & .143 \\
\hline & Doctoral Degree & 145 & 6.60 & 1.023 & .085 \\
\hline & Total & 232 & 6.69 & .892 & .059 \\
\hline \multirow{4}{*}{ OCQ Mean } & Master's Degree & 80 & 5.518 & .79458 & .08884 \\
\hline & $\begin{array}{l}\text { Specialist's or } \\
\text { Professional Degree }\end{array}$ & 7 & 5.733 & .48534 & .18344 \\
\hline & Doctoral Degree & 148 & 5.401 & .99535 & .08182 \\
\hline & Total & 235 & 5.450 & .92035 & .06004 \\
\hline
\end{tabular}


OCQ descriptive statistics by academic rank

\begin{tabular}{|c|c|c|c|c|c|}
\hline OCQ Questions & Academic Rank & $N$ & Mean & $\begin{array}{c}\text { Std. } \\
\text { Deviation }\end{array}$ & Std. Error \\
\hline \multirow{5}{*}{$\begin{array}{l}\text { OCQ 1: I am willing to put in a great } \\
\text { deal of effort beyond that normally } \\
\text { expected in order to help this institution } \\
\text { to be successful. }\end{array}$} & Other (Inst/Tech) & 12 & 6.17 & .835 & .241 \\
\hline & Assistant Professor & 78 & 6.38 & .810 & .092 \\
\hline & Associate Professor & 66 & 6.41 & 1.007 & .124 \\
\hline & Professor & 80 & 6.35 & .887 & .099 \\
\hline & Total & 236 & 6.37 & .892 & .058 \\
\hline \multirow{5}{*}{$\begin{array}{l}\text { OCQ 2: I talk up this institution to my } \\
\text { friends as a great institution to work for. }\end{array}$} & Other (Inst/Tech) & 12 & 6.25 & .866 & .250 \\
\hline & Assistant Professor & 78 & 6.05 & 1.308 & .148 \\
\hline & Associate Professor & 66 & 6.06 & 1.477 & .182 \\
\hline & Professor & 80 & 5.69 & 1.308 & .146 \\
\hline & Total & 236 & 5.94 & 1.345 & .088 \\
\hline \multirow{5}{*}{$\begin{array}{l}\text { OCQ 3: I feel very little loyalty to this } \\
\text { institution (reversed) }\end{array}$} & Other (Inst/Tech) & 12 & 4.92 & 2.429 & .701 \\
\hline & Assistant Professor & 77 & 5.35 & 2.229 & .254 \\
\hline & Associate Professor & 66 & 5.95 & 1.885 & .232 \\
\hline & Professor & 80 & 5.94 & 1.633 & .183 \\
\hline & Total & 235 & 5.70 & 1.972 & .129 \\
\hline \multirow{5}{*}{$\begin{array}{l}\text { OCQ 4: I would accept almost any type } \\
\text { of job assignment in order to keep } \\
\text { working for this institution. }\end{array}$} & Other (Inst/Tech) & 12 & 3.17 & 2.125 & .613 \\
\hline & Assistant Professor & 78 & 3.00 & 1.751 & .198 \\
\hline & Associate Professor & 66 & 2.92 & 1.492 & .184 \\
\hline & Professor & 80 & 2.86 & 1.833 & .205 \\
\hline & Total & 236 & 2.94 & 1.722 & .112 \\
\hline \multirow{5}{*}{$\begin{array}{l}\text { OCQ 5: I find my values and the } \\
\text { institution's values are very similar. }\end{array}$} & Other (Inst/Tech) & 12 & 5.92 & 1.165 & .336 \\
\hline & Assistant Professor & 78 & 6.04 & 1.133 & .128 \\
\hline & Associate Professor & 66 & 6.08 & 1.181 & .145 \\
\hline & Professor & 80 & 6.00 & 1.293 & .145 \\
\hline & Total & 236 & 6.03 & 1.197 & .078 \\
\hline \multirow{5}{*}{$\begin{array}{l}\text { OCQ 6: I am proud to tell others that I } \\
\text { am part of this institution. }\end{array}$} & Other (Inst/Tech) & 12 & 6.42 & .793 & .229 \\
\hline & Assistant Professor & 76 & 6.21 & 1.279 & .147 \\
\hline & Associate Professor & 66 & 6.39 & 1.036 & .128 \\
\hline & Professor & 80 & 5.96 & 1.307 & .146 \\
\hline & Total & 234 & 6.19 & 1.211 & .079 \\
\hline \multirow{5}{*}{$\begin{array}{l}\text { OCQ 7: I could just as well be working } \\
\text { for a different institution as long as the } \\
\text { type of work were similar. (reversed) }\end{array}$} & Other (Inst/Tech) & 12 & 4.00 & 1.758 & .508 \\
\hline & Assistant Professor & 78 & 4.06 & 1.746 & .198 \\
\hline & Associate Professor & 65 & 4.17 & 1.626 & .202 \\
\hline & Professor & 79 & 4.29 & 1.791 & .202 \\
\hline & Total & 234 & 4.17 & 1.721 & .113 \\
\hline \multirow{5}{*}{$\begin{array}{l}\text { OCQ 8: The institution really inspires } \\
\text { the very best in me in the way of job } \\
\text { performance. }\end{array}$} & Other (Inst/Tech) & 12 & 4.50 & 1.508 & .435 \\
\hline & Assistant Professor & 77 & 5.03 & 1.597 & .182 \\
\hline & Associate Professor & 66 & 5.23 & 1.465 & .180 \\
\hline & Professor & 80 & 4.90 & 1.635 & .183 \\
\hline & Total & 235 & 5.01 & 1.570 & .102 \\
\hline
\end{tabular}


OCQ descriptive statistics by academic rank (continued)

\begin{tabular}{|c|c|c|c|c|c|}
\hline \multirow{5}{*}{$\begin{array}{l}\text { OCQ 9: It would take very little change } \\
\text { in my present circumstances to cause } \\
\text { me to leave this institution. (reversed) }\end{array}$} & Other (Inst/Tech) & 12 & 4.92 & 1.505 & .434 \\
\hline & Assistant Professor & 77 & 5.47 & 1.729 & .197 \\
\hline & Associate Professor & 66 & 5.65 & 1.593 & .196 \\
\hline & Professor & 80 & 5.68 & 1.300 & .145 \\
\hline & Total & 235 & 5.56 & 1.544 & .101 \\
\hline \multirow{5}{*}{$\begin{array}{l}\text { OCQ 10: I am extremely glad that I } \\
\text { chose this institution to work for over } \\
\text { others I was considering at the time I } \\
\text { joined. }\end{array}$} & Other (Inst/Tech) & 12 & 5.25 & 1.288 & .372 \\
\hline & Assistant Professor & 76 & 5.64 & 1.503 & .172 \\
\hline & Associate Professor & 66 & 6.02 & 1.387 & .171 \\
\hline & Professor & 79 & 5.80 & 1.295 & .146 \\
\hline & Total & 233 & 5.78 & 1.396 & .091 \\
\hline \multirow{5}{*}{$\begin{array}{l}\text { OCQ 11: There's not too much to be } \\
\text { gained by sticking with this institution } \\
\text { indefinitely. (reversed) }\end{array}$} & Other (Inst/Tech) & 12 & 4.83 & 1.528 & .441 \\
\hline & Assistant Professor & 77 & 5.18 & 1.819 & .207 \\
\hline & Associate Professor & 66 & 5.58 & 1.683 & .207 \\
\hline & Professor & 79 & 5.54 & 1.517 & .171 \\
\hline & Total & 234 & 5.40 & 1.673 & .109 \\
\hline \multirow{5}{*}{$\begin{array}{l}\text { OCQ 12: Often I find it difficult to agree } \\
\text { with this institution's policies on } \\
\text { important matters relating to its } \\
\text { employees. (reversed) }\end{array}$} & Other (Inst/Tech) & 12 & 4.50 & 1.382 & .399 \\
\hline & Assistant Professor & 77 & 4.48 & 1.825 & .208 \\
\hline & Associate Professor & 66 & 4.79 & 1.902 & .234 \\
\hline & Professor & 79 & 4.52 & 1.804 & .203 \\
\hline & Total & 234 & 4.58 & 1.814 & .119 \\
\hline \multirow{5}{*}{$\begin{array}{l}\text { OCQ 13: I really care about the fate of } \\
\text { this institution. }\end{array}$} & Other (Inst/Tech) & 12 & 6.83 & .389 & .112 \\
\hline & Assistant Professor & 78 & 6.53 & 1.041 & .118 \\
\hline & Associate Professor & 66 & 6.71 & .674 & .083 \\
\hline & Professor & 80 & 6.54 & .871 & .097 \\
\hline & Total & 236 & 6.60 & .867 & .056 \\
\hline \multirow{5}{*}{$\begin{array}{l}\text { OCQ 14: For me this is the best of all } \\
\text { possible institutions for which to work. }\end{array}$} & Other (Inst/Tech) & 12 & 5.33 & .888 & .256 \\
\hline & Assistant Professor & 78 & 5.26 & 1.732 & .196 \\
\hline & Associate Professor & 66 & 5.45 & 1.647 & .203 \\
\hline & Professor & 79 & 5.05 & 1.753 & .197 \\
\hline & Total & 235 & 5.25 & 1.682 & .110 \\
\hline \multirow{5}{*}{$\begin{array}{l}\text { OCQ 15: Deciding to work for this } \\
\text { institution was a definite mistake on my } \\
\text { part. (reversed) }\end{array}$} & Other (Inst/Tech) & 12 & 7.00 & .000 & .000 \\
\hline & Assistant Professor & 77 & 6.70 & .974 & .111 \\
\hline & Associate Professor & 66 & 6.70 & .859 & .106 \\
\hline & Professor & 78 & 6.63 & .899 & .102 \\
\hline & Total & 233 & 6.69 & .890 & .058 \\
\hline \multirow{5}{*}{ OCQ Mean } & Other (Inst/Tech) & 12 & 5.333 & .54458 & .15721 \\
\hline & Assistant Professor & 78 & 5.378 & .94377 & .10686 \\
\hline & Associate Professor & 66 & $\begin{array}{r}5.603 \\
0 \\
\end{array}$ & .90215 & .11105 \\
\hline & Professor & 80 & 5.418 & .95058 & .10628 \\
\hline & Total & 236 & 5.452 & .91867 & .05980 \\
\hline
\end{tabular}


OCQ descriptive statistics by years teaching (career)

\begin{tabular}{|c|c|c|c|c|c|}
\hline OCQ Questions & $\begin{array}{l}\text { Years Teaching } \\
\text { (Career) }\end{array}$ & $N$ & Mean & $\begin{array}{l}\text { Standard } \\
\text { Deviation }\end{array}$ & $\begin{array}{l}\text { Standard } \\
\text { Error }\end{array}$ \\
\hline \multirow{4}{*}{$\begin{array}{l}\text { OCQ 1: I am willing to put in a great deal of } \\
\text { effort beyond that normally expected in order } \\
\text { to help this institution to be successful. }\end{array}$} & $1-5$ years & 42 & 6.43 & .770 & .119 \\
\hline & $6-11$ years & 55 & 6.42 & .762 & .103 \\
\hline & 12 or more years & 137 & 6.34 & .958 & .082 \\
\hline & Total & 234 & 6.38 & .881 & .058 \\
\hline \multirow{4}{*}{$\begin{array}{l}\text { OCQ 2: I talk up this institution to my friends } \\
\text { as a great institution to work for. }\end{array}$} & $1-5$ years & 42 & 6.26 & .912 & .141 \\
\hline & $6-11$ years & 55 & 5.98 & 1.569 & .212 \\
\hline & 12 or more years & 137 & 5.84 & 1.357 & .116 \\
\hline & Total & 234 & 5.95 & 1.348 & .088 \\
\hline \multirow{4}{*}{$\begin{array}{l}\text { OCQ 3: I feel very little loyalty to this } \\
\text { institution (reversed) }\end{array}$} & $1-5$ years & 41 & 5.22 & 2.242 & .350 \\
\hline & $6-11$ years & 55 & 5.89 & 1.802 & .243 \\
\hline & 12 or more years & 137 & 5.76 & 1.954 & .167 \\
\hline & Total & 233 & 5.70 & 1.978 & .130 \\
\hline \multirow{4}{*}{$\begin{array}{l}\text { OCQ 4: I would accept almost any type of job } \\
\text { assignment in order to keep working for this } \\
\text { institution. }\end{array}$} & $1-5$ years & 42 & 2.79 & 1.539 & .237 \\
\hline & 6-11 years & 55 & 2.85 & 1.704 & .230 \\
\hline & 12 or more years & 137 & 3.04 & 1.790 & .153 \\
\hline & Total & 234 & 2.95 & 1.724 & .113 \\
\hline \multirow{4}{*}{$\begin{array}{l}\text { OCQ 5: I find my values and the institution's } \\
\text { values are very similar. }\end{array}$} & $1-5$ years & 42 & 6.05 & 1.125 & .174 \\
\hline & 6-11 years & 55 & 5.96 & 1.232 & .166 \\
\hline & 12 or more years & 137 & 6.09 & 1.166 & .100 \\
\hline & Total & 234 & 6.05 & 1.171 & .077 \\
\hline \multirow{4}{*}{$\begin{array}{l}\text { OCQ 6: I am proud to tell others that I am part } \\
\text { of this institution. }\end{array}$} & $1-5$ years & 41 & 6.29 & 1.101 & .172 \\
\hline & $6-11$ years & 55 & 6.20 & 1.339 & .181 \\
\hline & 12 or more years & 136 & 6.15 & 1.204 & .103 \\
\hline & Total & 232 & 6.19 & 1.216 & .080 \\
\hline \multirow{4}{*}{$\begin{array}{l}\text { OCQ 7: I could just as well be working for a } \\
\text { different institution as long as the type of work } \\
\text { were similar. (reversed) }\end{array}$} & 1-5 years & 42 & 3.74 & 1.547 & .239 \\
\hline & $6-11$ years & 54 & 4.20 & 1.618 & .220 \\
\hline & 12 or more years & 136 & 4.28 & 1.804 & .155 \\
\hline & Total & 232 & 4.16 & 1.723 & .113 \\
\hline \multirow{4}{*}{$\begin{array}{l}\text { OCQ 8: The institution really inspires the very } \\
\text { best in me in the way of job performance. }\end{array}$} & $1-5$ years & 41 & 5.27 & 1.379 & .215 \\
\hline & $6-11$ years & 55 & 4.75 & 1.734 & .234 \\
\hline & 12 or more years & 137 & 5.04 & 1.562 & .133 \\
\hline & Total & 233 & 5.01 & 1.577 & .103 \\
\hline \multirow{4}{*}{$\begin{array}{l}\text { OCQ 9: It would take very little change in my } \\
\text { present circumstances to cause me to leave } \\
\text { this institution. (reversed) }\end{array}$} & $1-5$ years & 41 & 5.63 & 1.428 & .223 \\
\hline & $6-11$ years & 55 & 5.11 & 1.833 & .247 \\
\hline & 12 or more years & 137 & 5.72 & 1.433 & .122 \\
\hline & Total & 233 & 5.56 & 1.550 & .102 \\
\hline \multirow{4}{*}{$\begin{array}{l}\text { OCQ 10: I am extremely glad that I chose this } \\
\text { institution to work for over others I was } \\
\text { considering at the time I joined. }\end{array}$} & $1-5$ years & 40 & 5.85 & 1.167 & .184 \\
\hline & $6-11$ years & 55 & 5.60 & 1.822 & .246 \\
\hline & 12 or more years & 136 & 5.84 & 1.254 & .108 \\
\hline & Total & 231 & 5.78 & 1.394 & .092 \\
\hline
\end{tabular}


OCQ descriptive statistics by years teaching (career) (continued)

\begin{tabular}{|c|c|c|c|c|c|}
\hline \multirow{4}{*}{$\begin{array}{l}\text { OCQ 11: There's not too much to be gained } \\
\text { by sticking with this institution indefinitely. } \\
\text { (reversed) }\end{array}$} & $1-5$ years & 41 & 5.27 & 1.659 & .259 \\
\hline & 6-11 years & 55 & 5.24 & 1.934 & .261 \\
\hline & 12 or more years & 136 & 5.52 & 1.563 & .134 \\
\hline & Total & 232 & 5.41 & 1.672 & .110 \\
\hline \multirow{4}{*}{$\begin{array}{l}\text { OCQ 12: Often I find it difficult to agree with } \\
\text { this institution's policies on important matters } \\
\text { relating to its employees. (reversed) }\end{array}$} & 1-5 years & 41 & 4.68 & 1.709 & .267 \\
\hline & 6-11 years & 55 & 4.55 & 1.951 & .263 \\
\hline & 12 or more years & 136 & 4.58 & 1.799 & .154 \\
\hline & Total & 232 & 4.59 & 1.814 & .119 \\
\hline \multirow{4}{*}{$\begin{array}{l}\text { OCQ 13: I really care about the fate of this } \\
\text { institution. }\end{array}$} & $1-5$ years & 42 & 6.55 & 1.041 & .161 \\
\hline & 6-11 years & 55 & 6.67 & .904 & .122 \\
\hline & 12 or more years & 137 & 6.58 & .801 & .068 \\
\hline & Total & 234 & 6.60 & .870 & .057 \\
\hline \multirow{4}{*}{$\begin{array}{l}\text { OCQ 14: For me this is the best of all possible } \\
\text { institutions for which to work. }\end{array}$} & $1-5$ years & 42 & 5.60 & 1.380 & .213 \\
\hline & 6-11 years & 55 & 5.00 & 1.963 & .265 \\
\hline & 12 or more years & 136 & 5.23 & 1.642 & .141 \\
\hline & Total & 233 & 5.24 & 1.685 & .110 \\
\hline \multirow{4}{*}{$\begin{array}{l}\text { OCQ 15: Deciding to work for this institution } \\
\text { was a definite mistake on my part. (reversed) }\end{array}$} & 1-5 years & 41 & 6.95 & .218 & .034 \\
\hline & 6-11 years & 55 & 6.40 & 1.342 & .181 \\
\hline & 12 or more years & 135 & 6.73 & .757 & .065 \\
\hline & Total & 231 & 6.69 & .893 & .059 \\
\hline \multirow{4}{*}{ OCQ Mean } & $1-5$ years & 42 & 5.424 & .79943 & .12336 \\
\hline & 6-11 years & 55 & 5.383 & 1.03361 & .13937 \\
\hline & 12 or more years & 137 & 5.495 & .91315 & .07802 \\
\hline & Total & 234 & 5.456 & .92146 & .06024 \\
\hline
\end{tabular}


OCQ descriptive statistics by years teaching (institution)

\begin{tabular}{|c|c|c|c|c|c|}
\hline OCQ Questions & $\begin{array}{c}\text { Years Teaching } \\
\text { (Institution) }\end{array}$ & $N$ & Mean & $\begin{array}{l}\text { Standard } \\
\text { Deviation }\end{array}$ & $\begin{array}{l}\text { Standard } \\
\text { Error }\end{array}$ \\
\hline \multirow{4}{*}{$\begin{array}{l}\text { OCQ 1: I am willing to put in a great deal of } \\
\text { effort beyond that normally expected in order } \\
\text { to help this institution to be successful. }\end{array}$} & $1-5$ years & 74 & 6.36 & .837 & .097 \\
\hline & $6-11$ years & 64 & 6.23 & 1.123 & .140 \\
\hline & 12 or more years & 98 & 6.46 & .748 & .076 \\
\hline & Total & 236 & 6.37 & .892 & .058 \\
\hline \multirow{4}{*}{$\begin{array}{l}\text { OCQ 2: I talk up this institution to my friends } \\
\text { as a great institution to work for. }\end{array}$} & $1-5$ years & 74 & 6.09 & 1.273 & .148 \\
\hline & $6-11$ years & 64 & 6.05 & 1.396 & .175 \\
\hline & 12 or more years & 98 & 5.76 & 1.355 & .137 \\
\hline & Total & 236 & 5.94 & 1.345 & .088 \\
\hline \multirow{4}{*}{$\begin{array}{l}\text { OCQ 3: I feel very little loyalty to this } \\
\text { institution (reversed) }\end{array}$} & 1-5 years & 73 & 5.53 & 2.008 & .235 \\
\hline & $6-11$ years & 64 & 5.83 & 1.940 & .243 \\
\hline & 12 or more years & 98 & 5.73 & 1.977 & .200 \\
\hline & Total & 235 & 5.70 & 1.972 & .129 \\
\hline \multirow{4}{*}{$\begin{array}{l}\text { OCQ 4: I would accept almost any type of job } \\
\text { assignment in order to keep working for this } \\
\text { institution. }\end{array}$} & 1-5 years & 74 & 2.82 & 1.591 & .185 \\
\hline & $6-11$ years & 64 & 2.97 & 1.727 & .216 \\
\hline & 12 or more years & 98 & 3.01 & 1.825 & .184 \\
\hline & Total & 236 & 2.94 & 1.722 & .112 \\
\hline \multirow{4}{*}{$\begin{array}{l}\text { OCQ 5: I find my values and the institution's } \\
\text { values are very similar. }\end{array}$} & $1-5$ years & 74 & 6.11 & 1.105 & .128 \\
\hline & $6-11$ years & 64 & 5.80 & 1.449 & .181 \\
\hline & 12 or more years & 98 & 6.12 & 1.067 & .108 \\
\hline & Total & 236 & 6.03 & 1.197 & .078 \\
\hline \multirow{4}{*}{$\begin{array}{l}\text { OCQ 6: I am proud to tell others that I am part } \\
\text { of this institution. }\end{array}$} & $1-5$ years & 72 & 6.29 & 1.144 & .135 \\
\hline & $6-11$ years & 64 & 6.11 & 1.416 & .177 \\
\hline & 12 or more years & 98 & 6.16 & 1.119 & .113 \\
\hline & Total & 234 & 6.19 & 1.211 & .079 \\
\hline \multirow{4}{*}{$\begin{array}{l}\text { OCQ 7: I could just as well be working for a } \\
\text { different institution as long as the type of work } \\
\text { were similar. (reversed) }\end{array}$} & $1-5$ years & 74 & 3.76 & 1.719 & .200 \\
\hline & $6-11$ years & 63 & 4.32 & 1.721 & .217 \\
\hline & 12 or more years & 97 & 4.38 & 1.686 & .171 \\
\hline & Total & 234 & 4.17 & 1.721 & .113 \\
\hline \multirow{4}{*}{$\begin{array}{l}\text { OCQ 8: The institution really inspires the very } \\
\text { best in me in the way of job performance. }\end{array}$} & $1-5$ years & 73 & 5.10 & 1.547 & .181 \\
\hline & $6-11$ years & 64 & 4.83 & 1.667 & .208 \\
\hline & 12 or more years & 98 & 5.07 & 1.528 & .154 \\
\hline & Total & 235 & 5.01 & 1.570 & .102 \\
\hline \multirow{4}{*}{$\begin{array}{l}\text { OCQ 9: It would take very little change in my } \\
\text { present circumstances to cause me to leave } \\
\text { this institution. (reversed) }\end{array}$} & $1-5$ years & 73 & 5.44 & 1.641 & .192 \\
\hline & $6-11$ years & 64 & 5.34 & 1.606 & .201 \\
\hline & 12 or more years & 98 & 5.80 & 1.407 & .142 \\
\hline & Total & 235 & 5.56 & 1.544 & .101 \\
\hline \multirow{4}{*}{$\begin{array}{l}\text { OCQ 10: I am extremely glad that I chose this } \\
\text { institution to work for over others I was } \\
\text { considering at the time I joined. }\end{array}$} & $1-5$ years & 72 & 5.82 & 1.427 & .168 \\
\hline & $6-11$ years & 64 & 5.58 & 1.621 & .203 \\
\hline & 12 or more years & 97 & 5.89 & 1.198 & .122 \\
\hline & Total & 233 & 5.78 & 1.396 & .091 \\
\hline
\end{tabular}


OCQ descriptive statistics by years teaching (institution) (continued)

\begin{tabular}{|c|c|c|c|c|c|}
\hline \multirow{4}{*}{$\begin{array}{l}\text { OCQ 11: There's not too much to be gained } \\
\text { by sticking with this institution indefinitely. } \\
\text { (reversed) }\end{array}$} & $1-5$ years & 73 & 5.32 & 1.715 & .201 \\
\hline & 6-11 years & 64 & 5.27 & 1.793 & .224 \\
\hline & 12 or more years & 97 & 5.55 & 1.561 & .159 \\
\hline & Total & 234 & 5.40 & 1.673 & .109 \\
\hline \multirow{4}{*}{$\begin{array}{l}\text { OCQ 12: Often I find it difficult to agree with } \\
\text { this institution's policies on important matters } \\
\text { relating to its employees. (reversed) }\end{array}$} & $1-5$ years & 73 & 4.74 & 1.780 & .208 \\
\hline & 6-11 years & 64 & 4.67 & 1.791 & .224 \\
\hline & 12 or more years & 97 & 4.40 & 1.858 & .189 \\
\hline & Total & 234 & 4.58 & 1.814 & .119 \\
\hline \multirow{4}{*}{$\begin{array}{l}\text { OCQ 13: I really care about the fate of this } \\
\text { institution. }\end{array}$} & 1-5 years & 74 & 6.55 & .909 & .106 \\
\hline & 6-11 years & 64 & 6.52 & 1.008 & .126 \\
\hline & 12 or more years & 98 & 6.68 & .726 & .073 \\
\hline & Total & 236 & 6.60 & .867 & .056 \\
\hline \multirow{4}{*}{$\begin{array}{l}\text { OCQ 14: For me this is the best of all possible } \\
\text { institutions for which to work. }\end{array}$} & $1-5$ years & 74 & 5.20 & 1.798 & .209 \\
\hline & 6-11 years & 64 & 5.17 & 1.714 & .214 \\
\hline & 12 or more years & 97 & 5.33 & 1.579 & .160 \\
\hline & Total & 235 & 5.25 & 1.682 & .110 \\
\hline \multirow{4}{*}{$\begin{array}{l}\text { OCQ 15: Deciding to work for this institution } \\
\text { was a definite mistake on my part. (reversed) }\end{array}$} & $1-5$ years & 73 & 6.75 & .894 & .105 \\
\hline & 6-11 years & 64 & 6.53 & 1.112 & .139 \\
\hline & 12 or more years & 96 & 6.75 & .696 & .071 \\
\hline & Total & 233 & 6.69 & .890 & .058 \\
\hline \multirow{4}{*}{ OCQ Mean } & $1-5$ years & 74 & 5.408 & .93996 & .10927 \\
\hline & 6-11 years & 64 & 5.409 & .97074 & .12134 \\
\hline & 12 or more years & 98 & 5.513 & .87251 & .08814 \\
\hline & Total & 236 & 5.452 & .91867 & .05980 \\
\hline
\end{tabular}


OCQ descriptive statistics by expected retirement age

\begin{tabular}{|c|c|c|c|c|c|}
\hline OCQ Questions & $\begin{array}{c}\text { Expected } \\
\text { Retirement Age }\end{array}$ & $N$ & Mean & $\begin{array}{l}\text { Standard } \\
\text { Deviation }\end{array}$ & $\begin{array}{l}\text { Standard } \\
\text { Error }\end{array}$ \\
\hline \multirow{4}{*}{$\begin{array}{l}\text { OCQ 1: I am willing to put in a great deal of } \\
\text { effort beyond that normally expected in order } \\
\text { to help this institution to be successful. }\end{array}$} & 60 or less & 24 & 6.25 & 1.113 & .227 \\
\hline & $61-65$ & 93 & 6.23 & .946 & .098 \\
\hline & 66 or above & 108 & 6.49 & .803 & .077 \\
\hline & Total & 225 & 6.36 & .905 & .060 \\
\hline \multirow{4}{*}{$\begin{array}{l}\text { OCQ 2: I talk up this institution to my friends } \\
\text { as a great institution to work for. }\end{array}$} & 60 or less & 24 & 5.54 & 1.719 & .351 \\
\hline & $61-65$ & 93 & 5.98 & 1.268 & .132 \\
\hline & 66 or above & 108 & 6.02 & 1.325 & .128 \\
\hline & Total & 225 & 5.95 & 1.350 & .090 \\
\hline \multirow{4}{*}{$\begin{array}{l}\text { OCQ 3: I feel very little loyalty to this } \\
\text { institution (reversed) }\end{array}$} & 60 or less & 24 & 5.00 & 2.265 & .462 \\
\hline & $61-65$ & 93 & 5.59 & 2.044 & .212 \\
\hline & 66 or above & 107 & 5.92 & 1.838 & .178 \\
\hline & Total & 224 & 5.68 & 1.985 & .133 \\
\hline \multirow{4}{*}{$\begin{array}{l}\text { OCQ 4: I would accept almost any type of job } \\
\text { assignment in order to keep working for this } \\
\text { institution. }\end{array}$} & 60 or less & 24 & 2.83 & 1.551 & .317 \\
\hline & $61-65$ & 93 & 3.01 & 1.785 & .185 \\
\hline & 66 or above & 108 & 2.88 & 1.684 & .162 \\
\hline & Total & 225 & 2.93 & 1.707 & .114 \\
\hline \multirow{4}{*}{$\begin{array}{l}\text { OCQ 5: I find my values and the institution's } \\
\text { values are very similar. }\end{array}$} & 60 or less & 24 & 6.04 & .859 & .175 \\
\hline & $61-65$ & 93 & 6.04 & 1.276 & .132 \\
\hline & 66 or above & 108 & 6.02 & 1.184 & .114 \\
\hline & Total & 225 & 6.03 & 1.189 & .079 \\
\hline \multirow{4}{*}{$\begin{array}{l}\text { OCQ 6: I am proud to tell others that I am part } \\
\text { of this institution. }\end{array}$} & 60 or less & 23 & 5.91 & 1.379 & .288 \\
\hline & $61-65$ & 93 & 6.27 & 1.217 & .126 \\
\hline & 66 or above & 107 & 6.18 & 1.212 & .117 \\
\hline & Total & 223 & 6.19 & 1.230 & .082 \\
\hline \multirow{4}{*}{$\begin{array}{l}\text { OCQ 7: I could just as well be working for a } \\
\text { different institution as long as the type of work } \\
\text { were similar. (reversed) }\end{array}$} & 60 or less & 24 & 4.00 & 1.794 & .366 \\
\hline & $61-65$ & 93 & 3.92 & 1.689 & .175 \\
\hline & 66 or above & 106 & 4.35 & 1.762 & .171 \\
\hline & Total & 223 & 4.13 & 1.740 & .117 \\
\hline \multirow{4}{*}{$\begin{array}{l}\text { OCQ 8: The institution really inspires the very } \\
\text { best in me in the way of job performance. }\end{array}$} & 60 or less & 24 & 4.71 & 1.628 & .332 \\
\hline & $61-65$ & 93 & 5.09 & 1.479 & .153 \\
\hline & 66 or above & 107 & 5.21 & 1.534 & .148 \\
\hline & Total & 224 & 5.10 & 1.522 & .102 \\
\hline \multirow{4}{*}{$\begin{array}{l}\text { OCQ 9: It would take very little change in my } \\
\text { present circumstances to cause me to leave } \\
\text { this institution. (reversed) }\end{array}$} & 60 or less & 24 & 5.13 & 1.752 & .358 \\
\hline & $61-65$ & 93 & 5.38 & 1.648 & .171 \\
\hline & 66 or above & 107 & 5.85 & 1.393 & .135 \\
\hline & Total & 224 & 5.58 & 1.560 & .104 \\
\hline \multirow{4}{*}{$\begin{array}{l}\text { OCQ 10: I am extremely glad that I chose this } \\
\text { institution to work for over others I was } \\
\text { considering at the time I joined. }\end{array}$} & 60 or less & 24 & 5.50 & 1.383 & .282 \\
\hline & $61-65$ & 93 & 5.67 & 1.477 & .153 \\
\hline & 66 or above & 105 & 5.96 & 1.315 & .128 \\
\hline & Total & 222 & 5.79 & 1.397 & .094 \\
\hline
\end{tabular}


OCQ descriptive statistics by expected retirement age (continued)

\begin{tabular}{|c|c|c|c|c|c|}
\hline \multirow{4}{*}{$\begin{array}{l}\text { OCQ 11: There's not too much to be gained } \\
\text { by sticking with this institution indefinitely. } \\
\text { (reversed) }\end{array}$} & 60 or less & 24 & 4.63 & 1.929 & .394 \\
\hline & $61-65$ & 93 & 5.34 & 1.735 & .180 \\
\hline & 66 or above & 107 & 5.64 & 1.487 & .144 \\
\hline & Total & 224 & 5.41 & 1.665 & .111 \\
\hline \multirow{4}{*}{$\begin{array}{l}\text { OCQ 12: Often I find it difficult to agree with } \\
\text { this institution's policies on important matters } \\
\text { relating to its employees. (reversed) }\end{array}$} & 60 or less & 24 & 4.00 & 1.911 & .390 \\
\hline & $61-65$ & 92 & 4.72 & 1.818 & .190 \\
\hline & 66 or above & 107 & 4.61 & 1.768 & .171 \\
\hline & Total & 223 & 4.59 & 1.808 & .121 \\
\hline \multirow{4}{*}{$\begin{array}{l}\text { OCQ 13: I really care about the fate of this } \\
\text { institution. }\end{array}$} & 60 or less & 24 & 6.54 & .509 & .104 \\
\hline & $61-65$ & 93 & 6.48 & 1.069 & .111 \\
\hline & 66 or above & 108 & 6.67 & .761 & .073 \\
\hline & Total & 225 & 6.58 & .884 & .059 \\
\hline \multirow{4}{*}{$\begin{array}{l}\text { OCQ 14: For me this is the best of all possible } \\
\text { institutions for which to work. }\end{array}$} & 60 or less & 24 & 4.92 & 1.840 & .376 \\
\hline & $61-65$ & 92 & 5.33 & 1.658 & .173 \\
\hline & 66 or above & 108 & 5.30 & 1.687 & .162 \\
\hline & Total & 224 & 5.27 & 1.689 & .113 \\
\hline \multirow{4}{*}{$\begin{array}{l}\text { OCQ 15: Deciding to work for this institution } \\
\text { was a definite mistake on my part. (reversed) }\end{array}$} & 60 or less & 24 & 6.63 & 1.096 & .224 \\
\hline & $61-65$ & 93 & 6.65 & .963 & .100 \\
\hline & 66 or above & 105 & 6.75 & .769 & .075 \\
\hline & Total & 222 & 6.69 & .890 & .060 \\
\hline \multirow{4}{*}{ OCQ Mean } & 60 or less & 24 & 5.158 & .92935 & .18970 \\
\hline & $61-65$ & 93 & 5.439 & .98011 & .10163 \\
\hline & 66 or above & 108 & 5.540 & .88587 & .08524 \\
\hline & Total & 225 & 5.457 & .93331 & .06222 \\
\hline
\end{tabular}


OCQ descriptive statistics by academic field

\begin{tabular}{|c|c|c|c|c|c|}
\hline OCQ Questions & Field & $N$ & Mean & $\begin{array}{l}\text { Standard } \\
\text { Deviation }\end{array}$ & $\begin{array}{l}\text { Standard } \\
\text { Error }\end{array}$ \\
\hline \multirow{6}{*}{$\begin{array}{l}\text { OCQ 1: I am willing to put in a great deal } \\
\text { of effort beyond that normally expected in } \\
\text { order to help this institution to be } \\
\text { successful. }\end{array}$} & Humanities & 72 & 6.44 & .902 & .106 \\
\hline & Physical Sciences & 29 & 6.17 & .711 & .132 \\
\hline & Pre-Professional & 75 & 6.47 & .844 & .097 \\
\hline & Social Sciences & 41 & 6.22 & 1.107 & .173 \\
\hline & Other & 13 & 6.31 & .855 & .237 \\
\hline & Total & 230 & 6.37 & .900 & .059 \\
\hline \multirow{6}{*}{$\begin{array}{l}\text { OCQ 2: I talk up this institution to my } \\
\text { friends as a great institution to work for. }\end{array}$} & Humanities & 72 & 6.04 & 1.238 & .146 \\
\hline & Physical Sciences & 29 & 5.38 & 1.568 & .291 \\
\hline & Pre-Professional & 75 & 6.16 & 1.252 & .145 \\
\hline & Social Sciences & 41 & 5.88 & 1.345 & .210 \\
\hline & Other & 13 & 6.00 & 1.683 & .467 \\
\hline & Total & 230 & 5.97 & 1.344 & .089 \\
\hline \multirow{6}{*}{$\begin{array}{l}\text { OCQ 3: I feel very little loyalty to this } \\
\text { institution (reversed) }\end{array}$} & Humanities & 71 & 5.66 & 2.090 & .248 \\
\hline & Physical Sciences & 29 & 5.90 & 1.566 & .291 \\
\hline & Pre-Professional & 75 & 5.87 & 2.009 & .232 \\
\hline & Social Sciences & 41 & 5.59 & 1.897 & .296 \\
\hline & Other & 13 & 5.62 & 1.758 & .488 \\
\hline & Total & 229 & 5.74 & 1.940 & .128 \\
\hline \multirow{6}{*}{$\begin{array}{l}\text { OCQ 4: I would accept almost any type of } \\
\text { job assignment in order to keep working } \\
\text { for this institution. }\end{array}$} & Humanities & 72 & 2.92 & 1.782 & .210 \\
\hline & Physical Sciences & 29 & 2.28 & 1.556 & .289 \\
\hline & Pre-Professional & 75 & 3.21 & 1.679 & .194 \\
\hline & Social Sciences & 41 & 2.95 & 1.658 & .259 \\
\hline & Other & 13 & 3.31 & 2.136 & .593 \\
\hline & Total & 230 & 2.96 & 1.732 & .114 \\
\hline \multirow{6}{*}{$\begin{array}{l}\text { OCQ 5: I find my values and the } \\
\text { institution's values are very similar. }\end{array}$} & Humanities & 72 & 6.00 & 1.088 & .128 \\
\hline & Physical Sciences & 29 & 6.17 & .848 & .157 \\
\hline & Pre-Professional & 75 & 6.20 & 1.263 & .146 \\
\hline & Social Sciences & 41 & 5.80 & 1.327 & .207 \\
\hline & Other & 13 & 6.31 & .751 & .208 \\
\hline & Total & 230 & 6.07 & 1.154 & .076 \\
\hline \multirow{6}{*}{$\begin{array}{l}\text { OCQ 6: I am proud to tell others that I am } \\
\text { part of this institution. }\end{array}$} & Humanities & 72 & 6.18 & 1.179 & .139 \\
\hline & Physical Sciences & 29 & 6.00 & 1.165 & .216 \\
\hline & Pre-Professional & 73 & 6.53 & 1.015 & .119 \\
\hline & Social Sciences & 41 & 5.73 & 1.467 & .229 \\
\hline & Other & 13 & 6.62 & .506 & .140 \\
\hline & Total & 228 & 6.21 & 1.188 & .079 \\
\hline \multirow{6}{*}{$\begin{array}{l}\text { OCQ 7: I could just as well be working for } \\
\text { a different institution as long as the type of } \\
\text { work were similar. (reversed) }\end{array}$} & Humanities & 71 & 4.31 & 1.753 & .208 \\
\hline & Physical Sciences & 29 & 4.00 & 1.890 & .351 \\
\hline & Pre-Professional & 74 & 4.38 & 1.653 & .192 \\
\hline & Social Sciences & 41 & 3.93 & 1.634 & .255 \\
\hline & Other & 13 & 4.00 & 1.871 & .519 \\
\hline & Total & 228 & 4.21 & 1.720 & .114 \\
\hline
\end{tabular}


OCQ descriptive statistics by academic field (continued)

OCQ 8: The institution really inspires the very best in me in the way of job performance.

OCQ 9: It would take very little change in my present circumstances to cause me to leave this institution. (reversed)

OCQ 10: I am extremely glad that I chose this institution to work for over others I was considering at the time I joined.

OCQ 11: There's not too much to be gained by sticking with this institution indefinitely. (reversed)

OCQ 12: Often I find it difficult to agree with this institution's policies on important matters relating to its employees. (reversed)

OCQ 13: I really care about the fate of this institution.

OCQ 14: For me this is the best of all possible institutions for which to work.

\begin{tabular}{|c|c|c|c|c|}
\hline Humanities & 71 & 5.17 & 1.512 & .179 \\
\hline Physical Sciences & 29 & 4.72 & 1.486 & .276 \\
\hline Pre-Professional & 75 & 4.91 & 1.741 & .201 \\
\hline Social Sciences & 41 & 5.00 & 1.449 & .226 \\
\hline Other & 13 & 5.38 & 1.758 & .488 \\
\hline Total & 229 & 5.01 & 1.587 & .105 \\
\hline Humanities & 72 & 5.72 & 1.396 & .165 \\
\hline Physical Sciences & 29 & 5.31 & 1.892 & .351 \\
\hline Pre-Professional & 74 & 5.57 & 1.562 & .182 \\
\hline Social Sciences & 41 & 5.66 & 1.237 & .193 \\
\hline Other & 13 & 5.38 & 1.805 & .500 \\
\hline Total & 229 & 5.59 & 1.512 & .100 \\
\hline Humanities & 71 & 5.82 & 1.417 & .168 \\
\hline Physical Sciences & 29 & 5.79 & 1.264 & .235 \\
\hline Pre-Professional & 75 & 6.13 & 1.288 & .149 \\
\hline Social Sciences & 39 & 5.36 & 1.442 & .231 \\
\hline Other & 13 & 5.08 & 1.656 & .459 \\
\hline Total & 227 & 5.80 & 1.400 & .093 \\
\hline Humanities & 71 & 5.70 & 1.487 & .176 \\
\hline Physical Sciences & 29 & 4.93 & 1.791 & .333 \\
\hline Pre-Professional & 75 & 5.37 & 1.746 & .202 \\
\hline Social Sciences & 40 & 5.63 & 1.462 & .231 \\
\hline Other & 13 & 4.92 & 2.019 & .560 \\
\hline Total & 228 & 5.44 & 1.653 & .109 \\
\hline Humanities & 72 & 4.78 & 1.722 & .203 \\
\hline Physical Sciences & 29 & 4.62 & 1.935 & .359 \\
\hline Pre-Professional & 75 & 4.68 & 1.847 & .213 \\
\hline Social Sciences & 39 & 4.38 & 1.648 & .264 \\
\hline Other & 13 & 4.38 & 1.981 & .549 \\
\hline Total & 228 & 4.64 & 1.784 & .118 \\
\hline Humanities & 72 & 6.64 & .893 & .105 \\
\hline Physical Sciences & 29 & 6.52 & .634 & .118 \\
\hline Pre-Professional & 75 & 6.71 & .835 & .096 \\
\hline Social Sciences & 41 & 6.44 & 1.074 & .168 \\
\hline Other & 13 & 6.54 & .660 & .183 \\
\hline Total & 230 & 6.60 & .869 & .057 \\
\hline Humanities & 72 & 5.22 & 1.738 & .205 \\
\hline Physical Sciences & 29 & 4.76 & 1.826 & .339 \\
\hline Pre-Professional & 75 & 5.43 & 1.578 & .182 \\
\hline Social Sciences & 40 & 5.33 & 1.859 & .294 \\
\hline Other & 13 & 5.15 & 1.281 & .355 \\
\hline Total & 229 & 5.24 & 1.697 & .112 \\
\hline
\end{tabular}


OCQ descriptive statistics by academic field (continued)

\begin{tabular}{|l|l|r|r|r|r|}
\hline \hline \multirow{5}{*}{\begin{tabular}{l} 
OCQ 15: Deciding to work for this $\begin{array}{l}\text { institution was a definite mistake on my } \\
\text { part. (reversed) }\end{array}$ \\
\cline { 2 - 5 }
\end{tabular}} & Humanities & 70 & 6.63 & .920 & .110 \\
\cline { 2 - 6 } & Physical Sciences & 29 & 6.72 & .960 & .178 \\
\cline { 2 - 6 } & Pre-Professional & 75 & 6.80 & .658 & .076 \\
\cline { 2 - 6 } & Social Sciences & 40 & 6.60 & 1.150 & .182 \\
\cline { 2 - 6 } OCQ Mean & Other & 13 & 6.77 & .832 & .231 \\
\cline { 2 - 6 } & Total & 227 & 6.70 & .887 & .059 \\
\cline { 2 - 6 } & Humanities & 72 & 5.512 & .91016 & .10726 \\
\cline { 2 - 6 } & Physical Sciences & 29 & 5.285 & .91407 & .16974 \\
\cline { 2 - 6 } & Pre-Professional & 75 & 5.607 & .81160 & .09371 \\
\cline { 2 - 6 } & Social Sciences & 41 & 5.306 & 1.06916 & .16697 \\
\cline { 2 - 6 } & Other & 13 & 5.451 & .91779 & .25455 \\
\cline { 2 - 6 } & Total & 230 & 5.474 & .91189 & .06013 \\
\hline \hline
\end{tabular}


OCQ reliability information

\begin{tabular}{|l|r|r|r|r|r|}
\hline \hline & $\begin{array}{c}\text { Scale Mean if } \\
\text { Item Deleted }\end{array}$ & $\begin{array}{c}\text { Scale } \\
\text { Variance if } \\
\text { Item Deleted }\end{array}$ & $\begin{array}{c}\text { Corrected } \\
\text { Item-Total } \\
\text { Correlation }\end{array}$ & $\begin{array}{c}\text { Squared } \\
\text { Multiple } \\
\text { Correlation }\end{array}$ & $\begin{array}{c}\text { Cronbach's } \\
\text { Alpha if Item } \\
\text { Deleted }\end{array}$ \\
\hline OCQ 1 & 76.03 & 177.868 & .429 & .325 & .883 \\
\hline OCQ 2 & 76.43 & 161.355 & .751 & .704 & .870 \\
\hline OCQ 3 & 76.67 & 165.248 & .402 & .236 & .888 \\
\hline OCQ 4 & 79.41 & 170.487 & .342 & .180 & .889 \\
\hline OCQ 5 & 76.35 & 166.382 & .696 & .595 & .874 \\
\hline OCQ 6 & 76.19 & 164.190 & .755 & .725 & .871 \\
\hline OCQ 7 & 78.20 & 169.000 & .381 & .434 & .887 \\
\hline OCQ 8 & 77.37 & 162.370 & .603 & .446 & .876 \\
\hline OCQ 9 & 76.82 & 162.169 & .619 & .483 & .875 \\
\hline OCQ 10 & 76.60 & 163.772 & .649 & .467 & .874 \\
\hline OCQ 11 & 76.96 & 158.710 & .655 & .254 & .873 \\
\hline OCQ 12 & 77.84 & 164.785 & .444 & .434 & .884 \\
\hline OCQ 13 & 75.78 & 175.965 & .535 & .480 & .881 \\
\hline OCQ 14 & 77.11 & 154.568 & .752 & .897 & .879 \\
\hline OCQ 15 & 75.70 & 174.303 & & .597 & .868 \\
\hline \hline
\end{tabular}


NSOPF descriptive statistics by gender

\begin{tabular}{|c|c|c|c|c|c|}
\hline $\begin{array}{l}\text { How satisfied or dissatisfied do you personally feel } \\
\text { about each of the following aspects of your job at your } \\
\text { current institution }\end{array}$ & Gender & $N$ & Mean & $\begin{array}{l}\text { Standard } \\
\text { Deviation }\end{array}$ & $\begin{array}{l}\text { Standard } \\
\text { Error }\end{array}$ \\
\hline \multirow{3}{*}{ My work load } & Female & 89 & 2.92 & .882 & .093 \\
\hline & Male & 146 & 2.86 & .847 & .070 \\
\hline & Total & 235 & 2.88 & .859 & .056 \\
\hline \multirow{3}{*}{ My job security } & Female & 89 & 3.45 & .707 & .075 \\
\hline & Male & 145 & 3.37 & .866 & .072 \\
\hline & Total & 234 & 3.40 & .808 & .053 \\
\hline \multirow{3}{*}{ My salary } & Female & 89 & 2.63 & .858 & .091 \\
\hline & Male & 146 & 2.65 & .907 & .075 \\
\hline & Total & 235 & 2.64 & .887 & .058 \\
\hline \multirow{3}{*}{ My benefits } & Female & 88 & 2.90 & .803 & .086 \\
\hline & Male & 146 & 2.79 & .939 & .078 \\
\hline & Total & 234 & 2.83 & .890 & .058 \\
\hline \multirow{3}{*}{$\begin{array}{l}\text { The authority I have to make decisions about what } \\
\text { courses I teach }\end{array}$} & Female & 87 & 3.39 & .826 & .089 \\
\hline & Male & 146 & 3.46 & .771 & .064 \\
\hline & Total & 233 & 3.43 & .791 & .052 \\
\hline \multirow{3}{*}{$\begin{array}{l}\text { The authority I have to make decisions about the } \\
\text { content and methods in the courses I teach }\end{array}$} & Female & 87 & 3.75 & .533 & .057 \\
\hline & Male & 146 & 3.83 & .445 & .037 \\
\hline & Total & 233 & 3.80 & .480 & .031 \\
\hline \multirow{3}{*}{$\begin{array}{l}\text { The authority I have to make decisions about other } \\
\text { aspects of my job }\end{array}$} & Female & 88 & 3.36 & .664 & .071 \\
\hline & Male & 144 & 3.37 & .666 & .056 \\
\hline & Total & 232 & 3.37 & .664 & .044 \\
\hline \multirow{3}{*}{$\begin{array}{l}\text { The mix of teaching, research, administration, and } \\
\text { service that I am required to do }\end{array}$} & Female & 86 & 3.20 & .749 & .081 \\
\hline & Male & 146 & 3.04 & .813 & .067 \\
\hline & Total & 232 & 3.10 & .792 & .052 \\
\hline \multirow{3}{*}{$\begin{array}{l}\text { The opportunity for advancement in rank at my } \\
\text { institution }\end{array}$} & Female & 87 & 2.97 & .946 & .101 \\
\hline & Male & 145 & 3.19 & .892 & .074 \\
\hline & Total & 232 & 3.11 & .917 & .060 \\
\hline \multirow{3}{*}{ Time available for keeping current in my field } & Female & 87 & 2.36 & .821 & .088 \\
\hline & Male & 146 & 2.51 & .912 & .075 \\
\hline & Total & 233 & 2.45 & .880 & .058 \\
\hline \multirow{3}{*}{$\begin{array}{l}\text { Availability of support services and equipment (clerical } \\
\text { support, computers, etc.) }\end{array}$} & Female & 89 & 2.96 & .852 & .090 \\
\hline & Male & 146 & 2.84 & .907 & .075 \\
\hline & Total & 235 & 2.89 & .887 & .058 \\
\hline \multirow{3}{*}{ Freedom to do outside consulting } & Female & 83 & 3.20 & .712 & .078 \\
\hline & Male & 141 & 3.31 & .738 & .062 \\
\hline & Total & 224 & 3.27 & .729 & .049 \\
\hline \multirow{3}{*}{ Overall reputation of the institution } & Female & 88 & 3.48 & .694 & .074 \\
\hline & Male & 144 & 3.07 & .772 & .064 \\
\hline & Total & 232 & 3.22 & .768 & .050 \\
\hline \multirow{3}{*}{ Reputation of my department } & Female & 89 & 3.53 & .740 & .078 \\
\hline & Male & 146 & 3.26 & .806 & .067 \\
\hline & Total & 235 & 3.36 & .791 & .052 \\
\hline
\end{tabular}


NSOPF descriptive statistics by gender (continued)

\begin{tabular}{|c|c|c|c|c|c|}
\hline \multirow[b]{3}{*}{ Institutional mission or philosophy } & Female & 89 & 3.75 & .459 & .049 \\
\hline & Male & 145 & 3.59 & .583 & .048 \\
\hline & Total & 234 & 3.65 & .544 & .036 \\
\hline \multirow{3}{*}{ Quality of leadership in my department } & Female & 89 & 3.47 & .827 & .088 \\
\hline & Male & 145 & 3.32 & .857 & .071 \\
\hline & Total & 234 & 3.38 & .847 & .055 \\
\hline \multirow{3}{*}{ Quality of chief administrative officers at my institution } & Female & 88 & 3.28 & .830 & .088 \\
\hline & Male & 146 & 3.01 & .965 & .080 \\
\hline & Total & 234 & 3.11 & .924 & .060 \\
\hline \multirow{3}{*}{ Quality of my colleagues in my department } & Female & 89 & 3.56 & 639 & .068 \\
\hline & Male & 143 & 3.47 & .690 & .058 \\
\hline & Total & 232 & 3.50 & 671 & .044 \\
\hline \multirow{3}{*}{ Quality of faculty leadership at my institution } & Female & 88 & 3.35 & .743 & .079 \\
\hline & Male & 146 & 2.98 & .809 & .067 \\
\hline & Total & 234 & 3.12 & .804 & .053 \\
\hline \multirow{3}{*}{$\begin{array}{l}\text { Relationship between administration and faculty at this } \\
\text { institution }\end{array}$} & Female & 89 & 2.91 & .821 & .087 \\
\hline & Male & 145 & 2.70 & .966 & .080 \\
\hline & Total & 234 & 2.78 & .917 & .060 \\
\hline \multirow{3}{*}{ Interdepartmental cooperation at this institution } & Female & 88 & 2.82 & .810 & .086 \\
\hline & Male & 146 & 2.80 & .810 & .067 \\
\hline & Total & 234 & 2.81 & .809 & .053 \\
\hline \multirow{3}{*}{ Spirit of cooperation between faculty at this institution } & Female & 89 & 3.10 & .675 & .072 \\
\hline & Male & 146 & 3.08 & .797 & .066 \\
\hline & Total & 235 & 3.09 & .752 & .049 \\
\hline \multirow{3}{*}{ Quality of my research facilities and support } & Female & 86 & 2.51 & .864 & .093 \\
\hline & Male & 138 & 2.35 & .816 & .069 \\
\hline & Total & 224 & 2.41 & .837 & .056 \\
\hline \multirow{3}{*}{ Quality of students whom I have taught here } & Female & 89 & 3.27 & .687 & .073 \\
\hline & Male & 146 & 2.97 & .761 & .063 \\
\hline & Total & 235 & 3.09 & .746 & .049 \\
\hline \multirow{3}{*}{ Teaching assistance that I receive } & Female & 74 & 2.84 & .922 & .107 \\
\hline & Male & 140 & 2.63 & .843 & .071 \\
\hline & Total & 214 & 2.70 & .874 & .060 \\
\hline \multirow{3}{*}{ Research assistance that I receive } & Female & 73 & 2.45 & .883 & .103 \\
\hline & Male & 129 & 2.29 & .861 & .076 \\
\hline & Total & 202 & 2.35 & .870 & .061 \\
\hline \multirow{3}{*}{$\begin{array}{l}\text { Spouse employment opportunities in this geographic } \\
\text { area }\end{array}$} & Female & 74 & 3.23 & .900 & .105 \\
\hline & Male & 139 & 3.31 & .711 & .060 \\
\hline & Total & 213 & 3.28 & .780 & .053 \\
\hline \multirow{3}{*}{ My overall satisfaction with my job here } & Female & 88 & 3.59 & .539 & .057 \\
\hline & Male & 146 & 3.38 & .666 & .055 \\
\hline & Total & 234 & 3.46 & .629 & .041 \\
\hline
\end{tabular}


NSOPF descriptive statistics by gender (continued)

\begin{tabular}{|c|c|c|c|c|c|}
\hline $\begin{array}{l}\text { If you were to leave your current institution, how likely is } \\
\text { it that you would do so to? }\end{array}$ & Gender & $N$ & Mean & $\begin{array}{l}\text { Standard } \\
\text { Deviation }\end{array}$ & $\begin{array}{l}\text { Standard } \\
\text { Error }\end{array}$ \\
\hline \multirow{3}{*}{ Leave to Retire } & Female & 88 & 2.26 & .903 & .096 \\
\hline & Male & 147 & 2.08 & .918 & .076 \\
\hline & Total & 235 & 2.15 & .915 & .060 \\
\hline \multirow{3}{*}{ Return to school as a student } & Female & 86 & 1.27 & .541 & .058 \\
\hline & Male & 147 & 1.14 & .422 & .035 \\
\hline & Total & 233 & 1.19 & .472 & .031 \\
\hline \multirow{3}{*}{$\begin{array}{l}\text { Accept employment at another Christian college or } \\
\text { university }\end{array}$} & Female & 86 & 1.87 & .590 & .064 \\
\hline & Male & 147 & 2.11 & .704 & .058 \\
\hline & Total & 233 & 2.02 & .672 & .044 \\
\hline \multirow{3}{*}{ Accept employment at a secular college or university } & Female & 85 & 1.64 & .652 & .071 \\
\hline & Male & 147 & 1.65 & .670 & .055 \\
\hline & Total & 232 & 1.64 & .662 & .043 \\
\hline \multirow{3}{*}{$\begin{array}{l}\text { Accept employment in consulting or other for-profit } \\
\text { business or industry or become self-employed }\end{array}$} & Female & 86 & 1.59 & .692 & .075 \\
\hline & Male & 147 & 1.61 & .717 & .059 \\
\hline & Total & 233 & 1.60 & .707 & .046 \\
\hline \multirow{3}{*}{ Accept employment in a non-profit organization } & Female & 86 & 1.67 & .583 & .063 \\
\hline & Male & 146 & 1.75 & .662 & .055 \\
\hline & Total & 232 & 1.72 & .634 & .042 \\
\hline $\begin{array}{l}\text { If you were to leave your current institution to accept } \\
\text { another position, would you want to do more, less or } \\
\text { about the same amount of the following as you currently } \\
\text { do? }\end{array}$ & Gender & $N$ & Mean & $\begin{array}{l}\text { Standard } \\
\text { Deviation }\end{array}$ & $\begin{array}{l}\text { Standard } \\
\text { Error }\end{array}$ \\
\hline \multirow{3}{*}{ Research } & Female & 84 & 1.60 & .661 & .072 \\
\hline & Male & 146 & 1.57 & .631 & .052 \\
\hline & Total & 230 & 1.58 & .641 & .042 \\
\hline \multirow{3}{*}{ Teaching } & Female & 86 & 2.12 & .622 & .067 \\
\hline & Male & 145 & 2.16 & .549 & .046 \\
\hline & Total & 231 & 2.14 & .576 & .038 \\
\hline \multirow{3}{*}{ Advising } & Female & 84 & 2.24 & .551 & .060 \\
\hline & Male & 146 & 2.23 & .535 & .044 \\
\hline & Total & 230 & 2.23 & .540 & .036 \\
\hline \multirow{3}{*}{ Service } & Female & 86 & 2.14 & .535 & .058 \\
\hline & Male & 146 & 2.15 & .579 & .048 \\
\hline & Total & 232 & 2.15 & .562 & .037 \\
\hline \multirow{3}{*}{ Administration } & Female & 84 & 2.19 & .736 & .080 \\
\hline & Male & 145 & 2.32 & .644 & .054 \\
\hline & Total & 229 & 2.28 & .681 & .045 \\
\hline $\begin{array}{l}\text { If you were to leave your current institution to accept } \\
\text { another position, how important would each of the } \\
\text { following items be in your decision to accept another } \\
\text { position? }\end{array}$ & Gender & $N$ & Mean & $\begin{array}{l}\text { Standard } \\
\text { Deviation }\end{array}$ & $\begin{array}{l}\text { Standard } \\
\text { Error }\end{array}$ \\
\hline \multirow{3}{*}{ Salary Level } & Female & 89 & 2.55 & .522 & .055 \\
\hline & Male & 147 & 2.37 & .574 & .047 \\
\hline & Total & 236 & 2.44 & .561 & .037 \\
\hline
\end{tabular}


NSOPF descriptive statistics by gender (continued)

\begin{tabular}{|c|c|c|c|c|c|}
\hline \multirow[b]{3}{*}{ Position Level } & Female & 89 & 2.44 & .543 & .058 \\
\hline & Male & 146 & 2.28 & 641 & .053 \\
\hline & Total & 235 & 2.34 & .609 & .040 \\
\hline \multirow{3}{*}{ Job Security } & Female & 89 & 2.62 & .574 & .061 \\
\hline & Male & 146 & 2.49 & .646 & .053 \\
\hline & Total & 235 & 2.54 & .622 & .041 \\
\hline \multirow{3}{*}{ Opportunities for advancement } & Female & 89 & 2.43 & .562 & .060 \\
\hline & Male & 147 & 2.24 & .734 & .061 \\
\hline & Total & 236 & 2.31 & .679 & .044 \\
\hline \multirow{3}{*}{ Benefits } & Female & 89 & 2.75 & .459 & .049 \\
\hline & Male & 147 & 2.59 & .534 & .044 \\
\hline & Total & 236 & 2.65 & .513 & .033 \\
\hline \multirow{3}{*}{ No pressure to publish } & Female & 89 & 2.24 & .675 & .072 \\
\hline & Male & 147 & 2.10 & .747 & .062 \\
\hline & Total & 236 & 2.15 & .722 & .047 \\
\hline \multirow{3}{*}{ Academic Freedom } & Female & 89 & 2.56 & .563 & .060 \\
\hline & Male & 147 & 2.59 & .546 & .045 \\
\hline & Total & 236 & 2.58 & .551 & .036 \\
\hline \multirow{3}{*}{ Good research facilities and equipment } & Female & 87 & 2.16 & .645 & .069 \\
\hline & Male & 147 & 2.10 & .676 & .056 \\
\hline & Total & 234 & 2.12 & .664 & .043 \\
\hline \multirow{3}{*}{ Good instructional facilities and equipment } & Female & 88 & 2.69 & .511 & .054 \\
\hline & Male & 147 & 2.46 & .577 & .048 \\
\hline & Total & 235 & 2.55 & .563 & .037 \\
\hline \multirow{3}{*}{ Excellent Students } & Female & 89 & 2.54 & .545 & .058 \\
\hline & Male & 147 & 2.36 & .573 & .047 \\
\hline & Total & 236 & 2.43 & .568 & .037 \\
\hline \multirow{3}{*}{ Excellent Colleagues } & Female & 89 & 2.73 & .471 & .050 \\
\hline & Male & 147 & 2.62 & .487 & .040 \\
\hline & Total & 236 & 2.66 & .483 & .031 \\
\hline \multirow{3}{*}{ New institution is a Christian college } & Female & 89 & 2.35 & .676 & .072 \\
\hline & Male & 147 & 2.23 & .732 & .060 \\
\hline & Total & 236 & 2.28 & .712 & .046 \\
\hline \multirow{3}{*}{$\begin{array}{l}\text { Institutional mission or philosophy that is compatible } \\
\text { with my own view }\end{array}$} & Female & 89 & 2.65 & .524 & .056 \\
\hline & Male & 146 & 2.66 & .516 & .043 \\
\hline & Total & 235 & 2.66 & .518 & .034 \\
\hline \multirow{3}{*}{ Good job for my spouse } & Female & 80 & 2.20 & .892 & .100 \\
\hline & Male & 146 & 2.05 & .820 & .068 \\
\hline & Total & 226 & 2.11 & .847 & .056 \\
\hline \multirow{3}{*}{ Good Geographic Location } & Female & 86 & 2.56 & .586 & .063 \\
\hline & Male & 147 & 2.38 & .634 & .052 \\
\hline & Total & 233 & 2.45 & .621 & .041 \\
\hline \multirow{3}{*}{ Affordable Housing } & Female & 86 & 2.51 & .646 & .070 \\
\hline & Male & 147 & 2.51 & .578 & .048 \\
\hline & Total & 233 & 2.51 & .603 & .039 \\
\hline
\end{tabular}


NSOPF descriptive statistics by gender (continued)

\begin{tabular}{|c|c|c|c|c|c|}
\hline \multirow[b]{3}{*}{ Good environment/schools for my children } & Female & 78 & 1.95 & .952 & .108 \\
\hline & Male & 144 & 1.95 & .888 & .074 \\
\hline & Total & 222 & 1.95 & .909 & .061 \\
\hline \multirow{3}{*}{ A full-time position } & Female & 86 & 2.63 & .687 & .074 \\
\hline & Male & 144 & 2.80 & .510 & .042 \\
\hline & Total & 230 & 2.73 & .587 & .039 \\
\hline \multirow{3}{*}{ A part-time position } & Female & 82 & 1.51 & .689 & .076 \\
\hline & Male & 144 & 1.18 & .453 & .038 \\
\hline & Total & 226 & 1.30 & .572 & .038 \\
\hline $\begin{array}{l}\text { Please indicate the extent to which you agree or } \\
\text { disagree with each of the following statements. }\end{array}$ & Gender & $N$ & Mean & $\begin{array}{l}\text { Standard } \\
\text { Deviation }\end{array}$ & $\begin{array}{l}\text { Standard } \\
\text { Error }\end{array}$ \\
\hline \multirow{3}{*}{$\begin{array}{l}\text { It is important for faculty to participate in governing their } \\
\text { institution }\end{array}$} & Female & 89 & 3.71 & .482 & .051 \\
\hline & Male & 146 & 3.60 & .605 & .050 \\
\hline & Total & 235 & 3.64 & .563 & .037 \\
\hline \multirow{3}{*}{$\begin{array}{l}\text { Faculty promotions should be based at least in part on } \\
\text { formal student evaluations }\end{array}$} & Female & 89 & 3.02 & .690 & .073 \\
\hline & Male & 147 & 2.90 & .817 & .067 \\
\hline & Total & 236 & 2.94 & .773 & .050 \\
\hline \multirow{3}{*}{$\begin{array}{l}\text { The tenure system in higher education should be } \\
\text { preserved }\end{array}$} & Female & 88 & 2.67 & .880 & .094 \\
\hline & Male & 147 & 2.90 & .975 & .080 \\
\hline & Total & 235 & 2.82 & .945 & .062 \\
\hline \multirow{3}{*}{$\begin{array}{l}\text { Teaching effectiveness should be the primary criterion } \\
\text { for promotion of faculty }\end{array}$} & Female & 89 & 3.29 & .678 & .072 \\
\hline & Male & 146 & 3.31 & .649 & .054 \\
\hline & Total & 235 & 3.30 & .659 & .043 \\
\hline \multirow{3}{*}{$\begin{array}{l}\text { Research/publications should be the primary criterion } \\
\text { for promotion of college faculty }\end{array}$} & Female & 89 & 1.82 & .684 & .072 \\
\hline & Male & 147 & 1.96 & .701 & .058 \\
\hline & Total & 236 & 1.91 & .696 & .045 \\
\hline \multirow{3}{*}{$\begin{array}{l}\text { Years of service/advanced degree should be the } \\
\text { primary criterion for promotion of college faculty }\end{array}$} & Female & 89 & 2.46 & .739 & .078 \\
\hline & Male & 145 & 2.49 & .792 & .066 \\
\hline & Total & 234 & 2.48 & .771 & .050 \\
\hline \multirow{3}{*}{$\begin{array}{l}\text { The administrative function is taking an increasingly } \\
\text { heavy share of available resources at my institution }\end{array}$} & Female & 88 & 2.64 & .833 & .089 \\
\hline & Male & 142 & 2.82 & .886 & .074 \\
\hline & Total & 230 & 2.75 & .869 & .057 \\
\hline \multirow{3}{*}{$\begin{array}{l}\text { State or federally mandated assessment requirements } \\
\text { have improved the quality of undergraduate education } \\
\text { at my institution }\end{array}$} & Female & 85 & 2.33 & .892 & .097 \\
\hline & Male & 142 & 2.17 & .790 & .066 \\
\hline & Total & 227 & 2.23 & .831 & .055 \\
\hline \multirow{3}{*}{$\begin{array}{l}\text { Female faculty members are treated fairly at my } \\
\text { institution }\end{array}$} & Female & 89 & 3.06 & .803 & .085 \\
\hline & Male & 145 & 3.37 & .705 & .059 \\
\hline & Total & 234 & 3.25 & .757 & .050 \\
\hline \multirow{3}{*}{$\begin{array}{l}\text { Faculty who are members of racial or ethnic minorities } \\
\text { are treated fairly at my institution }\end{array}$} & Female & 86 & 3.22 & .758 & .082 \\
\hline & Male & 146 & 3.31 & .784 & .065 \\
\hline & Total & 232 & 3.28 & .774 & .051 \\
\hline \multirow{3}{*}{$\begin{array}{l}\text { My institution effectively meets the educational needs of } \\
\text { entering students }\end{array}$} & Female & 87 & 3.30 & .612 & .066 \\
\hline & Male & 146 & 3.18 & .743 & .061 \\
\hline & Total & 233 & 3.23 & .698 & .046 \\
\hline
\end{tabular}


NSOPF descriptive statistics by gender (continued)

\begin{tabular}{|l|l|r|r|r|r|}
\hline \multirow{4}{*}{$\begin{array}{l}\text { If I had it to do over again, I would choose an academic } \\
\text { career }\end{array}$} & Female & 89 & 3.84 & .520 & .055 \\
\cline { 2 - 6 } & Male & 147 & 3.75 & .508 & .042 \\
\cline { 2 - 6 } & Total & 236 & 3.78 & .514 & .033 \\
\hline
\end{tabular}


NSOPF descriptive statistics by age

\begin{tabular}{|c|c|c|c|c|c|}
\hline $\begin{array}{l}\text { How satisfied or dissatisfied do you personally } \\
\text { feel about each of the following aspects of your } \\
\text { job at your current institution }\end{array}$ & Age & $N$ & Mean & $\begin{array}{l}\text { Standard } \\
\text { Deviation }\end{array}$ & $\begin{array}{l}\text { Standard } \\
\text { Error }\end{array}$ \\
\hline \multirow{7}{*}{ My Work Load } & $20-29$ & 8 & 3.25 & .886 & .313 \\
\hline & $30-39$ & 40 & 2.78 & .862 & .136 \\
\hline & $40-49$ & 61 & 2.82 & .827 & .106 \\
\hline & $50-59$ & 87 & 2.85 & .856 & .092 \\
\hline & $60-69$ & 35 & 2.97 & .923 & .156 \\
\hline & 70 and above & 5 & 3.60 & .548 & .245 \\
\hline & Total & 236 & 2.88 & .859 & .056 \\
\hline \multirow{7}{*}{ My job security } & $20-29$ & 8 & 3.50 & .756 & .267 \\
\hline & $30-39$ & 39 & 3.31 & .832 & .133 \\
\hline & $40-49$ & 61 & 3.23 & .920 & .118 \\
\hline & $50-59$ & 87 & 3.44 & .742 & .080 \\
\hline & $60-69$ & 35 & 3.71 & .519 & .088 \\
\hline & 70 and above & 5 & 3.60 & .894 & .400 \\
\hline & Total & 235 & 3.41 & .792 & .052 \\
\hline \multirow{7}{*}{ My Salary } & $20-29$ & 8 & 2.38 & .916 & .324 \\
\hline & $30-39$ & 40 & 2.68 & .917 & .145 \\
\hline & $40-49$ & 61 & 2.57 & .846 & .108 \\
\hline & $50-59$ & 87 & 2.68 & .869 & .093 \\
\hline & $60-69$ & 35 & 2.74 & .886 & .150 \\
\hline & 70 and above & 5 & 2.80 & 1.304 & .583 \\
\hline & Total & 236 & 2.65 & .879 & .057 \\
\hline \multirow{7}{*}{ My Benefits } & $20-29$ & 8 & 3.13 & .641 & .227 \\
\hline & $30-39$ & 40 & 2.80 & .939 & .148 \\
\hline & $40-49$ & 60 & 2.70 & .869 & .112 \\
\hline & $50-59$ & 87 & 2.87 & .873 & .094 \\
\hline & $60-69$ & 35 & 3.00 & .907 & .153 \\
\hline & 70 and above & 5 & 3.00 & 1.000 & .447 \\
\hline & Total & 235 & 2.85 & .883 & .058 \\
\hline \multirow{7}{*}{$\begin{array}{l}\text { The authority I have to make decisions about } \\
\text { what courses I teach }\end{array}$} & $20-29$ & 8 & 3.50 & .756 & .267 \\
\hline & $30-39$ & 40 & 3.25 & .870 & .138 \\
\hline & $40-49$ & 61 & 3.48 & .721 & .092 \\
\hline & $50-59$ & 86 & 3.40 & .830 & .090 \\
\hline & $60-69$ & 34 & 3.65 & .597 & .102 \\
\hline & 70 and above & 5 & 3.40 & 1.342 & .600 \\
\hline & Total & 234 & 3.43 & .790 & .052 \\
\hline
\end{tabular}


NSOPF descriptive statistics by age (continued)

The authority I have to make decisions about the content and methods in the courses I teach

other aspects of my job

\begin{tabular}{|c|c|c|c|c|c|}
\hline \multirow{7}{*}{$\begin{array}{l}\text { The authority I have to make decisions about the } \\
\text { content and methods in the courses I teach }\end{array}$} & $20-29$ & 8 & 3.88 & .354 & .125 \\
\hline & $30-39$ & 40 & 3.70 & .723 & .114 \\
\hline & $40-49$ & 61 & 3.80 & .440 & .056 \\
\hline & $50-59$ & 86 & 3.79 & .437 & .047 \\
\hline & $60-69$ & 34 & 3.85 & .359 & .062 \\
\hline & 70 and above & 5 & 4.00 & .000 & .000 \\
\hline & Total & 234 & 3.79 & .482 & .032 \\
\hline \multirow{7}{*}{$\begin{array}{l}\text { The authority I have to make decisions about } \\
\text { other aspects of my job }\end{array}$} & $20-29$ & 8 & 3.50 & .535 & .189 \\
\hline & $30-39$ & 40 & 3.10 & .871 & .138 \\
\hline & $40-49$ & 60 & 3.38 & .640 & .083 \\
\hline & $50-59$ & 87 & 3.39 & .617 & .066 \\
\hline & $60-69$ & 33 & 3.52 & .566 & .098 \\
\hline & 70 and above & 5 & 3.40 & .548 & .245 \\
\hline & Total & 233 & 3.36 & .669 & .044 \\
\hline \multirow{7}{*}{$\begin{array}{l}\text { The mix of teaching, research, administration, } \\
\text { and service that I am required to do }\end{array}$} & $20-29$ & 8 & 3.38 & .916 & .324 \\
\hline & $30-39$ & 40 & 3.03 & .800 & .127 \\
\hline & $40-49$ & 61 & 2.98 & .846 & .108 \\
\hline & $50-59$ & 86 & 3.08 & .770 & .083 \\
\hline & $60-69$ & 33 & 3.30 & .684 & .119 \\
\hline & 70 and above & 5 & 3.60 & .548 & .245 \\
\hline & Total & 233 & 3.10 & .790 & .052 \\
\hline \multirow{7}{*}{$\begin{array}{l}\text { The opportunity for advancement in rank at my } \\
\text { institution }\end{array}$} & $20-29$ & 8 & 3.00 & 1.309 & .463 \\
\hline & $30-39$ & 40 & 3.10 & .841 & .133 \\
\hline & $40-49$ & 61 & 3.05 & .884 & .113 \\
\hline & $50-59$ & 85 & 3.13 & .973 & .106 \\
\hline & $60-69$ & 34 & 3.24 & .855 & .147 \\
\hline & 70 and above & 5 & 3.00 & 1.000 & .447 \\
\hline & Total & 233 & 3.11 & .917 & .060 \\
\hline \multirow{7}{*}{ Time available for keeping current in my field } & $20-29$ & 8 & 2.75 & 1.035 & .366 \\
\hline & $30-39$ & 40 & 2.30 & .992 & .157 \\
\hline & $40-49$ & 60 & 2.28 & .976 & .126 \\
\hline & $50-59$ & 87 & 2.55 & .759 & .081 \\
\hline & $60-69$ & 34 & 2.50 & .826 & .142 \\
\hline & 70 and above & 5 & 2.80 & .837 & .374 \\
\hline & Total & 234 & 2.44 & .883 & .058 \\
\hline
\end{tabular}

The mix of teaching, research, administration, and service that I am required to do

The opportunity for advancement in rank at my institution

Time available for keeping current in my field 
NSOPF descriptive statistics by age (continued)

Availability of support services and equipment (clerical support, computers, etc.)

\begin{tabular}{|c|c|c|c|c|}
\hline $20-29$ & 8 & 3.00 & .756 & 267 \\
\hline $30-39$ & 40 & 2.75 & .954 & .151 \\
\hline $40-49$ & 61 & 2.79 & .933 & .119 \\
\hline $50-59$ & 87 & 2.86 & .851 & .091 \\
\hline $60-69$ & 35 & 3.14 & 879 & 149 \\
\hline 70 and above & 5 & 3.20 & .837 & .374 \\
\hline Total & 236 & 2.88 & 893 & .058 \\
\hline $20-29$ & 8 & 3.38 & .744 & .263 \\
\hline $30-39$ & 37 & 3.19 & .811 & .133 \\
\hline $40-49$ & 60 & 3.37 & .610 & .079 \\
\hline $50-59$ & 83 & 3.16 & .773 & .085 \\
\hline $60-69$ & 32 & 3.44 & .669 & .118 \\
\hline 70 and above & 5 & 3.80 & .447 & .200 \\
\hline Total & 225 & 3.28 & .724 & .048 \\
\hline $20-29$ & 8 & 3.50 & 1.069 & .378 \\
\hline $30-39$ & 39 & 2.85 & .904 & .145 \\
\hline $40-49$ & 61 & 3.25 & .830 & .106 \\
\hline $50-59$ & 86 & 3.22 & .621 & .067 \\
\hline $60-69$ & 34 & 3.47 & .662 & .114 \\
\hline 70 and above & 5 & 3.80 & .447 & .200 \\
\hline Total & 233 & 3.22 & .772 & .051 \\
\hline $20-29$ & 8 & 3.38 & 1.061 & .375 \\
\hline $30-39$ & 40 & 3.00 & .847 & .134 \\
\hline $40-49$ & 61 & 3.34 & .947 & .121 \\
\hline $50-59$ & 87 & 3.40 & .655 & .070 \\
\hline $60-69$ & 35 & 3.57 & .608 & .103 \\
\hline 70 and above & 5 & 4.00 & .000 & .000 \\
\hline Total & 236 & 3.36 & .794 & .052 \\
\hline $20-29$ & 8 & 3.88 & .354 & .125 \\
\hline $30-39$ & 40 & 3.48 & .679 & .107 \\
\hline $40-49$ & 61 & 3.67 & .507 & .065 \\
\hline $50-59$ & 86 & 3.60 & .559 & .060 \\
\hline $60-69$ & 35 & 3.86 & .355 & .060 \\
\hline 70 and above & 5 & 4.00 & .000 & .000 \\
\hline Total & 235 & 3.66 & .543 & .035 \\
\hline $20-29$ & 8 & 3.25 & 1.035 & .366 \\
\hline $30-39$ & 40 & 3.10 & .955 & .151 \\
\hline $40-49$ & 61 & 3.30 & .882 & .113 \\
\hline $50-59$ & 87 & 3.43 & .816 & .087 \\
\hline $60-69$ & 34 & 3.71 & .629 & .108 \\
\hline 70 and above & 5 & 3.60 & .548 & .245 \\
\hline Total & 235 & 3.37 & .850 & .055 \\
\hline
\end{tabular}

Quality of leadership in my department

Overall reputation of the institution

Reputation of my department

Institutional mission or philosophy

\begin{tabular}{|l|l|r|r|r|r|}
\hline \multirow{5}{*}{ Quality of leadership in my department } & 70 and above & 5 & 4.00 & .000 & .000 \\
\cline { 2 - 6 } & Total & 235 & 3.66 & .543 & .035 \\
\hline & $20-29$ & 8 & 3.25 & 1.035 & .366 \\
\hline & $30-39$ & 40 & 3.10 & .955 & .151 \\
\hline & $40-49$ & 61 & 3.30 & .882 & .113 \\
\cline { 2 - 6 } & $50-59$ & 87 & 3.43 & .816 & .087 \\
\cline { 2 - 6 } & $60-69$ & 34 & 3.71 & .629 & .108 \\
\hline & 70 and above & 5 & 3.60 & .548 & .245 \\
\hline & Total & 235 & 3.37 & .850 & .055 \\
\hline
\end{tabular}


NSOPF descriptive statistics by age (continued)

Quality of chief administrative officers at my institution

\begin{tabular}{|c|c|c|c|c|c|}
\hline \multirow{7}{*}{$\begin{array}{l}\text { Quality of chief administrative officers at my } \\
\text { institution }\end{array}$} & $20-29$ & 8 & 3.63 & .518 & .183 \\
\hline & $30-39$ & 40 & 3.15 & .864 & .137 \\
\hline & $40-49$ & 61 & 3.11 & .877 & .112 \\
\hline & $50-59$ & 87 & 2.95 & .987 & .106 \\
\hline & $60-69$ & 34 & 3.38 & .888 & .152 \\
\hline & 70 and above & 5 & 3.60 & .548 & .245 \\
\hline & Total & 235 & 3.13 & .916 & .060 \\
\hline \multirow{7}{*}{ Quality of my colleagues in my department } & $20-29$ & 8 & 3.00 & 1.069 & .378 \\
\hline & $30-39$ & 40 & 3.45 & .749 & .118 \\
\hline & $40-49$ & 60 & 3.43 & .698 & .090 \\
\hline & $50-59$ & 86 & 3.52 & .608 & .066 \\
\hline & $60-69$ & 34 & 3.68 & .589 & .101 \\
\hline & 70 and above & 5 & 3.80 & .447 & .200 \\
\hline & Total & 233 & 3.50 & .677 & .044 \\
\hline \multirow{7}{*}{ Quality of faculty leadership at my institution } & $20-29$ & 8 & 3.38 & .744 & .263 \\
\hline & $30-39$ & 40 & 3.00 & .816 & .129 \\
\hline & $40-49$ & 61 & 2.97 & .912 & .117 \\
\hline & $50-59$ & 86 & 3.12 & .758 & .082 \\
\hline & $60-69$ & 35 & 3.46 & .657 & .111 \\
\hline & 70 and above & 5 & 3.20 & .837 & .374 \\
\hline & Total & 235 & 3.12 & .808 & .053 \\
\hline \multirow{7}{*}{$\begin{array}{l}\text { Relationship between administration and faculty } \\
\text { at this institution }\end{array}$} & $20-29$ & 8 & 3.25 & .707 & .250 \\
\hline & $30-39$ & 40 & 2.68 & .917 & .145 \\
\hline & $40-49$ & 61 & 2.74 & .929 & .119 \\
\hline & $50-59$ & 86 & 2.66 & .902 & .097 \\
\hline & $60-69$ & 35 & 3.20 & .833 & .141 \\
\hline & 70 and above & 5 & 3.20 & .837 & .374 \\
\hline & Total & 235 & 2.80 & .911 & .059 \\
\hline \multirow{7}{*}{ Interdepartmental cooperation at this institution } & $20-29$ & 8 & 2.75 & .707 & .250 \\
\hline & $30-39$ & 40 & 2.60 & .810 & .128 \\
\hline & $40-49$ & 61 & 2.70 & .919 & .118 \\
\hline & $50-59$ & 86 & 2.85 & .712 & .077 \\
\hline & $60-69$ & 35 & 3.17 & .747 & .126 \\
\hline & 70 and above & 5 & 2.60 & .894 & .400 \\
\hline & Total & 235 & 2.81 & .807 & .053 \\
\hline \multirow{7}{*}{$\begin{array}{l}\text { Spirit of cooperation between faculty at this } \\
\text { institution }\end{array}$} & $20-29$ & 8 & 3.00 & .756 & .267 \\
\hline & $30-39$ & 40 & 2.90 & .744 & .118 \\
\hline & $40-49$ & 61 & 2.92 & .862 & .110 \\
\hline & $50-59$ & 87 & 3.13 & .696 & .075 \\
\hline & 60-69 & 35 & 3.49 & .612 & .103 \\
\hline & 70 and above & 5 & 3.20 & .837 & .374 \\
\hline & Total & 236 & 3.08 & .762 & .050 \\
\hline
\end{tabular}


NSOPF descriptive statistics by age (continued)

\begin{tabular}{|c|c|c|c|c|c|}
\hline \multirow[b]{7}{*}{ Quality of my research facilities and support } & $20-29$ & 8 & 2.50 & .926 & .327 \\
\hline & $30-39$ & 39 & 2.21 & .864 & .138 \\
\hline & $40-49$ & 59 & 2.34 & .863 & .112 \\
\hline & $50-59$ & 82 & 2.49 & .724 & .080 \\
\hline & $60-69$ & 33 & 2.55 & .971 & .169 \\
\hline & 70 and above & 4 & 2.50 & 1.291 & .645 \\
\hline & Total & 225 & 2.41 & .841 & .056 \\
\hline \multirow{7}{*}{ Quality of students whom I have taught here } & $20-29$ & 8 & 3.00 & 1.069 & .378 \\
\hline & $30-39$ & 40 & 2.90 & .744 & .118 \\
\hline & $40-49$ & 61 & 3.13 & .763 & .098 \\
\hline & $50-59$ & 87 & 2.95 & .714 & .077 \\
\hline & $60-69$ & 35 & 3.37 & .690 & .117 \\
\hline & 70 and above & 5 & 3.80 & .447 & .200 \\
\hline & Total & 236 & 3.07 & .754 & .049 \\
\hline \multirow{7}{*}{ Teaching assistance that I receive } & $20-29$ & 7 & 2.71 & 1.113 & .421 \\
\hline & $30-39$ & 37 & 2.54 & .836 & .138 \\
\hline & $40-49$ & 56 & 2.50 & .831 & .111 \\
\hline & $50-59$ & 80 & 2.70 & .833 & .093 \\
\hline & $60-69$ & 31 & 3.00 & 1.033 & .185 \\
\hline & 70 and above & 4 & 3.75 & .500 & .250 \\
\hline & Total & 215 & 2.68 & .887 & .061 \\
\hline \multirow{7}{*}{ Research assistance that I receive } & $20-29$ & 7 & 2.71 & .951 & .360 \\
\hline & $30-39$ & 37 & 2.19 & .877 & .144 \\
\hline & $40-49$ & 52 & 2.15 & .849 & .118 \\
\hline & $50-59$ & 78 & 2.44 & .783 & .089 \\
\hline & $60-69$ & 26 & 2.46 & 1.104 & .216 \\
\hline & 70 and above & 3 & 3.00 & 1.000 & .577 \\
\hline & Total & 203 & 2.34 & .878 & .062 \\
\hline \multirow{7}{*}{$\begin{array}{l}\text { Spouse employment opportunities in this } \\
\text { geographic area }\end{array}$} & $20-29$ & 8 & 2.63 & 1.188 & .420 \\
\hline & $30-39$ & 36 & 3.11 & .785 & .131 \\
\hline & $40-49$ & 57 & 3.37 & .723 & .096 \\
\hline & $50-59$ & 81 & 3.27 & .775 & .086 \\
\hline & $60-69$ & 26 & 3.50 & .707 & .139 \\
\hline & 70 and above & 5 & 3.60 & .548 & .245 \\
\hline & Total & 213 & 3.28 & .780 & .053 \\
\hline \multirow{7}{*}{ My overall satisfaction with my job here } & $20-29$ & 8 & 3.50 & .535 & .189 \\
\hline & $30-39$ & 39 & 3.31 & .694 & .111 \\
\hline & $40-49$ & 61 & 3.49 & .622 & .080 \\
\hline & $50-59$ & 87 & 3.39 & .617 & .066 \\
\hline & $60-69$ & 35 & 3.71 & .519 & .088 \\
\hline & 70 and above & 5 & 4.00 & .000 & .000 \\
\hline & Total & 235 & 3.47 & .622 & .041 \\
\hline
\end{tabular}


NSOPF descriptive statistics by age (continued)

\begin{tabular}{|c|c|c|c|c|c|}
\hline $\begin{array}{c}\text { If you were to leave your current institution, how } \\
\text { likely is it that you would do so to? }\end{array}$ & Age & $N$ & Mean & $\begin{array}{l}\text { Standard } \\
\text { Deviation }\end{array}$ & $\begin{array}{l}\text { Standard } \\
\text { Error }\end{array}$ \\
\hline \multirow{7}{*}{ Leave to Retire } & $20-29$ & 8 & 1.25 & .463 & .164 \\
\hline & $30-39$ & 41 & 1.59 & .836 & .131 \\
\hline & $40-49$ & 61 & 2.03 & .912 & .117 \\
\hline & $50-59$ & 87 & 2.29 & .888 & .095 \\
\hline & $60-69$ & 35 & 2.86 & .430 & .073 \\
\hline & 70 and above & 4 & 3.00 & .000 & .000 \\
\hline & Total & 236 & 2.16 & .913 & .059 \\
\hline \multirow{7}{*}{ Return to school as a student } & $20-29$ & 8 & 1.50 & .756 & .267 \\
\hline & $30-39$ & 41 & 1.29 & .602 & .094 \\
\hline & $40-49$ & 61 & 1.11 & .370 & .047 \\
\hline & $50-59$ & 87 & 1.20 & .453 & .049 \\
\hline & $60-69$ & 34 & 1.15 & .436 & .075 \\
\hline & 70 and above & 3 & 1.00 & .000 & .000 \\
\hline & Total & 234 & 1.19 & .474 & .031 \\
\hline \multirow{7}{*}{$\begin{array}{l}\text { Accept employment at another Christian college } \\
\text { or university }\end{array}$} & $20-29$ & 8 & 2.38 & .518 & .183 \\
\hline & $30-39$ & 41 & 2.29 & .559 & .087 \\
\hline & $40-49$ & 61 & 2.10 & .597 & .076 \\
\hline & $50-59$ & 87 & 2.02 & .682 & .073 \\
\hline & $60-69$ & 34 & 1.44 & .613 & .105 \\
\hline & 70 and above & 3 & 1.67 & .577 & .333 \\
\hline & Total & 234 & 2.01 & .671 & .044 \\
\hline \multirow{7}{*}{$\begin{array}{l}\text { Accept employment at a secular college or } \\
\text { university }\end{array}$} & $20-29$ & 8 & 2.38 & .744 & .263 \\
\hline & $30-39$ & 41 & 1.88 & .714 & .112 \\
\hline & $40-49$ & 61 & 1.69 & .647 & .083 \\
\hline & $50-59$ & 86 & 1.57 & .624 & .067 \\
\hline & $60-69$ & 34 & 1.26 & .448 & .077 \\
\hline & 70 and above & 3 & 1.33 & .577 & .333 \\
\hline & Total & 233 & 1.64 & .663 & .043 \\
\hline \multirow{7}{*}{$\begin{array}{l}\text { Accept employment in consulting or other for- } \\
\text { profit business or industry or become self- } \\
\text { employed }\end{array}$} & $20-29$ & 8 & 2.00 & .756 & .267 \\
\hline & $30-39$ & 41 & 1.51 & .597 & .093 \\
\hline & $40-49$ & 61 & 1.69 & .743 & .095 \\
\hline & $50-59$ & 87 & 1.57 & .741 & .079 \\
\hline & $60-69$ & 34 & 1.47 & .662 & .114 \\
\hline & 70 and above & 3 & 1.67 & .577 & .333 \\
\hline & Total & 234 & 1.59 & .707 & .046 \\
\hline \multirow{7}{*}{ Accept employment in a non-profit organization } & $20-29$ & 8 & 1.88 & .641 & .227 \\
\hline & $30-39$ & 41 & 1.59 & .591 & .092 \\
\hline & $40-49$ & 61 & 1.85 & .679 & .087 \\
\hline & $50-59$ & 86 & 1.74 & .598 & .064 \\
\hline & $60-69$ & 34 & 1.59 & .657 & .113 \\
\hline & 70 and above & 3 & 1.33 & .577 & .333 \\
\hline & Total & 233 & 1.72 & .633 & .041 \\
\hline
\end{tabular}


NSOPF descriptive statistics by age (continued)

\begin{tabular}{|c|c|c|c|c|c|}
\hline $\begin{array}{l}\text { If you were to leave your current institution to } \\
\text { accept another position, would you want to do } \\
\text { more, less or about the same amount of the } \\
\text { following as you currently do? }\end{array}$ & Age & $N$ & Mean & $\begin{array}{l}\text { Standard } \\
\text { Deviation }\end{array}$ & $\begin{array}{l}\text { Standard } \\
\text { Error }\end{array}$ \\
\hline \multirow{7}{*}{ Research } & $20-29$ & 8 & 1.75 & .707 & .250 \\
\hline & $30-39$ & 41 & 1.49 & .553 & .086 \\
\hline & $40-49$ & 60 & 1.57 & .745 & .096 \\
\hline & $50-59$ & 86 & 1.59 & .621 & .067 \\
\hline & $60-69$ & 33 & 1.58 & .614 & .107 \\
\hline & 70 and above & 3 & 1.67 & .577 & .333 \\
\hline & Total & 231 & 1.57 & .641 & .042 \\
\hline \multirow{7}{*}{ Teaching } & $20-29$ & 8 & 2.00 & .535 & .189 \\
\hline & $30-39$ & 41 & 2.20 & .679 & .106 \\
\hline & $40-49$ & 61 & 2.11 & .608 & .078 \\
\hline & $50-59$ & 85 & 2.11 & .512 & .056 \\
\hline & $60-69$ & 34 & 2.26 & .567 & .097 \\
\hline & 70 and above & 3 & 2.33 & .577 & .333 \\
\hline & Total & 232 & 2.15 & .577 & .038 \\
\hline \multirow{7}{*}{ Advising } & $20-29$ & 8 & 2.13 & .641 & .227 \\
\hline & $30-39$ & 41 & 2.10 & .490 & .077 \\
\hline & $40-49$ & 61 & 2.28 & .552 & .071 \\
\hline & $50-59$ & 85 & 2.22 & .543 & .059 \\
\hline & $60-69$ & 33 & 2.33 & .540 & .094 \\
\hline & 70 and above & 3 & 2.33 & .577 & .333 \\
\hline & Total & 231 & 2.23 & .539 & .035 \\
\hline \multirow{7}{*}{ Service } & $20-29$ & 8 & 1.88 & .641 & .227 \\
\hline & $30-39$ & 41 & 2.12 & .510 & .080 \\
\hline & $40-49$ & 61 & 2.15 & .573 & .073 \\
\hline & $50-59$ & 86 & 2.08 & .536 & .058 \\
\hline & $60-69$ & 34 & 2.35 & .544 & .093 \\
\hline & 70 and above & 3 & 3.00 & .000 & .000 \\
\hline & Total & 233 & 2.15 & .556 & .036 \\
\hline \multirow{7}{*}{ Administration } & $20-29$ & 8 & 2.00 & .535 & .189 \\
\hline & $30-39$ & 40 & 2.17 & .594 & .094 \\
\hline & $40-49$ & 60 & 2.28 & .715 & .092 \\
\hline & $50-59$ & 86 & 2.26 & .723 & .078 \\
\hline & $60-69$ & 33 & 2.61 & .496 & .086 \\
\hline & 70 and above & 3 & 1.33 & .577 & .333 \\
\hline & Total & 230 & 2.28 & .681 & .045 \\
\hline
\end{tabular}


NSOPF descriptive statistics by age (continued)

\begin{tabular}{|c|c|c|c|c|c|}
\hline $\begin{array}{l}\text { If you were to leave your current institution to } \\
\text { accept another position, how important would } \\
\text { each of the following items be in your decision to } \\
\text { accept another position? }\end{array}$ & Age & $N$ & Mean & $\begin{array}{l}\text { Standard } \\
\text { Deviation }\end{array}$ & $\begin{array}{c}\text { Standard } \\
\text { Error }\end{array}$ \\
\hline \multirow{7}{*}{ Salary Level } & $20-29$ & 8 & 2.63 & .518 & .183 \\
\hline & $30-39$ & 41 & 2.51 & .506 & .079 \\
\hline & $40-49$ & 61 & 2.49 & .566 & .073 \\
\hline & $50-59$ & 87 & 2.45 & .523 & .056 \\
\hline & $60-69$ & 35 & 2.20 & .677 & .114 \\
\hline & 70 and above & 5 & 2.60 & .548 & .245 \\
\hline & Total & 237 & 2.44 & .562 & .036 \\
\hline \multirow{7}{*}{ Position Level } & $20-29$ & 8 & 2.25 & .707 & .250 \\
\hline & $30-39$ & 40 & 2.33 & .526 & .083 \\
\hline & $40-49$ & 61 & 2.34 & .544 & .070 \\
\hline & $50-59$ & 87 & 2.41 & .639 & .068 \\
\hline & $60-69$ & 35 & 2.20 & .719 & .122 \\
\hline & 70 and above & 5 & 2.60 & .548 & .245 \\
\hline & Total & 236 & 2.35 & .610 & .040 \\
\hline \multirow{7}{*}{ Job Security } & $20-29$ & 8 & 2.50 & .756 & .267 \\
\hline & $30-39$ & 40 & 2.68 & .526 & .083 \\
\hline & $40-49$ & 61 & 2.70 & .495 & .063 \\
\hline & $50-59$ & 87 & 2.53 & .607 & .065 \\
\hline & $60-69$ & 35 & 2.11 & .758 & .128 \\
\hline & 70 and above & 5 & 2.60 & .548 & .245 \\
\hline & Total & 236 & 2.54 & .621 & .040 \\
\hline \multirow{7}{*}{ Opportunities for advancement } & $20-29$ & 8 & 2.63 & .518 & .183 \\
\hline & $30-39$ & 41 & 2.41 & .591 & .092 \\
\hline & $40-49$ & 61 & 2.52 & .566 & .072 \\
\hline & $50-59$ & 87 & 2.20 & .713 & .076 \\
\hline & $60-69$ & 35 & 2.03 & .785 & .133 \\
\hline & 70 and above & 5 & 2.40 & .548 & .245 \\
\hline & Total & 237 & 2.31 & .679 & .044 \\
\hline \multirow{7}{*}{ Benefits } & $20-29$ & 8 & 2.63 & .744 & .263 \\
\hline & $30-39$ & 41 & 2.66 & .480 & .075 \\
\hline & $40-49$ & 61 & 2.72 & .452 & .058 \\
\hline & $50-59$ & 87 & 2.68 & .494 & .053 \\
\hline & $60-69$ & 35 & 2.49 & .612 & .103 \\
\hline & 70 and above & 5 & 2.60 & .548 & .245 \\
\hline & Total & 237 & 2.65 & .511 & .033 \\
\hline \multirow{7}{*}{ No pressure to publish } & $20-29$ & 8 & 1.88 & .835 & .295 \\
\hline & 30-39 & 41 & 2.07 & .685 & .107 \\
\hline & $40-49$ & 61 & 2.23 & .739 & .095 \\
\hline & $50-59$ & 87 & 2.03 & .723 & .077 \\
\hline & $60-69$ & 35 & 2.43 & .655 & .111 \\
\hline & 70 and above & 5 & 2.80 & .447 & .200 \\
\hline & Total & 237 & 2.16 & .725 & .047 \\
\hline
\end{tabular}


NSOPF descriptive statistics by age (continued)

\begin{tabular}{|c|c|c|c|c|c|}
\hline \multirow[b]{7}{*}{ Academic Freedom } & $20-29$ & 8 & 2.50 & .535 & .189 \\
\hline & $30-39$ & 41 & 2.44 & .634 & .099 \\
\hline & $40-49$ & 61 & 2.66 & .513 & .066 \\
\hline & $50-59$ & 87 & 2.55 & .545 & .058 \\
\hline & $60-69$ & 35 & 2.66 & .539 & .091 \\
\hline & 70 and above & 5 & 2.80 & .447 & .200 \\
\hline & Total & 237 & 2.58 & .552 & .036 \\
\hline \multirow{7}{*}{ Good research facilities and equipment } & $20-29$ & 8 & 2.25 & .707 & .250 \\
\hline & $30-39$ & 41 & 2.34 & .575 & .090 \\
\hline & $40-49$ & 61 & 2.11 & .608 & .078 \\
\hline & $50-59$ & 87 & 2.02 & .715 & .077 \\
\hline & $60-69$ & 33 & 2.15 & .667 & .116 \\
\hline & 70 and above & 5 & 1.80 & 837 & .374 \\
\hline & Total & 235 & 2.12 & .665 & .043 \\
\hline \multirow{7}{*}{ Good instructional facilities and equipment } & $20-29$ & 8 & 2.50 & .535 & .189 \\
\hline & $30-39$ & 41 & 2.56 & .550 & .086 \\
\hline & $40-49$ & 61 & 2.54 & .535 & .068 \\
\hline & $50-59$ & 87 & 2.54 & .606 & .065 \\
\hline & $60-69$ & 34 & 2.59 & .557 & .096 \\
\hline & 70 and above & 5 & 2.40 & .548 & .245 \\
\hline & Total & 236 & 2.55 & .563 & .037 \\
\hline \multirow{7}{*}{ Excellent Students } & $20-29$ & 8 & 2.38 & .518 & .183 \\
\hline & $30-39$ & 41 & 2.56 & .550 & .086 \\
\hline & $40-49$ & 61 & 2.38 & .522 & .067 \\
\hline & $50-59$ & 87 & 2.37 & .612 & .066 \\
\hline & $60-69$ & 35 & 2.46 & .561 & .095 \\
\hline & 70 and above & 5 & 2.80 & .447 & .200 \\
\hline & Total & 237 & 2.43 & .567 & .037 \\
\hline \multirow{7}{*}{ Excellent Colleagues } & $20-29$ & 8 & 2.38 & .518 & .183 \\
\hline & $30-39$ & 41 & 2.80 & .401 & .063 \\
\hline & $40-49$ & 61 & 2.62 & .489 & .063 \\
\hline & $50-59$ & 87 & 2.60 & .516 & .055 \\
\hline & $60-69$ & 35 & 2.77 & .426 & .072 \\
\hline & 70 and above & 5 & 2.80 & .447 & .200 \\
\hline & Total & 237 & 2.66 & .483 & .031 \\
\hline \multirow{7}{*}{ New institution is a Christian college } & $20-29$ & 8 & 1.88 & .835 & .295 \\
\hline & $30-39$ & 41 & 2.22 & .613 & .096 \\
\hline & $40-49$ & 61 & 2.23 & .739 & .095 \\
\hline & $50-59$ & 87 & 2.32 & .739 & .079 \\
\hline & $60-69$ & 35 & 2.34 & .684 & .116 \\
\hline & 70 and above & 5 & 2.80 & .447 & .200 \\
\hline & Total & 237 & 2.28 & .712 & .046 \\
\hline
\end{tabular}


NSOPF descriptive statistics by age (continued)

Institutional mission or philosophy that is compatible with my own view

\begin{tabular}{|c|c|c|c|c|c|}
\hline \multirow{7}{*}{$\begin{array}{l}\text { Institutional mission or philosophy that is } \\
\text { compatible with my own view }\end{array}$} & $20-29$ & 8 & 2.50 & .535 & .189 \\
\hline & $30-39$ & 41 & 2.66 & .530 & .083 \\
\hline & $40-49$ & 60 & 2.63 & .551 & .071 \\
\hline & $50-59$ & 87 & 2.67 & .521 & .056 \\
\hline & $60-69$ & 35 & 2.69 & .471 & .080 \\
\hline & 70 and above & 5 & 3.00 & .000 & .000 \\
\hline & Total & 236 & 2.66 & .517 & .034 \\
\hline \multirow{7}{*}{ Good job for my spouse } & $20-29$ & 8 & 2.50 & .756 & .267 \\
\hline & $30-39$ & 40 & 2.17 & .844 & .133 \\
\hline & $40-49$ & 57 & 2.14 & .811 & .107 \\
\hline & $50-59$ & 85 & 2.21 & .818 & .089 \\
\hline & $60-69$ & 32 & 1.56 & .840 & .148 \\
\hline & 70 and above & 4 & 1.75 & .957 & .479 \\
\hline & Total & 226 & 2.10 & .848 & .056 \\
\hline \multirow{7}{*}{ Good geographic location } & $20-29$ & 8 & 2.88 & .354 & .125 \\
\hline & $30-39$ & 41 & 2.39 & .586 & .092 \\
\hline & $40-49$ & 61 & 2.54 & .594 & .076 \\
\hline & $50-59$ & 86 & 2.44 & .625 & .067 \\
\hline & $60-69$ & 34 & 2.24 & .741 & .127 \\
\hline & 70 and above & 4 & 2.50 & .577 & .289 \\
\hline & Total & 234 & 2.44 & .628 & .041 \\
\hline \multirow{7}{*}{ Affordable Housing } & $20-29$ & 8 & 2.25 & .886 & .313 \\
\hline & $30-39$ & 41 & 2.49 & .506 & .079 \\
\hline & $40-49$ & 60 & 2.55 & .622 & .080 \\
\hline & $50-59$ & 87 & 2.60 & .516 & .055 \\
\hline & $60-69$ & 34 & 2.32 & .768 & .132 \\
\hline & 70 and above & 4 & 2.00 & .816 & .408 \\
\hline & Total & 234 & 2.50 & .609 & .040 \\
\hline \multirow{7}{*}{ Good environment/schools for my children } & $20-29$ & 8 & 2.13 & .991 & .350 \\
\hline & $30-39$ & 40 & 2.53 & .679 & .107 \\
\hline & $40-49$ & 57 & 2.23 & .887 & .117 \\
\hline & $50-59$ & 82 & 1.65 & .852 & .094 \\
\hline & $60-69$ & 32 & 1.50 & .803 & .142 \\
\hline & 70 and above & 4 & 1.00 & .000 & .000 \\
\hline & Total & 223 & 1.94 & .908 & .061 \\
\hline \multirow{7}{*}{ A full-time position } & $20-29$ & 8 & 2.75 & .463 & .164 \\
\hline & $30-39$ & 41 & 2.90 & .374 & .058 \\
\hline & $40-49$ & 60 & 2.95 & .220 & .028 \\
\hline & $50-59$ & 85 & 2.76 & .527 & .057 \\
\hline & $60-69$ & 32 & 2.09 & .893 & .158 \\
\hline & 70 and above & 5 & 2.40 & .894 & .400 \\
\hline & Total & 231 & 2.74 & .586 & .039 \\
\hline
\end{tabular}

A full-time position

Good geographic location

Affordable Housing

Good environment/schools for my children

\begin{tabular}{|c|c|c|c|c|c|}
\hline & & & & & \\
\hline & 70 and above & 4 & 1.75 & .957 & .479 \\
\hline & Total & 226 & 2.10 & .848 & .056 \\
\hline & $20-29$ & 8 & 2.88 & .354 & .125 \\
\hline & $30-39$ & 41 & 2.39 & .586 & .092 \\
\hline & $40-49$ & 61 & 2.54 & .594 & .076 \\
\hline Good geographic location & $50-59$ & 86 & 2.44 & .625 & .067 \\
\hline & $60-69$ & 34 & 2.24 & .741 & .127 \\
\hline & 70 and above & 4 & 2.50 & .577 & .289 \\
\hline & Total & 234 & 2.44 & .628 & .041 \\
\hline & $20-29$ & 8 & 2.25 & .886 & .313 \\
\hline & $30-39$ & 41 & 2.49 & .506 & .079 \\
\hline & $40-49$ & 60 & 2.55 & .622 & .080 \\
\hline Affordable Housing & $50-59$ & 87 & 2.60 & .516 & .055 \\
\hline & $60-69$ & 34 & 2.32 & .768 & .132 \\
\hline & 70 and above & 4 & 2.00 & .816 & .408 \\
\hline & Total & 234 & 2.50 & .609 & .040 \\
\hline & $20-29$ & 8 & 2.13 & .991 & .350 \\
\hline & $30-39$ & 40 & 2.53 & .679 & .107 \\
\hline & $40-49$ & 57 & 2.23 & .887 & .117 \\
\hline Good environment/schools for my children & $50-59$ & 82 & 1.65 & .852 & .094 \\
\hline & $60-69$ & 32 & 1.50 & .803 & .142 \\
\hline & 70 and above & 4 & 1.00 & .000 & .000 \\
\hline & Total & 223 & 1.94 & .908 & .061 \\
\hline & $20-29$ & 8 & 2.75 & .463 & .164 \\
\hline & $30-39$ & 41 & 2.90 & .374 & .058 \\
\hline & $40-49$ & 60 & 2.95 & .220 & .028 \\
\hline A full-time position & $50-59$ & 85 & 2.76 & .527 & .057 \\
\hline & $60-69$ & 32 & 2.09 & .893 & .158 \\
\hline & 70 and above & 5 & 2.40 & .894 & .400 \\
\hline & Total & 231 & 2.74 & .586 & .039 \\
\hline
\end{tabular}

Good job for my spouse 
NSOPF descriptive statistics by age (continued)

\begin{tabular}{|c|c|c|c|c|c|}
\hline \multirow[b]{7}{*}{ A part-time position } & $20-29$ & 8 & 1.38 & .518 & .183 \\
\hline & $30-39$ & 39 & 1.28 & .510 & .082 \\
\hline & $40-49$ & 59 & 1.17 & .461 & .060 \\
\hline & $50-59$ & 82 & 1.27 & .522 & .058 \\
\hline & $60-69$ & 35 & 1.63 & .808 & .136 \\
\hline & 70 and above & 4 & 1.25 & .500 & .250 \\
\hline & Total & 227 & 1.30 & .572 & .038 \\
\hline $\begin{array}{l}\text { Please indicate the extent to which you agree or } \\
\text { disagree with each of the following statements. }\end{array}$ & Age & $N$ & Mean & $\begin{array}{l}\text { Standard } \\
\text { Deviation }\end{array}$ & $\begin{array}{l}\text { Standard } \\
\text { Error }\end{array}$ \\
\hline \multirow{7}{*}{$\begin{array}{l}\text { It is important for faculty to participate in } \\
\text { governing their institution }\end{array}$} & $20-29$ & 8 & 3.75 & .707 & .250 \\
\hline & $30-39$ & 41 & 3.59 & .547 & .085 \\
\hline & $40-49$ & 61 & 3.64 & .606 & .078 \\
\hline & $50-59$ & 86 & 3.69 & .515 & .056 \\
\hline & $60-69$ & 35 & 3.60 & .604 & .102 \\
\hline & 70 and above & 5 & 3.40 & .548 & .245 \\
\hline & Total & 236 & 3.64 & .563 & .037 \\
\hline \multirow{7}{*}{$\begin{array}{l}\text { Faculty promotions should be based at least in } \\
\text { part on formal student evaluations }\end{array}$} & $20-29$ & 8 & 2.88 & .835 & .295 \\
\hline & $30-39$ & 41 & 3.05 & .805 & .126 \\
\hline & $40-49$ & 61 & 3.08 & .690 & .088 \\
\hline & $50-59$ & 87 & 2.85 & .785 & .084 \\
\hline & $60-69$ & 35 & 2.83 & .747 & .126 \\
\hline & 70 and above & 5 & 3.00 & 1.225 & .548 \\
\hline & Total & 237 & 2.95 & .771 & .050 \\
\hline \multirow{7}{*}{$\begin{array}{l}\text { The tenure system in higher education should be } \\
\text { preserved. }\end{array}$} & $20-29$ & 8 & 2.88 & .835 & .295 \\
\hline & 30-39 & 41 & 2.85 & .937 & .146 \\
\hline & $40-49$ & 61 & 2.75 & .960 & .123 \\
\hline & $50-59$ & 87 & 2.93 & .962 & .103 \\
\hline & $60-69$ & 34 & 2.56 & .927 & .159 \\
\hline & 70 and above & 5 & 2.80 & .837 & .374 \\
\hline & Total & 236 & 2.81 & .945 & .062 \\
\hline \multirow{7}{*}{$\begin{array}{l}\text { Teaching effectiveness should be the primary } \\
\text { criterion for promotion of faculty }\end{array}$} & $20-29$ & 8 & 3.25 & .707 & .250 \\
\hline & $30-39$ & 41 & 3.27 & .549 & .086 \\
\hline & $40-49$ & 61 & 3.25 & .699 & .089 \\
\hline & $50-59$ & 86 & 3.36 & .649 & .070 \\
\hline & $60-69$ & 35 & 3.26 & .741 & .125 \\
\hline & 70 and above & 5 & 3.80 & .447 & .200 \\
\hline & Total & 236 & 3.31 & .659 & .043 \\
\hline \multirow{7}{*}{$\begin{array}{l}\text { Research/publications should be the primary } \\
\text { criterion for promotion of college faculty }\end{array}$} & $20-29$ & 8 & 2.25 & .886 & .313 \\
\hline & $30-39$ & 41 & 2.05 & .590 & .092 \\
\hline & $40-49$ & 61 & 1.92 & .690 & .088 \\
\hline & $50-59$ & 87 & 1.89 & .706 & .076 \\
\hline & $60-69$ & 35 & 1.71 & .710 & .120 \\
\hline & 70 and above & 5 & 1.60 & .548 & .245 \\
\hline & Total & 237 & 1.90 & .691 & .045 \\
\hline
\end{tabular}


NSOPF descriptive statistics by age (continued)

Years of service/advanced degree should be the primary criterion for promotion of college faculty

The administrative function is taking an increasingly heavy share of available resources at my institution

\begin{tabular}{|l|r|r|r|r|}
\hline $20-29$ & 8 & 2.38 & 1.061 & .375 \\
\hline $30-39$ & 41 & 2.54 & .674 & .105 \\
\hline $40-49$ & 61 & 2.62 & .820 & .105 \\
\hline $50-59$ & 85 & 2.46 & .716 & .078 \\
\hline $60-69$ & 35 & 2.17 & .707 & .119 \\
\hline 70 and above & 5 & 2.60 & 1.140 & .510 \\
\hline Total & 235 & 2.47 & .764 & .050 \\
\hline $20-29$ & 8 & 2.50 & .535 & .189 \\
\hline $30-39$ & 39 & 2.64 & .811 & .130 \\
\hline $40-49$ & 60 & 2.75 & .836 & .108 \\
\hline $50-59$ & 85 & 2.80 & .897 & .097 \\
\hline $60-69$ & 34 & 2.76 & .987 & .169 \\
\hline 70 and above & 5 & 2.80 & .837 & .374 \\
\hline Total & 231 & 2.74 & .865 & .057 \\
\hline $20-29$ & 7 & 2.86 & .690 & .261 \\
\hline $30-39$ & 40 & 2.33 & .797 & .126 \\
\hline $40-49$ & 59 & 2.17 & .769 & .100 \\
\hline $50-59$ & 85 & 2.20 & .856 & .093 \\
\hline $60-69$ & 32 & 2.22 & .906 & .160 \\
\hline 70 and above & 5 & 1.80 & .837 & .374 \\
\hline Total & 228 & 2.23 & .829 & .055 \\
\hline $20-29$ & 8 & 3.38 & .518 & .183 \\
\hline $30-39$ & 40 & 3.25 & .742 & .117 \\
\hline $40-49$ & 61 & 3.23 & .824 & .106 \\
\hline $50-59$ & 87 & 3.22 & .784 & .084 \\
\hline $60-69$ & 34 & 3.32 & .638 & .109 \\
\hline 70 and above & 5 & 3.80 & .447 & .200 \\
\hline Total & 235 & 3.26 & .754 & .049 \\
\hline $20-29$ & 8 & 3.50 & .756 & .267 \\
\hline $30-39$ & 38 & 3.29 & .694 & .113 \\
\hline $40-49$ & 60 & 3.18 & .873 & .113 \\
\hline $50-59$ & 87 & 3.33 & .710 & .076 \\
\hline $60-69$ & 35 & 3.26 & .817 & .138 \\
\hline 70 and above & 5 & 3.60 & .894 & .400 \\
\hline Total & 233 & 3.29 & .771 & .050 \\
\hline $20-29$ & 30 & 3.50 & .756 & .267 \\
\hline $30-39$ & 3.23 & .832 & .131 \\
\hline $40-49$ & 3.21 & .772 & .099 \\
\hline $50-59$ & & .635 & .068 \\
\hline $60-69$ & .535 & .092 \\
\hline 70 and above & .548 & .245 \\
\hline Total & .703 & .046 \\
\hline & 51 & & \\
\hline
\end{tabular}

State or federally mandated assessment requirements have improved the quality of undergraduate education at my institution

Female faculty members are treated fairly at my institution

Faculty who are members of racial or ethnic minorities are treated fairly at my institution

My institution effectively meets the educational needs of entering students 
NSOPF descriptive statistics by age (continued)

\begin{tabular}{|l|l|r|r|r|r|}
\hline \hline & $20-29$ & 8 & 3.75 & .463 & .164 \\
\cline { 2 - 6 } & $30-39$ & 41 & 3.76 & .435 & .068 \\
\cline { 2 - 6 } & $40-49$ & 61 & 3.77 & .589 & .075 \\
\cline { 2 - 6 } & $50-59$ & 87 & 3.80 & .478 & .051 \\
\cline { 2 - 6 } & $60-69$ & 35 & 3.86 & .355 & .060 \\
\cline { 2 - 6 } $\begin{array}{l}\text { If I had it to do over again, I would choose an } \\
\text { academic career }\end{array}$ & 70 and above & 5 & 3.20 & 1.304 & .583 \\
\cline { 2 - 6 } & Total & 237 & 3.78 & .515 & .033 \\
\hline \hline
\end{tabular}


NSOPF descriptive statistics by institution

\begin{tabular}{|c|c|c|c|c|c|}
\hline $\begin{array}{l}\text { How satisfied or dissatisfied do you personally } \\
\text { feel about each of the following aspects of your } \\
\text { job at your current institution }\end{array}$ & Institution & $N$ & Mean & $\begin{array}{l}\text { Standard } \\
\text { Deviation }\end{array}$ & $\begin{array}{c}\text { Standard } \\
\text { Error }\end{array}$ \\
\hline \multirow{11}{*}{ My Work Load } & Institution 1 & 29 & 2.83 & .602 & .112 \\
\hline & Institution 2 & 19 & 2.95 & .970 & .223 \\
\hline & Institution 3 & 28 & 2.93 & .858 & .162 \\
\hline & Institution 4 & 19 & 2.63 & .831 & .191 \\
\hline & Institution 5 & 35 & 2.83 & .923 & .156 \\
\hline & Institution 6 & 14 & 2.50 & .760 & .203 \\
\hline & Institution 7 & 24 & 3.13 & .797 & .163 \\
\hline & Institution 8 & 9 & 2.44 & 1.130 & .377 \\
\hline & Institution 9 & 32 & 3.09 & .856 & .151 \\
\hline & Institution 10 & 26 & 2.92 & .935 & .183 \\
\hline & Total & 235 & 2.88 & .861 & .056 \\
\hline \multirow{11}{*}{ My job security } & Institution 1 & 29 & 3.59 & .568 & .105 \\
\hline & Institution 2 & 19 & 3.16 & .898 & .206 \\
\hline & Institution 3 & 27 & 3.37 & .884 & .170 \\
\hline & Institution 4 & 19 & 3.32 & .885 & .203 \\
\hline & Institution 5 & 35 & 3.63 & .646 & .109 \\
\hline & Institution 6 & 14 & 3.21 & 1.122 & .300 \\
\hline & Institution 7 & 24 & 3.33 & .761 & .155 \\
\hline & Institution 8 & 9 & 3.22 & .667 & .222 \\
\hline & Institution 9 & 32 & 3.63 & .660 & .117 \\
\hline & Institution 10 & 26 & 3.12 & .993 & .195 \\
\hline & Total & 234 & 3.40 & .808 & .053 \\
\hline \multirow{11}{*}{ My Salary } & Institution 1 & 29 & 2.31 & 1.004 & .186 \\
\hline & Institution 2 & 19 & 2.89 & .937 & .215 \\
\hline & Institution 3 & 28 & 2.79 & .917 & .173 \\
\hline & Institution 4 & 19 & 2.84 & .688 & .158 \\
\hline & Institution 5 & 35 & 2.63 & .690 & .117 \\
\hline & Institution 6 & 14 & 2.86 & 1.099 & .294 \\
\hline & Institution 7 & 24 & 2.50 & 1.063 & .217 \\
\hline & Institution 8 & 9 & 1.89 & .601 & .200 \\
\hline & Institution 9 & 32 & 2.78 & .659 & .117 \\
\hline & Institution 10 & 26 & 2.69 & .928 & .182 \\
\hline & Total & 235 & 2.65 & .886 & .058 \\
\hline
\end{tabular}


NSOPF descriptive statistics by institution (continued)

\begin{tabular}{|c|c|c|c|c|c|}
\hline \multirow[b]{11}{*}{ My Benefits } & Institution 1 & 29 & 2.34 & .936 & .174 \\
\hline & Institution 2 & 19 & 2.84 & .688 & .158 \\
\hline & Institution 3 & 28 & 3.14 & .756 & .143 \\
\hline & Institution 4 & 19 & 2.42 & .769 & .176 \\
\hline & Institution 5 & 35 & 2.91 & .781 & .132 \\
\hline & Institution 6 & 14 & 3.36 & .745 & .199 \\
\hline & Institution 7 & 23 & 2.91 & .996 & .208 \\
\hline & Institution 8 & 9 & 2.33 & .866 & .289 \\
\hline & Institution 9 & 32 & 3.25 & .803 & .142 \\
\hline & Institution 10 & 26 & 2.62 & .983 & .193 \\
\hline & Total & 234 & 2.84 & .891 & .058 \\
\hline \multirow{11}{*}{$\begin{array}{l}\text { The authority I have to make decisions about } \\
\text { what courses I teach }\end{array}$} & Institution 1 & 29 & 3.52 & .738 & .137 \\
\hline & Institution 2 & 19 & 3.05 & 1.079 & .247 \\
\hline & Institution 3 & 28 & 3.61 & .685 & .130 \\
\hline & Institution 4 & 19 & 3.32 & .885 & .203 \\
\hline & Institution 5 & 35 & 3.49 & .702 & .119 \\
\hline & Institution 6 & 14 & 3.50 & .760 & .203 \\
\hline & Institution 7 & 24 & 3.13 & .947 & .193 \\
\hline & Institution 8 & 8 & 3.75 & .463 & .164 \\
\hline & Institution 9 & 31 & 3.52 & .677 & .122 \\
\hline & Institution 10 & 26 & 3.38 & .804 & .158 \\
\hline & Total & 233 & 3.42 & .795 & .052 \\
\hline \multirow{11}{*}{$\begin{array}{l}\text { The authority I have to make decisions about the } \\
\text { content and methods in the courses I teach }\end{array}$} & Institution 1 & 29 & 3.76 & .577 & .107 \\
\hline & Institution 2 & 19 & 3.63 & .684 & .157 \\
\hline & Institution 3 & 28 & 3.79 & .630 & .119 \\
\hline & Institution 4 & 19 & 3.68 & .478 & .110 \\
\hline & Institution 5 & 35 & 3.86 & .430 & .073 \\
\hline & Institution 6 & 14 & 3.93 & .267 & .071 \\
\hline & Institution 7 & 24 & 3.71 & .464 & .095 \\
\hline & Institution 8 & 8 & 3.88 & .354 & .125 \\
\hline & Institution 9 & 31 & 3.94 & .250 & .045 \\
\hline & Institution 10 & 26 & 3.73 & .452 & .089 \\
\hline & Total & 233 & 3.79 & .486 & .032 \\
\hline \multirow{11}{*}{$\begin{array}{l}\text { The authority I have to make decisions about } \\
\text { other aspects of my job }\end{array}$} & Institution 1 & 29 & 3.31 & .604 & .112 \\
\hline & Institution 2 & 19 & 3.16 & .958 & .220 \\
\hline & Institution 3 & 28 & 3.32 & .772 & .146 \\
\hline & Institution 4 & 19 & 3.42 & .507 & .116 \\
\hline & Institution 5 & 34 & 3.41 & .609 & .104 \\
\hline & Institution 6 & 14 & 3.43 & .514 & .137 \\
\hline & Institution 7 & 24 & 3.29 & .624 & .127 \\
\hline & Institution 8 & 9 & 3.44 & .527 & .176 \\
\hline & Institution 9 & 31 & 3.42 & .765 & .137 \\
\hline & Institution 10 & 25 & 3.40 & .645 & .129 \\
\hline & Total & 232 & 3.36 & .669 & .044 \\
\hline
\end{tabular}


NSOPF descriptive statistics by institution (continued)

The mix of teaching, research, administration, and service that I am required to do

\begin{tabular}{|c|c|c|c|c|c|}
\hline \multirow{11}{*}{$\begin{array}{l}\text { The mix of teaching, research, administration, } \\
\text { and service that I am required to do }\end{array}$} & Institution 1 & 29 & 3.24 & .830 & .154 \\
\hline & Institution 2 & 19 & 2.89 & .875 & .201 \\
\hline & Institution 3 & 28 & 3.04 & .793 & .150 \\
\hline & Institution 4 & 19 & 3.00 & .667 & .153 \\
\hline & Institution 5 & 35 & 3.26 & .701 & .118 \\
\hline & Institution 6 & 14 & 2.86 & .663 & .177 \\
\hline & Institution 7 & 23 & 3.13 & .694 & .145 \\
\hline & Institution 8 & 9 & 2.67 & 1.000 & .333 \\
\hline & Institution 9 & 31 & 3.19 & .910 & .163 \\
\hline & Institution 10 & 26 & 3.12 & .816 & .160 \\
\hline & Total & 233 & 3.09 & .793 & .052 \\
\hline \multirow{11}{*}{$\begin{array}{l}\text { The opportunity for advancement in rank at my } \\
\text { institution }\end{array}$} & Institution 1 & 29 & 3.03 & 1.017 & .189 \\
\hline & Institution 2 & 19 & 3.11 & .809 & .186 \\
\hline & Institution 3 & 27 & 2.85 & 1.027 & .198 \\
\hline & Institution 4 & 19 & 3.11 & .809 & .186 \\
\hline & Institution 5 & 35 & 3.09 & .919 & .155 \\
\hline & Institution 6 & 14 & 2.93 & .829 & .221 \\
\hline & Institution 7 & 24 & 3.21 & .932 & .190 \\
\hline & Institution 8 & 9 & 3.22 & .833 & .278 \\
\hline & Institution 9 & 31 & 3.42 & .923 & .166 \\
\hline & Institution 10 & 26 & 3.12 & .909 & .178 \\
\hline & Total & 233 & 3.11 & .917 & .060 \\
\hline \multirow{11}{*}{ Time available for keeping current in my field } & Institution 1 & 29 & 2.38 & 1.015 & .188 \\
\hline & Institution 2 & 19 & 2.32 & .946 & .217 \\
\hline & Institution 3 & 28 & 2.54 & .922 & .174 \\
\hline & Institution 4 & 19 & 2.11 & .567 & .130 \\
\hline & Institution 5 & 35 & 2.54 & .780 & .132 \\
\hline & Institution 6 & 14 & 2.36 & .633 & .169 \\
\hline & Institution 7 & 23 & 2.78 & .850 & .177 \\
\hline & Institution 8 & 9 & 2.00 & .707 & .236 \\
\hline & Institution 9 & 31 & 2.48 & .962 & .173 \\
\hline & Institution 10 & 26 & 2.46 & 1.029 & .202 \\
\hline & Total & 233 & 2.44 & .884 & .058 \\
\hline
\end{tabular}

The opportunity for advancement in rank at my institution

Time available for keeping current in my field 
NSOPF descriptive statistics by institution (continued)

Availability of support services and equipment Institution 1 (clerical support, computers, etc.)

\begin{tabular}{|l|r|r|r|r|}
\hline Institution 1 & 29 & 2.66 & .936 & .174 \\
\hline Institution 2 & 19 & 2.58 & .838 & .192 \\
\hline Institution 3 & 28 & 2.86 & 1.113 & .210 \\
\hline Institution 4 & 19 & 3.16 & .501 & .115 \\
\hline Institution 5 & 35 & 3.11 & .718 & .121 \\
\hline Institution 6 & 14 & 2.50 & .941 & .251 \\
\hline Institution 7 & 24 & 3.00 & .885 & .181 \\
\hline Institution 8 & 9 & 2.00 & .866 & .289 \\
\hline Institution 9 & 32 & 3.00 & .803 & .142 \\
\hline Institution 10 & 26 & 3.00 & .938 & .184 \\
\hline Total & 235 & 2.87 & .894 & .058 \\
\hline Institution 1 & 27 & 3.37 & .742 & .143 \\
\hline Institution 2 & 19 & 3.11 & .875 & .201 \\
\hline Institution 3 & 27 & 3.26 & .813 & .156 \\
\hline Institution 4 & 17 & 3.12 & .485 & .118 \\
\hline Institution 5 & 35 & 3.46 & .505 & .085 \\
\hline Institution 6 & 13 & 3.08 & .760 & .211 \\
\hline Institution 7 & 24 & 3.00 & 1.022 & .209 \\
\hline Institution 8 & 7 & 3.14 & .690 & .261 \\
\hline Institution 9 & 31 & 3.35 & .608 & .109 \\
\hline Institution 10 & 25 & 3.48 & .653 & .131 \\
\hline Total & 225 & 3.28 & .729 & .049 \\
\hline Institution 1 & 29 & 3.34 & .614 & .114 \\
\hline Institution 2 & 19 & 3.11 & .937 & .215 \\
\hline Institution 3 & 28 & 2.93 & .858 & .162 \\
\hline Institution 4 & 19 & 2.84 & .765 & .175 \\
\hline Institution 5 & 35 & 3.71 & .458 & .077 \\
\hline Institution 6 & 14 & 2.93 & .616 & .165 \\
\hline Institution 7 & 23 & 3.43 & .590 & .123 \\
\hline Institution 8 & 9 & 2.89 & .601 & .200 \\
\hline Institution 9 & 31 & 3.35 & .839 & .151 \\
\hline Institution 10 & 25 & 3.04 & .22 & .774 \\
\hline Total & & & .179 \\
\hline
\end{tabular}

Overall reputation of the institution

Freedom to do outside consulting 
NSOPF descriptive statistics by institution (continued)

\begin{tabular}{|c|c|c|c|c|c|}
\hline \multirow[b]{11}{*}{ Reputation of my department } & Institution 1 & 29 & 3.41 & .733 & .136 \\
\hline & Institution 2 & 19 & 3.32 & .946 & .217 \\
\hline & Institution 3 & 28 & 3.21 & .787 & .149 \\
\hline & Institution 4 & 19 & 3.32 & .885 & .203 \\
\hline & Institution 5 & 35 & 3.77 & .598 & .101 \\
\hline & Institution 6 & 14 & 3.21 & .802 & .214 \\
\hline & Institution 7 & 24 & 3.42 & .776 & .158 \\
\hline & Institution 8 & 9 & 3.33 & .866 & .289 \\
\hline & Institution 9 & 32 & 3.34 & .745 & .132 \\
\hline & Institution 10 & 26 & 3.04 & .871 & .171 \\
\hline & Total & 235 & 3.36 & .796 & .052 \\
\hline \multirow{11}{*}{ Institutional mission or philosophy } & Institution 1 & 29 & 3.72 & .455 & .084 \\
\hline & Institution 2 & 19 & 3.47 & .841 & .193 \\
\hline & Institution 3 & 28 & 3.57 & .634 & .120 \\
\hline & Institution 4 & 19 & 3.68 & .582 & .134 \\
\hline & Institution 5 & 35 & 3.89 & .323 & .055 \\
\hline & Institution 6 & 14 & 3.50 & .519 & .139 \\
\hline & Institution 7 & 24 & 3.54 & .588 & .120 \\
\hline & Institution 8 & 9 & 3.89 & .333 & .111 \\
\hline & Institution 9 & 32 & 3.63 & .492 & .087 \\
\hline & Institution 10 & 25 & 3.60 & .500 & .100 \\
\hline & Total & 234 & 3.65 & .544 & .036 \\
\hline \multirow{11}{*}{ Quality of leadership in my department } & Institution 1 & 29 & 3.34 & .974 & .181 \\
\hline & Institution 2 & 19 & 3.37 & .955 & .219 \\
\hline & Institution 3 & 27 & 2.89 & 1.013 & .195 \\
\hline & Institution 4 & 19 & 3.42 & .838 & .192 \\
\hline & Institution 5 & 35 & 3.74 & .611 & .103 \\
\hline & Institution 6 & 14 & 3.14 & .949 & .254 \\
\hline & Institution 7 & 24 & 3.29 & .859 & .175 \\
\hline & Institution 8 & 9 & 3.67 & .500 & .167 \\
\hline & Institution 9 & 32 & 3.50 & .622 & .110 \\
\hline & Institution 10 & 26 & 3.35 & .846 & .166 \\
\hline & Total & 234 & 3.38 & .851 & .056 \\
\hline \multirow{11}{*}{$\begin{array}{l}\text { Quality of chief administrative officers at my } \\
\text { institution }\end{array}$} & Institution 1 & 29 & 3.31 & .891 & .165 \\
\hline & Institution 2 & 19 & 3.16 & .958 & .220 \\
\hline & Institution 3 & 28 & 2.86 & .891 & .168 \\
\hline & Institution 4 & 19 & 3.00 & 1.000 & .229 \\
\hline & Institution 5 & 35 & 3.11 & .993 & .168 \\
\hline & Institution 6 & 14 & 2.86 & 1.027 & .275 \\
\hline & Institution 7 & 24 & 2.67 & .868 & .177 \\
\hline & Institution 8 & 9 & 3.00 & .866 & .289 \\
\hline & Institution 9 & 31 & 3.52 & .570 & .102 \\
\hline & Institution 10 & 26 & 3.35 & 1.018 & .200 \\
\hline & Total & 234 & 3.12 & .926 & .061 \\
\hline
\end{tabular}


NSOPF descriptive statistics by institution (continued)

\begin{tabular}{|c|c|c|c|c|c|}
\hline \multirow[b]{11}{*}{ Quality of my colleagues in my department } & Institution 1 & 28 & 3.50 & .745 & .141 \\
\hline & Institution 2 & 18 & 3.78 & .428 & .101 \\
\hline & Institution 3 & 28 & 3.21 & .686 & .130 \\
\hline & Institution 4 & 19 & 3.53 & .772 & .177 \\
\hline & Institution 5 & 35 & 3.71 & .458 & .077 \\
\hline & Institution 6 & 14 & 3.71 & .611 & .163 \\
\hline & Institution 7 & 23 & 3.35 & .775 & .162 \\
\hline & Institution 8 & 9 & 3.56 & .527 & .176 \\
\hline & Institution 9 & 32 & 3.63 & .660 & .117 \\
\hline & Institution 10 & 26 & 3.19 & .749 & .147 \\
\hline & Total & 232 & 3.50 & .677 & .044 \\
\hline \multirow{11}{*}{ Quality of faculty leadership at my institution } & Institution 1 & 29 & 3.00 & .655 & .122 \\
\hline & Institution 2 & 19 & 3.16 & .834 & .191 \\
\hline & Institution 3 & 28 & 2.79 & .917 & .173 \\
\hline & Institution 4 & 19 & 2.84 & .898 & .206 \\
\hline & Institution 5 & 35 & 3.37 & .843 & .143 \\
\hline & Institution 6 & 14 & 3.14 & .663 & .177 \\
\hline & Institution 7 & 24 & 3.13 & .680 & .139 \\
\hline & Institution 8 & 9 & 3.22 & .833 & .278 \\
\hline & Institution 9 & 32 & 3.53 & .621 & .110 \\
\hline & Institution 10 & 26 & 2.88 & .864 & .169 \\
\hline & Total & 235 & 3.12 & .808 & .053 \\
\hline \multirow{11}{*}{$\begin{array}{l}\text { Relationship between administration and faculty } \\
\text { at this institution }\end{array}$} & Institution 1 & 29 & 2.93 & .799 & .148 \\
\hline & Institution 2 & 19 & 2.58 & 1.071 & .246 \\
\hline & Institution 3 & 28 & 2.43 & .836 & .158 \\
\hline & Institution 4 & 19 & 2.47 & 1.124 & .258 \\
\hline & Institution 5 & 35 & 2.83 & .954 & .161 \\
\hline & Institution 6 & 14 & 2.79 & .975 & .261 \\
\hline & Institution 7 & 24 & 2.58 & .830 & .169 \\
\hline & Institution 8 & 9 & 3.00 & .866 & .289 \\
\hline & Institution 9 & 31 & 3.26 & .682 & .122 \\
\hline & Institution 10 & 26 & 2.85 & .925 & .181 \\
\hline & Total & 234 & 2.78 & .917 & .060 \\
\hline \multirow{11}{*}{ Interdepartmental cooperation at this institution } & Institution 1 & 29 & 2.90 & .900 & .167 \\
\hline & Institution 2 & 19 & 3.11 & .459 & .105 \\
\hline & Institution 3 & 28 & 2.75 & .701 & .132 \\
\hline & Institution 4 & 19 & 2.53 & .905 & .208 \\
\hline & Institution 5 & 35 & 2.94 & .873 & .147 \\
\hline & Institution 6 & 14 & 3.00 & .877 & .234 \\
\hline & Institution 7 & 24 & 2.54 & .833 & .170 \\
\hline & Institution 8 & 9 & 2.89 & .782 & .261 \\
\hline & Institution 9 & 32 & 3.06 & .669 & .118 \\
\hline & Institution 10 & 26 & 2.31 & .788 & .155 \\
\hline & Total & 235 & 2.80 & .815 & .053 \\
\hline
\end{tabular}


NSOPF descriptive statistics by institution (continued)

\begin{tabular}{|c|c|c|c|c|c|}
\hline \multirow{11}{*}{$\begin{array}{l}\text { Spirit of cooperation between faculty at this } \\
\text { institution }\end{array}$} & Institution 1 & 29 & 2.93 & .884 & .164 \\
\hline & Institution 2 & 19 & 3.42 & .607 & 139 \\
\hline & Institution 3 & 28 & 3.00 & .816 & .154 \\
\hline & Institution 4 & 19 & 3.00 & .667 & 153 \\
\hline & Institution 5 & 35 & 3.40 & .736 & .124 \\
\hline & Institution 6 & 14 & 2.86 & .663 & .177 \\
\hline & Institution 7 & 24 & 2.88 & .850 & .174 \\
\hline & Institution 8 & 9 & 3.33 & .707 & .236 \\
\hline & Institution 9 & 32 & 3.31 & .535 & .095 \\
\hline & Institution 10 & 26 & 2.65 & .745 & 146 \\
\hline & Total & 235 & 3.08 & .766 & .050 \\
\hline \multirow{11}{*}{ Quality of my research facilities and support } & Institution 1 & 29 & 2.45 & .985 & 183 \\
\hline & Institution 2 & 18 & 1.94 & .802 & .189 \\
\hline & Institution 3 & 27 & 2.22 & .892 & .172 \\
\hline & Institution 4 & 18 & 2.44 & .784 & .185 \\
\hline & Institution 5 & 32 & 2.69 & .780 & .138 \\
\hline & Institution 6 & 12 & 2.58 & .515 & .149 \\
\hline & Institution 7 & 23 & 2.43 & .728 & .152 \\
\hline & Institution 8 & 8 & 2.75 & .707 & .250 \\
\hline & Institution 9 & 31 & 2.52 & .811 & .146 \\
\hline & Institution 10 & 26 & 2.19 & .895 & .176 \\
\hline & Total & 224 & 2.41 & .837 & .056 \\
\hline \multirow{11}{*}{ Quality of students whom I have taught here } & Institution 1 & 29 & 3.24 & .636 & .118 \\
\hline & Institution 2 & 19 & 2.84 & .688 & 158 \\
\hline & Institution 3 & 28 & 2.96 & .744 & .141 \\
\hline & Institution 4 & 19 & 3.00 & .577 & .132 \\
\hline & Institution 5 & 35 & 3.57 & .502 & .085 \\
\hline & Institution 6 & 14 & 2.64 & .745 & .199 \\
\hline & Institution 7 & 24 & 3.25 & .608 & .124 \\
\hline & Institution 8 & 9 & 2.89 & .782 & .261 \\
\hline & Institution 9 & 32 & 2.94 & .914 & .162 \\
\hline & Institution 10 & 26 & 2.92 & .935 & .183 \\
\hline & Total & 235 & 3.08 & .755 & .049 \\
\hline \multirow{11}{*}{ Teaching assistance that I receive } & Institution 1 & 25 & 2.52 & .770 & .154 \\
\hline & Institution 2 & 19 & 2.11 & .809 & .186 \\
\hline & Institution 3 & 27 & 2.74 & .984 & .189 \\
\hline & Institution 4 & 17 & 2.41 & .870 & .211 \\
\hline & Institution 5 & 34 & 3.21 & .845 & .145 \\
\hline & Institution 6 & 12 & 2.58 & .669 & .193 \\
\hline & Institution 7 & 21 & 2.81 & .814 & .178 \\
\hline & Institution 8 & 7 & 2.86 & .900 & .340 \\
\hline & Institution 9 & 30 & 2.67 & .802 & .146 \\
\hline & Institution 10 & 24 & 2.63 & .970 & .198 \\
\hline & Total & 216 & 2.69 & .886 & .060 \\
\hline
\end{tabular}


NSOPF descriptive statistics by institution (continued)

\begin{tabular}{|c|c|c|c|c|c|}
\hline \multirow[b]{11}{*}{ Research assistance that I receive } & Institution 1 & 23 & 2.39 & .783 & .163 \\
\hline & Institution 2 & 19 & 1.84 & .765 & .175 \\
\hline & Institution 3 & 25 & 2.28 & .980 & .196 \\
\hline & Institution 4 & 16 & 2.19 & .750 & .188 \\
\hline & Institution 5 & 30 & 2.67 & .959 & .175 \\
\hline & Institution 6 & 11 & 2.55 & .688 & .207 \\
\hline & Institution 7 & 19 & 2.53 & .772 & .177 \\
\hline & Institution 8 & 7 & 2.57 & .976 & .369 \\
\hline & Institution 9 & 30 & 2.27 & .907 & .166 \\
\hline & Institution 10 & 24 & 2.21 & .884 & .180 \\
\hline & Total & 204 & 2.34 & .876 & .061 \\
\hline \multirow{11}{*}{$\begin{array}{l}\text { Spouse employment opportunities in this } \\
\text { geographic area }\end{array}$} & Institution 1 & 26 & 3.04 & .720 & .141 \\
\hline & Institution 2 & 16 & 3.06 & .854 & .213 \\
\hline & Institution 3 & 25 & 3.32 & .690 & .138 \\
\hline & Institution 4 & 18 & 3.22 & .647 & .152 \\
\hline & Institution 5 & 34 & 3.59 & .657 & .113 \\
\hline & Institution 6 & 11 & 3.00 & 1.000 & .302 \\
\hline & Institution 7 & 22 & 3.68 & .477 & .102 \\
\hline & Institution 8 & 7 & 3.14 & .900 & .340 \\
\hline & Institution 9 & 30 & 3.40 & .675 & .123 \\
\hline & Institution 10 & 24 & 2.96 & 1.083 & .221 \\
\hline & Total & 213 & 3.29 & .782 & .054 \\
\hline \multirow{11}{*}{ My overall satisfaction with my job here } & Institution 1 & 29 & 3.52 & .574 & .107 \\
\hline & Institution 2 & 19 & 3.26 & .872 & .200 \\
\hline & Institution 3 & 28 & 3.43 & .573 & .108 \\
\hline & Institution 4 & 19 & 3.47 & .612 & .140 \\
\hline & Institution 5 & 35 & 3.63 & .490 & .083 \\
\hline & Institution 6 & 13 & 3.15 & .899 & .249 \\
\hline & Institution 7 & 24 & 3.46 & .588 & .120 \\
\hline & Institution 8 & 9 & 3.22 & .667 & .222 \\
\hline & Institution 9 & 32 & 3.63 & .492 & .087 \\
\hline & Institution 10 & 26 & 3.38 & .697 & .137 \\
\hline & Total & 234 & 3.46 & .629 & .041 \\
\hline
\end{tabular}


NSOPF descriptive statistics by institution (continued)

\begin{tabular}{|c|c|c|c|c|c|}
\hline $\begin{array}{l}\text { If you were to leave your current institution, how } \\
\text { likely is it that you would do so to? }\end{array}$ & Institution & $N$ & Mean & $\begin{array}{l}\text { Standard } \\
\text { Deviation }\end{array}$ & $\begin{array}{l}\text { Standard } \\
\text { Error }\end{array}$ \\
\hline \multirow{11}{*}{ Leave to Retire } & Institution 1 & 29 & 2.55 & .783 & .145 \\
\hline & Institution 2 & 19 & 1.84 & 1.015 & .233 \\
\hline & Institution 3 & 29 & 2.10 & .900 & .167 \\
\hline & Institution 4 & 19 & 2.16 & .958 & .220 \\
\hline & Institution 5 & 35 & 2.43 & .815 & .138 \\
\hline & Institution 6 & 14 & 2.14 & .949 & .254 \\
\hline & Institution 7 & 23 & 2.13 & .920 & .192 \\
\hline & Institution 8 & 9 & 1.78 & .972 & .324 \\
\hline & Institution 9 & 32 & 2.06 & .948 & .168 \\
\hline & Institution 10 & 26 & 1.96 & .916 & .180 \\
\hline & Total & 235 & 2.16 & .915 & .060 \\
\hline \multirow{11}{*}{ Return to school as a student } & Institution 1 & 29 & 1.10 & .310 & .058 \\
\hline & Institution 2 & 19 & 1.26 & .452 & .104 \\
\hline & Institution 3 & 28 & 1.29 & .600 & .113 \\
\hline & Institution 4 & 19 & 1.32 & .671 & .154 \\
\hline & Institution 5 & 35 & 1.06 & .236 & .040 \\
\hline & Institution 6 & 14 & 1.00 & .000 & .000 \\
\hline & Institution 7 & 23 & 1.13 & .344 & .072 \\
\hline & Institution 8 & 9 & 1.00 & .000 & .000 \\
\hline & Institution 9 & 31 & 1.16 & .454 & .082 \\
\hline & Institution 10 & 26 & 1.42 & .643 & .126 \\
\hline & Total & 233 & 1.18 & .460 & .030 \\
\hline \multirow{11}{*}{$\begin{array}{l}\text { Accept employment at another Christian college } \\
\text { or university }\end{array}$} & Institution 1 & 29 & 1.90 & .618 & .115 \\
\hline & Institution 2 & 19 & 2.16 & .834 & .191 \\
\hline & Institution 3 & 28 & 1.89 & .832 & .157 \\
\hline & Institution 4 & 19 & 1.84 & .602 & .138 \\
\hline & Institution 5 & 35 & 1.91 & .612 & .103 \\
\hline & Institution 6 & 14 & 2.00 & .679 & .182 \\
\hline & Institution 7 & 23 & 2.22 & .518 & .108 \\
\hline & Institution 8 & 9 & 2.22 & .833 & .278 \\
\hline & Institution 9 & 31 & 2.00 & .577 & .104 \\
\hline & Institution 10 & 26 & 2.19 & .694 & .136 \\
\hline & Total & 233 & 2.01 & .673 & .044 \\
\hline
\end{tabular}


NSOPF descriptive statistics by institution (continued)

\begin{tabular}{|c|c|c|c|c|c|}
\hline \multirow{11}{*}{$\begin{array}{l}\text { Accept employment at a secular college or } \\
\text { university }\end{array}$} & Institution 1 & 29 & 1.41 & .568 & .105 \\
\hline & Institution 2 & 19 & 1.58 & .692 & .159 \\
\hline & Institution 3 & 28 & 1.64 & .826 & .156 \\
\hline & Institution 4 & 19 & 1.63 & .684 & .157 \\
\hline & Institution 5 & 34 & 1.65 & .646 & .111 \\
\hline & Institution 6 & 14 & 1.50 & .519 & .139 \\
\hline & Institution 7 & 23 & 1.74 & .689 & .144 \\
\hline & Institution 8 & 9 & 1.33 & .500 & .167 \\
\hline & Institution 9 & 31 & 1.68 & .653 & .117 \\
\hline & Institution 10 & 26 & 1.92 & .628 & .123 \\
\hline & Total & 232 & 1.63 & .664 & .044 \\
\hline \multirow{11}{*}{$\begin{array}{l}\text { Accept employment in consulting or other for- } \\
\text { profit business or industry or become self- } \\
\text { employed }\end{array}$} & Institution 1 & 29 & 1.59 & .733 & .136 \\
\hline & Institution 2 & 19 & 1.63 & .761 & .175 \\
\hline & Institution 3 & 28 & 1.75 & .799 & .151 \\
\hline & Institution 4 & 19 & 1.37 & .496 & .114 \\
\hline & Institution 5 & 35 & 1.40 & .553 & .093 \\
\hline & Institution 6 & 14 & 1.50 & .650 & .174 \\
\hline & Institution 7 & 23 & 1.78 & .795 & .166 \\
\hline & Institution 8 & 9 & 2.00 & .866 & .289 \\
\hline & Institution 9 & 31 & 1.58 & .672 & .121 \\
\hline & Institution 10 & 26 & 1.62 & .752 & .148 \\
\hline & Total & 233 & 1.60 & .707 & .046 \\
\hline \multirow{11}{*}{ Accept employment in a non-profit organization } & Institution 1 & 29 & 1.76 & .636 & .118 \\
\hline & Institution 2 & 19 & 1.79 & .787 & .181 \\
\hline & Institution 3 & 28 & 1.57 & .690 & .130 \\
\hline & Institution 4 & 19 & 1.95 & .405 & .093 \\
\hline & Institution 5 & 35 & 1.60 & .604 & .102 \\
\hline & Institution 6 & 14 & 1.64 & .745 & .199 \\
\hline & Institution 7 & 23 & 1.74 & .619 & .129 \\
\hline & Institution 8 & 9 & 1.89 & .601 & .200 \\
\hline & Institution 9 & 30 & 1.60 & .498 & .091 \\
\hline & Institution 10 & 26 & 1.88 & .711 & .140 \\
\hline & Total & 232 & 1.72 & .634 & .042 \\
\hline
\end{tabular}


NSOPF descriptive statistics by institution (continued)

\begin{tabular}{|c|c|c|c|c|c|}
\hline $\begin{array}{l}\text { If you were to leave your current institution to } \\
\text { accept another position, would you want to do } \\
\text { more, less or about the same amount of the } \\
\text { following as you currently do? }\end{array}$ & Institution & $N$ & Mean & $\begin{array}{l}\text { Standard } \\
\text { Deviation }\end{array}$ & $\begin{array}{c}\text { Standard } \\
\text { Error }\end{array}$ \\
\hline \multirow{11}{*}{ Research } & Institution 1 & 29 & 1.55 & .686 & .127 \\
\hline & Institution 2 & 19 & 1.37 & .597 & .137 \\
\hline & Institution 3 & 27 & 1.74 & .712 & .137 \\
\hline & Institution 4 & 19 & 1.68 & .671 & .154 \\
\hline & Institution 5 & 34 & 1.56 & .561 & .096 \\
\hline & Institution 6 & 14 & 1.64 & .633 & .169 \\
\hline & Institution 7 & 24 & 1.83 & .637 & .130 \\
\hline & Institution 8 & 9 & 1.44 & .726 & .242 \\
\hline & Institution 9 & 30 & 1.53 & .629 & .115 \\
\hline & Institution 10 & 25 & 1.36 & .569 & .114 \\
\hline & Total & 230 & 1.58 & .641 & .042 \\
\hline \multirow{11}{*}{ Teaching } & Institution 1 & 29 & 2.24 & .511 & .095 \\
\hline & Institution 2 & 18 & 2.06 & .725 & .171 \\
\hline & Institution 3 & 27 & 2.15 & .662 & .127 \\
\hline & Institution 4 & 19 & 2.21 & .535 & .123 \\
\hline & Institution 5 & 35 & 2.14 & .550 & .093 \\
\hline & Institution 6 & 14 & 2.21 & .426 & .114 \\
\hline & Institution 7 & 24 & 1.83 & .565 & .115 \\
\hline & Institution 8 & 9 & 2.22 & .667 & .222 \\
\hline & Institution 9 & 31 & 2.13 & .499 & .090 \\
\hline & Institution 10 & 25 & 2.24 & .663 & .133 \\
\hline & Total & 231 & 2.14 & .581 & .038 \\
\hline \multirow{11}{*}{ Advising } & Institution 1 & 29 & 2.31 & .471 & .087 \\
\hline & Institution 2 & 19 & 2.11 & .658 & .151 \\
\hline & Institution 3 & 27 & 2.44 & .577 & .111 \\
\hline & Institution 4 & 19 & 2.26 & .562 & .129 \\
\hline & Institution 5 & 35 & 2.17 & .453 & .077 \\
\hline & Institution 6 & 14 & 2.21 & .426 & .114 \\
\hline & Institution 7 & 24 & 2.00 & .590 & .120 \\
\hline & Institution 8 & 7 & 1.86 & .378 & .143 \\
\hline & Institution 9 & 31 & 2.29 & .529 & .095 \\
\hline & Institution 10 & 25 & 2.28 & .542 & .108 \\
\hline & Total & 230 & 2.23 & .538 & .035 \\
\hline
\end{tabular}


NSOPF descriptive statistics by institution (continued)

\begin{tabular}{|c|c|c|c|c|c|}
\hline \multirow[b]{11}{*}{ Service } & Institution 1 & 29 & 2.28 & .591 & .110 \\
\hline & Institution 2 & 19 & 2.26 & .452 & .104 \\
\hline & Institution 3 & 27 & 2.30 & .542 & .104 \\
\hline & Institution 4 & 19 & 2.11 & .567 & .130 \\
\hline & Institution 5 & 35 & 2.06 & .539 & .091 \\
\hline & Institution 6 & 14 & 2.07 & .616 & .165 \\
\hline & Institution 7 & 24 & 2.08 & .654 & .133 \\
\hline & Institution 8 & 9 & 2.11 & .333 & .111 \\
\hline & Institution 9 & 31 & 2.13 & .619 & .111 \\
\hline & Institution 10 & 25 & 2.04 & .539 & .108 \\
\hline & Total & 232 & 2.15 & .562 & .037 \\
\hline \multirow{11}{*}{ Administration } & Institution 1 & 28 & 2.46 & .637 & .120 \\
\hline & Institution 2 & 19 & 2.21 & .787 & .181 \\
\hline & Institution 3 & 27 & 2.26 & .712 & .137 \\
\hline & Institution 4 & 18 & 2.28 & .669 & .158 \\
\hline & Institution 5 & 35 & 2.29 & .622 & .105 \\
\hline & Institution 6 & 14 & 2.43 & .756 & .202 \\
\hline & Institution 7 & 24 & 2.21 & .779 & .159 \\
\hline & Institution 8 & 8 & 2.63 & .744 & .263 \\
\hline & Institution 9 & 31 & 2.26 & .631 & .113 \\
\hline & Institution 10 & 25 & 2.04 & .611 & .122 \\
\hline & Total & 229 & 2.28 & .682 & .045 \\
\hline $\begin{array}{l}\text { If you were to leave your current institution to } \\
\text { accept another position, how important would } \\
\text { each of the following items be in your decision to } \\
\text { accept another position? }\end{array}$ & Age & $N$ & Mean & $\begin{array}{l}\text { Standard } \\
\text { Deviation }\end{array}$ & $\begin{array}{c}\text { Standard } \\
\text { Error }\end{array}$ \\
\hline \multirow{11}{*}{ Salary Level } & Institution 1 & 29 & 2.21 & .559 & .104 \\
\hline & Institution 2 & 19 & 2.53 & .612 & .140 \\
\hline & Institution 3 & 29 & 2.48 & .509 & .094 \\
\hline & Institution 4 & 19 & 2.26 & .562 & .129 \\
\hline & Institution 5 & 35 & 2.63 & .490 & .083 \\
\hline & Institution 6 & 14 & 2.29 & .469 & .125 \\
\hline & Institution 7 & 24 & 2.50 & .511 & .104 \\
\hline & Institution 8 & 9 & 2.33 & .500 & .167 \\
\hline & Institution 9 & 32 & 2.34 & .653 & .115 \\
\hline & Institution 10 & 26 & 2.62 & .571 & .112 \\
\hline & Total & 236 & 2.44 & .561 & .037 \\
\hline
\end{tabular}


NSOPF descriptive statistics by institution (continued)

\begin{tabular}{|c|c|c|c|c|c|}
\hline \multirow[b]{11}{*}{ Position Level } & Institution 1 & 29 & 2.31 & .660 & .123 \\
\hline & Institution 2 & 19 & 2.42 & .692 & .159 \\
\hline & Institution 3 & 29 & 2.38 & .677 & .126 \\
\hline & Institution 4 & 19 & 2.26 & .452 & .104 \\
\hline & Institution 5 & 35 & 2.43 & .608 & .103 \\
\hline & Institution 6 & 14 & 2.07 & .475 & .127 \\
\hline & Institution 7 & 23 & 2.43 & .507 & .106 \\
\hline & Institution 8 & 9 & 2.22 & .441 & .147 \\
\hline & Institution 9 & 32 & 2.34 & .653 & .115 \\
\hline & Institution 10 & 26 & 2.35 & .689 & .135 \\
\hline & Total & 235 & 2.34 & .610 & .040 \\
\hline \multirow{11}{*}{ Job Security } & Institution 1 & 29 & 2.62 & .677 & .126 \\
\hline & Institution 2 & 19 & 2.47 & .772 & .177 \\
\hline & Institution 3 & 29 & 2.62 & .494 & .092 \\
\hline & Institution 4 & 19 & 2.37 & .496 & .114 \\
\hline & Institution 5 & 35 & 2.60 & .604 & .102 \\
\hline & Institution 6 & 14 & 2.36 & .842 & .225 \\
\hline & Institution 7 & 23 & 2.48 & .665 & .139 \\
\hline & Institution 8 & 9 & 2.56 & .527 & .176 \\
\hline & Institution 9 & 32 & 2.56 & .564 & .100 \\
\hline & Institution 10 & 26 & 2.58 & .643 & .126 \\
\hline & Total & 235 & 2.54 & .621 & .041 \\
\hline \multirow{11}{*}{ Opportunities for advancement } & Institution 1 & 29 & 2.28 & .797 & .148 \\
\hline & Institution 2 & 19 & 2.42 & .607 & .139 \\
\hline & Institution 3 & 29 & 2.48 & .634 & .118 \\
\hline & Institution 4 & 19 & 2.16 & .602 & .138 \\
\hline & Institution 5 & 35 & 2.49 & .562 & .095 \\
\hline & Institution 6 & 14 & 1.71 & .914 & .244 \\
\hline & Institution 7 & 24 & 2.25 & .608 & .124 \\
\hline & Institution 8 & 9 & 2.22 & .833 & .278 \\
\hline & Institution 9 & 32 & 2.25 & .622 & .110 \\
\hline & Institution 10 & 26 & 2.42 & .643 & .126 \\
\hline & Total & 236 & 2.31 & .679 & .044 \\
\hline \multirow{11}{*}{ Benefits } & Institution 1 & 29 & 2.59 & .628 & .117 \\
\hline & Institution 2 & 19 & 2.74 & .452 & .104 \\
\hline & Institution 3 & 29 & 2.72 & .455 & .084 \\
\hline & Institution 4 & 19 & 2.58 & .507 & .116 \\
\hline & Institution 5 & 35 & 2.60 & .497 & .084 \\
\hline & Institution 6 & 14 & 2.57 & .514 & .137 \\
\hline & Institution 7 & 24 & 2.50 & .590 & .120 \\
\hline & Institution 8 & 9 & 2.67 & .500 & .167 \\
\hline & Institution 9 & 32 & 2.69 & .535 & .095 \\
\hline & Institution 10 & 26 & 2.81 & .402 & .079 \\
\hline & Total & 236 & 2.65 & .513 & .033 \\
\hline
\end{tabular}


NSOPF descriptive statistics by institution (continued)

\begin{tabular}{|c|c|c|c|c|c|}
\hline \multirow[b]{11}{*}{ No pressure to publish } & Institution 1 & 29 & 2.07 & .753 & .140 \\
\hline & Institution 2 & 19 & 2.11 & .737 & .169 \\
\hline & Institution 3 & 29 & 2.31 & .761 & .141 \\
\hline & Institution 4 & 19 & 2.05 & .848 & .195 \\
\hline & Institution 5 & 35 & 2.23 & .690 & .117 \\
\hline & Institution 6 & 14 & 2.14 & .770 & .206 \\
\hline & Institution 7 & 24 & 2.13 & .680 & .139 \\
\hline & Institution 8 & 9 & 2.11 & .333 & .111 \\
\hline & Institution 9 & 32 & 2.19 & .693 & .122 \\
\hline & Institution 10 & 26 & 2.12 & .816 & .160 \\
\hline & Total & 236 & 2.16 & .724 & .047 \\
\hline \multirow{11}{*}{ Academic Freedom } & Institution 1 & 29 & 2.69 & .541 & .101 \\
\hline & Institution 2 & 19 & 2.68 & .582 & .134 \\
\hline & Institution 3 & 29 & 2.72 & .455 & .084 \\
\hline & Institution 4 & 19 & 2.21 & .631 & .145 \\
\hline & Institution 5 & 35 & 2.51 & .562 & .095 \\
\hline & Institution 6 & 14 & 2.64 & .497 & .133 \\
\hline & Institution 7 & 24 & 2.46 & .658 & .134 \\
\hline & Institution 8 & 9 & 2.67 & .500 & .167 \\
\hline & Institution 9 & 32 & 2.59 & .499 & .088 \\
\hline & Institution 10 & 26 & 2.58 & .504 & .099 \\
\hline & Total & 236 & 2.58 & .552 & .036 \\
\hline \multirow{11}{*}{ Good research facilities and equipment } & Institution 1 & 29 & 2.38 & .677 & .126 \\
\hline & Institution 2 & 19 & 2.32 & .671 & .154 \\
\hline & Institution 3 & 29 & 2.03 & .680 & .126 \\
\hline & Institution 4 & 19 & 2.05 & .524 & .120 \\
\hline & Institution 5 & 34 & 2.03 & .717 & .123 \\
\hline & Institution 6 & 14 & 2.00 & .784 & .210 \\
\hline & Institution 7 & 24 & 1.83 & .637 & .130 \\
\hline & Institution 8 & 9 & 2.33 & .707 & .236 \\
\hline & Institution 9 & 31 & 2.06 & .574 & .103 \\
\hline & Institution 10 & 26 & 2.27 & .604 & .118 \\
\hline & Total & 234 & 2.12 & .664 & .043 \\
\hline \multirow{11}{*}{ Good instructional facilities and equipment } & Institution 1 & 29 & 2.72 & .528 & .098 \\
\hline & Institution 2 & 19 & 2.47 & .612 & .140 \\
\hline & Institution 3 & 29 & 2.59 & .501 & .093 \\
\hline & Institution 4 & 19 & 2.53 & .697 & .160 \\
\hline & Institution 5 & 35 & 2.57 & .502 & .085 \\
\hline & Institution 6 & 14 & 2.43 & .646 & .173 \\
\hline & Institution 7 & 24 & 2.33 & .637 & .130 \\
\hline & Institution 8 & 9 & 2.78 & .441 & .147 \\
\hline & Institution 9 & 31 & 2.55 & .568 & .102 \\
\hline & Institution 10 & 26 & 2.50 & .510 & .100 \\
\hline & Total & 235 & 2.54 & .563 & .037 \\
\hline
\end{tabular}


NSOPF descriptive statistics by institution (continued)

\begin{tabular}{|c|c|c|c|c|c|}
\hline \multirow[b]{11}{*}{ Excellent Students } & Institution 1 & 29 & 2.62 & .494 & .092 \\
\hline & Institution 2 & 19 & 2.42 & .507 & .116 \\
\hline & Institution 3 & 29 & 2.59 & .501 & .093 \\
\hline & Institution 4 & 19 & 2.37 & .684 & .157 \\
\hline & Institution 5 & 35 & 2.57 & .502 & .085 \\
\hline & Institution 6 & 14 & 2.21 & .579 & .155 \\
\hline & Institution 7 & 24 & 2.38 & .647 & .132 \\
\hline & Institution 8 & 9 & 2.44 & .527 & .176 \\
\hline & Institution 9 & 32 & 2.41 & .560 & .099 \\
\hline & Institution 10 & 26 & 2.04 & .528 & .103 \\
\hline & Total & 236 & 2.42 & .567 & .037 \\
\hline \multirow{11}{*}{ Excellent Colleagues } & Institution 1 & 29 & 2.79 & .412 & .077 \\
\hline & Institution 2 & 19 & 2.63 & .496 & .114 \\
\hline & Institution 3 & 29 & 2.66 & .484 & .090 \\
\hline & Institution 4 & 19 & 2.74 & .452 & .104 \\
\hline & Institution 5 & 35 & 2.63 & .490 & .083 \\
\hline & Institution 6 & 14 & 2.64 & .497 & .133 \\
\hline & Institution 7 & 24 & 2.63 & .576 & .118 \\
\hline & Institution 8 & 9 & 2.78 & .441 & .147 \\
\hline & Institution 9 & 32 & 2.69 & .471 & .083 \\
\hline & Institution 10 & 26 & 2.50 & .510 & .100 \\
\hline & Total & 236 & 2.66 & .483 & .031 \\
\hline \multirow{11}{*}{ New institution is a Christian college } & Institution 1 & 29 & 2.34 & .670 & .124 \\
\hline & Institution 2 & 19 & 2.21 & .918 & .211 \\
\hline & Institution 3 & 29 & 2.28 & .702 & .130 \\
\hline & Institution 4 & 19 & 2.21 & .631 & .145 \\
\hline & Institution 5 & 35 & 2.37 & .646 & .109 \\
\hline & Institution 6 & 14 & 2.29 & .726 & .194 \\
\hline & Institution 7 & 24 & 2.42 & .717 & .146 \\
\hline & Institution 8 & 9 & 2.67 & .500 & .167 \\
\hline & Institution 9 & 32 & 2.19 & .821 & .145 \\
\hline & Institution 10 & 26 & 2.08 & .688 & .135 \\
\hline & Total & 236 & 2.28 & .715 & .047 \\
\hline \multirow{11}{*}{$\begin{array}{l}\text { Institutional mission or philosophy that is } \\
\text { compatible with my own views }\end{array}$} & Institution 1 & 29 & 2.72 & .455 & .084 \\
\hline & Institution 2 & 19 & 2.58 & .692 & .159 \\
\hline & Institution 3 & 29 & 2.62 & .494 & .092 \\
\hline & Institution 4 & 19 & 2.74 & .452 & .104 \\
\hline & Institution 5 & 35 & 2.77 & .426 & .072 \\
\hline & Institution 6 & 14 & 2.79 & .426 & .114 \\
\hline & Institution 7 & 24 & 2.63 & .647 & .132 \\
\hline & Institution 8 & 8 & 3.00 & .000 & .000 \\
\hline & Institution 9 & 32 & 2.59 & .560 & .099 \\
\hline & Institution 10 & 26 & 2.46 & .508 & .100 \\
\hline & Total & 235 & 2.66 & .517 & .034 \\
\hline
\end{tabular}


NSOPF descriptive statistics by institution (continued)

\begin{tabular}{|c|c|c|c|c|c|}
\hline \multirow[b]{11}{*}{ Good job for my spouse } & Institution 1 & 27 & 1.96 & .854 & .164 \\
\hline & Institution 2 & 18 & 1.61 & .850 & .200 \\
\hline & Institution 3 & 29 & 1.83 & .759 & .141 \\
\hline & Institution 4 & 19 & 2.42 & .769 & .176 \\
\hline & Institution 5 & 34 & 2.32 & .843 & .145 \\
\hline & Institution 6 & 14 & 2.07 & .917 & .245 \\
\hline & Institution 7 & 22 & 2.23 & .813 & .173 \\
\hline & Institution 8 & 8 & 1.63 & .518 & .183 \\
\hline & Institution 9 & 31 & 2.29 & .864 & .155 \\
\hline & Institution 10 & 24 & 2.21 & .884 & .180 \\
\hline & Total & 226 & 2.10 & .850 & .057 \\
\hline \multirow{11}{*}{ Good geographic location } & Institution 1 & 29 & 2.31 & .660 & .123 \\
\hline & Institution 2 & 19 & 2.53 & .612 & .140 \\
\hline & Institution 3 & 29 & 2.59 & .501 & .093 \\
\hline & Institution 4 & 19 & 2.63 & .496 & .114 \\
\hline & Institution 5 & 35 & 2.69 & .530 & .090 \\
\hline & Institution 6 & 14 & 2.14 & .663 & .177 \\
\hline & Institution 7 & 23 & 2.04 & .767 & .160 \\
\hline & Institution 8 & 9 & 2.22 & .441 & .147 \\
\hline & Institution 9 & 32 & 2.47 & .621 & .110 \\
\hline & Institution 10 & 25 & 2.44 & .651 & .130 \\
\hline & Total & 234 & 2.44 & .627 & .041 \\
\hline \multirow{11}{*}{ Affordable Housing } & Institution 1 & 29 & 2.48 & .688 & .128 \\
\hline & Institution 2 & 19 & 2.58 & .607 & .139 \\
\hline & Institution 3 & 29 & 2.45 & .632 & .117 \\
\hline & Institution 4 & 19 & 2.47 & .513 & .118 \\
\hline & Institution 5 & 35 & 2.77 & .490 & .083 \\
\hline & Institution 6 & 14 & 2.36 & .633 & .169 \\
\hline & Institution 7 & 23 & 2.35 & .647 & .135 \\
\hline & Institution 8 & 8 & 2.63 & .518 & .183 \\
\hline & Institution 9 & 31 & 2.48 & .570 & .102 \\
\hline & Institution 10 & 26 & 2.42 & .703 & .138 \\
\hline & Total & 233 & 2.51 & 610 & .040 \\
\hline \multirow{11}{*}{ Good environment/schools for my children } & Institution 1 & 27 & 1.96 & .980 & .189 \\
\hline & Institution 2 & 18 & 1.94 & .802 & .189 \\
\hline & Institution 3 & 28 & 1.96 & .962 & .182 \\
\hline & Institution 4 & 18 & 2.22 & .808 & .191 \\
\hline & Institution 5 & 34 & 2.15 & .925 & .159 \\
\hline & Institution 6 & 13 & 1.46 & .877 & .243 \\
\hline & Institution 7 & 22 & 1.91 & .921 & .196 \\
\hline & Institution 8 & 7 & 2.14 & 1.069 & .404 \\
\hline & Institution 9 & 31 & 1.74 & .855 & .154 \\
\hline & Institution 10 & 25 & 1.92 & .909 & .182 \\
\hline & Total & 223 & 1.95 & .909 & .061 \\
\hline
\end{tabular}


NSOPF descriptive statistics by institution (continued)

\begin{tabular}{|c|c|c|c|c|c|}
\hline \multirow[b]{11}{*}{ A full-time position } & Institution 1 & 27 & 2.74 & .594 & .114 \\
\hline & Institution 2 & 19 & 2.74 & .653 & .150 \\
\hline & Institution 3 & 28 & 2.71 & .600 & .113 \\
\hline & Institution 4 & 18 & 2.78 & .548 & .129 \\
\hline & Institution 5 & 35 & 2.66 & .684 & .116 \\
\hline & Institution 6 & 14 & 2.57 & .852 & .228 \\
\hline & Institution 7 & 24 & 2.83 & .482 & .098 \\
\hline & Institution 8 & 8 & 3.00 & .000 & .000 \\
\hline & Institution 9 & 32 & 2.81 & .397 & .070 \\
\hline & Institution 10 & 25 & 2.64 & .638 & .128 \\
\hline & Total & 230 & 2.73 & .587 & .039 \\
\hline \multirow{11}{*}{ A part-time position } & Institution 1 & 26 & 1.27 & .604 & .118 \\
\hline & Institution 2 & 19 & 1.32 & .671 & .154 \\
\hline & Institution 3 & 29 & 1.24 & .511 & .095 \\
\hline & Institution 4 & 18 & 1.28 & .461 & .109 \\
\hline & Institution 5 & 35 & 1.23 & .547 & .092 \\
\hline & Institution 6 & 14 & 1.21 & .426 & .114 \\
\hline & Institution 7 & 22 & 1.41 & .590 & .126 \\
\hline & Institution 8 & 8 & 1.13 & .354 & .125 \\
\hline & Institution 9 & 31 & 1.35 & .661 & .119 \\
\hline & Institution 10 & 26 & 1.46 & .647 & .127 \\
\hline & Total & 228 & 1.30 & .571 & .038 \\
\hline $\begin{array}{l}\text { Please indicate the extent to which you agree or } \\
\text { disagree with each of the following statements. }\end{array}$ & Institution & $N$ & Mean & $\begin{array}{l}\text { Standard } \\
\text { Deviation }\end{array}$ & $\begin{array}{l}\text { Standard } \\
\text { Error }\end{array}$ \\
\hline \multirow{11}{*}{$\begin{array}{l}\text { It is important for faculty to participate in } \\
\text { governing their institution }\end{array}$} & Institution 1 & 28 & 3.57 & .573 & .108 \\
\hline & Institution 2 & 19 & 3.79 & .419 & .096 \\
\hline & Institution 3 & 29 & 3.62 & .677 & .126 \\
\hline & Institution 4 & 19 & 3.58 & .507 & .116 \\
\hline & Institution 5 & 35 & 3.71 & .519 & .088 \\
\hline & Institution 6 & 14 & 3.64 & .497 & .133 \\
\hline & Institution 7 & 24 & 3.75 & .532 & .109 \\
\hline & Institution 8 & 9 & 3.44 & .527 & .176 \\
\hline & Institution 9 & 32 & 3.56 & .619 & .109 \\
\hline & Institution 10 & 26 & 3.62 & .637 & .125 \\
\hline & Total & 235 & 3.64 & .563 & .037 \\
\hline
\end{tabular}


NSOPF descriptive statistics by institution (continued)

Faculty promotions should be based at least in part on formal student evaluations

\begin{tabular}{|c|c|c|c|c|}
\hline Institution 1 & 29 & 3.21 & .726 & .135 \\
\hline Institution 2 & 19 & 2.68 & .820 & .188 \\
\hline Institution 3 & 29 & 3.00 & .886 & .165 \\
\hline Institution 4 & 19 & 3.00 & .667 & .153 \\
\hline Institution 5 & 35 & 2.94 & .765 & .129 \\
\hline Institution 6 & 14 & 2.71 & .825 & .221 \\
\hline Institution 7 & 24 & 3.08 & .776 & .158 \\
\hline Institution 8 & 9 & 3.11 & .601 & .200 \\
\hline Institution 9 & 32 & 2.84 & .677 & .120 \\
\hline Institution 10 & 26 & 2.81 & .849 & .167 \\
\hline Total & 236 & 2.94 & .773 & .050 \\
\hline Institution 1 & 29 & 3.24 & .988 & .183 \\
\hline Institution 2 & 19 & 3.11 & .937 & .215 \\
\hline Institution 3 & 29 & 2.97 & .944 & .175 \\
\hline Institution 4 & 19 & 2.42 & .692 & .159 \\
\hline Institution 5 & 34 & 2.76 & .955 & .164 \\
\hline Institution 6 & 14 & 3.07 & .829 & .221 \\
\hline Institution 7 & 24 & 2.38 & .875 & .179 \\
\hline Institution 8 & 9 & 3.00 & 1.000 & .333 \\
\hline Institution 9 & 32 & 2.59 & .875 & .155 \\
\hline Institution 10 & 26 & 2.73 & 1.002 & .197 \\
\hline Total & 235 & 2.81 & .944 & .062 \\
\hline Institution 1 & 29 & 3.10 & .772 & .143 \\
\hline Institution 2 & 19 & 3.47 & .697 & .160 \\
\hline Institution 3 & 28 & 3.57 & .634 & .120 \\
\hline Institution 4 & 19 & 3.26 & .733 & .168 \\
\hline Institution 5 & 35 & 3.26 & .701 & .118 \\
\hline Institution 6 & 14 & 3.43 & .514 & .137 \\
\hline Institution 7 & 24 & 3.29 & .624 & .127 \\
\hline Institution 8 & 9 & 3.22 & .441 & .147 \\
\hline Institution 9 & 32 & 3.16 & .574 & .101 \\
\hline Institution 10 & 26 & 3.38 & .637 & .125 \\
\hline Total & 235 & 3.31 & .660 & .043 \\
\hline Institution 1 & 29 & 1.79 & .675 & .125 \\
\hline Institution 2 & 19 & 1.84 & .602 & .138 \\
\hline Institution 3 & 29 & 2.00 & .707 & .131 \\
\hline Institution 4 & 19 & 2.05 & .621 & .143 \\
\hline Institution 5 & 35 & 1.69 & .676 & .114 \\
\hline Institution 6 & 14 & 2.21 & .699 & .187 \\
\hline Institution 7 & 24 & 1.67 & .565 & .115 \\
\hline Institution 8 & 9 & 2.11 & .601 & .200 \\
\hline Institution 9 & 32 & 1.91 & .734 & .130 \\
\hline Institution 10 & 26 & 2.12 & .816 & .160 \\
\hline Total & 236 & 1.90 & .693 & .045 \\
\hline
\end{tabular}

Research/publications should be the primary criterion for promotion of college faculty

Teaching effectiveness should be the primary criterion for promotion of faculty

The tenure system in higher education should be preserved.

Teaching effectiveness should be the primary
criterion for promotion of faculty
Research/publications should be the primary
criterion for promotion of college faculty


NSOPF descriptive statistics by institution (continued)

Years of service/advanced degree should be the primary criterion for promotion of college faculty

The administrative function is taking an increasingly heavy share of available resources at my institution

State or federally mandated assessment requirements have improved the quality of undergraduate education at my institution

Female faculty members are treated fairly at my institution

\begin{tabular}{|c|c|c|c|c|}
\hline Institution 1 & 28 & 2.14 & .803 & .152 \\
\hline Institution 2 & 19 & 2.53 & .697 & .160 \\
\hline Institution 3 & 29 & 2.38 & .903 & .168 \\
\hline Institution 4 & 18 & 2.56 & .616 & .145 \\
\hline Institution 5 & 35 & 2.37 & .770 & .130 \\
\hline Institution 6 & 14 & 2.57 & .756 & .202 \\
\hline Institution 7 & 24 & 2.79 & .658 & .134 \\
\hline Institution 8 & 9 & 2.56 & .527 & .176 \\
\hline Institution 9 & 32 & 2.47 & .718 & .127 \\
\hline Institution 10 & 26 & 2.62 & .852 & .167 \\
\hline Total & 234 & 2.47 & .765 & .050 \\
\hline Institution 1 & 28 & 3.00 & .903 & .171 \\
\hline Institution 2 & 18 & 2.72 & .895 & .211 \\
\hline Institution 3 & 28 & 2.89 & .737 & .139 \\
\hline Institution 4 & 19 & 3.16 & .765 & .175 \\
\hline Institution 5 & 35 & 2.40 & .914 & .154 \\
\hline Institution 6 & 14 & 3.07 & .730 & .195 \\
\hline Institution 7 & 24 & 2.92 & .881 & .180 \\
\hline Institution 8 & 9 & 3.22 & .667 & .222 \\
\hline Institution 9 & 31 & 2.48 & .890 & .160 \\
\hline Institution 10 & 25 & 2.36 & .700 & .140 \\
\hline Total & 231 & 2.75 & .867 & .057 \\
\hline Institution 1 & 28 & 2.07 & .716 & .135 \\
\hline Institution 2 & 18 & 1.89 & .832 & .196 \\
\hline Institution 3 & 27 & 2.48 & .893 & .172 \\
\hline Institution 4 & 18 & 2.06 & .802 & .189 \\
\hline Institution 5 & 35 & 2.49 & .887 & .150 \\
\hline Institution 6 & 14 & 2.07 & .829 & .221 \\
\hline Institution 7 & 23 & 2.43 & .843 & .176 \\
\hline Institution 8 & 9 & 2.44 & .882 & .294 \\
\hline Institution 9 & 30 & 1.97 & .809 & .148 \\
\hline Institution 10 & 25 & 2.24 & .663 & .133 \\
\hline Total & 227 & 2.22 & .830 & .055 \\
\hline Institution 1 & 28 & 2.89 & .832 & .157 \\
\hline Institution 2 & 19 & 3.26 & .806 & .185 \\
\hline Institution 3 & 28 & 3.14 & .848 & .160 \\
\hline Institution 4 & 19 & 3.37 & .597 & .137 \\
\hline Institution 5 & 35 & 3.49 & .781 & .132 \\
\hline Institution 6 & 14 & 3.14 & .535 & .143 \\
\hline Institution 7 & 24 & 3.13 & .797 & .163 \\
\hline Institution 8 & 9 & 3.33 & .866 & .289 \\
\hline Institution 9 & 32 & 3.22 & .659 & .117 \\
\hline Institution 10 & 26 & 3.54 & .647 & .127 \\
\hline Total & 234 & 3.25 & .759 & .050 \\
\hline
\end{tabular}


NSOPF descriptive statistics by institution (continued)

Faculty who are members of racial or ethnic

\begin{tabular}{|c|c|c|c|c|}
\hline Institution 1 & 29 & 2.97 & .823 & .153 \\
\hline Institution 2 & 19 & 3.32 & .820 & .188 \\
\hline Institution 3 & 28 & 3.32 & .819 & .155 \\
\hline Institution 4 & 18 & 3.06 & .725 & .171 \\
\hline Institution 5 & 35 & 3.46 & .852 & .144 \\
\hline Institution 6 & 14 & 3.21 & .699 & .187 \\
\hline Institution 7 & 23 & 3.30 & .703 & .147 \\
\hline Institution 8 & 9 & 3.78 & .441 & .147 \\
\hline Institution 9 & 32 & 3.19 & .693 & .122 \\
\hline Institution 10 & 25 & 3.48 & .714 & .143 \\
\hline Total & 232 & 3.28 & .771 & .051 \\
\hline Institution 1 & 29 & 3.38 & .677 & .126 \\
\hline Institution 2 & 19 & 3.11 & .809 & .186 \\
\hline Institution 3 & 28 & 3.07 & .766 & .145 \\
\hline Institution 4 & 19 & 3.16 & .602 & .138 \\
\hline Institution 5 & 34 & 3.68 & .638 & .109 \\
\hline Institution 6 & 14 & 3.00 & .555 & .148 \\
\hline Institution 7 & 24 & 3.21 & .509 & .104 \\
\hline Institution 8 & 9 & 3.22 & .667 & .222 \\
\hline Institution 9 & 32 & 3.09 & .641 & .113 \\
\hline Institution 10 & 26 & 3.08 & .845 & .166 \\
\hline Total & 234 & 3.23 & .703 & .046 \\
\hline Institution 1 & 29 & 3.76 & .511 & .095 \\
\hline Institution 2 & 19 & 3.95 & .229 & .053 \\
\hline Institution 3 & 29 & 3.72 & .649 & .121 \\
\hline Institution 4 & 19 & 3.63 & .597 & .137 \\
\hline Institution 5 & 35 & 3.91 & .284 & .048 \\
\hline Institution 6 & 14 & 3.57 & .514 & .137 \\
\hline Institution 7 & 24 & 3.71 & .690 & .141 \\
\hline Institution 8 & 9 & 3.56 & .527 & .176 \\
\hline Institution 9 & 32 & 3.91 & .296 & .052 \\
\hline Institution 10 & 26 & 3.77 & .652 & .128 \\
\hline Total & 236 & 3.78 & .516 & .034 \\
\hline
\end{tabular}

If I had it to do over again, I would choose an academic career

My institution effectively meets the educational needs of entering students minorities are treated fairly at my institution

\begin{tabular}{|c|c|c|c|c|c|}
\hline & Institution 7 & 24 & 3.21 & .509 & .104 \\
\hline & Institution 8 & 9 & 3.22 & .667 & .222 \\
\hline & Institution 9 & 32 & 3.09 & .641 & .113 \\
\hline & Institution 10 & 26 & 3.08 & .845 & .166 \\
\hline & Total & 234 & 3.23 & .703 & .046 \\
\hline \multirow{11}{*}{$\begin{array}{l}\text { If I had it to do over again, I would choose an } \\
\text { academic career }\end{array}$} & Institution 1 & 29 & 3.76 & .511 & .095 \\
\hline & Institution 2 & 19 & 3.95 & .229 & .053 \\
\hline & Institution 3 & 29 & 3.72 & .649 & .121 \\
\hline & Institution 4 & 19 & 3.63 & .597 & .137 \\
\hline & Institution 5 & 35 & 3.91 & .284 & .048 \\
\hline & Institution 6 & 14 & 3.57 & .514 & .137 \\
\hline & Institution 7 & 24 & 3.71 & .690 & .141 \\
\hline & Institution 8 & 9 & 3.56 & .527 & .176 \\
\hline & Institution 9 & 32 & 3.91 & .296 & .052 \\
\hline & Institution 10 & 26 & 3.77 & .652 & .128 \\
\hline & Total & 236 & 3.78 & .516 & .034 \\
\hline
\end{tabular}


NSOPF descriptive statistics by church membership

\begin{tabular}{|c|c|c|c|c|c|}
\hline $\begin{array}{c}\text { How satisfied or } \\
\text { dissatisfied do you } \\
\text { personally feel about } \\
\text { each of the following } \\
\text { aspects of your job at } \\
\text { your current institution }\end{array}$ & Church Membership & $N$ & Mean & $\begin{array}{l}\text { Standard } \\
\text { Deviation }\end{array}$ & $\begin{array}{c}\text { Standard } \\
\text { Error }\end{array}$ \\
\hline \multirow{3}{*}{ My Work Load } & Membership Required & 40 & 2.73 & .877 & .139 \\
\hline & $\begin{array}{l}\text { Membership Not } \\
\text { Required }\end{array}$ & 197 & 2.90 & .855 & .061 \\
\hline & Total & 237 & 2.87 & .859 & .056 \\
\hline \multirow{3}{*}{ My job security } & Membership Required & 40 & 3.58 & .675 & .107 \\
\hline & $\begin{array}{l}\text { Membership Not } \\
\text { Required }\end{array}$ & 196 & 3.36 & .827 & .059 \\
\hline & Total & 236 & 3.40 & .806 & .052 \\
\hline \multirow{3}{*}{ My Salary } & Membership Required & 40 & 2.70 & .687 & .109 \\
\hline & $\begin{array}{l}\text { Membership Not } \\
\text { Required }\end{array}$ & 197 & 2.63 & .919 & .066 \\
\hline & Total & 237 & 2.65 & .884 & .057 \\
\hline \multirow{3}{*}{ My Benefits } & Membership Required & 40 & 2.88 & .791 & .125 \\
\hline & $\begin{array}{l}\text { Membership Not } \\
\text { Required }\end{array}$ & 196 & 2.83 & .910 & .065 \\
\hline & Total & 236 & 2.84 & .889 & .058 \\
\hline \multirow{3}{*}{$\begin{array}{l}\text { The authority I have to } \\
\text { make decisions about } \\
\text { what courses I teach }\end{array}$} & Membership Required & 40 & 3.45 & .815 & .129 \\
\hline & $\begin{array}{l}\text { Membership Not } \\
\text { Required }\end{array}$ & 195 & 3.42 & .791 & .057 \\
\hline & Total & 235 & 3.43 & .794 & .052 \\
\hline \multirow{3}{*}{$\begin{array}{l}\text { The authority I have to } \\
\text { make decisions about the } \\
\text { content and methods in } \\
\text { the courses I teach }\end{array}$} & Membership Required & 40 & 3.80 & .464 & .073 \\
\hline & $\begin{array}{l}\text { Membership Not } \\
\text { Required }\end{array}$ & 195 & 3.79 & .489 & .035 \\
\hline & Total & 235 & 3.79 & .484 & .032 \\
\hline \multirow{3}{*}{$\begin{array}{l}\text { The authority I have to } \\
\text { make decisions about } \\
\text { other aspects of my job }\end{array}$} & Membership Required & 39 & 3.36 & .628 & .101 \\
\hline & $\begin{array}{l}\text { Membership Not } \\
\text { Required }\end{array}$ & 195 & 3.36 & .677 & .048 \\
\hline & Total & 234 & 3.36 & .668 & .044 \\
\hline \multirow{3}{*}{$\begin{array}{l}\text { The mix of teaching, } \\
\text { research, administration, } \\
\text { and service that I am } \\
\text { required to do }\end{array}$} & Membership Required & 40 & 3.10 & .810 & .128 \\
\hline & $\begin{array}{l}\text { Membership Not } \\
\text { Required }\end{array}$ & 194 & 3.09 & .790 & .057 \\
\hline & Total & 234 & 3.09 & .791 & .052 \\
\hline \multirow{3}{*}{$\begin{array}{l}\text { The opportunity for } \\
\text { advancement in rank at } \\
\text { my institution }\end{array}$} & Membership Required & 40 & 3.03 & .920 & .145 \\
\hline & $\begin{array}{l}\text { Membership Not } \\
\text { Required }\end{array}$ & 194 & 3.13 & .916 & .066 \\
\hline & Total & 234 & 3.11 & .915 & .060 \\
\hline \multirow{3}{*}{$\begin{array}{l}\text { Time available for } \\
\text { keeping current in my } \\
\text { field }\end{array}$} & Membership Required & 40 & 2.40 & .841 & .133 \\
\hline & $\begin{array}{l}\text { Membership Not } \\
\text { Required }\end{array}$ & 195 & 2.45 & .892 & .064 \\
\hline & Total & 235 & 2.44 & .882 & .058 \\
\hline
\end{tabular}


NSOPF descriptive statistics by church membership (continued)

\begin{tabular}{|c|c|c|c|c|c|}
\hline \multirow{3}{*}{$\begin{array}{l}\text { Availability of support } \\
\text { services and equipment } \\
\text { (clerical support, } \\
\text { computers, etc.) }\end{array}$} & Membership Required & 40 & 3.03 & .733 & .116 \\
\hline & $\begin{array}{l}\text { Membership Not } \\
\text { Required }\end{array}$ & 197 & 2.84 & .921 & .066 \\
\hline & Total & 237 & 2.87 & .893 & .058 \\
\hline \multirow{3}{*}{$\begin{array}{l}\text { Freedom to do outside } \\
\text { consulting }\end{array}$} & Membership Required & 40 & 3.33 & .656 & .104 \\
\hline & $\begin{array}{l}\text { Membership Not } \\
\text { Required }\end{array}$ & 186 & 3.26 & .743 & .054 \\
\hline & Total & 226 & 3.27 & .727 & .048 \\
\hline \multirow{3}{*}{$\begin{array}{l}\text { Overall reputation of the } \\
\text { institution }\end{array}$} & Membership Required & 40 & 3.65 & .580 & .092 \\
\hline & $\begin{array}{l}\text { Membership Not } \\
\text { Required }\end{array}$ & 194 & 3.13 & .777 & .056 \\
\hline & Total & 234 & 3.22 & .771 & .050 \\
\hline \multirow{3}{*}{$\begin{array}{l}\text { Reputation of my } \\
\text { department }\end{array}$} & Membership Required & 40 & 3.75 & .588 & .093 \\
\hline & $\begin{array}{l}\text { Membership Not } \\
\text { Required }\end{array}$ & 197 & 3.28 & .807 & .057 \\
\hline & Total & 237 & 3.36 & .793 & .052 \\
\hline \multirow{3}{*}{$\begin{array}{l}\text { Institutional mission or } \\
\text { philosophy }\end{array}$} & Membership Required & 40 & 3.85 & .427 & .067 \\
\hline & $\begin{array}{l}\text { Membership Not } \\
\text { Required }\end{array}$ & 196 & 3.61 & .557 & .040 \\
\hline & Total & 236 & 3.65 & .544 & .035 \\
\hline \multirow{3}{*}{$\begin{array}{l}\text { Quality of leadership in } \\
\text { my department }\end{array}$} & Membership Required & 40 & 3.50 & .751 & .119 \\
\hline & $\begin{array}{l}\text { Membership Not } \\
\text { Required }\end{array}$ & 196 & 3.35 & .867 & .062 \\
\hline & Total & 236 & 3.38 & .849 & .055 \\
\hline \multirow{3}{*}{$\begin{array}{l}\text { Quality of chief } \\
\text { administrative officers at } \\
\text { my institution }\end{array}$} & Membership Required & 40 & 3.18 & .903 & .143 \\
\hline & $\begin{array}{l}\text { Membership Not } \\
\text { Required }\end{array}$ & 196 & 3.11 & .930 & .066 \\
\hline & Total & 236 & 3.12 & .924 & .060 \\
\hline \multirow{3}{*}{$\begin{array}{l}\text { Quality of my colleagues } \\
\text { in my department }\end{array}$} & Membership Required & 39 & 3.62 & .590 & .094 \\
\hline & $\begin{array}{l}\text { Membership Not } \\
\text { Required }\end{array}$ & 195 & 3.48 & .691 & .049 \\
\hline & Total & 234 & 3.50 & .676 & .044 \\
\hline \multirow{3}{*}{$\begin{array}{l}\text { Quality of faculty } \\
\text { leadership at my } \\
\text { institution }\end{array}$} & Membership Required & 40 & 3.30 & .823 & .130 \\
\hline & $\begin{array}{l}\text { Membership Not } \\
\text { Required }\end{array}$ & 196 & 3.08 & .800 & .057 \\
\hline & Total & 236 & 3.12 & .806 & .052 \\
\hline \multirow{3}{*}{$\begin{array}{l}\text { Relationship between } \\
\text { administration and faculty } \\
\text { at this institution }\end{array}$} & Membership Required & 40 & 2.75 & .870 & .138 \\
\hline & $\begin{array}{l}\text { Membership Not } \\
\text { Required }\end{array}$ & 196 & 2.80 & .928 & .066 \\
\hline & Total & 236 & 2.79 & .917 & .060 \\
\hline \multirow{3}{*}{$\begin{array}{l}\text { Interdepartmental } \\
\text { cooperation at this } \\
\text { institution }\end{array}$} & Membership Required & 40 & 2.93 & .730 & .115 \\
\hline & $\begin{array}{l}\text { Membership Not } \\
\text { Required }\end{array}$ & 196 & 2.78 & .829 & .059 \\
\hline & Total & 236 & 2.80 & .814 & .053 \\
\hline
\end{tabular}


NSOPF descriptive statistics by church membership (continued)

\begin{tabular}{|c|c|c|c|c|c|}
\hline \multirow{3}{*}{$\begin{array}{l}\text { Spirit of cooperation } \\
\text { between faculty at this } \\
\text { institution }\end{array}$} & Membership Required & 40 & 3.30 & .723 & .114 \\
\hline & $\begin{array}{l}\text { Membership Not } \\
\text { Required }\end{array}$ & 197 & 3.04 & .765 & .055 \\
\hline & Total & 237 & 3.08 & .763 & .050 \\
\hline \multirow{3}{*}{$\begin{array}{l}\text { Quality of my research } \\
\text { facilities and support }\end{array}$} & Membership Required & 38 & 2.55 & .860 & .140 \\
\hline & $\begin{array}{l}\text { Membership Not } \\
\text { Required }\end{array}$ & 188 & 2.38 & .834 & .061 \\
\hline & Total & 226 & 2.41 & .839 & .056 \\
\hline \multirow{3}{*}{$\begin{array}{l}\text { Quality of students whom } \\
\text { I have taught here }\end{array}$} & Membership Required & 40 & 3.40 & .545 & .086 \\
\hline & $\begin{array}{l}\text { Membership Not } \\
\text { Required }\end{array}$ & 197 & 3.01 & .776 & .055 \\
\hline & Total & 237 & 3.08 & .755 & .049 \\
\hline \multirow{3}{*}{$\begin{array}{l}\text { Teaching assistance that } \\
\text { I receive }\end{array}$} & Membership Required & 39 & 3.00 & .946 & .151 \\
\hline & $\begin{array}{l}\text { Membership Not } \\
\text { Required }\end{array}$ & 177 & 2.62 & .859 & .065 \\
\hline & Total & 216 & 2.69 & .886 & .060 \\
\hline \multirow{3}{*}{$\begin{array}{l}\text { Research assistance that } \\
\text { I receive }\end{array}$} & Membership Required & 36 & 2.44 & .969 & .162 \\
\hline & $\begin{array}{l}\text { Membership Not } \\
\text { Required }\end{array}$ & 168 & 2.32 & .856 & .066 \\
\hline & Total & 204 & 2.34 & .876 & .061 \\
\hline \multirow{3}{*}{$\begin{array}{l}\text { Spouse employment } \\
\text { opportunities in this } \\
\text { geographic area }\end{array}$} & Membership Required & 39 & 3.44 & .788 & .126 \\
\hline & $\begin{array}{l}\text { Membership Not } \\
\text { Required }\end{array}$ & 175 & 3.25 & .777 & .059 \\
\hline & Total & 214 & 3.29 & .780 & .053 \\
\hline \multirow{3}{*}{$\begin{array}{l}\text { My overall satisfaction } \\
\text { with my job here }\end{array}$} & Membership Required & 40 & 3.60 & .496 & .078 \\
\hline & $\begin{array}{l}\text { Membership Not } \\
\text { Required }\end{array}$ & 196 & 3.43 & .649 & .046 \\
\hline & Total & 236 & 3.46 & .628 & .041 \\
\hline $\begin{array}{l}\text { If you were to leave your } \\
\text { current institution, how } \\
\text { likely is it that you would } \\
\text { do so to? }\end{array}$ & Church Membership & $N$ & Mean & $\begin{array}{l}\text { Standard } \\
\text { Deviation }\end{array}$ & $\begin{array}{c}\text { Standard } \\
\text { Error }\end{array}$ \\
\hline \multirow{3}{*}{ Leave to Retire } & Membership Required & 40 & 2.33 & .888 & .140 \\
\hline & $\begin{array}{l}\text { Membership Not } \\
\text { Required }\end{array}$ & 197 & 2.12 & .918 & .065 \\
\hline & Total & 237 & 2.16 & .914 & .059 \\
\hline \multirow{3}{*}{$\begin{array}{l}\text { Return to school as a } \\
\text { student }\end{array}$} & Membership Required & 39 & 1.08 & .270 & .043 \\
\hline & $\begin{array}{l}\text { Membership Not } \\
\text { Required }\end{array}$ & 196 & 1.21 & .501 & .036 \\
\hline & Total & 235 & 1.19 & .473 & .031 \\
\hline \multirow{3}{*}{$\begin{array}{l}\text { Accept employment at } \\
\text { another Christian college } \\
\text { or university }\end{array}$} & Membership Required & 39 & 1.95 & .605 & .097 \\
\hline & $\begin{array}{l}\text { Membership Not } \\
\text { Required }\end{array}$ & 196 & 2.03 & .686 & .049 \\
\hline & Total & 235 & 2.02 & .673 & .044 \\
\hline \multirow{3}{*}{$\begin{array}{l}\text { Accept employment at a } \\
\text { secular college or } \\
\text { university }\end{array}$} & Membership Required & 38 & 1.68 & .662 & .107 \\
\hline & $\begin{array}{l}\text { Membership Not } \\
\text { Required }\end{array}$ & 196 & 1.63 & .663 & .047 \\
\hline & Total & 234 & 1.64 & .662 & .043 \\
\hline
\end{tabular}


NSOPF descriptive statistics by church membership (continued)

\begin{tabular}{|c|c|c|c|c|c|}
\hline \multirow{3}{*}{$\begin{array}{l}\text { Accept employment in } \\
\text { consulting or other for- } \\
\text { profit business or industry } \\
\text { or become self-employed }\end{array}$} & Membership Required & 39 & 1.44 & .552 & .088 \\
\hline & $\begin{array}{l}\text { Membership Not } \\
\text { Required }\end{array}$ & 196 & 1.63 & .730 & .052 \\
\hline & Total & 235 & 1.60 & .706 & .046 \\
\hline \multirow{3}{*}{$\begin{array}{l}\text { Accept employment in a } \\
\text { non-profit organization }\end{array}$} & Membership Required & 38 & 1.63 & .541 & .088 \\
\hline & $\begin{array}{l}\text { Membership Not } \\
\text { Required }\end{array}$ & 196 & 1.73 & .649 & .046 \\
\hline & Total & 234 & 1.72 & .633 & .041 \\
\hline $\begin{array}{l}\text { If you were to leave your } \\
\text { current institution to } \\
\text { accept another position, } \\
\text { would you want to do } \\
\text { more, less or about the } \\
\text { same amount of the } \\
\text { following as you currently } \\
\text { do? }\end{array}$ & Church Membership & N & Mean & $\begin{array}{l}\text { Standard } \\
\text { Deviation }\end{array}$ & $\begin{array}{c}\text { Standard } \\
\text { Error }\end{array}$ \\
\hline \multirow{3}{*}{ Research } & Membership Required & 38 & 1.61 & .595 & .096 \\
\hline & $\begin{array}{l}\text { Membership Not } \\
\text { Required }\end{array}$ & 194 & 1.57 & .650 & .047 \\
\hline & Total & 232 & 1.57 & .640 & .042 \\
\hline \multirow{3}{*}{ Teaching } & Membership Required & 38 & 2.13 & .529 & .086 \\
\hline & $\begin{array}{l}\text { Membership Not } \\
\text { Required }\end{array}$ & 195 & 2.14 & .592 & .042 \\
\hline & Total & 233 & 2.14 & .581 & .038 \\
\hline \multirow{3}{*}{ Advising } & Membership Required & 39 & 2.26 & .498 & .080 \\
\hline & $\begin{array}{l}\text { Membership Not } \\
\text { Required }\end{array}$ & 193 & 2.22 & .547 & .039 \\
\hline & Total & 232 & 2.23 & .538 & .035 \\
\hline \multirow{3}{*}{ Service } & Membership Required & 39 & 2.05 & .560 & .090 \\
\hline & $\begin{array}{l}\text { Membership Not } \\
\text { Required }\end{array}$ & 195 & 2.16 & .560 & .040 \\
\hline & Total & 234 & 2.15 & .560 & .037 \\
\hline \multirow{3}{*}{ Administration } & Membership Required & 39 & 2.21 & .656 & .105 \\
\hline & $\begin{array}{l}\text { Membership Not } \\
\text { Required }\end{array}$ & 192 & 2.29 & .685 & .049 \\
\hline & Total & 231 & 2.28 & .680 & .045 \\
\hline $\begin{array}{l}\text { If you were to leave your } \\
\text { current institution to } \\
\text { accept another position, } \\
\text { how important would } \\
\text { each of the following } \\
\text { items be in your decision } \\
\text { to accept another } \\
\text { position? }\end{array}$ & Church Membership & $N$ & Mean & $\begin{array}{l}\text { Standard } \\
\text { Deviation }\end{array}$ & $\begin{array}{c}\text { Standard } \\
\text { Error }\end{array}$ \\
\hline \multirow{3}{*}{ Salary Level } & Membership Required & 40 & 2.58 & .501 & .079 \\
\hline & $\begin{array}{l}\text { Membership Not } \\
\text { Required }\end{array}$ & 198 & 2.41 & .570 & .041 \\
\hline & Total & 238 & 2.44 & .561 & .036 \\
\hline
\end{tabular}


NSOPF descriptive statistics by church membership (continued)

\begin{tabular}{|c|c|c|c|c|c|}
\hline \multirow[b]{3}{*}{ Position Level } & Membership Required & 40 & 2.42 & .549 & .087 \\
\hline & $\begin{array}{l}\text { Membership Not } \\
\text { Required }\end{array}$ & 197 & 2.33 & .621 & .044 \\
\hline & Total & 237 & 2.35 & .609 & .040 \\
\hline \multirow{3}{*}{ Job Security } & Membership Required & 40 & 2.60 & .591 & .093 \\
\hline & $\begin{array}{l}\text { Membership Not } \\
\text { Required }\end{array}$ & 197 & 2.53 & .627 & .045 \\
\hline & Total & 237 & 2.54 & .621 & .040 \\
\hline \multirow{3}{*}{$\begin{array}{l}\text { Opportunities for } \\
\text { advancement }\end{array}$} & Membership Required & 40 & 2.50 & .555 & .088 \\
\hline & $\begin{array}{l}\text { Membership Not } \\
\text { Required }\end{array}$ & 198 & 2.28 & .697 & .050 \\
\hline & Total & 238 & 2.32 & .679 & .044 \\
\hline \multirow{3}{*}{ Benefits } & Membership Required & 40 & 2.65 & .483 & .076 \\
\hline & $\begin{array}{l}\text { Membership Not } \\
\text { Required }\end{array}$ & 198 & 2.65 & .518 & .037 \\
\hline & Total & 238 & 2.65 & .512 & .033 \\
\hline \multirow{3}{*}{ No pressure to publish } & Membership Required & 40 & 2.20 & .648 & .103 \\
\hline & $\begin{array}{l}\text { Membership Not } \\
\text { Required }\end{array}$ & 198 & 2.15 & .739 & .052 \\
\hline & Total & 238 & 2.16 & .723 & .047 \\
\hline \multirow{3}{*}{ Academic Freedom } & Membership Required & 40 & 2.45 & .552 & .087 \\
\hline & $\begin{array}{l}\text { Membership Not } \\
\text { Required }\end{array}$ & 198 & 2.61 & .549 & .039 \\
\hline & Total & 238 & 2.58 & .551 & .036 \\
\hline \multirow{3}{*}{$\begin{array}{l}\text { Good research facilities } \\
\text { and equipment }\end{array}$} & Membership Required & 39 & 2.21 & .695 & .111 \\
\hline & $\begin{array}{l}\text { Membership Not } \\
\text { Required }\end{array}$ & 197 & 2.11 & .661 & .047 \\
\hline & Total & 236 & 2.13 & .666 & .043 \\
\hline \multirow{3}{*}{$\begin{array}{l}\text { Good instructional } \\
\text { facilities and equipment }\end{array}$} & Membership Required & 40 & 2.65 & .533 & .084 \\
\hline & $\begin{array}{l}\text { Membership Not } \\
\text { Required }\end{array}$ & 197 & 2.53 & .567 & .040 \\
\hline & Total & 237 & 2.55 & .563 & .037 \\
\hline \multirow{3}{*}{ Excellent Students } & Membership Required & 40 & 2.55 & .552 & .087 \\
\hline & $\begin{array}{l}\text { Membership Not } \\
\text { Required }\end{array}$ & 198 & 2.40 & .569 & .040 \\
\hline & Total & 238 & 2.43 & .567 & .037 \\
\hline \multirow{3}{*}{ Excellent Colleagues } & Membership Required & 40 & 2.68 & .474 & .075 \\
\hline & $\begin{array}{l}\text { Membership Not } \\
\text { Required }\end{array}$ & 198 & 2.66 & .485 & .034 \\
\hline & Total & 238 & 2.66 & .482 & .031 \\
\hline \multirow{3}{*}{$\begin{array}{l}\text { New institution is a } \\
\text { Christian college }\end{array}$} & Membership Required & 40 & 2.38 & .705 & .111 \\
\hline & $\begin{array}{l}\text { Membership Not } \\
\text { Required }\end{array}$ & 198 & 2.26 & .714 & .051 \\
\hline & Total & 238 & 2.28 & .712 & .046 \\
\hline
\end{tabular}


NSOPF descriptive statistics by church membership (continued)

\begin{tabular}{|c|c|c|c|c|c|}
\hline \multirow{3}{*}{$\begin{array}{l}\text { Institutional mission or } \\
\text { philosophy that is } \\
\text { compatible with my own } \\
\text { views }\end{array}$} & Membership Required & 40 & 2.80 & .405 & .064 \\
\hline & $\begin{array}{l}\text { Membership Not } \\
\text { Required }\end{array}$ & 197 & 2.63 & .533 & .038 \\
\hline & Total & 237 & 2.66 & .517 & .034 \\
\hline \multirow{3}{*}{ Good job for my spouse } & Membership Required & 40 & 2.30 & .883 & .140 \\
\hline & $\begin{array}{l}\text { Membership Not } \\
\text { Required }\end{array}$ & 187 & 2.06 & .837 & .061 \\
\hline & Total & 227 & 2.10 & .848 & .056 \\
\hline \multirow{3}{*}{ Good geographic location } & Membership Required & 40 & 2.75 & .439 & .069 \\
\hline & $\begin{array}{l}\text { Membership Not } \\
\text { Required }\end{array}$ & 195 & 2.38 & .642 & .046 \\
\hline & Total & 235 & 2.44 & .627 & .041 \\
\hline \multirow{3}{*}{ Affordable Housing } & Membership Required & 39 & 2.62 & .633 & .101 \\
\hline & $\begin{array}{l}\text { Membership Not } \\
\text { Required }\end{array}$ & 196 & 2.48 & .603 & .043 \\
\hline & Total & 235 & 2.51 & .609 & .040 \\
\hline \multirow{3}{*}{$\begin{array}{l}\text { Good } \\
\text { environment/schools for } \\
\text { my children }\end{array}$} & Membership Required & 40 & 2.05 & .904 & .143 \\
\hline & $\begin{array}{l}\text { Membership Not } \\
\text { Required }\end{array}$ & 184 & 1.92 & .911 & .067 \\
\hline & Total & 224 & 1.94 & .909 & .061 \\
\hline \multirow{3}{*}{ A full-time position } & Membership Required & 40 & 2.78 & .577 & .091 \\
\hline & $\begin{array}{l}\text { Membership Not } \\
\text { Required }\end{array}$ & 192 & 2.73 & .587 & .042 \\
\hline & Total & 232 & 2.74 & .585 & .038 \\
\hline \multirow{3}{*}{ A part-time position } & Membership Required & 40 & 1.23 & .480 & .076 \\
\hline & $\begin{array}{l}\text { Membership Not } \\
\text { Required }\end{array}$ & 188 & 1.32 & .589 & .043 \\
\hline & Total & 228 & 1.30 & .571 & .038 \\
\hline $\begin{array}{l}\text { Please indicate the extent } \\
\text { to which you agree or } \\
\text { disagree with each of the } \\
\text { following statements. }\end{array}$ & Church Membership & $N$ & Mean & $\begin{array}{l}\text { Standard } \\
\text { Deviation }\end{array}$ & $\begin{array}{c}\text { Standard } \\
\text { Error }\end{array}$ \\
\hline \multirow{3}{*}{$\begin{array}{l}\text { It is important for faculty } \\
\text { to participate in governing } \\
\text { their institution }\end{array}$} & Membership Required & 40 & 3.70 & .516 & .082 \\
\hline & $\begin{array}{l}\text { Membership Not } \\
\text { Required }\end{array}$ & 197 & 3.63 & .571 & .041 \\
\hline & Total & 237 & 3.64 & .562 & .036 \\
\hline \multirow{3}{*}{$\begin{array}{l}\text { Faculty promotions } \\
\text { should be based at least } \\
\text { in part on formal student } \\
\text { evaluations }\end{array}$} & Membership Required & 40 & 2.98 & .698 & .110 \\
\hline & $\begin{array}{l}\text { Membership Not } \\
\text { Required }\end{array}$ & 198 & 2.94 & .785 & .056 \\
\hline & Total & 238 & 2.95 & .769 & .050 \\
\hline \multirow{3}{*}{$\begin{array}{l}\text { The tenure system in } \\
\text { higher education should } \\
\text { be preserved }\end{array}$} & Membership Required & 39 & 2.72 & .999 & .160 \\
\hline & $\begin{array}{l}\text { Membership Not } \\
\text { Required }\end{array}$ & 198 & 2.83 & .933 & .066 \\
\hline & Total & 237 & 2.81 & .943 & .061 \\
\hline \multirow{3}{*}{$\begin{array}{l}\text { Teaching effectiveness } \\
\text { should be the primary } \\
\text { criterion for promotion of } \\
\text { faculty }\end{array}$} & Membership Required & 40 & 3.23 & .698 & .110 \\
\hline & $\begin{array}{l}\text { Membership Not } \\
\text { Required }\end{array}$ & 197 & 3.32 & .652 & .046 \\
\hline & Total & 237 & 3.31 & .659 & .043 \\
\hline
\end{tabular}


NSOPF descriptive statistics by church membership (continued)

\begin{tabular}{|c|c|c|c|c|c|}
\hline \multirow{3}{*}{$\begin{array}{l}\text { Research/publications } \\
\text { should be the primary } \\
\text { criterion for promotion of } \\
\text { college faculty }\end{array}$} & Membership Required & 40 & 1.85 & .662 & .105 \\
\hline & $\begin{array}{l}\text { Membership Not } \\
\text { Required }\end{array}$ & 198 & 1.92 & .701 & .050 \\
\hline & Total & 238 & 1.91 & .693 & .045 \\
\hline \multirow{3}{*}{$\begin{array}{l}\text { Years of } \\
\text { service/advanced degree } \\
\text { should be the primary } \\
\text { criterion for promotion of } \\
\text { college faculty }\end{array}$} & Membership Required & 40 & 2.42 & .813 & .129 \\
\hline & $\begin{array}{l}\text { Membership Not } \\
\text { Required }\end{array}$ & 196 & 2.49 & .761 & .054 \\
\hline & Total & 236 & 2.48 & .769 & .050 \\
\hline \multirow{3}{*}{$\begin{array}{l}\text { The administrative } \\
\text { function is taking an } \\
\text { increasingly heavy share } \\
\text { of available resources at } \\
\text { my institution }\end{array}$} & Membership Required & 40 & 2.48 & .877 & .139 \\
\hline & $\begin{array}{l}\text { Membership Not } \\
\text { Required }\end{array}$ & 192 & 2.81 & .856 & .062 \\
\hline & Total & 232 & 2.75 & .867 & .057 \\
\hline \multirow{3}{*}{$\begin{array}{l}\text { State or federally } \\
\text { mandated assessment } \\
\text { requirements have } \\
\text { improved the quality of } \\
\text { undergraduate education } \\
\text { at my institution }\end{array}$} & Membership Required & 40 & 2.40 & .900 & .142 \\
\hline & $\begin{array}{l}\text { Membership Not } \\
\text { Required }\end{array}$ & 189 & 2.19 & .809 & .059 \\
\hline & Total & 229 & 2.23 & .828 & .055 \\
\hline \multirow{3}{*}{$\begin{array}{l}\text { Female faculty members } \\
\text { are treated fairly at my } \\
\text { institution }\end{array}$} & Membership Required & 40 & 3.38 & .740 & .117 \\
\hline & $\begin{array}{l}\text { Membership Not } \\
\text { Required }\end{array}$ & 196 & 3.23 & .760 & .054 \\
\hline & Total & 236 & 3.25 & .757 & .049 \\
\hline \multirow{3}{*}{$\begin{array}{l}\text { Faculty who are members } \\
\text { of racial or ethnic } \\
\text { minorities are treated } \\
\text { fairly at my institution }\end{array}$} & Membership Required & 40 & 3.38 & .774 & .122 \\
\hline & $\begin{array}{l}\text { Membership Not } \\
\text { Required }\end{array}$ & 194 & 3.26 & .774 & .056 \\
\hline & Total & 234 & 3.28 & .773 & .051 \\
\hline \multirow{3}{*}{$\begin{array}{l}\text { My institution effectively } \\
\text { meets the educational } \\
\text { needs of entering } \\
\text { students }\end{array}$} & Membership Required & 40 & 3.55 & .639 & .101 \\
\hline & $\begin{array}{l}\text { Membership Not } \\
\text { Required }\end{array}$ & 195 & 3.16 & .696 & .050 \\
\hline & Total & 235 & 3.23 & .701 & .046 \\
\hline \multirow{3}{*}{$\begin{array}{l}\text { If I had it to do over } \\
\text { again, I would choose an } \\
\text { academic career }\end{array}$} & Membership Required & 40 & 3.88 & .335 & .053 \\
\hline & $\begin{array}{l}\text { Membership Not } \\
\text { Required }\end{array}$ & 198 & 3.76 & .542 & .039 \\
\hline & Total & 238 & 3.78 & .514 & .033 \\
\hline
\end{tabular}


NSOPF descriptive statistics by alma mater

\begin{tabular}{|c|c|c|c|c|c|}
\hline $\begin{array}{c}\text { How satisfied or } \\
\text { dissatisfied do you } \\
\text { personally feel about each } \\
\text { of the following aspects of } \\
\text { your job at your current } \\
\text { institution } \\
\end{array}$ & Alma Mater & $N$ & Mean & $\begin{array}{l}\text { Standard } \\
\text { Deviation }\end{array}$ & $\begin{array}{c}\text { Standard } \\
\text { Error }\end{array}$ \\
\hline \multirow{5}{*}{ My Work Load } & Current Institution & 76 & 2.91 & .803 & .092 \\
\hline & Another CCCU Institution & 58 & 2.97 & .878 & .115 \\
\hline & Another non-CCCU Christian Institution & 26 & 2.96 & .958 & .188 \\
\hline & Non-Christian Institution & 77 & 2.74 & .865 & .099 \\
\hline & Total & 237 & 2.87 & .859 & .056 \\
\hline \multirow{5}{*}{ My job security } & Current Institution & 76 & 3.55 & .790 & .091 \\
\hline & Another CCCU Institution & 58 & 3.45 & .820 & .108 \\
\hline & Another non-CCCU Christian Institution & 25 & 3.68 & .476 & .095 \\
\hline & Non-Christian Institution & 77 & 3.12 & .827 & .094 \\
\hline & Total & 236 & 3.40 & .806 & .052 \\
\hline \multirow{5}{*}{ My Salary } & Current Institution & 76 & 2.66 & .888 & .102 \\
\hline & Another CCCU Institution & 58 & 2.64 & .931 & .122 \\
\hline & Another non-CCCU Christian Institution & 26 & 3.04 & .871 & .171 \\
\hline & Non-Christian Institution & 77 & 2.51 & .821 & .094 \\
\hline & Total & 237 & 2.65 & .884 & .057 \\
\hline \multirow{5}{*}{ My Benefits } & Current Institution & 76 & 2.91 & .912 & .105 \\
\hline & Another CCCU Institution & 57 & 2.89 & .880 & .117 \\
\hline & Another non-CCCU Christian Institution & 26 & 2.96 & .774 & .152 \\
\hline & Non-Christian Institution & 77 & 2.69 & .907 & .103 \\
\hline & Total & 236 & 2.84 & .889 & .058 \\
\hline \multirow{5}{*}{$\begin{array}{l}\text { The authority I have to } \\
\text { make decisions about } \\
\text { what courses I teach }\end{array}$} & Current Institution & 76 & 3.49 & .739 & .085 \\
\hline & Another CCCU Institution & 57 & 3.37 & .816 & .108 \\
\hline & Another non-CCCU Christian Institution & 26 & 3.73 & .452 & .089 \\
\hline & Non-Christian Institution & 76 & 3.30 & .895 & .103 \\
\hline & Total & 235 & 3.43 & .794 & .052 \\
\hline \multirow{5}{*}{$\begin{array}{l}\text { The authority I have to } \\
\text { make decisions about the } \\
\text { content and methods in } \\
\text { the courses I teach }\end{array}$} & Current Institution & 76 & 3.80 & .462 & .053 \\
\hline & Another CCCU Institution & 57 & 3.79 & .411 & .054 \\
\hline & Another non-CCCU Christian Institution & 26 & 3.88 & .326 & .064 \\
\hline & Non-Christian Institution & 76 & 3.75 & .592 & .068 \\
\hline & Total & 235 & 3.79 & .484 & .032 \\
\hline
\end{tabular}


NSOPF descriptive statistics by alma mater (continued)

\begin{tabular}{|c|c|c|c|c|c|}
\hline \multirow{5}{*}{$\begin{array}{l}\text { The authority I have to } \\
\text { make decisions about } \\
\text { other aspects of my job }\end{array}$} & Current Institution & 75 & 3.32 & .701 & .081 \\
\hline & Another CCCU Institution & 57 & 3.39 & .559 & .074 \\
\hline & Another non-CCCU Christian Institution & 26 & 3.65 & .485 & .095 \\
\hline & Non-Christian Institution & 76 & 3.28 & .741 & .085 \\
\hline & Total & 234 & 3.36 & .668 & .044 \\
\hline \multirow{5}{*}{$\begin{array}{l}\text { The mix of teaching, } \\
\text { research, administration, } \\
\text { and service that I am } \\
\text { required to do }\end{array}$} & Current Institution & 76 & 3.09 & .751 & .086 \\
\hline & Another CCCU Institution & 56 & 3.05 & .862 & .115 \\
\hline & Another non-CCCU Christian Institution & 26 & 3.15 & .784 & .154 \\
\hline & Non-Christian Institution & 76 & 3.11 & .793 & .091 \\
\hline & Total & 234 & 3.09 & .791 & .052 \\
\hline \multirow{5}{*}{$\begin{array}{l}\text { The opportunity for } \\
\text { advancement in rank at } \\
\text { my institution }\end{array}$} & Current Institution & 76 & 3.08 & .906 & .104 \\
\hline & Another CCCU Institution & 57 & 3.23 & .846 & .112 \\
\hline & Another non-CCCU Christian Institution & 25 & 3.16 & 1.068 & .214 \\
\hline & Non-Christian Institution & 76 & 3.04 & .930 & .107 \\
\hline & Total & 234 & 3.11 & .915 & .060 \\
\hline \multirow{5}{*}{$\begin{array}{l}\text { Time available for keeping } \\
\text { current in my field }\end{array}$} & Current Institution & 76 & 2.53 & .916 & .105 \\
\hline & Another CCCU Institution & 57 & 2.39 & .861 & .114 \\
\hline & Another non-CCCU Christian Institution & 26 & 2.62 & .898 & .176 \\
\hline & Non-Christian Institution & 76 & 2.34 & .857 & .098 \\
\hline & Total & 235 & 2.44 & .882 & .058 \\
\hline \multirow{5}{*}{$\begin{array}{l}\text { Availability of support } \\
\text { services and equipment } \\
\text { (clerical support, } \\
\text { computers, etc.) }\end{array}$} & Current Institution & 76 & 3.04 & .824 & .094 \\
\hline & Another CCCU Institution & 58 & 2.83 & .939 & .123 \\
\hline & Another non-CCCU Christian Institution & 26 & 3.08 & .744 & .146 \\
\hline & Non-Christian Institution & 77 & 2.68 & .938 & .107 \\
\hline & Total & 237 & 2.87 & .893 & .058 \\
\hline \multirow{5}{*}{$\begin{array}{l}\text { Freedom to do outside } \\
\text { consulting }\end{array}$} & Current Institution & 73 & 3.29 & .754 & .088 \\
\hline & Another CCCU Institution & 56 & 3.30 & .711 & .095 \\
\hline & Another non-CCCU Christian Institution & 25 & 3.44 & .712 & .142 \\
\hline & Non-Christian Institution & 72 & 3.18 & .718 & .085 \\
\hline & Total & 226 & 3.27 & .727 & .048 \\
\hline \multirow{5}{*}{$\begin{array}{l}\text { Overall reputation of the } \\
\text { institution }\end{array}$} & Current Institution & 75 & 3.40 & .717 & .083 \\
\hline & Another CCCU Institution & 57 & 3.02 & .790 & .105 \\
\hline & Another non-CCCU Christian Institution & 25 & 3.44 & .712 & .142 \\
\hline & Non-Christian Institution & 77 & 3.13 & .784 & .089 \\
\hline & Total & 234 & 3.22 & .771 & .050 \\
\hline
\end{tabular}


NSOPF descriptive statistics by alma mater (continued)

\begin{tabular}{|c|c|c|c|c|c|}
\hline \multirow{5}{*}{$\begin{array}{l}\text { Reputation of my } \\
\text { department }\end{array}$} & Current Institution & 76 & 3.47 & .774 & .089 \\
\hline & Another CCCU Institution & 58 & 3.21 & .833 & .109 \\
\hline & Another non-CCCU Christian Institution & 26 & 3.54 & .582 & .114 \\
\hline & Non-Christian Institution & 77 & 3.30 & .828 & .094 \\
\hline & Total & 237 & 3.36 & .793 & .052 \\
\hline \multirow{5}{*}{$\begin{array}{l}\text { Institutional mission or } \\
\text { philosophy }\end{array}$} & Current Institution & 76 & 3.68 & .496 & .057 \\
\hline & Another CCCU Institution & 58 & 3.59 & .563 & .074 \\
\hline & Another non-CCCU Christian Institution & 26 & 3.81 & .402 & .079 \\
\hline & Non-Christian Institution & 76 & 3.62 & .610 & .070 \\
\hline & Total & 236 & 3.65 & .544 & .035 \\
\hline \multirow{5}{*}{$\begin{array}{l}\text { Quality of leadership in my } \\
\text { department }\end{array}$} & Current Institution & 76 & 3.34 & .841 & .097 \\
\hline & Another CCCU Institution & 57 & 3.30 & .801 & .106 \\
\hline & Another non-CCCU Christian Institution & 26 & 3.50 & .762 & .149 \\
\hline & Non-Christian Institution & 77 & 3.43 & .924 & .105 \\
\hline & Total & 236 & 3.38 & .849 & .055 \\
\hline \multirow{5}{*}{$\begin{array}{l}\text { Quality of chief } \\
\text { administrative officers at } \\
\text { my institution }\end{array}$} & Current Institution & 76 & 3.18 & .890 & .102 \\
\hline & Another CCCU Institution & 57 & 2.91 & .931 & .123 \\
\hline & Another non-CCCU Christian Institution & 26 & 3.38 & .804 & .158 \\
\hline & Non-Christian Institution & 77 & 3.12 & .973 & .111 \\
\hline & Total & 236 & 3.12 & .924 & .060 \\
\hline \multirow{5}{*}{$\begin{array}{l}\text { Quality of my colleagues } \\
\text { in my department }\end{array}$} & Current Institution & 75 & 3.61 & .634 & .073 \\
\hline & Another CCCU Institution & 57 & 3.46 & .734 & .097 \\
\hline & Another non-CCCU Christian Institution & 26 & 3.54 & .647 & .127 \\
\hline & Non-Christian Institution & 76 & 3.41 & .677 & .078 \\
\hline & Total & 234 & 3.50 & .676 & .044 \\
\hline \multirow{5}{*}{$\begin{array}{l}\text { Quality of faculty } \\
\text { leadership at my } \\
\text { institution }\end{array}$} & Current Institution & 76 & 3.29 & .745 & .085 \\
\hline & Another CCCU Institution & 58 & 3.02 & .783 & .103 \\
\hline & Another non-CCCU Christian Institution & 26 & 3.31 & .549 & .108 \\
\hline & Non-Christian Institution & 76 & 2.96 & .916 & .105 \\
\hline & Total & 236 & 3.12 & .806 & .052 \\
\hline \multirow{5}{*}{$\begin{array}{l}\text { Relationship between } \\
\text { administration and faculty } \\
\text { at this institution }\end{array}$} & Current Institution & 75 & 2.85 & .849 & .098 \\
\hline & Another CCCU Institution & 58 & 2.74 & .870 & .114 \\
\hline & Another non-CCCU Christian Institution & 26 & 2.77 & .908 & .178 \\
\hline & Non-Christian Institution & 77 & 2.77 & 1.025 & .117 \\
\hline & Total & 236 & 2.79 & .917 & .060 \\
\hline
\end{tabular}


NSOPF descriptive statistics by alma mater (continued)

\begin{tabular}{|c|c|c|c|c|c|}
\hline \multirow{5}{*}{$\begin{array}{l}\text { Interdepartmental } \\
\text { cooperation at this } \\
\text { institution }\end{array}$} & Current Institution & 76 & 2.80 & .895 & .103 \\
\hline & Another CCCU Institution & 58 & 2.78 & .750 & .099 \\
\hline & Another non-CCCU Christian Institution & 26 & 2.85 & .784 & .154 \\
\hline & Non-Christian Institution & 76 & 2.80 & .800 & .092 \\
\hline & Total & 236 & 2.80 & 814 & .053 \\
\hline \multirow{5}{*}{$\begin{array}{l}\text { Spirit of cooperation } \\
\text { between faculty at this } \\
\text { institution }\end{array}$} & Current Institution & 76 & 3.03 & .832 & .095 \\
\hline & Another CCCU Institution & 58 & 3.05 & .686 & .090 \\
\hline & Another non-CCCU Christian Institution & 26 & 3.15 & .732 & .143 \\
\hline & Non-Christian Institution & 77 & 3.13 & .767 & .087 \\
\hline & Total & 237 & 3.08 & .763 & .050 \\
\hline \multirow{5}{*}{$\begin{array}{l}\text { Quality of my research } \\
\text { facilities and support }\end{array}$} & Current Institution & 73 & 2.45 & .883 & .103 \\
\hline & Another CCCU Institution & 55 & 2.40 & .807 & .109 \\
\hline & Another non-CCCU Christian Institution & 23 & 2.61 & .722 & .151 \\
\hline & Non-Christian Institution & 75 & 2.31 & .854 & .099 \\
\hline & Total & 226 & 2.41 & .839 & .056 \\
\hline \multirow{5}{*}{$\begin{array}{l}\text { Quality of students whom I } \\
\text { have taught here }\end{array}$} & Current Institution & 76 & 3.20 & .766 & .088 \\
\hline & Another CCCU Institution & 58 & 3.03 & .700 & .092 \\
\hline & Another non-CCCU Christian Institution & 26 & 3.04 & .774 & .152 \\
\hline & Non-Christian Institution & 77 & 3.00 & .778 & .089 \\
\hline & Total & 237 & 3.08 & .755 & .049 \\
\hline \multirow{5}{*}{$\begin{array}{l}\text { Teaching assistance that I } \\
\text { receive }\end{array}$} & Current Institution & 68 & 2.71 & .830 & .101 \\
\hline & Another CCCU Institution & 53 & 2.68 & .827 & .114 \\
\hline & Another non-CCCU Christian Institution & 25 & 2.84 & .898 & .180 \\
\hline & Non-Christian Institution & 70 & 2.61 & .982 & .117 \\
\hline & Total & 216 & 2.69 & .886 & .060 \\
\hline \multirow{5}{*}{$\begin{array}{l}\text { Research assistance that I } \\
\text { receive }\end{array}$} & Current Institution & 65 & 2.38 & .842 & .104 \\
\hline & Another CCCU Institution & 51 & 2.33 & .864 & .121 \\
\hline & Another non-CCCU Christian Institution & 23 & 2.48 & .790 & .165 \\
\hline & Non-Christian Institution & 65 & 2.25 & .952 & .118 \\
\hline & Total & 204 & 2.34 & .876 & .061 \\
\hline \multirow{5}{*}{$\begin{array}{l}\text { Spouse employment } \\
\text { opportunities in this } \\
\text { geographic area }\end{array}$} & Current Institution & 72 & 3.22 & .843 & .099 \\
\hline & Another CCCU Institution & 50 & 3.38 & .667 & .094 \\
\hline & Another non-CCCU Christian Institution & 25 & 3.24 & .831 & .166 \\
\hline & Non-Christian Institution & 67 & 3.30 & .779 & .095 \\
\hline & Total & 214 & 3.29 & .780 & .053 \\
\hline
\end{tabular}


NSOPF descriptive statistics by alma mater (continued)

\begin{tabular}{|c|c|c|c|c|c|}
\hline \multirow{5}{*}{$\begin{array}{l}\text { My overall satisfaction } \\
\text { with my job here }\end{array}$} & Current Institution & 76 & 3.46 & .662 & .076 \\
\hline & Another CCCU Institution & 58 & 3.41 & .593 & .078 \\
\hline & Another non-CCCU Christian Institution & 26 & 3.73 & .452 & .089 \\
\hline & Non-Christian Institution & 76 & 3.41 & .657 & .075 \\
\hline & Total & 236 & 3.46 & .628 & .041 \\
\hline $\begin{array}{l}\text { If you were to leave your } \\
\text { current institution, how } \\
\text { likely is it that you would } \\
\text { do so to? }\end{array}$ & Alma Mater & $\mathrm{N}$ & Mean & $\begin{array}{l}\text { Standard } \\
\text { Deviation }\end{array}$ & $\begin{array}{c}\text { Standard } \\
\text { Error }\end{array}$ \\
\hline \multirow{5}{*}{ Leave to Retire } & Current Institution & 75 & 2.17 & .921 & .106 \\
\hline & Another CCCU Institution & 59 & 2.20 & .924 & .120 \\
\hline & Another non-CCCU Christian Institution & 26 & 2.42 & .758 & .149 \\
\hline & Non-Christian Institution & 77 & 2.01 & .939 & .107 \\
\hline & Total & 237 & 2.16 & .914 & .059 \\
\hline \multirow{5}{*}{$\begin{array}{l}\text { Return to school as a } \\
\text { student }\end{array}$} & Current Institution & 74 & 1.16 & .439 & .051 \\
\hline & Another CCCU Institution & 58 & 1.21 & .487 & .064 \\
\hline & Another non-CCCU Christian Institution & 26 & 1.23 & .514 & .101 \\
\hline & Non-Christian Institution & 77 & 1.19 & .488 & .056 \\
\hline & Total & 235 & 1.19 & .473 & .031 \\
\hline \multirow{5}{*}{$\begin{array}{l}\text { Accept employment at } \\
\text { another Christian college } \\
\text { or university }\end{array}$} & Current Institution & 74 & 1.99 & .608 & .071 \\
\hline & Another CCCU Institution & 58 & 2.12 & .677 & .089 \\
\hline & Another non-CCCU Christian Institution & 26 & 1.96 & .720 & .141 \\
\hline & Non-Christian Institution & 77 & 1.99 & .716 & .082 \\
\hline & Total & 235 & 2.02 & .673 & .044 \\
\hline \multirow{5}{*}{$\begin{array}{l}\text { Accept employment at a } \\
\text { secular college or } \\
\text { university }\end{array}$} & Current Institution & 74 & 1.65 & .711 & .083 \\
\hline & Another CCCU Institution & 58 & 1.52 & .569 & .075 \\
\hline & Another non-CCCU Christian Institution & 25 & 1.56 & .651 & .130 \\
\hline & Non-Christian Institution & 77 & 1.74 & .677 & .077 \\
\hline & Total & 234 & 1.64 & .662 & .043 \\
\hline \multirow{5}{*}{$\begin{array}{l}\text { Accept employment in } \\
\text { consulting or other for- } \\
\text { profit business or industry } \\
\text { or become self-employed }\end{array}$} & Current Institution & 74 & 1.65 & .711 & .083 \\
\hline & Another CCCU Institution & 58 & 1.66 & .785 & .103 \\
\hline & Another non-CCCU Christian Institution & 26 & 1.69 & .679 & .133 \\
\hline & Non-Christian Institution & 77 & 1.47 & .640 & .073 \\
\hline & Total & 235 & 1.60 & .706 & .046 \\
\hline \multirow{5}{*}{$\begin{array}{l}\text { Accept employment in a } \\
\text { non-profit organization }\end{array}$} & Current Institution & 73 & 1.82 & .653 & .076 \\
\hline & Another CCCU Institution & 58 & 1.81 & .606 & .080 \\
\hline & Another non-CCCU Christian Institution & 26 & 1.65 & .629 & .123 \\
\hline & Non-Christian Institution & 77 & 1.57 & .616 & .070 \\
\hline & Total & 234 & 1.72 & .633 & .041 \\
\hline
\end{tabular}


NSOPF descriptive statistics by alma mater (continued)

\begin{tabular}{|c|c|c|c|c|c|}
\hline $\begin{array}{l}\text { If you were to leave your } \\
\text { current institution to } \\
\text { accept another position, } \\
\text { would you want to do } \\
\text { more, less or about the } \\
\text { same amount of the } \\
\text { following as you currently } \\
\text { do? }\end{array}$ & Alma Mater & N & Mean & $\begin{array}{l}\text { Standard } \\
\text { Deviation }\end{array}$ & $\begin{array}{l}\text { Standard } \\
\text { Error }\end{array}$ \\
\hline \multirow{5}{*}{ Research } & Current Institution & 74 & 1.61 & .699 & .081 \\
\hline & Another CCCU Institution & 58 & 1.62 & .671 & .088 \\
\hline & Another non-CCCU Christian Institution & 25 & 1.60 & .577 & .115 \\
\hline & Non-Christian Institution & 75 & 1.49 & .578 & .067 \\
\hline & Total & 232 & 1.57 & .640 & .042 \\
\hline \multirow{5}{*}{ Teaching } & Current Institution & 75 & 2.13 & .577 & .067 \\
\hline & Another CCCU Institution & 58 & 2.07 & .588 & .077 \\
\hline & Another non-CCCU Christian Institution & 25 & 1.96 & .539 & .108 \\
\hline & Non-Christian Institution & 75 & 2.27 & .577 & .067 \\
\hline & Total & 233 & 2.14 & .581 & .038 \\
\hline \multirow{5}{*}{ Advising } & Current Institution & 75 & 2.24 & .541 & .063 \\
\hline & Another CCCU Institution & 58 & 2.26 & .515 & .068 \\
\hline & Another non-CCCU Christian Institution & 25 & 2.24 & .597 & .119 \\
\hline & Non-Christian Institution & 74 & 2.19 & .541 & .063 \\
\hline & Total & 232 & 2.23 & .538 & .035 \\
\hline \multirow{5}{*}{ Service } & Current Institution & 75 & 2.09 & .574 & .066 \\
\hline & Another CCCU Institution & 58 & 2.14 & .544 & .071 \\
\hline & Another non-CCCU Christian Institution & 25 & 2.16 & .554 & .111 \\
\hline & Non-Christian Institution & 76 & 2.20 & .566 & .065 \\
\hline & Total & 234 & 2.15 & .560 & .037 \\
\hline \multirow{5}{*}{ Administration } & Current Institution & 75 & 2.28 & .689 & .080 \\
\hline & Another CCCU Institution & 58 & 2.43 & .596 & .078 \\
\hline & Another non-CCCU Christian Institution & 25 & 2.32 & .748 & .150 \\
\hline & Non-Christian Institution & 73 & 2.14 & .694 & .081 \\
\hline & Total & 231 & 2.28 & .680 & .045 \\
\hline
\end{tabular}


NSOPF descriptive statistics by alma mater (continued)

\begin{tabular}{|c|c|c|c|c|c|}
\hline $\begin{array}{l}\text { If you were to leave your } \\
\text { current institution to } \\
\text { accept another position, } \\
\text { how important would each } \\
\text { of the following items be in } \\
\text { your decision to accept } \\
\text { another position? }\end{array}$ & Alma Mater & $N$ & Mean & $\begin{array}{l}\text { Standard } \\
\text { Deviation }\end{array}$ & $\begin{array}{c}\text { Standard } \\
\text { Error }\end{array}$ \\
\hline \multirow{5}{*}{ Salary Level } & Current Institution & 76 & 2.47 & .553 & .063 \\
\hline & Another CCCU Institution & 59 & 2.37 & .522 & .068 \\
\hline & Another non-CCCU Christian Institution & 26 & 2.31 & .549 & .108 \\
\hline & Non-Christian Institution & 77 & 2.51 & .599 & .068 \\
\hline & Total & 238 & 2.44 & .561 & .036 \\
\hline \multirow{5}{*}{ Position Level } & Current Institution & 75 & 2.32 & .573 & .066 \\
\hline & Another CCCU Institution & 59 & 2.39 & .588 & .077 \\
\hline & Another non-CCCU Christian Institution & 26 & 2.15 & .613 & .120 \\
\hline & Non-Christian Institution & 77 & 2.40 & .654 & .075 \\
\hline & Total & 237 & 2.35 & .609 & .040 \\
\hline \multirow{5}{*}{ Job Security } & Current Institution & 75 & 2.57 & .640 & .074 \\
\hline & Another CCCU Institution & 59 & 2.53 & .626 & .081 \\
\hline & Another non-CCCU Christian Institution & 26 & 2.31 & .618 & .121 \\
\hline & Non-Christian Institution & 77 & 2.60 & .591 & .067 \\
\hline & Total & 237 & 2.54 & .621 & .040 \\
\hline \multirow{5}{*}{$\begin{array}{l}\text { Opportunities for } \\
\text { advancement }\end{array}$} & Current Institution & 76 & 2.24 & .671 & .077 \\
\hline & Another CCCU Institution & 59 & 2.29 & .671 & .087 \\
\hline & Another non-CCCU Christian Institution & 26 & 2.27 & .667 & .131 \\
\hline & Non-Christian Institution & 77 & 2.43 & .696 & .079 \\
\hline & Total & 238 & 2.32 & .679 & .044 \\
\hline \multirow{5}{*}{ Benefits } & Current Institution & 76 & 2.64 & .509 & .058 \\
\hline & Another CCCU Institution & 59 & 2.59 & .529 & .069 \\
\hline & Another non-CCCU Christian Institution & 26 & 2.69 & .471 & .092 \\
\hline & Non-Christian Institution & 77 & 2.69 & .520 & .059 \\
\hline & Total & 238 & 2.65 & .512 & .033 \\
\hline \multirow{5}{*}{ No pressure to publish } & Current Institution & 76 & 2.11 & .741 & .085 \\
\hline & Another CCCU Institution & 59 & 2.19 & .656 & .085 \\
\hline & Another non-CCCU Christian Institution & 26 & 2.23 & .765 & .150 \\
\hline & Non-Christian Institution & 77 & 2.17 & .750 & .086 \\
\hline & Total & 238 & 2.16 & .723 & .047 \\
\hline
\end{tabular}


NSOPF descriptive statistics by alma mater (continued)

\begin{tabular}{|c|c|c|c|c|c|}
\hline \multirow[b]{5}{*}{ Academic Freedom } & Current Institution & 76 & 2.45 & .620 & .071 \\
\hline & Another CCCU Institution & 59 & 2.53 & .537 & .070 \\
\hline & Another non-CCCU Christian Institution & 26 & 2.77 & .430 & .084 \\
\hline & Non-Christian Institution & 77 & 2.69 & .494 & .056 \\
\hline & Total & 238 & 2.58 & .551 & .036 \\
\hline \multirow{5}{*}{$\begin{array}{l}\text { Good research facilities } \\
\text { and equipment }\end{array}$} & Current Institution & 76 & 2.03 & .632 & .072 \\
\hline & Another CCCU Institution & 58 & 2.07 & .697 & .092 \\
\hline & Another non-CCCU Christian Institution & 26 & 2.23 & .587 & .115 \\
\hline & Non-Christian Institution & 76 & 2.24 & .690 & .079 \\
\hline & Total & 236 & 2.13 & .666 & .043 \\
\hline \multirow{5}{*}{$\begin{array}{l}\text { Good instructional } \\
\text { facilities and equipment }\end{array}$} & Current Institution & 76 & 2.46 & .576 & .066 \\
\hline & Another CCCU Institution & 58 & 2.57 & .565 & .074 \\
\hline & Another non-CCCU Christian Institution & 26 & 2.65 & .485 & .095 \\
\hline & Non-Christian Institution & 77 & 2.58 & .570 & .065 \\
\hline & Total & 237 & 2.55 & .563 & .037 \\
\hline \multirow{5}{*}{ Excellent Students } & Current Institution & 76 & 2.46 & .576 & .066 \\
\hline & Another CCCU Institution & 59 & 2.44 & .595 & .077 \\
\hline & Another non-CCCU Christian Institution & 26 & 2.38 & .571 & .112 \\
\hline & Non-Christian Institution & 77 & 2.40 & .544 & .062 \\
\hline & Total & 238 & 2.43 & .567 & .037 \\
\hline \multirow{5}{*}{ Excellent Colleagues } & Current Institution & 76 & 2.72 & .479 & .055 \\
\hline & Another CCCU Institution & 59 & 2.68 & .471 & .061 \\
\hline & Another non-CCCU Christian Institution & 26 & 2.54 & .508 & .100 \\
\hline & Non-Christian Institution & 77 & 2.64 & .484 & .055 \\
\hline & Total & 238 & 2.66 & .482 & .031 \\
\hline \multirow{5}{*}{$\begin{array}{l}\text { New institution is a } \\
\text { Christian college }\end{array}$} & Current Institution & 76 & 2.42 & .698 & .080 \\
\hline & Another CCCU Institution & 59 & 2.46 & .625 & .081 \\
\hline & Another non-CCCU Christian Institution & 26 & 2.15 & .613 & .120 \\
\hline & Non-Christian Institution & 77 & 2.05 & .759 & .087 \\
\hline & Total & 238 & 2.28 & .712 & .046 \\
\hline \multirow{5}{*}{$\begin{array}{l}\text { Institutional mission or } \\
\text { philosophy that is } \\
\text { compatible with my own } \\
\text { views }\end{array}$} & Current Institution & 76 & 2.66 & .555 & .064 \\
\hline & Another CCCU Institution & 58 & 2.79 & .409 & .054 \\
\hline & Another non-CCCU Christian Institution & 26 & 2.62 & .496 & .097 \\
\hline & Non-Christian Institution & 77 & 2.58 & .547 & .062 \\
\hline & Total & 237 & 2.66 & .517 & .034 \\
\hline
\end{tabular}


NSOPF descriptive statistics by alma mater (continued)

\begin{tabular}{|c|c|c|c|c|c|}
\hline \multirow[b]{5}{*}{ Good job for my spouse } & Current Institution & 72 & 2.26 & .856 & .101 \\
\hline & Another CCCU Institution & 56 & 2.13 & .788 & .105 \\
\hline & Another non-CCCU Christian Institution & 26 & 2.04 & .824 & .162 \\
\hline & Non-Christian Institution & 73 & 1.95 & .880 & .103 \\
\hline & Total & 227 & 2.10 & .848 & .056 \\
\hline \multirow{5}{*}{ Good geographic location } & Current Institution & 75 & 2.39 & .695 & .080 \\
\hline & Another CCCU Institution & 58 & 2.31 & .598 & .079 \\
\hline & Another non-CCCU Christian Institution & 26 & 2.50 & .510 & .100 \\
\hline & Non-Christian Institution & 76 & 2.58 & .595 & .068 \\
\hline & Total & 235 & 2.44 & .627 & .041 \\
\hline \multirow{5}{*}{ Affordable Housing } & Current Institution & 75 & 2.47 & .622 & .072 \\
\hline & Another CCCU Institution & 59 & 2.44 & .595 & .077 \\
\hline & Another non-CCCU Christian Institution & 26 & 2.35 & .689 & .135 \\
\hline & Non-Christian Institution & 75 & 2.65 & .557 & .064 \\
\hline & Total & 235 & 2.51 & .609 & .040 \\
\hline \multirow{5}{*}{$\begin{array}{l}\text { Good } \\
\text { environment/schools for } \\
\text { my children }\end{array}$} & Current Institution & 72 & 2.08 & .946 & .111 \\
\hline & Another CCCU Institution & 55 & 2.09 & .867 & .117 \\
\hline & Another non-CCCU Christian Institution & 25 & 1.72 & .843 & .169 \\
\hline & Non-Christian Institution & 72 & 1.76 & .896 & .106 \\
\hline & Total & 224 & 1.94 & .909 & .061 \\
\hline \multirow{5}{*}{ A full-time position } & Current Institution & 75 & 2.76 & .566 & .065 \\
\hline & Another CCCU Institution & 58 & 2.83 & .500 & .066 \\
\hline & Another non-CCCU Christian Institution & 25 & 2.48 & .714 & .143 \\
\hline & Non-Christian Institution & 74 & 2.73 & .604 & .070 \\
\hline & Total & 232 & 2.74 & .585 & .038 \\
\hline \multirow{5}{*}{ A part-time position } & Current Institution & 74 & 1.34 & .556 & .065 \\
\hline & Another CCCU Institution & 56 & 1.27 & .587 & .079 \\
\hline & Another non-CCCU Christian Institution & 24 & 1.67 & .761 & .155 \\
\hline & Non-Christian Institution & 74 & 1.18 & .449 & .052 \\
\hline & Total & 228 & 1.30 & .571 & .038 \\
\hline $\begin{array}{l}\text { Please indicate the extent } \\
\text { to which you agree or } \\
\text { disagree with each of the } \\
\text { following statements. }\end{array}$ & Alma Mater & N & Mean & $\begin{array}{l}\text { Standard } \\
\text { Deviation }\end{array}$ & $\begin{array}{l}\text { Standard } \\
\text { Error }\end{array}$ \\
\hline \multirow{5}{*}{$\begin{array}{l}\text { It is important for faculty to } \\
\text { participate in governing } \\
\text { their institution }\end{array}$} & Current Institution & 76 & 3.67 & .500 & .057 \\
\hline & Another CCCU Institution & 59 & 3.58 & .649 & .084 \\
\hline & Another non-CCCU Christian Institution & 26 & 3.65 & .562 & .110 \\
\hline & Non-Christian Institution & 76 & 3.66 & .555 & .064 \\
\hline & Total & 237 & 3.64 & .562 & .036 \\
\hline
\end{tabular}


NSOPF descriptive statistics by alma mater (continued)

\begin{tabular}{|c|c|c|c|c|c|}
\hline \multirow{5}{*}{$\begin{array}{l}\text { Faculty promotions should } \\
\text { be based at least in part } \\
\text { on formal student } \\
\text { evaluations }\end{array}$} & Current Institution & 76 & 3.01 & .702 & .081 \\
\hline & Another CCCU Institution & 59 & 2.95 & .705 & .092 \\
\hline & Another non-CCCU Christian Institution & 26 & 2.92 & .891 & .175 \\
\hline & Non-Christian Institution & 77 & 2.88 & .843 & .096 \\
\hline & Total & 238 & 2.95 & .769 & .050 \\
\hline \multirow{5}{*}{$\begin{array}{l}\text { The tenure system in } \\
\text { higher education should } \\
\text { be preserved. }\end{array}$} & Current Institution & 76 & 2.63 & .950 & .109 \\
\hline & Another CCCU Institution & 59 & 2.85 & .805 & .105 \\
\hline & Another non-CCCU Christian Institution & 26 & 2.77 & .951 & .187 \\
\hline & Non-Christian Institution & 76 & 2.99 & 1.013 & .116 \\
\hline & Total & 237 & 2.81 & .943 & .061 \\
\hline \multirow{5}{*}{$\begin{array}{l}\text { Teaching effectiveness } \\
\text { should be the primary } \\
\text { criterion for promotion of } \\
\text { faculty }\end{array}$} & Current Institution & 76 & 3.42 & .572 & .066 \\
\hline & Another CCCU Institution & 59 & 3.27 & .611 & .080 \\
\hline & Another non-CCCU Christian Institution & 26 & 3.54 & .647 & .127 \\
\hline & Non-Christian Institution & 76 & 3.14 & .743 & .085 \\
\hline & Total & 237 & 3.31 & .659 & .043 \\
\hline \multirow{5}{*}{$\begin{array}{l}\text { Research/publications } \\
\text { should be the primary } \\
\text { criterion for promotion of } \\
\text { college faculty }\end{array}$} & Current Institution & 76 & 1.91 & .677 & .078 \\
\hline & Another CCCU Institution & 59 & 1.97 & .742 & .097 \\
\hline & Another non-CCCU Christian Institution & 26 & 2.00 & .632 & .124 \\
\hline & Non-Christian Institution & 77 & 1.83 & .696 & .079 \\
\hline & Total & 238 & 1.91 & .693 & .045 \\
\hline \multirow{5}{*}{$\begin{array}{l}\text { Years of service/advanced } \\
\text { degree should be the } \\
\text { primary criterion for } \\
\text { promotion of college } \\
\text { faculty }\end{array}$} & Current Institution & 76 & 2.58 & .788 & .090 \\
\hline & Another CCCU Institution & 59 & 2.44 & .749 & .098 \\
\hline & Another non-CCCU Christian Institution & 25 & 2.56 & .712 & .142 \\
\hline & Non-Christian Institution & 76 & 2.38 & .783 & .090 \\
\hline & Total & 236 & 2.48 & .769 & .050 \\
\hline \multirow{5}{*}{$\begin{array}{l}\text { The administrative } \\
\text { function is taking an } \\
\text { increasingly heavy share } \\
\text { of available resources at } \\
\text { my institution }\end{array}$} & Current Institution & 76 & 2.83 & .839 & .096 \\
\hline & Another CCCU Institution & 57 & 2.88 & .803 & .106 \\
\hline & Another non-CCCU Christian Institution & 25 & 2.80 & .957 & .191 \\
\hline & Non-Christian Institution & 74 & 2.55 & .894 & .104 \\
\hline & Total & 232 & 2.75 & .867 & .057 \\
\hline \multirow{5}{*}{$\begin{array}{l}\text { State or federally } \\
\text { mandated assessment } \\
\text { requirements have } \\
\text { improved the quality of } \\
\text { undergraduate education } \\
\text { at my institution }\end{array}$} & Current Institution & 75 & 2.16 & .823 & .095 \\
\hline & Another CCCU Institution & 55 & 2.38 & .782 & .105 \\
\hline & Another non-CCCU Christian Institution & 25 & 2.32 & .748 & .150 \\
\hline & Non-Christian Institution & 74 & 2.15 & .886 & .103 \\
\hline & Total & 229 & 2.23 & .828 & .055 \\
\hline
\end{tabular}


NSOPF descriptive statistics by alma mater (continued)

\begin{tabular}{|c|c|c|c|c|c|}
\hline \multirow{5}{*}{$\begin{array}{l}\text { Female faculty members } \\
\text { are treated fairly at my } \\
\text { institution }\end{array}$} & Current Institution & 76 & 3.29 & .708 & .081 \\
\hline & Another CCCU Institution & 59 & 3.20 & .738 & .096 \\
\hline & Another non-CCCU Christian Institution & 25 & 3.36 & .907 & .181 \\
\hline & Non-Christian Institution & 76 & 3.22 & .776 & .089 \\
\hline & Total & 236 & 3.25 & .757 & .049 \\
\hline \multirow{5}{*}{$\begin{array}{l}\text { Faculty who are members } \\
\text { of racial or ethnic } \\
\text { minorities are treated fairly } \\
\text { at my institution }\end{array}$} & Current Institution & 74 & 3.32 & .704 & .082 \\
\hline & Another CCCU Institution & 59 & 3.24 & .837 & .109 \\
\hline & Another non-CCCU Christian Institution & 25 & 3.40 & .764 & .153 \\
\hline & Non-Christian Institution & 76 & 3.24 & .798 & .092 \\
\hline & Total & 234 & 3.28 & .773 & .051 \\
\hline \multirow{5}{*}{$\begin{array}{l}\text { My institution effectively } \\
\text { meets the educational } \\
\text { needs of entering students }\end{array}$} & Current Institution & 76 & 3.34 & .703 & .081 \\
\hline & Another CCCU Institution & 59 & 3.08 & .651 & .085 \\
\hline & Another non-CCCU Christian Institution & 25 & 3.44 & .583 & .117 \\
\hline & Non-Christian Institution & 75 & 3.15 & .748 & .086 \\
\hline & Total & 235 & 3.23 & .701 & .046 \\
\hline \multirow{5}{*}{$\begin{array}{l}\text { If I had it to do over again, } \\
\text { I would choose an } \\
\text { academic career }\end{array}$} & Current Institution & 76 & 3.84 & .367 & .042 \\
\hline & Another CCCU Institution & 59 & 3.75 & .512 & .067 \\
\hline & Another non-CCCU Christian Institution & 26 & 3.81 & .634 & .124 \\
\hline & Non-Christian Institution & 77 & 3.74 & .594 & .068 \\
\hline & Total & 238 & 3.78 & .514 & .033 \\
\hline
\end{tabular}


NSOPF descriptive statistics by highest degree earned

\begin{tabular}{|c|c|c|c|c|c|}
\hline $\begin{array}{l}\text { How satisfied or dissatisfied do you } \\
\text { personally feel about each of the } \\
\text { following aspects of your job at your } \\
\text { current institution }\end{array}$ & Highest Degree & $N$ & Mean & $\begin{array}{l}\text { Standard } \\
\text { Deviation }\end{array}$ & $\begin{array}{l}\text { Standard } \\
\text { Error }\end{array}$ \\
\hline \multirow{4}{*}{ My Work Load } & Master's & 81 & 3.11 & .775 & .086 \\
\hline & Specialist/Professional & 7 & 3.00 & .816 & .309 \\
\hline & Doctorate & 148 & 2.74 & .883 & .073 \\
\hline & Total & 236 & 2.87 & .861 & .056 \\
\hline \multirow{4}{*}{ My job security } & Master's & 80 & 3.33 & .823 & .092 \\
\hline & Specialist/Professional & 7 & 3.57 & .535 & .202 \\
\hline & Doctorate & 148 & 3.44 & .802 & .066 \\
\hline & Total & 235 & 3.40 & .802 & .052 \\
\hline \multirow{4}{*}{ My Salary } & Master's & 81 & 2.56 & .866 & .096 \\
\hline & Specialist/Professional & 7 & 2.86 & .690 & .261 \\
\hline & Doctorate & 148 & 2.68 & .904 & .074 \\
\hline & Total & 236 & 2.64 & .885 & .058 \\
\hline \multirow{4}{*}{ My Benefits } & Master's & 80 & 2.89 & .795 & .089 \\
\hline & Specialist/Professional & 7 & 2.71 & .488 & .184 \\
\hline & Doctorate & 148 & 2.82 & .955 & .079 \\
\hline & Total & 235 & 2.84 & .891 & .058 \\
\hline \multirow{4}{*}{$\begin{array}{l}\text { The authority I have to make decisions } \\
\text { about what courses I teach }\end{array}$} & Master's & 79 & 3.37 & .771 & .087 \\
\hline & Specialist/Professional & 7 & 3.86 & .378 & .143 \\
\hline & Doctorate & 148 & 3.43 & .818 & .067 \\
\hline & Total & 234 & 3.42 & .795 & .052 \\
\hline \multirow{4}{*}{$\begin{array}{l}\text { The authority I have to make decisions } \\
\text { about the content and methods in the } \\
\text { courses I teach }\end{array}$} & Master's & 79 & 3.76 & .486 & .055 \\
\hline & Specialist/Professional & 7 & 4.00 & .000 & .000 \\
\hline & Doctorate & 148 & 3.80 & .494 & .041 \\
\hline & Total & 234 & 3.79 & .485 & .032 \\
\hline \multirow{4}{*}{$\begin{array}{l}\text { The authority I have to make decisions } \\
\text { about other aspects of my job }\end{array}$} & Master's & 80 & 3.36 & .716 & .080 \\
\hline & Specialist/Professional & 7 & 3.57 & .535 & .202 \\
\hline & Doctorate & 146 & 3.34 & .648 & .054 \\
\hline & Total & 233 & 3.36 & .668 & .044 \\
\hline \multirow{4}{*}{$\begin{array}{l}\text { The mix of teaching, research, } \\
\text { administration, and service that I am } \\
\text { required to do }\end{array}$} & Master's & 79 & 3.22 & .710 & .080 \\
\hline & Specialist/Professional & 7 & 3.00 & 1.000 & .378 \\
\hline & Doctorate & 147 & 3.03 & .823 & .068 \\
\hline & Total & 233 & 3.09 & .793 & .052 \\
\hline \multirow{4}{*}{$\begin{array}{l}\text { The opportunity for advancement in rank } \\
\text { at my institution }\end{array}$} & Master's & 80 & 2.90 & .949 & .106 \\
\hline & Specialist/Professional & 7 & 2.86 & 1.069 & .404 \\
\hline & Doctorate & 146 & 3.24 & .873 & .072 \\
\hline & Total & 233 & 3.11 & .917 & .060 \\
\hline \multirow{4}{*}{$\begin{array}{l}\text { Time available for keeping current in my } \\
\text { field }\end{array}$} & Master's & 79 & 2.67 & .828 & .093 \\
\hline & Specialist/Professional & 7 & 2.14 & 1.069 & .404 \\
\hline & Doctorate & 148 & 2.33 & .884 & .073 \\
\hline & Total & 234 & 2.44 & .883 & .058 \\
\hline
\end{tabular}


NSOPF descriptive statistics by highest degree earned (continued)

\begin{tabular}{|c|c|c|c|c|c|}
\hline \multirow{4}{*}{$\begin{array}{l}\text { Availability of support services and } \\
\text { equipment (clerical support, computers, } \\
\text { etc.) }\end{array}$} & Master's & 81 & 3.04 & .798 & .089 \\
\hline & Specialist/Professional & 7 & 2.86 & .900 & .340 \\
\hline & Doctorate & 148 & 2.79 & .935 & .077 \\
\hline & Total & 236 & 2.88 & .893 & .058 \\
\hline \multirow{4}{*}{ Freedom to do outside consulting } & Master's & 78 & 3.24 & .724 & .082 \\
\hline & Specialist/Professional & 7 & 3.71 & .488 & 184 \\
\hline & Doctorate & 140 & 3.26 & .736 & .062 \\
\hline & Total & 225 & 3.27 & .727 & .048 \\
\hline \multirow{4}{*}{ Overall reputation of the institution } & Master's & 79 & 3.29 & .770 & .087 \\
\hline & Specialist/Professional & 7 & 3.57 & .787 & .297 \\
\hline & Doctorate & 147 & 3.16 & .768 & .063 \\
\hline & Total & 233 & 3.22 & .771 & .050 \\
\hline \multirow{4}{*}{ Reputation of my department } & Master's & 81 & 3.30 & .813 & .090 \\
\hline & Specialist/Professional & 7 & 3.57 & .535 & .202 \\
\hline & Doctorate & 148 & 3.39 & .796 & .065 \\
\hline & Total & 236 & 3.36 & .795 & .052 \\
\hline \multirow{4}{*}{ Institutional mission or philosophy } & Master's & 80 & 3.69 & .466 & .052 \\
\hline & Specialist/Professional & 7 & 3.71 & .488 & .184 \\
\hline & Doctorate & 148 & 3.64 & .585 & .048 \\
\hline & Total & 235 & 3.66 & .543 & .035 \\
\hline \multirow{4}{*}{ Quality of leadership in my department } & Master's & 81 & 3.42 & .804 & .089 \\
\hline & Specialist/Professional & 7 & 3.57 & .787 & .297 \\
\hline & Doctorate & 147 & 3.35 & .881 & .073 \\
\hline & Total & 235 & 3.38 & .851 & .055 \\
\hline \multirow{4}{*}{$\begin{array}{l}\text { Quality of chief administrative officers at } \\
\text { my institution }\end{array}$} & Master's & 80 & 3.15 & .969 & .108 \\
\hline & Specialist/Professional & 7 & 3.86 & .378 & .143 \\
\hline & Doctorate & 148 & 3.06 & .905 & .074 \\
\hline & Total & 235 & 3.11 & .924 & .060 \\
\hline \multirow{4}{*}{$\begin{array}{l}\text { Quality of my colleagues in my } \\
\text { department }\end{array}$} & Master's & 80 & 3.51 & .675 & .075 \\
\hline & Specialist/Professional & 7 & 3.57 & .787 & .297 \\
\hline & Doctorate & 146 & 3.49 & .677 & .056 \\
\hline & Total & 233 & 3.50 & .677 & .044 \\
\hline \multirow{4}{*}{$\begin{array}{l}\text { Quality of faculty leadership at my } \\
\text { institution }\end{array}$} & Master's & 81 & 3.28 & .746 & .083 \\
\hline & Specialist/Professional & 7 & 3.14 & .690 & .261 \\
\hline & Doctorate & 147 & 3.03 & .835 & .069 \\
\hline & Total & 235 & 3.12 & .808 & .053 \\
\hline \multirow{4}{*}{$\begin{array}{l}\text { Relationship between administration and } \\
\text { faculty at this institution }\end{array}$} & Master's & 81 & 2.81 & .976 & .108 \\
\hline & Specialist/Professional & 7 & 2.86 & .900 & .340 \\
\hline & Doctorate & 147 & 2.77 & .892 & .074 \\
\hline & Total & 235 & 2.79 & .918 & .060 \\
\hline \multirow{4}{*}{$\begin{array}{l}\text { Interdepartmental cooperation at this } \\
\text { institution }\end{array}$} & Master's & 81 & 2.74 & .877 & .097 \\
\hline & Specialist/Professional & 7 & 3.00 & .816 & .309 \\
\hline & Doctorate & 147 & 2.82 & .783 & .065 \\
\hline & Total & 235 & 2.80 & .815 & .053 \\
\hline
\end{tabular}


NSOPF descriptive statistics by highest degree earned (continued)

\begin{tabular}{|c|c|c|c|c|c|}
\hline \multirow{4}{*}{$\begin{array}{l}\text { Spirit of cooperation between faculty at } \\
\text { this institution }\end{array}$} & Master's & 81 & 3.07 & .803 & .089 \\
\hline & Specialist/Professional & 7 & 3.14 & .690 & .261 \\
\hline & Doctorate & 148 & 3.08 & .752 & .062 \\
\hline & Total & 236 & 3.08 & .765 & .050 \\
\hline \multirow{4}{*}{$\begin{array}{l}\text { Quality of my research facilities and } \\
\text { support }\end{array}$} & Master's & 77 & 2.65 & .757 & .086 \\
\hline & Specialist/Professional & 7 & 2.29 & 1.113 & .421 \\
\hline & Doctorate & 141 & 2.28 & .848 & .071 \\
\hline & Total & 225 & 2.41 & .841 & .056 \\
\hline \multirow{4}{*}{$\begin{array}{l}\text { Quality of students whom I have taught } \\
\text { here }\end{array}$} & Master's & 81 & 3.12 & .781 & .087 \\
\hline & Specialist/Professional & 7 & 3.14 & .690 & .261 \\
\hline & Doctorate & 148 & 3.05 & .745 & .061 \\
\hline & Total & 236 & 3.08 & .754 & .049 \\
\hline \multirow{4}{*}{ Teaching assistance that I receive } & Master's & 72 & 2.99 & .864 & .102 \\
\hline & Specialist/Professional & 6 & 2.67 & 1.033 & .422 \\
\hline & Doctorate & 137 & 2.53 & .858 & .073 \\
\hline & Total & 215 & 2.68 & .887 & .061 \\
\hline \multirow{4}{*}{ Research assistance that I receive } & Master's & 67 & 2.60 & .799 & .098 \\
\hline & Specialist/Professional & 6 & 2.17 & .983 & .401 \\
\hline & Doctorate & 130 & 2.21 & .887 & .078 \\
\hline & Total & 203 & 2.33 & .877 & .062 \\
\hline \multirow{4}{*}{$\begin{array}{l}\text { Spouse employment opportunities in this } \\
\text { geographic area }\end{array}$} & Master's & 68 & 3.28 & .878 & .107 \\
\hline & Specialist/Professional & 6 & 2.67 & 1.211 & .494 \\
\hline & Doctorate & 139 & 3.31 & .700 & .059 \\
\hline & Total & 213 & 3.28 & .780 & .053 \\
\hline \multirow{4}{*}{ My overall satisfaction with my job here } & Master's & 81 & 3.44 & .632 & .070 \\
\hline & Specialist/Professional & 7 & 3.86 & .378 & .143 \\
\hline & Doctorate & 147 & 3.45 & .632 & .052 \\
\hline & Total & 235 & 3.46 & .628 & .041 \\
\hline $\begin{array}{l}\text { If you were to leave your current } \\
\text { institution, how likely is it that you would } \\
\text { do so to? }\end{array}$ & Highest Degree & $N$ & Mean & $\begin{array}{l}\text { Standard } \\
\text { Deviation }\end{array}$ & $\begin{array}{l}\text { Standard } \\
\text { Error }\end{array}$ \\
\hline \multirow{4}{*}{ Leave to Retire } & Master's & 81 & 2.16 & .901 & .100 \\
\hline & Specialist/Professional & 7 & 2.00 & 1.000 & .378 \\
\hline & Doctorate & 148 & 2.17 & .921 & .076 \\
\hline & Total & 236 & 2.16 & .913 & .059 \\
\hline \multirow{4}{*}{ Return to school as a student } & Master's & 79 & 1.37 & .603 & .068 \\
\hline & Specialist/Professional & 7 & 1.43 & .787 & .297 \\
\hline & Doctorate & 148 & 1.09 & .328 & .027 \\
\hline & Total & 234 & 1.19 & .474 & .031 \\
\hline \multirow{4}{*}{$\begin{array}{l}\text { Accept employment at another Christian } \\
\text { college or university }\end{array}$} & Master's & 79 & 2.08 & .675 & .076 \\
\hline & Specialist/Professional & 7 & 1.71 & .756 & .286 \\
\hline & Doctorate & 148 & 1.99 & .665 & .055 \\
\hline & Total & 234 & 2.01 & .671 & .044 \\
\hline
\end{tabular}


NSOPF descriptive statistics by highest degree earned (continued)

\begin{tabular}{|c|c|c|c|c|c|}
\hline \multirow{4}{*}{$\begin{array}{l}\text { Accept employment at a secular college } \\
\text { or university }\end{array}$} & Master's & 78 & 1.72 & .662 & .075 \\
\hline & Specialist/Professional & 7 & 1.43 & .787 & .297 \\
\hline & Doctorate & 148 & 1.60 & .657 & .054 \\
\hline & Total & 233 & 1.64 & .663 & .043 \\
\hline \multirow{4}{*}{$\begin{array}{l}\text { Accept employment in consulting or } \\
\text { other for-profit business or industry or } \\
\text { become self-employed }\end{array}$} & Master's & 79 & 1.67 & .746 & .084 \\
\hline & Specialist/Professional & 7 & 1.29 & .488 & .184 \\
\hline & Doctorate & 148 & 1.57 & .692 & .057 \\
\hline & Total & 234 & 1.59 & .707 & .046 \\
\hline \multirow{4}{*}{$\begin{array}{l}\text { Accept employment in a non-profit } \\
\text { organization }\end{array}$} & Master's & 79 & 1.72 & .619 & .070 \\
\hline & Specialist/Professional & 7 & 1.29 & .488 & .184 \\
\hline & Doctorate & 147 & 1.73 & .645 & .053 \\
\hline & Total & 233 & 1.72 & .634 & .042 \\
\hline $\begin{array}{l}\text { If you were to leave your current } \\
\text { institution to accept another position, } \\
\text { would you want to do more, less or } \\
\text { about the same amount of the following } \\
\text { as you currently do? }\end{array}$ & Highest Degree & N & Mean & $\begin{array}{l}\text { Standard } \\
\text { Deviation }\end{array}$ & $\begin{array}{l}\text { Standard } \\
\text { Error }\end{array}$ \\
\hline \multirow{4}{*}{ Research } & Master's & 76 & 1.75 & .614 & .070 \\
\hline & Specialist/Professional & 7 & 2.00 & 1.000 & .378 \\
\hline & Doctorate & 148 & 1.46 & .610 & .050 \\
\hline & Total & 231 & 1.57 & .641 & .042 \\
\hline \multirow{4}{*}{ Teaching } & Master's & 78 & 1.99 & .614 & .069 \\
\hline & Specialist/Professional & 7 & 1.86 & .378 & .143 \\
\hline & Doctorate & 147 & 2.23 & .550 & .045 \\
\hline & Total & 232 & 2.14 & .580 & .038 \\
\hline \multirow{4}{*}{ Advising } & Master's & 76 & 2.12 & .541 & .062 \\
\hline & Specialist/Professional & 7 & 2.43 & .535 & .202 \\
\hline & Doctorate & 148 & 2.28 & .532 & .044 \\
\hline & Total & 231 & 2.23 & .539 & .035 \\
\hline \multirow{4}{*}{ Service } & Master's & 78 & 2.04 & .521 & .059 \\
\hline & Specialist/Professional & 7 & 1.86 & .690 & .261 \\
\hline & Doctorate & 148 & 2.21 & .562 & .046 \\
\hline & Total & 233 & 2.14 & .558 & .037 \\
\hline \multirow{4}{*}{ Administration } & Master's & 76 & 2.20 & .633 & .073 \\
\hline & Specialist/Professional & 7 & 2.29 & .951 & .360 \\
\hline & Doctorate & 147 & 2.32 & .692 & .057 \\
\hline & Total & 230 & 2.28 & .681 & .045 \\
\hline $\begin{array}{l}\text { If you were to leave your current } \\
\text { institution to accept another position, } \\
\text { how important would each of the } \\
\text { following items be in your decision to } \\
\text { accept another position? }\end{array}$ & Highest Degree & $N$ & Mean & $\begin{array}{l}\text { Standard } \\
\text { Deviation }\end{array}$ & $\begin{array}{l}\text { Standard } \\
\text { Error }\end{array}$ \\
\hline \multirow{4}{*}{ Salary Level } & Master's & 81 & 2.54 & .501 & .056 \\
\hline & Specialist/Professional & 7 & 2.00 & .577 & .218 \\
\hline & Doctorate & 149 & 2.40 & .580 & .048 \\
\hline & Total & 237 & 2.44 & .561 & .036 \\
\hline
\end{tabular}


NSOPF descriptive statistics by highest degree earned (continued)

\begin{tabular}{|c|c|c|c|c|c|}
\hline \multirow[b]{4}{*}{ Position Level } & Master's & 80 & 2.31 & .628 & .070 \\
\hline & Specialist/Professional & 7 & 2.29 & .488 & .184 \\
\hline & Doctorate & 149 & 2.37 & .608 & .050 \\
\hline & Total & 236 & 2.35 & .610 & .040 \\
\hline \multirow{4}{*}{ Job Security } & Master's & 80 & 2.56 & .633 & .071 \\
\hline & Specialist/Professional & 7 & 2.71 & .488 & .184 \\
\hline & Doctorate & 149 & 2.52 & .622 & .051 \\
\hline & Total & 236 & 2.54 & .621 & .040 \\
\hline \multirow{4}{*}{ Opportunities for advancement } & Master's & 81 & 2.35 & .616 & .068 \\
\hline & Specialist/Professional & 7 & 2.43 & .787 & .297 \\
\hline & Doctorate & 149 & 2.29 & .710 & .058 \\
\hline & Total & 237 & 2.31 & .679 & .044 \\
\hline \multirow{4}{*}{ Benefits } & Master's & 81 & 2.64 & .508 & .056 \\
\hline & Specialist/Professional & 7 & 2.71 & .488 & .184 \\
\hline & Doctorate & 149 & 2.66 & .517 & .042 \\
\hline & Total & 237 & 2.65 & .511 & .033 \\
\hline \multirow{4}{*}{ No pressure to publish } & Master's & 81 & 2.28 & .729 & .081 \\
\hline & Specialist/Professional & 7 & 2.43 & .787 & .297 \\
\hline & Doctorate & 149 & 2.09 & .706 & .058 \\
\hline & Total & 237 & 2.16 & .721 & .047 \\
\hline \multirow{4}{*}{ Academic Freedom } & Master's & 81 & 2.56 & .524 & .058 \\
\hline & Specialist/Professional & 7 & 2.57 & .535 & .202 \\
\hline & Doctorate & 149 & 2.59 & .570 & .047 \\
\hline & Total & 237 & 2.58 & .552 & .036 \\
\hline \multirow{4}{*}{ Good research facilities and equipment } & Master's & 79 & 2.11 & .679 & .076 \\
\hline & Specialist/Professional & 7 & 2.00 & .577 & .218 \\
\hline & Doctorate & 149 & 2.14 & .668 & .055 \\
\hline & Total & 235 & 2.13 & .667 & .044 \\
\hline \multirow{4}{*}{$\begin{array}{l}\text { Good instructional facilities and } \\
\text { equipment }\end{array}$} & Master's & 80 & 2.61 & .490 & .055 \\
\hline & Specialist/Professional & 7 & 2.57 & .535 & .202 \\
\hline & Doctorate & 149 & 2.52 & .600 & .049 \\
\hline & Total & 236 & 2.55 & .563 & .037 \\
\hline \multirow{4}{*}{ Excellent Students } & Master's & 81 & 2.44 & .548 & .061 \\
\hline & Specialist/Professional & 7 & 2.43 & .535 & .202 \\
\hline & Doctorate & 149 & 2.42 & .583 & .048 \\
\hline & Total & 237 & 2.43 & .568 & .037 \\
\hline \multirow{4}{*}{ Excellent Colleagues } & Master's & 81 & 2.68 & .470 & .052 \\
\hline & Specialist/Professional & 7 & 2.29 & .488 & .184 \\
\hline & Doctorate & 149 & 2.68 & .483 & .040 \\
\hline & Total & 237 & 2.67 & .481 & .031 \\
\hline \multirow{4}{*}{ New institution is a Christian college } & Master's & 81 & 2.27 & .652 & .072 \\
\hline & Specialist/Professional & 7 & 2.43 & .976 & .369 \\
\hline & Doctorate & 149 & 2.28 & .736 & .060 \\
\hline & Total & 237 & 2.28 & .713 & .046 \\
\hline
\end{tabular}


NSOPF descriptive statistics by highest degree earned (continued)

\begin{tabular}{|c|c|c|c|c|c|}
\hline \multirow{4}{*}{$\begin{array}{l}\text { Institutional mission or philosophy that is } \\
\text { compatible with my own views }\end{array}$} & Master's & 81 & 2.67 & .524 & .058 \\
\hline & Specialist/Professional & 7 & 2.57 & .535 & .202 \\
\hline & Doctorate & 148 & 2.67 & .514 & .042 \\
\hline & Total & 236 & 2.67 & .516 & .034 \\
\hline \multirow{4}{*}{ Good job for my spouse } & Master's & 74 & 2.19 & .886 & .103 \\
\hline & Specialist/Professional & 7 & 1.86 & .900 & .340 \\
\hline & Doctorate & 145 & 2.07 & .830 & .069 \\
\hline & Total & 226 & 2.10 & .850 & .057 \\
\hline \multirow{4}{*}{ Good geographic location } & Master's & 80 & 2.50 & .636 & .071 \\
\hline & Specialist/Professional & 7 & 2.43 & .787 & .297 \\
\hline & Doctorate & 147 & 2.41 & .617 & .051 \\
\hline & Total & 234 & 2.44 & .627 & .041 \\
\hline \multirow{4}{*}{ Affordable Housing } & Master's & 79 & 2.59 & .610 & .069 \\
\hline & Specialist/Professional & 7 & 2.29 & .756 & .286 \\
\hline & Doctorate & 148 & 2.47 & .599 & .049 \\
\hline & Total & 234 & 2.50 & .609 & .040 \\
\hline \multirow{4}{*}{$\begin{array}{l}\text { Good environment/schools for my } \\
\text { children }\end{array}$} & Master's & 75 & 2.07 & .935 & .108 \\
\hline & Specialist/Professional & 7 & 1.86 & 1.069 & .404 \\
\hline & Doctorate & 141 & 1.89 & .887 & .075 \\
\hline & Master's & 223 & 1.95 & .909 & .061 \\
\hline \multirow{4}{*}{ A full-time position } & Specialist/Professional & 78 & 2.72 & .579 & .066 \\
\hline & Doctorate & 7 & 2.57 & .787 & .297 \\
\hline & Total & 146 & 2.75 & .582 & .048 \\
\hline & Master's & 231 & 2.74 & .586 & .039 \\
\hline \multirow{4}{*}{ A part-time position } & Specialist/Professional & 78 & 1.45 & .677 & .077 \\
\hline & Doctorate & 7 & 1.71 & .951 & .360 \\
\hline & Total & 142 & 1.20 & .454 & .038 \\
\hline & Master's & 227 & 1.30 & .572 & .038 \\
\hline $\begin{array}{l}\text { Please indicate the extent to which you } \\
\text { agree or disagree with each of the } \\
\text { following statements. }\end{array}$ & Highest Degree & N & Mean & $\begin{array}{l}\text { Standard } \\
\text { Deviation }\end{array}$ & $\begin{array}{l}\text { Standard } \\
\text { Error }\end{array}$ \\
\hline \multirow{4}{*}{$\begin{array}{l}\text { It is important for faculty to participate in } \\
\text { governing their institution }\end{array}$} & Specialist/Professional & 81 & 3.64 & .532 & .059 \\
\hline & Doctorate & 7 & 3.57 & .535 & .202 \\
\hline & Total & 148 & 3.64 & .583 & .048 \\
\hline & Master's & 236 & 3.64 & .563 & .037 \\
\hline \multirow{4}{*}{$\begin{array}{l}\text { Faculty promotions should be based at } \\
\text { least in part on formal student } \\
\text { evaluations }\end{array}$} & Specialist/Professional & 81 & 2.89 & .725 & .081 \\
\hline & Doctorate & 7 & 2.43 & .787 & .297 \\
\hline & Total & 149 & 3.01 & .784 & .064 \\
\hline & Master's & 237 & 2.95 & .769 & .050 \\
\hline \multirow{4}{*}{$\begin{array}{l}\text { The tenure system in higher education } \\
\text { should be preserved. }\end{array}$} & Specialist/Professional & 80 & 2.65 & .873 & .098 \\
\hline & Doctorate & 7 & 3.29 & .488 & .184 \\
\hline & Total & 149 & 2.87 & .982 & .080 \\
\hline & Master's & 236 & 2.81 & .942 & .061 \\
\hline
\end{tabular}


NSOPF descriptive statistics by highest degree earned (continued)

\begin{tabular}{|c|c|c|c|c|c|}
\hline \multirow{4}{*}{$\begin{array}{l}\text { Teaching effectiveness should be the } \\
\text { primary criterion for promotion of faculty }\end{array}$} & Specialist/Professional & 80 & 3.36 & .601 & .067 \\
\hline & Doctorate & 7 & 3.29 & .756 & .286 \\
\hline & Total & 149 & 3.28 & .689 & .056 \\
\hline & Master's & 236 & 3.31 & .660 & .043 \\
\hline \multirow{4}{*}{$\begin{array}{l}\text { Research/publications should be the } \\
\text { primary criterion for promotion of college } \\
\text { faculty }\end{array}$} & Specialist/Professional & 81 & 1.81 & .654 & .073 \\
\hline & Doctorate & 7 & 1.86 & .690 & .261 \\
\hline & Total & 149 & 1.97 & .711 & .058 \\
\hline & Master's & 237 & 1.91 & .692 & .045 \\
\hline \multirow{4}{*}{$\begin{array}{l}\text { Years of service/advanced degree } \\
\text { should be the primary criterion for } \\
\text { promotion of college faculty }\end{array}$} & Specialist/Professional & 81 & 2.59 & .721 & .080 \\
\hline & Doctorate & 7 & 2.71 & .756 & .286 \\
\hline & Total & 147 & 2.41 & .784 & .065 \\
\hline & Total & 235 & 2.49 & .764 & .050 \\
\hline \multirow{4}{*}{$\begin{array}{l}\text { The administrative function is taking an } \\
\text { increasingly heavy share of available } \\
\text { resources at my institution }\end{array}$} & Master's & 79 & 2.59 & .760 & .085 \\
\hline & Specialist/Professional & 7 & 2.57 & .787 & .297 \\
\hline & Doctorate & 145 & 2.85 & .915 & .076 \\
\hline & Total & 231 & 2.75 & .867 & .057 \\
\hline \multirow{4}{*}{$\begin{array}{l}\text { State or federally mandated assessment } \\
\text { requirements have improved the quality } \\
\text { of undergraduate education at my } \\
\text { institution }\end{array}$} & Master's & 76 & 2.39 & .834 & .096 \\
\hline & Specialist/Professional & 7 & 2.14 & .900 & .340 \\
\hline & Doctorate & 145 & 2.15 & .811 & .067 \\
\hline & Total & 228 & 2.23 & .825 & .055 \\
\hline \multirow{4}{*}{$\begin{array}{l}\text { Female faculty members are treated } \\
\text { fairly at my institution }\end{array}$} & Master's & 80 & 3.23 & .729 & .081 \\
\hline & Specialist/Professional & 7 & 3.29 & .756 & .286 \\
\hline & Doctorate & 148 & 3.28 & .772 & .063 \\
\hline & Total & 235 & 3.26 & .754 & .049 \\
\hline \multirow{4}{*}{$\begin{array}{l}\text { Faculty who are members of racial or } \\
\text { ethnic minorities are treated fairly at my } \\
\text { institution }\end{array}$} & Master's & 78 & 3.24 & .793 & .090 \\
\hline & Specialist/Professional & 7 & 3.43 & .535 & .202 \\
\hline & Doctorate & 148 & 3.30 & .771 & .063 \\
\hline & Total & 233 & 3.29 & .771 & .050 \\
\hline \multirow{4}{*}{$\begin{array}{l}\text { My institution effectively meets the } \\
\text { educational needs of entering students }\end{array}$} & Master's & 79 & 3.15 & .786 & .088 \\
\hline & Specialist/Professional & 7 & 3.14 & .900 & .340 \\
\hline & Doctorate & 148 & 3.28 & .637 & .052 \\
\hline & Total & 234 & 3.23 & .698 & .046 \\
\hline \multirow{4}{*}{$\begin{array}{l}\text { If I had it to do over again, I would } \\
\text { choose an academic career }\end{array}$} & Master's & 81 & 3.77 & .576 & .064 \\
\hline & Specialist/Professional & 7 & 4.00 & .000 & .000 \\
\hline & Doctorate & 149 & 3.78 & .491 & .040 \\
\hline & Total & 237 & 3.78 & .515 & .033 \\
\hline
\end{tabular}


NSOPF descriptive statistics by academic rank

\begin{tabular}{|c|c|c|c|c|c|}
\hline $\begin{array}{l}\text { How satisfied or dissatisfied do you } \\
\text { personally feel about each of the following } \\
\text { aspects of your job at your current institution }\end{array}$ & Academic Rank & $N$ & Mean & $\begin{array}{l}\text { Standard } \\
\text { Deviation }\end{array}$ & $\begin{array}{l}\text { Standard } \\
\text { Error }\end{array}$ \\
\hline \multirow{5}{*}{ My Work Load } & Other (Inst/Tech) & 12 & 3.08 & .515 & .149 \\
\hline & Assistant Professor & 78 & 3.03 & .805 & .091 \\
\hline & Associate Professor & 67 & 2.79 & 1.023 & .125 \\
\hline & Professor & 80 & 2.76 & .783 & .088 \\
\hline & Total & 237 & 2.87 & .859 & .056 \\
\hline \multirow{5}{*}{ My job security } & Other (Inst/Tech) & 12 & 3.25 & .866 & .250 \\
\hline & Assistant Professor & 77 & 3.23 & .857 & .098 \\
\hline & Associate Professor & 67 & 3.33 & .911 & .111 \\
\hline & Professor & 80 & 3.64 & .579 & .065 \\
\hline & Total & 236 & 3.40 & .806 & .052 \\
\hline \multirow{5}{*}{ My Salary } & Other (Inst/Tech) & 12 & 2.33 & 1.155 & .333 \\
\hline & Assistant Professor & 78 & 2.63 & .854 & .097 \\
\hline & Associate Professor & 67 & 2.67 & .894 & .109 \\
\hline & Professor & 80 & 2.69 & .866 & .097 \\
\hline & Total & 237 & 2.65 & .884 & .057 \\
\hline \multirow{5}{*}{ My Benefits } & Other (Inst/Tech) & 12 & 2.75 & .754 & .218 \\
\hline & Assistant Professor & 77 & 2.90 & .852 & .097 \\
\hline & Associate Professor & 67 & 2.82 & .936 & .114 \\
\hline & Professor & 80 & 2.81 & .915 & .102 \\
\hline & Total & 236 & 2.84 & .889 & .058 \\
\hline \multirow{5}{*}{$\begin{array}{l}\text { The authority I have to make decisions } \\
\text { about what courses I teach }\end{array}$} & Other (Inst/Tech) & 11 & 3.36 & .809 & .244 \\
\hline & Assistant Professor & 78 & 3.37 & .775 & .088 \\
\hline & Associate Professor & 66 & 3.39 & .802 & .099 \\
\hline & Professor & 80 & 3.51 & .811 & .091 \\
\hline & Total & 235 & 3.43 & .794 & .052 \\
\hline \multirow{5}{*}{$\begin{array}{l}\text { The authority I have to make decisions } \\
\text { about the content and methods in the } \\
\text { courses I teach }\end{array}$} & Other (Inst/Tech) & 11 & 3.45 & .688 & .207 \\
\hline & Assistant Professor & 78 & 3.77 & .556 & .063 \\
\hline & Associate Professor & 66 & 3.85 & .402 & .049 \\
\hline & Professor & 80 & 3.81 & .424 & .047 \\
\hline & Total & 235 & 3.79 & .484 & .032 \\
\hline \multirow{5}{*}{$\begin{array}{l}\text { The authority I have to make decisions } \\
\text { about other aspects of my job }\end{array}$} & Other (Inst/Tech) & 11 & 3.09 & .539 & .163 \\
\hline & Assistant Professor & 77 & 3.32 & .768 & .088 \\
\hline & Associate Professor & 66 & 3.42 & .609 & .075 \\
\hline & Professor & 80 & 3.38 & .624 & .070 \\
\hline & Total & 234 & 3.36 & .668 & .044 \\
\hline \multirow{5}{*}{$\begin{array}{l}\text { The mix of teaching, research, } \\
\text { administration, and service that I am } \\
\text { required to do }\end{array}$} & Other (Inst/Tech) & 11 & 2.91 & .831 & .251 \\
\hline & Assistant Professor & 78 & 3.15 & .774 & .088 \\
\hline & Associate Professor & 66 & 3.09 & .836 & .103 \\
\hline & Professor & 79 & 3.06 & .774 & .087 \\
\hline & Total & 234 & 3.09 & .791 & .052 \\
\hline
\end{tabular}


NSOPF descriptive statistics by academic rank (continued)

\begin{tabular}{|c|c|c|c|c|c|}
\hline \multirow{5}{*}{$\begin{array}{l}\text { The opportunity for advancement in rank at } \\
\text { my institution }\end{array}$} & Other (Inst/Tech) & 11 & 2.55 & 1.036 & .312 \\
\hline & Assistant Professor & 78 & 2.95 & .866 & .098 \\
\hline & Associate Professor & 67 & 3.03 & .953 & .116 \\
\hline & Professor & 78 & 3.42 & .830 & .094 \\
\hline & Total & 234 & 3.11 & .915 & .060 \\
\hline \multirow{5}{*}{$\begin{array}{l}\text { Time available for keeping current in my } \\
\text { field }\end{array}$} & Other (Inst/Tech) & 11 & 2.36 & .809 & .244 \\
\hline & Assistant Professor & 77 & 2.55 & .897 & .102 \\
\hline & Associate Professor & 67 & 2.39 & .969 & .118 \\
\hline & Professor & 80 & 2.40 & .805 & .090 \\
\hline & Total & 235 & 2.44 & .882 & .058 \\
\hline \multirow{5}{*}{$\begin{array}{l}\text { Availability of support services and } \\
\text { equipment (clerical support, computers, etc.) }\end{array}$} & Other (Inst/Tech) & 12 & 2.75 & .866 & .250 \\
\hline & Assistant Professor & 78 & 2.90 & .906 & .103 \\
\hline & Associate Professor & 67 & 2.97 & .904 & .110 \\
\hline & Professor & 80 & 2.79 & .882 & .099 \\
\hline & Total & 237 & 2.87 & .893 & .058 \\
\hline \multirow{5}{*}{ Freedom to do outside consulting } & Other (Inst/Tech) & 12 & 2.92 & .900 & .260 \\
\hline & Assistant Professor & 75 & 3.36 & .650 & .075 \\
\hline & Associate Professor & 64 & 3.23 & .729 & .091 \\
\hline & Professor & 75 & 3.28 & .763 & .088 \\
\hline & Total & 226 & 3.27 & .727 & .048 \\
\hline \multirow{5}{*}{ Overall reputation of the institution } & Other (Inst/Tech) & 11 & 3.27 & .647 & .195 \\
\hline & Assistant Professor & 77 & 3.25 & .905 & .103 \\
\hline & Associate Professor & 67 & 3.31 & .633 & .077 \\
\hline & Professor & 79 & 3.11 & .751 & .084 \\
\hline & Total & 234 & 3.22 & .771 & .050 \\
\hline \multirow{5}{*}{ Reputation of my department } & Other (Inst/Tech) & 12 & 3.17 & .718 & .207 \\
\hline & Assistant Professor & 78 & 3.23 & .882 & .100 \\
\hline & Associate Professor & 67 & 3.46 & .765 & .093 \\
\hline & Professor & 80 & 3.43 & .725 & .081 \\
\hline & Total & 237 & 3.36 & .793 & .052 \\
\hline \multirow{5}{*}{ Institutional mission or philosophy } & Other (Inst/Tech) & 12 & 3.58 & .515 & .149 \\
\hline & Assistant Professor & 77 & 3.61 & .588 & .067 \\
\hline & Associate Professor & 67 & 3.78 & .420 & .051 \\
\hline & Professor & 80 & 3.60 & .587 & .066 \\
\hline & Total & 236 & 3.65 & .544 & .035 \\
\hline \multirow{5}{*}{ Quality of leadership in my department } & Other (Inst/Tech) & 12 & 3.17 & .718 & .207 \\
\hline & Assistant Professor & 78 & 3.26 & .918 & .104 \\
\hline & Associate Professor & 67 & 3.55 & .764 & .093 \\
\hline & Professor & 79 & 3.38 & .852 & .096 \\
\hline & Total & 236 & 3.38 & .849 & .055 \\
\hline \multirow{5}{*}{$\begin{array}{l}\text { Quality of chief administrative officers at my } \\
\text { institution }\end{array}$} & Other (Inst/Tech) & 11 & 3.27 & .786 & .237 \\
\hline & Assistant Professor & 78 & 3.23 & .836 & .095 \\
\hline & Associate Professor & 67 & 3.19 & .957 & .117 \\
\hline & Professor & 80 & 2.93 & .978 & .109 \\
\hline & Total & 236 & 3.12 & .924 & .060 \\
\hline
\end{tabular}


NSOPF descriptive statistics by academic rank (continued)

\begin{tabular}{|c|c|c|c|c|c|}
\hline \multirow[b]{5}{*}{ Quality of my colleagues in my department } & Other (Inst/Tech) & 12 & 3.58 & .669 & .193 \\
\hline & Assistant Professor & 78 & 3.42 & .730 & .083 \\
\hline & Associate Professor & 66 & 3.62 & .602 & .074 \\
\hline & Professor & 78 & 3.46 & .678 & .077 \\
\hline & Total & 234 & 3.50 & .676 & .044 \\
\hline \multirow{5}{*}{ Quality of faculty leadership at my institution } & Other (Inst/Tech) & 12 & 3.00 & .953 & .275 \\
\hline & Assistant Professor & 78 & 3.17 & .796 & .090 \\
\hline & Associate Professor & 67 & 3.18 & .851 & .104 \\
\hline & Professor & 79 & 3.04 & .759 & .085 \\
\hline & Total & 236 & 3.12 & .806 & .052 \\
\hline \multirow{5}{*}{$\begin{array}{l}\text { Relationship between administration and } \\
\text { faculty at this institution }\end{array}$} & Other (Inst/Tech) & 12 & 2.92 & .669 & .193 \\
\hline & Assistant Professor & 78 & 2.82 & .936 & .106 \\
\hline & Associate Professor & 67 & 2.88 & 1.008 & .123 \\
\hline & Professor & 79 & 2.66 & .846 & .095 \\
\hline & Total & 236 & 2.79 & .917 & .060 \\
\hline \multirow{5}{*}{$\begin{array}{l}\text { Interdepartmental cooperation at this } \\
\text { institution }\end{array}$} & Other (Inst/Tech) & 12 & 2.50 & .674 & .195 \\
\hline & Assistant Professor & 78 & 2.73 & .878 & .099 \\
\hline & Associate Professor & 67 & 2.78 & .850 & .104 \\
\hline & Professor & 79 & 2.94 & .722 & .081 \\
\hline & Total & 236 & 2.80 & .814 & .053 \\
\hline \multirow{5}{*}{$\begin{array}{l}\text { Spirit of cooperation between faculty at this } \\
\text { institution }\end{array}$} & Other (Inst/Tech) & 12 & 2.67 & .651 & .188 \\
\hline & Assistant Professor & 78 & 2.99 & .845 & .096 \\
\hline & Associate Professor & 67 & 3.19 & .657 & .080 \\
\hline & Professor & 80 & 3.14 & .759 & .085 \\
\hline & Total & 237 & 3.08 & .763 & .050 \\
\hline \multirow{5}{*}{ Quality of my research facilities and support } & Other (Inst/Tech) & 11 & 2.55 & .820 & .247 \\
\hline & Assistant Professor & 76 & 2.45 & .823 & .094 \\
\hline & Associate Professor & 65 & 2.40 & .880 & .109 \\
\hline & Professor & 74 & 2.35 & .835 & .097 \\
\hline & Total & 226 & 2.41 & .839 & .056 \\
\hline \multirow{5}{*}{ Quality of students whom I have taught here } & Other (Inst/Tech) & 12 & 3.00 & .853 & .246 \\
\hline & Assistant Professor & 78 & 3.00 & .837 & .095 \\
\hline & Associate Professor & 67 & 3.19 & .657 & .080 \\
\hline & Professor & 80 & 3.06 & .735 & .082 \\
\hline & Total & 237 & 3.08 & .755 & .049 \\
\hline \multirow{5}{*}{ Teaching assistance that I receive } & Other (Inst/Tech) & 9 & 2.44 & .882 & .294 \\
\hline & Assistant Professor & 71 & 2.75 & .906 & .108 \\
\hline & Associate Professor & 61 & 2.77 & .956 & .122 \\
\hline & Professor & 75 & 2.59 & .807 & .093 \\
\hline & Total & 216 & 2.69 & .886 & .060 \\
\hline \multirow{5}{*}{ Research assistance that I receive } & Other (Inst/Tech) & 9 & 2.33 & .866 & .289 \\
\hline & Assistant Professor & 70 & 2.41 & .860 & .103 \\
\hline & Associate Professor & 57 & 2.30 & .963 & .128 \\
\hline & Professor & 68 & 2.29 & .830 & .101 \\
\hline & Total & 204 & 2.34 & .876 & .061 \\
\hline
\end{tabular}


NSOPF descriptive statistics by academic rank (continued)

\begin{tabular}{|c|c|c|c|c|c|}
\hline \multirow{5}{*}{$\begin{array}{l}\text { Spouse employment opportunities in this } \\
\text { geographic area }\end{array}$} & Other (Inst/Tech) & 9 & 2.78 & .972 & .324 \\
\hline & Assistant Professor & 71 & 3.17 & .894 & .106 \\
\hline & Associate Professor & 60 & 3.37 & .736 & .095 \\
\hline & Professor & 74 & 3.39 & .637 & .074 \\
\hline & Total & 214 & 3.29 & .780 & .053 \\
\hline \multirow{5}{*}{ My overall satisfaction with my job here } & Other (Inst/Tech) & 12 & 3.17 & .389 & .112 \\
\hline & Assistant Professor & 77 & 3.45 & .680 & .077 \\
\hline & Associate Professor & 67 & 3.54 & .636 & .078 \\
\hline & Professor & 80 & 3.45 & .593 & .066 \\
\hline & Total & 236 & 3.46 & .628 & .041 \\
\hline $\begin{array}{l}\text { If you were to leave your current institution, } \\
\text { how likely is it that you would do so to? }\end{array}$ & Academic Rank & $N$ & Mean & $\begin{array}{l}\text { Standard } \\
\text { Deviation }\end{array}$ & $\begin{array}{l}\text { Standard } \\
\text { Error }\end{array}$ \\
\hline \multirow{5}{*}{ Leave to Retire } & Other (Inst/Tech) & 12 & 1.67 & .888 & .256 \\
\hline & Assistant Professor & 78 & 1.92 & .894 & .101 \\
\hline & Associate Professor & 67 & 2.30 & .905 & .111 \\
\hline & Professor & 80 & 2.34 & .885 & .099 \\
\hline & Total & 237 & 2.16 & .914 & .059 \\
\hline \multirow{5}{*}{ Return to school as a student } & Other (Inst/Tech) & 10 & 1.60 & .699 & .221 \\
\hline & Assistant Professor & 78 & 1.29 & .561 & .064 \\
\hline & Associate Professor & 67 & 1.12 & .370 & .045 \\
\hline & Professor & 80 & 1.10 & .377 & .042 \\
\hline & Total & 235 & 1.19 & .473 & .031 \\
\hline \multirow{5}{*}{$\begin{array}{l}\text { Accept employment at another Christian } \\
\text { college or university }\end{array}$} & Other (Inst/Tech) & 10 & 2.20 & .422 & .133 \\
\hline & Assistant Professor & 78 & 2.10 & .636 & .072 \\
\hline & Associate Professor & 67 & 1.99 & .707 & .086 \\
\hline & Professor & 80 & 1.94 & .700 & .078 \\
\hline & Total & 235 & 2.02 & .673 & .044 \\
\hline \multirow{5}{*}{$\begin{array}{l}\text { Accept employment at a secular college or } \\
\text { university }\end{array}$} & Other (Inst/Tech) & 10 & 2.30 & .675 & .213 \\
\hline & Assistant Professor & 77 & 1.77 & .705 & .080 \\
\hline & Associate Professor & 67 & 1.54 & .611 & .075 \\
\hline & Professor & 80 & 1.51 & .595 & .067 \\
\hline & Total & 234 & 1.64 & .662 & .043 \\
\hline \multirow{5}{*}{$\begin{array}{l}\text { Accept employment in consulting or other } \\
\text { for-profit business or industry or become } \\
\text { self-employed }\end{array}$} & Other (Inst/Tech) & 10 & 1.80 & .789 & .249 \\
\hline & Assistant Professor & 78 & 1.62 & .725 & .082 \\
\hline & Associate Professor & 67 & 1.66 & .686 & .084 \\
\hline & Professor & 80 & 1.50 & .694 & .078 \\
\hline & Total & 235 & 1.60 & .706 & .046 \\
\hline \multirow{5}{*}{$\begin{array}{l}\text { Accept employment in a non-profit } \\
\text { organization }\end{array}$} & Other (Inst/Tech) & 10 & 1.80 & .789 & .249 \\
\hline & Assistant Professor & 78 & 1.65 & .621 & .070 \\
\hline & Associate Professor & 67 & 1.79 & .616 & .075 \\
\hline & Professor & 79 & 1.71 & .644 & .072 \\
\hline & Total & 234 & 1.72 & .633 & .041 \\
\hline
\end{tabular}


NSOPF descriptive statistics by academic rank (continued)

\begin{tabular}{|c|c|c|c|c|c|}
\hline $\begin{array}{c}\text { If you were to leave your current institution } \\
\text { to accept another position, would you want } \\
\text { to do more, less or about the same amount } \\
\text { of the following as you currently do? }\end{array}$ & Academic Rank & $N$ & Mean & $\begin{array}{l}\text { Standard } \\
\text { Deviation }\end{array}$ & $\begin{array}{c}\text { Standard } \\
\text { Error }\end{array}$ \\
\hline \multirow{5}{*}{ Research } & Other (Inst/Tech) & 10 & 1.50 & .527 & .167 \\
\hline & Assistant Professor & 77 & 1.62 & .650 & .074 \\
\hline & Associate Professor & 65 & 1.68 & .709 & .088 \\
\hline & Professor & 80 & 1.45 & .571 & .064 \\
\hline & Total & 232 & 1.57 & 640 & .042 \\
\hline \multirow{5}{*}{ Teaching } & Other (Inst/Tech) & 10 & 1.70 & .483 & .153 \\
\hline & Assistant Professor & 78 & 2.14 & 618 & .070 \\
\hline & Associate Professor & 66 & 2.14 & .579 & .071 \\
\hline & Professor & 79 & 2.20 & .540 & .061 \\
\hline & Total & 233 & 2.14 & .581 & .038 \\
\hline \multirow{5}{*}{ Advising } & Other (Inst/Tech) & 10 & 2.10 & .738 & .233 \\
\hline & Assistant Professor & 77 & 2.12 & .537 & .061 \\
\hline & Associate Professor & 65 & 2.20 & .440 & .055 \\
\hline & Professor & 80 & 2.38 & .560 & .063 \\
\hline & Total & 232 & 2.23 & .538 & .035 \\
\hline \multirow{5}{*}{ Service } & Other (Inst/Tech) & 10 & 1.90 & .316 & .100 \\
\hline & Assistant Professor & 78 & 2.06 & .566 & .064 \\
\hline & Associate Professor & 66 & 2.17 & .543 & .067 \\
\hline & Professor & 80 & 2.24 & .579 & .065 \\
\hline & Total & 234 & 2.15 & .560 & .037 \\
\hline \multirow{5}{*}{ Administration } & Other (Inst/Tech) & 10 & 2.00 & .667 & .211 \\
\hline & Assistant Professor & 76 & 2.18 & .687 & .079 \\
\hline & Associate Professor & 65 & 2.25 & .662 & .082 \\
\hline & Professor & 80 & 2.42 & 671 & .075 \\
\hline & Total & 231 & 2.28 & 680 & .045 \\
\hline $\begin{array}{l}\text { If you were to leave your current institution } \\
\text { to accept another position, how important } \\
\text { would each of the following items be in your } \\
\text { decision to accept another position? }\end{array}$ & Academic Rank & $N$ & Mean & $\begin{array}{l}\text { Standard } \\
\text { Deviation }\end{array}$ & $\begin{array}{c}\text { Standard } \\
\text { Error }\end{array}$ \\
\hline \multirow{5}{*}{ Salary Level } & Other (Inst/Tech) & 12 & 2.58 & .515 & .149 \\
\hline & Assistant Professor & 79 & 2.51 & .552 & .062 \\
\hline & Associate Professor & 67 & 2.43 & .557 & .068 \\
\hline & Professor & 80 & 2.36 & .579 & .065 \\
\hline & Total & 238 & 2.44 & .561 & .036 \\
\hline \multirow{5}{*}{ Position Level } & Other (Inst/Tech) & 12 & 2.42 & .515 & .149 \\
\hline & Assistant Professor & 78 & 2.31 & .610 & .069 \\
\hline & Associate Professor & 67 & 2.34 & .565 & .069 \\
\hline & Professor & 80 & 2.38 & .663 & .074 \\
\hline & Total & 237 & 2.35 & .609 & .040 \\
\hline
\end{tabular}


NSOPF descriptive statistics by academic rank (continued)

\begin{tabular}{|c|c|c|c|c|c|}
\hline \multirow[b]{5}{*}{ Job Security } & Other (Inst/Tech) & 12 & 2.83 & .389 & .112 \\
\hline & Assistant Professor & 78 & 2.55 & .638 & .072 \\
\hline & Associate Professor & 67 & 2.55 & .610 & .075 \\
\hline & Professor & 80 & 2.48 & .636 & .071 \\
\hline & Total & 237 & 2.54 & .621 & .040 \\
\hline \multirow{5}{*}{ Opportunities for advancement } & Other (Inst/Tech) & 12 & 2.58 & .515 & .149 \\
\hline & Assistant Professor & 79 & 2.42 & .612 & .069 \\
\hline & Associate Professor & 67 & 2.36 & .644 & .079 \\
\hline & Professor & 80 & 2.14 & .759 & .085 \\
\hline & Total & 238 & 2.32 & .679 & .044 \\
\hline \multirow{5}{*}{ Benefits } & Other (Inst/Tech) & 12 & 2.83 & .389 & .112 \\
\hline & Assistant Professor & 79 & 2.71 & .484 & .055 \\
\hline & Associate Professor & 67 & 2.64 & .513 & .063 \\
\hline & Professor & 80 & 2.58 & .546 & .061 \\
\hline & Total & 238 & 2.65 & .512 & .033 \\
\hline \multirow{5}{*}{ No pressure to publish } & Other (Inst/Tech) & 12 & 2.42 & .669 & .193 \\
\hline & Assistant Professor & 79 & 2.23 & .715 & .080 \\
\hline & Associate Professor & 67 & 2.16 & .751 & .092 \\
\hline & Professor & 80 & 2.05 & .710 & .079 \\
\hline & Total & 238 & 2.16 & .723 & .047 \\
\hline \multirow{5}{*}{ Academic Freedom } & Other (Inst/Tech) & 12 & 2.25 & .622 & .179 \\
\hline & Assistant Professor & 79 & 2.59 & .494 & .056 \\
\hline & Associate Professor & 67 & 2.64 & .569 & .070 \\
\hline & Professor & 80 & 2.56 & .570 & .064 \\
\hline & Total & 238 & 2.58 & .551 & .036 \\
\hline \multirow{5}{*}{ Good research facilities and equipment } & Other (Inst/Tech) & 11 & 2.45 & .688 & .207 \\
\hline & Assistant Professor & 79 & 2.16 & .608 & .068 \\
\hline & Associate Professor & 66 & 2.05 & .666 & .082 \\
\hline & Professor & 80 & 2.11 & .711 & .080 \\
\hline & Total & 236 & 2.13 & .666 & .043 \\
\hline \multirow{5}{*}{ Good instructional facilities and equipment } & Other (Inst/Tech) & 11 & 2.73 & .467 & .141 \\
\hline & Assistant Professor & 79 & 2.53 & .502 & .057 \\
\hline & Associate Professor & 67 & 2.58 & .581 & .071 \\
\hline & Professor & 80 & 2.51 & .616 & .069 \\
\hline & Total & 237 & 2.55 & .563 & .037 \\
\hline \multirow{5}{*}{ Excellent Students } & Other (Inst/Tech) & 12 & 2.58 & .515 & .149 \\
\hline & Assistant Professor & 79 & 2.41 & .543 & .061 \\
\hline & Associate Professor & 67 & 2.48 & .560 & .068 \\
\hline & Professor & 80 & 2.39 & .606 & .068 \\
\hline & Total & 238 & 2.43 & .567 & .037 \\
\hline \multirow{5}{*}{ Excellent Colleagues } & Other (Inst/Tech) & 12 & 2.75 & .452 & .131 \\
\hline & Assistant Professor & 79 & 2.65 & .481 & .054 \\
\hline & Associate Professor & 67 & 2.75 & .472 & .058 \\
\hline & Professor & 80 & 2.60 & .493 & .055 \\
\hline & Total & 238 & 2.66 & .482 & .031 \\
\hline
\end{tabular}


NSOPF descriptive statistics by academic rank (continued)

\begin{tabular}{|c|c|c|c|c|c|}
\hline \multirow[b]{5}{*}{ New institution is a Christian college } & Other (Inst/Tech) & 12 & 2.08 & .793 & .229 \\
\hline & Assistant Professor & 79 & 2.18 & .694 & .078 \\
\hline & Associate Professor & 67 & 2.43 & .657 & .080 \\
\hline & Professor & 80 & 2.29 & .750 & .084 \\
\hline & Total & 238 & 2.28 & .712 & .046 \\
\hline \multirow{5}{*}{$\begin{array}{l}\text { Institutional mission or philosophy that is } \\
\text { compatible with my own views }\end{array}$} & Other (Inst/Tech) & 12 & 2.50 & .522 & .151 \\
\hline & Assistant Professor & 79 & 2.63 & .535 & .060 \\
\hline & Associate Professor & 66 & 2.73 & .513 & .063 \\
\hline & Professor & 80 & 2.66 & .502 & .056 \\
\hline & Total & 237 & 2.66 & .517 & .034 \\
\hline \multirow{5}{*}{ Good job for my spouse } & Other (Inst/Tech) & 11 & 2.27 & .905 & .273 \\
\hline & Assistant Professor & 73 & 2.21 & .833 & .097 \\
\hline & Associate Professor & 65 & 2.00 & .919 & .114 \\
\hline & Professor & 78 & 2.06 & .795 & .090 \\
\hline & Total & 227 & 2.10 & .848 & .056 \\
\hline \multirow{5}{*}{ Good geographic location } & Other (Inst/Tech) & 12 & 2.33 & .492 & .142 \\
\hline & Assistant Professor & 78 & 2.51 & .639 & .072 \\
\hline & Associate Professor & 66 & 2.53 & .613 & .075 \\
\hline & Professor & 79 & 2.32 & .631 & .071 \\
\hline & Total & 235 & 2.44 & .627 & .041 \\
\hline \multirow{5}{*}{ Affordable Housing } & Other (Inst/Tech) & 12 & 2.25 & .754 & .218 \\
\hline & Assistant Professor & 76 & 2.55 & .620 & .071 \\
\hline & Associate Professor & 67 & 2.60 & .552 & .067 \\
\hline & Professor & 80 & 2.42 & .612 & .068 \\
\hline & Total & 235 & 2.51 & .609 & .040 \\
\hline \multirow{5}{*}{ Good environment/schools for my children } & Other (Inst/Tech) & 11 & 2.00 & .894 & .270 \\
\hline & Assistant Professor & 73 & 2.16 & .913 & .107 \\
\hline & Associate Professor & 62 & 2.00 & .941 & .119 \\
\hline & Professor & 78 & 1.68 & .830 & .094 \\
\hline & Total & 224 & 1.94 & .909 & .061 \\
\hline \multirow{5}{*}{ A full-time position } & Other (Inst/Tech) & 12 & 2.83 & .389 & .112 \\
\hline & Assistant Professor & 77 & 2.79 & .496 & .056 \\
\hline & Associate Professor & 64 & 2.64 & .721 & .090 \\
\hline & Professor & 79 & 2.75 & .565 & .064 \\
\hline & Total & 232 & 2.74 & .585 & .038 \\
\hline \multirow{5}{*}{ A part-time position } & Other (Inst/Tech) & 11 & 1.27 & .467 & .141 \\
\hline & Assistant Professor & 75 & 1.41 & .660 & .076 \\
\hline & Associate Professor & 66 & 1.35 & .620 & .076 \\
\hline & Professor & 76 & 1.16 & .402 & .046 \\
\hline & Total & 228 & 1.30 & .571 & .038 \\
\hline
\end{tabular}


NSOPF descriptive statistics by academic rank (continued)

\begin{tabular}{|c|c|c|c|c|c|}
\hline $\begin{array}{l}\text { Please indicate the extent to which you } \\
\text { agree or disagree with each of the following } \\
\text { statements. }\end{array}$ & Academic Rank & $N$ & Mean & $\begin{array}{l}\text { Standard } \\
\text { Deviation }\end{array}$ & $\begin{array}{c}\text { Standard } \\
\text { Error }\end{array}$ \\
\hline \multirow{5}{*}{$\begin{array}{l}\text { It is important for faculty to participate in } \\
\text { governing their institution }\end{array}$} & Other (Inst/Tech) & 12 & 3.42 & .515 & .149 \\
\hline & Assistant Professor & 79 & 3.62 & .562 & .063 \\
\hline & Associate Professor & 66 & 3.64 & .515 & .063 \\
\hline & Professor & 80 & 3.70 & .604 & .068 \\
\hline & Total & 237 & 3.64 & .562 & .036 \\
\hline \multirow{5}{*}{$\begin{array}{l}\text { Faculty promotions should be based at least } \\
\text { in part on formal student evaluations }\end{array}$} & Other (Inst/Tech) & 12 & 2.67 & .651 & .188 \\
\hline & Assistant Professor & 79 & 2.94 & .852 & .096 \\
\hline & Associate Professor & 67 & 2.91 & .733 & .090 \\
\hline & Professor & 80 & 3.03 & .729 & .081 \\
\hline & Total & 238 & 2.95 & .769 & .050 \\
\hline \multirow{5}{*}{$\begin{array}{l}\text { The tenure system in higher education } \\
\text { should be preserved. }\end{array}$} & Other (Inst/Tech) & 12 & 2.50 & .674 & .195 \\
\hline & Assistant Professor & 79 & 2.68 & .941 & .106 \\
\hline & Associate Professor & 66 & 2.98 & .920 & .113 \\
\hline & Professor & 80 & 2.85 & .982 & .110 \\
\hline & Total & 237 & 2.81 & .943 & .061 \\
\hline \multirow{5}{*}{$\begin{array}{l}\text { Teaching effectiveness should be the } \\
\text { primary criterion for promotion of faculty }\end{array}$} & Other (Inst/Tech) & 12 & 3.17 & .718 & .207 \\
\hline & Assistant Professor & 79 & 3.28 & .619 & .070 \\
\hline & Associate Professor & 66 & 3.39 & .677 & .083 \\
\hline & Professor & 80 & 3.29 & .679 & .076 \\
\hline & Total & 237 & 3.31 & .659 & .043 \\
\hline \multirow{5}{*}{$\begin{array}{l}\text { Research/publications should be the primary } \\
\text { criterion for promotion of college faculty }\end{array}$} & Other (Inst/Tech) & 12 & 2.00 & .739 & .213 \\
\hline & Assistant Professor & 79 & 1.87 & .648 & .073 \\
\hline & Associate Professor & 67 & 1.94 & .736 & .090 \\
\hline & Professor & 80 & 1.90 & .704 & .079 \\
\hline & Total & 238 & 1.91 & .693 & .045 \\
\hline \multirow{5}{*}{$\begin{array}{l}\text { Years of service/advanced degree should be } \\
\text { the primary criterion for promotion of college } \\
\text { faculty }\end{array}$} & Other (Inst/Tech) & 12 & 2.17 & .937 & .271 \\
\hline & Assistant Professor & 79 & 2.56 & .747 & .084 \\
\hline & Associate Professor & 67 & 2.63 & .714 & .087 \\
\hline & Professor & 78 & 2.32 & .781 & .088 \\
\hline & Total & 236 & 2.48 & .769 & .050 \\
\hline \multirow{5}{*}{$\begin{array}{l}\text { The administrative function is taking an } \\
\text { increasingly heavy share of available } \\
\text { resources at my institution }\end{array}$} & Other (Inst/Tech) & 12 & 2.67 & .651 & .188 \\
\hline & Assistant Professor & 77 & 2.47 & .771 & .088 \\
\hline & Associate Professor & 65 & 2.83 & .894 & .111 \\
\hline & Professor & 78 & 2.97 & .897 & .102 \\
\hline & Total & 232 & 2.75 & .867 & .057 \\
\hline \multirow{5}{*}{$\begin{array}{l}\text { State or federally mandated assessment } \\
\text { requirements have improved the quality of } \\
\text { undergraduate education at my institution }\end{array}$} & Other (Inst/Tech) & 11 & 2.09 & .701 & .211 \\
\hline & Assistant Professor & 74 & 2.32 & .760 & .088 \\
\hline & Associate Professor & 67 & 2.25 & .910 & .111 \\
\hline & Professor & 77 & 2.13 & .833 & .095 \\
\hline & Total & 229 & 2.23 & .828 & .055 \\
\hline
\end{tabular}


NSOPF descriptive statistics by academic rank (continued)

\begin{tabular}{|c|c|c|c|c|c|}
\hline \multirow{5}{*}{$\begin{array}{l}\text { Female faculty members are treated fairly at } \\
\text { my institution }\end{array}$} & Other (Inst/Tech) & 12 & 3.17 & .577 & .167 \\
\hline & Assistant Professor & 78 & 3.18 & .818 & .093 \\
\hline & Associate Professor & 67 & 3.33 & .746 & .091 \\
\hline & Professor & 79 & 3.28 & .733 & .082 \\
\hline & Total & 236 & 3.25 & .757 & .049 \\
\hline \multirow{5}{*}{$\begin{array}{l}\text { Faculty who are members of racial or ethnic } \\
\text { minorities are treated fairly at my institution }\end{array}$} & Other (Inst/Tech) & 12 & 3.08 & .900 & .260 \\
\hline & Assistant Professor & 76 & 3.29 & .745 & .085 \\
\hline & Associate Professor & 66 & 3.29 & .799 & .098 \\
\hline & Professor & 80 & 3.30 & .770 & .086 \\
\hline & Total & 234 & 3.28 & .773 & .051 \\
\hline \multirow{5}{*}{$\begin{array}{l}\text { My institution effectively meets the } \\
\text { educational needs of entering students }\end{array}$} & Other (Inst/Tech) & 12 & 3.25 & .754 & .218 \\
\hline & Assistant Professor & 78 & 3.15 & .774 & .088 \\
\hline & Associate Professor & 66 & 3.29 & .674 & .083 \\
\hline & Professor & 79 & 3.24 & .645 & .073 \\
\hline & Total & 235 & 3.23 & .701 & .046 \\
\hline \multirow{5}{*}{$\begin{array}{l}\text { If I had it to do over again, I would choose } \\
\text { an academic career }\end{array}$} & Other (Inst/Tech) & 12 & 3.67 & .492 & .142 \\
\hline & Assistant Professor & 79 & 3.80 & .490 & .055 \\
\hline & Associate Professor & 67 & 3.73 & .642 & .078 \\
\hline & Professor & 80 & 3.83 & .414 & .046 \\
\hline & Total & 238 & 3.78 & .514 & .033 \\
\hline
\end{tabular}


NSOPF descriptive statistics by years teaching (career)

\begin{tabular}{|c|c|c|c|c|c|}
\hline $\begin{array}{l}\text { How satisfied or dissatisfied do you personally } \\
\text { feel about each of the following aspects of your } \\
\text { job at your current institution }\end{array}$ & $\begin{array}{l}\text { Years Teaching } \\
\text { (Career) }\end{array}$ & $N$ & Mean & $\begin{array}{l}\text { Standard } \\
\text { Deviation }\end{array}$ & $\begin{array}{l}\text { Standard } \\
\text { Error }\end{array}$ \\
\hline \multirow{4}{*}{ My Work Load } & $1-5$ years & 42 & 3.21 & .750 & .116 \\
\hline & $6-11$ years & 55 & 2.82 & .925 & .125 \\
\hline & 12 or more years & 138 & 2.78 & .844 & .072 \\
\hline & Total & 235 & 2.87 & .860 & .056 \\
\hline \multirow{4}{*}{ My job security } & 1-5 years & 41 & 3.44 & .594 & .093 \\
\hline & $6-11$ years & 55 & 3.00 & 1.106 & 149 \\
\hline & 12 or more years & 138 & 3.54 & .663 & .056 \\
\hline & Total & 234 & 3.40 & .808 & .053 \\
\hline \multirow{4}{*}{ My Salary } & $1-5$ years & 42 & 2.55 & .803 & .124 \\
\hline & $6-11$ years & 55 & 2.64 & .969 & .131 \\
\hline & 12 or more years & 138 & 2.70 & .868 & .074 \\
\hline & Total & 235 & 2.66 & .880 & .057 \\
\hline \multirow{4}{*}{ My Benefits } & $1-5$ years & 42 & 2.88 & .832 & .128 \\
\hline & $6-11$ years & 55 & 2.75 & .985 & .133 \\
\hline & 12 or more years & 137 & 2.87 & .873 & .075 \\
\hline & Total & 234 & 2.84 & .891 & .058 \\
\hline \multirow{4}{*}{$\begin{array}{l}\text { The authority I have to make decisions about } \\
\text { what courses I teach }\end{array}$} & $1-5$ years & 42 & 3.43 & .630 & .097 \\
\hline & $6-11$ years & 55 & 3.25 & .907 & .122 \\
\hline & 12 or more years & 136 & 3.49 & .789 & .068 \\
\hline & Total & 233 & 3.42 & .796 & .052 \\
\hline \multirow{4}{*}{$\begin{array}{l}\text { The authority I have to make decisions about the } \\
\text { content and methods in the courses I teach }\end{array}$} & $1-5$ years & 42 & 3.81 & .397 & .061 \\
\hline & $6-11$ years & 55 & 3.78 & .599 & .081 \\
\hline & 12 or more years & 136 & 3.79 & .457 & .039 \\
\hline & Total & 233 & 3.79 & .483 & .032 \\
\hline \multirow{4}{*}{$\begin{array}{l}\text { The authority I have to make decisions about } \\
\text { other aspects of my job }\end{array}$} & 1-5 years & 42 & 3.36 & .656 & .101 \\
\hline & $6-11$ years & 54 & 3.17 & .818 & .111 \\
\hline & 12 or more years & 136 & 3.43 & .593 & .051 \\
\hline & Total & 232 & 3.36 & .669 & .044 \\
\hline \multirow{4}{*}{$\begin{array}{l}\text { The mix of teaching, research, administration, } \\
\text { and service that I am required to do }\end{array}$} & $1-5$ years & 42 & 3.31 & .680 & .105 \\
\hline & 6-11 years & 54 & 2.98 & .879 & .120 \\
\hline & 12 or more years & 136 & 3.07 & .785 & .067 \\
\hline & Total & 232 & 3.09 & .795 & .052 \\
\hline \multirow{4}{*}{$\begin{array}{l}\text { The opportunity for advancement in rank at my } \\
\text { institution }\end{array}$} & 1-5 years & 42 & 3.17 & .824 & .127 \\
\hline & 6-11 years & 55 & 3.02 & .933 & .126 \\
\hline & 12 or more years & 135 & 3.14 & .940 & .081 \\
\hline & Total & 232 & 3.12 & .916 & .060 \\
\hline \multirow{4}{*}{ Time available for keeping current in my field } & $1-5$ years & 41 & 2.85 & .910 & .142 \\
\hline & $6-11$ years & 55 & 2.22 & .917 & .124 \\
\hline & 12 or more years & 137 & 2.42 & .828 & .071 \\
\hline & Total & 233 & 2.45 & .885 & .058 \\
\hline
\end{tabular}


NSOPF descriptive statistics by years teaching (career) (continued)

\begin{tabular}{|c|c|c|c|c|c|}
\hline \multirow{4}{*}{$\begin{array}{l}\text { Availability of support services and equipment } \\
\text { (clerical support, computers, etc.) }\end{array}$} & $1-5$ years & 42 & 3.00 & .855 & .132 \\
\hline & 6-11 years & 55 & 2.75 & .886 & .120 \\
\hline & 12 or more years & 138 & 2.88 & .913 & .078 \\
\hline & Total & 235 & 2.87 & .897 & .058 \\
\hline \multirow{4}{*}{ Freedom to do outside consulting } & $1-5$ years & 42 & 3.45 & .593 & .091 \\
\hline & $6-11$ years & 51 & 3.18 & .767 & .107 \\
\hline & 12 or more years & 131 & 3.26 & .750 & .066 \\
\hline & Total & 224 & 3.28 & .730 & .049 \\
\hline \multirow{4}{*}{ Overall reputation of the institution } & $1-5$ years & 42 & 3.40 & .734 & .113 \\
\hline & $6-11$ years & 54 & 3.04 & .931 & .127 \\
\hline & 12 or more years & 136 & 3.24 & .704 & .060 \\
\hline & Total & 232 & 3.22 & .774 & .051 \\
\hline \multirow{4}{*}{ Reputation of my department } & $1-5$ years & 42 & 3.21 & .842 & .130 \\
\hline & $6-11$ years & 55 & 3.25 & .907 & .122 \\
\hline & 12 or more years & 138 & 3.44 & .725 & .062 \\
\hline & Total & 235 & 3.36 & .795 & .052 \\
\hline \multirow{4}{*}{ Institutional mission or philosophy } & $1-5$ years & 42 & 3.62 & .492 & .076 \\
\hline & $6-11$ years & 54 & 3.61 & .627 & .085 \\
\hline & 12 or more years & 138 & 3.68 & .526 & .045 \\
\hline & Total & 234 & 3.65 & .544 & .036 \\
\hline \multirow{4}{*}{ Quality of leadership in my department } & $1-5$ years & 42 & 3.48 & .740 & .114 \\
\hline & $6-11$ years & 55 & 3.20 & 1.043 & .141 \\
\hline & 12 or more years & 137 & 3.41 & .791 & .068 \\
\hline & Total & 234 & 3.37 & .851 & .056 \\
\hline \multirow{4}{*}{$\begin{array}{l}\text { Quality of chief administrative officers at my } \\
\text { institution }\end{array}$} & $1-5$ years & 42 & 3.40 & .587 & .091 \\
\hline & $6-11$ years & 55 & 3.22 & .937 & .126 \\
\hline & 12 or more years & 137 & 3.00 & .970 & .083 \\
\hline & Total & 234 & 3.12 & .916 & .060 \\
\hline \multirow{4}{*}{ Quality of my colleagues in my department } & $1-5$ years & 42 & 3.33 & .786 & .121 \\
\hline & $6-11$ years & 54 & 3.54 & .665 & .090 \\
\hline & 12 or more years & 136 & 3.54 & .643 & .055 \\
\hline & Total & 232 & 3.50 & .677 & .044 \\
\hline \multirow{4}{*}{ Quality of faculty leadership at my institution } & $1-5$ years & 42 & 3.19 & .804 & .124 \\
\hline & $6-11$ years & 55 & 3.02 & .892 & .120 \\
\hline & 12 or more years & 137 & 3.13 & .775 & .066 \\
\hline & Total & 234 & 3.12 & .807 & .053 \\
\hline \multirow{4}{*}{$\begin{array}{l}\text { Relationship between administration and faculty } \\
\text { at this institution }\end{array}$} & $1-5$ years & 42 & 3.02 & .680 & .105 \\
\hline & $6-11$ years & 55 & 2.75 & 1.004 & .135 \\
\hline & 12 or more years & 137 & 2.74 & .926 & .079 \\
\hline & Total & 234 & 2.79 & .910 & .059 \\
\hline \multirow{4}{*}{ Interdepartmental cooperation at this institution } & $1-5$ years & 42 & 2.67 & .874 & .135 \\
\hline & $6-11$ years & 55 & 2.71 & .916 & .124 \\
\hline & 12 or more years & 137 & 2.89 & .734 & .063 \\
\hline & Total & 234 & 2.81 & .809 & .053 \\
\hline
\end{tabular}


NSOPF descriptive statistics by years teaching (career) (continued)

\begin{tabular}{|c|c|c|c|c|c|}
\hline \multirow{4}{*}{$\begin{array}{l}\text { Spirit of cooperation between faculty at this } \\
\text { institution }\end{array}$} & 1-5 years & 42 & 2.95 & .825 & .127 \\
\hline & $6-11$ years & 55 & 2.95 & .756 & .102 \\
\hline & 12 or more years & 138 & 3.17 & .744 & .063 \\
\hline & Total & 235 & 3.08 & .766 & .050 \\
\hline \multirow{4}{*}{ Quality of my research facilities and support } & $1-5$ years & 41 & 2.51 & .746 & .116 \\
\hline & $6-11$ years & 53 & 2.21 & .927 & .127 \\
\hline & 12 or more years & 130 & 2.45 & .827 & .072 \\
\hline & Total & 224 & 2.40 & .841 & .056 \\
\hline \multirow{4}{*}{ Quality of students whom I have taught here } & $1-5$ years & 42 & 3.05 & .882 & .136 \\
\hline & $6-11$ years & 55 & 2.91 & .776 & .105 \\
\hline & 12 or more years & 138 & 3.14 & .700 & .060 \\
\hline & Total & 235 & 3.07 & .756 & .049 \\
\hline \multirow{4}{*}{ Teaching assistance that I receive } & $1-5$ years & 39 & 2.74 & .818 & .131 \\
\hline & $6-11$ years & 50 & 2.56 & 1.013 & .143 \\
\hline & 12 or more years & 125 & 2.72 & .858 & .077 \\
\hline & Total & 214 & 2.69 & .888 & .061 \\
\hline \multirow{4}{*}{ Research assistance that I receive } & $1-5$ years & 36 & 2.39 & .728 & .121 \\
\hline & $6-11$ years & 49 & 2.18 & .993 & .142 \\
\hline & 12 or more years & 117 & 2.39 & .861 & .080 \\
\hline & Total & 202 & 2.34 & .874 & .061 \\
\hline \multirow{4}{*}{$\begin{array}{l}\text { Spouse employment opportunities in this } \\
\text { geographic area }\end{array}$} & $1-5$ years & 39 & 3.03 & .986 & .158 \\
\hline & $6-11$ years & 52 & 3.23 & .783 & .109 \\
\hline & 12 or more years & 122 & 3.40 & .676 & .061 \\
\hline & Total & 213 & 3.29 & .777 & .053 \\
\hline \multirow{4}{*}{ My overall satisfaction with my job here } & $1-5$ years & 42 & 3.57 & .501 & .077 \\
\hline & $6-11$ years & 54 & 3.35 & .731 & .099 \\
\hline & 12 or more years & 138 & 3.48 & .619 & .053 \\
\hline & Total & 234 & 3.47 & .629 & .041 \\
\hline $\begin{array}{l}\text { If you were to leave your current institution, how } \\
\text { likely is it that you would do so to? }\end{array}$ & $\begin{array}{c}\text { Years Teaching } \\
\text { (Career) }\end{array}$ & $N$ & Mean & $\begin{array}{l}\text { Standard } \\
\text { Deviation }\end{array}$ & $\begin{array}{l}\text { Standard } \\
\text { Error }\end{array}$ \\
\hline \multirow{4}{*}{ Leave to Retire } & $1-5$ years & 42 & 1.93 & .894 & .138 \\
\hline & $6-11$ years & 55 & 1.87 & .944 & .127 \\
\hline & 12 or more years & 138 & 2.34 & .867 & .074 \\
\hline & Total & 235 & 2.16 & .913 & .060 \\
\hline \multirow{4}{*}{ Return to school as a student } & $1-5$ years & 42 & 1.26 & .544 & .084 \\
\hline & $6-11$ years & 55 & 1.24 & .543 & .073 \\
\hline & 12 or more years & 136 & 1.15 & .413 & .035 \\
\hline & Total & 233 & 1.19 & .472 & .031 \\
\hline \multirow{4}{*}{$\begin{array}{l}\text { Accept employment at another Christian college } \\
\text { or university }\end{array}$} & $1-5$ years & 42 & 2.10 & .532 & .082 \\
\hline & $6-11$ years & 55 & 2.16 & .660 & .089 \\
\hline & 12 or more years & 136 & 1.94 & .707 & .061 \\
\hline & Total & 233 & 2.02 & .672 & .044 \\
\hline
\end{tabular}


NSOPF descriptive statistics by years teaching (career) (continued)

\begin{tabular}{|c|c|c|c|c|c|}
\hline \multirow{4}{*}{$\begin{array}{l}\text { Accept employment at a secular college or } \\
\text { university }\end{array}$} & $1-5$ years & 42 & 1.86 & .751 & .116 \\
\hline & $6-11$ years & 55 & 1.75 & .726 & .098 \\
\hline & 12 or more years & 135 & 1.53 & .583 & .050 \\
\hline & Total & 232 & 1.64 & .662 & .043 \\
\hline \multirow{4}{*}{$\begin{array}{l}\text { Accept employment in consulting or other for- } \\
\text { profit business or industry or become self- } \\
\text { employed }\end{array}$} & $1-5$ years & 42 & 1.71 & .708 & .109 \\
\hline & $6-11$ years & 55 & 1.53 & .663 & .089 \\
\hline & 12 or more years & 136 & 1.58 & .726 & .062 \\
\hline & Total & 233 & 1.59 & .708 & .046 \\
\hline \multirow{4}{*}{ Accept employment in a non-profit organization } & $1-5$ years & 42 & 1.71 & .554 & .085 \\
\hline & $6-11$ years & 55 & 1.73 & .679 & .092 \\
\hline & 12 or more years & 135 & 1.72 & .642 & .055 \\
\hline & Total & 232 & 1.72 & .634 & .042 \\
\hline $\begin{array}{l}\text { If you were to leave your current institution to } \\
\text { accept another position, would you want to do } \\
\text { more, less or about the same amount of the } \\
\text { following as you currently do? }\end{array}$ & $\begin{array}{l}\text { Years Teaching } \\
\text { (Career) }\end{array}$ & $N$ & Mean & $\begin{array}{l}\text { Standard } \\
\text { Deviation }\end{array}$ & $\begin{array}{l}\text { Standard } \\
\text { Error }\end{array}$ \\
\hline \multirow{4}{*}{ Research } & $1-5$ years & 43 & 1.60 & .695 & .106 \\
\hline & $6-11$ years & 52 & 1.42 & .605 & .084 \\
\hline & 12 or more years & 135 & 1.62 & .633 & .055 \\
\hline & Total & 230 & 1.57 & .642 & .042 \\
\hline \multirow{4}{*}{ Teaching } & $1-5$ years & 43 & 2.07 & .552 & .084 \\
\hline & $6-11$ years & 53 & 2.13 & .680 & .093 \\
\hline & 12 or more years & 135 & 2.16 & .549 & .047 \\
\hline & Total & 231 & 2.14 & .581 & .038 \\
\hline \multirow{4}{*}{ Advising } & $1-5$ years & 43 & 2.16 & .531 & .081 \\
\hline & $6-11$ years & 53 & 2.15 & .533 & .073 \\
\hline & 12 or more years & 134 & 2.27 & .537 & .046 \\
\hline & Total & 230 & 2.22 & .536 & .035 \\
\hline \multirow{4}{*}{ Service } & $1-5$ years & 43 & 2.07 & .552 & .084 \\
\hline & $6-11$ years & 53 & 2.09 & .597 & .082 \\
\hline & 12 or more years & 136 & 2.18 & .547 & .047 \\
\hline & Total & 232 & 2.14 & .559 & .037 \\
\hline \multirow{4}{*}{ Administration } & $1-5$ years & 43 & 2.07 & .704 & .107 \\
\hline & $6-11$ years & 52 & 2.12 & .704 & .098 \\
\hline & 12 or more years & 134 & 2.40 & .639 & .055 \\
\hline & Total & 229 & 2.28 & .681 & .045 \\
\hline $\begin{array}{l}\text { If you were to leave your current institution to } \\
\text { accept another position, how important would } \\
\text { each of the following items be in your decision to } \\
\text { accept another position? }\end{array}$ & $\begin{array}{c}\text { Years Teaching } \\
\text { (Career) }\end{array}$ & $N$ & Mean & $\begin{array}{l}\text { Standard } \\
\text { Deviation }\end{array}$ & $\begin{array}{l}\text { Standard } \\
\text { Error }\end{array}$ \\
\hline \multirow{4}{*}{ Salary Level } & $1-5$ years & 43 & 2.51 & .592 & .090 \\
\hline & $6-11$ years & 55 & 2.40 & .596 & .080 \\
\hline & 12 or more years & 138 & 2.43 & .540 & .046 \\
\hline & Total & 236 & 2.44 & .562 & .037 \\
\hline
\end{tabular}


NSOPF descriptive statistics by years teaching (career) (continued)

\begin{tabular}{|c|c|c|c|c|c|}
\hline \multirow[b]{4}{*}{ Position Level } & $1-5$ years & 43 & 2.37 & .655 & .100 \\
\hline & $6-11$ years & 54 & 2.24 & .612 & .083 \\
\hline & 12 or more years & 138 & 2.38 & .594 & .051 \\
\hline & Total & 235 & 2.34 & .610 & .040 \\
\hline \multirow{4}{*}{ Job Security } & 1-5 years & 43 & 2.60 & .660 & .101 \\
\hline & $6-11$ years & 54 & 2.52 & .606 & .083 \\
\hline & 12 or more years & 138 & 2.52 & .619 & .053 \\
\hline & Total & 235 & 2.54 & .622 & .041 \\
\hline \multirow{4}{*}{ Opportunities for advancement } & $1-5$ years & 43 & 2.47 & .631 & .096 \\
\hline & $6-11$ years & 55 & 2.35 & .615 & .083 \\
\hline & 12 or more years & 138 & 2.25 & .713 & .061 \\
\hline & Total & 236 & 2.31 & .679 & .044 \\
\hline \multirow{4}{*}{ Benefits } & $1-5$ years & 43 & 2.67 & .566 & .086 \\
\hline & $6-11$ years & 55 & 2.69 & .466 & .063 \\
\hline & 12 or more years & 138 & 2.62 & .515 & .044 \\
\hline & Total & 236 & 2.65 & .513 & .033 \\
\hline \multirow{4}{*}{ No pressure to publish } & $1-5$ years & 43 & 2.02 & .771 & .118 \\
\hline & $6-11$ years & 55 & 2.09 & .701 & .095 \\
\hline & 12 or more years & 138 & 2.22 & .712 & .061 \\
\hline & Total & 236 & 2.15 & .722 & .047 \\
\hline \multirow{4}{*}{ Academic Freedom } & $1-5$ years & 43 & 2.47 & .550 & .084 \\
\hline & $6-11$ years & 55 & 2.58 & .567 & .077 \\
\hline & 12 or more years & 138 & 2.62 & .545 & .046 \\
\hline & Total & 236 & 2.58 & .551 & .036 \\
\hline \multirow{4}{*}{ Good research facilities and equipment } & $1-5$ years & 43 & 2.09 & .610 & .093 \\
\hline & 6-11 years & 55 & 2.20 & .558 & .075 \\
\hline & 12 or more years & 136 & 2.10 & .723 & .062 \\
\hline & Total & 234 & 2.12 & .666 & .044 \\
\hline \multirow{4}{*}{ Good instructional facilities and equipment } & $1-5$ years & 43 & 2.33 & .566 & .086 \\
\hline & $6-11$ years & 55 & 2.58 & .567 & .077 \\
\hline & 12 or more years & 137 & 2.60 & .549 & .047 \\
\hline & Total & 235 & 2.54 & .563 & .037 \\
\hline \multirow{4}{*}{ Excellent Students } & $1-5$ years & 43 & 2.37 & .578 & .088 \\
\hline & 6-11 years & 55 & 2.40 & .564 & .076 \\
\hline & 12 or more years & 138 & 2.45 & .568 & .048 \\
\hline & Total & 236 & 2.42 & .567 & .037 \\
\hline \multirow{4}{*}{ Excellent Colleagues } & $1-5$ years & 43 & 2.49 & .551 & .084 \\
\hline & $6-11$ years & 55 & 2.73 & .449 & .061 \\
\hline & 12 or more years & 138 & 2.69 & .465 & .040 \\
\hline & Total & 236 & 2.66 & .483 & .031 \\
\hline \multirow{4}{*}{ New institution is a Christian college } & $1-5$ years & 43 & 2.21 & .742 & .113 \\
\hline & $6-11$ years & 55 & 2.18 & .722 & .097 \\
\hline & 12 or more years & 138 & 2.34 & .699 & .060 \\
\hline & Total & 236 & 2.28 & .713 & .046 \\
\hline
\end{tabular}


NSOPF descriptive statistics by years teaching (career) (continued)

\begin{tabular}{|c|c|c|c|c|c|}
\hline \multirow{4}{*}{$\begin{array}{l}\text { Institutional mission or philosophy that is } \\
\text { compatible with my own views }\end{array}$} & $1-5$ years & 43 & 2.58 & .587 & .089 \\
\hline & $6-11$ years & 55 & 2.73 & .449 & .061 \\
\hline & 12 or more years & 137 & 2.66 & .518 & .044 \\
\hline & Total & 235 & 2.66 & .517 & .034 \\
\hline \multirow{4}{*}{ Good job for my spouse } & 1-5 years & 39 & 2.10 & .852 & .136 \\
\hline & $6-11$ years & 54 & 2.07 & .866 & .118 \\
\hline & 12 or more years & 133 & 2.11 & .846 & .073 \\
\hline & Total & 226 & 2.10 & .848 & .056 \\
\hline \multirow{4}{*}{ Good geographic location } & $1-5$ years & 42 & 2.40 & .734 & .113 \\
\hline & $6-11$ years & 55 & 2.51 & .573 & .077 \\
\hline & 12 or more years & 136 & 2.42 & .615 & .053 \\
\hline & Total & 233 & 2.44 & .627 & .041 \\
\hline \multirow{4}{*}{ Affordable Housing } & $1-5$ years & 42 & 2.36 & .692 & .107 \\
\hline & 6-11 years & 55 & 2.62 & .527 & .071 \\
\hline & 12 or more years & 136 & 2.50 & 609 & .052 \\
\hline & Total & 233 & 2.50 & 610 & .040 \\
\hline \multirow{4}{*}{ Good environment/schools for my children } & $1-5$ years & 40 & 1.95 & .904 & .143 \\
\hline & $6-11$ years & 53 & 2.23 & .891 & .122 \\
\hline & 12 or more years & 130 & 1.82 & .896 & .079 \\
\hline & Total & 223 & 1.94 & .908 & .061 \\
\hline \multirow{4}{*}{ A full-time position } & $1-5$ years & 43 & 2.74 & .539 & .082 \\
\hline & $6-11$ years & 54 & 2.78 & .572 & .078 \\
\hline & 12 or more years & 133 & 2.73 & .592 & .051 \\
\hline & Total & 230 & 2.74 & .576 & .038 \\
\hline \multirow{4}{*}{ A part-time position } & 1-5 years & 41 & 1.41 & .631 & .099 \\
\hline & $6-11$ years & 54 & 1.22 & .502 & .068 \\
\hline & 12 or more years & 131 & 1.29 & .561 & .049 \\
\hline & Total & 226 & 1.30 & .562 & .037 \\
\hline $\begin{array}{l}\text { Please indicate the extent to which you agree or } \\
\text { disagree with each of the following statements. }\end{array}$ & $\begin{array}{l}\text { Years Teaching } \\
\text { (Career) }\end{array}$ & $N$ & Mean & $\begin{array}{l}\text { Standard } \\
\text { Deviation } \\
\end{array}$ & $\begin{array}{l}\text { Standard } \\
\text { Error }\end{array}$ \\
\hline \multirow{4}{*}{$\begin{array}{l}\text { It is important for faculty to participate in } \\
\text { governing their institution }\end{array}$} & $1-5$ years & 43 & 3.58 & .587 & .089 \\
\hline & 6-11 years & 55 & 3.60 & .627 & .084 \\
\hline & 12 or more years & 137 & 3.68 & .528 & .045 \\
\hline & Total & 235 & 3.64 & .562 & .037 \\
\hline \multirow{4}{*}{$\begin{array}{l}\text { Faculty promotions should be based at least in } \\
\text { part on formal student evaluations }\end{array}$} & $1-5$ years & 43 & 3.07 & .737 & .112 \\
\hline & $6-11$ years & 55 & 2.76 & .942 & .127 \\
\hline & 12 or more years & 138 & 2.98 & .699 & .060 \\
\hline & Total & 236 & 2.94 & .773 & .050 \\
\hline \multirow{4}{*}{$\begin{array}{l}\text { The tenure system in higher education should be } \\
\text { preserved. }\end{array}$} & $1-5$ years & 43 & 2.65 & .842 & .128 \\
\hline & $6-11$ years & 55 & 2.80 & 1.007 & .136 \\
\hline & 12 or more years & 137 & 2.88 & .951 & .081 \\
\hline & Total & 235 & 2.82 & .945 & .062 \\
\hline
\end{tabular}


NSOPF descriptive statistics by years teaching (career) (continued)

\begin{tabular}{|c|c|c|c|c|c|}
\hline \multirow{4}{*}{$\begin{array}{l}\text { Teaching effectiveness should be the primary } \\
\text { criterion for promotion of faculty }\end{array}$} & $1-5$ years & 43 & 3.40 & .623 & .095 \\
\hline & 6-11 years & 55 & 3.22 & .712 & .096 \\
\hline & 12 or more years & 137 & 3.31 & .650 & .056 \\
\hline & Total & 235 & 3.31 & .660 & .043 \\
\hline \multirow{4}{*}{$\begin{array}{l}\text { Research/publications should be the primary } \\
\text { criterion for promotion of college faculty }\end{array}$} & $1-5$ years & 43 & 2.05 & .754 & .115 \\
\hline & 6-11 years & 55 & 1.93 & .604 & .081 \\
\hline & 12 or more years & 138 & 1.86 & .707 & .060 \\
\hline & Total & 236 & 1.91 & .694 & .045 \\
\hline \multirow{4}{*}{$\begin{array}{l}\text { Years of service/advanced degree should be the } \\
\text { primary criterion for promotion of college faculty }\end{array}$} & $1-5$ years & 43 & 2.42 & .823 & .126 \\
\hline & 6-11 years & 55 & 2.56 & .688 & .093 \\
\hline & 12 or more years & 136 & 2.46 & .788 & .068 \\
\hline & Total & 234 & 2.48 & .771 & .050 \\
\hline \multirow{4}{*}{$\begin{array}{l}\text { The administrative function is taking an } \\
\text { increasingly heavy share of available resources } \\
\text { at my institution }\end{array}$} & $1-5$ years & 41 & 2.51 & .779 & .122 \\
\hline & 6-11 years & 53 & 2.72 & .841 & .115 \\
\hline & 12 or more years & 136 & 2.85 & .893 & .077 \\
\hline & Total & 230 & 2.76 & .868 & .057 \\
\hline \multirow{4}{*}{$\begin{array}{l}\text { State or federally mandated assessment } \\
\text { requirements have improved the quality of } \\
\text { undergraduate education at my institution }\end{array}$} & $1-5$ years & 41 & 2.44 & .709 & .111 \\
\hline & 6-11 years & 52 & 2.10 & .869 & .121 \\
\hline & 12 or more years & 134 & 2.21 & .841 & .073 \\
\hline & Total & 227 & 2.22 & .830 & .055 \\
\hline \multirow{4}{*}{$\begin{array}{l}\text { Female faculty members are treated fairly at my } \\
\text { institution }\end{array}$} & $1-5$ years & 42 & 3.29 & .673 & .104 \\
\hline & 6-11 years & 55 & 3.24 & .793 & .107 \\
\hline & 12 or more years & 137 & 3.26 & .767 & .066 \\
\hline & Total & 234 & 3.26 & .754 & .049 \\
\hline \multirow{4}{*}{$\begin{array}{l}\text { Faculty who are members of racial or ethnic } \\
\text { minorities are treated fairly at my institution }\end{array}$} & $1-5$ years & 41 & 3.37 & .623 & .097 \\
\hline & 6-11 years & 53 & 3.25 & .853 & .117 \\
\hline & 12 or more years & 138 & 3.28 & .764 & .065 \\
\hline & Total & 232 & 3.29 & .761 & .050 \\
\hline \multirow{4}{*}{$\begin{array}{l}\text { My institution effectively meets the educational } \\
\text { needs of entering students }\end{array}$} & $1-5$ years & 42 & 3.31 & .749 & .116 \\
\hline & 6-11 years & 55 & 3.07 & .766 & .103 \\
\hline & 12 or more years & 137 & 3.26 & .653 & .056 \\
\hline & Total & 234 & 3.22 & .701 & .046 \\
\hline \multirow{4}{*}{$\begin{array}{l}\text { If I had it to do over again, I would choose an } \\
\text { academic career }\end{array}$} & 1-5 years & 43 & 3.74 & .581 & .089 \\
\hline & 6-11 years & 55 & 3.69 & .605 & .082 \\
\hline & 12 or more years & 138 & 3.83 & .451 & .038 \\
\hline & Total & 236 & 3.78 & .516 & .034 \\
\hline
\end{tabular}


NSOPF descriptive statistics by years teaching (institution)

\begin{tabular}{|c|c|c|c|c|c|}
\hline $\begin{array}{l}\text { How satisfied or dissatisfied do you personally } \\
\text { feel about each of the following aspects of your } \\
\text { job at your current institution }\end{array}$ & $\begin{array}{l}\text { Years Teaching } \\
\text { (Career) }\end{array}$ & $N$ & Mean & $\begin{array}{l}\text { Standard } \\
\text { Deviation }\end{array}$ & $\begin{array}{l}\text { Standard } \\
\text { Error }\end{array}$ \\
\hline \multirow{4}{*}{ My Work Load } & $1-5$ years & 74 & 3.00 & .936 & .109 \\
\hline & $6-11$ years & 64 & 2.84 & .877 & .110 \\
\hline & 12 or more years & 99 & 2.80 & .782 & .079 \\
\hline & Total & 237 & 2.87 & .859 & .056 \\
\hline \multirow{4}{*}{ My job security } & 1-5 years & 73 & 3.32 & .743 & .087 \\
\hline & $6-11$ years & 64 & 3.16 & .979 & .122 \\
\hline & 12 or more years & 99 & 3.62 & .666 & .067 \\
\hline & Total & 236 & 3.40 & .806 & .052 \\
\hline \multirow{4}{*}{ My Salary } & $1-5$ years & 74 & 2.59 & .792 & .092 \\
\hline & $6-11$ years & 64 & 2.80 & .929 & .116 \\
\hline & 12 or more years & 99 & 2.59 & .915 & .092 \\
\hline & Total & 237 & 2.65 & .884 & .057 \\
\hline \multirow{4}{*}{ My Benefits } & $1-5$ years & 74 & 2.88 & .843 & .098 \\
\hline & $6-11$ years & 63 & 2.86 & .877 & .111 \\
\hline & 12 or more years & 99 & 2.80 & .937 & .094 \\
\hline & Total & 236 & 2.84 & .889 & .058 \\
\hline \multirow{4}{*}{$\begin{array}{l}\text { The authority I have to make decisions about } \\
\text { what courses I teach }\end{array}$} & $1-5$ years & 74 & 3.30 & .735 & .085 \\
\hline & $6-11$ years & 64 & 3.36 & .966 & .121 \\
\hline & 12 or more years & 97 & 3.57 & .691 & .070 \\
\hline & Total & 235 & 3.43 & .794 & .052 \\
\hline \multirow{4}{*}{$\begin{array}{l}\text { The authority I have to make decisions about the } \\
\text { content and methods in the courses I teach }\end{array}$} & $1-5$ years & 74 & 3.78 & .504 & .059 \\
\hline & $6-11$ years & 64 & 3.77 & .556 & .070 \\
\hline & 12 or more years & 97 & 3.81 & .417 & .042 \\
\hline & Total & 235 & 3.79 & .484 & .032 \\
\hline \multirow{4}{*}{$\begin{array}{l}\text { The authority I have to make decisions about } \\
\text { other aspects of my job }\end{array}$} & 1-5 years & 72 & 3.33 & .650 & .077 \\
\hline & $6-11$ years & 64 & 3.20 & .780 & .098 \\
\hline & 12 or more years & 98 & 3.48 & .578 & .058 \\
\hline & Total & 234 & 3.36 & .668 & .044 \\
\hline \multirow{4}{*}{$\begin{array}{l}\text { The mix of teaching, research, administration, } \\
\text { and service that I am required to do }\end{array}$} & $1-5$ years & 73 & 3.22 & .786 & .092 \\
\hline & 6-11 years & 64 & 2.94 & .833 & .104 \\
\hline & 12 or more years & 97 & 3.10 & .757 & .077 \\
\hline & Total & 234 & 3.09 & .791 & .052 \\
\hline \multirow{4}{*}{$\begin{array}{l}\text { The opportunity for advancement in rank at my } \\
\text { institution }\end{array}$} & 1-5 years & 74 & 3.22 & .880 & .102 \\
\hline & 6-11 years & 63 & 2.95 & .869 & .110 \\
\hline & 12 or more years & 97 & 3.13 & .964 & .098 \\
\hline & Total & 234 & 3.11 & .915 & .060 \\
\hline \multirow{4}{*}{ Time available for keeping current in my field } & $1-5$ years & 73 & 2.64 & .933 & .109 \\
\hline & $6-11$ years & 64 & 2.25 & .891 & .111 \\
\hline & 12 or more years & 98 & 2.42 & .811 & .082 \\
\hline & Total & 235 & 2.44 & .882 & .058 \\
\hline
\end{tabular}


NSOPF descriptive statistics by years teaching (institution) (continued)

\begin{tabular}{|c|c|c|c|c|c|}
\hline \multirow{4}{*}{$\begin{array}{l}\text { Availability of support services and equipment } \\
\text { (clerical support, computers, etc.) }\end{array}$} & $1-5$ years & 74 & 2.89 & .945 & .110 \\
\hline & $6-11$ years & 64 & 2.69 & .871 & .109 \\
\hline & 12 or more years & 99 & 2.98 & .857 & .086 \\
\hline & Total & 237 & 2.87 & .893 & .058 \\
\hline \multirow{4}{*}{ Freedom to do outside consulting } & $1-5$ years & 71 & 3.32 & .650 & .077 \\
\hline & $6-11$ years & 62 & 3.26 & .828 & .105 \\
\hline & 12 or more years & 93 & 3.25 & .717 & .074 \\
\hline & Total & 226 & 3.27 & .727 & .048 \\
\hline \multirow{4}{*}{ Overall reputation of the institution } & $1-5$ years & 73 & 3.22 & .854 & .100 \\
\hline & $6-11$ years & 64 & 3.27 & .802 & .100 \\
\hline & 12 or more years & 97 & 3.20 & .687 & .070 \\
\hline & Total & 234 & 3.22 & .771 & .050 \\
\hline \multirow{4}{*}{ Reputation of my department } & $1-5$ years & 74 & 3.20 & .844 & .098 \\
\hline & $6-11$ years & 64 & 3.44 & .852 & .107 \\
\hline & 12 or more years & 99 & 3.42 & .701 & .070 \\
\hline & Total & 237 & 3.36 & .793 & .052 \\
\hline \multirow{4}{*}{ Institutional mission or philosophy } & $1-5$ years & 74 & 3.62 & .542 & .063 \\
\hline & $6-11$ years & 63 & 3.60 & .636 & .080 \\
\hline & 12 or more years & 99 & 3.71 & .479 & .048 \\
\hline & Total & 236 & 3.65 & .544 & .035 \\
\hline \multirow{4}{*}{ Quality of leadership in my department } & $1-5$ years & 74 & 3.36 & .837 & .097 \\
\hline & $6-11$ years & 64 & 3.38 & .900 & .112 \\
\hline & 12 or more years & 98 & 3.39 & .833 & .084 \\
\hline & Total & 236 & 3.38 & .849 & .055 \\
\hline \multirow{4}{*}{$\begin{array}{l}\text { Quality of chief administrative officers at my } \\
\text { institution }\end{array}$} & $1-5$ years & 74 & 3.32 & .760 & .088 \\
\hline & $6-11$ years & 64 & 3.16 & .946 & .118 \\
\hline & 12 or more years & 98 & 2.94 & .993 & .100 \\
\hline & Total & 236 & 3.12 & .924 & .060 \\
\hline \multirow{4}{*}{ Quality of my colleagues in my department } & $1-5$ years & 74 & 3.38 & .771 & .090 \\
\hline & $6-11$ years & 63 & 3.56 & .590 & .074 \\
\hline & 12 or more years & 97 & 3.56 & .645 & .065 \\
\hline & Total & 234 & 3.50 & .676 & .044 \\
\hline \multirow{4}{*}{ Quality of faculty leadership at my institution } & $1-5$ years & 74 & 3.15 & .855 & .099 \\
\hline & $6-11$ years & 64 & 3.02 & .826 & .103 \\
\hline & 12 or more years & 98 & 3.16 & .756 & .076 \\
\hline & Total & 236 & 3.12 & .806 & .052 \\
\hline \multirow{4}{*}{$\begin{array}{l}\text { Relationship between administration and faculty } \\
\text { at this institution }\end{array}$} & $1-5$ years & 74 & 2.89 & .837 & .097 \\
\hline & $6-11$ years & 64 & 2.78 & 1.015 & .127 \\
\hline & 12 or more years & 98 & 2.71 & .908 & .092 \\
\hline & Total & 236 & 2.79 & .917 & .060 \\
\hline \multirow{4}{*}{ Interdepartmental cooperation at this institution } & $1-5$ years & 74 & 2.76 & .873 & .101 \\
\hline & $6-11$ years & 64 & 2.75 & .836 & .104 \\
\hline & 12 or more years & 98 & 2.87 & .755 & .076 \\
\hline & Total & 236 & 2.80 & .814 & .053 \\
\hline
\end{tabular}


NSOPF descriptive statistics by years teaching (institution) (continued)

\begin{tabular}{|c|c|c|c|c|c|}
\hline \multirow{4}{*}{$\begin{array}{l}\text { Spirit of cooperation between faculty at this } \\
\text { institution }\end{array}$} & $1-5$ years & 74 & 3.04 & .784 & .091 \\
\hline & $6-11$ years & 64 & 3.08 & 697 & .087 \\
\hline & 12 or more years & 99 & 3.11 & .794 & .080 \\
\hline & Total & 237 & 3.08 & .763 & .050 \\
\hline \multirow{4}{*}{ Quality of my research facilities and support } & 1-5 years & 72 & 2.39 & .832 & .098 \\
\hline & 6-11 years & 62 & 2.42 & .915 & 116 \\
\hline & 12 or more years & 92 & 2.41 & .800 & .083 \\
\hline & Total & 226 & 2.41 & .839 & .056 \\
\hline \multirow{4}{*}{ Quality of students whom I have taught here } & $1-5$ years & 74 & 2.96 & .851 & .099 \\
\hline & $6-11$ years & 64 & 3.09 & .750 & .094 \\
\hline & 12 or more years & 99 & 3.15 & .676 & .068 \\
\hline & Total & 237 & 3.08 & .755 & .049 \\
\hline \multirow{4}{*}{ Teaching assistance that I receive } & 1-5 years & 68 & 2.63 & .879 & 107 \\
\hline & 6-11 years & 59 & 2.68 & .899 & 117 \\
\hline & 12 or more years & 89 & 2.73 & .889 & .094 \\
\hline & Total & 216 & 2.69 & 886 & .060 \\
\hline \multirow{4}{*}{ Research assistance that I receive } & $1-5$ years & 65 & 2.37 & .876 & .109 \\
\hline & $6-11$ years & 59 & 2.29 & .911 & .119 \\
\hline & 12 or more years & 80 & 2.35 & .858 & .096 \\
\hline & Total & 204 & 2.34 & .876 & .061 \\
\hline \multirow{4}{*}{$\begin{array}{l}\text { Spouse employment opportunities in this } \\
\text { geographic area }\end{array}$} & 1-5 years & 65 & 3.02 & .857 & .106 \\
\hline & $6-11$ years & 61 & 3.33 & .811 & .104 \\
\hline & 12 or more years & 88 & 3.45 & 642 & .068 \\
\hline & Total & 214 & 3.29 & .780 & .053 \\
\hline \multirow{4}{*}{ My overall satisfaction with my job here } & 1-5 years & 73 & 3.51 & .580 & .068 \\
\hline & $6-11$ years & 64 & 3.41 & .660 & .082 \\
\hline & 12 or more years & 99 & 3.46 & .644 & .065 \\
\hline & Total & 236 & 3.46 & .628 & .041 \\
\hline $\begin{array}{l}\text { If you were to leave your current institution, how } \\
\text { likely is it that you would do so to? }\end{array}$ & $\begin{array}{c}\text { Years Teaching } \\
\text { (Institution) }\end{array}$ & $N$ & Mean & $\begin{array}{l}\text { Standard } \\
\text { Deviation } \\
\end{array}$ & $\begin{array}{l}\text { Standard } \\
\text { Error }\end{array}$ \\
\hline \multirow{4}{*}{ Leave to Retire } & $1-5$ years & 74 & 1.82 & .881 & .102 \\
\hline & 6-11 years & 64 & 2.05 & .950 & .119 \\
\hline & 12 or more years & 99 & 2.47 & .812 & .082 \\
\hline & Total & 237 & 2.16 & .914 & .059 \\
\hline \multirow{4}{*}{ Return to school as a student } & $1-5$ years & 74 & 1.28 & .586 & .068 \\
\hline & $6-11$ years & 64 & 1.23 & .496 & .062 \\
\hline & 12 or more years & 97 & 1.09 & .325 & .033 \\
\hline & Total & 235 & 1.19 & .473 & .031 \\
\hline \multirow{4}{*}{$\begin{array}{l}\text { Accept employment at another Christian college } \\
\text { or university }\end{array}$} & $1-5$ years & 74 & 2.12 & .618 & .072 \\
\hline & $6-11$ years & 64 & 2.05 & .653 & .082 \\
\hline & 12 or more years & 97 & 1.92 & .717 & .073 \\
\hline & Total & 235 & 2.02 & .673 & .044 \\
\hline
\end{tabular}


NSOPF descriptive statistics by years teaching (institution) (continued)

\begin{tabular}{|c|c|c|c|c|c|}
\hline \multirow{4}{*}{$\begin{array}{l}\text { Accept employment at a secular college or } \\
\text { university }\end{array}$} & $1-5$ years & 74 & 1.82 & .709 & .082 \\
\hline & $6-11$ years & 64 & 1.70 & .683 & .085 \\
\hline & 12 or more years & 96 & 1.45 & .560 & .057 \\
\hline & Total & 234 & 1.64 & .662 & .043 \\
\hline \multirow{4}{*}{$\begin{array}{l}\text { Accept employment in consulting or other for- } \\
\text { profit business or industry or become self- } \\
\text { employed }\end{array}$} & $1-5$ years & 74 & 1.58 & .702 & .082 \\
\hline & $6-11$ years & 64 & 1.58 & .662 & .083 \\
\hline & 12 or more years & 97 & 1.62 & .742 & .075 \\
\hline & Total & 235 & 1.60 & .706 & .046 \\
\hline \multirow{4}{*}{ Accept employment in a non-profit organization } & $1-5$ years & 74 & 1.69 & .639 & .074 \\
\hline & $6-11$ years & 63 & 1.68 & .643 & .081 \\
\hline & 12 or more years & 97 & 1.76 & .625 & .063 \\
\hline & Total & 234 & 1.72 & .633 & .041 \\
\hline $\begin{array}{l}\text { If you were to leave your current institution to } \\
\text { accept another position, would you want to do } \\
\text { more, less or about the same amount of the } \\
\text { following as you currently do? }\end{array}$ & $\begin{array}{c}\text { Years Teaching } \\
\text { (Institution) }\end{array}$ & $N$ & Mean & $\begin{array}{l}\text { Standard } \\
\text { Deviation }\end{array}$ & $\begin{array}{l}\text { Standard } \\
\text { Error }\end{array}$ \\
\hline \multirow{4}{*}{ Research } & $1-5$ years & 75 & 1.57 & .661 & .076 \\
\hline & $6-11$ years & 61 & 1.52 & .595 & .076 \\
\hline & 12 or more years & 96 & 1.60 & .657 & .067 \\
\hline & Total & 232 & 1.57 & .640 & .042 \\
\hline \multirow{4}{*}{ Teaching } & $1-5$ years & 75 & 2.13 & .600 & .069 \\
\hline & $6-11$ years & 62 & 2.10 & .646 & .082 \\
\hline & 12 or more years & 96 & 2.18 & .523 & .053 \\
\hline & Total & 233 & 2.14 & .581 & .038 \\
\hline \multirow{4}{*}{ Advising } & 1-5 years & 74 & 2.19 & .515 & .060 \\
\hline & $6-11$ years & 62 & 2.16 & .578 & .073 \\
\hline & 12 or more years & 96 & 2.30 & .526 & .054 \\
\hline & Total & 232 & 2.23 & .538 & .035 \\
\hline \multirow{4}{*}{ Service } & $1-5$ years & 75 & 2.11 & .559 & .065 \\
\hline & $6-11$ years & 62 & 2.16 & .578 & .073 \\
\hline & 12 or more years & 97 & 2.16 & .553 & .056 \\
\hline & Total & 234 & 2.15 & .560 & .037 \\
\hline \multirow{4}{*}{ Administration } & $1-5$ years & 74 & 2.05 & .680 & .079 \\
\hline & $6-11$ years & 60 & 2.20 & .659 & .085 \\
\hline & 12 or more years & 97 & 2.49 & .631 & .064 \\
\hline & Total & 231 & 2.28 & .680 & .045 \\
\hline $\begin{array}{l}\text { If you were to leave your current institution to } \\
\text { accept another position, how important would } \\
\text { each of the following items be in your decision to } \\
\text { accept another position? }\end{array}$ & $\begin{array}{c}\text { Years Teaching } \\
\text { (Institution) }\end{array}$ & $N$ & Mean & $\begin{array}{l}\text { Standard } \\
\text { Deviation }\end{array}$ & $\begin{array}{l}\text { Standard } \\
\text { Error }\end{array}$ \\
\hline \multirow{4}{*}{ Salary Level } & $1-5$ years & 75 & 2.53 & .528 & .061 \\
\hline & $6-11$ years & 64 & 2.34 & .597 & .075 \\
\hline & 12 or more years & 99 & 2.43 & .556 & .056 \\
\hline & Total & 238 & 2.44 & .561 & .036 \\
\hline
\end{tabular}


NSOPF descriptive statistics by years teaching (institution) (continued)

\begin{tabular}{|c|c|c|c|c|c|}
\hline \multirow[b]{4}{*}{ Position Level } & $1-5$ years & 74 & 2.41 & 618 & .072 \\
\hline & 6-11 years & 64 & 2.23 & .584 & .073 \\
\hline & 12 or more years & 99 & 2.37 & .616 & .062 \\
\hline & Total & 237 & 2.35 & .609 & .040 \\
\hline \multirow{4}{*}{ Job Security } & $1-5$ years & 74 & 2.58 & .619 & .072 \\
\hline & $6-11$ years & 64 & 2.50 & .617 & .077 \\
\hline & 12 or more years & 99 & 2.54 & .628 & .063 \\
\hline & Total & 237 & 2.54 & .621 & .040 \\
\hline \multirow{4}{*}{ Opportunities for advancement } & $1-5$ years & 75 & 2.44 & .598 & .069 \\
\hline & $6-11$ years & 64 & 2.33 & .668 & .083 \\
\hline & 12 or more years & 99 & 2.21 & .732 & .074 \\
\hline & Total & 238 & 2.32 & .679 & .044 \\
\hline \multirow{4}{*}{ Benefits } & $1-5$ years & 75 & 2.68 & .524 & .061 \\
\hline & $6-11$ years & 64 & 2.67 & .506 & .063 \\
\hline & 12 or more years & 99 & 2.62 & .509 & .051 \\
\hline & Total & 238 & 2.65 & .512 & .033 \\
\hline \multirow{4}{*}{ No pressure to publish } & $1-5$ years & 75 & 2.01 & .762 & .088 \\
\hline & $6-11$ years & 64 & 2.20 & .717 & .090 \\
\hline & 12 or more years & 99 & 2.24 & .686 & .069 \\
\hline & Total & 238 & 2.16 & .723 & .047 \\
\hline \multirow{4}{*}{ Academic Freedom } & $1-5$ years & 75 & 2.51 & .578 & .067 \\
\hline & 6-11 years & 64 & 2.66 & .541 & .068 \\
\hline & 12 or more years & 99 & 2.59 & .535 & .054 \\
\hline & Total & 238 & 2.58 & .551 & .036 \\
\hline \multirow{4}{*}{ Good research facilities and equipment } & $1-5$ years & 75 & 2.13 & .622 & .072 \\
\hline & $6-11$ years & 64 & 2.14 & .614 & .077 \\
\hline & 12 or more years & 97 & 2.11 & .734 & .075 \\
\hline & Total & 236 & 2.13 & .666 & .043 \\
\hline \multirow{4}{*}{ Good instructional facilities and equipment } & $1-5$ years & 75 & 2.47 & .553 & .064 \\
\hline & $6-11$ years & 64 & 2.52 & .617 & .077 \\
\hline & 12 or more years & 98 & 2.63 & .525 & .053 \\
\hline & Total & 237 & 2.55 & .563 & .037 \\
\hline \multirow{4}{*}{ Excellent Students } & $1-5$ years & 75 & 2.40 & .593 & .068 \\
\hline & $6-11$ years & 64 & 2.38 & .549 & .069 \\
\hline & 12 or more years & 99 & 2.48 & .560 & .056 \\
\hline & Total & 238 & 2.43 & .567 & .037 \\
\hline \multirow{4}{*}{ Excellent Colleagues } & $1-5$ years & 75 & 2.60 & .520 & .060 \\
\hline & $6-11$ years & 64 & 2.67 & .473 & .059 \\
\hline & 12 or more years & 99 & 2.71 & .457 & .046 \\
\hline & Total & 238 & 2.66 & .482 & .031 \\
\hline \multirow{4}{*}{ New institution is a Christian college } & $1-5$ years & 75 & 2.15 & .748 & .086 \\
\hline & $6-11$ years & 64 & 2.20 & .760 & .095 \\
\hline & 12 or more years & 99 & 2.43 & .625 & .063 \\
\hline & Total & 238 & 2.28 & .712 & .046 \\
\hline
\end{tabular}


NSOPF descriptive statistics by years teaching (institution) (continued)

\begin{tabular}{|c|c|c|c|c|c|}
\hline \multirow{4}{*}{$\begin{array}{l}\text { Institutional mission or philosophy that is } \\
\text { compatible with my own views }\end{array}$} & $1-5$ years & 75 & 2.60 & .545 & .063 \\
\hline & $6-11$ years & 64 & 2.66 & .570 & .071 \\
\hline & 12 or more years & 98 & 2.71 & .454 & .046 \\
\hline & Total & 237 & 2.66 & .517 & .034 \\
\hline \multirow{4}{*}{ Good job for my spouse } & 1-5 years & 69 & 1.96 & .848 & .102 \\
\hline & $6-11$ years & 63 & 2.17 & .853 & .107 \\
\hline & 12 or more years & 95 & 2.16 & .842 & .086 \\
\hline & Total & 227 & 2.10 & .848 & .056 \\
\hline \multirow{4}{*}{ Good geographic location } & $1-5$ years & 74 & 2.38 & .676 & .079 \\
\hline & $6-11$ years & 64 & 2.53 & .590 & .074 \\
\hline & 12 or more years & 97 & 2.43 & .611 & .062 \\
\hline & Total & 235 & 2.44 & .627 & .041 \\
\hline \multirow{4}{*}{ Affordable Housing } & $1-5$ years & 73 & 2.44 & .623 & .073 \\
\hline & 6-11 years & 63 & 2.52 & .644 & .081 \\
\hline & 12 or more years & 99 & 2.55 & .576 & .058 \\
\hline & Total & 235 & 2.51 & .609 & .040 \\
\hline \multirow{4}{*}{ Good environment/schools for my children } & $1-5$ years & 69 & 2.06 & .906 & .109 \\
\hline & $6-11$ years & 61 & 1.97 & .912 & .117 \\
\hline & 12 or more years & 94 & 1.84 & .908 & .094 \\
\hline & Total & 224 & 1.94 & .909 & .061 \\
\hline \multirow{4}{*}{ A full-time position } & $1-5$ years & 73 & 2.79 & .499 & .058 \\
\hline & $6-11$ years & 63 & 2.75 & .595 & .075 \\
\hline & 12 or more years & 96 & 2.69 & .638 & .065 \\
\hline & Total & 232 & 2.74 & .585 & .038 \\
\hline \multirow{4}{*}{ A part-time position } & 1-5 years & 72 & 1.35 & .609 & .072 \\
\hline & $6-11$ years & 61 & 1.20 & .440 & .056 \\
\hline & 12 or more years & 95 & 1.34 & .612 & .063 \\
\hline & Total & 228 & 1.30 & .571 & .038 \\
\hline $\begin{array}{l}\text { Please indicate the extent to which you agree or } \\
\text { disagree with each of the following statements. }\end{array}$ & $\begin{array}{c}\text { Years Teaching } \\
\text { (Institution) }\end{array}$ & $N$ & Mean & $\begin{array}{l}\text { Standard } \\
\text { Deviation } \\
\end{array}$ & $\begin{array}{l}\text { Standard } \\
\text { Error }\end{array}$ \\
\hline \multirow{4}{*}{$\begin{array}{l}\text { It is important for faculty to participate in } \\
\text { governing their institution }\end{array}$} & $1-5$ years & 75 & 3.63 & .564 & .065 \\
\hline & 6-11 years & 64 & 3.58 & .612 & .077 \\
\hline & 12 or more years & 98 & 3.69 & .526 & .053 \\
\hline & Total & 237 & 3.64 & .562 & .036 \\
\hline \multirow{4}{*}{$\begin{array}{l}\text { Faculty promotions should be based at least in } \\
\text { part on formal student evaluations }\end{array}$} & $1-5$ years & 75 & 2.99 & .726 & .084 \\
\hline & $6-11$ years & 64 & 2.89 & .819 & .102 \\
\hline & 12 or more years & 99 & 2.95 & .774 & .078 \\
\hline & Total & 238 & 2.95 & .769 & .050 \\
\hline \multirow{4}{*}{$\begin{array}{l}\text { The tenure system in higher education should be } \\
\text { preserved }\end{array}$} & $1-5$ years & 75 & 2.79 & .890 & .103 \\
\hline & $6-11$ years & 64 & 2.72 & 1.105 & .138 \\
\hline & 12 or more years & 98 & 2.90 & .867 & .088 \\
\hline & Total & 237 & 2.81 & .943 & .061 \\
\hline
\end{tabular}


NSOPF descriptive statistics by years teaching (institution) (continued)

\begin{tabular}{|c|c|c|c|c|c|}
\hline \multirow{4}{*}{$\begin{array}{l}\text { Teaching effectiveness should be the primary } \\
\text { criterion for promotion of faculty }\end{array}$} & $1-5$ years & 75 & 3.36 & .584 & .067 \\
\hline & 6-11 years & 64 & 3.30 & .706 & .088 \\
\hline & 12 or more years & 98 & 3.28 & .685 & .069 \\
\hline & Total & 237 & 3.31 & .659 & .043 \\
\hline \multirow{4}{*}{$\begin{array}{l}\text { Research/publications should be the primary } \\
\text { criterion for promotion of college faculty }\end{array}$} & 1-5 years & 75 & 2.08 & .731 & .084 \\
\hline & $6-11$ years & 64 & 1.88 & .577 & .072 \\
\hline & 12 or more years & 99 & 1.80 & .714 & .072 \\
\hline & Total & 238 & 1.91 & .693 & .045 \\
\hline \multirow{4}{*}{$\begin{array}{l}\text { Years of service/advanced degree should be the } \\
\text { primary criterion for promotion of college faculty }\end{array}$} & $1-5$ years & 75 & 2.48 & .795 & .092 \\
\hline & $6-11$ years & 64 & 2.59 & .684 & .085 \\
\hline & 12 or more years & 97 & 2.40 & .799 & .081 \\
\hline & Total & 236 & 2.48 & .769 & .050 \\
\hline \multirow{4}{*}{$\begin{array}{l}\text { The administrative function is taking an } \\
\text { increasingly heavy share of available resources } \\
\text { at my institution }\end{array}$} & 1-5 years & 70 & 2.59 & .860 & .103 \\
\hline & $6-11$ years & 64 & 2.66 & .895 & .112 \\
\hline & 12 or more years & 98 & 2.93 & .828 & .084 \\
\hline & Total & 232 & 2.75 & .867 & .057 \\
\hline \multirow{4}{*}{$\begin{array}{l}\text { State or federally mandated assessment } \\
\text { requirements have improved the quality of } \\
\text { undergraduate education at my institution }\end{array}$} & $1-5$ years & 71 & 2.38 & .834 & .099 \\
\hline & $6-11$ years & 62 & 2.05 & .688 & .087 \\
\hline & 12 or more years & 96 & 2.23 & .888 & .091 \\
\hline & Total & 229 & 2.23 & .828 & .055 \\
\hline \multirow{4}{*}{$\begin{array}{l}\text { Female faculty members are treated fairly at my } \\
\text { institution }\end{array}$} & $1-5$ years & 74 & 3.34 & .708 & .082 \\
\hline & $6-11$ years & 63 & 3.19 & .820 & .103 \\
\hline & 12 or more years & 99 & 3.23 & .754 & .076 \\
\hline & Total & 236 & 3.25 & .757 & .049 \\
\hline \multirow{4}{*}{$\begin{array}{l}\text { Faculty who are members of racial or ethnic } \\
\text { minorities are treated fairly at my institution }\end{array}$} & $1-5$ years & 72 & 3.43 & .624 & .074 \\
\hline & $6-11$ years & 63 & 3.24 & .837 & .105 \\
\hline & 12 or more years & 99 & 3.20 & .820 & .082 \\
\hline & Total & 234 & 3.28 & .773 & .051 \\
\hline \multirow{4}{*}{$\begin{array}{l}\text { My institution effectively meets the educational } \\
\text { needs of entering students }\end{array}$} & $1-5$ years & 74 & 3.31 & .681 & .079 \\
\hline & $6-11$ years & 64 & 3.09 & .791 & .099 \\
\hline & 12 or more years & 97 & 3.25 & .646 & .066 \\
\hline & Total & 235 & 3.23 & .701 & .046 \\
\hline \multirow{4}{*}{$\begin{array}{l}\text { If I had it to do over again, I would choose an } \\
\text { academic career }\end{array}$} & 1-5 years & 75 & 3.79 & .527 & .061 \\
\hline & $6-11$ years & 64 & 3.78 & .519 & .065 \\
\hline & 12 or more years & 99 & 3.78 & .506 & .051 \\
\hline & Total & 238 & 3.78 & .514 & .033 \\
\hline
\end{tabular}


NSOPF descriptive statistics by expected retirement age

\begin{tabular}{|c|c|c|c|c|c|}
\hline $\begin{array}{l}\text { How satisfied or dissatisfied do you personally } \\
\text { feel about each of the following aspects of your } \\
\text { job at your current institution }\end{array}$ & $\begin{array}{c}\text { Expected } \\
\text { Retirement Age }\end{array}$ & $N$ & Mean & $\begin{array}{l}\text { Standard } \\
\text { Deviation }\end{array}$ & $\begin{array}{c}\text { Standard } \\
\text { Error }\end{array}$ \\
\hline \multirow{4}{*}{ My Work Load } & 60 or less & 24 & 3.04 & .806 & .165 \\
\hline & $61-65$ & 92 & 2.86 & .872 & .091 \\
\hline & 66 or above & 110 & 2.85 & .869 & .083 \\
\hline & Total & 226 & 2.87 & .862 & .057 \\
\hline \multirow{4}{*}{ My job security } & 60 or less & 24 & 3.25 & .847 & .173 \\
\hline & $61-65$ & 92 & 3.45 & .803 & .084 \\
\hline & 66 or above & 109 & 3.42 & .773 & .074 \\
\hline & Total & 225 & 3.41 & .792 & .053 \\
\hline \multirow{4}{*}{ My Salary } & 60 or less & 24 & 2.42 & .881 & .180 \\
\hline & $61-65$ & 92 & 2.68 & .925 & .096 \\
\hline & 66 or above & 110 & 2.69 & .821 & .078 \\
\hline & Total & 226 & 2.66 & .871 & .058 \\
\hline \multirow{4}{*}{ My Benefits } & 60 or less & 24 & 2.54 & 1.103 & .225 \\
\hline & $61-65$ & 91 & 2.90 & .844 & .088 \\
\hline & 66 or above & 110 & 2.91 & .852 & .081 \\
\hline & Total & 225 & 2.87 & .881 & .059 \\
\hline \multirow{4}{*}{$\begin{array}{l}\text { The authority I have to make decisions about } \\
\text { what courses I teach }\end{array}$} & 60 or less & 24 & 3.50 & .590 & .120 \\
\hline & $61-65$ & 92 & 3.40 & .813 & .085 \\
\hline & 66 or above & 108 & 3.44 & .812 & .078 \\
\hline & Total & 224 & 3.43 & .789 & .053 \\
\hline \multirow{4}{*}{$\begin{array}{l}\text { The authority I have to make decisions about the } \\
\text { content and methods in the courses I teach }\end{array}$} & 60 or less & 24 & 3.88 & .338 & .069 \\
\hline & $61-65$ & 92 & 3.67 & .576 & .060 \\
\hline & 66 or above & 108 & 3.85 & .428 & .041 \\
\hline & Total & 224 & 3.78 & .493 & .033 \\
\hline \multirow{4}{*}{$\begin{array}{l}\text { The authority I have to make decisions about } \\
\text { other aspects of my job }\end{array}$} & 60 or less & 24 & 3.33 & .482 & .098 \\
\hline & $61-65$ & 92 & 3.37 & .722 & .075 \\
\hline & 66 or above & 108 & 3.39 & .624 & .060 \\
\hline & Total & 224 & 3.38 & .651 & .043 \\
\hline \multirow{4}{*}{$\begin{array}{l}\text { The mix of teaching, research, administration, } \\
\text { and service that I am required to do }\end{array}$} & 60 or less & 24 & 3.08 & .776 & .158 \\
\hline & $61-65$ & 92 & 3.12 & .754 & .079 \\
\hline & 66 or above & 108 & 3.08 & .810 & .078 \\
\hline & Total & 224 & 3.10 & .780 & .052 \\
\hline \multirow{4}{*}{$\begin{array}{l}\text { The opportunity for advancement in rank at my } \\
\text { institution }\end{array}$} & 60 or less & 24 & 2.79 & .932 & .190 \\
\hline & $61-65$ & 92 & 3.14 & .933 & .097 \\
\hline & 66 or above & 108 & 3.19 & .877 & .084 \\
\hline & Total & 224 & 3.13 & .910 & .061 \\
\hline \multirow{4}{*}{ Time available for keeping current in my field } & 60 or less & 23 & 2.52 & .730 & .152 \\
\hline & $61-65$ & 92 & 2.41 & .904 & .094 \\
\hline & 66 or above & 109 & 2.46 & .918 & .088 \\
\hline & Total & 224 & 2.45 & .892 & .060 \\
\hline
\end{tabular}


NSOPF descriptive statistics by expected retirement age (continued)

\begin{tabular}{|c|c|c|c|c|c|}
\hline \multirow{4}{*}{$\begin{array}{l}\text { Availability of support services and equipment } \\
\text { (clerical support, computers, etc.) }\end{array}$} & 60 or less & 24 & 2.96 & .908 & .185 \\
\hline & $61-65$ & 92 & 2.83 & .956 & .100 \\
\hline & 66 or above & 110 & 2.88 & .854 & .081 \\
\hline & Total & 226 & 2.87 & .899 & .060 \\
\hline \multirow{4}{*}{ Freedom to do outside consulting } & 60 or less & 23 & 3.35 & .714 & .149 \\
\hline & $61-65$ & 89 & 3.25 & .727 & .077 \\
\hline & 66 or above & 106 & 3.30 & .733 & .071 \\
\hline & Total & 218 & 3.28 & .726 & .049 \\
\hline \multirow{4}{*}{ Overall reputation of the institution } & 60 or less & 24 & 3.21 & .884 & .180 \\
\hline & $61-65$ & 92 & 3.24 & .790 & .082 \\
\hline & 66 or above & 107 & 3.21 & .753 & .073 \\
\hline & Total & 223 & 3.22 & .779 & .052 \\
\hline \multirow{4}{*}{ Reputation of my department } & 60 or less & 24 & 3.29 & .908 & .185 \\
\hline & $61-65$ & 92 & 3.37 & .822 & .086 \\
\hline & 66 or above & 110 & 3.36 & .763 & .073 \\
\hline & Total & 226 & 3.36 & .800 & .053 \\
\hline \multirow{4}{*}{ Institutional mission or philosophy } & 60 or less & 24 & 3.67 & .482 & .098 \\
\hline & $61-65$ & 91 & 3.68 & .575 & .060 \\
\hline & 66 or above & 110 & 3.62 & .542 & .052 \\
\hline & Total & 225 & 3.65 & .548 & .037 \\
\hline \multirow{4}{*}{ Quality of leadership in my department } & 60 or less & 24 & 3.33 & .868 & .177 \\
\hline & $61-65$ & 92 & 3.39 & .851 & .089 \\
\hline & 66 or above & 109 & 3.39 & .828 & .079 \\
\hline & Total & 225 & 3.39 & .838 & .056 \\
\hline \multirow{4}{*}{$\begin{array}{l}\text { Quality of chief administrative officers at my } \\
\text { institution }\end{array}$} & 60 or less & 24 & 3.04 & .859 & .175 \\
\hline & $61-65$ & 92 & 3.20 & .867 & .090 \\
\hline & 66 or above & 109 & 3.07 & .979 & .094 \\
\hline & Total & 225 & 3.12 & .920 & .061 \\
\hline \multirow{4}{*}{ Quality of my colleagues in my department } & 60 or less & 23 & 3.35 & .832 & .173 \\
\hline & $61-65$ & 92 & 3.58 & .615 & .064 \\
\hline & 66 or above & 108 & 3.46 & .703 & .068 \\
\hline & Total & 223 & 3.50 & .684 & .046 \\
\hline \multirow{4}{*}{ Quality of faculty leadership at my institution } & 60 or less & 24 & 2.92 & .929 & .190 \\
\hline & $61-65$ & 92 & 3.18 & .769 & .080 \\
\hline & 66 or above & 110 & 3.11 & .817 & .078 \\
\hline & Total & 226 & 3.12 & .810 & .054 \\
\hline \multirow{4}{*}{$\begin{array}{l}\text { Relationship between administration and faculty } \\
\text { at this institution }\end{array}$} & 60 or less & 24 & 2.71 & .806 & .165 \\
\hline & $61-65$ & 92 & 2.92 & .880 & .092 \\
\hline & 66 or above & 109 & 2.71 & .956 & .092 \\
\hline & Total & 225 & 2.80 & .913 & .061 \\
\hline \multirow{4}{*}{ Interdepartmental cooperation at this institution } & 60 or less & 24 & 2.50 & .659 & .135 \\
\hline & $61-65$ & 92 & 2.86 & .921 & .096 \\
\hline & 66 or above & 110 & 2.85 & .744 & .071 \\
\hline & Total & 226 & 2.81 & .817 & .054 \\
\hline
\end{tabular}


NSOPF descriptive statistics by expected retirement age (continued)

\begin{tabular}{|c|c|c|c|c|c|}
\hline \multirow{4}{*}{$\begin{array}{l}\text { Spirit of cooperation between faculty at this } \\
\text { institution }\end{array}$} & 60 or less & 24 & 2.79 & .721 & .147 \\
\hline & $61-65$ & 92 & 3.12 & .796 & .083 \\
\hline & 66 or above & 110 & 3.13 & .731 & .070 \\
\hline & Total & 226 & 3.09 & .761 & .051 \\
\hline \multirow{4}{*}{ Quality of my research facilities and support } & 60 or less & 23 & 2.39 & .783 & .163 \\
\hline & $61-65$ & 91 & 2.44 & .897 & .094 \\
\hline & 66 or above & 103 & 2.41 & .785 & .077 \\
\hline & Total & 217 & 2.42 & .830 & .056 \\
\hline \multirow{4}{*}{ Quality of students whom I have taught here } & 60 or less & 24 & 3.17 & .917 & .187 \\
\hline & $61-65$ & 92 & 3.07 & .753 & .079 \\
\hline & 66 or above & 110 & 3.07 & .726 & .069 \\
\hline & Total & 226 & 3.08 & .756 & .050 \\
\hline \multirow{4}{*}{ Teaching assistance that I receive } & 60 or less & 21 & 2.86 & .727 & .159 \\
\hline & 61-65 & 83 & 2.67 & .885 & .097 \\
\hline & 66 or above & 105 & 2.67 & .895 & .087 \\
\hline & Total & 209 & 2.69 & .874 & .060 \\
\hline \multirow{4}{*}{ Research assistance that I receive } & 60 or less & 20 & 2.55 & .759 & .170 \\
\hline & $61-65$ & 81 & 2.42 & .906 & 101 \\
\hline & 66 or above & 97 & 2.24 & .863 & .088 \\
\hline & Total & 198 & 2.34 & .874 & .062 \\
\hline \multirow{4}{*}{$\begin{array}{l}\text { Spouse employment opportunities in this } \\
\text { geographic area }\end{array}$} & 60 or less & 24 & 3.33 & .637 & .130 \\
\hline & $61-65$ & 84 & 3.23 & .827 & .090 \\
\hline & 66 or above & 95 & 3.37 & .745 & .076 \\
\hline & Total & 203 & 3.31 & .768 & .054 \\
\hline \multirow{4}{*}{ My overall satisfaction with my job here } & 60 or less & 24 & 3.21 & .779 & .159 \\
\hline & $61-65$ & 92 & 3.49 & .620 & .065 \\
\hline & 66 or above & 109 & 3.54 & .553 & .053 \\
\hline & Total & 225 & 3.48 & .613 & .041 \\
\hline $\begin{array}{l}\text { If you were to leave your current institution, how } \\
\text { likely is it that you would do so to? }\end{array}$ & $\begin{array}{c}\text { Expected } \\
\text { Retirement Age }\end{array}$ & N & Mean & $\begin{array}{l}\text { Standard } \\
\text { Deviation }\end{array}$ & $\begin{array}{l}\text { Standard } \\
\text { Error }\end{array}$ \\
\hline \multirow{4}{*}{ Leave to Retire } & 60 or less & 23 & 1.83 & .887 & .185 \\
\hline & $61-65$ & 93 & 2.23 & .886 & .092 \\
\hline & 66 or above & 110 & 2.24 & .928 & .088 \\
\hline & Total & 226 & 2.19 & .911 & .061 \\
\hline \multirow{4}{*}{ Return to school as a student } & 60 or less & 23 & 1.22 & .518 & .108 \\
\hline & $61-65$ & 93 & 1.27 & .554 & .057 \\
\hline & 66 or above & 109 & 1.14 & .396 & .038 \\
\hline & Total & 225 & 1.20 & .482 & .032 \\
\hline \multirow{4}{*}{$\begin{array}{l}\text { Accept employment at another Christian college } \\
\text { or university }\end{array}$} & 60 or less & 23 & 1.87 & .548 & .114 \\
\hline & $61-65$ & 93 & 1.88 & .673 & .070 \\
\hline & 66 or above & 109 & 2.14 & .673 & .064 \\
\hline & Total & 225 & 2.00 & .671 & .045 \\
\hline
\end{tabular}


NSOPF descriptive statistics by expected retirement age (continued)

\begin{tabular}{|c|c|c|c|c|c|}
\hline \multirow{4}{*}{$\begin{array}{l}\text { Accept employment at a secular college or } \\
\text { university }\end{array}$} & 60 or less & 23 & 1.78 & .600 & .125 \\
\hline & $61-65$ & 93 & 1.65 & .702 & .073 \\
\hline & 66 or above & 108 & 1.58 & .643 & .062 \\
\hline & Total & 224 & 1.63 & .664 & .044 \\
\hline \multirow{4}{*}{$\begin{array}{l}\text { Accept employment in consulting or other for- } \\
\text { profit business or industry or become self- } \\
\text { employed }\end{array}$} & 60 or less & 23 & 2.04 & .638 & .133 \\
\hline & $61-65$ & 93 & 1.65 & .761 & .079 \\
\hline & 66 or above & 109 & 1.44 & .615 & .059 \\
\hline & Total & 225 & 1.59 & .703 & .047 \\
\hline \multirow{4}{*}{ Accept employment in a non-profit organization } & 60 or less & 23 & 1.65 & .714 & .149 \\
\hline & $61-65$ & 93 & 1.77 & .694 & .072 \\
\hline & 66 or above & 108 & 1.68 & .577 & .056 \\
\hline & Total & 224 & 1.71 & .641 & .043 \\
\hline $\begin{array}{l}\text { If you were to leave your current institution to } \\
\text { accept another position, would you want to do } \\
\text { more, less or about the same amount of the } \\
\text { following as you currently do? }\end{array}$ & $\begin{array}{c}\text { Expected } \\
\text { Retirement Age }\end{array}$ & $N$ & Mean & $\begin{array}{l}\text { Standard } \\
\text { Deviation }\end{array}$ & $\begin{array}{l}\text { Standard } \\
\text { Error }\end{array}$ \\
\hline \multirow{4}{*}{ Research } & 60 or less & 24 & 1.92 & .654 & .133 \\
\hline & $61-65$ & 90 & 1.67 & .653 & .069 \\
\hline & 66 or above & 108 & 1.45 & .602 & .058 \\
\hline & Total & 222 & 1.59 & .644 & .043 \\
\hline \multirow{4}{*}{ Teaching } & 60 or less & 24 & 2.21 & .509 & .104 \\
\hline & $61-65$ & 92 & 2.10 & .594 & .062 \\
\hline & 66 or above & 107 & 2.17 & .574 & .056 \\
\hline & Total & 223 & 2.14 & .575 & .039 \\
\hline \multirow{4}{*}{ Advising } & 60 or less & 24 & 2.29 & .550 & .112 \\
\hline & $61-65$ & 92 & 2.17 & .567 & .059 \\
\hline & 66 or above & 106 & 2.25 & .518 & .050 \\
\hline & Total & 222 & 2.23 & .541 & .036 \\
\hline \multirow{4}{*}{ Service } & 60 or less & 24 & 2.00 & .511 & .104 \\
\hline & $61-65$ & 92 & 2.10 & .536 & .056 \\
\hline & 66 or above & 108 & 2.23 & .590 & .057 \\
\hline & Total & 224 & 2.15 & .564 & .038 \\
\hline \multirow{4}{*}{ Administration } & 60 or less & 24 & 1.96 & .690 & .141 \\
\hline & $61-65$ & 91 & 2.35 & .639 & .067 \\
\hline & 66 or above & 106 & 2.28 & .700 & .068 \\
\hline & Total & 221 & 2.28 & .681 & .046 \\
\hline $\begin{array}{l}\text { If you were to leave your current institution to } \\
\text { accept another position, how important would } \\
\text { each of the following items be in your decision to } \\
\text { accept another position? }\end{array}$ & $\begin{array}{c}\text { Expected } \\
\text { Retirement Age }\end{array}$ & $N$ & Mean & $\begin{array}{l}\text { Standard } \\
\text { Deviation }\end{array}$ & $\begin{array}{l}\text { Standard } \\
\text { Error }\end{array}$ \\
\hline \multirow{4}{*}{ Salary Level } & 60 or less & 24 & 2.54 & .509 & .104 \\
\hline & $61-65$ & 93 & 2.44 & .598 & .062 \\
\hline & 66 or above & 110 & 2.44 & .534 & .051 \\
\hline & Total & 227 & 2.45 & .557 & .037 \\
\hline
\end{tabular}


NSOPF descriptive statistics by expected retirement age (continued)

\begin{tabular}{|c|c|c|c|c|c|}
\hline \multirow[b]{4}{*}{ Position Level } & 60 or less & 24 & 2.50 & .590 & .120 \\
\hline & $61-65$ & 93 & 2.26 & .641 & .066 \\
\hline & 66 or above & 109 & 2.39 & .593 & .057 \\
\hline & Total & 226 & 2.35 & .616 & .041 \\
\hline \multirow{4}{*}{ Job Security } & 60 or less & 24 & 2.50 & .722 & .147 \\
\hline & $61-65$ & 93 & 2.52 & .619 & .064 \\
\hline & 66 or above & 109 & 2.57 & .614 & .059 \\
\hline & Total & 226 & 2.54 & .626 & .042 \\
\hline \multirow{4}{*}{ Opportunities for advancement } & 60 or less & 24 & 2.46 & .658 & .134 \\
\hline & $61-65$ & 93 & 2.26 & .706 & .073 \\
\hline & 66 or above & 110 & 2.35 & .656 & .063 \\
\hline & Total & 227 & 2.32 & .677 & .045 \\
\hline \multirow{4}{*}{ Benefits } & 60 or less & 24 & 2.63 & .647 & .132 \\
\hline & $61-65$ & 93 & 2.62 & .530 & .055 \\
\hline & 66 or above & 110 & 2.67 & .471 & .045 \\
\hline & Total & 227 & 2.65 & .514 & .034 \\
\hline \multirow{4}{*}{ No pressure to publish } & 60 or less & 24 & 2.46 & .721 & .147 \\
\hline & $61-65$ & 93 & 2.17 & .746 & .077 \\
\hline & 66 or above & 110 & 2.07 & .700 & .067 \\
\hline & Total & 227 & 2.15 & .727 & .048 \\
\hline \multirow{4}{*}{ Academic Freedom } & 60 or less & 24 & 2.50 & .659 & .135 \\
\hline & $61-65$ & 93 & 2.52 & .601 & .062 \\
\hline & 66 or above & 110 & 2.65 & .478 & .046 \\
\hline & Total & 227 & 2.58 & .554 & .037 \\
\hline \multirow{4}{*}{ Good research facilities and equipment } & 60 or less & 24 & 1.96 & .690 & .141 \\
\hline & $61-65$ & 92 & 2.12 & .709 & .074 \\
\hline & 66 or above & 109 & 2.15 & .606 & .058 \\
\hline & Total & 225 & 2.12 & .658 & .044 \\
\hline \multirow{4}{*}{ Good instructional facilities and equipment } & 60 or less & 24 & 2.46 & .588 & .120 \\
\hline & $61-65$ & 93 & 2.57 & .579 & .060 \\
\hline & 66 or above & 109 & 2.55 & .553 & .053 \\
\hline & Total & 226 & 2.55 & .566 & .038 \\
\hline \multirow{4}{*}{ Excellent Students } & 60 or less & 24 & 2.33 & .637 & .130 \\
\hline & $61-65$ & 93 & 2.45 & .581 & .060 \\
\hline & 66 or above & 110 & 2.42 & .548 & .052 \\
\hline & Total & 227 & 2.42 & .570 & .038 \\
\hline \multirow{4}{*}{ Excellent Colleagues } & 60 or less & 24 & 2.63 & .576 & .118 \\
\hline & $61-65$ & 93 & 2.67 & .474 & .049 \\
\hline & 66 or above & 110 & 2.66 & .475 & .045 \\
\hline & Total & 227 & 2.66 & .484 & .032 \\
\hline \multirow{4}{*}{ New institution is a Christian college } & 60 or less & 24 & 2.08 & .654 & .133 \\
\hline & $61-65$ & 93 & 2.15 & .751 & .078 \\
\hline & 66 or above & 110 & 2.45 & .658 & .063 \\
\hline & Total & 227 & 2.29 & .711 & .047 \\
\hline
\end{tabular}


NSOPF descriptive statistics by expected retirement age (continued)

\begin{tabular}{|c|c|c|c|c|c|}
\hline \multirow{4}{*}{$\begin{array}{l}\text { Institutional mission or philosophy that is } \\
\text { compatible with my own views }\end{array}$} & 60 or less & 24 & 2.46 & .658 & .134 \\
\hline & $61-65$ & 92 & 2.64 & .482 & .050 \\
\hline & 66 or above & 110 & 2.71 & .513 & .049 \\
\hline & Total & 226 & 2.65 & .521 & .035 \\
\hline \multirow{4}{*}{ Good job for my spouse } & 60 or less & 23 & 2.30 & .765 & .159 \\
\hline & $61-65$ & 89 & 2.15 & .833 & .088 \\
\hline & 66 or above & 104 & 2.02 & .870 & .085 \\
\hline & Total & 216 & 2.10 & .846 & .058 \\
\hline \multirow{4}{*}{ Good geographic location } & 60 or less & 23 & 2.48 & .665 & .139 \\
\hline & $61-65$ & 93 & 2.48 & .653 & .068 \\
\hline & 66 or above & 109 & 2.42 & .598 & .057 \\
\hline & Total & 225 & 2.45 & .626 & .042 \\
\hline \multirow{4}{*}{ Affordable Housing } & 60 or less & 22 & 2.41 & .666 & .142 \\
\hline & $61-65$ & 93 & 2.57 & .632 & .066 \\
\hline & 66 or above & 109 & 2.50 & .571 & .055 \\
\hline & Total & 224 & 2.52 & .606 & .040 \\
\hline \multirow{4}{*}{ Good environment/schools for my children } & 60 or less & 23 & 2.35 & .832 & .173 \\
\hline & $61-65$ & 88 & 1.95 & .921 & .098 \\
\hline & 66 or above & 103 & 1.85 & .890 & .088 \\
\hline & Total & 214 & 1.95 & .905 & .062 \\
\hline \multirow{4}{*}{ A full-time position } & 60 or less & 24 & 2.63 & .711 & .145 \\
\hline & $61-65$ & 92 & 2.70 & .624 & .065 \\
\hline & 66 or above & 106 & 2.81 & .500 & .049 \\
\hline & Total & 222 & 2.74 & .580 & .039 \\
\hline \multirow{4}{*}{ A part-time position } & 60 or less & 23 & 1.57 & .728 & .152 \\
\hline & $61-65$ & 89 & 1.36 & .626 & .066 \\
\hline & 66 or above & 107 & 1.21 & .476 & .046 \\
\hline & Total & 219 & 1.31 & .578 & .039 \\
\hline $\begin{array}{l}\text { Please indicate the extent to which you agree or } \\
\text { disagree with each of the following statements. }\end{array}$ & $\begin{array}{c}\text { Expected } \\
\text { Retirement Age }\end{array}$ & N & Mean & $\begin{array}{l}\text { Standard } \\
\text { Deviation }\end{array}$ & $\begin{array}{l}\text { Standard } \\
\text { Error }\end{array}$ \\
\hline \multirow{4}{*}{$\begin{array}{l}\text { It is important for faculty to participate in } \\
\text { governing their institution }\end{array}$} & 60 or less & 24 & 3.50 & .659 & .135 \\
\hline & $61-65$ & 92 & 3.64 & .526 & .055 \\
\hline & 66 or above & 110 & 3.67 & .576 & .055 \\
\hline & Total & 226 & 3.64 & .566 & .038 \\
\hline \multirow{4}{*}{$\begin{array}{l}\text { Faculty promotions should be based at least in } \\
\text { part on formal student evaluations }\end{array}$} & 60 or less & 24 & 3.13 & .797 & .163 \\
\hline & $61-65$ & 93 & 2.92 & .726 & .075 \\
\hline & 66 or above & 110 & 2.95 & .771 & .073 \\
\hline & Total & 227 & 2.96 & .754 & .050 \\
\hline \multirow{4}{*}{$\begin{array}{l}\text { The tenure system in higher education should be } \\
\text { preserved }\end{array}$} & 60 or less & 24 & 2.46 & .932 & .190 \\
\hline & $61-65$ & 92 & 2.73 & .950 & .099 \\
\hline & 66 or above & 110 & 2.95 & .913 & .087 \\
\hline & Total & 226 & 2.81 & .940 & .063 \\
\hline
\end{tabular}


NSOPF descriptive statistics by expected retirement age (continued)

\begin{tabular}{|c|c|c|c|c|c|}
\hline & 60 or less & 24 & 3.25 & .608 & .124 \\
\hline \multirow{3}{*}{$\begin{array}{l}\text { Teaching effectiveness should be the primary } \\
\text { criterion for promotion of faculty }\end{array}$} & $61-65$ & 92 & 3.26 & .693 & .072 \\
\hline & 66 or above & 110 & 3.37 & .619 & .059 \\
\hline & Total & 226 & 3.31 & .649 & .043 \\
\hline \multirow{4}{*}{$\begin{array}{l}\text { Research/publications should be the primary } \\
\text { criterion for promotion of college faculty }\end{array}$} & 60 or less & 24 & 1.83 & .637 & .130 \\
\hline & $61-65$ & 93 & 1.87 & .711 & .074 \\
\hline & 66 or above & 110 & 1.98 & .704 & .067 \\
\hline & Total & 227 & 1.92 & 699 & .046 \\
\hline \multirow{4}{*}{$\begin{array}{l}\text { Years of service/advanced degree should be the } \\
\text { primary criterion for promotion of college faculty }\end{array}$} & 60 or less & 24 & 2.79 & .779 & .159 \\
\hline & $61-65$ & 92 & 2.51 & .777 & .081 \\
\hline & 66 or above & 109 & 2.44 & .726 & .070 \\
\hline & Total & 225 & 2.51 & .757 & .050 \\
\hline \multirow{4}{*}{$\begin{array}{l}\text { The administrative function is taking an } \\
\text { increasingly heavy share of available resources } \\
\text { at my institution }\end{array}$} & 60 or less & 24 & 2.67 & .816 & .167 \\
\hline & $61-65$ & 92 & 2.83 & .909 & .095 \\
\hline & 66 or above & 107 & 2.68 & .853 & .082 \\
\hline & Total & 223 & 2.74 & .872 & .058 \\
\hline \multirow{4}{*}{$\begin{array}{l}\text { State or federally mandated assessment } \\
\text { requirements have improved the quality of } \\
\text { undergraduate education at my institution }\end{array}$} & 60 or less & 23 & 2.26 & .915 & .191 \\
\hline & $61-65$ & 90 & 2.30 & .867 & .091 \\
\hline & 66 or above & 106 & 2.17 & .798 & .078 \\
\hline & Total & 219 & 2.23 & .838 & .057 \\
\hline \multirow{4}{*}{$\begin{array}{l}\text { Female faculty members are treated fairly at my } \\
\text { institution }\end{array}$} & 60 or less & 24 & 3.13 & .947 & .193 \\
\hline & $61-65$ & 92 & 3.23 & .713 & .074 \\
\hline & 66 or above & 109 & 3.28 & .768 & .074 \\
\hline & Total & 225 & 3.24 & .765 & .051 \\
\hline \multirow{4}{*}{$\begin{array}{l}\text { Faculty who are members of racial or ethnic } \\
\text { minorities are treated fairly at my institution }\end{array}$} & 60 or less & 22 & 3.23 & .922 & .197 \\
\hline & $61-65$ & 93 & 3.24 & .743 & .077 \\
\hline & 66 or above & 108 & 3.29 & .786 & .076 \\
\hline & Total & 223 & 3.26 & .780 & .052 \\
\hline \multirow{4}{*}{$\begin{array}{l}\text { My institution effectively meets the educational } \\
\text { needs of entering students }\end{array}$} & 60 or less & 24 & 3.21 & .588 & .120 \\
\hline & $61-65$ & 93 & 3.24 & .728 & .076 \\
\hline & 66 or above & 108 & 3.22 & .715 & .069 \\
\hline & Total & 225 & 3.23 & .705 & .047 \\
\hline \multirow{4}{*}{$\begin{array}{l}\text { If I had it to do over again, I would choose an } \\
\text { academic career }\end{array}$} & 60 or less & 24 & 3.50 & .722 & .147 \\
\hline & $61-65$ & 93 & 3.83 & .433 & .045 \\
\hline & 66 or above & 110 & 3.82 & .510 & .049 \\
\hline & Total & 227 & 3.79 & .515 & .034 \\
\hline
\end{tabular}


NSOPF descriptive statistics by academic field

\begin{tabular}{|c|c|c|c|c|c|}
\hline $\begin{array}{c}\text { How satisfied or dissatisfied do you personally } \\
\text { feel about each of the following aspects of } \\
\text { your job at your current institution }\end{array}$ & Academic Field & $N$ & Mean & $\begin{array}{l}\text { Standard } \\
\text { Deviation }\end{array}$ & $\begin{array}{c}\text { Standard } \\
\text { Error }\end{array}$ \\
\hline \multirow{6}{*}{ My Work Load } & Humanities & 71 & 2.76 & .783 & .093 \\
\hline & Physical Sciences & 29 & 2.38 & .903 & .168 \\
\hline & Pre-Professional & 77 & 3.19 & .859 & .098 \\
\hline & Social Sciences & 41 & 2.73 & .837 & .131 \\
\hline & Other & 13 & 3.00 & .707 & .196 \\
\hline & Total & 231 & 2.87 & .867 & .057 \\
\hline \multirow{6}{*}{ My job security } & Humanities & 71 & 3.30 & .868 & .103 \\
\hline & Physical Sciences & 29 & 3.48 & .738 & .137 \\
\hline & Pre-Professional & 76 & 3.43 & .736 & .084 \\
\hline & Social Sciences & 41 & 3.54 & .778 & .121 \\
\hline & Other & 13 & 3.31 & .855 & .237 \\
\hline & Total & 230 & 3.41 & .792 & .052 \\
\hline \multirow{6}{*}{ My Salary } & Humanities & 71 & 2.75 & .806 & .096 \\
\hline & Physical Sciences & 29 & 2.72 & .841 & .156 \\
\hline & Pre-Professional & 77 & 2.65 & .900 & .103 \\
\hline & Social Sciences & 41 & 2.46 & .925 & .144 \\
\hline & Other & 13 & 2.77 & .927 & .257 \\
\hline & Total & 231 & 2.66 & .869 & .057 \\
\hline \multirow{6}{*}{ My Benefits } & Humanities & 71 & 2.90 & .928 & .110 \\
\hline & Physical Sciences & 29 & 2.86 & .875 & .163 \\
\hline & Pre-Professional & 77 & 2.88 & .843 & .096 \\
\hline & Social Sciences & 41 & 2.66 & .911 & .142 \\
\hline & Other & 12 & 2.83 & .937 & .271 \\
\hline & Total & 230 & 2.84 & .887 & .059 \\
\hline \multirow{6}{*}{$\begin{array}{l}\text { The authority I have to make decisions about } \\
\text { what courses I teach }\end{array}$} & Humanities & 71 & 3.39 & .819 & .097 \\
\hline & Physical Sciences & 29 & 3.59 & .568 & .105 \\
\hline & Pre-Professional & 75 & 3.37 & .785 & .091 \\
\hline & Social Sciences & 41 & 3.56 & .776 & .121 \\
\hline & Other & 13 & 3.62 & .768 & .213 \\
\hline & Total & 229 & 3.45 & .769 & .051 \\
\hline \multirow{6}{*}{$\begin{array}{l}\text { The authority I have to make decisions about } \\
\text { the content and methods in the courses I teach }\end{array}$} & Humanities & 71 & 3.77 & .566 & .067 \\
\hline & Physical Sciences & 29 & 3.86 & .351 & .065 \\
\hline & Pre-Professional & 75 & 3.76 & .489 & .056 \\
\hline & Social Sciences & 41 & 3.93 & .346 & .054 \\
\hline & Other & 13 & 3.62 & .506 & .140 \\
\hline & Total & 229 & 3.80 & .481 & .032 \\
\hline
\end{tabular}


NSOPF descriptive statistics by academic field (continued)

\begin{tabular}{|c|c|c|c|c|c|}
\hline \multirow{6}{*}{$\begin{array}{l}\text { The authority I have to make decisions about } \\
\text { other aspects of my job }\end{array}$} & Humanities & 69 & 3.36 & .707 & .085 \\
\hline & Physical Sciences & 29 & 3.45 & .632 & .117 \\
\hline & Pre-Professional & 76 & 3.36 & .626 & .072 \\
\hline & Social Sciences & 41 & 3.29 & .750 & .117 \\
\hline & Other & 13 & 3.46 & .519 & .144 \\
\hline & Total & 228 & 3.36 & .666 & .044 \\
\hline \multirow{6}{*}{$\begin{array}{l}\text { The mix of teaching, research, administration, } \\
\text { and service that I am required to do }\end{array}$} & Humanities & 70 & 3.06 & .759 & .091 \\
\hline & Physical Sciences & 29 & 2.86 & .693 & .129 \\
\hline & Pre-Professional & 76 & 3.29 & .830 & .095 \\
\hline & Social Sciences & 40 & 2.95 & .815 & .129 \\
\hline & Other & 13 & 3.15 & .689 & .191 \\
\hline & Total & 228 & 3.10 & .791 & .052 \\
\hline \multirow{6}{*}{$\begin{array}{l}\text { The opportunity for advancement in rank at my } \\
\text { institution }\end{array}$} & Humanities & 71 & 3.20 & .904 & .107 \\
\hline & Physical Sciences & 29 & 3.10 & .939 & .174 \\
\hline & Pre-Professional & 76 & 3.04 & .930 & .107 \\
\hline & Social Sciences & 40 & 3.28 & .847 & .134 \\
\hline & Other & 12 & 2.92 & .996 & .288 \\
\hline & Total & 228 & 3.13 & .910 & .060 \\
\hline \multirow{6}{*}{ Time available for keeping current in my field } & Humanities & 71 & 2.31 & .855 & .101 \\
\hline & Physical Sciences & 29 & 2.17 & .805 & .149 \\
\hline & Pre-Professional & 75 & 2.69 & .900 & .104 \\
\hline & Social Sciences & 41 & 2.37 & .888 & .139 \\
\hline & Other & 13 & 2.69 & .855 & .237 \\
\hline & Total & 229 & 2.45 & .885 & .058 \\
\hline \multirow{6}{*}{$\begin{array}{l}\text { Availability of support services and equipment } \\
\text { (clerical support, computers, etc.) }\end{array}$} & Humanities & 71 & 2.77 & .944 & .112 \\
\hline & Physical Sciences & 29 & 2.69 & .891 & .165 \\
\hline & Pre-Professional & 77 & 3.06 & .864 & .098 \\
\hline & Social Sciences & 41 & 2.83 & .834 & .130 \\
\hline & Other & 13 & 2.92 & .954 & .265 \\
\hline & Total & 231 & 2.88 & .896 & .059 \\
\hline \multirow{6}{*}{ Freedom to do outside consulting } & Humanities & 68 & 3.37 & .644 & .078 \\
\hline & Physical Sciences & 26 & 3.08 & .845 & .166 \\
\hline & Pre-Professional & 75 & 3.37 & .673 & .078 \\
\hline & Social Sciences & 39 & 3.26 & .751 & .120 \\
\hline & Other & 12 & 2.92 & .996 & .288 \\
\hline & Total & 220 & 3.29 & .726 & .049 \\
\hline \multirow{6}{*}{ Overall reputation of the institution } & Humanities & 71 & 3.15 & .768 & .091 \\
\hline & Physical Sciences & 29 & 3.00 & .756 & .140 \\
\hline & Pre-Professional & 75 & 3.49 & .665 & .077 \\
\hline & Social Sciences & 40 & 3.05 & .876 & .138 \\
\hline & Other & 13 & 3.38 & .506 & .140 \\
\hline & Total & 228 & 3.24 & .762 & .050 \\
\hline
\end{tabular}


NSOPF descriptive statistics by academic field (continued)

\begin{tabular}{|c|c|c|c|c|c|}
\hline \multirow[b]{6}{*}{ Reputation of my department } & Humanities & 71 & 3.18 & .833 & .099 \\
\hline & Physical Sciences & 29 & 3.31 & .712 & .132 \\
\hline & Pre-Professional & 77 & 3.45 & .770 & .088 \\
\hline & Social Sciences & 41 & 3.41 & .805 & .126 \\
\hline & Other & 13 & 3.85 & .376 & .104 \\
\hline & Total & 231 & 3.37 & .785 & .052 \\
\hline \multirow{6}{*}{ Institutional mission or philosophy } & Humanities & 71 & 3.62 & .544 & .065 \\
\hline & Physical Sciences & 29 & 3.76 & .435 & .081 \\
\hline & Pre-Professional & 76 & 3.68 & .496 & .057 \\
\hline & Social Sciences & 41 & 3.61 & .666 & .104 \\
\hline & Other & 13 & 3.77 & .439 & .122 \\
\hline & Total & 230 & 3.67 & .534 & .035 \\
\hline \multirow{6}{*}{ Quality of leadership in my department } & Humanities & 71 & 3.08 & .982 & .117 \\
\hline & Physical Sciences & 29 & 3.52 & .574 & .107 \\
\hline & Pre-Professional & 77 & 3.52 & .771 & .088 \\
\hline & Social Sciences & 40 & 3.48 & .784 & .124 \\
\hline & Other & 13 & 3.77 & .439 & .122 \\
\hline & Total & 230 & 3.39 & .833 & .055 \\
\hline \multirow{6}{*}{$\begin{array}{l}\text { Quality of chief administrative officers at my } \\
\text { institution }\end{array}$} & Humanities & 71 & 3.03 & .925 & .110 \\
\hline & Physical Sciences & 29 & 2.86 & .990 & .184 \\
\hline & Pre-Professional & 76 & 3.30 & .880 & .101 \\
\hline & Social Sciences & 41 & 3.24 & .830 & .130 \\
\hline & Other & 13 & 2.92 & 1.038 & .288 \\
\hline & Total & 230 & 3.13 & .916 & .060 \\
\hline \multirow{6}{*}{ Quality of my colleagues in my department } & Humanities & 71 & 3.42 & .710 & .084 \\
\hline & Physical Sciences & 29 & 3.62 & .677 & .126 \\
\hline & Pre-Professional & 75 & 3.57 & .597 & .069 \\
\hline & Social Sciences & 40 & 3.43 & .747 & .118 \\
\hline & Other & 13 & 3.69 & .480 & .133 \\
\hline & Total & 228 & 3.51 & .667 & .044 \\
\hline \multirow{6}{*}{ Quality of faculty leadership at my institution } & Humanities & 71 & 3.07 & .867 & .103 \\
\hline & Physical Sciences & 29 & 2.93 & .704 & .131 \\
\hline & Pre-Professional & 77 & 3.21 & .800 & .091 \\
\hline & Social Sciences & 40 & 3.15 & .770 & .122 \\
\hline & Other & 13 & 3.15 & .801 & .222 \\
\hline & Total & 230 & 3.12 & .803 & .053 \\
\hline \multirow{6}{*}{$\begin{array}{l}\text { Relationship between administration and } \\
\text { faculty at this institution }\end{array}$} & Humanities & 70 & 2.76 & .842 & .101 \\
\hline & Physical Sciences & 29 & 2.55 & 1.055 & .196 \\
\hline & Pre-Professional & 77 & 2.96 & .880 & .100 \\
\hline & Social Sciences & 41 & 2.80 & .872 & .136 \\
\hline & Other & 13 & 2.54 & 1.127 & .312 \\
\hline & Total & 230 & 2.80 & .909 & .060 \\
\hline
\end{tabular}


NSOPF descriptive statistics by academic field (continued)

\begin{tabular}{|c|c|c|c|c|c|}
\hline \multirow[b]{6}{*}{ Interdepartmental cooperation at this institution } & Humanities & 71 & 2.83 & .845 & .100 \\
\hline & Physical Sciences & 29 & 2.97 & .823 & .153 \\
\hline & Pre-Professional & 77 & 2.69 & .831 & .095 \\
\hline & Social Sciences & 40 & 2.85 & .662 & .105 \\
\hline & Other & 13 & 2.85 & .899 & .249 \\
\hline & Total & 230 & 2.80 & .810 & .053 \\
\hline \multirow{6}{*}{$\begin{array}{l}\text { Spirit of cooperation between faculty at this } \\
\text { institution }\end{array}$} & Humanities & 71 & 3.08 & .806 & .096 \\
\hline & Physical Sciences & 29 & 3.28 & .591 & .110 \\
\hline & Pre-Professional & 77 & 3.00 & .827 & .094 \\
\hline & Social Sciences & 41 & 3.07 & .685 & .107 \\
\hline & Other & 13 & 3.15 & .689 & .191 \\
\hline & Total & 231 & 3.08 & .762 & .050 \\
\hline \multirow{6}{*}{ Quality of my research facilities and support } & Humanities & 69 & 2.43 & .757 & .091 \\
\hline & Physical Sciences & 27 & 2.07 & .874 & .168 \\
\hline & Pre-Professional & 71 & 2.62 & .834 & .099 \\
\hline & Social Sciences & 41 & 2.20 & .901 & 141 \\
\hline & Other & 12 & 2.58 & .793 & .229 \\
\hline & Total & 220 & 2.41 & 842 & .057 \\
\hline \multirow{6}{*}{ Quality of students whom I have taught here } & Humanities & 71 & 2.97 & .696 & .083 \\
\hline & Physical Sciences & 29 & 2.86 & .743 & .138 \\
\hline & Pre-Professional & 77 & 3.26 & .696 & .079 \\
\hline & Social Sciences & 41 & 3.02 & .851 & .133 \\
\hline & Other & 13 & 3.38 & .650 & .180 \\
\hline & Total & 231 & 3.09 & .741 & .049 \\
\hline \multirow{6}{*}{ Teaching assistance that I receive } & Humanities & 67 & 2.37 & .850 & .104 \\
\hline & Physical Sciences & 28 & 2.86 & .756 & .143 \\
\hline & Pre-Professional & 66 & 3.00 & .911 & .112 \\
\hline & Social Sciences & 38 & 2.55 & .760 & .123 \\
\hline & Other & 12 & 3.08 & .793 & .229 \\
\hline & Total & 211 & 2.71 & .878 & .060 \\
\hline \multirow{6}{*}{ Research assistance that I receive } & Humanities & 66 & 2.23 & .760 & .094 \\
\hline & Physical Sciences & 24 & 2.17 & .868 & .177 \\
\hline & Pre-Professional & 62 & 2.61 & 1.014 & .129 \\
\hline & Social Sciences & 35 & 2.20 & .759 & .128 \\
\hline & Other & 12 & 2.58 & .669 & .193 \\
\hline & Total & 199 & 2.36 & .869 & .062 \\
\hline \multirow{6}{*}{$\begin{array}{l}\text { Spouse employment opportunities in this } \\
\text { geographic area }\end{array}$} & Humanities & 64 & 3.25 & .816 & .102 \\
\hline & Physical Sciences & 26 & 3.35 & .689 & .135 \\
\hline & Pre-Professional & 68 & 3.34 & .803 & .097 \\
\hline & Social Sciences & 39 & 3.23 & .706 & .113 \\
\hline & Other & 13 & 3.31 & .947 & .263 \\
\hline & Total & 210 & 3.29 & .780 & .054 \\
\hline
\end{tabular}


NSOPF descriptive statistics by academic field (continued)

\begin{tabular}{|c|c|c|c|c|c|}
\hline \multirow[b]{6}{*}{ My overall satisfaction with my job here } & Humanities & 70 & 3.46 & .582 & .070 \\
\hline & Physical Sciences & 29 & 3.45 & .632 & .117 \\
\hline & Pre-Professional & 77 & 3.48 & .620 & .071 \\
\hline & Social Sciences & 41 & 3.46 & .711 & .111 \\
\hline & Other & 13 & 3.54 & .660 & .183 \\
\hline & Total & 230 & 3.47 & .624 & .041 \\
\hline $\begin{array}{l}\text { If you were to leave your current institution, } \\
\text { how likely is it that you would do so to? }\end{array}$ & Academic Field & $N$ & Mean & $\begin{array}{l}\text { Standard } \\
\text { Deviation }\end{array}$ & $\begin{array}{l}\text { Standard } \\
\text { Error }\end{array}$ \\
\hline \multirow{6}{*}{ Leave to Retire } & Humanities & 72 & 2.18 & .924 & .109 \\
\hline & Physical Sciences & 29 & 2.14 & .953 & .177 \\
\hline & Pre-Professional & 76 & 2.17 & .885 & .102 \\
\hline & Social Sciences & 41 & 2.10 & .970 & .151 \\
\hline & Other & 13 & 2.15 & .899 & .249 \\
\hline & Total & 231 & 2.16 & .915 & .060 \\
\hline \multirow{6}{*}{ Return to school as a student } & Humanities & 71 & 1.11 & .398 & .047 \\
\hline & Physical Sciences & 29 & 1.21 & .491 & .091 \\
\hline & Pre-Professional & 75 & 1.31 & .592 & .068 \\
\hline & Social Sciences & 41 & 1.12 & .331 & .052 \\
\hline & Other & 13 & 1.15 & .376 & .104 \\
\hline & Total & 229 & 1.19 & .475 & .031 \\
\hline \multirow{6}{*}{$\begin{array}{l}\text { Accept employment at another Christian } \\
\text { college or university }\end{array}$} & Humanities & 71 & 2.18 & .661 & .078 \\
\hline & Physical Sciences & 29 & 1.93 & .799 & .148 \\
\hline & Pre-Professional & 75 & 1.92 & .632 & .073 \\
\hline & Social Sciences & 41 & 2.05 & .631 & .098 \\
\hline & Other & 13 & 1.92 & .641 & .178 \\
\hline & Total & 229 & 2.03 & .668 & .044 \\
\hline \multirow{6}{*}{$\begin{array}{l}\text { Accept employment at a secular college or } \\
\text { university }\end{array}$} & Humanities & 70 & 1.53 & .607 & .073 \\
\hline & Physical Sciences & 29 & 1.55 & .632 & .117 \\
\hline & Pre-Professional & 75 & 1.69 & .697 & .080 \\
\hline & Social Sciences & 41 & 1.73 & .672 & .105 \\
\hline & Other & 13 & 1.69 & .630 & .175 \\
\hline & Total & 228 & 1.63 & .654 & .043 \\
\hline \multirow{6}{*}{$\begin{array}{l}\text { Accept employment in consulting or other for- } \\
\text { profit business or industry or become self- } \\
\text { employed }\end{array}$} & Humanities & 71 & 1.42 & .669 & .079 \\
\hline & Physical Sciences & 29 & 1.59 & .628 & .117 \\
\hline & Pre-Professional & 75 & 1.64 & .782 & .090 \\
\hline & Social Sciences & 41 & 1.78 & .613 & .096 \\
\hline & Other & 13 & 1.62 & .650 & .180 \\
\hline & Total & 229 & 1.59 & .699 & .046 \\
\hline \multirow{6}{*}{$\begin{array}{l}\text { Accept employment in a non-profit } \\
\text { organization }\end{array}$} & Humanities & 70 & 1.80 & .694 & .083 \\
\hline & Physical Sciences & 29 & 1.66 & .484 & .090 \\
\hline & Pre-Professional & 75 & 1.60 & .615 & .071 \\
\hline & Social Sciences & 41 & 1.85 & .573 & .089 \\
\hline & Other & 13 & 1.62 & .650 & .180 \\
\hline & Total & 228 & 1.71 & .624 & .041 \\
\hline
\end{tabular}


NSOPF descriptive statistics by academic field (continued)

\begin{tabular}{|c|c|c|c|c|c|}
\hline $\begin{array}{c}\text { If you were to leave your current institution to } \\
\text { accept another position, would you want to do } \\
\text { more, less or about the same amount of the } \\
\text { following as you currently do? }\end{array}$ & Academic Field & $N$ & Mean & $\begin{array}{l}\text { Standard } \\
\text { Deviation }\end{array}$ & $\begin{array}{c}\text { Standard } \\
\text { Error }\end{array}$ \\
\hline \multirow{6}{*}{ Research } & Humanities & 70 & 1.47 & .607 & .073 \\
\hline & Physical Sciences & 29 & 1.66 & .721 & .134 \\
\hline & Pre-Professional & 74 & 1.61 & .615 & .072 \\
\hline & Social Sciences & 40 & 1.55 & .677 & .107 \\
\hline & Other & 13 & 1.85 & .689 & .191 \\
\hline & Total & 226 & 1.58 & .644 & .043 \\
\hline \multirow{6}{*}{ Teaching } & Humanities & 71 & 2.30 & .571 & .068 \\
\hline & Physical Sciences & 29 & 2.14 & .516 & .096 \\
\hline & Pre-Professional & 73 & 2.00 & .553 & .065 \\
\hline & Social Sciences & 41 & 2.24 & .582 & .091 \\
\hline & Other & 13 & 1.77 & .599 & .166 \\
\hline & Total & 227 & 2.14 & .578 & .038 \\
\hline \multirow{6}{*}{ Advising } & Humanities & 71 & 2.21 & .476 & .056 \\
\hline & Physical Sciences & 29 & 2.24 & .511 & .095 \\
\hline & Pre-Professional & 72 & 2.24 & .569 & .067 \\
\hline & Social Sciences & 41 & 2.27 & .549 & .086 \\
\hline & Other & 13 & 2.00 & .577 & .160 \\
\hline & Total & 226 & 2.22 & .529 & .035 \\
\hline \multirow{6}{*}{ Service } & Humanities & 71 & 2.08 & .554 & .066 \\
\hline & Physical Sciences & 29 & 2.31 & .541 & .101 \\
\hline & Pre-Professional & 74 & 2.08 & .568 & .066 \\
\hline & Social Sciences & 41 & 2.27 & .501 & .078 \\
\hline & Other & 13 & 2.15 & .689 & .191 \\
\hline & Total & 228 & 2.15 & .559 & .037 \\
\hline \multirow{6}{*}{ Administration } & Humanities & 70 & 2.34 & .657 & .079 \\
\hline & Physical Sciences & 29 & 2.55 & .572 & .106 \\
\hline & Pre-Professional & 73 & 2.12 & .686 & .080 \\
\hline & Social Sciences & 40 & 2.38 & .628 & .099 \\
\hline & Other & 13 & 1.77 & .725 & .201 \\
\hline & Total & 225 & 2.27 & .676 & .045 \\
\hline $\begin{array}{l}\text { If you were to leave your current institution to } \\
\text { accept another position, how important would } \\
\text { each of the following items be in your decision } \\
\text { to accept another position? }\end{array}$ & Academic Field & $N$ & Mean & $\begin{array}{l}\text { Standard } \\
\text { Deviation }\end{array}$ & $\begin{array}{c}\text { Standard } \\
\text { Error }\end{array}$ \\
\hline \multirow{6}{*}{ Salary Level } & Humanities & 72 & 2.43 & .552 & .065 \\
\hline & Physical Sciences & 29 & 2.28 & .591 & .110 \\
\hline & Pre-Professional & 77 & 2.49 & .553 & .063 \\
\hline & Social Sciences & 41 & 2.44 & .550 & .086 \\
\hline & Other & 13 & 2.38 & .650 & .180 \\
\hline & Total & 232 & 2.43 & .562 & .037 \\
\hline
\end{tabular}


NSOPF descriptive statistics by academic field (continued)

\begin{tabular}{|c|c|c|c|c|c|}
\hline \multirow[b]{6}{*}{ Position Level } & Humanities & 72 & 2.40 & .548 & .065 \\
\hline & Physical Sciences & 29 & 2.17 & .658 & .122 \\
\hline & Pre-Professional & 76 & 2.39 & .655 & .075 \\
\hline & Social Sciences & 41 & 2.24 & .624 & .097 \\
\hline & Other & 13 & 2.38 & .506 & .140 \\
\hline & Total & 231 & 2.34 & .611 & .040 \\
\hline \multirow{6}{*}{ Job Security } & Humanities & 72 & 2.63 & .542 & .064 \\
\hline & Physical Sciences & 29 & 2.28 & .649 & .121 \\
\hline & Pre-Professional & 76 & 2.54 & .662 & .076 \\
\hline & Social Sciences & 41 & 2.54 & .674 & .105 \\
\hline & Other & 13 & 2.69 & .480 & .133 \\
\hline & Total & 231 & 2.54 & .623 & .041 \\
\hline \multirow{6}{*}{ Opportunities for advancement } & Humanities & 72 & 2.44 & .625 & .074 \\
\hline & Physical Sciences & 29 & 1.97 & .566 & .105 \\
\hline & Pre-Professional & 77 & 2.32 & .733 & .084 \\
\hline & Social Sciences & 41 & 2.29 & .716 & .112 \\
\hline & Other & 13 & 2.38 & .506 & .140 \\
\hline & Total & 232 & 2.31 & .677 & .044 \\
\hline \multirow{6}{*}{ Benefits } & Humanities & 72 & 2.72 & .451 & .053 \\
\hline & Physical Sciences & 29 & 2.45 & .572 & .106 \\
\hline & Pre-Professional & 77 & 2.70 & .488 & .056 \\
\hline & Social Sciences & 41 & 2.59 & .591 & .092 \\
\hline & Other & 13 & 2.62 & .506 & .140 \\
\hline & Total & 232 & 2.65 & .513 & .034 \\
\hline \multirow{6}{*}{ No pressure to publish } & Humanities & 72 & 1.94 & .729 & .086 \\
\hline & Physical Sciences & 29 & 2.38 & .561 & .104 \\
\hline & Pre-Professional & 77 & 2.32 & .751 & .086 \\
\hline & Social Sciences & 41 & 2.10 & .700 & .109 \\
\hline & Other & 13 & 2.08 & .641 & .178 \\
\hline & Total & 232 & 2.16 & .724 & .048 \\
\hline \multirow{6}{*}{ Academic Freedom } & Humanities & 72 & 2.61 & .519 & .061 \\
\hline & Physical Sciences & 29 & 2.52 & .634 & .118 \\
\hline & Pre-Professional & 77 & 2.49 & .576 & .066 \\
\hline & Social Sciences & 41 & 2.80 & .459 & .072 \\
\hline & Other & 13 & 2.46 & .519 & .144 \\
\hline & Total & 232 & 2.59 & .552 & .036 \\
\hline \multirow{6}{*}{ Good research facilities and equipment } & Humanities & 71 & 2.31 & .689 & .082 \\
\hline & Physical Sciences & 29 & 2.07 & .593 & .110 \\
\hline & Pre-Professional & 76 & 1.96 & .701 & .080 \\
\hline & Social Sciences & 41 & 2.17 & .587 & .092 \\
\hline & Other & 13 & 2.00 & .577 & .160 \\
\hline & Total & 230 & 2.12 & .669 & .044 \\
\hline
\end{tabular}


NSOPF descriptive statistics by academic field (continued)

\begin{tabular}{|c|c|c|c|c|c|}
\hline \multirow[b]{6}{*}{ Good instructional facilities and equipment } & Humanities & 72 & 2.56 & .579 & .068 \\
\hline & Physical Sciences & 29 & 2.59 & .501 & .093 \\
\hline & Pre-Professional & 76 & 2.49 & .577 & .066 \\
\hline & Social Sciences & 41 & 2.59 & .591 & .092 \\
\hline & Other & 13 & 2.54 & .519 & .144 \\
\hline & Total & 231 & 2.54 & .565 & .037 \\
\hline \multirow{6}{*}{ Excellent Students } & Humanities & 72 & 2.47 & .530 & .062 \\
\hline & Physical Sciences & 29 & 2.34 & .670 & .124 \\
\hline & Pre-Professional & 77 & 2.40 & .591 & .067 \\
\hline & Social Sciences & 41 & 2.44 & .550 & .086 \\
\hline & Other & 13 & 2.38 & .506 & .140 \\
\hline & Total & 232 & 2.42 & .568 & .037 \\
\hline \multirow{6}{*}{ Excellent Colleagues } & Humanities & 72 & 2.69 & .464 & .055 \\
\hline & Physical Sciences & 29 & 2.55 & .506 & .094 \\
\hline & Pre-Professional & 77 & 2.68 & .498 & .057 \\
\hline & Social Sciences & 41 & 2.66 & .480 & .075 \\
\hline & Other & 13 & 2.62 & .506 & .140 \\
\hline & Total & 232 & 2.66 & .484 & .032 \\
\hline \multirow{6}{*}{ New institution is a Christian college } & Humanities & 72 & 2.36 & .657 & .077 \\
\hline & Physical Sciences & 29 & 2.24 & .689 & .128 \\
\hline & Pre-Professional & 77 & 2.27 & .737 & .084 \\
\hline & Social Sciences & 41 & 2.12 & .781 & .122 \\
\hline & Other & 13 & 2.46 & .660 & .183 \\
\hline & Total & 232 & 2.28 & .711 & .047 \\
\hline \multirow{6}{*}{$\begin{array}{l}\text { Institutional mission or philosophy that is } \\
\text { compatible with my own views }\end{array}$} & Humanities & 71 & 2.70 & .490 & .058 \\
\hline & Physical Sciences & 29 & 2.66 & .484 & .090 \\
\hline & Pre-Professional & 77 & 2.66 & .528 & .060 \\
\hline & Social Sciences & 41 & 2.63 & .581 & .091 \\
\hline & Other & 13 & 2.69 & .480 & .133 \\
\hline & Total & 231 & 2.67 & .515 & .034 \\
\hline \multirow{6}{*}{ Good job for my spouse } & Humanities & 70 & 2.14 & .804 & .096 \\
\hline & Physical Sciences & 28 & 1.89 & .832 & .157 \\
\hline & Pre-Professional & 72 & 2.07 & .924 & .109 \\
\hline & Social Sciences & 39 & 2.05 & .826 & .132 \\
\hline & Other & 13 & 2.46 & .776 & .215 \\
\hline & Total & 222 & 2.09 & .851 & .057 \\
\hline \multirow{6}{*}{ Good geographic location } & Humanities & 72 & 2.31 & .597 & .070 \\
\hline & Physical Sciences & 29 & 2.34 & .670 & .124 \\
\hline & Pre-Professional & 75 & 2.56 & .620 & .072 \\
\hline & Social Sciences & 40 & 2.50 & .641 & .101 \\
\hline & Other & 13 & 2.46 & .660 & .183 \\
\hline & Total & 229 & 2.44 & .629 & .042 \\
\hline
\end{tabular}


NSOPF descriptive statistics by academic field (continued)

\begin{tabular}{|c|c|c|c|c|c|}
\hline \multirow[b]{6}{*}{ Affordable Housing } & Humanities & 72 & 2.47 & .581 & .068 \\
\hline & Physical Sciences & 29 & 2.45 & .632 & .117 \\
\hline & Pre-Professional & 75 & 2.51 & .623 & .072 \\
\hline & Social Sciences & 40 & 2.55 & .677 & .107 \\
\hline & Other & 13 & 2.62 & .506 & .140 \\
\hline & Total & 229 & 2.50 & .611 & .040 \\
\hline \multirow{6}{*}{ Good environment/schools for my children } & Humanities & 70 & 2.00 & .933 & .111 \\
\hline & Physical Sciences & 28 & 1.89 & .916 & .173 \\
\hline & Pre-Professional & 72 & 1.85 & .914 & .108 \\
\hline & Social Sciences & 39 & 1.90 & .852 & .136 \\
\hline & Other & 11 & 2.55 & .820 & .247 \\
\hline & Total & 220 & 1.95 & .910 & .061 \\
\hline \multirow{6}{*}{ A full-time position } & Humanities & 71 & 2.80 & .496 & .059 \\
\hline & Physical Sciences & 29 & 2.62 & .728 & .135 \\
\hline & Pre-Professional & 74 & 2.65 & .671 & .078 \\
\hline & Social Sciences & 41 & 2.85 & .422 & .066 \\
\hline & Other & 11 & 2.82 & .405 & .122 \\
\hline & Total & 226 & 2.74 & .580 & .039 \\
\hline \multirow{6}{*}{ A part-time position } & Humanities & 69 & 1.28 & .539 & .065 \\
\hline & Physical Sciences & 28 & 1.29 & .535 & .101 \\
\hline & Pre-Professional & 73 & 1.42 & .665 & .078 \\
\hline & Social Sciences & 40 & 1.10 & .304 & .048 \\
\hline & Other & 12 & 1.42 & .669 & .193 \\
\hline & Total & 222 & 1.30 & .566 & .038 \\
\hline $\begin{array}{l}\text { Please indicate the extent to which you agree } \\
\text { or disagree with each of the following } \\
\text { statements. }\end{array}$ & Academic Field & $N$ & Mean & $\begin{array}{l}\text { Standard } \\
\text { Deviation }\end{array}$ & $\begin{array}{l}\text { Standard } \\
\text { Error }\end{array}$ \\
\hline \multirow{6}{*}{$\begin{array}{l}\text { It is important for faculty to participate in } \\
\text { governing their institution }\end{array}$} & Humanities & 72 & 3.69 & .521 & .061 \\
\hline & Physical Sciences & 28 & 3.54 & .744 & .141 \\
\hline & Pre-Professional & 77 & 3.57 & .548 & .062 \\
\hline & Social Sciences & 41 & 3.76 & .538 & .084 \\
\hline & Other & 13 & 3.69 & .480 & .133 \\
\hline & Total & 231 & 3.65 & .563 & .037 \\
\hline \multirow{6}{*}{$\begin{array}{l}\text { Faculty promotions should be based at least in } \\
\text { part on formal student evaluations }\end{array}$} & Humanities & 72 & 2.92 & .783 & .092 \\
\hline & Physical Sciences & 29 & 3.03 & .731 & .136 \\
\hline & Pre-Professional & 77 & 2.97 & .778 & .089 \\
\hline & Social Sciences & 41 & 2.93 & .818 & .128 \\
\hline & Other & 13 & 3.08 & .277 & .077 \\
\hline & Total & 232 & 2.96 & .758 & .050 \\
\hline \multirow{6}{*}{$\begin{array}{l}\text { The tenure system in higher education should } \\
\text { be preserved }\end{array}$} & Humanities & 71 & 3.07 & .816 & .097 \\
\hline & Physical Sciences & 29 & 2.90 & .860 & .160 \\
\hline & Pre-Professional & 77 & 2.49 & 1.034 & .118 \\
\hline & Social Sciences & 41 & 2.93 & .932 & .146 \\
\hline & Other & 13 & 2.62 & .870 & .241 \\
\hline & Total & 231 & 2.81 & .947 & .062 \\
\hline
\end{tabular}


NSOPF descriptive statistics by academic field (continued)

\begin{tabular}{|c|c|c|c|c|c|}
\hline \multirow{6}{*}{$\begin{array}{l}\text { Teaching effectiveness should be the primary } \\
\text { criterion for promotion of faculty }\end{array}$} & Humanities & 72 & 3.26 & .671 & .079 \\
\hline & Physical Sciences & 29 & 3.34 & .670 & .124 \\
\hline & Pre-Professional & 76 & 3.46 & .642 & .074 \\
\hline & Social Sciences & 41 & 3.12 & .640 & .100 \\
\hline & Other & 13 & 3.15 & .555 & .154 \\
\hline & Total & 231 & 3.31 & .657 & .043 \\
\hline \multirow{6}{*}{$\begin{array}{l}\text { Research/publications should be the primary } \\
\text { criterion for promotion of college faculty }\end{array}$} & Humanities & 72 & 2.00 & .671 & .079 \\
\hline & Physical Sciences & 29 & 1.86 & .743 & .138 \\
\hline & Pre-Professional & 77 & 1.84 & .689 & .079 \\
\hline & Social Sciences & 41 & 1.85 & .727 & .113 \\
\hline & Other & 13 & 2.08 & .641 & .178 \\
\hline & Total & 232 & 1.91 & .694 & .046 \\
\hline \multirow{6}{*}{$\begin{array}{l}\text { Years of service/advanced degree should be } \\
\text { the primary criterion for promotion of college } \\
\text { faculty }\end{array}$} & Humanities & 71 & 2.46 & .734 & .087 \\
\hline & Physical Sciences & 29 & 2.41 & .780 & .145 \\
\hline & Pre-Professional & 76 & 2.47 & .791 & .091 \\
\hline & Social Sciences & 41 & 2.39 & .802 & .125 \\
\hline & Other & 13 & 2.77 & .725 & .201 \\
\hline & Total & 230 & 2.47 & .768 & .051 \\
\hline \multirow{6}{*}{$\begin{array}{l}\text { The administrative function is taking an } \\
\text { increasingly heavy share of available } \\
\text { resources at my institution }\end{array}$} & Humanities & 69 & 2.74 & .885 & .107 \\
\hline & Physical Sciences & 28 & 3.25 & .645 & .122 \\
\hline & Pre-Professional & 76 & 2.51 & .841 & .096 \\
\hline & Social Sciences & 40 & 2.83 & .903 & .143 \\
\hline & Other & 13 & 2.92 & .862 & .239 \\
\hline & Total & 226 & 2.75 & .870 & .058 \\
\hline \multirow{6}{*}{$\begin{array}{l}\text { State or federally mandated assessment } \\
\text { requirements have improved the quality of } \\
\text { undergraduate education at my institution }\end{array}$} & Humanities & 70 & 2.37 & .783 & .094 \\
\hline & Physical Sciences & 29 & 1.97 & .865 & .161 \\
\hline & Pre-Professional & 72 & 2.13 & .804 & .095 \\
\hline & Social Sciences & 39 & 2.23 & .872 & .140 \\
\hline & Other & 13 & 2.54 & .776 & .215 \\
\hline & Total & 223 & 2.22 & .824 & .055 \\
\hline \multirow{6}{*}{$\begin{array}{l}\text { Female faculty members are treated fairly at } \\
\text { my institution }\end{array}$} & Humanities & 72 & 3.31 & .725 & .085 \\
\hline & Physical Sciences & 29 & 3.41 & .682 & .127 \\
\hline & Pre-Professional & 76 & 3.33 & .681 & .078 \\
\hline & Social Sciences & 40 & 3.05 & .846 & .134 \\
\hline & Other & 13 & 3.00 & 1.080 & .300 \\
\hline & Total & 230 & 3.27 & .756 & .050 \\
\hline \multirow{6}{*}{$\begin{array}{l}\text { Faculty who are members of racial or ethnic } \\
\text { minorities are treated fairly at my institution }\end{array}$} & Humanities & 71 & 3.41 & .667 & .079 \\
\hline & Physical Sciences & 28 & 3.57 & .573 & .108 \\
\hline & Pre-Professional & 75 & 3.35 & .688 & .079 \\
\hline & Social Sciences & 41 & 2.95 & .893 & .139 \\
\hline & Other & 13 & 3.23 & .927 & .257 \\
\hline & Total & 228 & 3.32 & .743 & .049 \\
\hline
\end{tabular}


NSOPF descriptive statistics by academic field (continued)

\begin{tabular}{|l|l|r|r|r|r|}
\hline \hline \multirow{5}{*}{$\begin{array}{l}\text { My institution effectively meets the educational } \\
\text { needs of entering students }\end{array}$} & Humanities & 72 & 3.31 & .705 & .083 \\
\cline { 2 - 6 } & Physical Sciences & 29 & 3.17 & .658 & .122 \\
\cline { 2 - 6 } & Pre-Professional & 76 & 3.18 & .647 & .074 \\
\cline { 2 - 6 } & Social Sciences & 40 & 3.15 & .834 & .132 \\
\cline { 2 - 6 } & Other & 13 & 3.54 & .519 & .144 \\
\cline { 2 - 6 } & Total & 230 & 3.23 & .697 & .046 \\
\hline \multirow{4}{*}{$\begin{array}{l}\text { If I had it to do over again, I would choose an } \\
\text { academic career }\end{array}$} & Humanities & 72 & 3.81 & .432 & .051 \\
\cline { 2 - 6 } & Physical Sciences & 29 & 3.83 & .384 & .071 \\
\cline { 2 - 6 } & Pre-Professional & 77 & 3.70 & .670 & .076 \\
\cline { 2 - 6 } & Social Sciences & 41 & 3.85 & .422 & .066 \\
\cline { 2 - 6 } & Other & 13 & 3.92 & .277 & .077 \\
\cline { 2 - 6 } & Total & 232 & 3.79 & .512 & .034 \\
\hline \hline
\end{tabular}


APPENDIX B.

SURVEY INSTRUMENT 


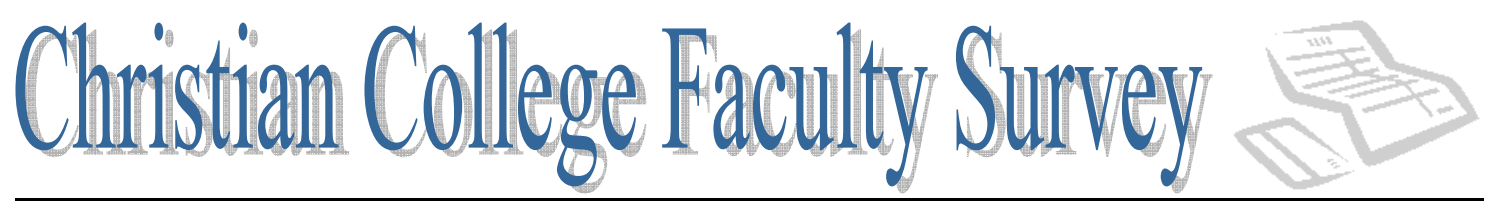

You are invited to participate in a dissertation research study to explore the backgrounds, opinions, experiences and perceptions of faculty members at several institutions belonging to the Council for Christian Colleges and Universities (CCCU). Many of the survey questions in this instrument are taken from the National Study of Postsecondary Faculty (NSOPF-93) administered by the U.S. Department of Education and the Organizational Commitment Questionnaire (OCQ), as reported by Mowday, Steers, and Porter (1979).

The data obtained in this survey will be used by the researcher primarily for a doctoral dissertation, but may also be used to provide aggregate reports to the participating institutions and for future publications. All individual responses will be held in strict confidence. All reporting of data from the survey will be done in the aggregate; no individual survey reports will be released. The questions in the survey are non threatening and should cause no discomfort to the participants. Participation in this study is voluntary and respondents have the opportunity to skip any questions with which they are uncomfortable. Consent will be implied by a participant's submission of the survey.

\section{Directions}

Completion of the electronic survey should take less than 15 minutes. When you are finished with all of the questions, click the <Send Survey $>$ button at the end of the document. You may also clear the survey by clicking the $<$ Reset Survey Form $>$ button at the end of the document. It may be most expedient to $<T A B>$ your way through the survey questions. You may submit comments or ask questions of the researcher by clicking on the email link at the end of the survey.

Thank you for your participation.

Please enter the last four digits of your social security number.

(this information is being collected to track whether individuals inadvertently complete the survey more than one time)

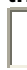

Please specify your gender.

$\square$ Female $\mathbb{C}$ Male

Please indicate your age by selecting one of the following.

Select one please $\checkmark$

Select one please

20-29

30-39

40-49

50-59

60-69

70-79

$80+$ 
Please select the name of the institution at which you work.

Select one please

Select one please

Institution 1

Institution 2

Institution 3

Institution 4

Institution 5

Institution 6

Institution 7

Institution 8

[note: the actual names

of the ten institutions have

been removed from this

Institution 9

nstitution 10

to protect confidentiality]

Does your institution require membership in a particular denomination or church?

C Yes ${ }^{\text {No }}$

If yes, are you a member of that denomination or church?

$\square$ Yes $\mathbb{C}$ Not applicable

If yes, and if possible, would you choose to be a member of a different denomination or church?

$\mathbb{G}{ }_{\text {Yes }} \mathbb{G}$ Not applicable

\section{Please select one of the following:}

C I received my baccalaureate degree from the institution at which I currently work.

C I received my baccalaureate degree from another college that is a member of the Council for Christian Colleges and Universities

(Click here if you are uncertain if your alma mater is a CCCU institution).

$\mathrm{C}$ I received my baccalaureate degree from a non-CCCU Christian college or university.

Q I received my baccalaureate degree from a non Christian college or university. 
Please indicate the highest level of education that you have attained.

\begin{tabular}{|l|}
\hline Select one please \\
\hline Select one please \\
\hline No post secondary training \\
Associate's degree or equivalent \\
Bachelor's degree or equivalent \\
Graduate work not resulting in a degree \\
Master's degree or equivalent \\
Specialist's or Professional degree \\
Doctoral degree \\
\hline
\end{tabular}

In what year did you complete this degree?

Please choose the title that best describes your principal field or discipline of teaching.

\begin{tabular}{|l|}
\hline Select one please \\
\hline Select one please \\
\hline Agriculture \\
Architecture \& Environmental Design \\
Business \\
Communications \\
Computer Science \\
Education \\
Engineering \\
English and Literature (including ESL \& Linguistics) \\
Fine Arts (including Art Music \& Drama) \\
Foreign Languages \\
Health Sciences \\
Home Economics \\
Industrial Arts \\
Law \\
Library \& Archival Sciences \\
Natural Sciences: Biological Sciences \\
Natural Sciences: Physical Sciences \\
Mathematics \& Statistics \\
Military Studies \\
Multi/lnterdisciplinary Studies \\
Parks \& Recreation \\
Philosophy. Religion \& Theology \\
Protective Services (including Criminal Justice) \\
Psychology \\
Public Affairs (including Public Administration \& Social Work) \\
Science Technologies \\
Social Sciences and History \\
Vocational Training \\
Other Fields \\
\hline
\end{tabular}


What is the nature of your current appointment?

$\square$ Full-Time $\square$ Part-Time

If part-time, is this by choice?

$[$ Yes $\mathbb{N}$ No

If part-time, how many courses did you teach in 2002-2003?

How many years have you been teaching at the college/university level?

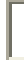

Have any of these years been on a part-time basis?

$[$ Yes $\mathbb{N}$

If yes, how many years?

How many years have you been teaching at your current institution?

Have any of these years been on a part-time basis?

C Yes ${ }^{\text {No }}$

If yes, how many years?

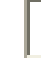

At what age do you think you are most likely to stop teaching at the college or university level?

Which of the following best describes your academic
\begin{tabular}{|l|}
\hline Select one please \\
\hline Select one please \\
\hline Professor \\
Associate Professor \\
Assistant Professor \\
Instructor \\
Lecturer \\
Adjunct \\
Technical Activities (e.g. programmer, technician, etc. \\
Non-Teaching Faculty(e.g. librarian) \\
Other \\
\hline
\end{tabular}


Including this academic year, how many years have you held this rank?

From the options listed below, please select the three most important reasons why you initially chose to accept a position at your current institution.

\begin{tabular}{|l|}
\hline First choice \\
\hline First choice \\
\hline Academic freedom \\
Academic quality of colleagues \\
Acceptance of diversity \\
Administrative leadership \\
Characteristics or quality of students \\
Christian environment/atmosphere \\
Denomination of institution \\
Institutional mission/philosophy \\
Location of institution \\
Only institution that offered me a job \\
Opportunities to conduct research \\
Opportunities for spouse/family \\
Personal friendship with colleagues \\
Professional development funds \\
Quality of facilities or resources \\
Reputation of institution or program \\
Wages and benefits \\
Other
\end{tabular}

Second choice

Second choice

No second choice

Academic freedom

Academic quality of colleagues

Acceptance of diversity

Administrative leadership

Characteristics or quality of students

Christian environment/atmosphere

Denomination of institution

Institutional mission/philosophy

Location of institution

Only institution that offered me a job

Opportunities to conduct research

Opportunities for spouse/family

Personal friendship with colleagues

Professional development funds

Quality of facilities or resources

Reputation of institution or program

Wages and benefits

Other 


\begin{tabular}{|l|}
\hline Third choice \\
\hline Third choice \\
\hline No third choice \\
Academic freedom \\
Academic quality of colleagues \\
Acceptance of diversity \\
Administrative leadership \\
Characteristics or quality of students \\
Christian environment/atmosphere \\
Denomination of institution \\
Institutional mission/philosophy \\
Location of institution \\
Only institution that offered me a job \\
Opportunities to conduct research \\
Opportunities for spouse/family \\
Personal friendship with colleagues \\
Professional development funds \\
Quality of facilities or resources \\
Reputation of institution or program \\
Wages and benefits \\
Other
\end{tabular}

From the options listed below, please select the three characteristics that you currently appreciate most about your institution.

\begin{tabular}{|l|}
\hline First choice \\
\hline First choice \\
\hline Academic freedom \\
Academic quality of colleagues \\
Acceptance of diversity \\
Administrative leadership \\
Characteristics or quality of students \\
Christian environment/atmosphere \\
Denomination of institution \\
Institutional mission/philosophy \\
Location of institution \\
Only employment opportunity available to me \\
Opportunities to conduct research \\
Opportunities for spouse/family \\
Personal friendship with colleagues \\
Professional development funds \\
Quality of facilities or resources \\
Reputation of institution or program \\
Wages and benefits \\
Other
\end{tabular}




\begin{tabular}{|l|}
\hline Second choice \\
\hline Second choice \\
No second choice \\
Academic freedom \\
Academic quality of colleagues \\
Acceptance of diversity \\
Administrative leadership \\
Characteristics or quality of students \\
Christian environment/atmosphere \\
Denomination of institution \\
Institutional mission/philosophy \\
Location of institution \\
Only employment opportunity available to me \\
Opportunities to conduct research \\
Opportunities for spouse/family \\
Personal friendship with colleagues \\
Professional development funds \\
Quality of facilities or resources \\
Reputation of institution or program \\
Wages and benefits \\
Other
\end{tabular}

Third choice

\section{Third choice}

No third choice

Academic freedom

Academic quality of colleagues

Acceptance of diversity

Administrative leadership

Characteristics or quality of students

Christian environment/atmosphere

Denomination of institution

Institutional mission/philosophy

Location of institution

Only employment opportunity available to me

Opportunities to conduct research

Opportunities for spouse/family

Personal friendship with colleagues

Professional development funds

Quality of facilities or resources

Reputation of institution or program

Wages and benefits

Other

From the options listed below, please select the three things that are most problematic about working at your current institution. 


\begin{tabular}{|l|}
\hline First choice \\
\hline First choice \\
\hline Change happens too quickly \\
Change happens too slowly \\
Curriculum is too broad \\
Curriculum is too narrow \\
Curriculum is too professionalized \\
Demands on faculty are too heawy \\
Discrimination against faculty or students \\
Hostile political environment \\
Ineffective administrative or academic leadership \\
Institutional values not sufficiently clarified \\
Lack of flexibility among colleagues or students \\
Lack of professional development resources \\
Location of institution \\
Nepotism among faculty or staff \\
Quality of facilities or resources \\
Quality of students \\
Too little denominational influence \\
Too much denominational influence \\
Wages or benefits are insufficient \\
Other
\end{tabular}

\begin{tabular}{|l|}
\hline Second choice \\
\hline Second choice \\
No second choice \\
Change happens too quickly \\
Change happens too slowly \\
Curriculum is too broad \\
Curriculum is too narrow \\
Curriculum is too professionalized \\
Demands on faculty are too heawy \\
Discrimination against faculty or students \\
Hostile political environment \\
Ineffective administrative or academic leadership \\
Institutional values not sufficiently clarified \\
Lack of flexibility among colleagues or students \\
Lack of professional development resources \\
Location of institution \\
Nepotism among faculty or staff \\
Quality of facilities or resources \\
Quality of students \\
Too little denominational influence \\
Too much denominational influence \\
Wages or benefits are insufficient \\
Other
\end{tabular}




\begin{tabular}{|l|}
\hline Third choice \\
\hline Third choice \\
\hline No third choice \\
Change happens too quickly \\
Change happens too slowly \\
Curriculum is too broad \\
Curriculum is too narrow \\
Curriculum is too professionalized \\
Demands on faculty are too heawy \\
Discrimination against faculty or students \\
Hostile political environment \\
Ineffective administrative or academic leadership \\
Institutional values not sufficiently clarified \\
Lack of flexibility among colleagues or students \\
Lack of professional development resources \\
Location of institution \\
Nepotism among faculty or staff \\
Quality of facilities or resources \\
Quality of students \\
Too little denominational influence \\
Too much denominational influence \\
Wages or benefits are insufficient \\
Other
\end{tabular}

Listed below are a series of statements that represent possible feelings that individuals might have about the institution for which they work. With respect to your own feelings about the particular institution for which you are now working, please indicate the degree of your agreement or disagreement with each statement by checking one of the seven alternatives adjacent to each statement.

Neither

Strongly Moderately Slightly Disagree Slightly Moderately Strongly Disagree Disagree Disagree nor Agree Agree Agree

I am willing to put in a great deal of effort beyond that normally expected in order to help this institution to be successful.

I talk up this institution to my friends as a great institution to work for.

I feel very little loyalty to this institution.

I would accept almost any type of job assignment in order to keep working for this institution.

I find my values and the institution's values are
Agree
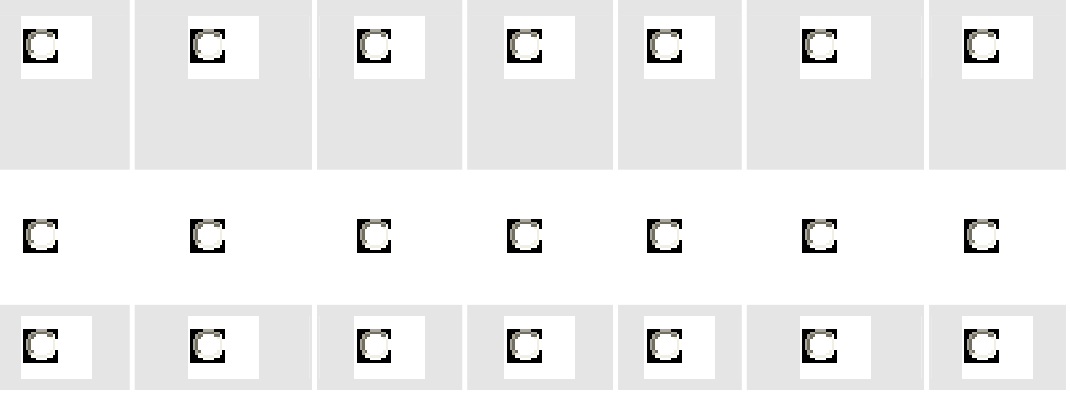

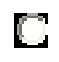

$E$

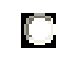

$E$

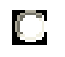

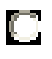
E
E
E
C
E
B
E 
very similar.

I am proud to tell others that I am part of this institution.

I could just as well be working for a different institution as long as the type of work were similar.

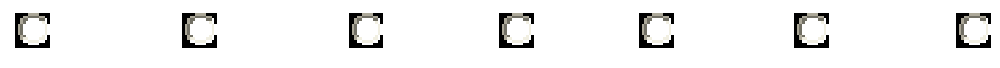

This institution really inspires the very best in me in the way of job performance.

It would take very little change in my present circumstances to cause me to leave this institution.

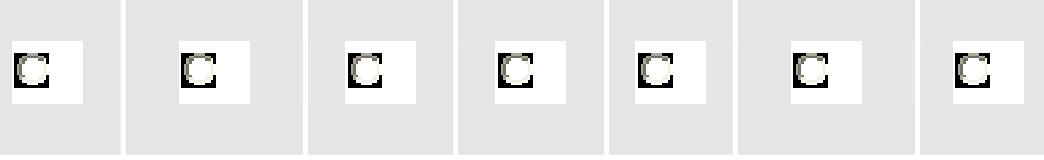

I am extremely glad that I chose this institution to work for over others I was considering at the time I joined.

There's not too much to be gained by sticking with this institution indefinitely.

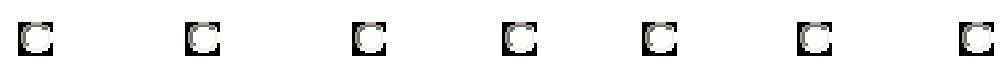

Often, I find it difficult to agree with this institution's policies on important matters relating to its employees.

\section{I really care about the} fate of this institution.
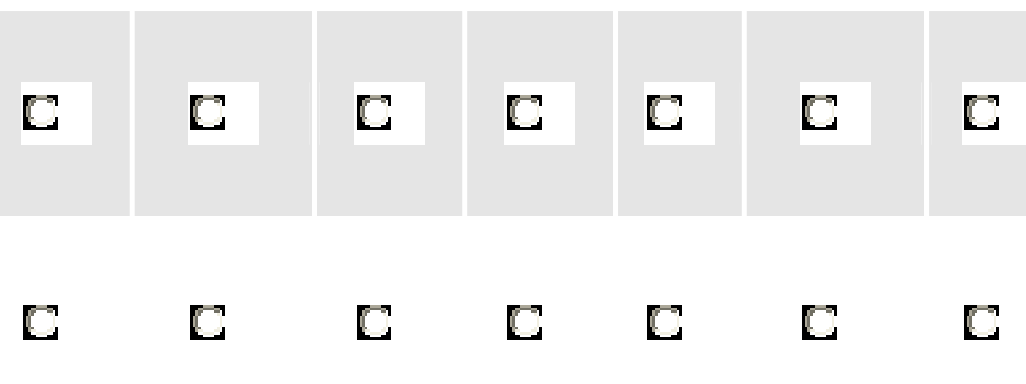

For me this is the best of all possible institutions for which to work.

Deciding to work for this institution was a definite mistake on my part.
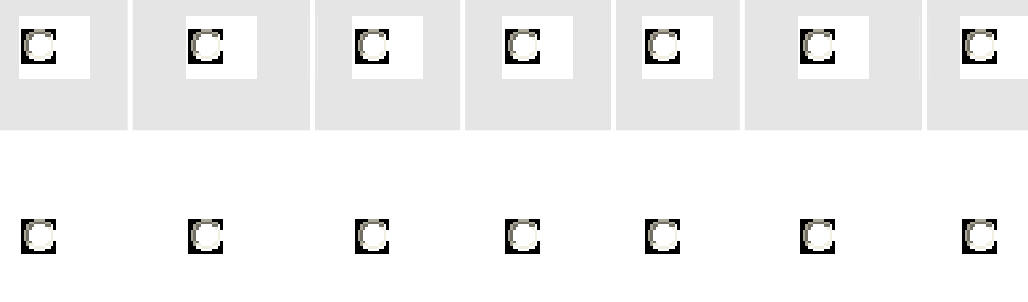

How satisfied or dissatisfied do you personally feel about each of the following aspects of your job at your current institution?

Very Somewhat Somewhat Very Dissatisfied Dissatisfied Satisfied Satisfied

\begin{tabular}{l|l|l|l|l|}
\hline My work load & $\mathbf{C}$ & $\mathbf{C}$ & $\mathbf{C}$ & $\mathbf{C}$ \\
\hline My job security & $\mathbf{C}$ & $\mathbf{C}$ & $\mathbf{C}$ & $\mathbf{C}$ \\
\hline My salary & $\mathbf{C}$ & $\mathbf{C}$ & $\mathbf{C}$ & $\mathbf{C}$ \\
\hline My benefits & $\mathbf{C}$ & $\mathbf{C}$ & $\mathbf{C}$ & $\mathbf{C}$
\end{tabular}


The authority I have to make decisions about what courses I teach

C $\quad$ C $\quad$ C $\quad$ C

The authority I have to make decisions about content and methods in the courses I teach

The authority I have to make decisions about other aspects of my job

C $\quad$ C $\quad$ C $\quad$ C

The mix of teaching, research, administration, and service that I am required to do

\begin{tabular}{l|l|l|l} 
C & C & C
\end{tabular}

The opportunity for advancement in rank at my institution

C $\quad$ C $\quad$ C $\quad$ C

\begin{tabular}{l|l|l|l} 
C & C & C & C
\end{tabular}

Time available for keeping current in my field

Availability of support services and equipment (clerical support, computers, etc.)

C $\quad$ C $\quad$ C $\quad \square$

Freedom to do outside consulting

Overall reputation of the institution

Reputation of my department

\begin{tabular}{l|l|l|l} 
C & C & C
\end{tabular}

Institutional mission or philosophy

C $\quad$ C $\quad$ C $\quad$ C

Quality of leadership in my department

Quality of chief administrative officers at my institution

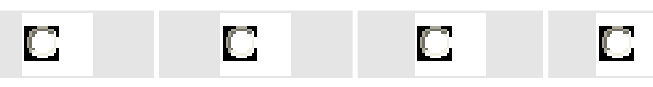

Quality of my colleagues in my department

Quality of faculty leadership at my institution

C E $\quad$ E $\quad$ E

Relationship between administration and faculty at this institution

Interdepartmental cooperation at this institution

Spirit of cooperation between faculty at this institution

Quality of my research facilities and support

C

C $\quad$ C

C

Quality of students whom I have taught here

Teaching assistance that I receive

C E E E E

\begin{tabular}{l|l|l|l} 
E & E & E
\end{tabular}

E E E E

Research assistance that I receive

Spouse employment opportunities in this geographic area

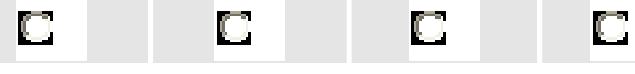

C E C E

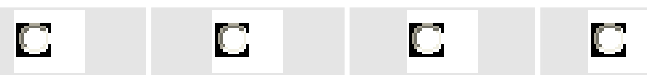

My overall satisfaction with my job here
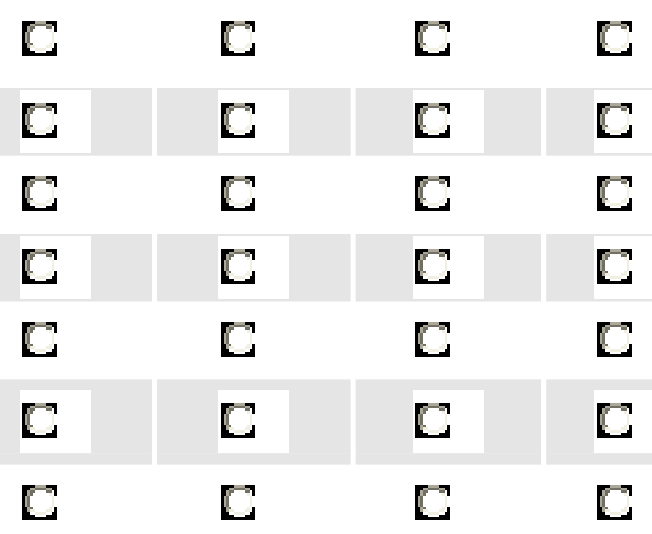
If you were to leave your current institution, how likely is it that you would do so to:

Retire

Return to school as a student

Accept employment at another Christian college or university

Accept employment at a secular college or university

Accept employment in consulting or other for-profit business or industry or become self-employed

Accept employment in a non-profit organization

Not Likely Somewhat

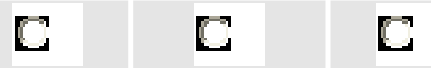

C $\mathrm{C}$
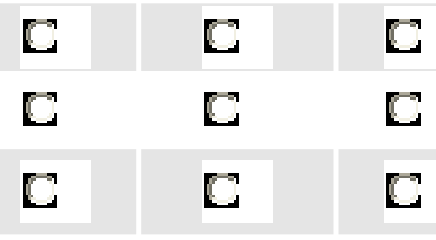

C $\mathrm{C}$

If you were to leave your current institution to accept another position, would you want to do more, less or about the same amount of the following as you currently do:

\begin{tabular}{l|c|c|c|} 
& More of this & Same Amount & Less of this \\
\hline Research & $\mathbf{C}$ & $\mathbf{C}$ & $\mathbf{C}$ \\
\hline Teaching & $\mathbf{C}$ & $\mathbf{C}$ \\
\hline Advising Students & $\mathbf{C}$ & $\mathbf{C}$ & $\mathbf{C}$ \\
\hline Service Activities & $\mathbf{C}$ & $\mathbf{C}$ & $\mathbf{C}$ \\
\hline Administration & $\mathbf{C}$ & $\mathbf{C}$ & $\mathbf{C}$ \\
\hline
\end{tabular}

If you were to leave your current institution to accept another position, how important would each of the following items be in your decision to accept another position?

\begin{tabular}{l|c|c|c|} 
& Not & Somewhat & Very \\
\hline Salary Level & Important & Important & Important \\
\hline Position Level & $\mathbf{C}$ & $\mathbf{C}$ & $\mathbf{C}$ \\
\hline Job Security & $\mathbf{C}$ & $\mathbf{C}$ & $\mathbf{C}$ \\
\hline Opportunities for advancement & $\mathbf{C}$ & $\mathbf{C}$ & $\mathbf{C}$ \\
\hline Benefits & $\mathbf{C}$ & $\mathbf{C}$ & $\mathbf{C}$ \\
\hline No pressure to publish & $\mathbf{C}$ & $\mathbf{C}$ & $\mathbf{C}$ \\
\hline Academic Freedom & $\mathbf{C}$ & $\mathbf{C}$ & $\mathbf{C}$ \\
\hline Good research facilities and equipment & $\mathbf{C}$ & $\mathbf{C}$ & $\mathbf{C}$
\end{tabular}




\begin{tabular}{l|c|c|c|}
\hline Good instructional facilities and equipment & $\mathbf{C}$ & $\mathbf{C}$ & $\mathbf{C}$ \\
\hline Excellent Students & $\mathbf{C}$ & $\mathbf{C}$ & $\mathbf{C}$ \\
\hline Excellent Colleagues & $\mathbf{C}$ & $\mathbf{C}$ \\
\hline $\begin{array}{l}\text { New institution is a Christian college } \\
\text { Institutional mission or philosophy that is compatible with } \\
\text { my own views }\end{array}$ & $\mathbf{C}$ & $\mathbf{C}$ & $\mathbf{C}$ \\
\hline Good job for my spouse & $\mathbf{C}$ & $\mathbf{C}$ & $\mathbf{C}$ \\
\hline Good geographic location & $\mathbf{C}$ & $\mathbf{C}$ & $\mathbf{C}$ \\
\hline Affordable housing & $\mathbf{C}$ & $\mathbf{C}$ & $\mathbf{C}$ \\
\hline Good environment/schools for my children & $\mathbf{C}$ & $\mathbf{C}$ & $\mathbf{C}$ \\
\hline A full-time position & $\mathbf{C}$ & $\mathbf{C}$ & $\mathbf{C}$ \\
\hline A part-time position & $\mathbf{C}$ & $\mathbf{C}$ & $\mathbf{C}$ \\
\hline
\end{tabular}

Please indicate the extent to which you agree or disagree with each of the following statements.

\begin{tabular}{|c|c|c|c|c|}
\hline & $\begin{array}{l}\text { Strongly } \\
\text { Disagree }\end{array}$ & $\begin{array}{l}\text { Somewhat } \\
\text { Disagree }\end{array}$ & $\begin{array}{l}\text { Somewhat } \\
\text { Agree }\end{array}$ & $\begin{array}{l}\text { Strongly } \\
\text { Agree }\end{array}$ \\
\hline $\begin{array}{l}\text { It is important for faculty to participate in } \\
\text { governing their institution }\end{array}$ & $\mathrm{C}$ & $\mathbb{C}$ & $\mathbb{E}$ & $\mathrm{C}$ \\
\hline $\begin{array}{l}\text { Faculty promotions should be based at } \\
\text { least in part on formal student } \\
\text { evaluations }\end{array}$ & $\mathbb{C}$ & $\mathrm{C}$ & $\mathrm{E}$ & 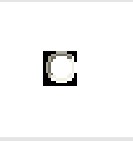 \\
\hline $\begin{array}{l}\text { The tenure system in higher education } \\
\text { should be preserved }\end{array}$ & $\mathrm{C}$ & 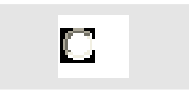 & $\mathrm{C}$ & $\mathrm{C}$ \\
\hline $\begin{array}{l}\text { Teaching effectiveness should be the } \\
\text { primary criterion for promotion of college } \\
\text { faculty }\end{array}$ & $C$ & $C$ & $\mathrm{E}$ & 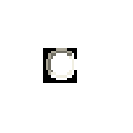 \\
\hline $\begin{array}{l}\text { Research/publications should be the } \\
\text { primary criterion for promotion of college } \\
\text { faculty }\end{array}$ & $\mathrm{C}$ & $B$ & $C$ & $\mathrm{C}$ \\
\hline $\begin{array}{l}\text { Years of service/advanced degree } \\
\text { should be the primary criterion for } \\
\text { promotion of college faculty }\end{array}$ & $\mathrm{C}$ & $C$ & $\mathrm{E}$ & $C$ \\
\hline $\begin{array}{l}\text { The administrative function is taking an } \\
\text { increasingly heavy share of available } \\
\text { resources at my institution }\end{array}$ & $\mathbb{C}$ & $\mathrm{C}$ & $\mathrm{E}$ & 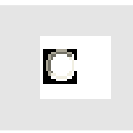 \\
\hline $\begin{array}{l}\text { Student Services are taking an } \\
\text { increasingly heavy share of available } \\
\text { resources at my institution }\end{array}$ & $B$ & $B$ & $E$ & $B$ \\
\hline $\begin{array}{l}\text { State or federally mandated assessment } \\
\text { requirements have improved the quality } \\
\text { of undergraduate education at my } \\
\text { institution }\end{array}$ & {[} & 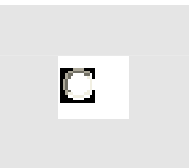 & C & $C$ \\
\hline
\end{tabular}


Female faculty members are treated fairly at my institution

\begin{tabular}{l|l|l|l|}
\hline & $E$ & $E$ & $E$ \\
\hline$E$ & $E$ & $E$ & $E$ \\
\hline$E$ & $E$ & $E$ & $E$ \\
\hline$E$ & $E$ & $E$ & $E$
\end{tabular}

If you would like to make additional comments or ask questions of the researcher, please use the email address below.

Thank you for completing this survey!

\begin{tabular}{l|l} 
Send Survey & Reset Survey Form \\
\hline
\end{tabular}

Comments or Questions? Contact Curtis Taylor at curtis@dordt.edu $(10 / 24 / 2003 ; 11: 21)$ 


\section{APPENDIX C.}

CCCU INSTITUTIONS 
The following North American colleges and universities are members of the CCCU as of April 1, 2005:

\author{
A \\ Abilene Christian University \\ Anderson University \\ Asbury College \\ Azusa Pacific University \\ B \\ Belhaven College \\ Bethel College--IN \\ Bethel University \\ Biola University \\ Bluffton University \\ Bryan College \\ C \\ California Baptist University \\ Calvin College \\ Campbellsville University \\ Carson-Newman College \\ Cedarville University \\ College of the Ozarks \\ Colorado Christian University \\ Cornerstone University \\ Covenant College \\ Crichton College \\ Crown College \\ D \\ Dallas Baptist University \\ Dordt College \\ E \\ East Texas Baptist University \\ Eastern Mennonite University \\ Eastern Nazarene College \\ Eastern University \\ Erskine College \\ Evangel University \\ F \\ Fresno Pacific University \\ G \\ Geneva College \\ George Fox University
}

Abilene, TX

USA

Anderson, IN

USA

Wilmore, $\mathrm{KY}$

USA

Azusa, CA

USA

Jackson, MS

USA

Mishawaka, IN

USA

Saint Paul, MN

USA

La Mirada, CA

USA

Bluffton, $\mathrm{OH}$

USA

Dayton, TN

USA

Riverside, CA

USA

Grand Rapids, MI

USA

Campbellsville, $\mathrm{KY}$

USA

Jefferson City, TN

USA

Cedarville, $\mathrm{OH}$

USA

Point Lookout, MO USA

Lakewood, CO USA

Grand Rapids, MI USA

Lookout Mountain, GA USA

Memphis, TN

USA

St. Bonifacius, MN

USA

Dallas, TX

USA

Sioux Center, IA

USA

Marshall, TX

USA

Harrisonburg, VA USA

Quincy, MA

USA

St. Davids, PA

USA

Due West, SC

USA

Springfield, MO

USA

Fresno, CA

USA

Beaver Falls, PA

USA

Newberg, OR

USA 
Gordon College

Goshen College

Grace College \& Seminary

Greenville College

H

Hardin-Simmons University

Hope International University

Houghton College

Houston Baptist University

Howard Payne University

Huntington College

I

Indiana Wesleyan University

J

John Brown University

Judson College--AL

Judson College--IL

K

Kentucky Christian University

King College

King's University College, The

$\mathbf{L}$

Lee University

LeTourneau University

Lipscomb University

Louisiana College

M

Malone College

Master's College \& Seminary, The

Messiah College

MidAmerica Nazarene University

Milligan College

Mississippi College

Missouri Baptist University

Montreat College

Mount Vernon Nazarene University

$\mathbf{N}$

North Greenville College

North Park University

Northwest Christian College

Northwest Nazarene University

Northwest University
Wenham, MA USA

Goshen, IN USA

Winona Lake, IN USA

Greenville, IL USA

Abilene, TX USA

Fullerton, CA USA

Houghton, NY USA

Houston, TX USA

Brownwood, TX USA

Huntington, IN USA

Marion, IN USA

Siloam Springs, AR USA

Marion, AL USA

Elgin, IL USA

Grayson, KY USA

Bristol, TN USA

Edmonton, $\mathrm{AB} \quad$ CANADA

Cleveland, TN USA

Longview, TX USA

Nashville, TN USA

Pineville, LA USA

Canton, $\mathrm{OH}$ USA

Santa Clarita, CA USA

Grantham, PA USA

Olathe, KS USA

Milligan College, TN USA

Clinton, MS USA

Saint Louis, MO USA

Montreat, NC USA

Mount Vernon, $\mathrm{OH} \quad$ USA

Tigerville, SC USA

Chicago, IL USA

Eugene, OR USA

Nampa, ID USA

Kirkland, WA USA 
Northwestern College--IA

Northwestern College--MN

Nyack College

0

Oklahoma Baptist University

Oklahoma Christian University

Oklahoma Wesleyan University

Olivet Nazarene University

Oral Roberts University

$\mathbf{P}$

Palm Beach Atlantic University

Point Loma Nazarene University

$\mathbf{R}$

Redeemer University College

Roberts Wesleyan College

S

Seattle Pacific University

Simpson University

Southeastern College

Southern Nazarene University

Southern Wesleyan University

Southwest Baptist University

Spring Arbor University

Sterling College

T

Tabor College

Taylor University

Trevecca Nazarene University

Trinity Christian College

Trinity International University

Trinity Western University

U

Union University

University of Sioux Falls

V

Vanguard University of Southern California

w

Warner Pacific College

Warner Southern College

Wayland Baptist University

Waynesburg College

Western Baptist College
Orange City, IA

Saint Paul, MN

Nyack, NY

USA

USA

USA

Shawnee, OK

USA

Oklahoma City, OK

USA

Bartlesville, OK

USA

Bourbonnais, IL

USA

Tulsa, OK

USA

West Palm Beach, FL

USA

San Diego, CA

USA

Ancaster, ON

Rochester, NY

CANADA

USA

Seattle, WA

USA

Redding, CA

USA

Lakeland, FL

USA

Bethany, OK

USA

Central, SC

USA

Bolivar, MO

USA

Spring Arbor, MI

USA

Sterling, KS

USA

Hillsboro, KS

USA

Upland, IN

USA

Nashville, TN

USA

Palos Heights, IL

USA

Deerfield, IL

USA

Blaine, WA

USA

Jackson, TN

USA

Sioux Falls, SD

USA

Costa Mesa, CA

USA

Portland, OR

USA

Lake Wales, FL

USA

Plainview, TX

USA

Waynesburg, PA

USA

Salem, OR 
Westmont College

Wheaton College

Whitworth College

Williams Baptist College
Santa Barbara, CA

Wheaton, IL

Spokane, WA

Walnut Ridge, AR
USA

USA

USA

USA 
APPENDIX D.

HUMAN SUBJECTS APPROVAL 


\section{IOWA STATE UNIVERSITY}

OF SCIENCE AND TECHNOLOGY

TO: Curtis J. Taylor

FROM: Ginny Austin, IRB Coordinator
Institutional Review Board

Office of Research Compliance Vice Provost for Research and Advanced Studies

2810 Beardshear Hall

Ames. Iowa 50011-2036

$515294-4566$

FAX $515294-7288$

RE: IRB ID \# 03-872

DATE REVIEWED: December 4, 2003

The project, "Organizational Commitment in Christian College Faculty" regulations as described in 45 CFR 46.101(b)(2).

(2) Research involving the use of educational tests (cognitive, diagnastic, aptitude, achievement), survey procedures, interview procedures or observation of public behavior, unless: (i) information obtained is recorded in such a manner that human subjects can be identified, directly or through identifiers linked to the subjects; and (ii) any disclosure of the human subjects' responses outside the research could reasonably place the subjects at risk of criminal or civil liability or be damaging to the subjects' financial standing, employability, or reputation.

To be in compliance with ISU's Federal Wide Assurance through the Office of Human Research Protections (OHRP) all projects involving human subjects, must be reviewed by the Institutional Review Board (IRB). Only the IRB may determine if the project must follow the requirements of 45 CFR 46 or is exempt from the requirements specified in this law. Therefore, all human subject projects must be submitted and reviewed by the IRB.

Because this project is exempt it does not require further IRB review and is exempt from the Department of Health and Human Service (DHHS) regulations for the protection of human subjects.

We do, however, urge you to protect the rights of your participants in the same ways that you would if IRB approval were required. This includes providing relevant information about the research to the participants. Although this project is exempt, you must carry out the research as proposed in the IRB application, including obtaining and documenting (signed) informed consent, if applicable to your project.

Any modification of this research should be submitted to the IRB on a Continuation and/or Modification form to determine if the project still meets the Federal criteria for exemption. If it is determined that exemption is no longer warranted, then an IRB proposal will need to be submitted and approved before proceeding with data collection.

cc: ELPS 


\section{REFERENCES}

Abraham, S. Y., Steiger, D. M., Montgomery, M., Kuhr, B. D., Tourangeau, R., Montgomery, B., et al. (2002). 1999 National study of postsecondary faculty (NSOPF:99) methodology report (NCES 2002-154). U. S. Department of Education, National Center for Education Statistics. Washington, DC: U.S. Government Printing Office.

Achieving the mission of church-related institutions of liberal learning. (1977). Washington, DC: Association of American Colleges. (ERIC Document Reproduction Service No. ED136656)

Adams, K. H. (1995). Unexpected journeys: The experiences of women in Christian college administration (Doctoral Dissertation, Indiana University, 1995). Dissertation Abstracts International, 56, 3465.

Alger, J. B. (1998). Academic freedom meets active faith. Academe, 84(1), 1.

Altbach, P. G., \& Lewis, L. S. (1995). Professorial attitudes—an international survey. Change, 27(6), 50-57.

Benkhoff, B. (1997). Disentangling organizational commitment: The dangers of the OCQ for research and policy. Personnel Review, 26(1/2), 114-131.

Boostrom, R. (1994). Learning to pay attention. International Journal of Qualitative Studies in Education, 7(1), 51-64.

Braskamp, L. A. \& Ory, J. C. (1994). Assessing faculty work: Enhancing individual and institutional performance. San Francisco, CA: Jossey-Bass. 
Brookover, R. S., IV. (2002). An assessment of organizational commitment among faculty at Clemson University (South Carolina). (Doctoral Dissertation, Clemson University, 2002). Dissertation Abstracts International, 63, 873.

Browde, J. A. (1976, November). The role of the faculty in the church-related college. Speech presented to the administration and faculty of Meredith College at a retreat, Asheboro, NC. (ERIC Document Reproduction Service No. ED132945)

Brubacher, J. S. \& Rudy, W. (1976). Higher education in transition. New York: Harper \& Row.

Burtchaell, J. T. (1998). The dying of the light: The disengagement of colleges and universities from their Christian churches. Grand Rapids, MI: Eerdmans.

Cagney, M. (1997, December 8). Do Christian colleges treat their women faculty fairly? Christianity Today, 41(14), 72.

Cameron, N. M. (1994, July 18). Christian colleges’ urgent mission. Christianity Today, 38(8), 18-19.

Carlburg, R. J. (1994, November 14). Why Christian colleges make sense for Christians. Christianity Today, 38(13), 121-128.

Carroll, M. G. (2002). Exploring the relationship between organizational commitment and employee eliefs, expectations, and experiences of mission in a values-based organization (Doctoral Dissertation, Gonzaga University, 2001). Dissertation Abstracts International, 62, 3847.

Christian College Consortium. (1997). Mission statement. Retrieved April 7, 2000, from http://www.ccconsortium.org/mission_statement.asp 
Conrad, C. F. \& Wyer, J. C. (1982). Incest in academe: The case for selective inbreeding. Change, 14, 45-48.

Cooper, M. V. (1999). Faculty perspectives on the intergration of faith and academic discipline in Southern Baptist higher education. Religious Education, 94(4), 380-395.

Council for Christian Colleges \& Universities. (2000). Facts about the CCCU. Retrieved March 23, 2000, from http://www.cccu.org/about.html

Crabtree, D. (1996, March 4). A Christian college education: is it worth the financial investment? Christianity Today, 40(3), 36-46.

Dannelly, C. M. (1931). The denominational college. Journal of Higher Education, 2(4), 183-189.

Dattilo, J. (1987). The scholarly productivity of inbred and noninbred full-time doctorallyprepared nursing faculty in teaching positions in the south. (Doctoral Dissertation, Georgia State University, 1987). Dissertation Abstracts International, 48, 1668.

Diekema, A. J. (2000). Academic freedom and Christian scholarship. Grand Rapids, MI: Eerdmans.

Dutton, J. E. (1980, April). The impact of inbreeding and immobility on the professional role and scholarly performance of academic scientists. Paper presented at the annual meeting of the American Educational Research Association, Boston, MA. Washington, DC: National Science Foundation. (ERIC Document Reproduction Service No. ED196714)

Edwards, M. U., Jr. (1999, April 21). Christian colleges: A dying light or a new refraction? The Christian Century, 116(13), 459-463. 
Eells, W. C. \& Cleveland, A. C. (1999). Faculty inbreeding. Journal of Higher Education, 70(5), 579-588 (Original work published 1935)

Ellis, B. D. (2001). Searching for the perfect fit: An examination of the job satisfaction of middle management student affairs professionals in Christian institutions of higher education (Doctoral Dissertation, Indiana University, 2001). Dissertation Abstracts International, 62, 856.

Faculty attitudes and characteristics: Results of a 1998-99 survey. (1999, September 3). The Chronicle of Higher Education, A20-21.

Fairweather, J. S. (1996). Faculty work and public trust: Restoring the value of teaching and public service in American academic life. Needham Heights, MA: Allyn \& Bacon.

Flowers, M. E., Jr. (1992). Christian college distinctives: A study of the institutional satisfaction and morale at Christian College Coalition institutions. (Doctoral Dissertation, University of California at Los Angeles, 1992). Dissertation Abstracts International, 53, 731.

Frame, R. (1997, March 3). Boom years for Christian higher education. Christianity Today, 41(3), 80-94.

Garlett, M. W. (1997). Waiting in the wings: Women of God in the evangelical academy (Doctoral Dissertation, The Claremont Graduate University, 1997). Dissertation Abstracts International, 58, 521.

Hagedorn, L. S. (2000). Conceptualizing faculty job satisfaction: Components, theories, and outcomes. In L. S. Hagedorn (Ed.), What contributes to job satisfaction among faculty and staff (pp. 5-20). San Francisco: Jossey-Bass. 
Hargens, L. L., \& Farr, G. M. (1973). An examination of recent hypotheses about institutional inbreeding. The American Journal of Sociology, 78(6), 1381-1402.

Harshbarger, B. (1989). Faculty commitment to the university: Influences and issues. Review of Higher Education, 13(1), 29-45.

How my Christian college surprised me. (1993, March 8). Christianity Today, 37(3), 69-76. Jacobson, J. (2001, May 7). 2 professors must leave a Baptist seminary for refusing to sign statement of faith. The Chronicle: Today's News. Retrieved August 28, 2003, from http://chronicle.com/daily/2001/05/2001050707n.htm

Johnsrud, L. K. (1991). Administrative promotion: The power of gender. Journal of Higher Education, 62(2), 119-49.

Kirshstein, R. J., Matheson, N. \& Jing, Z. (1997). 1993 National study of postsecondary faculty (NSOPF-93) instructional faculty and staff in higher education institutions: Fall 1987 and Fall 1992 (NCES 97-447). U. S. Department of Education, National Center for Education Statistics. Washington, DC: U.S. Government Printing Office.

Kleiner, C. (1999, April 26). Nearer to God, one freshman at a time. U.S. News \& World Report, 126(16), p. 60.

Kuh, G. D., Schuh, J. H., Whitt, E. J., Andreas, R. E., Lyons, J. W., Strange, C. C., et al. (1991). Involving colleges: Successful approaches to fostering student learning and development outside the classroom. San Francisco: Jossey-Bass.

Lam, S. S. K. (1998). Test-retest reliability of the organizational commitment questionnaire. Journal of Social Psychology, 138(6), 787-788. . 
Lamport, M. A. (1994). Student-faculty informal interaction and its relation to college student outcomes in Christian college settings: Research and implications. Research on Christian Higher Education, 1(1), 66-78.

Lovejoy, A. O. (1930). Academic freedom. In R. H. Seligman \& A. Johnson (Eds.), Encyclopedia of the social sciences (p. 84). New York: Macmillan.

Maehr, M. L. \& Braskamp, L. A. (1986). The motivation factor. Lexington, MA: D. C. Heath.

Magner, D. K. The graying professoriate. (1999, September 3). The Chronicle of Higher Education, A18-19.

Marty, M. (1998). In the crossfire between academic and religious freedom. Academe, 84(1), 63-67.

Mathieu, J. E. \& Zajac, D. M. (1990). A review and meta-analysis of the antecedents, correlates, and consequences of organizational commitment. Psychological Bulletin, 108(2), 171-194.

McCaul, H. S. \& Hinsz, V. B. (1995). Assessing organizational commitment: An employee's global attitude toward the organization. Journal of Applied Behavioral Science, 31(1), 80-90. Retrieved May 16, 2001, from EBSCOhost Academic Search Elite database.

McGee, R. J. (1960). The function of institutional inbreeding. The American Journal of Sociology, 65, 483-488.

McMurtrie, B. (2002, May 24). Do professors lose academic freedom by signing statements of faith? The Chronicle of Higher Education, A12-14.

McNeely, J. H. (1932). Faculty inbreeding in land-grant colleges and universities. Washington, D. C.: Office of Education. 
McPherren, A. C. (1994). Faculty workload: Hours and activities in Christian College Coalition and small public universities. Research on Christian Higher Education, 1(1), 89-105.

Meehan, M. J. (2001). Decision-making and organizational commitment: A comparison of faculty perceptions at unionized and non-unionized private colleges and universities (Doctoral Dissertation, Seton Hall University, 2001). Dissertation Abstracts International, 62, 413.

Miller, G. A. (1918, January 12). Academic inbreeding. School and Society, 7, 53-54.

Miller, M. H. (1977). Academic inbreeding in nursing. Nursing Outlook, 24(3), 172-177.

Moe, Y. K. (1988). An analysis of faculty inbreeding in chemistry and physics departments at selected doctoral-granting universities. (Doctoral Dissertation, The George Washington University, 1988). Dissertation Abstracts International, 50, 1229.

Mowday, R. T., Porter, L. W., \& Steers, R. M. (1982). Employee-organizational linkages: The psychology of commitment, absenteeism, and turnover. New York: Academic Press.

Mowday, R. T., Steers, R. M., \& Porter, L. W. (1979). The measurement of organizational commitment. Journal of Vocational Behavior, 14(2), 224-247.

Nation: Average pay of full-time faculty members. (1999, August 27). The Chronicle of Higher Education [Alamanc], p. 7.

Nation: Faculty and staff. (1999, August 27). The Chronicle of Higher Education [Almanac], 34-38. 
Niehoff, R. L. (1995). Job satisfaction, organizational commitment and individual and organizational mission values congruence: Investigating the relationships. Unpublished doctoral dissertation, Gonzaga University, Spokane, WA.

Olsen, T. (1996, February 5). Enrollment booms at Christian colleges. Christianity Today, 40(2), 108-109.

Pan, S. (1993). A study of faculty inbreeding at eleven land-grant universities. (Doctoral dissertation, Iowa State University, 1993). Dissertation Abstracts International,54, 2485.

Parsons, J. \& Fenwick T. J. (1996). The Christian post-secondary teacher's vocational task. Edmonton, Alberta: University of Alberta. (ERIC Document Reproduction Service No. ED393364)

Patterson, J.A. (2001). Shining lights: A history of the Council for Christian Colleges \& Universities. Grand Rapids, MI: Baker Academic.

Pattillo, M. M., Jr., \& Mackenzie, D. M. (1966). Church-sponsored higher education in the United States: Report of the Danforth Commission. Washington, DC: American Council on Education.

Peterson’s Christian colleges and universities. (1999). Princeton, NJ: Peterson’s.

Poppens, B. B. (2001). Perceived and preferred organizational culture types and organizational commitment at Midwestern private, nonprofit colleges (Doctoral Dissertation, University of South Dakota, 2000). Dissertation Abstracts International, 61, 3919. 
Porter, L. W., Steers, R. M., Mowday, R. T., \& Boulian, P. (1974). Organizational commitment, job satisfaction and turnover among psychiatric technicians. Journal of Applied Psychology, 59, 603-609.

Professor loses job over erotic poem. (1997, April 4). The Chronicle of Higher Education, p. A8.

Ramirez, J. \& Brock, B. (1996). The coherent institutional philosophy: Myth or mandate? An ethnography of faculty world views at a Christian university. Journal of Research on Christian Education, 5(1), 3-32.

Ringenberg, W. C. (1984). The Christian college: A history of Protestant higher education in America. Grand Rapids, MI: Eerdmans.

Rudolph, F. (1990). The American college and university: A history. Athens, GA: University of Georgia Press.

Runkel, J. E. (1987). Liberal arts college presidents: Credentials, affiliations, socialization and inbreeding. (Doctoral dissertation, Northwestern University, 1987). Dissertation Abstracts International, 48, 2000.

Russell, S. H., Fairweather, J. S., Hendrickson, R. M., \& Zimbler, L. J. (1991). 1988 National Study of Postsecondary Faculty (NSOPF-88) Profiles of faculty in higher education institutions, 1988 (NCES 91-389). U. S. Department of Education, National Center for Education Statistics. Washington, DC: U.S. Government Printing Office.

Sheridan, D. A. (1995). The role of faculty members in institutional decision-making in church-related liberal arts colleges. (Doctoral dissertation, University of California at Los Angeles, 1995). Dissertation Abstracts International, 56, 4361. 
Splete, A. (1987). Community, commitment and congruence: A different kind of excellence. Washington DC: Council of Independent Colleges. (ERIC Document Reproduction Service No. ED292370)

Stellway, R. J. (1984). World-changing Christians: An outcome of Christian higher education. Faculty Dialogue, 1, 73-86.

Stewart, G. B. (1992). Institutional inbreeding among mathematics faculty in American colleges and universities. (Doctoral dissertation, University of North Texas, 1992). Dissertation Abstracts International, 53, 2710.

Thompson, D. T. (1995). Turning points for successful institutions: A look at 18 private, Christian liberal arts colleges and universities in California. (Doctoral dissertation, Pepperdine University, 1995). Dissertation Abstracts International, 56, 1207.

Tierney, W. G. \& Rhoads, R. A. (1994). Faculty socialization as cultural process: A mirror of institutional commitment. Washington, DC: School of Education and Human Development, George Washington University.

Tonsor, S. J. (1970). The church-related college: Special mission or educational anachronism. Liberal Education, 56(3), 403-11.

U.S. Department of Education, National Center for Education Statistics (2003). Integrated postsecondary education data System (IPEDS) peer analysis system: institutions data report [Data file]. Available from National Center for Education Statistics Web site, http://www.nces.ed.gov

Why attend a Christian college? (1992, November 9). Christianity Today, 36(13), 88-94.

Wolterstorff, N. (1984). The mission of the Christian college at the end of the 20th century. Faculty Dialogue, 1, 39-48. 
Zimbler, L. J. (2001). National study of postsecondary faculty (NOSPF:99) public access data analysis system [CD-ROM] (NCES 2001-203). U. S. Department of Education, National Center for Education Statistics. Washington, DC: U.S. Government Printing Office. 


\section{BIOGRAPHICAL SKETCH}

Curtis J. Taylor was born December 12, 1964 in Grand Rapids, Michigan. He received the Bachelor of Arts in Psychology from Calvin College in 1987 and the Master of Arts in College and University Administration from Michigan State University in 1989. He has served as a Graduate Resident Director at Michigan State University, a Residence Hall Director at the University of Washington, the Director of Residence Life at Dordt College in Sioux Center, Iowa, and the Vice President for Student Services at Dordt College. He is currently serving as the Special Assistant to the President and Director of Institutional Planning at Dordt College.

Curtis married Sheryl Sheeres in 1987 and together they enjoy their three wonderful children - Ian Curtis (10), Willem Levi (6), and Mia Soo-Jee (2). 